UNIVERSIDAdE de SÃo PAUlo

FACULDADE DE ECONOMIA, ADMINISTRAÇÃO E CONTABILIDADE Programa de Pós-GraduAÇÃo EM AdMINISTRAÇÃo

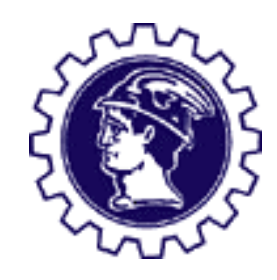

\title{
INTERNET E MARKETING DE RELACIONAMENTO: IMPACTOS EM EMPRESAS QUE ATUAM NO MERCADO CONSUMIDOR
}

\author{
SANDRA SAYURI YAMASHITA
}

Orientadora: PROF ${ }^{\mathrm{a}}$. DR ${ }^{\mathrm{a}}$. MARIA APARECIDA GOUVÊA 
Reitor da Universidade de São Paulo

Prof. Dr. Adolpho José Melfi

Diretor da Faculdade de Economia, Administração e Contabilidade Prof ${ }^{a}$. Dr ${ }^{a}$ Maria Tereza Leme Fleury

Chefe do Departamento de Administração

Prof. Dr. Eduardo Pinheiro Gondim de Vasconcellos 


\title{
INTERNET E MARKETING DE RELACIONAMENTO: IMPACTOS EM EMPRESAS QUE ATUAM NO MERCADO CONSUMIDOR
}

\author{
SANDRA SAYURI YAMASHITA \\ Orientadora: PROF ${ }^{\mathrm{a}}$. DR ${ }^{\mathrm{a}}$. MARIA APARECIDA GOUVÊA
}

Dissertação apresentada à Faculdade de Economia, Administração

Contabilidade da Universidade de São Paulo para a obtenção do título de Mestre em Administração. 


\section{FICHA CATALOGRÁFICA}

Elaborada pela Seção de Publicações e Divulgação do SBD/FEA/USP

\section{Yamashita, Sandra Sayuri}

Internet e marketing de relacionamento: impactos em empresas que atuam no mercado consumidor / Sandra Sayuri Yamashita. -São Paulo : FEA/USP, 2003.

$288 \mathrm{f}$.

Dissertação (Mestrado) - Universidade de São Paulo, 2003

Bibliografia.

1. Administração de marketing 2. Marketing de relacionamento 3. Internet 4. Comércio eletrônico I. Faculdade de Economia, Administração e Contabilidade da USP II. Título

CDD - 658.8 


\section{Agradecimentos}

Este trabalho representa, para mim, uma indescritível realização pessoal, a qual não teria o mesmo êxito sem a contribuição de várias pessoas. Embora não mencione todos nominalmente, agradeço imensamente a estas pessoas, a quem especialmente dedico este esforço:

- À Prof ${ }^{a}$ Maria Aparecida, pelo comprometimento, profissionalismo, dedicação, amizade e precisão na orientação, e por ter doado um "pouco" de si para a concretização deste trabalho. Afinal, não é fácil ler, minuciosamente e por repetidas vezes, tantas páginas de dissertação...

- Ao Prof. Geraldo, “guru” de várias pessoas eminentes, e também fonte de inspiração e de conhecimento aos iniciantes: seu incentivo e apoio foram muito significativos.

- À Prof ${ }^{a}$ Bernadete, cujos comentários, com seriedade e profissionalismo, foram valiosos para o aprimoramento deste estudo.

- Ao pessoal da Secretaria da Pós-Graduação, da Coordenação do PPGA, da Biblioteca da FEA e à Ivanete, pelas informações precisas e pela amizade.

- Às pessoas que intermediaram os contatos com as empresas pesquisadas, aos profissionais entrevistados e aos companheiros de curso Maurício e Sigfried.

- Aos amigos do Banco Central, especialmente ao Akira, Marinês, Elina e Carlão, e da Abril, principalmente ao Toti, Akiko, Henri, Cristina e Marcos: agora vocês podem ver concluído o que parecia interminável... sua amizade estimulante e seu apoio foram essenciais.

- A todos que souberam compreender minhas ausências durante o período de mergulho no curso de mestrado: família, amigos...

- A todos que intencionaram e que de fato tornaram minha vida de alguma maneira mais fácil durante esse mergulho: vocês me deram força e coragem.

- A meus pais, Katuki e Rosa, e meu irmão Rogério, pela torcida, pelo apoio e carinho em todos os momentos: vocês estiveram sempre comigo...

- Ao meu marido Marcelo, pela cumplicidade, companheirismo e amizade: temos muitas batalhas ainda pela frente! 


\section{Resumo}

Ao longo dos anos, com o principal intuito de manter seus clientes, as organizações têm aplicado diversas abordagens para aproximar-se dos mesmos por meio do cultivo de relacionamentos lucrativos e duradouros. De que modo tais práticas poderiam ser influenciadas pelo uso de alta tecnologia dentro de um cenário cada vez mais competitivo? A fim de elucidar esta questão, este estudo teve como objetivo principal analisar os impactos da Internet sobre as práticas de Marketing de Relacionamento e suas implicações em empresas atuantes no mercado consumidor.

Ao realizar um retrospecto teórico sobre o Marketing de Relacionamento, a Internet, e os resultados das interações entre ambos observados por uma diversidade de autores, foi possível angariar subsídios para pesquisar e compreender as práticas de algumas empresas no Brasil.

Assim, por meio de pesquisa exploratória na forma de estudo de multi-casos, identificaram-se nas empresas pesquisadas variados níveis de evolução das práticas voltadas ao objetivo de perpetuar o relacionamento com clientes, aproveitando-se das características sem precedentes da Internet. Observou-se um amplo espectro de medidas, conforme o setor de atividade da empresa, a natureza de seus produtos/serviços, o seu grau de compreensão e assimilação do conceito de relacionamento, a sua orientação estratégica e disponibilidade de recursos, além das expectativas e do nível de familiaridade de seus clientes com a tecnologia. Este estudo sinaliza, por fim, uma compreensão e uma receptividade das empresas às diversas oportunidades de crescimento geradas pelo emprego bem sucedido deste ferramental. 


\begin{abstract}
In order to maintain customers in their portfolios, organizations have developed several strategies to approach them by building long term and profitable relationships. But how such strategies would be influenced by the use of high technology tools? To find answers to this question, this study aimed to analyze the impacts of Internet on Relationship Marketing practices and related implications to the consumer market companies.

By developing a comprehensive theoretical research on Relationship Marketing, Internet and the their interactions, it was able to organize key knowledge to understand the current practices adopted by companies in Brazil.

Therefore, by developing an exploratory research through a multiple cases study, it was identified distinct evolution levels in customer relationship practices of the sample companies which have already taken advantages of Internet. It was observed a large range of results depending on company industry, type of products/services, understanding level of relationship concept, strategic orientation, available resources, customer expectations and technology familiarities.

Despite the observed different stages of Internet usage in Marketing practices, this study demonstrates the clear awareness and the interest of companies in capturing the growth opportunities allowed by Internet tools.
\end{abstract}




\section{Sumário}

LISTA DE TABELAS __ XI

LISTA DE QUADROS _ XI

LISTA DE FIGURAS __ XII

1. INTRODUÇÃO _ 1

1.1. Contexto — 2

1.2. Situação-problema __ 3

1.3. Definições operacionais __ 6

1.4. Premissas___ 7

1.5. Objetivos do estudo — 7

1.6. Justificativa do estudo _ 8

1.7. Interface com outras disciplinas do estudo de Administração_ 10

1.8. Organização do estudo__ 10

2. REVISÃO DA LITERATURA __ 11

2.1. Marketing de Relacionamento __ 12

2.1.1. O marketing de relacionamento: das suas origens aos dias atuais __ 13

2.1.1.1. Qualidade e satisfação dos clientes _ 24

2.1.1.2. Valor _ 28

2.1.1.3. Orientação para o mercado __ 33

2.1.2. A importância do marketing de relacionamento para a organização ___ 37

2.1.2.1. Acirramento da concorrência e sofisticação das necessidades do consumidor 38

2.1.2.2. Aumento da lucratividade da organização___ 40

2.1.3. As implicações do marketing de relacionamento __ 44

2.1.3.1. Os diferentes níveis de relacionamento entre a empresa e seus clientes __ 44

2.1.3.2. A importância de se ouvir o cliente___ 50

2.1.3.3. Outras implicações _ 52

2.2. Internet 56

2.2.1. A evolução da Internet _ 58

2.2.2. As implicações da Internet para a empresa ___ 63

2.2.2.1. Comércio eletrônico _ 65

2.2.3. As implicações da Internet para o marketing __ 71

2.3. Impactos e implicações da Internet sobre o Marketing de Relacionamento _

2.3.1. Impactos da Internet sobre as práticas de Marketing de Relacionamento ___ 77

2.3.2. Implicações da Internet relacionadas ao Marketing de Relacionamento ___ 89

2.3.2.1. Marketing de Relacionamento e Internet____ 91

2.3.2.2. CRM: Customer Relationship Management ___ 105

2.3.2.3. O CRM sob a ótica de uma especialista ___ 116

2.4. Considerações Finais _ 118

3. METODOLOGIA DE PESQUISA __ 119

3.1. Objetivo da pesquisa 120

3.2. Tipo de pesquisa e justificativa da metodologia de pesquisa _ 120 
3.3. Hipóteses/questões _— 125

3.4. População — 126

3.5. Amostragem — 130

3.6. Dados necessários e fontes de obtenção dos dados __ 132

3.7. Instrumento de coleta de dados e variáveis _ 132

3.7.1. Instrumento de coleta de dados___ 133

3.7.2. Variáveis _ـ 133

3.8. Forma de abordagem __ 134

3.9. Coleta de dados 134

3.10. Validade___ 134

3.10.1. Tipos de erros não amostrais __ 135

3.10.2. Pré-teste _ 138

3.11. Validade de conteúdo__ 139

3.12. Análise dos dados _ 139

4. ORGANIZAÇÃO E ANÁLISE DOS DADOS COLETADOS _ 143

4.1. Caracterização da empresa em relação a práticas de Marketing de Relacionamento 145

4.1.1. Existência de departamento formalmente responsável pelos relacionamentos com clientes

4.1.2. Programas de Fidelidade __ 148

4.1.3. Pesquisas de satisfação e fixação de parâmetros relacionados ao atendimento ao cliente na definição de metas anuais

4.1.4. Realização de treinamento/reciclagem para funcionários, relacionado a atendimento 160

4.1.5. Autonomia para efetuar pequenos gastos para atendimento além do padrão __ 164

4.1.6. Premiação de funcionários que promovem um bom marketing de relacionamento _ 166

4.1.7. Oferta de produtos/serviços personalizados antes das vendas pela Internet ___ 168

4.1.8. CRM 169

4.1.8.1. Definição _ـ 169

4.1.8.2. Política e estrutura de CRM__ 170

4.1.8.3. Motivações e áreas participantes ___ 176

4.1.8.4. Análise de custos e benefícios para implantação___ 179

4.1.8.5. Avaliação de resultados___ 180

4.1.9. Outras iniciativas de marketing de relacionamento existentes e novas práticas a serem implantadas

4.1.10. Critérios para avaliação de desempenho ___ 184

4.1.11. Opinião sobre o sucesso das práticas de Marketing de Relacionamento ___ 188

4.1.12. Considerações Gerais ___ 192

4.2. Caracterização da empresa em relação às suas operações como fornecedora pela Internet

4.2.1. Objetivos da criação do site da empresa na Internet ___ 199

4.2.2. Fases da Internet como ferramenta de negócios __ 201

4.2.3. Vantagens da realização de negócios pela Internet__ 202

4.2.4. Desvantagens da realização de negócios pela Internet __ 204

4.2.5. O cliente que compra pela Internet

4.2.6. Considerações Gerais _ 208 
4.3. Impactos sobre o Marketing de Relacionamento verificados pela introdução da Internet como intermediadora das atividades de comércio na empresa

4.3.1. Vendas pela Internet

4.3.2. Impactos da Internet sobre o negócio da empresa

4.3.3. Posição estratégica das empresas

4.3.4. Impactos da Internet sobre o marketing de relacionamento

4.3.5. Implicações para as empresas da nova situação configurada pela Internet___ 222

4.3.6. Outras implicações

4.3.7. Expectativas/necessidades dos clientes em relação às compras pela Internet e esforços da empresa para satisfazê-las

4.3.8. Benefícios desejados num relacionamento com a própria empresa pela Internet, supondo-se cliente da mesma

4.3.9. Situação do relacionamento entre empresa e clientes, após a introdução das vendas pela Internet

4.3.10. Considerações gerais

4.4. Panorama das práticas das empresas no contexto do binômio marketing de relacionamento e Internet

5. CONCLUSÕES _ 256

6. RESTRIÇÕES/LIMITAÇÕES DO ESTUDO _ 257

7. SUGESTÕES PARA ESTUDOS FUTUROS _ 258

8. REFERÊNCIAS BIBLIOGRÁFICAS E OBRAS CONSULTADAS___ 259

8.1. Referências bibliográficas _ 259

8.2. Obras Consultadas _ 268

9. APÊNDICES 273

9.1. Apêndice A - Roteiro de Pesquisa _ 273

9.2. Apêndice B - Extratos das entrevistas _ 282

10. ANEXOS 285

10.1. Anexo A - Sistema de Referência Utilizado___ 285

10.2. Anexo B - Carta de Apresentação da FEA/USP__ 287

10.3. Anexo C - Esquema CRM - Três tipos de CRM _ 288 


\section{Lista de Tabelas}

Tabela 1 - Número de empresas para a amostra 131

Tabela 2 - Empresas entrevistadas 144

Tabela 3 - Percentual de vendas pela Internet em relação às vendas totais da empresa 212

\section{Lista de Quadros}

Quadro 1 - Quatro eras na história do Marketing 15

Quadro 2 - Comparação entre estratégias do marketing de transações e do marketing de relacionamento

Quadro 3 - Definições selecionadas que enfatizam diferentes aspectos do marketing de relacionamento

Quadro 4 - Determinantes do comportamento de compra online 69

Quadro 5 - Características de um site que incentivam a retenção de clientes

Quadro 6 - Troca de valores: um processo de quatro estágios

Quadro 7 - Comparação entre satisfação e valor

Quadro 8 - A evolução do CRM 108

Quadro 9 - Módulos componentes dos softwares de CRM 109

Quadro 10 - Departamentos formalmente responsáveis pelos relacionamentos com clientes 146

Quadro 11 - Planejamento e Implantação de Programas de Fidelidade 149

Quadro 12 - Formas de pesquisa utilizadas pelas empresas entrevistadas 151

Quadro 13 - Canais abertos para manifestação espontânea dos clientes

Quadro 14 - Padronização de procedimentos para atendimento a reclamações

Quadro 15 - Autonomia para gastos segundo julgamento próprio

Quadro 16 - Concordância com definição de CRM

Quadro 17 - Avaliação dos resultados do CRM 181

Quadro 18 - Avaliação pessoal das práticas de marketing de relacionamento na respectiva empresa

Quadro 19 - Principal motivação para criação do site da empresa na Internet

Quadro 20 -Vantagens da comercialização de serviços e produtos pela Internet 199

Quadro 21 - Desvantagens da comercialização de serviços e produtos pela Internet ___ 204

Quadro 22 - O comprador pela Internet

Quadro 23 - Visão das empresas sobre o crescimento das vendas eletrônicas

Quadro 24 - Variações observadas no negócio da empresa após adoção das vendas pela Internet 213

Quadro 25 - Implicações decorrentes dos impactos da Internet sobre aspectos do marketing de relacionamento

Quadro 26 - Mudanças no desenho e funcionamento do site em função do marketing de relacionamento

Quadro 27 - Principais diferenças entre compras pela Internet e compras pelas vias tradicionais 237

Quadro 28 - Expectativas dos clientes em relação às compras pela Internet, segundo visão das empresas

Quadro 29 - Panorama das empresas: Marketing de Relacionamento e Internet 


\section{Lista de Figuras}

Figura 1 - Organização do estudo

Figura 2 - Revisão bibliográfica

Figura 3 - Estrutura da seção: Marketing de relacionamento __ 13

Figura 4 - Um modelo genérico de relacionamento com clientes __ 25

Figura 5 - Motivos de troca de fornecedor__ 26

Figura 6 - Modelo de Satisfação do Cliente___ 27

Figura 7 - Criando valor que os clientes podem ver _ 30

Figura 8 - As conseqüências de um valor superior para os clientes___ 32

Figura 9 - O relacionamento comprador-vendedor ___ 39

Figura 10 - O relacionamento comprador-vendedor __ 39

Figura 11 - O relacionamento comprador-vendedor _ 39

Figura 12 - Porque os clientes leais são mais rentáveis __ 41

Figura 13 - A Escada da Lealdade __ 45

Figura 14 - A Pirâmide do Relacionamento___ 45

Figura 15 - Dimensões da Lealdade___ 48

Figura 16 - Estrutura da seção: Internet___ 56

Figura 17 - Formas de conexão à Internet __ 58

Figura 18 - Estágios da Internet ___ 59

Figura 19 - Evolução da adoção da Internet como ferramenta de negócios __ 61

Figura 20 - Adoção da Internet __ 62

Figura 21 - O ciclo do comércio eletrônico __ 66

Figura 22 - Dimensões do comércio eletrônico __ 66

Figura 23 - Digitalização da loja __ 67

Figura 24 - Digitalização do produto __ 67

Figura 25 - Ciclo de consumo na Internet __ Erro! Indicador não definido.

Figura 26 - O e-Marketing Mix ___ 73

Figura 27 - Estrutura da seção: Impactos e implicações da Internet sobre o Marketing de Relacionamento

Figura 28 - Impacto dos níveis de performance sobre a probabilidade de comprar novamente do mesmo fornecedor 95

Figura 29 - O imperativo do CRM__ 114

Figura 30 - Estrutura de CRM da Empresa B __ 171

Figura 31 - Estrutura de CRM da Empresa C _ 171

Figura 32 - Estrutura de CRM da Empresa D _ 172

Figura 33 - Estrutura de CRM da Empresa E __ 173

Figura 34 - Estrutura de CRM da Empresa F__ 174

Figura 35 - Estrutura de CRM da Empresa G__ 175

Figura 36 - Estrutura de CRM da Empresa H 175

Figura 37 -Visão sobre o CRM _— 196

Figura 38 - Estágios da Internet__ 201

Figura 39 - Fases da Internet.____ 202

Figura 40 - Serviços oferecidos pelas 100 maiores empresas de comércio eletrônico do Brasil__ 250 


\section{Introdução}

O conceito de Marketing de Relacionamento, de uma forma ou de outra, existe desde que as trocas comerciais passaram a ocorrer de maneira organizada. Sheth e Parvatiyar (1995) citam exemplos da era Pré-Revolução Industrial quando agricultores e artesãos desenvolviam relacionamentos individuais com seus clientes. Entretanto, este conceito somente passou a ganhar a atenção de pesquisadores a partir da década de 1980, adquirindo mais importância na década de 1990, principalmente como abordagem para enfrentar o acirramento da concorrência. Percebeu-se que manter clientes era muito mais barato, conceitualmente, mais simples, e mais lucrativo do que conquistar novos.

Paralelamente ao crescimento da percepção da importância deste conceito neste último período, observaram-se também intensos avanços em aplicações da tecnologia da informação nas corporações. Uma nova classe de estratégias e softwares corporativos, como o ERP (Enterprise Resources Planning), SCM (Supply Chain Management), CRM (Customer Relationship Management), BI (Business Intelligence), KM (Knowledge Management), tem permitido que empresas integrem processos administrativos, tenham melhores controles sobre seus recursos e gerenciem sua base de conhecimento existente. Além de automatizar processos corporativos legados, a associação destas estratégias e softwares às capacidades da Internet tem permitido que empresas desenvolvam novas formas de relacionamento com funcionários, parceiros e clientes, objetivando projetar seus negócios acima dos níveis atingidos pela concorrência.

Estas novas formas de relacionamento, especialmente no que diz respeito à Internet, agregam novas configurações às empresas, cujas implicações ainda não estão plenamente compreendidas, mesmo porque a própria Internet ainda está em constante evolução, seja na sua capacidade de transmissão, na sua taxa de penetração, ou ainda, na sua forma de acesso. Estas novas configurações também atingem o Marketing de Relacionamento, e requerem que se faça uma reflexão acerca de possíveis implicações sobre as suas práticas, contribuindo para o aumento de sua importância na formulação das estratégias corporativas. Tal cenário instigou o desenvolvimento de um estudo que gerou esta dissertação de mestrado.

Com a disseminação dos resultados deste estudo na comunidade acadêmica e na sociedade em geral, pretende-se oferecer contribuições, quer seja abrindo novos horizontes de pesquisa ou 
suscitando críticas aos modelos atuais, quer seja incitando reflexões sobre os conceitos apresentados.

Nesta introdução serão apresentados os antecedentes deste estudo, seus objetivos, a sua justificativa, as premissas e definições operacionais adotadas para a realização do estudo e a situação-problema que o motivou. Além disso, serão apresentadas as interfaces com outras disciplinas e uma visão geral sobre como o estudo está organizado.

\subsection{Contexto}

Em pouco espaço de tempo, puderam-se observar as cidades sendo povoadas por milhares de outdoors com endereço “ponto-com”. Além disso, nas bancas de jornal começaram a ser lançados inúmeros títulos focados unicamente em Internet. Têm sido vistos também cadernos de jornais e revistas especializadas em informática transformando-se preponderantemente em publicações com dicas e informações sobre as novidades do mundo da Internet, criando rankings, fazendo comparações e classificações entre os milhões de sites existentes, sem mencionar a batalha entre os provedores de acesso pago e gratuito, os fornecedores de acesso de alta velocidade com ofertas de serviços cada vez mais poderosos e até a nova função da televisão: via de acesso à rede mundial.

Mundialmente falando, vírus de computador criados no hemisfério diametralmente oposto chegam aqui instantaneamente, aterrorizando até mesmo as instituições com sofisticadíssimos sistemas de segurança de informação. Ao mesmo tempo, é possível mandar entregar flores em outro continente ou até mesmo fazer contato com amigos e parentes que vivem em outros países, com recursos de som e imagem, em tempo real. Além disso, o mundo convive diariamente com um índice especial na bolsa norte-americana que inclui empresas de tecnologia (Nasdaq) enquanto, paralelamente, bilhões de dólares são transacionados a cada minuto pela rede, sem contar os inúmeros negócios complementares ou decorrentes das transações pela Internet. Contudo, Porter (2001:63) alerta para o fato de que é chegado o momento de se ter uma visão mais clara da Internet. É preciso que se deixe a retórica sobre as “indústrias da Internet”, as “estratégias de e-business” e uma “nova economia” e se veja a Internet como ela é: uma tecnologia habilitadora, um conjunto poderoso de ferramentas que podem ser utilizadas, sabiamente ou não, em quase todos os setores de atividade e que podem integrar o conjunto das estratégias adotadas pelas empresas.

Em termos de Marketing de Relacionamento, é possível encontrar muitos autores de relevância. No entanto, devido à alta velocidade com que as novas tecnologias de informação e de 
comunicação estão tomando conta da realidade mundial, é um desafio deveras grande produzir e consumir literatura de vanguarda - e até mesmo de referência - relacionada a esta explosão e seus efeitos, mais especificamente sobre a Internet, pois o período para a obsolescência deste tipo de material é muito curto. A bibliografia com consistência satisfatória sobre o assunto é escassa, sendo que muito do que já se escreveu a respeito encontra-se em forma de artigos especializados, de revistas de algumas universidades, de opiniões em reportagens publicadas em jornais, revistas, sites, de relatórios produzidos por empresas de consultoria, e de alguns poucos livros.

\subsection{Situação-problema}

Vários modelos de negócios surgem em tempos de crise como uma resposta às mudanças ambientais e aos desafios que a nova realidade impõe. Muitas vezes, estes modelos são apoiados por avanços em tecnologia e acessos crescentes à informação. Em meados do século XIX, as empresas começaram a adotar um modelo de produtividade, com a emergência da era industrial. Inovações tecnológicas em manufatura, paralelamente à criação de canais regionais e nacionais de distribuição, capacitaram as organizações a produzirem em massa produtos para clientes situados além de seus mercados locais. Como resultado, a lucratividade de uma companhia começou a depender da escala de suas operações, ou seja, de sua habilidade em atingir produção e distribuição a custos eficientes. Sob este modelo, o foco dos gerentes foi direcionado para custos e capacidade.

Já em fins da década de 1960 e no início da década seguinte, contudo, com a reconstrução pós-guerra de infra-estrutura comercial e a emergência da competição global, a capacidade evoluiu mais rapidamente que a demanda. Conseqüentemente, tornou-se necessário adotar um modelo competitivo de negócios, a partir do momento em que se evidenciou a relevância da competição pelos fluxos de caixa dos clientes. Com dados setoriais e de participação de mercado disponíveis pela primeira vez, as empresas descobriram uma forte correlação entre liderança na participação de mercado e lucratividade. Muitos gerentes começaram, então, a preocupar-se em atingir a posição de liderança em participação de mercado em suas indústrias.

Como o ambiente de negócios continuava a evoluir, em meados da década de 80 , nasceu o modelo da qualidade. As empresas começaram a explorar novas capacidades de coleta e uso de informações para competir a partir da qualidade de seus produtos e serviços. Com técnicas de melhorias contínuas no processo, identificaram e reduziram os custos de retrabalho, ineficiência e desperdício. As organizações começaram também a examinar os custos incorridos por fornecedores 
e clientes num esforço de reduzir genericamente os custos do sistema e aumentar a satisfação do cliente. Em um grande número de setores, organizações aplicando com sucesso o modelo de qualidade mostraram como uma performance financeira superior poderia ser atingida apesar das posições inferiores de participação de mercado. Vavra (1992) lembra ainda que, nos anos 80, a estrutura do mercado tornou-se mais complexa, o mercado consumidor fracionou-se e as ofertas de produtos proliferaram. Entretanto, ao mesmo tempo em que o mercado crescia e se tornava mais complexo, a tecnologia computacional experimentava melhorias significativas tanto em custo como em capacidade de armazenagem, o que proporcionou exatamente o que as empresas necessitavam para conhecer um pouco melhor seus clientes.

A década de 90 assistiu, maravilhada, a uma mudança de comportamento dos mercados e dos consumidores que antes não se imaginava. A chamada globalização rompeu fronteiras, derrubou mitos e permitiu uma fabulosa interação comercial e cultural entre nações. Nos anos 90, a informação deixou de ser um recurso escasso entre os concorrentes: capacidades de pesquisa extensiva faziam parte da meta da maioria dos concorrentes (Vavra, 1992:22). O Código de Defesa do Consumidor passou a ser invocado em diversas situações; os consumidores começaram a crer que, amparados pela lei, teriam resultados positivos ao reclamar e fazer valer seus direitos, em decorrência da infinidade de alternativas de escolha. As empresas passaram progressivamente a esforçar-se em competir pelo relacionamento com o cliente.

A virada do milênio nos países orientais, os primeiros a celebrarem o novo ano, foi vista pelos habitantes dos países ocidentais em tempo real por meio da televisão e da Internet. O conceito de tecnologia que permitiria a comunicação independente dos meios convencionais entre pontos estratégicos militares norte-americanos, após trinta anos, já oferecia aplicações as mais diversas possíveis, de fornecedora de informações a entretenimento, de meio de comunicação a mercado de trocas, de lazer a negócios.

Em cada período, os modelos de negócios prevalecentes meticulosamente descreveram os caminhos relevantes para a lucratividade. Mas as capacidades necessárias para focar diretamente a máxima lucratividade das relações com o cliente não eram óbvias e facilmente encontradas. Hoje, usando as ferramentas de informação e tecnologia disponíveis, as empresas podem associar seus investimentos em relacionamento com clientes diretamente aos retornos que estes clientes geram. 
Na última década, o marketing de relacionamento começou a ser desenvolvido com maior ênfase, trazendo políticas e procedimentos que visavam ao envolvimento de todas as áreas da empresa numa filosofia até então pouco praticada. Aos poucos, as empresas começaram a surpreender os clientes com atendimentos personalizados e cordiais, pesquisas de opinião, e até mesmo com esforços que num primeiro momento poderiam significar alguma perda para a empresa, mas que potencialmente lhe trariam resultados positivos futuramente. Assim, ainda que, de certo modo, mecanicamente, os caixas dos supermercados passaram a iniciar o atendimento com um “Bom dia!”, as pizzarias passaram a enviar cumprimentos pelo aniversário de seus clientes, os altos executivos das empresas, sempre muito ocupados, passaram a reservar um tempo em suas agendas apenas para ouvir pessoalmente seus clientes, e algumas empresas passaram a desenvolver projetos em conjunto com seus clientes de modo a melhor atendê-los.

McKenna (1992:1) afirma que “a tecnologia está transformando a escolha, e a escolha está transformando o mercado”. Segundo esse autor, o marketing evolui junto com a tecnologia. A tecnologia envolve capacidade de adaptação, programação e “customização”; em seguida, o marketing faz estas características chegarem até os clientes. A tecnologia criou a promessa de “qualquer coisa, em qualquer lugar, a qualquer momento”. Com a competição se estendendo para mercados globais e com tantos recursos de informação e de comunicação que a tecnologia e os novos métodos proporcionam, o cliente tem adquirido cada vez mais poder. E, ao contrário do que se possa imaginar, a empresa não perde espaço com isto.

A tecnologia de informação tem evoluído num ritmo alucinante, com grande destaque tanto para a capacidade de processamento e armazenamento de informações, como para a capacidade de transmissão das mesmas, o que têm favorecido a ocorrência de um número maior de interações entre pessoas e instituições de diversas partes do mundo. Como fator catalisador dos processos que envolvem o tratamento de informações, esta tecnologia pode influenciar todos os processos os quais apóia, de maneira estratégica, substituindo, em muitos casos, o trabalho humano.

Contudo, tendo em vista a combinação destas duas realidades - transformações observadas tanto no âmbito do marketing como no ambiente tecnológico -, aflorou a seguinte inquietação: quais os efeitos que tais tecnologias poderiam produzir sobre os processos que foram idealizados com base no relacionamento entre as pessoas? 
Face ao exposto, no campo do Marketing, o foco deste estudo é o Marketing de Relacionamento, sendo que o tema geral pode ser definido como as influências da Internet sobre o Marketing de Relacionamento.

Tem-se, então, a seguinte situação-problema: quais os impactos da Internet sobre as práticas de Marketing de Relacionamento adotadas pelas empresas e como as mesmas estão reagindo a estes impactos?

\subsection{Definições operacionais}

As definições operacionais auxiliam na clarificação aos leitores sobre como os conceitos colocados no trabalho serão operacionalmente tratados. Constituem definições importantes para que haja um entendimento claro sobre como serão materializados os termos utilizados no estudo ou sob quais ângulos serão considerados os conceitos em estudo.

Neste trabalho, os impactos e as implicações pesquisados foram considerados segundo a ótica da empresa com relação ao marketing de relacionamento com seus clientes. Foram analisados fatores trazidos pela Internet que pudessem ter configurado uma nova situação para a empresa ou desencadeado mudanças em seu modo de operar - impactos, e elementos que pudessem ter sido alvo de modificações e/ou demandado ações da empresa para adequação à nova situação, ressaltando os aspectos positivos e negativos resultantes do processo - implicações.

Procurou-se, neste estudo, detectar possíveis impactos traduzidos em termos das mudanças por força da utilização da Internet como intermediadora de negócios. Para a verificação dos impactos, foram usados alguns parâmetros e/ou indicadores, como variações no faturamento da empresa, variações no número de clientes, variações nos segmentos atingidos, entre outros, e, adicionalmente, alguns elementos relacionados ao tema de estudo não tão objetivamente mensuráveis, como por exemplo, oportunidades ou ameaças à posição estratégica e competitiva da empresa, formas e freqüência de interação e de relacionamento, inadequação ou insuficiência de estrutura organizacional e de perfil de pessoal, funcionalidade das operações, entre outros.

As implicações decorrentes dos impactos verificados pelas empresas foram observadas pelo exame de elementos como modificações estruturais, mudanças operacionais no atendimento ao cliente, e outros, incluindo, por exemplo, variações na dimensão do quadro de vendedores/ representantes de vendas, variações no número de postos de atendimento ao cliente etc. Da mesma 
maneira, pesquisou-se a ocorrência de outras mudanças não tão diretamente mensuráveis, tais como a adoção de novas práticas de marketing de relacionamento, mudanças no site da empresa ou alterações em procedimentos já existentes, abrangendo questões que envolvem desde a comunicação da empresa com seus clientes, o processamento dos pedidos e pagamentos, políticas de investimento em tecnologia de informação, e até aspectos estratégicos e culturais, como alterações no perfil dos profissionais e mudanças na estrutura da empresa, entre outros.

Estas conjecturas subsidiaram o desenvolvimento deste trabalho e a análise dos resultados extraídos dos depoimentos das empresas pesquisadas.

\subsection{Premissas}

Para nortear o estudo, considerou-se a seguinte premissa:

- As empresas que optaram pela realização de negócios via Internet, com diferentes níveis de adoção e adaptação, viram-se, em maior ou menor intensidade, levadas a tomarem ações para se ajustarem à nova condição; estas ações podem se refletir em resultados positivos ou negativos para o negócio da empresa, envolvendo questões que incluem os vários aspectos funcionais do relacionamento com o cliente, podendo até mesmo acarretar novos direcionamentos estratégicos para a empresa.

\subsection{Objetivos do estudo}

O objetivo principal deste trabalho foi estudar a evolução do Marketing de Relacionamento no que tange aos seus aspectos críticos e os impactos por ele sofridos em função do surgimento da Internet, e, por conseqüência, do e-commerce, e identificar as ações praticadas para se manter um Marketing de Relacionamento ativo e bem sucedido, nesse contexto, em empresas cuja sede brasileira se restringe à delimitação geográfica da Grande São Paulo.

Para a consecução do objetivo principal, foi necessário o alcance dos seguintes objetivos específicos:

- Realizar um retrospecto teórico das práticas de Marketing de Relacionamento, incluindo as estratégias, a comunicação e os procedimentos que têm envolvido toda a organização para que se conquistem e se mantenham clientes importantes para ela;

- Fazer uma apuração das principais mudanças no ambiente de negócios provocadas pela Internet, especialmente em relação ao marketing; 
- Entender melhor o que é e como se estrutura o e-commerce, na atualidade;

- Entender como as empresas que estão transacionando por meio da Internet estão lidando com o Marketing de Relacionamento. Tal intuito foi alcançado mediante a compreensão de como as empresas estão definindo suas estratégias de Marketing, de como estão desenvolvendo a comunicação necessária para criar e preservar o relacionamento, e de outros procedimentos relacionados, quando o contato rotineiro com o cliente passa a ser feito prioritariamente por intermédio de um computador;

- Investigar quais as vantagens e desvantagens detectadas pelas empresas que já praticam o marketing de relacionamento apoiado pelas ferramentas de Internet.

\subsection{Justificativa do estudo}

McKenna (1992:38) observa que o casamento tecnologia-marketing alterou substancialmente o relacionamento cliente-empresa, bem como o trabalho dos representantes de vendas, os quais passaram a ser muito mais consultores de marketing, fornecendo um valioso serviço educacional a seus clientes, com dados de análises de mercado, artigos e relatórios técnicos. Embora consista em um modo óbvio e primitivo de combinar tecnologia e marketing, o profissional de marketing tem, cada vez mais à sua disposição, capacidades convergentes das tecnologias existentes, como computadores pessoais e de mão, bancos de dados, maior capacidade de armazenamento, melhor resolução de imagens, recursos multimídia, microprocessadores que podem ser implementados em qualquer local, com o propósito de criar inteligência, e redes capazes de gerar e distribuir grandes quantidades de informação, instantaneamente. A Internet faz parte deste contexto, no qual os processos em tempo real são imprescindíveis e estão cada vez mais presentes na realidade do cotidiano. Graças aos avanços na tecnologia da informação, os profissionais de marketing estão ligados mais intimamente do que nunca a seus fornecedores e clientes no mundo todo, criando inúmeras oportunidades para incremento de suas vendas (Churchill e Peter, 2000:47).

Assim, a contribuição maior deste estudo é oferecer um aprofundamento da discussão sobre a aplicação da Internet a empresas que praticam marketing de relacionamento, desvendando alguns impactos em termos de mudanças nas estratégias corporativa, no nível de negócios e operacional, aliadas à adequação do perfil do pessoal, mudanças estruturais, e outros fatores, que as novas tecnologias, mais especificamente a Internet, podem trazer ao modo de as empresas fazerem negócios, com foco no Marketing de Relacionamento. O assunto se mostra relevante na medida em que traz à tona alguns aspectos da tecnologia, principalmente a Internet, que rompem de certa forma 
com todo o esforço observado ao longo dos anos de se promover uma maior interação pessoal entre clientes e fornecedores, criando, talvez, algumas outras formas de interação. Além disso, há expectativas de crescimento no volume de transações comerciais realizadas pela Internet. Em 2002, R \$125,8 bilhões (cerca de US\$35,9 bilhões) foram movimentados pelos 100 maiores nomes do ecommerce no Brasil, segundo dados da pesquisa INFO100, realizada pela Info Exame, 129\% superior aos R \$4,9 bilhões (cerca de US\$23,8 bilhões) registrados em 2001, que, por sua vez, correspondiam a mais que o dobro do computado no ano anterior (Reggiani, 2003:70). Segundo pesquisas do instituto Yankee Group, espera-se que em 2005 sejam negociados pela Internet US\$ 63,7 bilhões entre empresas da América Latina. “As cifras podem ser até fantasiosas, mas a revolução em curso é crível” (Sermoud, 2001:4). Percebe-se também nas empresas, pela crescente busca de consultores especializados em tecnologias que viabilizam a Internet, que muitas delas estudam a possibilidade de sua adoção como meio de realizar negócios, o que pode tornar os impactos da Internet e as implicações das empresas ainda mais interessantes do ponto de vista do marketing e da administração como um todo.

Este estudo se justifica pela escassez de literatura e de pesquisas a respeito dos impactos da Internet sobre o Marketing de Relacionamento. A pesquisa e a prática no marketing durante os últimos 20 anos apontam particularmente para a relevância dos relacionamentos, redes e interação. A literatura sobre o marketing de relacionamento tem aumentado exponencialmente em muitas línguas (Gummesson, 1999:7), gerando um grande filão para as empresas de consultoria, tão envolvidas em projetos de reengenharia e terceirização. Entretanto, esse mesmo autor ressalta que, com certas exceções, a literatura é, em geral, restrita, caracterizada por tratar assuntos isolados em marketing de relacionamento, como lealdade do consumidor, bases de dados para melhoria do marketing direto, call centers ou clubes de consumidores. Tratam-se de assuntos interessantes, porém ainda não esgotados em termos de pesquisas.

Quanto à viabilidade da realização deste trabalho, o prazo determinado pela coordenação do curso permitiu que o desenvolvimento do mesmo ocorresse sem maiores atropelos, exigindo, porém, envolvimento intenso, disciplina e continuidade das atividades. O prazo estabelecido no cronograma para o planejamento do campo e a coleta de dados precisou ser dilatado, em parte devido à opção pela busca de maior maturidade no desenvolvimento de idéias a respeito do tema - e a sua tradução em um roteiro de pesquisa que refletisse fielmente os anseios deste estudo - e, também, pela dificuldade em receber os retornos dos contatos com as empresas selecionadas como 
parte da amostra, que dariam o aporte decisivo às informações necessárias para a elaboração deste estudo. Os aspectos dificultadores que surgiram durante as etapas de planejamento e coleta de dados foram superados, sendo possível o acesso às informações necessárias para o aumento do nível de conhecimento sobre o tema em estudo.

\subsection{Interface com outras disciplinas do estudo de Administração}

A Internet afetou de tal maneira a vida das pessoas que ela pode ser relacionada a um conjunto multidisciplinar de contextos. Primeiramente, pode-se fazer um mapeamento de seu alcance em alguns campos externos à Administração. Várias áreas do conhecimento são afetadas pelas mudanças aportadas pela Internet: a Economia, em relação à estruturação do mercado, às oscilações dos índices da bolsa de valores e ao novo perfil do mercado de trabalho; as Ciências Exatas no que se refere à infra-estrutura tecnológica e de telecomunicações; o Jornalismo, no que diz respeito à agilidade e versatilidade na divulgação de informações, ao grande número de títulos de publicações especializadas, e ao novo tipo de pauta dos cadernos de informática; a Comunicação, pelas oportunidades e desafios da nova mídia, entre outras áreas.

Especificamente no estudo da Administração de Empresas, também estão relacionadas a este trabalho, além do Marketing, as disciplinas Métodos Quantitativos e Informática, nas questões referentes à Internet, e também Administração Geral, em relação aos aspectos estratégicos envolvidos nesta questão.

\subsection{Organização do estudo}

A organização deste trabalho compreende dez capítulos. Tendo em vista as considerações apresentadas nesta introdução, este estudo envolveu uma revisão bibliográfica para melhor compreensão e apresentação de conceitos, características e detalhes relacionados ao tema em questão, abrangendo a filosofia do Marketing de Relacionamento e sua evolução, posteriormente levantando aspectos relacionados à aplicação comercial da Internet, buscando-se, a seguir, registros bibliográficos sobre a relação entre os dois assuntos (capítulo 2). No capítulo 3, é apresentado um detalhamento dos principais aspectos metodológicos observados na pesquisa de campo, bem como o referencial teórico que orientou a análise dos dados coletados. Com base no arcabouço teórico levantado no capítulo 2, é apresentada, no capítulo 4, uma análise dos resultados obtidos a partir da pesquisa de campo, com averiguação das práticas, efeitos, ganhos e dificuldades encontrados na experiência de algumas empresas que vivem a realidade do comércio eletrônico e, ao mesmo tempo, 
procuram manter suas práticas de marketing de relacionamento. Com base na análise dos resultados obtidos na pesquisa de campo, são apresentadas as conclusões do estudo, suas limitações e sugestões para estudos futuros (capítulos 5, 6 e 7), seguidos da apresentação das referências bibliográficas, obras consultadas e sites visitados na Internet (capítulo 8), e dos apêndices e anexos (capítulos 9 e 10, respectivamente). Este trabalho encontra-se estruturado conforme a figura 1:

Figura 1 - Organização do estudo

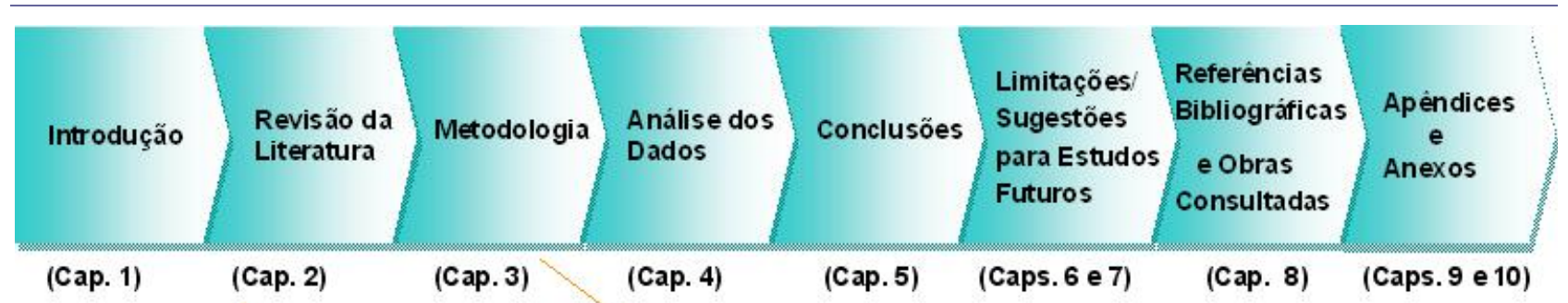

(Cap. 1)

(Cap. 2)

(Cap. 3)

(Cap. 4)

(Cap. 5)

(Caps. 6 e 7 )

(Cap. 8)

(Caps. 9 e 10)

- Objetivo da pesquisa

- Tipo de pesquisa e justificativa da metodologia

- Hipóteses/questôes

- Marketing de relacionamento

- Internet

- Populaçãó

- Amostragem

- Impactos e implicaçôes

- Dados necessários e suas fontes de obtenção

- Instrumento de coleta de dados e variáveis

- Forma de abordagem

- Coleta de Dados

- Validade

- Análise dos dados

Fonte: a autora.

\section{Revisão da literatura}

A revisão da literatura concentrou-se em três assuntos principais, pilares deste estudo: marketing de relacionamento, Internet e a interação entre estes assuntos, a qual resulta em impactos e reações decorrentes. Para melhor compreensão do marketing de relacionamento, estudou-se brevemente o marketing nas organizações, sua evolução histórica e epistemológica, e o protagonismo do marketing de relacionamento nas interações de negócios da empresa, notadamente com seu consumidor final. A revisão bibliográfica sobre a Internet voltou-se à percepção e constatação da evolução da sua importância como ferramenta de negócios na figura de elemento facilitador e habilitador, como é o caso do comércio eletrônico. Por fim, a revisão bibliográfica avançou sobre o fenômeno de estudo desta dissertação, ou seja, o marketing de relacionamento sob os impactos da Internet. 
Por abordar assuntos dinâmicos, já que tanto o marketing de relacionamento como a Internet estão em contínua mudança, a própria revisão bibliográfica constituiu um desafio real e gratificante cujo resultado pode ser útil para estudos futuros sobre variações do mesmo tema. A seguir, são apresentados os principais conceitos que fundamentaram o presente estudo e que constituem o arcabouço teórico para o desenvolvimento da pesquisa de campo e sua análise. Um esquema ilustrativo do conteúdo dessa revisão é apresentado na figura 2.

\section{Figura 2 - Revisão bibliográfica}

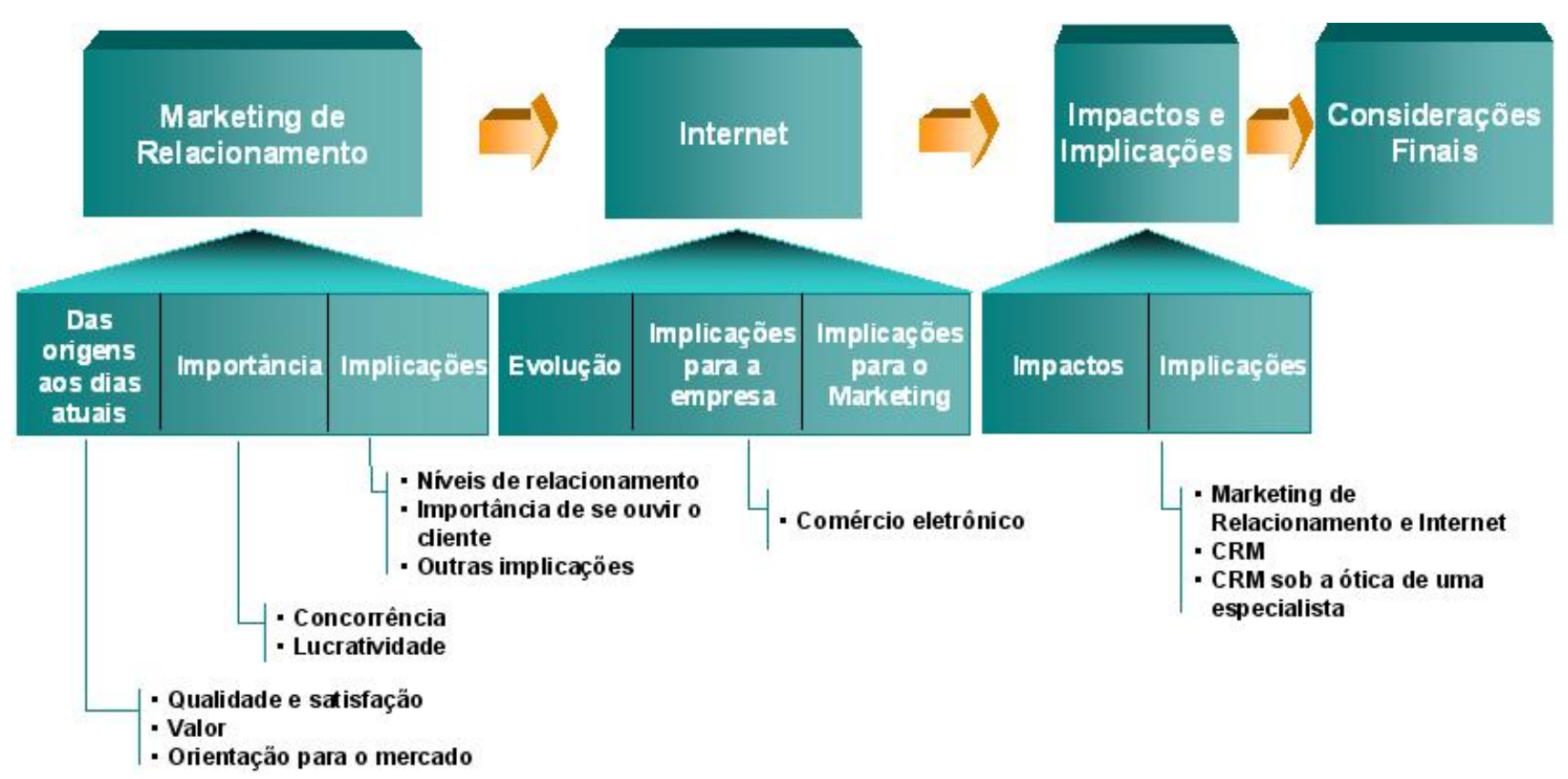

Fonte: a autora.

\subsection{Marketing de Relacionamento}

A figura 3, a seguir, salienta a parte da figura 2 que corresponde ao conteúdo desta seção. 


\section{Figura 3 - Estrutura da seção: Marketing de relacionamento}

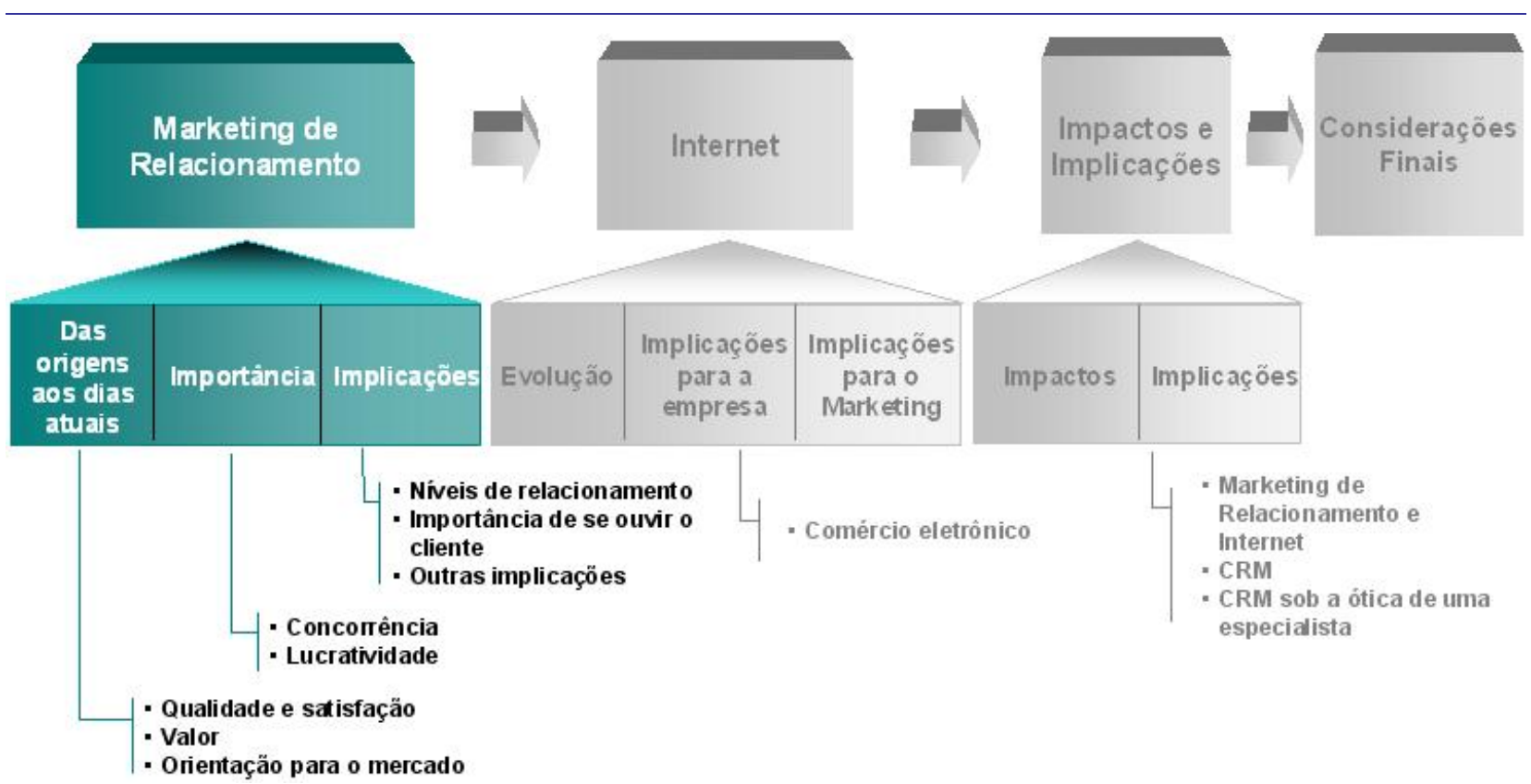

Fonte: a autora.

O termo "marketing de relacionamento” tem sido utilizado com vários significados diferentes (Nevin, 1995), uma situação semelhante ao que ocorre com o termo “marketing”, freqüentemente empregado em situações diversas para representar fenômenos específicos bastante díspares (Serralvo, 1993). Os autores Sheth e Parvatiyar (1999) observam que o marketing de relacionamento tem sido abordado sob uma perspectiva mais estreita, no sentido de se utilizar de banco de dados para enfatizar os aspectos promocionais do marketing, ou de táticas de pós-vendas para manter o contato com o cliente após a efetivação da venda, quando, em sua essência, o marketing de relacionamento objetiva o desenvolvimento contínuo de um relacionamento construtivo mútuo entre a empresa e seus parceiros e clientes, não se limitando a um esforço que culmina com a efetuação de uma transação independente. Nas seções seguintes, abordam-se a evolução histórica do marketing de relacionamento, a sua importância para as empresas e as suas implicações para as mesmas.

\subsubsection{O marketing de relacionamento: das suas origens aos dias atuais}

De certa forma, a noção do marketing de relacionamento remete ao passado, talvez não muito distante, ou a situações que ainda podem ser observadas em pequenas cidades do interior, onde o “dono” do estabelecimento conhece cada um dos seus clientes pelo seu nome e, por já conhecê-los 
há muito tempo, também tem algum conhecimento sobre hábitos e necessidades de cada um. Esta noção sinaliza que o conceito de marketing de relacionamento não é um fenômeno novo.

Sheth e Parvatiyar (1995), ao estudar a evolução histórica do marketing de relacionamento, constataram que esta idéia procede. Esses autores assumem que a noção de marketing de relacionamento já existia bem antes de 1900, época que Bartels (1962) considera como o início da abordagem do marketing como disciplina organizacional. Sheth e Parvatiyar (1995) relatam também que, durante a era pré-industrial, agricultores e artesãos vendiam sua produção diretamente para seus clientes finais, o que favorecia o desenvolvimento de um forte relacionamento entre as partes, possibilitando, por exemplo, que artesãos desenvolvessem produtos personalizados, segundo necessidades pessoais de cada cliente.

Mais de um século depois, o marketing de relacionamento deixa de ser uma noção para ganhar status de disciplina, tema de estudos de muitos pesquisadores (Berry, 1983, in Sheth e Parvatiyar, 1999:10; McCarthy e Perreault Jr., 1990; McKenna, 1992; Vavra, 1992, Shapiro e Sviokla, 1994, Ravald e Grönroos, 1996; Nickles e Wood, 1999; Gummesson, 2001, e outros), e orientação estratégica de diversas empresas (Boone e Kurtz, 2001). Observando-se a evolução histórica das condições de negócios, torna-se mais fácil entender as razões da emergência da importância do marketing de relacionamento nos dias atuais.

Ao caracterizarem a pesquisa histórica em marketing, Jones e Shaw (2002:39) sugerem que "os historiadores de marketing têm seguido a tradição dos economistas que separam a história da prática da história do pensamento, focando seus estudos em uma das abordagens”. Desta forma, os próprios Jones e Shaw (2002), Sheth e Gardner (1984), Sheth, Gardner e Garrett (1988) e Bartels (1962) concentram estudos na história do pensamento, enquanto outros autores, mais didáticos e introdutórios, como Boone e Kurtz (2001) e McCarthy e Perreault Jr. (1990) apresentam a história da prática do marketing. Na classificação da história do pensamento de marketing, esses últimos autores citados pertenceriam à "escola gerencial”, observada a classificação de Sheth, Gardner e Garrett (1988:25), já que é esta a escola que enfatiza as práticas do marketing por meio de conceitos como o conceito de marketing, marketing mix, ciclo de vida do produto e segmentação de mercado.

Por questões didáticas, optou-se pela história da prática pois entendeu-se que esta oferece melhores subsídios para o entendimento dos dois momentos históricos onde a importância do 
marketing de relacionamento está mais caracterizada, segundo análise de Sheth e Parvatiyar (1995), na era pré-industrial e em seu resgate nos anos 1990.

Entre outros autores, McCarthy e Perreault Jr. (1990), Bartels (1962) e Boone e Kurtz (2001) apresentam uma evolução histórica do marketing, dividindo-a em eras (Boone e Kurtz, 2001:11; McCarthy e Perreault Jr., 1990:14) ou períodos (Bartels, 1962:190), e levando-se em consideração o direcionamento prático observado nas empresas em cada momento. Enquanto Bartels (1962) se concentra no pensamento de marketing por si, os demais se preocupam com as suas práticas. As eras definidas por Boone e Kurtz (2001) podem ser observadas no quadro 1, a seguir.

\section{Quadro 1 - Quatro eras na história do Marketing}

\begin{tabular}{c|c|l}
\hline Era & Período Aproximado* & Atitude Prevalecente \\
\hline Produção & Até a década de 1920 & “Um bom produto se vende por si só” \\
\hline Vendas & $\begin{array}{c}\text { Entre as décadas de } \\
1920 \text { e } 1950\end{array}$ & “Propaganda e venda criativa conquistarão os consumidores” \\
\hline Marketing & Desde a década de 1950 & “O consumidor é o rei! Encontre uma necessidade e satisfaça-a” \\
\hline Relacionamento & Início na década de 1990** & $\begin{array}{l}\text { “Os relacionamentos de longo-prazo com os clientes e outros } \\
\text { parceiros levam ao sucesso” }\end{array}$ \\
\hline
\end{tabular}

* nos EUA e em outras economias altamente industrializadas.

** Berry e Jackson já haviam conceituado o marketing de relacionamento na década de 1980, como se verá mais adiante, no quadro 3.

Fonte: Boone e Kurtz (2001:11).

McCarthy e Perreault Jr. (1990:33) lembram que a classificação temporal é genérica, sendo possível identificar exemplos de empresas que ainda concentram seus esforços de marketing segundo características de eras passadas. Kotler e Armstrong (1993:6) apresentam classificação próxima à de Boone e Kurtz (2001), mas não enfatizam o caráter temporal de suas filosofias de administração de marketing, argumentando que a organização pode conduzir suas atividades de marketing seguindo os conceitos de produção, produto, venda, marketing e marketing social.

Guardadas as limitações das classificações genéricas, a abordagem de Boone e Kurtz (2001:11) mostrou-se bastante interessante para o desenvolvimento deste estudo por enfatizar o marketing de relacionamento como uma nova era e uma alternativa de longo prazo.

Sheth e Parvatiyar (1995:473) esclarecem que o marketing de relacionamento predominava no período pré-industrial: "se olharmos para a prática do marketing antes de 1900, perceberemos que a orientação para o relacionamento no marketing prevalecia”. McCarthy e Perreault Jr. (1990:33) 
classificam este período como "era do comércio simples”, o qual marca o renascimento comercial na Europa, quando o sistema de trocas deixou de ser eficaz e surgiu a figura do comerciante. Jones e Shaw (2002:41) ressaltam que este tipo de marketing, surgido no final da Idade Média, já havia existido na Grécia Antiga, mencionando inclusive pensamentos de Platão e Aristóteles sobre as transações comerciais. Em ambos os momentos, Jones e Shaw (2002:41) observam que o “marketing representava uma estranha forma de comportamento. Enfatizando o ganho individual e a competição, a atividade de marketing parecia deprimente para uma sociedade baseada no altruísmo e na cooperação”. Como os comerciantes eram vistos, muitas vezes, como oportunistas (Jones e Shaw, 2002:43), o sucesso das transações passou a depender do desenvolvimento de relações de confiança, que privilegiava o horizonte de longo prazo (Sheth e Parvatiyar, 1995).

Esta idéia de marketing de relacionamento permaneceu até os primeiros anos da Revolução Industrial (Sheth e Parvatiyar, 1995). Os autores McCarthy e Perreault Jr. (1990:33) propõem que o período entre a Revolução Industrial e a década de 1920 marque a "era da produção", mesma denominação dada por Boone e Kurtz (2001:11) para o primeiro período indicado no quadro 1, discutido a seguir.

1. A Era da Produção: esta era foi marcada pelas Revoluções Industriais e pelo desenvolvimento de uma série de produtos e processos inovadores como novos meios de transportes (ferrovias, automóveis), novos processos (vulcanização da borracha, domínio da corrente elétrica, linhas de produção) e novos produtos (eletrodomésticos, alimentos processados). As empresas que atuaram na "Era da Produção" acreditavam que apenas fabricar um produto de qualidade era argumento suficiente para garantir sua venda, ficando em segundo plano os anseios do consumidor. Boone e Kurtz (2001:12) citam uma frase de Ralph Waldo Emerson que dizia que "se um homem escreve um livro melhor, prega um sermão melhor, ou constrói uma ratoeira melhor que seu vizinho, mesmo que construa sua casa no meio de um bosque, o mundo fará um caminho de terra batida até sua porta”. McCarthy e Perreault Jr. (1990:33) salientam que, em 1896, “uma empresa poderia facilmente vender todas as máquinas de escrever que pudesse fabricar porque havia poucas disponíveis no mercado.” Estas posições, explicadas pela escassez de produção e intensa demanda pelos produtos, tornam fácil compreender quão priorizadas foram as atividades de produção nessa época. Embora a orientação para a produção seja muito criticada atualmente (Kotler e Armstrong, 1993:12), Churchill e Peter (2000:7) argumentam que há situações nas quais ela é apropriada, como nos mercados de alta tecnologia com mudanças rápidas, nos quais não haveria tempo suficiente para 
realizar pesquisas de marketing objetivando descobrir o que os clientes desejam. A estratégia, neste caso, seria desenvolver produtos superiores aos da concorrência, informando os seus benefícios aos clientes. Esses autores evidenciam também que a orientação para a produção pode ser adequada quando a demanda por produtos e serviços é bem maior que a oferta.

Entretanto, como se constatou posteriormente, não é suficiente simplesmente entregar um produto melhor para garantir o sucesso; o produto deve também satisfazer a uma necessidade percebida do mercado (Boone e Kurtz, 2001:12). Voltando à questão das ratoeiras, Kotler e Armstrong (1993:6) afirmam que "os compradores podem estar procurando uma solução para o problema dos ratos, mas não necessariamente uma ratoeira melhor”.

Por fim, a “era da produção” também é importante dentro do contexto histórico do pensamento de marketing. O levantamento histórico realizado por Bartels (1962) indica a década de 1910 como o período inicial da visão do marketing como disciplina, que ele próprio chama de "Período da Descoberta”, quando os primeiros cursos relacionados ao marketing são criados, sendo o termo marketing utilizado pela primeira vez em 1910 (Bartels, 1962:43-48).

2. A Era das Vendas: à medida que as técnicas de produção se tornaram mais sofisticadas, provocando um aumento significativo no volume de produção entre as décadas de 1920 e 1950, os empresários começaram a concentrar-se na eficácia da força de vendas, na busca de clientes para seus produtos, tentando adequar sua produção ao número potencial de clientes que poderiam desejála. Sheth e Parvatiyar (1995) e McCarthy e Perreault Jr.(1990) relatam que a orientação de marketing para transações acentuou-se durante a Grande Depressão de 1929, quando o excesso de produção aumentou a pressão na questão das vendas e em formas de persuadir o consumidor a comprar os produtos.

Nessa época, a chamada orientação para as vendas predominava e os departamentos de marketing começavam a surgir. Bartels (1962) destaca o surgimento dos “princípios de marketing” neste período. Esta orientação tinha por premissa que os consumidores resistiriam à compra de bens e serviços não essenciais, além da atitude de que somente a propaganda criativa e as vendas pessoais poderiam superar a resistência dos consumidores e convencê-los a comprar. Contudo, embora Churchill e Peter (2000:9) admitam que a orientação para vendas seja a mais adequada em situações em que, por exemplo, uma loja possua mercadorias antigas em excesso e resolva baixar os 
preços para aumentar a demanda, Boone e Kurtz (2001:12) lembram que as vendas constituem apenas um componente do marketing.

3. A Era do Marketing: a renda pessoal e a demanda dos consumidores por bens e serviços caíram rapidamente durante o período da Grande Depressão, no início da década de 1930, confiando ao marketing um papel ainda mais importante. Talvez, dele dependesse até mesmo a sobrevivência da empresa, devido à crescente necessidade de atenção aos mercados de seus bens e serviços. Esta tendência foi interrompida com a deflagração da Segunda Guerra Mundial, a qual trouxe o racionamento e a escassez de bens de consumo. Tal interrupção foi apenas uma pausa para uma mudança de foco cada vez mais comum nos negócios: de produção e vendas, para a satisfação das necessidades dos consumidores (Boone e Kurtz, 2001:12). Autores como Churchill e Peter (2000:9) acrescentam ainda que, ao compreender as necessidades e desejos dos clientes e produzir produtos e serviços para satisfazê-los, as empresas poderiam criar lealdade e competir de forma eficiente com outras empresas.

O conceito de marketing é entendido por Boone e Kurtz (2001:12) como uma mudança substancial na abordagem da administração, observadas as mudanças das interações de mercado, como a evolução de um mercado vendedor, caracterizado pela escassez de produtos e serviços, para um mercado comprador, caracterizado pela abundância de bens e serviços, ocorrida por volta de 1942. Esta nova condição de mercado faz com que as forças se invertam, passando o comprador a ter mais importância nas relações comerciais e definindo a necessidade de uma orientação para o consumidor na administração dos negócios. A orientação para o consumidor consistia numa filosofia de negócios que incorporava o conceito de marketing, o qual enfatizava, em primeiro lugar, a determinação das necessidades não atendidas dos consumidores, e então o desenho de uma abordagem para satisfazê-las. Webster Jr. (1989:16) acrescenta que o ponto de vista tático e de curto prazo, característico da era das vendas, foi substituído por uma orientação estratégica e de longo prazo. As empresas passaram a ter que conquistar espaço para seus produtos no mercado, e não apenas produzi-los e vendê-los; daí surgiu o conceito de marketing (Boone e Kurtz, 2001:12). O reconhecimento deste conceito e de seu papel dominante nos negócios data de 1952, quando o Relatório Anual da General Electric definiu uma nova filosofia de administração:

(O conceito) introduz (o profissional de marketing) no começo do ciclo de produção ao invés de no seu final, e integra o marketing em cada fase do negócio. Assim, o marketing, por meio de seus estudos e pesquisas, estabelecerá para o engenheiro, o designer e o pessoal de produção, o que o cliente deseja em um dado produto, qual preço estaria disposto a pagar, e onde e quando o produto seria desejado. O marketing terá autoridade no planejamento do produto, 
na programação de produção, e no controle do inventário, assim como em vendas, distribuição, e serviços ao cliente (General Electric Company, Annual Report, 1952:21, in Boone e Kurtz, 2001:13).

Um conceito mais atual do marketing sugerido por McCarthy e Perreault Jr. (1990:34) prevê a era da empresa de marketing (Company Marketing Era), quando todos os esforços da empresa são direcionados para o consumidor, com o objetivo de atingir sucesso a longo prazo. Churchill e Peter (2000:10) destacam algumas limitações desta orientação para o marketing. A primeira delas seria a sua inadequação a situações nas quais outro tipo de orientação é claramente mais apropriado. Segunda, ao centrar-se apenas nos clientes, poderia incentivar as empresas a não dispensarem atenção suficiente a outros grupos importantes, como empregados e fornecedores. Além disso, esta orientação ignora a capacidade de a concorrência satisfazer as necessidades dos clientes de forma mais eficaz e eficiente e, por fim, fornece às empresas poucas orientações sobre como satisfazer os clientes, como competir com outras empresas, e como executar atividades de marketing coerentes com tais orientações.

4. A Era do Relacionamento: apesar de o marketing de relacionamento ter sido formalmente introduzido na literatura de marketing apenas em 1983 por Leonard Berry (Sheth e Parvatiyar, 1999:11), muitas das suas idéias já tinham sido desenvolvidas anteriormente. Sheth e Parvatiyar (1999:12) citam como exemplo os relacionamentos de longo prazo no mercado empresarial, questões relativas a repetição de compras ou segmentação de mercados, sem mencionar as relações de confiança valorizadas nas eras pré-industriais (Sheth e Parvatiyar, 1995). Tendo ganhado impulso na década de 1990, o esforço de relacionamento, para alguns autores, como Boone e Kurtz (2001), representou uma expressiva mudança do conceito tradicional de marketing como uma simples troca (transação) entre compradores e vendedores, avançando um passo além na era de orientação ao cliente ao focar o estabelecimento e a manutenção de relacionamentos tanto com clientes como com fornecedores.

O marketing baseado em transações envolve trocas entre comprador e vendedor, caracterizadas por comunicações limitadas e pouca ou nenhuma relação contínua entre as partes. A meta primária é induzir um comprador a realizar uma compra com base em razões como preço baixo, conveniência, embalagem ou incentivos similares (Boone e Kurtz, 2001:153). Os autores Boone e Kurtz (1999:155), com base em Christopher, Payne e Ballantyne (1993:4), apresentam uma comparação entre as estratégias do marketing baseado em transações e do marketing de relacionamento, conforme o quadro 2: 
Quadro 2 - Comparação entre estratégias do marketing de transações e do marketing de relacionamento

\begin{tabular}{l|l|l}
\hline Característica & Marketing de Transações & Marketing de Relacionamento \\
\hline Orientação de prazo & Curto prazo & Longo prazo \\
\hline Meta organizacional & Realizar a venda & Ênfase na retenção de clientes \\
\hline Prioridade de serviço ao cliente & Relativamente baixa & Componente-chave \\
\hline Contato com o cliente & Baixo a moderado & Freqüente \\
\hline Grau de comprometimento com o cliente & Baixo & Alto \\
\hline Base para interações fornecedor-cliente & Manipulação de conflitos & Cooperação; confiança \\
\hline Fonte de qualidade & Primariamente da produção & Comprometimento de toda a empresa \\
\hline
\end{tabular}

Fonte: adaptado de Christopher, Payne e Ballantyne (1993:4, in Boone e Kurtz, 2001:155).

Notem-se as diferenças de foco entre o marketing de transações e o marketing de relacionamento apresentadas pelos autores, em que se ressalta a grande atenção dada ao cliente no marketing de relacionamento, visando a um horizonte de longo prazo. Gummesson (1999:10) evidencia que, no marketing de transações, o fato de um consumidor ter comprado um produto não prevê a probabilidade de uma nova compra, nem mesmo se uma série de compras foi realizada. Um cliente pode utilizar repetidamente o mesmo fornecedor devido aos altos custos de mudança, e não se sentir comprometido com ele e nem desejar aprofundar o relacionamento. As transações têm carência de história e memória e não são sentimentais; no marketing de relacionamento, a lealdade do cliente é enfatizada.

Jackson (1985, in Kotler, 2000:642) argumenta que o marketing de relacionamento não é eficaz em todas as situações, mas extremamente eficaz nas situações corretas. Segundo essa autora, o marketing de transações é mais apropriado a clientes com horizonte de curto prazo e baixos custos de mudança, como os compradores de commodities. Os investimentos em marketing de relacionamento, ao contrário, são pagos com clientes com horizonte de longo prazo e altos custos de mudanças, como os compradores de sistemas de automação de escritórios: tanto o cliente como o fornecedor investem muito tempo e dinheiro no relacionamento. Por outro lado, Anderson e Narus (1991, in Kotler, 2000:642) acreditam que as diferenças entre o marketing de transações e o marketing de relacionamento estão mais relacionadas aos desejos dos clientes do que ao tipo de setor. Alguns clientes valorizam o conjunto de altos níveis de serviço, e estarão com o mesmo fornecedor por um longo tempo; outros, desejam reduzir seus custos e mudarão de fornecedor por custos menores. Neste caso, a empresa pode ainda reter o cliente ao reduzir o preço, uma vez que o cliente está disposto a aceitar um menor nível de serviço, ou abdicar de entrega gratuita ou 
treinamento. Este cliente, acreditam esses autores, deve ser tratado preferencialmente em base transacional. Na medida em que a empresa corta seus custos tanto quanto ou mais que sua redução nos preços, o cliente orientado para a transação ainda será lucrativo.

A personalização crescente do marketing se traduz em uma variedade de termos: Marketing com banco de dados (database marketing); Marketing individualizado; Micromarketing; Marketing personalizado; Marketing one-to-one; Marketing de retenção; Marketing de freqüência; Marketing de relacionamento; Marketing de segmentação; Marketing integrado; Marketing interativo; Marketing de diálogo; Marketing de currículo; Marketing de nichos. Apesar da terminologia variada, a ênfase é a mesma: o reconhecimento da importância de se tratar cada cliente individualmente e de se conduzirem negócios de forma totalmente personalizada, não importando o tamanho da empresa (Vavra, 1992:47). Pelo fato de, como mencionado anteriormente, o termo “marketing de relacionamento" ser utilizado com vários significados diferentes (Nevin, 1995), é importante, portanto, atentar para o significado do marketing de relacionamento e abordá-lo como uma disciplina e não apenas como a noção evidenciada por Sheth e Parvatiyar (1995) em períodos pré-industriais.

Gummesson (1999:243) fez uma seleção de definições de marketing de relacionamento propostas por diversos autores, as quais variam em escopo e ênfase, relacionadas no quadro 3:

Quadro 3 - Definições selecionadas que enfatizam diferentes aspectos do marketing de relacionamento

\begin{tabular}{c|l}
\hline Fonte & \multicolumn{1}{c}{ Definição } \\
\hline Berry (1983:25) & $\begin{array}{l}\text { "Marketing de relacionamento é atrair, manter e - em organizações multi- } \\
\text { serviços - desenvolver relacionamentos com os clientes.” }\end{array}$ \\
\hline $\begin{array}{c}\text { Jackson } \\
(1985: 165)\end{array}$ & $\begin{array}{l}\text { "Marketing de relacionamento é o marketing para ganhar, construir e manter } \\
\text { relacionamentos fortes e duradouros com clientes industriais.” }\end{array}$ \\
\hline $\begin{array}{c}\text { Gummesson } \\
(1994: 1-5)\end{array}$ & $\begin{array}{l}\text { "Marketing de relacionamento é o marketing visto como relacionamentos, redes e } \\
\text { interação.” }\end{array}$ \\
\hline $\begin{array}{c}\text { Grönroos } \\
(1996: 11)\end{array}$ & $\begin{array}{l}\text { "Marketing de relacionamento é identificar e estabelecer, manter e desenvolver } \\
\text { relacionamento com clientes e outros stakeholders, a um certo nível de lucro, de } \\
\text { modo que os objetivos de todas as partes envolvidas são alcançados; e isto é feito }\end{array}$ \\
\hline $\begin{array}{c}\text { Ballantyne } \\
(1994: 3)\end{array}$ & $\begin{array}{l}\text { "Um arcabouço disciplinar emergente para criar, desenvolver e sustentar trocas } \\
\text { de valor entre as partes envolvidas, por meio do qual os relacionamentos de troca } \\
\text { evoluem para fornecer ligações contínuas e estáveis na cadeia de fornecimento.” }\end{array}$ \\
\hline
\end{tabular}




\begin{tabular}{c|l}
\hline $\begin{array}{c}\text { Morgan e Hunt } \\
\text { (1994:22) }\end{array}$ & $\begin{array}{l}\text { "O marketing de relacionamento se refere a todas as atividades de marketing } \\
\text { direcionadas a estabelecer, desenvolver e manter trocas relacionais bem } \\
\text { sucedidas.” }\end{array}$ \\
\hline Sheth (1994) & $\begin{array}{l}\text { "O entendimento, explicação e gerenciamento dos relacionamentos de negócios } \\
\text { colaborativos continuados entre fornecedores e clientes” e "uma escola } \\
\text { emergente de pensamento de marketing.” }\end{array}$ \\
\hline Porter (1993:14) & $\begin{array}{l}\text { "O marketing de relacionamento é o processo pelo qual ambas as partes - o } \\
\text { comprador e o vendedor - estabelecem um relacionamento eficaz, eficiente, } \\
\text { prazeroso, entusiástico e ético: um relacionamento que seja pessoal, profissional } \\
\text { e lucrativamente recompensador para ambas as partes.” }\end{array}$ \\
\hline
\end{tabular}

Fonte: Gummesson (1999:243).

Em que pesem as distinções entre estas definições, elas são relevantes sob o ponto de vista de sua complementaridade. Embora as definições de marketing de relacionamento de Berry e de Jackson sejam bastante semelhantes, dedicando maior ênfase à manutenção de clientes que à sua atração, enquanto a definição de Berry mostra uma evolução do pensamento a partir do marketing de serviços, a de Jackson, por sua vez, se concentra no marketing industrial. Gummesson, por outro lado, concentra-se em três variáveis essenciais: relacionamentos, redes e interação, como veículos para pensamento e ação. Em sua definição, uma rede é um conjunto de relacionamentos que podem crescer em modelos altamente complexos; quando, nos relacionamentos, as partes entram em contato ativo umas com as outras, ocorre uma interação. Morgan e Hunt, assim como Ballantyne, oferecem definições amplas. Grönroos também fornece uma definição mais ampla, incluindo ainda os stakeholders, com lucro para a empresa e ganhos para todos; da mesma maneira, Porter e Ballantyne oferecem definições que enfatizam o aspecto "ganha-ganha" dos relacionamentos e, como Jackson e Sheth, incluem o caráter de longo prazo. Sheth destaca o aspecto colaborativo dos relacionamentos, em contraste à competição e, assim como Ballantyne, considera o marketing de relacionamento como uma nova escola de administração. Porter acrescenta que, além de eficientes e eficazes, os relacionamentos devem ser prazerosos, entusiásticos, éticos, e pessoal, profissional e lucrativamente recompensadores. Morgan e Hunt também dão importância à questão ética nos relacionamentos e Ballantyne enfatiza o valor.

Ravald e Grönroos (1996:19) acreditam que a idéia do marketing de relacionamento seja, fundamentalmente, despertar a lealdade do cliente, de forma que um relacionamento estável, mutuamente lucrativo e de longo prazo seja desenvolvido. Winer (1999:21) observa ainda que o marketing de relacionamento envolve várias atividades distintas, as quais auxiliam na melhoria do 
valor do cliente para a empresa. Outro termo bastante utilizado é “pós-marketing”, entendido como o processo de proporcionar satisfação contínua e reforço aos indivíduos ou organizações que são clientes atuais ou que já foram clientes, que devem ser identificados, reconhecidos, comunicados, auditados em relação à satisfação e respondidos. O objetivo do pós-marketing é construir relacionamentos duradouros com todos os clientes (Vavra, 1992:40), o que interfere nas políticas operacionais de grande número de diferentes funções ou atividades: serviços ao cliente, orientação ao consumidor, políticas de devolução e até boletins ou comunicações ao consumidor. Há autores que discordam de se abrangerem todos os clientes nas práticas de relacionamento, questão a ser discutida na seção 2.1.2.2. Pode-se observar, também, que algumas empresas consideram que o aftermarketing ou pós-marketing ainda faz parte do marketing e não é sinônimo de marketing de relacionamento.

Scanzoni (1979:61-98, in Sudharshan, 1995:149) define três estágios no desenvolvimento de um relacionamento: exploração, consolidação e comprometimento. Dwyer, Schurr e Oh (1987:1127, in Sudharshan, 1995:149) acrescentam, também, consciência e dissolução. No entanto, esta abordagem não parece ser interessante para bens de consumo. Homans (1979, in Sudharshan, 1995:150) afirma que um relacionamento não ocorre até que várias trocas ocorram: estrategicamente, uma implicação que merece destaque é que um único item de uma categoria de produtos comprado a intervalos muito longos não constrói um relacionamento e não fornece alavancagem adequada, à exceção de categorias de produtos extremamente caros e de altas margens, como os automóveis Rolls Royce, por exemplo.

O marketing de relacionamento é baseado em promessas de empresas que vão além das certezas óbvias que os potenciais clientes esperam (Bitner, 1995, in Boone e Kurtz, 2001:157). Muito além da propaganda, as promoções especiais de vendas, desenho físico das instalações de uma empresa, sua limpeza e conservação e o processo do serviço são aspectos que fornecem outros meios para promessas das empresas a seus potenciais clientes. Tais promessas devem ser realistas e consistentes entre si; do contrário, podem-se criar clientes desapontados que não retornarão à empresa (Boone e Kurtz, 2001:157). “Os clientes desejam que as empresas sejam capazes de manter suas promessas. (...) Os produtos tornaram-se muito complexos e a repetição de negociações é difícil e muito dispendiosa. Sob estas condições, o sucesso do marketing é transformado na inevitabilidade do relacionamento. E o que era interface se transforma em interdependência” (Levitt, 1994:44). Os autores Boone e Kurtz (2001:157), porém, alertam para o fato de que a 
empresa somente pode honrar suas promessas se elas forem habilitadas por meio de marketing interno, ou seja, mediante ações gerenciais que levem todos os membros da empresa a compreender e aceitar seus respectivos papéis na implementação da sua estratégia de marketing.

Esses autores afirmam ainda que toda interação do cliente com uma empresa atinge seu momento da verdade quando um bem ou serviço é entregue ao cliente - o processo de troca. A troca define o ponto no qual a empresa mantém sua promessa e também marca o ponto onde os relacionamentos de longo prazo se desenvolvem entre compradores e vendedores. Os encontros positivos auxiliam na construção de relacionamentos de longo prazo, com o benefício adicional de recomendações verbais de clientes satisfeitos a outros clientes potenciais. Por outro lado, uma empresa que falha em cumprir sua promessa no processo de troca pode destruir qualquer esperança de continuidade do relacionamento vendedor-comprador. Os momentos da verdade são os pontos críticos para o relacionamento (Carlzon, 1987, in Winer, 1999:370), e compõem o produto ampliado.

Conceitos como qualidade, satisfação, valor e orientação para o mercado dão sustentação ao marketing de relacionamento e não podem ser dissociados do mesmo. Tais conceitos são apresentados nas seções seguintes.

\subsubsection{Qualidade e satisfação dos clientes}

No modelo genérico de relacionamento com clientes desenvolvido por Sudharshan (1995:145), apresentado na figura 4, a satisfação do cliente é baseada na diferença (gap) entre expectativas e experiências. Essa satisfação fornece feedback para mudar o estágio do

relacionamento, bem como as suas expectativas. A gerência de marketing antecipa as expectativas do cliente, toma decisões, e torna disponíveis um conjunto de ofertas num modo particular de relacionamento, que constituem a experiência do cliente, a qual, comparada positivamente às expectativas, cria sua satisfação ou prazer. Esta reação do cliente influi nas mudanças necessárias no gerenciamento da satisfação e, com novas antecipações das expectativas dos clientes, levam a mudanças nas decisões gerenciais. 
Em seu modelo, Sudharshan (1995:145) apresenta inicialmente o que chama de estágios de relacionamento. Nesta fase, esse autor recorre aos modelos de hierarquia de efeitos, sendo o mais conhecido deles o AIDA (Atenção, Interesse, Desejo e Ação), alertando para o fato de que esses modelos, em geral, voltam-se para a primeira transação de um indíviduo, sendo o desafio para o marketing de

Figura 4 - Um modelo genérico de relacionamento com clientes

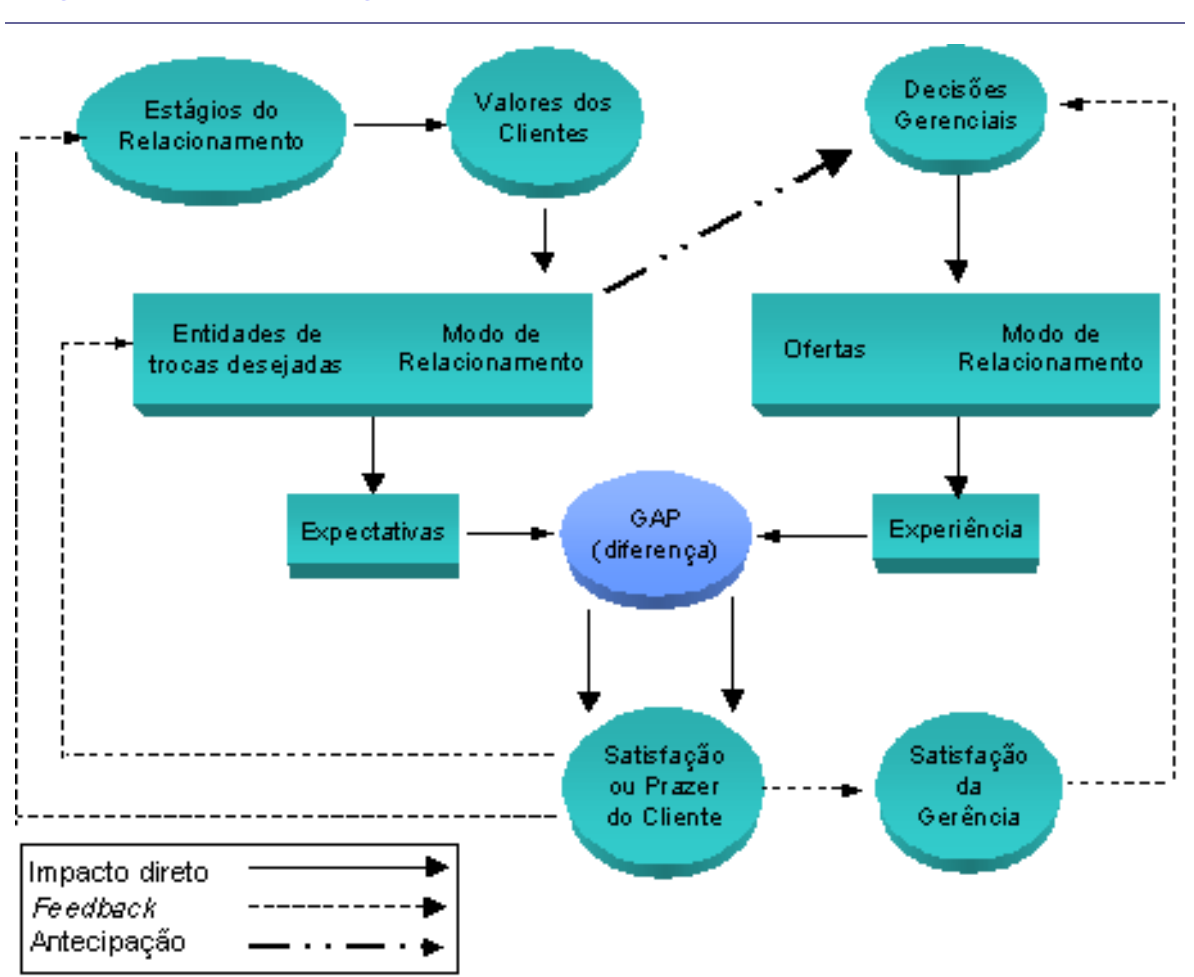

Fonte: adaptado de Sudharshan (1995:145).

relacionamento fazer com que haja um início de um relacionamento duradouro e vantajoso para ambas as partes. Daí emerge a importância de se pensar em estágios de relacionamentos, como os identificados por Scanzoni (1979:61-98, in Sudharshan, 1995:149), e referidos anteriormente na seção 2.1.1.: exploração, consolidação e comprometimento. O esforço em fazer com que o cliente volte para efetuar novas transações é o principal desafio entre a fase de exploração e consolidação.

Assim, enquanto cuidar dos clientes existentes costumava ser secundário em relação a atrair novos clientes, passam a ter prioridade manter, cuidar e desenvolver os relacionamentos existentes. Um dos principais fatores de manutenção do cliente tem sido a qualidade do serviço prestado, inclusive o serviço associado à efetivação de uma venda. Na mente do cliente, o serviço envolve cada ponto de contato com o fornecedor: a sua conveniência, economia de tempo, informações úteis (Hutchison e Stolle, 1994:119). Outro autor, Silveira (1999:80), acrescenta alguns outros serviços mais freqüentemente disponíveis aos clientes: crédito; entrega em domicílio, eficiente e rápida; horário estendido; devolução de produtos defeituosos ou problemáticos, com compensação; pacotes e embalagens; estacionamento; ajustes de roupas; serviços pessoais, como consultor de moda, de alimentos finos, assistente para composição de lista de casamentos; clientes com necessidades especiais, como pessoas com dificuldades de locomoção ou deficiência visual, ou até mesmo 
turistas que não falam a língua corrente; terminais para transferência eletrônica de fundos, linhas telefônicas de discagem gratuita para recepção de chamados de clientes, ombudsman, e outros. Cada contato é um momento crítico, que a empresa pode utilizar em seu favor.

Figura 5 - Motivos de troca de fornecedor

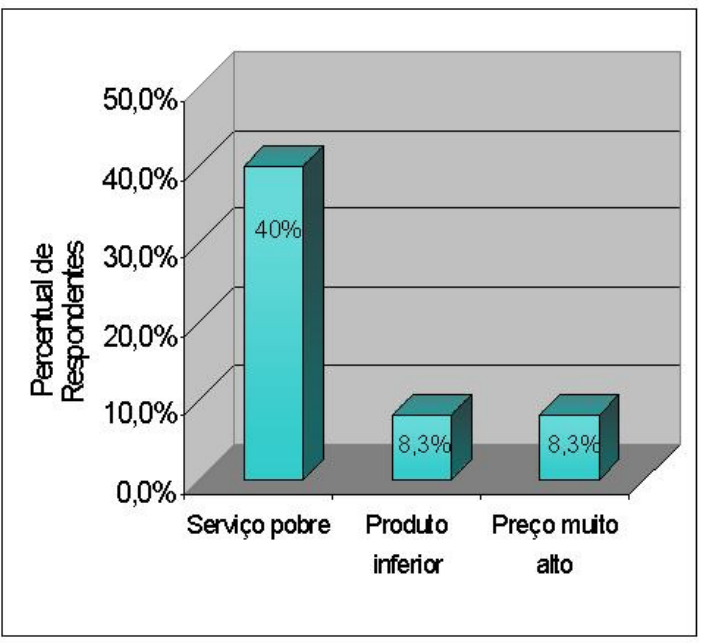

Fonte: Hirsh (1996:23).
Hirsh (1996:23) destaca uma pesquisa realizada pela Forum Corporation e analisada pela Booz·Allen e Hamilton junto a 2500 pessoas com necessidade contínua de um produto/serviço da empresa, mas que não compram mais dela. Alguns resultados dessa pesquisa podem ser observados na figura 5 . Em $40 \%$ dos casos, o motivo pelo qual o cliente deixa a empresa em busca de um concorrente é a pobreza do serviço, o que inclui falta de atenção do pessoal, atendimento rude e desinteressado etc.

Sobre esse assunto, Toledo, Gouvêa e Rodrigues Filho (2000) ponderam que a relação entre a qualidade e a vantagem competitiva é inerente às empresas: "produtos ou serviços de baixa qualidade podem deixar a empresa em uma posição desfavorável em relação à concorrência. Nas decisões de marketing, há, portanto, um crescente interesse em identificar a qualidade percebida pelos usuários de produtos e serviços ofertados e seu nível correspondente de satisfação”.

Winer (1999:364), além de Heskett et al. (1994, in Ravald e Grönroos, 1996:20), aponta como um dos requisitos básicos para a lealdade do cliente a sua satisfação, pois "seria mais provável que clientes satisfeitos realizassem novas compras e se tornassem bons clientes, que clientes insatisfeitos”. De fato, alguns estudos mostraram uma relação positiva entre satisfação, lealdade e lucratividade ${ }^{1}$. Cobra (1991:153) alerta ainda para o fato de que "um produto ou serviço inócuo, de baixa qualidade, ou de desempenho insatisfatório, poderá sofrer sanções não só por meio de dispositivos legais, como o Código de Defesa do Consumidor, mas, o que é mais cruel, por meio da indiferença do consumidor”.

\footnotetext{
${ }^{1}$ Citadas por Winer (1999:364), referências em Anderson, Fornell e Lehmann (1993).
} 
Winer (1999:364) apresenta um modelo básico de satisfação do cliente, também conhecido por modelo de confirmação/não confirmação de expectativas, por pressupor que os níveis de satisfação do cliente são determinados pela comparação do desempenho do produto ou serviço em relação às suas expectativas, representado na figura 6 .

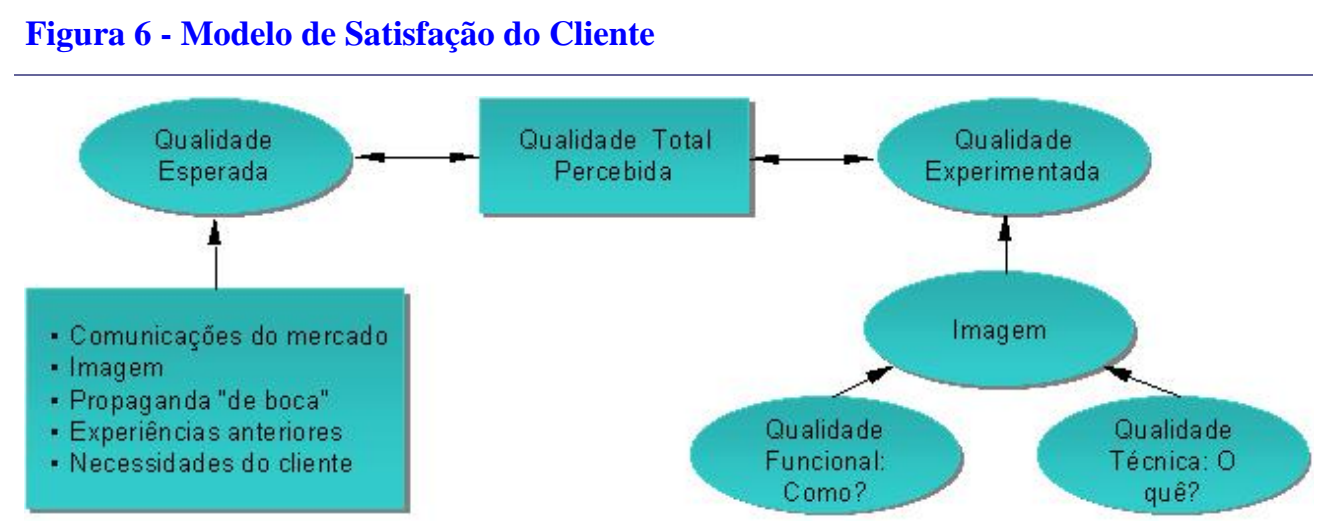

Fonte: Winer (1999:364).

Nesse modelo, a qualidade total percebida corresponde à satisfação percebida do cliente, resultado da comparação entre a qualidade experimentada, ou seja, a performance real do produto, e a qualidade esperada do mesmo. Esta expectativa de qualidade é formada a partir de várias fontes de informação, as quais incluem, entre outros fatores, propaganda, opiniões de parentes e amigos e experiências anteriores do cliente. Grönroos (1990:41, in Winer, 1999:392) esclarece que a qualidade experimentada resulta de uma imagem ou percepção que o cliente forma após a prestação do serviço. Tal percepção é, segundo esse autor, baseada em dois componentes: a qualidade técnica, que consiste no conjunto de características ou atributos do serviço em si, e a qualidade funcional, que corresponde à forma pela qual o serviço é entregue, ou a qualidade da real interação com a empresa.

Shapiro e Sviokla (1994:XVII), por sua vez, sustentam que a "alta qualidade gera lealdade à marca, referências verbais favoráveis, e uma disposição por parte dos clientes em pagar preços mais elevados. O conceito de qualidade constitui mais do que apenas atender às especificações do produto; implica cumprir ou exceder expectativas do cliente em termos de pontualidade, precisão, presteza e performance. O gerenciamento da qualidade competitiva reconhece que o produto ou serviço de hoje se tornará uma mercadoria não diferenciada no futuro”.

À medida que se analisa qualidade, descobrem-se dois elos complementares entre qualidade e lucro (Shapiro e Sviokla, 1994:121): (1) benefícios externos da satisfação do cliente; (2) benefícios 
internos da melhoria e eficiência da produção. Num determinado nível, qualidade de produto e de serviço criam uma percepção positiva da empresa que resulta na satisfação do cliente, e que, por sua vez, estimula a sua longevidade. Por outro lado, há produção de valor também internamente, à medida que impulsiona melhorias no processo, tais como maior rigor no controle de projetos e materiais, utilização mais eficiente de matérias-primas, menos ocorrências de retrabalhos etc. Com isso, há mais chances de se estabelecer uma maior lucratividade.

Entretanto, enquanto o conceito de qualidade e sua relação com a satisfação do cliente podem ser rapidamente assimilados, o mesmo não acontece com o conceito de valor, discutido a seguir.

\subsubsection{Valor}

A afirmação de que a satisfação do cliente depende do valor percebido (Howard e Sheth, 1969, in Ravald e Grönroos, 1996:20; Kotler e Levy, 1969, in Ravald e Grönroos, 1996:20) pode levar muitas pessoas a considerar que valor percebido e qualidade percebida são sinônimos. Contudo, diversos autores discordam dessa associação. Peter e Olson (1993, in Ravald e Grönroos, 1996:21), sob a ótica da Economia, por exemplo, definem valor como a utilidade que os clientes recebem quando compram um produto. Em outra visão, Porter (1989) define valor em termos competitivos como sendo o montante que os compradores estão dispostos a pagar por aquilo que uma empresa lhes fornece; o valor superior provém da oferta de preços mais baixos que os da concorrência por benefícios equivalentes, ou do fornecimento de benefícios singulares os quais mais do que compensam um preço mais alto. Na definição de Zeithaml (1988, in Narver e Slater, 1990:21), o valor da oferta de um vendedor para um comprador é a diferença entre o que o comprador percebe como benefícios esperados da oferta e o que ele percebe como custos totais esperados de uso e aquisição. Similarmente, Churchill e Peter (2000:13) definem o valor para o cliente como a diferença entre as percepções do cliente quanto aos benefícios da compra e uso dos produtos e serviços e os custos em que ele incorre para obtê-los. Lovelock (1991:237, in Toledo, Gouvêa e Rodrigues Filho, 2000) utiliza o termo "valor líquido”, como a soma de todos os benefícios percebidos (valor bruto) menos a soma de todos os custos percebidos. Kotler (1994:349) argumenta ainda que os clientes compram da empresa que oferece o mais alto valor de entrega, que define como "a diferença entre o valor total percebido pelo cliente (valor do produto, dos serviços, dos funcionários, da imagem da empresa) e o preço total pago por ele (preço, custo de tempo, de energia física e psíquica)”. 
Monroe (1991, in Ravald e Grönroos, 1996:20) define o valor percebido como a razão entre os benefícios percebidos e o sacrifício percebido. Os benefícios percebidos combinam atributos físicos, serviço e suporte técnico, além do preço de compra e outros indicadores de qualidade percebida; o sacrifício percebido, por sua vez, inclui todos os custos que o consumidor incorre ao adquirir um produto: preço de compra, custos de aquisição, transporte, instalação, pedido, manuseio, reparos e manutenção, risco de falhas ou baixa performance. Zeithaml (1988, in Ravald e Grönroos, 1996:22) acrescenta que o valor percebido é subjetivo e individual, variando de acordo com os valores pessoais, necessidades e preferências, além dos recursos financeiros disponíveis. Ao avaliar a atratividade de uma oferta, os clientes geralmente se utilizam de preços de referência (Monroe, 1991, in Ravald e Grönroos, 1996:20), e de valores de referência (Berkowitz, 1994, Ravald e Grönroos, 1996:20). A autora Szafir-Goldstein (2000), ao estudar várias concepções de valor e modelos de avaliação de valor, partindo da Economia e situando-as no contexto estratégico da organização, com maior foco em marketing, destaca, em suas análises, o conceito de valor percebido, valor do cliente e a distinção entre o que a empresa acredita estar oferecendo como valor a seus clientes e o que estes enxergam como valor recebido da empresa. Evidencia ainda a relação do conceito de valor percebido com a orientação para o mercado, com a satisfação do cliente, com a qualidade e com o preço.

Desta forma, valor percebido se distancia do conceito de qualidade percebida, porém ambos aproximam-se na importância para o desenvolvimento de um relacionamento com o cliente, já que influenciam o seu grau de satisfação e precisam estar bastante evidentes para ele. Reichheld (1996:22-23) observa que “a lealdade está intrinsecamente associada à criação de valor, tanto como causa quanto como efeito. Como efeito, a lealdade mede de forma confiável se uma empresa ofereceu ou não valor superior: ou os clientes voltam a comprar mais ou compram de outro. Como causa, a lealdade inicia uma série de efeitos econômicos”: aumento nas receitas e na participação de mercado, estimulando o crescimento sustentado, que atrai melhores funcionários, reforçando a sua lealdade e estimulando-os a oferecer ainda mais valor; os funcionários aprendem a reduzir custos e a melhorar a qualidade, com altas taxas de produtividade, as quais permitem à empresa melhorar níveis de treinamento e remuneração; com maior produtividade e maior eficiência em atender os clientes, cria-se uma vantagem de custos difícil de ser equiparada, atraindo a lealdade dos investidores, que atuam como parceiros e financiam o potencial de criação de valor da empresa. 
O gerenciamento do valor do cliente é outra abordagem para a completa satisfação dos clientes na qual a chave para atingir um valor excepcional é um alto nível de qualidade percebida por parte do mesmo, como ilustra a figura 7. No gerenciamento do valor do cliente, o foco da empresa se concentra no papel crucial da qualidade e do valor na estratégia global. Com ferramentas e medidas para

Figura 7 - Criando valor que os clientes podem ver

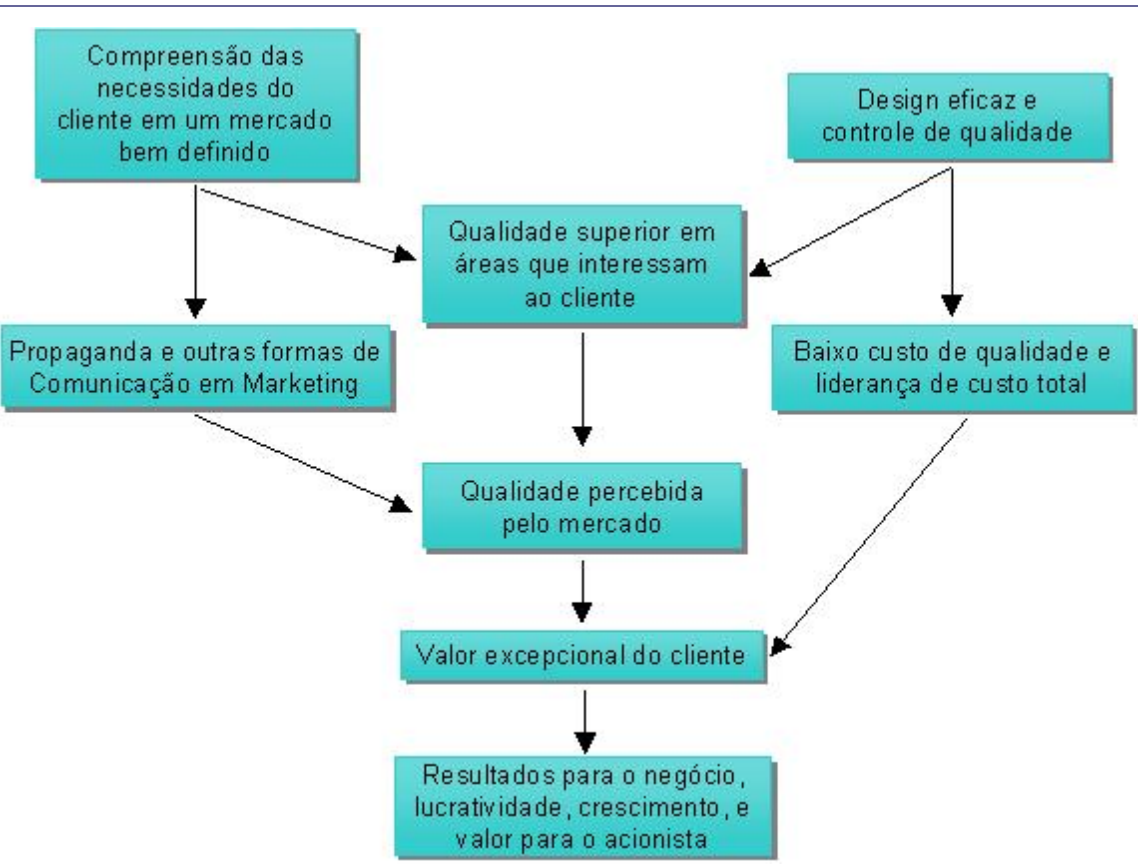

Fonte: Gale (1994:19).

análise do valor do cliente, a empresa analisa sua competitividade, decide em quais negócios entrar, realiza investimentos e avalia aquisições. Além disso, toda a organização, incluindo pessoas e processos, deve ser alinhada às necessidades de seu mercado-alvo em constante evolução (Gale, 1994:9). As informações subsidiarão decisões, as quais permitirão à empresa produzir o máximo valor e, assim, obter o máximo benefício no longo prazo para acionistas, clientes e a sociedade (Gale, 1994:18).

Um fornecedor pode aumentar o valor criando benefícios adicionais para o cliente ou diminuindo seus custos totais de aquisição e uso (Forbis e Mehta, 1981, in Narver e Slater, 1990:21; Churchill e Peter, 2000:13). Enquanto Ravald e Grönroos (1996:19) sugerem que um meio bem sucedido de fornecer valor ao cliente é reduzir o sacrifício percebido por ele, reduzindo seus custos de relacionamento, Monroe (1991, in Ravald e Grönroos, 1996:20) vai além ao afirmar que os clientes valorizam mais uma redução nos custos que um acréscimo correspondente nos benefícios. Agindo sobre os benefícios, é válido introduzir características adicionais, mas sempre com foco no cliente.

Woodruff (1997, in Silveira, 2002:13-14) ressalta as diferenças entre as várias definições de valor para o cliente, especialmente em relação: (1) às diferentes acepções assumidas de conceitos como utilidade, benefícios e qualidade, com base nos quais tais definições foram construídas; (2) às 
circunstâncias em que os consumidores pensam a respeito de valor; (3) às possíveis classificações de tipos de valor para o cliente. Desta forma, Woodruff (1997:142, in Silveira, 2002:14) define valor para o cliente como “a preferência e avaliação, percebida pelo cliente, dos atributos do produto, performance dos mesmos, e conseqüências geradas pelo uso que facilitam ou bloqueiam o atingimento dos objetivos e propósitos dos clientes nestas situações”.

Assim, “o processo de geração de valor inicia-se com a compreensão das necessidades e metas de cada cliente em potencial e com a demonstração da forma pela qual a empresa é a mais bem qualificada para satisfazer tais demandas. É importante estar atento ao modo pelo qual o cliente percebe os benefícios de fazer negócio com uma empresa e não com suas concorrentes; ao mesmo tempo, ela não pode perder de vista seus interesses; a satisfação dos clientes não deve ser obtida à custa da lucratividade a longo prazo" (Shapiro e Sviokla, 1994:XIV). Acredita-se que os relacionamentos entre empresas e clientes se estabelecem verdadeiramente quando há ganho de valor por ambas as partes.

Churchill e Peter (2000:10) enunciam, a seguir, os princípios do marketing voltado para o valor, entendendo-se "princípios” como regras fundamentais e abrangentes para a ação.

- Princípio do cliente: concentrar-se nas atividades de marketing que criam e fornecem valor para o cliente, o que requer que as empresas os compreendam, saibam o que pensam, o que sentem e como compram e usam produtos e serviços.

- Princípio do concorrente: reconhecendo que as estratégias competitivas exercem grande influência sobre os clientes, é preciso que as empresas lhes ofereçam valor superior às opções da concorrência, sob pena de defrontarem-se com dificuldades de sobrevivência no longo prazo.

- Princípio pró-ativo: mais que reagir ao ambiente, as empresas também devem ser próativas e procurar mudar mercados e ambientes para melhorar sua posição competitiva (Nord e Peter, 1980, in Churchill e Peter, 2000:10; Zeithaml e Zeithaml, 1984, in Churchill e Peter, 2000:10; Kotler, 1986, in Churchill e Peter, 2000:10). Pró-atividade, nesse contexto, pode ser definida como a habilidade de utilizar o canal direto com o cliente para informá-lo de ofertas específicas que possam ir ao encontro de seus interesses e padrões de compra (Dutta, Kwan e Segev, 1997:9). Esta filosofia reconhece que a sociedade dá às organizações e aos profissionais de marketing o direito e a responsabilidade de sobreviver e alcançar sucesso alterando relações ambientais. A prática 
das atividades destinadas a tal fim, realizada de forma ética e com vistas a criar valor superior para os clientes, faz do marketing uma força positiva na sociedade.

- Princípio interfuncional: usar equipes interfuncionais quando puderem melhorar a eficiência e a eficácia das atividades de marketing, interagindo continuamente para realização de tarefas de planejamento, implementação e controle. Segundo esta filosofia, fazer com que os setores executem independentemente suas próprias tarefas leva, muitas vezes, a estratégias de marketing mais caras e de menor sucesso.

- Princípio da melhoria contínua: melhorar continuamente o planejamento, a implantação e o controle de marketing. Embora controlar as atividades de marketing com revisões e auditorias periódicas seja um recurso valioso, também é útil que constantemente todo o pessoal de marketing e de outras áreas busque melhores maneiras de criar valor para os clientes.

- Princípio do stakeholder: embora o principal foco esteja no cliente, é preciso considerar o impacto das atividades de marketing, suas obrigações e relações com outros públicos interessados na organização.

O marketing voltado para o valor é baseado numa visão simples do motivo que leva clientes a comprarem produtos e serviços, e sugere que os clientes muitas vezes consideram vários benefícios e custos ao tomarem suas decisões de compra, provavelmente de maneira pouco estruturada. Um cliente que perde a visão do valor total da empresa tende a se concentrar apenas no preço de etiqueta para realizar suas compras (Narver e Slater, 1990:27), ou basear suas compras na satisfação com produtos e serviços comprados anteriormente, e fazer pouca ou nenhuma avaliação do valor das outras opções (Churchill e Peter, 2000:13). Por ser, muitas vezes, difícil e caro para a empresa atrair novos clientes, é importante manter os clientes atuais.

\footnotetext{
Churchill e Peter

(2000:18) analisam as conseqüências de um valor superior para os clientes, Figura 8 - As conseqüências de um valor superior para os clientes conforme a figura 8, e acreditam que oferecê-lo possa deixá-los satisfeitos; por conseqüência, isto pode conduzi-los à fidelidade desejável, uma vez que manter os clientes atuais é muito mais eficiente que atrair novos clientes; esta fidelidade, por sua vez, pode levar a relações duradouras e lucrativas entre clientes e empresas. Em suma, esses autores acreditam que o marketing voltado
} 
para o valor é projetado para oferecer uma melhor orientação para as organizações alcançarem seus objetivos.

“O profissional de marketing procura obter valor do mercado oferecendo valor a ele. $\mathrm{O}$ problema desse profissional é criar valores atrativos. O valor é completamente subjetivo e existe nos olhos do mercado que o vê. Os profissionais de marketing precisam entender o mercado a fim de serem eficazes na criação de valor. Este é o significado essencial do conceito de marketing” (Kotler, 1994:94).

A discussão sobre a qualidade percebida e o valor percebido que, por sua vez, tem impactos diretos sobre a lealdade do cliente, é um ponto chave no marketing de relacionamento e em sua importância para a organização. A idéia de que a qualidade percebida é positivamente relacionada à lucratividade é exemplo desta importância e tem sido objeto de vários estudos (Winer, 1999:368). Um deles é o projeto Profit Impact of Market Strategies (PIMS) ${ }^{2}$, que analisou 3000 unidades de negócios e empresas de serviços e verificou um relacionamento positivo entre a qualidade percebida e a lucratividade (Whiteley, 1997). Neste contexto, o valor para o cliente pode ser definido como a oferta de um alto nível de qualidade percebida ao cliente, ao preço certo, relativo à concorrência. O valor para o cliente que maximiza sua satisfação pode ser visto como a razão favorável entre o valor percebido e o preço, não importando a magnitude destes itens (Winer, 1999:368). Vários autores, entre eles, Bates e Didion, citados por Silveira (1999:84), apóiam a idéia da necessidade de análise entre o custo do empreendimento para a empresa e o valor do serviço ao cliente.

Não se pretende, com este estudo, esgotar a discussão sobre valor para o cliente, e sim, compreender a importância do seu conceito para o marketing de relacionamento. Referências adicionais podem ser encontradas em (Dominguez, 2000), Silveira (2002) e Szafir-Goldstein (2000). Apresentam-se a seguir, os fundamentos da orientação para o mercado e sua relevância para o tema deste estudo.

\subsubsection{Orientação para o mercado}

“Uma empresa que aumenta sua orientação para o mercado melhorará sua performance de mercado”. A julgar pela atenção dedicada a esta afirmação por práticos e acadêmicos em palestras,

${ }^{2}$ Maiores informações em: BUZZEL, Robert D.; GALE, Bradley T. The PIMS principles: linking strategy to performance. New York: Free Press, 1987. 
livros e artigos, a orientação para o mercado tem se mostrado o centro da administração e da estratégia moderna de marketing, ainda que, até o momento, não se tenha conhecimento do desenvolvimento de uma medida válida para ela ou da avaliação de sua influência na performance do negócio (Narver e Slater, 1990:20).

McKenna (1992:33) distingue as abordagens voltadas para o marketing das voltadas para o mercado. As primeiras baseiam-se "no uso de truques, macetes, e promoções de marketing, a fim de capturar a mente do consumidor. As abordagens voltadas para o mercado envolvem o diálogo entre a empresa e o cliente, e entre a empresa e o mercado”. McKenna (1992:81) observa ainda que os produtos voltados para o mercado baseiam-se, para seu sucesso, na compreensão das necessidades dos clientes, no ambiente competitivo, nas questões essenciais para o setor, na propaganda de boca, na aceitação da infra-estrutura, na adaptabilidade, na eficácia da solução em relação aos custos e na credibilidade e reputação do fornecedor. Por outro lado, os produtos voltados para o marketing são menos adaptáveis e baseiam-se em uma definição específica e limitada.

Sob outra perspectiva, o termo “orientação para o mercado” é preferível ao termo “orientação para o marketing” por três razões. O primeiro termo clarifica que o constructo não é exclusivamente uma preocupação da função marketing, pois vários departamentos participam da geração, disseminação e tomada de ações em resposta à inteligência de mercado. Além disso, não aumenta a importância da função marketing dentro da empresa, removendo o constructo do âmbito do departamento de marketing, tornando-o responsabilidade de toda a empresa. E, por fim, o termo focaliza os mercados, que incluem os clientes e as forças que os afetam (Shapiro, 1988, in Kohli e Jaworski, 1990:3).

A orientação para o mercado é a cultura da organização que mais eficaz e eficientemente cria os comportamentos necessários para a criação de valor superior para compradores e, adicionalmente, performance superior para o negócio (vários autores ${ }^{3}$, in Narver e Slater, 1990:21). Desta forma, a definição de orientação para o mercado desenvolvida por Kohli e Jaworski (1990:6) é a seguinte: “orientação para o mercado é a geração de inteligência de mercado em toda a organização, relacionada às necessidades atuais e futuras dos clientes, à disseminação da inteligência entre todos os departamentos, e à capacidade de resposta de toda a empresa a ela”. A

\footnotetext{
${ }^{3}$ Peters e Waterman, 1982; Kotler, 1984; Peters e Austin, 1985; Kotler e Andreasen, 1987; Aaker, 1988; Kohli e Jaworski, 1990; Shapiro, 1988; Webster, 1988
} 
geração de inteligência, mais que um conjunto de necessidades e preferências verbalizadas de clientes, inclui não só pesquisas com os mesmos, mas também mecanismos complementares como encontros e discussões com parceiros de comércio, análises de relatórios de vendas, análises de bases de dados de clientes do mundo todo, e pesquisas de mercado formais como pesquisas de atitude, resposta de vendas nos testes de mercado etc. A direção de uma empresa é resultado da educação e da comunicação dos gerentes de marketing com os gerentes de outras áreas funcionais (Levitt, 1969, in Kohli e Jaworski, 1990:5). A inteligência pode fluir de qualquer departamento e, a partir de uma disseminação eficaz, pode fornecer uma base para ações planejadas de diferentes áreas, o que fortalece ainda mais a relevância do papel da comunicação horizontal (Zeithaml, Berry e Parasuraman, 1988, in Kohli e Jaworski, 1990:6). Além disso, não se atingem objetivos relevantes quando nenhuma ação é tomada em resposta às necessidades do mercado, traduzindo-se, em geral, na seleção de mercados-alvo, projeto e oferta de produtos e serviços que vão ao encontro de necessidades atuais e antecipadas, e na produção, distribuição e promoção de produtos que provoquem resposta favorável do cliente final. Shapiro (1994:7), complementarmente, defende a idéia de que uma empresa é orientada ao mercado se aplica os seguintes princípios: (1) a importância da compra efetuada por cada um dos clientes da empresa deve ser divulgada e influenciada em toda a organização; (2) decisões estratégicas e táticas devem ser tomadas de forma integrada entre funções e divisões da empresa; (3) as decisões tomadas pelas divisões e funções devem ser bem coordenadas e executadas com senso de compromisso e responsabilidade.

Faz-se necessário destacar que, embora tradicionalmente os clientes tenham sido considerados o foco primário de uma orientação para o mercado, uma perspectiva mais ampla mostra que forças adicionais num mercado como concorrência, tecnologia, regulamentação e outras também são consideradas pertencentes ao domínio do constructo da orientação para o mercado (Lusch e Laczniak, 1987, in Jaworski e Kohli, 1993:54). Assim, certas contingências como a turbulência do mercado, a intensidade da concorrência e a turbulência tecnológica moderam, aumentando ou diminuindo, a força do relacionamento entre a orientação do mercado e a performance dos negócios (Jaworski e Kohli, 1993:57; Kohli e Jaworski, 1990:14). O contexto em que se insere uma empresa geralmente influencia seu nível de orientação para o mercado; desta forma, as empresas em ambientes competitivos tendem a ser mais orientadas para o mercado, ou, em outras palavras, a 
ligação entre a orientação para o mercado e a performance depende das características ambientais da organização (vários autores ${ }^{4}$, in Jaworski e Kohli, 1993:57).

Sob análise um pouco distinta, Narver e Slater (1990:21) acreditam que a orientação para o mercado consiste de três componentes comportamentais - a orientação para o cliente, a orientação para a concorrência e a coordenação interfuncional -, e de dois critérios de decisão - o foco de longo prazo e a lucratividade. Segundo esses autores, a orientação para o cliente é a compreensão suficiente dos compradores-alvo da empresa e suas respectivas cadeias de valor, de forma a criarlhes continuamente valor superior. Já a orientação para a concorrência pressupõe que a empresa compreende as forças e fraquezas de curto prazo e as capacidades e estratégias de longo prazo tanto dos concorrentes-chave atuais, como dos potenciais. A coordenação interfuncional, ou seja, a utilização coordenada dos recursos da empresa, assume que qualquer indivíduo em qualquer função na empresa pode, em potencial, contribuir com a criação de valor para os clientes. Em suma, estes componentes abrangem as atividades de aquisição e disseminação de informação sobre os compradores e concorrentes do mercado-alvo entre as unidades da empresa, e a criação coordenada de valor para o cliente.

Mason, Mayer e Wilkinson (1978, in Menezes e Angelo, 1999:74) sugerem quatro etapas distintas para facilitar a preparação de uma empresa voltada ao mercado: (1) estudar a atual orientação da empresa e identificar as barreiras para tornar-se orientada para o mercado; (2) obter concordância da administração superior para uma orientação dirigida para o mercado; (3) alinhar a estratégia de suporte ao cliente com a estrutura organizacional e seus recursos humanos; (4) encorajar e recompensar comportamentos voltados para o mercado em todos os níveis da empresa.

Tal preocupação com a orientação para o mercado representa a base sobre a qual o marketing de relacionamento é praticado pelas empresas. A coleta e análise de dados sobre os clientes e sobre a concorrência, disseminando-os por toda a empresa, de forma a alinhar políticas de procedimentos válidos para toda a empresa, com vistas à criação de valor para os clientes e à busca da lucratividade, são elementos essenciais para o marketing de relacionamento.

\footnotetext{
${ }^{4}$ Lusch e Laczniak, 1987; Bennett e Cooper, 1981; Houston, 1986; Tauber, 1974
} 
Uma vez feitas algumas considerações sobre o surgimento do marketing de relacionamento e sobre alguns dos principais conceitos a ele relacionados, faz-se necessário compreender a sua importância no contexto estratégico das organizações.

\subsubsection{A importância do marketing de relacionamento para a organização}

“Há somente uma definição válida do propósito de um negócio: criar um cliente.” (Drucker, 1954:37, in Webster Jr., 1989:16).

Por definição, o marketing de relacionamento prevê o estabelecimento de relacionamentos de longo prazo entre a organização e clientes e parceiros, onde seja percebido o desenvolvimento de uma relação altamente vantajosa para ambas as partes (Gummesson, 1999:243). Esta abordagem contrapõe-se à ênfase na transação apresentada na literatura tradicional de marketing. Por esta razão, o marketing de relacionamento representa uma mudança. Para alguns, uma mudança de era (Boone e Kurtz, 2001), de estratégia (Christopher, Payne e Ballantyne, 1993:4, in Boone e Kurtz, 2001:155), de orientação (Vavra, 1992), ou ainda, para alguns mais radicais, uma mudança de paradigma (Sheth e Parvatiyar, 1995) no marketing. E como toda mudança envolve custos, esta também gera muitos questionamentos sobre se o marketing de relacionamento realmente se paga (Fournier, Dobscha e Mick, 1998:43). A resposta dada por Gummesson (1999:7) é que o marketing de relacionamento não só oferece um caminho para aumentar a retenção de clientes, mas também relacionamentos de longo prazo com vendedores, concorrentes, governos, a mídia etc. e, assim, quando utilizado com habilidade, leva a receitas maiores, custos reduzidos e melhoria da performance financeira da empresa. Gummesson (1999:183) destaca a idéia de Retorno sobre o Relacionamento (Return on Relationship, ROR), ou seja, o resultado financeiro líquido a longo prazo proporcionado pelo estabelecimento e manutenção de uma rede de relacionamentos de uma empresa. Os sistemas de apuração deste retorno, no entanto, ainda estão em estágio incipiente.

Além da questão financeira, a mudança no horizonte estratégico é apresentada como a melhor opção de abordagem para ameaças e oportunidades geradas pelos efeitos da concorrência, e também pela ampliação do acesso à informação por parte do consumidor, lembrada por Armstrong e Hagel (1996, in Dholakia e Bagozzi, 2001:191), Boone e Kurtz (2001:141), Gurley (1997, in Ruefli, Whinston e Wiggins, 2001:51), McKenna (1995:87), entre outros. A combinação destes dois fatores, que crescem constantemente em complexidade, desencadeia novos desafios de 
sobrevivência para as organizações, fato que requer o desenvolvimento de capacidades que criem vantagens competitivas para as empresas.

São apresentados, a seguir, elementos que atestam a importância do marketing de relacionamento para a organização, relacionados essencialmente à competitividade e à lucratividade do negócio.

\subsubsection{Acirramento da concorrência e sofisticação das necessidades do consumidor}

Gummesson (1999:33) crê que a concorrência parece tender a uma hipercompetição, um estado de mudança contínua e de guerrilha; é intensa, rápida e avança continuamente com rupturas das vantagens competitivas, tanto da própria empresa como de seus concorrentes. Na busca de soluções para tal fenômeno, esse autor propõe um modelo para o equilíbrio de mercado no ambiente competitivo, chamado de "equilíbrio de marketing”; sua tese é a de que “o foco na colaboração é a mais importante contribuição do marketing de relacionamento, com impacto tanto no gerenciamento de marketing como na economia”.

Winer (1999:358) afirma que, no atual ambiente competitivo, os relacionamentos de longo prazo são críticos para o sucesso do negócio. Segundo este autor, os fornecedores de produtos e serviços de compras freqüentes, assim como de bens duráveis e industriais de compras menos freqüentes, têm procurado construir altos níveis de satisfação do cliente por meio do desenvolvimento de melhores relacionamentos, com o intuito de que sejam fortes e duradouros. As intenções por trás de tais ações visam ao aumento das taxas de compras repetitivas e, portanto, das vendas e lucros no longo prazo. Takeuchi e Quelch (1994:154) relatam que algumas grandes empresas dos EUA concluíram que a operação de alta qualidade em serviço ao cliente pode ser uma forma eficaz de alcançar os seguintes objetivos: (1) diferenciar a empresa de suas concorrentes; (2) liderar o estímulo de novas vendas e desestimular a mudança para fornecedores alternativos; (3) reforçar a lealdade dos revendedores. Winer (1999:358), com base em Levitt (1986:113-114), analisa diferentes perspectivas dos relacionamentos entre vendedores e compradores, conforme ilustrações a seguir. 
Figura 9 - O relacionamento comprador-vendedor
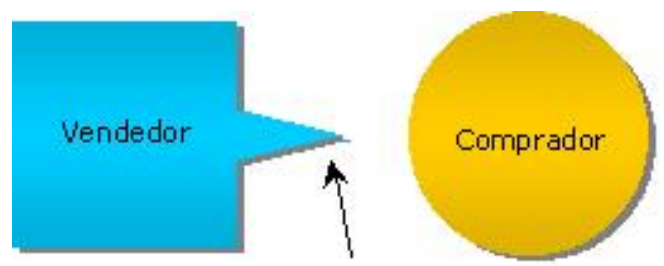

Departamento de Vendas

Fonte: Levitt (1986:113-114, in Winer, 1999:359).
Na situação representada na figura 9, típica da orientação para vendas, a empresa vendedora pretende realizar a venda para o comprador, mas como ela tem feito pouco para tentar compreender suas motivações e necessidades, o relacionamento entre ambos é distante. O profissional de vendas tem se utilizado apenas de sua criatividade e personalidade para realizar a venda.

Já nesta situação (figura 10), a empresa que fornece o produto ou serviço realizou um trabalho melhor ao entender o comprador, aproximando-se dele e descobrindo o suficiente sobre suas necessidades para realizar a venda. Este é o conceito de marketing mais tradicional, ou

Figura 10 - O relacionamento comprador-vendedor

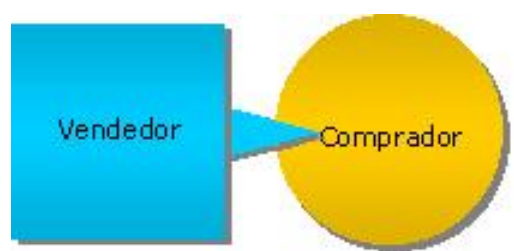

Fonte: Levitt (1986:113-114, in Winer, 1999:359). orientação para o cliente. No entanto, Winer (1999:358) argumenta que nenhum conceito é suficiente no atual ambiente competitivo global. O autor cita Levitt (1986, cap. 6), que observa: "Para o vendedor, a venda é o final do processo; para o comprador, é o começo".

Figura 11 - O relacionamento comprador-vendedor

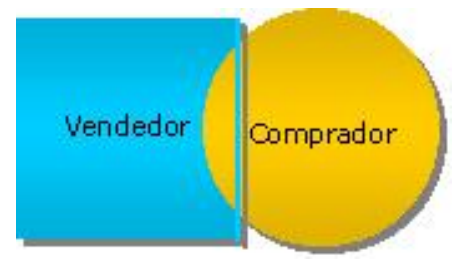

Fonte: Levitt (1986:113-114, in Winer, 1999:359).

Contudo, no atual ambiente competitivo, em que os relacionamentos de longo prazo são críticos ao sucesso do marketing e dos negócios em geral, é necessário mais que a aplicação do conceito de marketing para satisfazer os clientes por um longo período de tempo. Na situação representada na figura 11, a qual traz um novo modelo de marketing de relacionamento, comprador e vendedor se tornam interdependentes de alguma maneira.

Apesar de ser conceitualmente simples, a situação representada na figura 11 passa a ser fundamental a partir do momento em que se têm contextos de alta competição, já que uma das mais importantes decisões estratégicas que uma empresa toma é a base pela qual os clientes preferirão seu produto aos da concorrência, o que requer o desenvolvimento de uma vantagem competitiva ou diferencial (Winer, 1999:52). Há várias formas de se desenvolver vantagem competitiva, porém 
Aaker (1995, in Winer, 1999:52) sugere que a estrutura para isso deve compreender três características:

1. A empresa deve gerar valor para o cliente, ou seja, melhorar alguma característica ou ser relevante em algum aspecto do produto ou serviço que é valorizado pelo cliente;

2. O valor adicionado deve ser percebido pelo cliente, isto é, mesmo que o produto seja melhor que o da concorrência, se o cliente não puder discernir esta diferença, não constitui uma vantagem competitiva;

3. A vantagem deve ser difícil de ser copiada; do contrário, deixa de ser vantagem.

Porter (1989) acrescenta que a vantagem competitiva surge fundamentalmente do valor que uma empresa consegue criar para seus compradores e que ultrapassa o custo de fabricação pela empresa.

McKenna (1992:45) complementa que os consumidores avaliam produtos e empresas comparando-os com outros produtos e empresas. Assim, o que realmente importa é como os possíveis clientes e os já existentes vêem uma empresa em relação às suas outras opções, ou seja, em relação às concorrentes. Os consumidores definem uma hierarquia de valores, desejos e necessidades com base em dados empíricos, opiniões, referências obtidas por propaganda de boca e experiências anteriores com produtos e serviços, usando essas informações para tomar suas decisões de compra.

Além desta visão clássica do desenvolvimento de vantagens competitivas, o próprio sucesso da orientação para o marketing de relacionamento já representa uma vantagem competitiva para a organização, de equacionamento difícil pela concorrência, dado que isto dependerá do desenvolvimento de relações de confiança, que por sua vez, demandam tempo e disciplina.

\subsubsection{Aumento da lucratividade da organização}

Em uma abordagem mais ampla e genérica, só é possível aumentar a lucratividade operacional da empresa obtendo aumento de receitas e/ou reduções de custos, incluindo-se aí as despesas e gastos. Estudiosos do marketing de relacionamento acreditam que esta filosofia oferece bons subsídios para o aumento de receitas e/ou redução de custos (Reichheld, 1996; Winer, 1999).

No que se refere ao aumento das receitas, Vavra (1992:17) avalia que, face ao atual ambiente competitivo, “o que é consideravelmente mais difícil em tal dinâmica de mercado é manter os 
clientes comprando regularmente uma marca ou serviço. Dados os custos decorrentes de conquistar novos clientes, a única maneira de lucrar em tal situação é aumentar o tempo de vida de compra dos clientes atuais. Portanto, a retenção de clientes é muito mais importante que a atração de clientes”. É possível que haja um certo exagero nesta avaliação, se tomada isoladamente, dado que ela não se aplica a toda e qualquer situação: quando a empresa deseja crescer, expandir seus negócios, ela necessariamente deve aumentar sua base de clientes, pois há um limite de incremento de vendas para a base já existente.

Reichheld (1996:69-70) considera clientes “certos” os que oferecem fluxos de caixa constantes e retorno rentável para o investimento da empresa nos anos seguintes, cuja lealdade pode ser conquistada e mantida. É preciso ter em mente três regras básicas: (1) alguns clientes são inerentemente previsíveis e leais, independentemente da empresa com a qual estejam fazendo negócio, simplesmente preferindo relacionamentos estáveis e duradouros; (2) alguns clientes são mais rentáveis que outros: gastam mais, pagam as contas com mais presteza e demandam menos serviço; (3) alguns clientes acharão os produtos e serviços da empresa mais valiosos que os da concorrência, mais adequados às suas necessidades e oportunidades. Quanto mais clientes pertencentes a esses grupos a empresa lograr atrair, maiores serão as suas chances de colher as recompensas que acompanham a retenção de clientes.

Da mesma maneira, com base em Reichheld (1996:39), Winer (1999:361) analisa as razões pelas quais os clientes leais são mais lucrativos, detalhando os componentes da figura 12.

Figura 12 - Porque os clientes leais são mais rentáveis

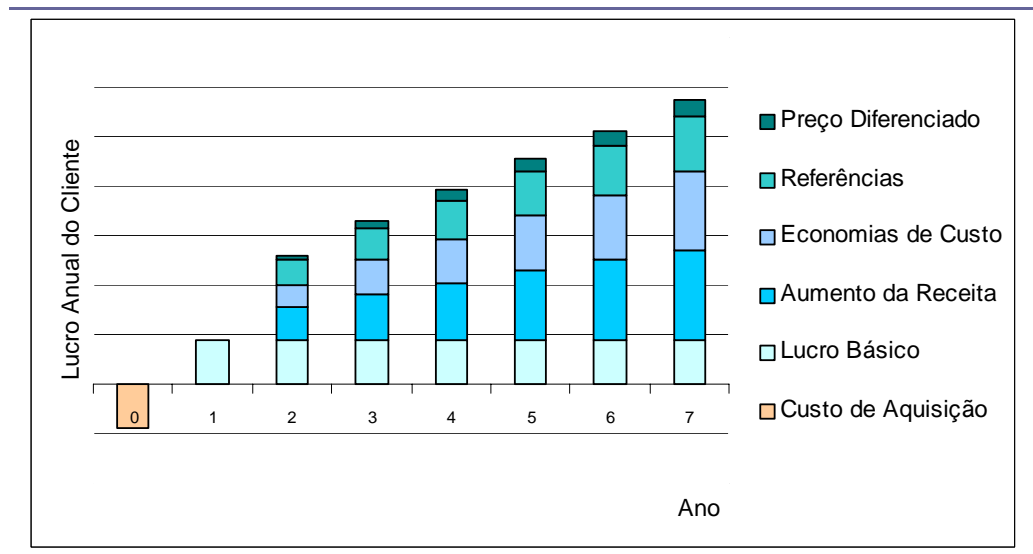

Fonte: Reichheld (1996:39).
- Custo de aquisição: todo cliente novo envolve algum custo incremental, chamado de custo de aquisição, quer seja com envio de malas diretas, telemarketing, promoção ou outro tipo de gasto necessário para conquistar um novo cliente.

- Lucro básico: margem de lucro obtida a partir de um cliente médio. Quanto maior o período de retenção do cliente, maior o lucro básico obtido. 
- Crescimento da receita: acredita-se, intuitivamente, que os clientes leais aumentam suas compras ao longo do tempo. Um cliente que compra regularmente em um determinado estabelecimento tenderia a comprar mais itens neste mesmo estabelecimento.

- Custos operacionais: custa menos servir clientes já existentes que servir novos clientes, pois os primeiros conhecem melhor os sistemas e procedimentos da organização, demandando menos tempo da empresa com verificação de erros nos pedidos ou na resposta a dúvidas.

- Indicações: clientes satisfeitos fazem propaganda verbal favorável sobre a empresa a seus amigos e colegas. Como a qualidade do serviço é mais difícil de ser verificada antes da compra, é particularmente importante uma indicação de quem já o tenha experimentado e esteja satisfeito.

- Preço prêmio: clientes leais são, em geral, menos sensíveis a preços que os que necessitam de um incentivo de preço para mudar de fornecedor ou para se tornar um novo cliente.

A filosofia por trás destes componentes é que, com o passar dos anos, os seus efeitos sobre o lucro se acumulam, superando, em muito, os custos de aquisição iniciais, descontados ao valor presente líquido. Winer (1999:363) argumenta que, embora haja alguma discussão sobre a eficácia de diferentes abordagens para retenção de clientes, um grande número de profissionais e estudiosos compartilham a idéia de que é mais lucrativo manter os clientes pelo tempo mais longo possível que despender mais dinheiro para conquistar novos clientes.

Além do aumento das receitas, o marketing de relacionamento também aborda a questão da otimização dos custos recorrentes e do efeito contaminador da insatisfação de algum cliente. Os administradores freqüentemente subestimam os lucros perdidos quando um cliente se despede insatisfeito e, portanto, administram de forma precária as possíveis formas de prevenir tais perdas. Levando-se em conta os custos da perda de um cliente, seriam poucos os esforços de recuperação que pudessem ser considerados extremos. No Club Med, um hóspede leal dirige-se às estações de veraneio, em média, quatro vezes após a primeira visita, despendendo aproximadamente US\$ 1 mil em cada vez. Sendo a renda marginal da empresa de 60\%, quando um cliente do Club Med não retorna, a empresa perde $60 \%$ de US\$ 4 mil, ou seja, US\$ 2,4 mil. Além disso, ela passa a ter a necessidade de substituir aquele cliente por meio de dispendiosos esforços de marketing (Hart, Heskett e Sasser Jr., 1994:279). Outro autor, Crescitelli (2003:34), observa que "um cliente perdido vale, efetivamente, por dois: é um cliente a menos para a empresa e um cliente a mais para a concorrência”. 
Alguns resultados de estudos conduzidos e patrocinados por vários grupos e organizações, citados por Vavra (1992:30), valorizam a manutenção de clientes atuais:

- Custa cinco vezes mais conquistar um novo cliente do que manter um cliente atual (Forum Consulting, Boston, MA; Customer Service Institute, Silver Spring, MD).

- Noventa e um por cento de clientes insatisfeitos com uma empresa jamais comprarão dessa mesma empresa e comunicarão sua insatisfação a pelo menos nove outras pessoas (Technical Assistance Research Programs, Washington, D.C.).

Além da perda de oportunidade de negócios, estes estudos mostram o alto poder destrutivo dos clientes insatisfeitos, que não reclamam, simplesmente passam a comprar da concorrência e, ao revelar suas queixas a outros nove clientes atuais ou potenciais, multiplicam por nove o grau de insatisfação.

Outros dados, obtidos por uma pesquisa realizada em âmbito nacional nos EUA, conduzida pelo United States Office of Consumer Affairs (USOCA): 63\% dos consumidores que experimentaram uma perda percebida entre US\$1 e US\$5 e não reclamaram, disseram que não comprariam da mesma marca novamente; 54\% daqueles cuja reclamação não foi satisfatoriamente resolvida também disseram que não comprariam daquela marca novamente; por outro lado, 30\% dos consumidores com reclamações atendidas seriam perdidos por aquela marca (Sudharshan, 1995:143-4). Daí pode-se entender as razões pelas quais as empresas estão perseguindo tanto a satisfação dos clientes na atualidade.

Por outro lado, Gummesson (1999:26) questiona até que ponto é lucrativo manter um relacionamento, e quando a empresa deve aceitar que uma venda é um negócio de uma única vez. Tendo em vista novamente a afirmação freqüente de profissionais de marketing, de que é de cinco a dez vezes mais caro conquistar um novo cliente que manter um antigo, para tentar responder ao seu questionamento, vale lembrar um adágio de vendedores semelhante à citação de Drucker: "a venda real não é fazer vendas, mas fazer clientes”.

Shapiro e Sviokla (1994:353), Reichheld (1996:253) e Winer (1999:21) evidenciam a importância do estabelecimento de sistemas de controles permanentes que permitam auferir o valor da base de clientes, analisando conceitos como lifetime customer value (valor do cliente durante sua existência), ou seja, o valor presente do fluxo de receitas que pode ser produzido por um cliente, e o 
valor presente líquido (VPL) do cliente, que representa o fluxo descontado de lucro deduzido o investimento de aquisição.

O relacionamento, contudo, não é uma panacéia mágica. Um relacionamento não deve ser mantido se não estiver funcionando bem. Os relacionamentos de longo prazo e os cuidados com o consumidor não são o mesmo que "admitir clientes para a ala geriátrica do fornecedor, colocá-lo em um leito e mantê-lo sobrevivendo com aparelhos” (Gummesson, 1999:12). Entretanto, os relacionamentos não devem ser necessariamente quebrados somente porque há um conflito. Eles podem, muitas vezes, ser restaurados e aprimorados ou podem ser a melhor opção para ambas as partes, apesar do conflito.

Reichheld e Sasser Jr. (1994:347), e Booz·Allen e Hamilton e Wharton School (2002:2) apóiam a idéia de que desenvolver o marketing de relacionamento não significa manter servilmente todos os clientes a qualquer custo. Há clientes que a empresa não deveria tentar manter, como os volúveis que não permanecem, e que não se tornam lucrativos; nem mesmo deveria investir para tentar atraí-los.

Com a compreensão da importância do marketing de relacionamento, passa-se a discutir as suas implicações para as empresas no exercício de suas atividades.

\subsubsection{As implicações do marketing de relacionamento}

A abordagem do marketing de relacionamento oferece uma série de elementos que auxiliam a organização a desenvolver vantagem competitiva sustentável e aumentar sua lucratividade (Winer, 1999; Reichheld e Sasser Jr., 1994). Contudo, para obter sucesso, o marketing de relacionamento origina uma série de implicações de trato bastante complexo para a organização. Assim é que Fournier, Dobscha e Mick (1998:43) advertem: “o marketing de relacionamento é poderoso em teoria, mas problemático em prática”. Daí a importância do entendimento das implicações, algumas delas discutidas nesta seção, do marketing de relacionamento quando posto em prática.

\subsubsection{Os diferentes níveis de relacionamento entre a empresa e seus clientes}

As implicações do marketing de relacionamento podem também ser depreendidas a partir do entendimento das formas de relacionamento do cliente em relação à empresa e vice-versa, também evidenciado por Sudharshan (1995:145) em seu modelo, apresentado na seção 2.1.1.1. 
Segundo Kotler (1987, in Sudharshan, 1995:158), os clientes podem ver as empresas como inimigos, estranhos, auxiliadores ou amigos, e infelizmente, as empresas vêem os clientes como alvo, quando na verdade deveriam abordá-los como amigos. É interessante saber como a empresa é vista por seus clientes, e então desenvolver estratégias que forneçam uma plataforma apropriada para a construção de relacionamentos significativos.

Nesta mesma linha de abordagem, Gummesson (1999:10) apresenta uma escala dos modos de relacionamento que a empresa precisa promover para transfomar um potencial cliente em um fiel defensor da sua marca. No conceito de “escada da lealdade” (figura 13) desenvolvido por esse autor, o degrau mais baixo representa o contato com um prospect (cliente potencial), o qual se espera que venha a se tornar um comprador. Os compradores reincidentes passam a ser clientes; estes retornam e um relacionamento de longo prazo começa a se formar. Nos estágios seguintes, o cliente se torna um apoiador e, finalmente, um defensor de seu fornecedor.

Figura 13 - A Escada da Lealdade

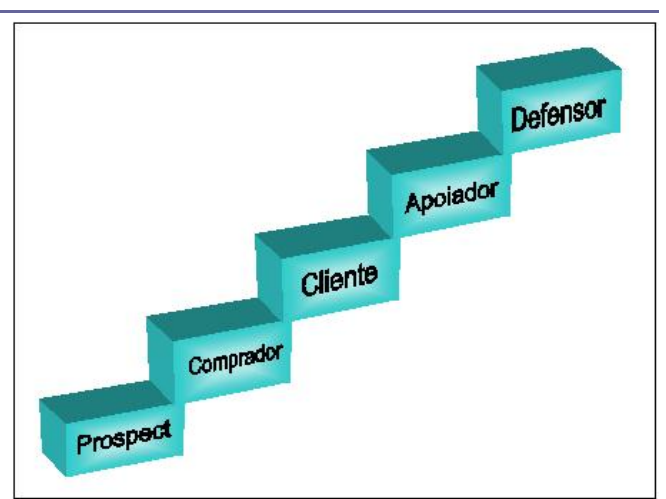

Fonte: Gummesson (1999:10).
Figura 14 - A Pirâmide do Relacionamento

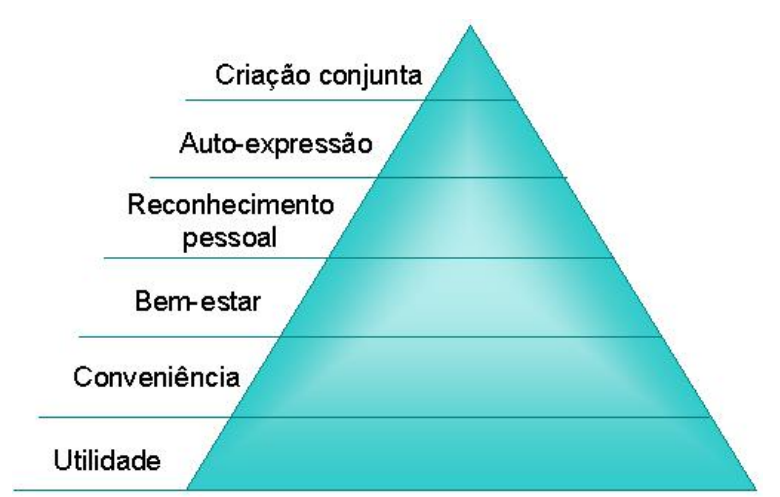

Fonte: Malaviya e Spargo (2002:11).
Partindo também do princípio de que os relacionamentos são construídos progressivamente e segundo uma seqüência lógica, Malaviya e Spargo (2002:11) desenvolveram um modelo denominado Pirâmide do Relacionamento com o Cliente, representado na figura 14, no qual identificam seis níveis de necessidades de relacionamento. Na base da pirâmide estão os níveis de utilidade e conveniência, que refletem uma orientação racional

do cliente, que busca apenas um produto que atenda às suas necessidades específicas. Os dois níveis intermediários de necessidades de interação são o bem-estar e reconhecimento pessoal, que possuem um elemento afetivo que torna a experiência de compra agradável. Os níveis mais profundos de necessidade de interação estão no topo da pirâmide - auto-expressão e criação conjunta - caracterizados por fatores pessoais e pela satisfação das necessidades racionais e afetivas, com alto nível de lealdade e confiança. 
Enquanto Gummesson (1999) traz uma visão dinâmica dos clientes, Jones e Sasser Jr. (1995:88-99) apresentam uma visão estática, mas também importante. Para esses autores, os clientes podem ser classificados em quatro categorias, com base em seu nível de satisfação e lealdade atuais:

- Leais/apóstolos: completamente satisfeitos, possuem alto nível de lealdade e são partidários da empresa; auxiliam a conseguir novos clientes para a empresa por meio de indicações.

- Retirantes/terroristas: tendem a estar insatisfeitos ou em uma posição intermediária, e mudar para a concorrência; espalham referências negativas sobre a empresa.

- Mercenários: embora possam ter alta satisfação, possuem altas taxas de mudança de fornecedor também. Com baixo compromisso com a empresa e geralmente sensíveis a preços e promoções, raramente ficam com ela por tempo suficiente para se tornarem lucrativos.

- Reféns: estão “presos” à empresa; podem estar insatisfeitos, mas são altamente leais por falta de uma alternativa viável. Entretanto, assim que surgir tal alternativa, mudarão de fornecedor.

É possível observar que apóstolos e mercenários, inerentemente satisfeitos, podem, mesmo assim, exibir padrões de lealdade totalmente distintos. Da mesma forma, os apóstolos e os reféns são ambos altamente leais, mas por razões diferentes. Assim, é crítico entender o contexto dentro do qual se está medindo lealdade e satisfação (Winer, 1999:366). Os clientes leais, em geral, não requerem custos de marketing ou de configuração, geralmente oferecem uma alta receita por compra, são menos sensíveis a preço e indicam novos clientes para a empresa (Reichheld, 1996, in Wiegran e Koth, 1999). Os autores Coyles e Gokey (2002:1) afirmam que diferenciar e medir os graus de lealdade é uma tarefa em evolução. As empresas, inicialmente, tentaram medir e gerenciar a satisfação de seus clientes no começo dos anos 70, sob a crença de que aumentar a satisfação auxiliaria a sua prosperidade. Nos anos 80 , as empresas começaram a medir as taxas de abandono e a investigar suas causas. Ao medir o valor dos próprios clientes, algumas empresas identificaram os de mais alto valor, e melhoraram a sua performance na prevenção de sua partida para a concorrência. Há diferentes formas de se aferir a satisfação/lealdade, de medidas baseadas em pesquisas junto ao cliente, como intenção de compra, a medidas comportamentais, como o percentual de todas as compras de um produto de uma marca particular, ou com um indicador objetivo, como o número de reclamações (Winer, 1999:365-366). Podem-se utilizar também 
modelos de avaliação multiatributos, como o desenvolvido por Gale (1994:31-33, in Winer, 1999:368), que propõe a análise de alguns atributos, com pesos relacionados à sua importância como fator de ponderação para as notas atribuídas ao seu desempenho, e que representam a sua performance relativa aos concorrentes. Winer (1999:370) afirma que tais informações são interessantes, entre outras razões, como uma orientação para as estratégias de marketing: os itens nos quais o produto é superior à concorrência constituem vantagens competitivas e são parte da proposição de valor comunicada aos clientes. Além da discussão de elementos que influenciam a lealdade do cliente, deve-se também refletir sobre as formas de avaliação: as ações tomadas pela empresa com o intuito de fidelizar o cliente estão, de fato, surtindo efeito ou são apenas resultado de uma inércia determinada pela ausência de alternativas?

Coyles e Gokey (2002:1) afirmam que uma boa apreciação das forças subjacentes que influenciam a lealdade dos clientes, em particular, suas atitudes e necessidades em constante mutação, pode auxiliar as empresas a desenvolver esforços mais direcionados para corrigir qualquer migração negativa em seus hábitos de compra, e pode ter até dez vezes mais valor que apenas prevenir os abandonos, bem antes que eles ocorram. Entretanto, um grande número de evidências sugere que apenas satisfazer os clientes não é suficiente para mantê-los leais a uma empresa ou produto (Winer, 1999:366). Uma pesquisa realizada pela Xerox mostrou que clientes "totalmente satisfeitos” eram seis vezes mais propensos a recomprar produtos Xerox nos próximos dezoito meses que aqueles que estavam apenas "satisfeitos” (Jones e Sasser Jr., 1995:88-99). Além disso, Neal (1996, in Dominguez, 2000:62), ao analisar a relação entre satisfação e lealdade, observa que ela não é totalmente linear, havendo um ponto - nível mínimo de aceitação - abaixo do qual os índices de satisfação não se transformam em recompra, e outro ponto - nível de aceitação universal - acima do qual acréscimos de satisfação pouco adicionam à recompra. Coyles e Gokey (2002:2-5) advertem também que a satisfação, por si, não diz a uma empresa o que torna os clientes leais; nem mesmo medir os níveis de satisfação revela o quão suscetíveis seus clientes são a mudar seus hábitos de compra. Ao compreender porque os clientes exibem diferentes graus de lealdade, e combinar este conhecimento com dados sobre os modelos de compra, as empresas podem desenvolver perfis de lealdade que definem e quantificam segmentos de clientes. Esses autores desenvolveram uma classificação do comportamento da base de clientes, ilustrada na figura 15, na qual definem migrantes como clientes que apresentam mudanças significantes no relacionamento com a empresa. 


\section{Figura 15 - Dimensões da Lealdade}

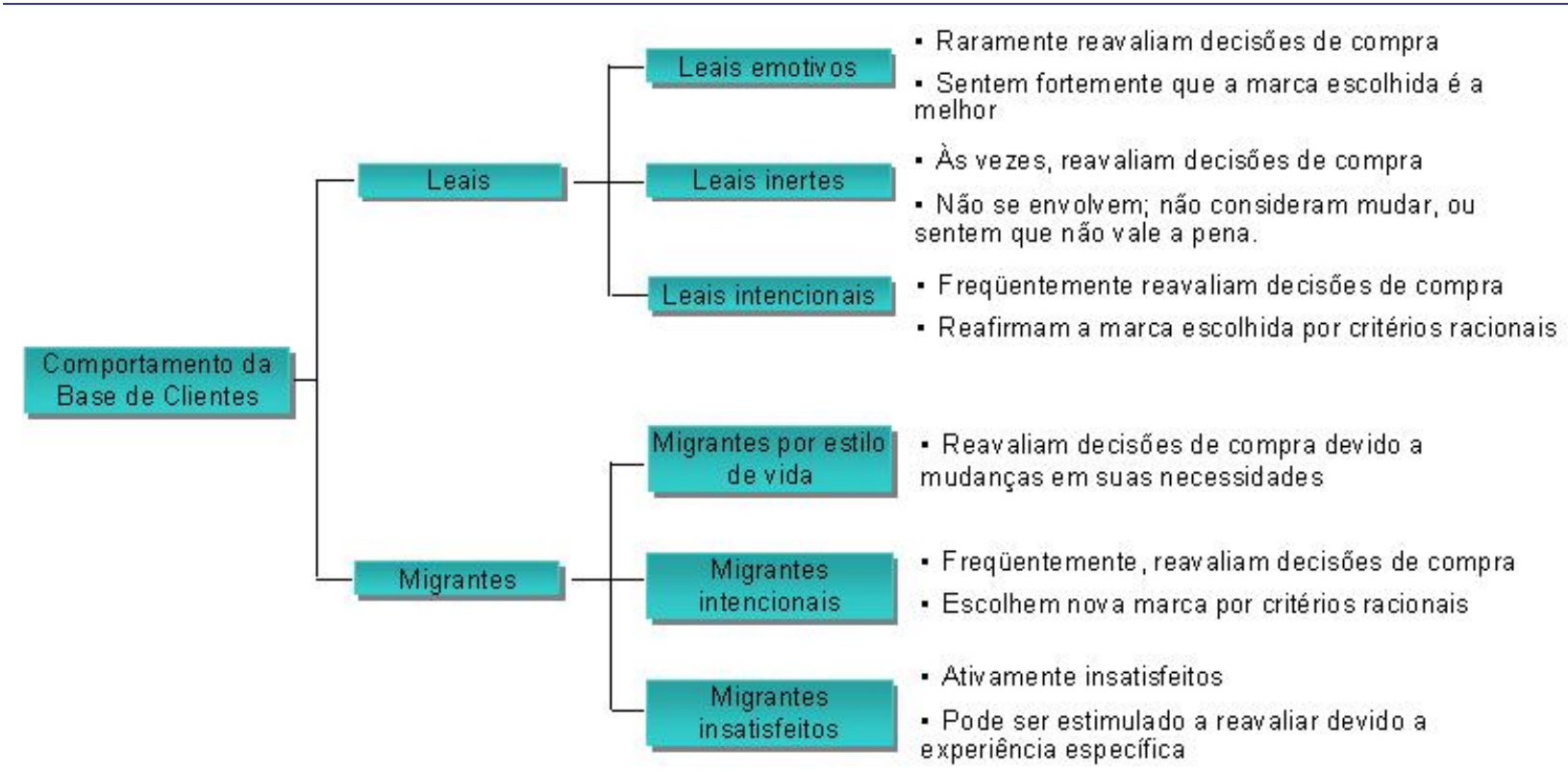

Fonte: Coyles e Gokey (2002:3)

Coyles e Gokey (2002:3) vêem algumas vantagens na análise do perfil de lealdade do cliente. Em primeiro lugar, esta análise reforça a idéia de que a criação de lealdade, ao contrário da visão tradicional, não significa apenas a prevenção da perda de clientes para a concorrência e o encorajamento de mais compras. Segundo, o perfil evidencia as diferentes táticas requeridas para administrar cada um dos segmentos e a necessidade de execução de uma série de ações para alcançá-los; um único ato raramente aumenta a lealdade dos clientes. Terceiro, quando combinado à análise de valor do cliente, o perfil auxilia a empresa a basear suas prioridades de construção de lealdade de acordo com cada oportunidade. Três grupos podem ser vistos como leais, isto é, mantêm ou aumentam seus gastos pois são emocionalmente ligados ao seu atual fornecedor, escolheram-no racionalmente como sua melhor opção, ou não vêem vantagens em mudanças. Os migrantes para a concorrência podem ter uma das seguintes razões para isso: seu estilo de vida mudou, gerando novas necessidades que a empresa não está satisfazendo, continuamente reavaliam suas opções e encontraram uma melhor; ou estão realmente insatisfeitos, geralmente devido a uma única experiência ruim.

Reichheld (1996:338) acredita que a lealdade não é apenas filosofia e estratégia; aplica-se também às operações, pois oferece um conjunto de medidas práticas para a implementação da estratégia, em sua missão de criar valor duradouro. Segundo esse autor, as empresas líderes em lealdade, embora com estratégias distintas, baseiam-se nos seguintes princípios: 
1. Desenvolver uma proposição de valor superior para o cliente, em relação à concorrência.

2. Encontrar o cliente certo: a seleção adversa pode diminuir seriamente o valor disponível aos clientes essenciais.

3. Conquistar a lealdade do cliente: fazer o possível para reter os clientes e aumentar seu valor ao longo do tempo de vida, com políticas de preço, linhas de produtos, incentivos aos funcionários e níveis de serviço que aumentem a lealdade do cliente.

4. Encontrar os funcionários certos: pessoas que compartilhem os valores da empresa, com talento e habilidade para alcançar níveis de produtividade e carreiras longas e satisfatórias.

5. Conquistar a lealdade do funcionário: investir maciçamente no treinamento e desenvolvimento dos funcionários, com planos de carreira e estruturas organizacionais que maximizem a validade de seu treinamento e suas habilidades; compartilhar o excedente de produtividade resultante com os funcionários sob a forma de maiores salários, o que retroalimenta a espiral ascendente de lealdade.

6. Ganhar vantagem de custos com maior produtividade: estruturar seus incentivos de modo que os funcionários tratem as despesas como se estivessem gastando seu próprio dinheiro.

7. Encontrar os investidores certos: são os predispostos a relacionamentos de longo prazo, que escolhem cuidadosamente seus investimentos e acreditam que só prosperarão quando clientes e funcionários prosperarem; não se baseiam nas expectativas do mercado financeiro, e sim, na criação de oportunidades suficientes para as pessoas dentro do sistema de negócios.

8. Conquistar a lealdade do investidor: tratar o dinheiro do investidor da mesma forma que trataria seu próprio dinheiro, o que proporciona um forte incentivo às empresas para reinvestir os lucros somente em projetos com potencial considerável de geração de valor.

O feedback, destacado no modelo de Sudharshan (1995:145) apresentado na seção 2.1.1.1., está intimamente relacionado com o contínuo aprendizado da empresa e da melhoria do relacionamento com o cliente. Na seção a seguir, são evidenciadas a sua importância e a necessidade de se ouvir além do que os clientes dizem. 


\subsubsection{A importância de se ouvir o cliente}

Neste quesito, os autores sugerem uma série de técnicas. Hart (1994:168), por exemplo, relata que o método mais comum de coleta de feedback dos clientes por parte das empresas é a utilização de formulários; porém, em sua opinião, tal método é inadequado por estes serem impessoais e geralmente possuírem poucas questões, para maximizar a taxa de respostas. Entretanto, apenas alguns poucos clientes, em geral, os mais satisfeitos ou mais insatisfeitos, expressam-se por esse meio, e uma proporção ainda menor fornece feedback significativo. Também é comum em algumas empresas exigir-se que funcionários do setor de engenharia e de produção tenham contato direto com clientes e usuários, não apenas para obter idéias sobre novos produtos ou para obter feedback dos já existentes, mas também para conhecer e responder aos clientes de forma profunda e permanente, com o propósito de desenvolver relacionamentos e laços que perdurem (Levitt, 1994:51-53). Os autores Hart, Heskett e Sasser Jr. (1994:280) sugerem que o modo mais simples de se fazer isto é facilitar aos clientes a apresentação de suas queixas. Números de telefone de ligação gratuita (Boone e Kurtz, 2001:162) e e-mails enviados a partir do próprio site da empresa são uma forma fácil de se entrar em contato com ela e relatar seus problemas. Além disso, as linhas de acesso imediato devem ter suporte adequado para se evitarem inconvenientes comuns em sistemas telefônicos centralizados: sinal de ocupado, gravação ou música repetitiva não contribuem para o aprimoramento das relações com os clientes.

Adicionalmente, partindo de um dos princípios básicos do atendimento, de que toda compra deve ser vista estrategicamente, o comitê de clientes, inspirado no focus group, pode gerar uma experiência de relacionamento significativa para ambos os lados. Nesses encontros, o cliente questiona, reclama, sugere, elogia ou confirma seu ponto de vista com outros clientes participantes e a empresa explica o que é possível ou não fazer, quando, limitações etc. A empresa pode ainda conhecer hábitos de vida dos clientes, preocupações e o que ela representa em seu cotidiano. A partir de ligações afetivas, sintonias, simpatias que acontecem em cada reunião entre os participantes, os laços entre clientes e empresa se fortalecem (Holovko, 1999:119-122). Por outro lado, Shapiro (1994:9) observa que, além dos relatórios de pesquisas e das gravações dos atendimentos, as informações sobre os clientes devem provir de outras fontes. Executivos de alto nível devem realizar visitas a clientes importantes para vê-los utilizando seus produtos, fazendo uso de seus serviços ou vendendo seus produtos no varejo. Com isso, podem ter melhor compreensão das necessidades do cliente quanto à qualidade e tolerância das especificações. É preciso, no entanto, entender o que é um “cliente importante”. Da mesma maneira, visitas a feiras setoriais 
proporcionam oportunidades para que funcionários de áreas técnico-operacionais possam conversar com clientes. Dispositivos mais formais como questionários, caixas para recebimento de sugestões e $e$-mail são eficazes apenas quando alguém os monitora continuamente e age com rapidez em relação às reclamações e sugestões recebidas (Hart, Heskett e Sasser Jr., 1994:281).

É preciso ainda que a empresa procure ouvir além do que foi dito, ou o que não foi dito. Há várias coisas que os clientes sempre quiseram dizer, mas as empresas teimam em não ouvir. Todo contato com os clientes é uma oportunidade de ouvi-los, inclusive o que eles não dizem por meio de palavras. Cada vez mais é fundamental ouvir o cliente e agir para satisfazê-lo. É importante buscar não só a opinião do cliente externo, mas também do intermediário e do interno. O que realmente faz a diferença para o cliente, qual sua avaliação do desempenho da organização e o que está errado, falta fazer ou pode ser feito de um modo melhor, são as informações básicas para se começar a mudança. É fácil descobrir que mesmo clientes satisfeitos são capazes de abandonar o produto; ouvir a opinião do cliente significa escutar e agir após escutar. Ao olhar para os clientes externos, é preciso ouvir vários grupos. Um grupo óbvio é o dos clientes atuais, mas há também o grupo dos clientes potenciais e o dos clientes em poder da concorrência, não conquistados ou perdidos. Todos são muito importantes, pois fornecem informações que podem auxiliar a melhorar os produtos, os serviços e a imagem da empresa como um todo. Boone e Kurtz (2001:162-163) lembram que as empresas devem procurar entender porque os clientes terminam os relacionamentos com as mesmas. Se estiverem insatisfeitos ou incomodados com seus fornecedores atuais, provavelmente irão procurar a concorrência; muitos clientes também não apreciam o sentimento de estarem presos a um relacionamento com uma empresa.

Giangrande (1999:21) destaca a figura do ombudsman, interlocutor criado na Suécia, em 1809, e que representava inicialmente o cidadão perante o parlamento. Logo a seguir, foram criados o ombudsman dos presídios, representando os presos, o das minorias raciais e, no início do século $\mathrm{XX}$, o dos consumidores. Sendo o ombudsman o representante de determinado público, pode haver numa mesma empresa mais de um ombudsman, até mesmo para representar os funcionários. Ao estabelecer uma "ouvidoria”, a empresa objetiva: (1) atender melhor a seus clientes; (2) preservar e melhorar a imagem pública da organização; (3) reduzir a exposição a litígio com consumidores e usuários; (4) assimilar críticas e sugestões; (5) aprimorar processos, produtos e serviços; (6) melhorar sua comunicação; (7) manter o foco; (8) ajustar seu posicionamento no mercado (Centurião, s.d., in Volpi, 2002:32). Segundo Giangrande (1999:21), espera-se que o ombudsman 
seja um facilitador no desenvolvimento do marketing de relacionamento e da cultura da qualidade nas empresas, pois "ouvir o cliente e transmitir imediatamente a todas as áreas da empresa o resultado de seu contato, auxilia a empresa a conhecer e compreender como suas ações e sua postura são percebidas por seu público prioritário”. Ele deve zelar para que os direitos do cliente sejam respeitados e suas expectativas, satisfeitas; por fim, deve agir como mediador, e não como juiz, honrando os preceitos éticos.

A divulgação e discussão dos resultados das pesquisas de satisfação e das manifestações espontâneas dos clientes sinalizam uma atitude que pode trazer resultados bastante positivos em relação ao marketing de relacionamento, como ponderam autores como Shapiro e Sviokla (1994:XVIII) e Hart, Heskett e Sasser Jr. (1994:288).

Contudo, o marketing de relacionamento também exige preparo e adequação das pessoas envolvidas, dos processos, e da organização como um todo, como será discutido a seguir.

\subsubsection{Outras implicações}

Marcelo Amaral, jornalista e consultor de qualidade afirmou, em entrevista à Rádio CBN, em 30/03/03, que a empresa que possuir bons relacionamentos com clientes terá bons resultados nos negócios. Contudo, o consultor diferencia cliente de consumidor. O consumidor é o comprador que realiza uma única transação com a empresa; já o cliente é o comprador que compra várias vezes e, por isto, se torna lucrativo para ela. “Consumidores são estatísticas. Clientes são pessoas.” (Stanley Marcus, presidente honorário, Lojas de Departamento Neiman Marcus, in Boone e Kurtz, 2001).

Giangrande (1999:18) afirma que um dos primeiros pré-requisitos para o marketing de relacionamento é o desenvolvimento de uma cultura de serviços, a qual valoriza os bons serviços tanto para o público interno como para os públicos externos. Whiteley (1997:21) enumera três pontos para que se alcance uma conduta favorável à estratégia de servir bem aos clientes de uma empresa: (1) determinar cuidadosamente quem deve ser seus clientes; (2) procurar conhecê-los bem; (3) solicitar a todos da organização que meçam cada ação em relação às necessidades e expectativas dos clientes, e que procurem constantemente superar tais expectativas. Fonseca (1999:56) também ressalta a importância do desenvolvimento de uma cultura de atendimento nas empresas, que depende de questões como a forma pela qual a empresa quer relacionar-se com seus clientes, como deseja ser vista por eles, quais os valores implícitos no atendimento, qual a visão da empresa e do cliente sobre o binômio cliente/produto, como são tratados os clientes internos, que 
ações adotar para que todos estejam envolvidos, como obter feedback do atendimento oferecido etc. Como complemento, aposta na capacitação do pessoal de atendimento, que se inicia com a seleção de pessoal com perfil adequado à cultura que se deseja desenvolver, e segue com programas de formação, especialização e aperfeiçoamento. O atendimento, contudo, é apenas uma parte do relacionamento; é preciso, antes de tudo, agir com bom senso, independentemente de conceitos e teorias. As regras do jogo de marketing são reescritas por intermédio de eventos políticos e mudanças nos valores, padrões de consumo e tecnologia; a realidade do marketing exige viver com complexidade, paradoxos, incertezas, ambigüidades e instabilidade. Muitos mercados são vistos como caóticos, mas o caos reserva oportunidades para os que podem vê-las e usá-las melhor que a concorrência.

Cymbaum (1997:184-204, in Cymbaum e Málacco, 1999:27), novamente enfatizando a necessidade de toda a empresa tomar parte do desenvolvimento do marketing de relacionamento, afirma que, caso o objetivo da empresa seja fortalecer a sua identidade ou diferenciação pela qualidade do atendimento, as ações de recursos humanos devem estar voltadas para aspectos como desenvolvimento de uma cultura orientada aos clientes, motivação para o alcance de metas e resultados, e capacitação para o desempenho com maior qualidade, produtividade e flexibilidade. E, acima de tudo, os líderes devem reproduzir o padrão desejado de conduta em sua postura cotidiana. Gummesson (1999:9) define e resume valores fundamentais para o marketing de relacionamento: (1) colaboração de longo prazo e ganha-ganha (para ambas as partes: empresa e clientes); (2) reconhecimento de todas as partes como ativas; (3) valores de relacionamento e serviços em vez de valores burocrático-legais.

Winer (1999:373) aponta ainda como uma forma de demonstrar excelência em serviço ao cliente a recuperação de serviços. Um momento crítico para a empresa ocorre quando um produto ou serviço não apresenta o desempenho esperado ou não funciona como deveria; a reação da empresa nestas situações é determinante para a manutenção de relacionamentos. Uma boa recuperação pode transformar clientes irados e frustrados em clientes leais. Ron Zemke (Finkelman e Goland, 1994:268) descobriu em seus estudos que a boa recuperação é responsável por 38,7\% das diferenças existentes entre empresas percebidas como muito boas ou muito ruins na prestação de serviços aos seus clientes, principalmente no varejo. Assim, as empresas devem deixar clara a atribuição dos funcionários em contato com os clientes de fazer todo o possível para solucionar o problema dos mesmos, estabelecendo padrões tanto para o tempo de resposta como para a forma de 
compensar erros cometidos, e assegurando que todo o treinamento necessário seja ministrado para que os funcionários possam tratar adequadamente os clientes, principalmente os que tenham sido, ou pensem ter sido, injustamente tratados pela empresa, idéia compartilhada por Winer (1999:373). A empresa deverá, paralelamente, além de estimular atitudes que reduzam o número de queixas recebidas, criar um sistema de compensação que dê aos seus funcionários reforço positivo para o seu comprometimento e às ações capazes de solucionar problemas e, ao mesmo tempo, agradar aos clientes (Hart, Heskett e Sasser Jr., 1994:288). Os autores Hart, Heskett e Sasser Jr. (1994:279) acreditam que todo problema de clientes é uma nova oportunidade para que a empresa possa provar seu compromisso com o serviço, mesmo não sendo responsável pelo ocorrido. No entanto, os problemas não são repetitivos. A administração do Minneapolis Marriot City Center, da cadeia Marriot, autorizou seus funcionários a gastarem até US\$10, segundo seu próprio julgamento, para satisfazer eventuais necessidades de clientes.

Hart, Heskett e Sasser Jr. (1994:287) definem a autoridade para agir como o conjunto de recursos aos quais o funcionário tem acesso, e das decisões que lhe são permitidas tomar. Ao delegarem poderes a funcionários, as empresas devem deixar claro que eles poderão utilizar julgamento próprio para fazer ligações telefônicas, creditar contas, ou até enviar flores e bombons. Já a responsabilidade reside num outro nível: os funcionários são responsáveis pelo reconhecimento e pelo atendimento das necessidades dos clientes. Responsabilidade significa obrigação de agir, e não apenas de aceitar a culpa. Além do treinamento para as pessoas que interagem diretamente com seus clientes, a empresa terá que lhes delegar poderes, conferindo-lhes autoridade, responsabilidade e incentivos para que reconheçam, interessem-se pelos clientes e atendam às suas necessidades. $\mathrm{O}$ treinamento deve focalizar o aspecto de tomada de decisões próprias e o desenvolvimento de técnicas criativas de comunicação e de percepção em relação às preocupações dos clientes (Hart, Heskett e Sasser Jr., 1994:285), além da visão global dos processos dentro da empresa.

Algumas empresas utilizam-se de compradores contratados, geralmente um terceiro imparcial, sem experiência anterior com a empresa, para avaliar o serviço recebido. Este método não tendencioso serve para monitorar os funcionários, diagnosticar pontos problemáticos no serviço ao cliente e medir o impacto do treinamento de funcionários (Boone e Kurtz, 2001:160). Além disso, sabe-se que é prática comum em algumas empresas um supervisor monitorar os atendimentos telefônicos de seus funcionários, sem que estes saibam o momento em que estão sendo monitorados, com atribuição de notas e registro de comentários relacionados à performance do 
atendimento. Tal avaliação foca desde pontos como cortesia e atenção ao cliente, até aspectos relacionados ao conteúdo das informações transmitidas a ele e a efetiva resolução do problema. Hutchison e Stolle (1994:106) exaltam a importância da existência de controles para os serviços prestados pela empresa, com o estabelecimento de padrões de performance, a sua medição real, uma análise do serviço prestado em relação ao padrão definido, e a aplicação de medidas corretivas, se necessário, visando ao realinhamento da performance real. Whiteley (1997) e Winer (1999:365) afirmam que empresas em processo mais evoluído analisam seu desempenho não apenas em relação ao próprio passado e aos desejos dos clientes, mas também em relação à performance de quem, em qualquer parte do mundo, esteja realizando melhor uma tarefa semelhante, a fim de determinar tendências em diferentes segmentos de mercado ou áreas de produtos.

Nenhuma atividade isolada é capaz de criar uma empresa voltada ao cliente. Pelo contrário, a manutenção de clientes requer que ações gerenciais coordenadas sejam implementadas ao longo do tempo para que se desenvolvam e se aprimorem os relacionamentos com clientes, ao mesmo tempo em que a eficiência organizacional é incrementada (Shapiro e Sviokla, 1994:XVI). "O relacionamento entre vendedor e comprador raramente termina quando uma venda é realizada. Esse relacionamento vai sendo intensificado cada vez mais (...) e auxilia na decisão de escolha do comprador por ocasião de sua próxima aquisição. (...) A qualidade dessa união irá depender de como o vendedor será capaz de administrar o relacionamento, (...) o que requer particular atenção com relação a um aspecto freqüentemente esquecido nos relacionamentos: o tempo (...)” (Levitt, 1994:41). Relacionamentos que são cultivados com vistas a um horizonte de longo prazo têm maior probabilidade de frutificar, ou seja, de gerar novas transações.

Tendo sido apresentados vários aspectos do marketing de relacionamento, nas seções seguintes, serão analisados elementos relacionados à evolução da Internet como ferramenta de negócios, suas implicações para a empresa e para o marketing, em especial. 


\subsection{Internet}

A figura 16 destaca o conteúdo teórico a ser apresentado nesta seção.

Figura 16 - Estrutura da seção: Internet

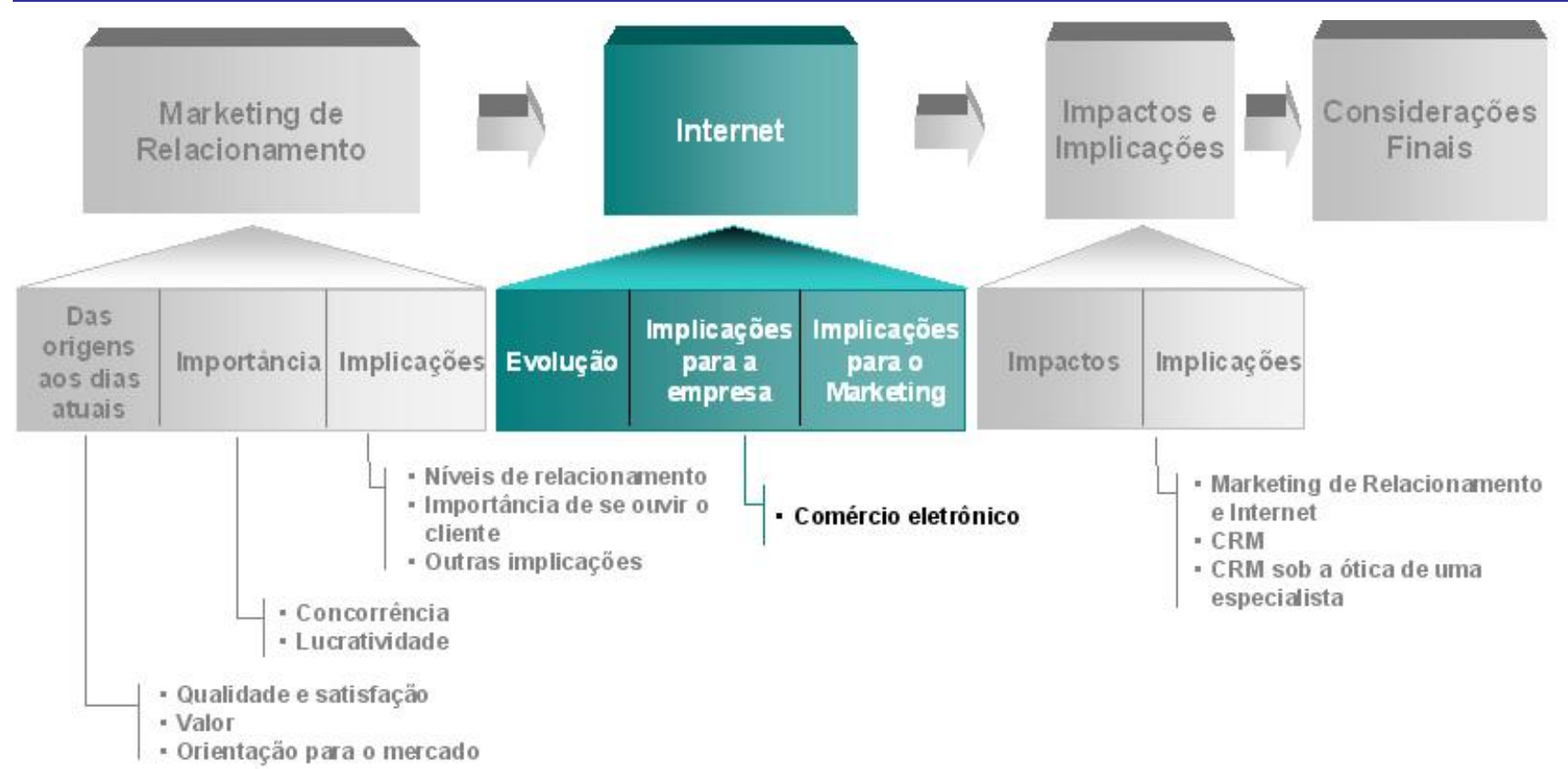

Fonte: a autora.

No entendimento de Boone e Kurtz (2001:25), a tecnologia é a aplicação, aos negócios, do conhecimento baseado em descobertas científicas, invenções e inovações, os quais, aliados à pesquisa (Churchill e Peter, 2000:45), resultam em bens e serviços novos ou aperfeiçoados e constituem o ambiente tecnológico do marketing, um dos que podem interferir nas decisões de uma empresa. As tecnologias de multimídia interativa, como as redes de computadores, vídeoconferências, serviços online, a Internet, quiosques interativos, catálogos em CD-ROM e assistentes pessoais digitais (handhelds) têm revolucionado o armazenamento, distribuição, recuperação e apresentação das informações. As redes de computadores e outras tecnologias de telecomunicação conectam funcionários de uma mesma empresa, fornecedores e clientes em localidades distintas por meio da Internet, de intranets ou de extranets. As intranets são, em uma descrição sucinta, uma Internet de acesso privado, utilizada corporativa e exclusivamente pelos funcionários das empresas para comunicação, análise de informações e tomada de decisões. Já as extranets são redes de comunicação entre a empresa e seus fornecedores, clientes e parceiros de negócios (Boone e Kurtz, 2001:120). Estes avanços tecnológicos abrem caminho para o surgimento de transformações significativas no marketing. 
Muito se tem discutido sobre a Internet, mas este assunto ainda está bem longe de se esgotar. E, por esta razão, talvez não seja mais necessário discutir a origem da Internet, uma vez que vários outros autores como Roberts (2003); Turban et al. (2000); Laudon e Laudon (2000); Dodd (2000); Winer (1999); Kosiur (1997) e Gralla (1996) já abordaram este tema. Desta forma, “neste momento, a Internet precisa ser abordada como o que realmente é: uma poderosa tecnologia que é a base de várias novas soluções que estão sendo utilizadas em quase todos os setores econômicos” (Porter, 2001:64).

Roberts (2003:7) afirma que a “a Internet possui uma série de características que a diferenciam de qualquer outra mídia ou canal na história e que contribui para sua rápida difusão”. Entre estas características, essa autora evidencia que a Internet:

- É uma plataforma comum para comunicação e transação;

- Reduz as assimetrias informacionais ao permitir o acesso de indivíduos e empresas a uma quantidade exorbitante de informações a um custo pequeno ou próximo do nulo;

- Permite um processo de comunicação interativo, próximo de um diálogo;

- Possui alcance global;

- Oferece, ao menos em teoria, oportunidade para que organizações concorram no mercado sem interferência de questões como tamanho ou distância;

- É uma rede em funcionamento constante;

- É uma rede de comunicação “muitos para muitos”, se comparada com a situação "um para um” do telefone, ou “um para muitos” da televisão ou rádio.

Com essas características e o fato de que a tecnologia da informação está cada vez mais acessível a todos os tipos de organizações (Carr, 2003), já não é possível ignorar a Internet como um elemento de negócios. Contudo, em função do recente colapso da economia "ponto-com”, devido à queda drástica do valor das ações das empresas baseadas em Internet no início de 2000, um dos focos principais de discussão recai sobre como a Internet pode ser utilizada pelas empresas para alavancar seus negócios (Porter, 2001).

Para Drucker (2000), o real impacto da Revolução da Informação está apenas começando a ser sentido. Entretanto, não é a informação que vai gerar tal impacto, nem a inteligência artificial, nem o efeito dos computadores sobre os processos decisórios, nem a determinação de políticas ou criação de estratégias. Para esse autor, é o comércio eletrônico via Internet que está causando o maior impacto, provocando alterações significativas na economia, nos mercados e nas estruturas de 
setores inteiros: em produtos e serviços, no fluxo de informações, na segmentação, nos valores e comportamento dos consumidores, no mercado de trabalho e no nível de emprego. Porter (2001:64) acredita que a Internet, por si, raramente é uma vantagem competitiva: as empresas que utilizam a Internet aliada às formas normais de competição é que terão maiores chances de sucesso do que se mantivessem as iniciativas associadas à Internet separadas do corpo de suas principais operações.

\subsubsection{A evolução da Internet}

A evolução da Internet é usualmente lembrada pelo seu rápido crescimento comercial (Wehling, 1995, in Churchill e Peter, 2000:46), ao atingir 50 milhões de usuários em 5 anos, comparado ao de outras mídias tradicionais como rádio, televisão ou televisão a cabo - 38, 13 e 10 anos, respectivamente (Roberts, 2003:7). Porém, mais relevante para este estudo é perceber a evolução das capacidades e das funcionalidades da Internet, já que estas características possuem relação direta com o modo como as organizações estão utilizando a Internet para conduzir seus negócios em geral, e para desenvolver seu marketing de relacionamento, em particular.

Figura 17 - Formas de conexão à Internet

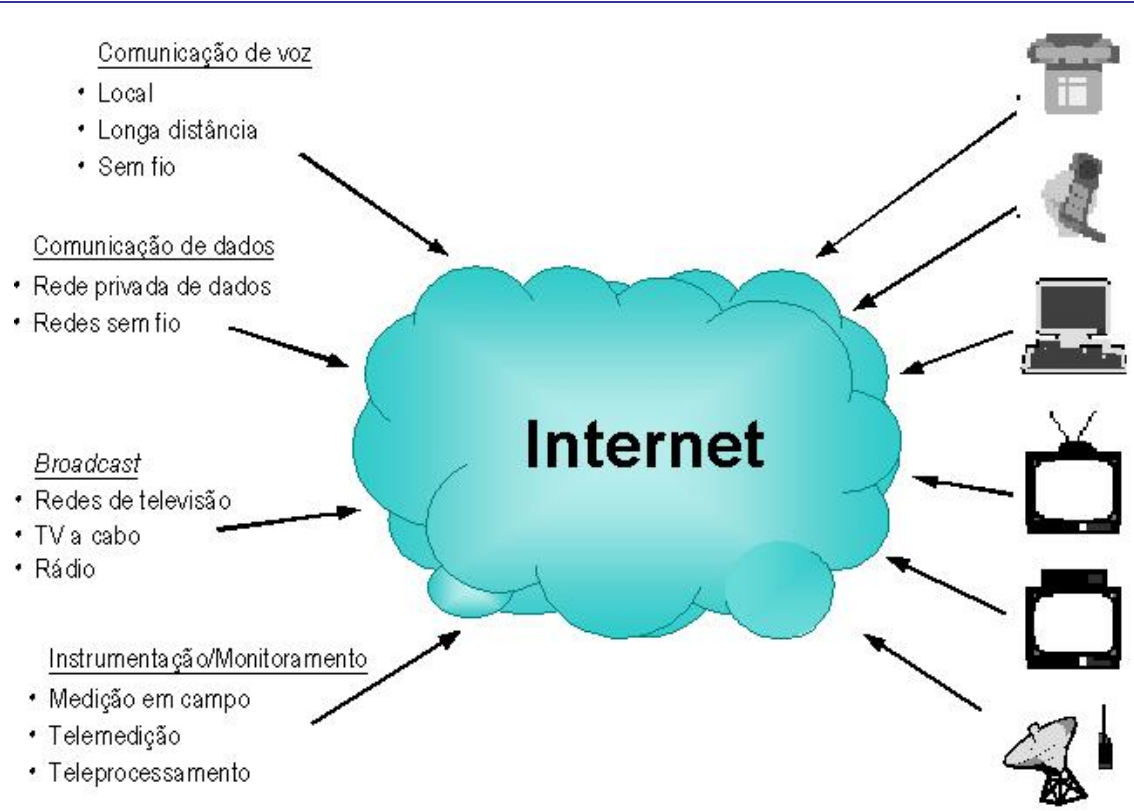

Fonte: Salomon Smith Barney, in Mahedy e Joe (2000: 05).

A primeira evolução relevante está ocorrendo na forma de acesso à Internet. Antes restrita a redes acadêmicas de computadores, atualmente a Internet pode ser acessada a partir de telefones celulares e equipamentos sem fio. Em função do avanço desta forma de acesso, serviços de campo, coleta de informações

monitoramentos remotos podem ser feitos com utilização da Internet. O mesmo ocorre com serviços de voz e comunicação de dados, o que permite a integração com outras mídias como rádio e televisão, como pode ser observado na figura 17. Uma segunda evolução importante diz respeito à velocidade de conexão entre os computadores interligados pela Internet, o que permite o aperfeiçoamento de 
funcionalidades e o desenvolvimento de novos serviços e aplicações. O trabalho cooperativo e simultâneo entre várias equipes de desenvolvimento situadas em locais diferentes é um exemplo de atividade que se beneficia da evolução da velocidade de conexão. No Brasil, em especial, a evolução desta capacidade é observada no crescimento de acessos em banda larga. Segundo o instituto de pesquisa IDC, o número de usuários de Internet em banda larga cresceu de 53 mil em 1999, para 695 mil em 2002, o que representa um crescimento médio anual de 135\% (Silveira, 2003:09).

A evolução do número de usuários também traz impactos à forma como as empresas utilizam a Internet. No caso brasileiro, houve um avanço de 1,3 milhões de usuários em 1997, para cerca de 14,3 milhões em 2002 (International Telecommunications Union, 2003). Uma outra pesquisa indica que o número de usuários teria ultrapassado os 20 milhões em 2002 (IBOPE eRatings, Junho de 2003, in e-Bit, 2003). Apesar de esse número ainda expressar uma baixa taxa de penetração da Internet, se comparado ao de outros países, há uma forte concentração de potencial de consumo neste segmento, já que 96\% dos usuários brasileiros pertencem às classes A e B (Revista da Sociedade Digital, 2001:11). Em 2003, mais de dois milhões de pessoas já tiveram pelo menos uma experiência de compra pela Internet, o que equivale a um crescimento de mais de $60 \%$ em relação ao início de 2002, quando apenas 1,2 milhões de pessoas haviam comprado em alguma loja virtual. Mesmo assim, uma grande parcela da população de internautas ainda não realizou nenhuma compra pela Internet (e-Bit, 2003).

A evolução da Internet não se restringe aos aspectos estruturais como formas de acesso, velocidade de conexão ou número de usuários. Sua aplicação nos negócios também evoluiu.

Em 1997, Kosiur, então pesquisador de uma grande empresa de software, propôs uma evolução das funcionalidades da Internet, como se pode observar na figura 18. Segundo Kosiur (1997:107), a primeira fase da Internet como ferramenta de negócios foi a fase da "Presença", na qual as empresas desenvolviam sites para tornar públicas e disponíveis informações institucionais e de seus produtos e serviços. Nos EUA, esta fase

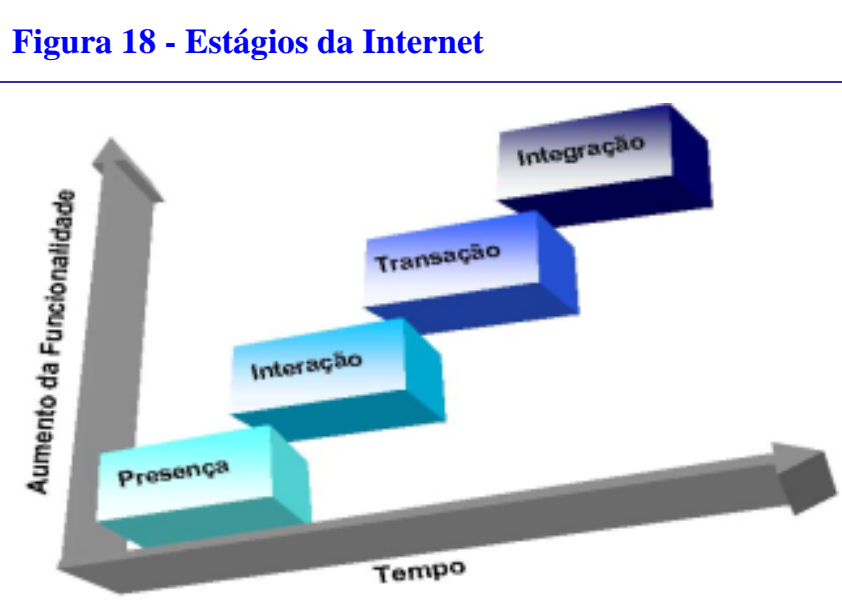

Fonte: Kosiur, 1997. 
iniciou-se por volta de 1993 e, no Brasil, cerca de dois anos depois. A partir da segunda fase Interação - os sites institucionais ganharam interatividade mediante consultas no próprio site, formulários, registros de informações, consultas online ao banco de dados e facilidade no envio de mensagens eletrônicas (e-mails) a partir do próprio site. O comércio eletrônico com o recurso da Internet surgiu na terceira fase - Transação - com o aperfeiçoamento da criptografia, a qual permitiu que informações sigilosas, como números de cartões de crédito, fossem enviadas de maneira mais segura. Também nesta fase iniciou-se a transferência eletrônica de fundos via Internet. Com o surgimento do comércio eletrônico, o usuário de Internet passou a adquirir bens ou serviços remotamente, ou seja, à distância, sem necessidade de dirigir-se fisicamente à loja. Kosiur (1997) chama a quarta fase de "Processo", enquanto a empresa de consultoria Andersen Consulting expande esta fase para o que chama de "Integração". Ambos os conceitos são complementares e retratam o estágio corrente, marcado pela automatização quase total dos processos da empresa, incluindo os que envolvem o relacionamento com fornecedores e clientes, como os sistemas de pedidos e de pagamentos.

Numa visão similar, Sterne (2000:2) identifica as fases da Web cujo uso comercial, em sua opinião, não surgiu como uma ferramenta voltada para o serviço ao cliente, mas sim, como uma mídia de marketing:

- Fase 1: a Página do Produto, na qual os cliques no site seriam uma alternativa a folhear um catálogo.

- Fase 2: o Web site Corporativo, com informações sobre a empresa e seus produtos, políticas e opiniões, white papers e press releases, programações de eventos, organograma, mensagem da presidência etc.

- Fase 3: o Web site Participativo, o qual permite aos visitantes do site interagir e até brincar com ele, ao invés de apenas visualizar anúncios estáticos. Nesta fase, as empresas passaram a considerar interessante a venda de espaço para anúncios em seu site - era fácil convencer os anunciantes de que sua mensagem poderia ser vista por milhões de pessoas ao redor do mundo -, além de perceberem as vantagens das aplicações de serviços ao cliente via Internet.

Em 2001, Leggett et al., analistas de tecnologia de um banco de investimentos, propuseram um modelo de evolução semelhante ao de Kosiur (1997:107), porém com análise de um espectro maior de adoção, que extrapola os limites da empresa, como se pode notar na figura 19. Leggett et 
al. (2001:14) esclarecem que as empresas, ao utilizar a Internet como ferramenta de negócios, passam pelas fases de experiência, inovação, otimização e alavancagem/expansão.

Em cada uma destas fases, segundo esses autores, Figura 19 - Evolução da adoção da Internet como ferramenta de negócios a empresa utiliza a Internet com fim específico, incorporando a finalidade da fase anterior. A fase da experiência inicia-se com a criação de um Web site para divulgação institucional e com a utilização de intranets. Um dos benefícios da intranet é a possibilidade de superação

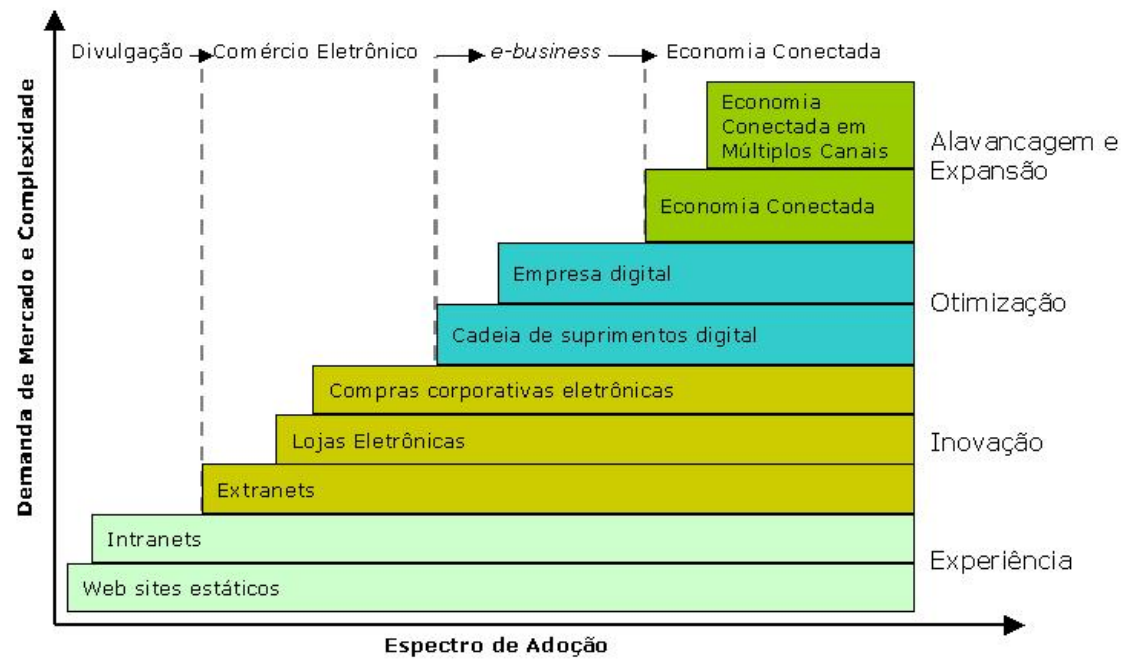

Fonte: Leggett et al. (2001:14). da distância geográfica entre pessoas de uma mesma equipe de projeto, que podem trocar informações via rede (Winer, 1999:19).

A fase de inovação pressupõe que a empresa já tenha passado pela fase de experiência, e tenha desenvolvido conhecimento para criar uma extranet, para troca de informações com parceiros. Uma de suas principais utilizações são as compras corporativas, que passaram a ser eletrônicas com a integração entre os sistemas da empresa fornecedora e os da empresa cliente. As extranets estão aprimorando conceitos como just-in-time e efficient consumer response. O primeiro benefício direto é a redução drástica do estoque de produtos acabados e de matérias-primas, uma vez que o planejamento e o controle de produção pode ser feito com informações em tempo real. Outro benefício relevante é a fabricação de itens personalizados e “customizados” para a necessidade de um determinado cliente, mesmo para produtos que envolvam maior complexidade, como um automóvel, por exemplo.

No próximo momento, a empresa lança mão do comércio eletrônico também com clientes finais e fornecedores. O aperfeiçoamento e integração das fases de experiência e inovação oferecem elementos de aprendizado para que a empresa entre no estágio que Leggett et al. (2001:14) chamam de fase de otimização, onde são previstas a integração da cadeia de suprimentos e o que os autores chamam de 'empresa digital', na qual todos os sistemas internos e externos da empresa estão 
conectados e integrados. A fase final prevista por esses autores é a fase de alavancagem e expansão, na qual várias empresas passam a estar conectadas e integradas, expandindo esta condição para toda a economia.

É possível classificar uma empresa seguindo o modelo de Kosiur (1997) ou de Leggett et al. (2001), porém tal classificação terá forte influência do porte da empresa, do seu setor de atuação e também da sua localização.

Um estudo de 1999 do instituto

Figura 20 - Adoção da Internet

The Economist Intelligence Unit sinalizava que empresas dos Estados Unidos, Canadá e América Latina já tinham passado pela fase de Presença (Kosiur, 1997:107) ou de Web sites estáticos de Leggett et al. (2001:14) e estavam rumando para a fase de Interação de Kosiur (1997:107) ou de Inovação de Leggett et al. (2001:14). Segundo o estudo, para as empresas

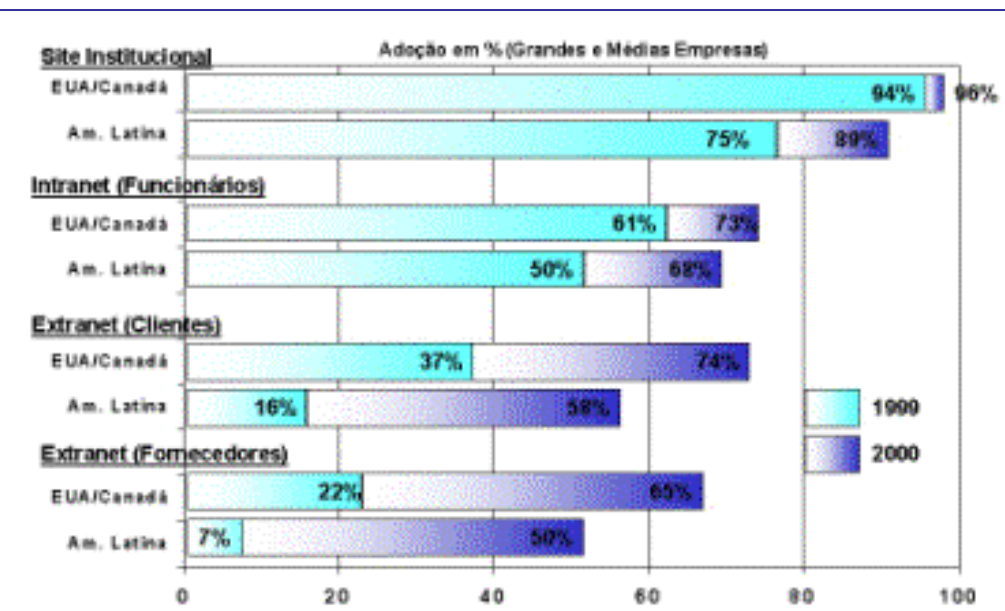

Fonte: adaptado de The Economist, 1999. norte-americanas, a Internet é uma realidade; as grandes e médias empresas da América Latina têm realizado investimentos crescentes, reduzindo a diferença em relação às empresas da América do Norte, conforme pesquisa conduzida pelo The Economist Intelligence Unit (The Economist, 1999). Segundo essa pesquisa (figura 20), cerca de 89\% das médias e grandes empresas da América Latina teriam sites institucionais no final de 2000; contudo, a agradável surpresa apontada por essa pesquisa é a rápida adoção de intranets e extranets também pelas empresas latino-americanas. A crescente adoção destes instrumentos na América Latina mostra que, apesar das restrições, as empresas da região estão se preparando para adquirir mais competitividade.

Observado o estudo do The Economist Intelligence Unit anteriormente mencionado, o desafio atual é o da fase da Transação de Kosiur (1997:107) ou da fase de Inovação de Leggett et al. (2001:14), que considera como principal elemento o comércio eletrônico, assunto discutido na próxima seção. 


\subsubsection{As implicações da Internet para a empresa}

Por possuir tantas características únicas (Roberts, 2003), a Internet oferece uma série de oportunidades de negócios, com capacidades distintivas, (Porter, 2001; Drucker, 2000), porém talvez não tão revolucionárias como imaginavam vários autores (Schartz, 1999; Windham e Samsel, 1999) no auge de uma fase que passou para a história dos negócios como “nova economia”.

Os modelos de evolução apresentados na seção anterior servem como subsídio para se ter uma noção da complexidade da Internet e de suas implicações para a empresa. O grau de complexidade é ampliado com as aplicações mencionadas por Wind e Mahajan (2001:4), que examinaram as principais mudanças no ambiente de negócios em função da Internet e observaram algumas características, dentre as quais se destacam:

- Soluções integradas interfuncionais, como por exemplo, a necessidade trazida pela “customização”, que envolve marketing, operações, e serviços ao cliente;

- Perspectiva global: alcance global, porém com o risco de não se conhecerem o comportamento de compra e as necessidades e preferências dos compradores de todas as localidades.

Winer (1999:17), além das características apresentadas por Roberts (2003:7) na seção 2.2., acrescenta que a Internet também é:

- Um meio de disseminar informações sobre o produto ou serviço: quase todo Web site corporativo inclui informação sobre as linhas de produtos da empresa, lançamentos e indicação de formas de contato para informações adicionais.

- Uma forma de responder a questões técnicas sobre o uso do produto: inclui desde a possibilidade de se enviarem e-mails à empresa a partir do seu próprio Web site até respostas a perguntas mais freqüentes.

Laudon e Laudon (2000) complementam essas observações apresentando outros elementos que devem ser também considerados no panorama da Internet como:

- Redução do custo de comunicação: o custo de transmissão, processamento e armazenagem de informações cai significativamente quando a comunicação é realizada pela Internet. Campanhas de mala direta na Internet, por exemplo, não implicam em custos de papel, impressão ou postagem. 
- Redução do custo de transação: na transação pela Internet, por não se envolver uma rede física, não se incorre em muitos dos custos inerentes ao processo. Além do exemplo da mala direta, podem ser citadas as transações bancárias, dentre outros.

- Redução dos custos de administração: muitos dos custos administrativos, principalmente os relacionados à estrutura física, podem ser automatizados pela Internet, o que gera sensíveis reduções de custos para a empresa.

- Interatividade, flexibilidade e personalização: as páginas Web oferecem experiências interativas para o visitante, fato que não seria possível em uma mídia impressa, além de permitir a utilização de soluções com conteúdo personalizado.

- Aceleração da distribuição do conhecimento: como já observado nos modelos de evolução das funcionalidades da Internet de Kosiur (1997) e Leggett et al. (2001), a Internet prevê a disseminação de aplicações como Web sites institucionais, intranets e extranets, além de permitir que o usuário tenha acesso a uma base de dados incomensurável, disponível em vários Web sites, o que possibilita que a distribuição do conhecimento seja acelerada e ampliada.

Roberts (2003:8) esclarece que, para a empresa, vários benefícios podem ser observados nos resultados da redução de custos, aumento da qualidade, ampliação do acesso e das opções de escolha:

- Custo: uma transação bancária passa de, aproximadamente, US\$1,00 em agência bancária tradicional para US\$ 0,04 quando realizada via Internet;

- Qualidade: o processo de desenvolvimento compartilhado via Internet do novo modelo 777 da Boeing gerou apenas um décimo do número de erros observados no desenvolvimento do modelo anterior, realizado por meio de reuniões físicas tradicionais.

- Acesso: enquanto uma boa loja de varejo atrai 50 mil visitantes por mês, um site de comércio eletrônico pode receber cinco milhões de visitas no mesmo período.

- Escolha: é possível acessar até quatro milhões de títulos em uma livraria online enquanto que, em livrarias tradicionais, este número pode chegar até 160 mil títulos.

Um Web site eficaz também constrói lealdade dos clientes (Boone e Kurtz, 2001:135). Contudo, em função da complexidade de seu desenvolvimento, a Internet, apesar de oferecer boas oportunidades para as empresas, pode representar também uma ameaça à continuidade do modelo de negócios (Ghosh, 1998). 
As funcionalidades oferecidas pela Internet podem implicar, por exemplo, em novos modelos de negócios por meio da virtualização do negócio, de novos processos de intermediação ou por meio de novas estruturas organizacionais. A respeito deste assunto, Laudon e Laudon (2000:305) ressaltam que as empresas produtoras podem vender seus produtos e serviços diretamente aos consumidores finais, independentemente de intermediários, o que pode reduzir os custos das transações de compras, possibilitando à empresa auferir maiores margens de lucros, sem aumentar preços. A tecnologia permite à empresa ignorar ou antecipar-se a outras na cadeia de valor (Ghosh, 1998:127), o que pode gerar muitos conflitos, principalmente, com os canais de distribuição.

Sterne (2000:4) observa que reduzir custos pela entrega eletrônica de informação já poderia ser suficiente para a maioria dos vendedores finais justificarem a sua entrada no mundo Web. Entretanto, argumenta que, adicionalmente, a Web pode ser vista como uma "via de mão-dupla, um meio de comunicação, não como uma TV, um rádio ou uma revista, mas mais próxima de um telefone, com a habilidade de 'ouvir e ser ouvida'”: ela permite que ocorra a conversação, a qual, no passado, era escrita, na atualidade, é verbal e, em breve, será visual. As áreas de serviços ao cliente de algumas empresas, por exemplo, já operam nesse novo formato.

A Internet também implica em um novo comportamento do consumidor, que tem maior acesso a informações, à possibilidade de comparar preços e a efetuar a compra, entre outras capacidades, e tudo pelo computador, sem sair de sua residência. A Internet como mídia também é outra implicação nova para a empresa (Nakagawa, 2003). A Internet oferece a oportunidade de permitir que a empresa simultaneamente anuncie, execute a venda e receba o pagamento (Schumann, Artis e Rivera, 2001).

\subsubsection{Comércio eletrônico}

Dentre as implicações da Internet para as organizações, o comércio eletrônico (electronic commerce/e-commerce) é uma das aplicações mais facilmente observadas e que está trazendo resultados práticos a algumas empresas (Drucker, 2000). Winer (1999:256) destaca que, embora a Internet sirva a uma grande variedade de propósitos que não as vendas, como informações sobre produtos e serviços ao cliente, sua maior força está em sua habilidade de dar aos clientes acesso direto a produtos e serviços. Apesar de não ser conceitualmente novo, já que as primeiras aplicações de comércio eletrônico remontam à década de 1970, com a transferência eletrônica de fundos (EFT) e a troca eletrônica de dados (EDI) (Kosiur, 1997:1), o comércio eletrônico ganhou impulso com a 
Internet (Turban et al., 2000:13). Zwass (1996, in Boone e Kurtz, 2001:117) define o comércio eletrônico (electronic commerce/e-commerce) como a busca por clientes por intermédio da coleta e análise de informações de negócios, a condução de transações com os clientes, e a manutenção de relacionamentos online com clientes por meio de redes de telecomunicações.

Similarmente, para Kosiur (1997:4), o comércio eletrônico é um sistema que inclui não apenas as transações que se concentram na compra e venda de bens e serviços para, diretamente, gerar receitas, mas inclui também as transações que dão suporte à geração de receitas como, por exemplo, a geração de demanda por bens e serviços, a oferta de suporte de vendas e serviço ao cliente e a facilitação da comunicação entre parceiros de negócios, como ilustra a figura 21.

Figura 21 - O ciclo do comércio eletrônico

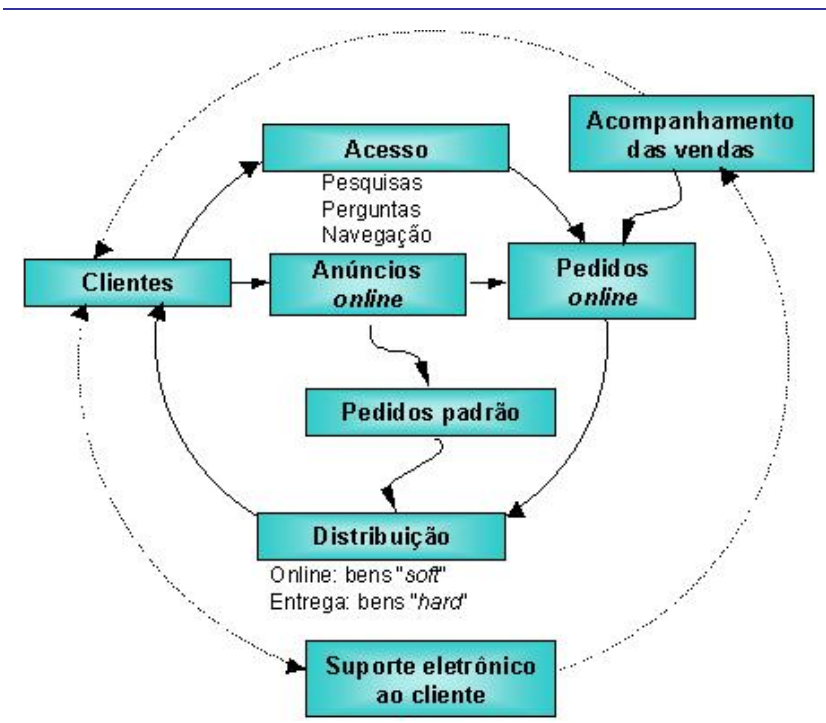

No processo tradicional de compras, o Fonte: Kosiur (1997:5). comprador gera uma solicitação, ganha aprovação, seleciona um fornecedor apropriado, verifica a disponibilidade e emite um pedido de compra. Segundo esse autor, o uso de um único meio para todos os passos do ciclo de compras é muito mais eficiente. Além disso, o comércio eletrônico pode simplificar a comunicação e mudar os relacionamentos.

Choi, Whinston e Stahl (1997) elaboraram um modelo simples, porém significativo para representar a dinâmica do comércio eletrônico e entender o impacto da Internet sobre o Composto de Marketing. Segundo esses autores, o comércio eletrônico é composto de três dimensões básicas, como se pode observar na figura 22:

1. do produto: o executivo de marketing precisa entender se seu produto pode ser negociado também na forma digital, além de na forma atômica tradicional.

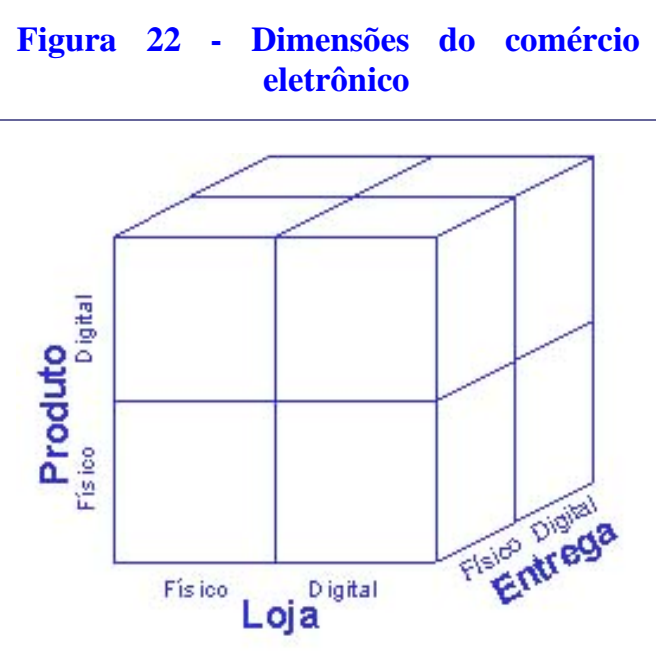

Fonte: Choi, Whinston e Stahl (1997). 
2. da loja, onde o consumidor pode adquirir o produto ou serviço. A loja pode ser feita de tijolos e concreto, em uma esquina movimentada do mundo físico, ou pode ser uma loja virtual, hospedada em um computador conectado à Internet em qualquer lugar do mundo.

3. da entrega do bem adquirido. A entrega tradicional é feita ao consumidor dentro da loja, ou entregue em sua residência por transportadores ou entregadores convencionais. Dependendo da natureza do produto ou serviço, é possível fazer a entrega digital, seja mediante um arquivo enviado pela Internet, ou gravado em disquete, CD ou DVD.

Figura 23 - Digitalização da loja

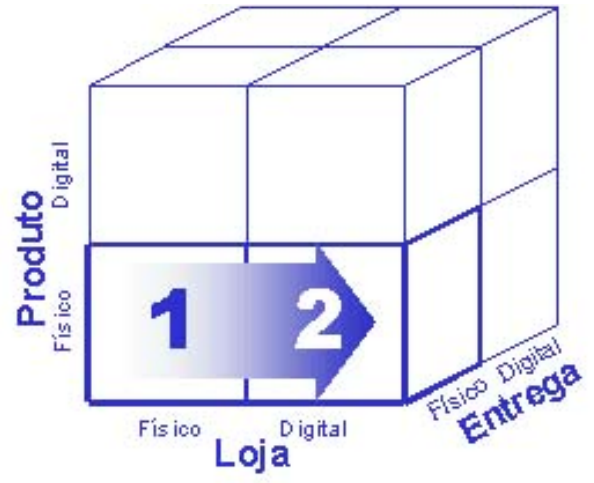

Fonte: Choi, Whinston e Stahl (1997).
A maioria das empresas não possui produtos “digitalizáveis”. Fabricantes de cimento, de máquinas e equipamentos, e produtores de laranja poderão utilizar a Internet como um canal de negociação. Segundo o modelo de Choi, Whinston e Stahl (1997) representado na figura 23, estas empresas estão migrando da situação 1 (“tijolos-eargamassa”, ou "bricks and mortar”) para a situação 2 (“tijolos-e-cliques”, ou “bricks and clicks”). É o caso das empresas Pão de Açúcar, Ponto Frio, Livraria Saraiva, Lojas Americanas e Clark Calçados ${ }^{5}$. Outras empresas, como Submarino.com, Shoptime.com, Closet.com.br, já foram criadas diretamente nesta situação. Alguns fabricantes passaram a vender diretamente para o consumidor final como a Dell.com.br, Hpstore.com.br e Compaq.com.br/loja. Todas estas empresas comercializam produtos físicos por intermédio de lojas digitais e fazem a entrega física do produto.

Entretanto, parcelas menores de empresas, as que negociam produtos “digitalizáveis”, iniciarão processos de reinvenção de seus setores de atividade. Estas empresas precisarão se reinventar para continuar existindo. É o caso das locadoras de fita de vídeo, por exemplo, que correm o risco de serem absorvidas pela Internet de banda larga. Livros já podem ser comprados em formato de arquivos, ou mesmo lidos online

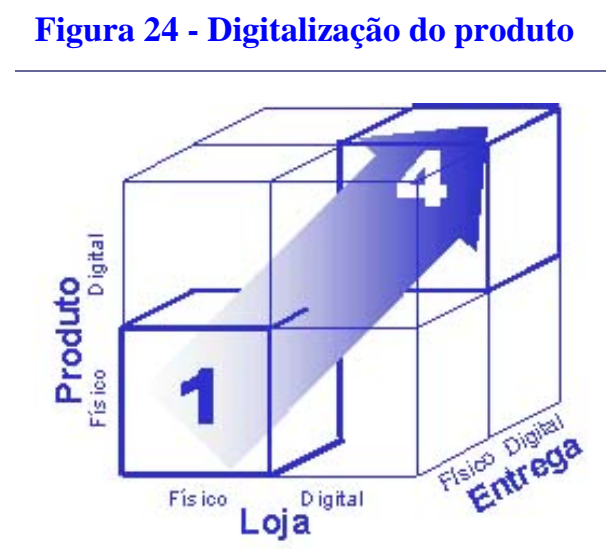

Fonte: Choi, Whinston e Stahl (1997).

5 Pão de Açúcar Delivery, e depois Amelia.com.br e Paodeacucar.com.br; Pontofrio.com.br; Americanas.com; Saraiva.com.br e Clarkcalcados.com.br, respectivamente. 
diretamente do computador, ou de qualquer outro aparelho conectado à Internet. Agências de bancos, agências de viagens e de seguros já estão vendendo seus produtos com o recurso de lojas virtuais, que funcionam 24 horas por dia, 365 dias por ano. Neste caso, as empresas estão saindo da situação 1 (“tijolos-e-argamassa”) para a situação 4 (cliques), representada na figura 24, onde produto, loja e entrega são digitais. Sites como MP3.com ou Amazon.com já vendem música e livros, respectivamente, em formato digitalizado.

O processo de digitalização da loja, do produto e da entrega tende a evoluir e a se consolidar no Brasil, causando impacto no processo gerencial de marketing, com intensidade variável, dependendo da natureza do negócio e do setor de atividades em que ele se insere - comércio, indústria ou serviços (Toledo, Nakagawa e Yamashita, 2001:51). Boone e Kurtz (2001:117), sob outra perspectiva, afirmam que o comércio eletrônico fornece fundamentos para o lançamento de novos negócios, ampliação do alcance das empresas existentes, e a construção e manutenção dos relacionamentos com clientes.

Entretanto, muitas das questões tradicionais de marketing ainda precisam ser resolvidas, tais como preço, distribuição, estoques, propaganda e promoção e serviço ao cliente. O comércio eletrônico oferece um número ilimitado de oportunidades para que os profissionais de marketing alcancem seus clientes (Boone e Kurtz , 2001:118).

Inúmeras pesquisas têm sido dedicadas a avaliar os determinantes do comportamento dos consumidores nas compras via Internet. Uma delas correlacionou as compras de produtos online a um estilo de vida “wired”, ou “conectado” (Bellman et al., 1999, in Dholakia e Bagozzi, 2001:189). Tal pesquisa descobriu que usuários de Internet experientes e com pouca disponibilidade de tempo seriam mais propensos a realizar compras online. Outra pesquisa, conduzida por Hoffman, Novak e Peralta (1999, in Dholakia e Bagozzi, 2001:189), identificou três principais barreiras à ampla adoção dos ambientes digitais para a realização de compras:

- Perda percebida da privacidade da informação, definida como a habilidade do consumidor em controlar o acesso de outras pessoas a suas informações pessoais;

- Perda percebida de controle ambiental, definida como a habilidade do consumidor em controlar as ações de outras entidades no ambiente durante uma transação comercial;

- Possibilidade de uso secundário da informação, relacionada à habilidade do consumidor em controlar a disseminação de informação relacionada ou fornecida durante as transações ou comportamentos comerciais a terceiros. 
Dholakia e Bagozzi (2001:190) destacam algumas variáveis psicológicas que podem influenciar as compras online:

- Familiaridade e satisfação com os métodos correntes de compra de produtos, como o caso dos consumidores que gostam de percorrer os corredores de lojas e shopping centers e que estariam menos propensos a comprarem online.

- Emoções antecipadas, como medo ou esperança, porém ainda com estudos incipientes.

- Fatores pessoais, como propensão à busca de variedade (Baumgartner e Steenkamp, 1999, in Dholakia e Bagozzi, 2001:190), ou necessidade de avaliação (Jarvis, Blair e Petty, 1996, in Dholakia e Bagozzi, 2001:190).

- Normas sociais, relacionadas aos laços fortes e fracos do consumidor.

- A influência da experiência com o ambiente digital sobre o comportamento de compra.

Algumas pesquisas mostram que os consumidores modificam seus comportamentos na Internet ou Web à medida que adquirem experiência. Hammond et al. (1998, in Dholakia e Bagozzi, 2001:190) descobriram que os consumidores novatos desenvolvem apreciação pelos ambientes digitais como uma fonte de informação, à medida que se tornam mais familiarizados com os mesmos. Da mesma maneira, outros pesquisadores notaram que os experts estão mais bem habilitados a inferir os benefícios pretendidos do produto a partir de informações técnicas, e a inferir causas técnicas prováveis dos benefícios anunciados (Alba e Hutchison, 1987, in Dholakia e Bagozzi, 2001:190).

O quadro 4 apresenta os resultados de uma pesquisa sobre as razões pelas quais alguns clientes realizam compras online, ou, no extremo oposto, evitam realizar transações online:

Quadro 4 - Determinantes do comportamento de compra online

\begin{tabular}{llll}
\hline \multicolumn{1}{c}{ Motivadores } & \multicolumn{2}{c}{ Desestimuladores } \\
\hline Economia & $75 \%$ & Privacidade/Segurança & $53 \%$ \\
\hline Conveniência & $50 \%$ & Navegação pobre & $35 \%$ \\
\hline Melhor seleção & $48 \%$ & Nenhum reconhecimento de marca & $24 \%$ \\
\hline Diversão & $29 \%$ & Preços mais altos & $20 \%$ \\
\hline Evitar multidões/ vendedores & $11 \%$ & Impossibilidade de ver ou tocar o produto & $20 \%$ \\
\hline
\end{tabular}

Fonte: Boone e Kurtz (2001:129). 
Os benefícios para os compradores online podem ser classificados em três categorias: menores preços, conveniência e personalização. Algumas ferramentas, como os bots ${ }^{6}$, podem auxiliar os consumidores nas compras comparativas, como também alguns pacotes de software e até mesmo alguns Web sites que oferecem comparações automáticas de preços e produtos. Os profissionais de marketing devem assegurar-se de que seus Web sites ofereçam tais vantagens básicas aos seus clientes sobre as compras tradicionais em lojas varejistas, por telefone, e por correio. Além disso, os Web sites devem ser de fácil navegação, oferecer segurança, privacidade e informações para que os consumidores possam comparar os produtos e tomar decisões de compra (Boone e Kurtz, 2001:128).

Bain (1999, in Barwise, Elberse e Hammond, 2002:13) examinou fatores relacionados à adoção da Internet como meio de compra. Um forte relacionamento negativo foi verificado entre as percepções dos clientes acerca dos riscos de compra pela Web e o comportamento de compra, mas não entre as percepções relativas à privacidade da informação e o comportamento de compra, o que não pode ser claramente observado no quadro 4. Também complementando as informações contidas no quadro 4, Swaminathan et al. (1999, in Barwise, Elberse e Hammond, 2002:14) descobriram por meio de pesquisas que o principal determinante da freqüência de compra online são as características percebidas do vendedor, especialmente competitividade de preços e facilidade de cancelamento de pedidos. Outros fatores examinados sugerem que os consumidores motivados por conveniência (maioria constituída por homens) são mais prováveis de realizarem compras online que aqueles que valorizam interação social (maioria constituída por mulheres). Outro fator-chave descoberto como determinante de compras online levantado por Becker-Olsen (2000, in Barwise, Elberse e Hammond, 2002:14) é se estas compras se encaixam no estilo de vida do consumidor, e em que medida ele percebe estas compras como fáceis e convenientes. Outros fatores apontados incluem a credibilidade global da empresa/site, especialmente por quem nunca havia comprado online; também foram mencionados fatores como a necessidade de ver/tocar o produto e a necessidade de o consumidor ter o produto imediatamente.

Como Rubini et al. (1996, in Barwise, Elberse e Hammond, 2002:21) afirmam, mesmo com a chegada das novas tecnologias, "o processo de compra permanece inalterado. A base subjacente de todo o varejo, quer seja físico ou virtual, permanece como um processo de resolução de problemas

\footnotetext{
${ }^{6}$ Bots: redução de robots, são programas de busca que verificam centenas de sites, buscando e processando informação, trazendo os resultados ao solicitante, segundo alguns critérios.
} 
com uma troca de valor-por-valor, em sua essência”. Resultados de estudos de Moe e Fader (2000, in Barwise, Elberse e Hammond, 2002:21) confirmam que as pessoas que visitam uma loja com maior freqüência estão mais propensas a comprar. Daí a grande sede por tráfego de visitantes de alguns sites que, além disso, podem ser expostos a mais propaganda de seus anunciantes. Contudo, a avaliação do sucesso da empresa com esforços do marketing pela Internet é um verdadeiro desafio.

\subsubsection{As implicações da Internet para o marketing}

Considerada a evolução da Internet abordada nos itens anteriores, principalmente no que se refere à capacidade da Internet de ser uma mídia de comunicação e um canal transacional, a importância da Internet para o marketing torna-se cada vez maior. Por outro lado, apesar de decorridos quase dez anos desde que a Internet passou a ser utilizada comercialmente, ainda persiste uma certa confusão sobre como os impactos da Internet repercutem sobre o marketing. Enquanto alguns autores (Tapscott, 2001; Novak, Hoffman e Duhachek, 2001) acreditam que a Internet mudará radicalmente o marketing, outros (Porter, 2001) acreditam que ela é tão somente uma ferramenta poderosa que contribui para que as organizações possam atingir melhores resultados. Assim é que Kalyanam e McIntyre (2002:484) observam que, no que diz respeito à sua definição, há pelo menos trinta expressões relacionadas ao assunto, como Internet marketing, Web marketing, online marketing, entre outras.

Alguns autores defendem uma definição específica e particular para o marketing na Internet (Kalyanam e McIntyre, 2002; Wind e Mahajan, 2001; Mohammed et al., 2001; Leonard, 2000). Mohammed et al. (2001:4), por exemplo, definiram marketing na Internet como sendo o "processo de construção e manutenção do relacionamento com o consumidor por meio de atividades online para facilitar a troca de idéias, produtos e serviços que satisfaçam os objetivos do consumidor e empresa”.

Contudo, apesar de a Internet influenciar uma série de elementos do marketing, como pesquisa de marketing (Wind e Mahajan, 2001; Churchill e Peter, 2000), propaganda (Nakagawa, 2003; Bishop 2000; Godin, 2000; Ellsworth e Ellsworth, 1997), distribuição (Erden e Utecht, 2002; Reichheld e Schefter, 2000; Windham, 1999; Winer, 1999; Hoffman et al., 1995, in Barwise, Elberse e Hammond, 2002), construção de marcas (Dayal et al., 2000, in Barwise, Elberse e Hammond, 2002), serviço ao cliente e gerenciamento do relacionamento com clientes (Barwise, 
Elberse e Hammond, 2002; Boone e Kurtz, 2001:130), o marketing na Internet não deve ser tratado como algo isolado. Autores como Boone e Kurtz (2001) e Belch e Belch (2003) defendem a abordagem integrada da Internet com os outros canais ditos tradicionais utilizados pelo marketing. Esses últimos autores, por exemplo, já incluíram as iniciativas relacionadas à Internet em seu modelo de mix promocional. Hou e Rego (2002) entendem que, na estratégia de marketing, a Internet precisa ser percebida não só como uma mídia de comunicação, como observado por Belch e Belch (2003), mas também como um canal de transações.

O que torna a Internet algo tão discutido no marketing são suas características únicas, as quais permitem que atividades relacionadas ao marketing em si, como vendas, distribuição e suporte, em particular, sejam desenvolvidas de várias formas, como sugerem Windham e Samsel (1999: 25). Peterson et al. (1997) também acreditam que as capacidades da Internet, como a de armazenamento de grandes quantidades de informações, independentemente da localização física, de oferecer soluções de busca, organização e disseminação destas informações, e a interatividade e capacidade de fornecer informações sob demanda, podem ser úteis para as atividades de marketing.

Barwise, Elberse e Hammond (2002) adicionam que a Internet também detém o potencial de: (1) permitir uma interação mais rápida, mais barata e mais personalizada com o consumidor do que qualquer outra mídia; (2) reduzir os custos do consumidor no que se refere à busca de informações e nas decisões de compra; (3) possibilitar uma comunicação independentemente das barreiras de distância; (4) prover comunicação ininterrupta, 24 horas por dia, em 365 dias do ano, com clientes em casa, no trabalho, no ponto de compra ou em qualquer local com conexão; (5) ser utilizada e acessada em vários aparelhos móveis como telefones celulares e assistentes pessoais digitais (handhelds), aparelhos convergentes como televisões digitais, aparelhos embarcados em carros, eletrodomésticos etc. Em função destas novas características e capacidades, Barwise, Elberse e Hammond (2002) defendem que, em princípio, a Internet pode causar impactos em aspectos do marketing como o processo de segmentação, precificação, atendimento e relacionamento com o consumidor, comunicação, promoção, canais, gerenciamento e construção de marcas, presença global, entre outros assuntos. Para esses autores, cabe aos executivos de marketing desenvolver soluções que aproveitem plenamente as capacidades oferecidas pela Internet para obter e sustentar novas vantagens competitivas. Desta forma, a Internet já é um integrante obrigatório no planejamento da estratégia da organização (Porter, 2001). A discussão atual, portanto, deixa de ser a 
importância da Internet para o marketing (Erden e Utecht, 2002), e passa a ser a sua utilização de forma eficiente.

No que se refere especificamente ao planejamento de estratégias de marketing na Internet há, pelo menos, duas correntes principais. A primeira, defendida por Tapscott (2001), Constantinides (2002) e a empresa de consultoria A.T. Kearney (2000) entre outros, aponta novos modelos exclusivos para a Internet. No modelo desenvolvido pela empresa de consultoria A.T. Kearney (2000), por exemplo, os 7 “Cs” (Conteúdo, Conveniência, Comunicação, Cuidados com o Consumidor, Conectividade, Comunidade e “Customização”) devem ser observados e considerados no desenvolvimento de estratégias de marketing na Internet.

Uma segunda corrente, representada por Kalyanam e McIntyre (2002), entre outros, defende a validade do Marketing Mix (Produto, Praça, Preço e Promoção) com a inclusão de novos elementos.

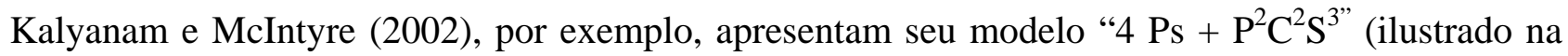
figura 26), o qual, além dos 4 "Ps" do marketing mix, acrescenta 2 "Ps" (Personalização e Privacidade), 2 “Cs” (Serviços aos clientes 'Customer service' e Comunidade) e 3 “Ss” (Site, Segurança e Promoção de vendas (Sales promotion’).

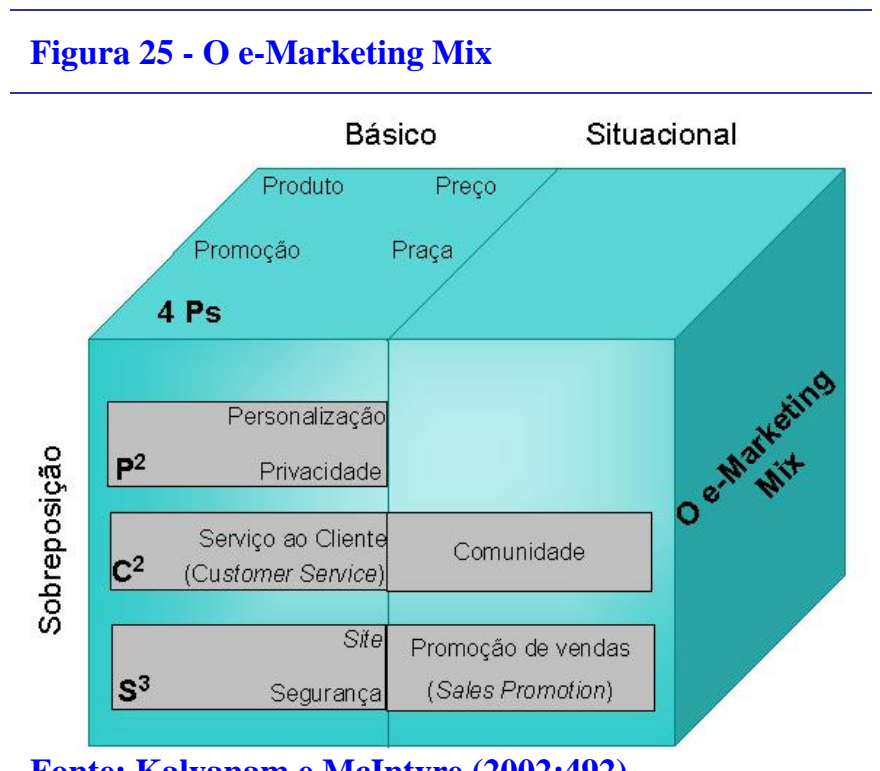

Fonte: Kalyanam e McIntyre (2002:492).

As funções de Produto, Preço, Praça e promoção, de acordo com as distinções de Waterschoot e Van den Bulte (1992, in Kalyanam e McIntyre, 2002), permanecem como as descritas no Marketing Mix tradicional. Nota-se, porém, que os novos elementos são considerados essenciais 
sob a perspectiva do e-marketing e geram certa sobreposição sobre os outros elementos, moderando-os (Kalyanam e McIntyre, 2002:492).

Esta abordagem, no entanto, não substitui a abordagem tradicional do composto de marketing - cujo conceito foi introduzido em 1953 por Borden, com base em Culliton, e que se traduziu nos 4 “Ps” cunhados por McCarthy em 1960, passando a ser bastante discutido por vários autores, desde então (Waterschoot, 1992, in Toledo, Nakagawa e Yamashita, 2001:37) - mas convida à reflexão sobre outras variáveis, em função da necessidade de adaptação ao novo contexto, uma vez que, em função das várias mudanças que vêm sendo observadas por conseqüência da Internet, é demasiado complexo analisar e até mesmo descrever quais são as implicações no composto de marketing. Erden e Utecht (2002:105) evidenciam que, apesar da imaturidade do assunto, a Internet já implica em novas alterações nas práticas do marketing.

Com a compreensão das implicações da Internet para a empresa e para o marketing, são discutidos, a seguir, alguns dos impactos da Internet sobre o marketing de relacionamento e os efeitos decorrentes desses impactos.

\subsection{Impactos e implicações da Internet sobre o Marketing de Relacionamento}

Destaca-se na figura 27 o conteúdo da fundamentação teórica abordado nesta seção. 
Figura 26 - Estrutura da seção: Impactos e implicações da Internet sobre o Marketing de Relacionamento

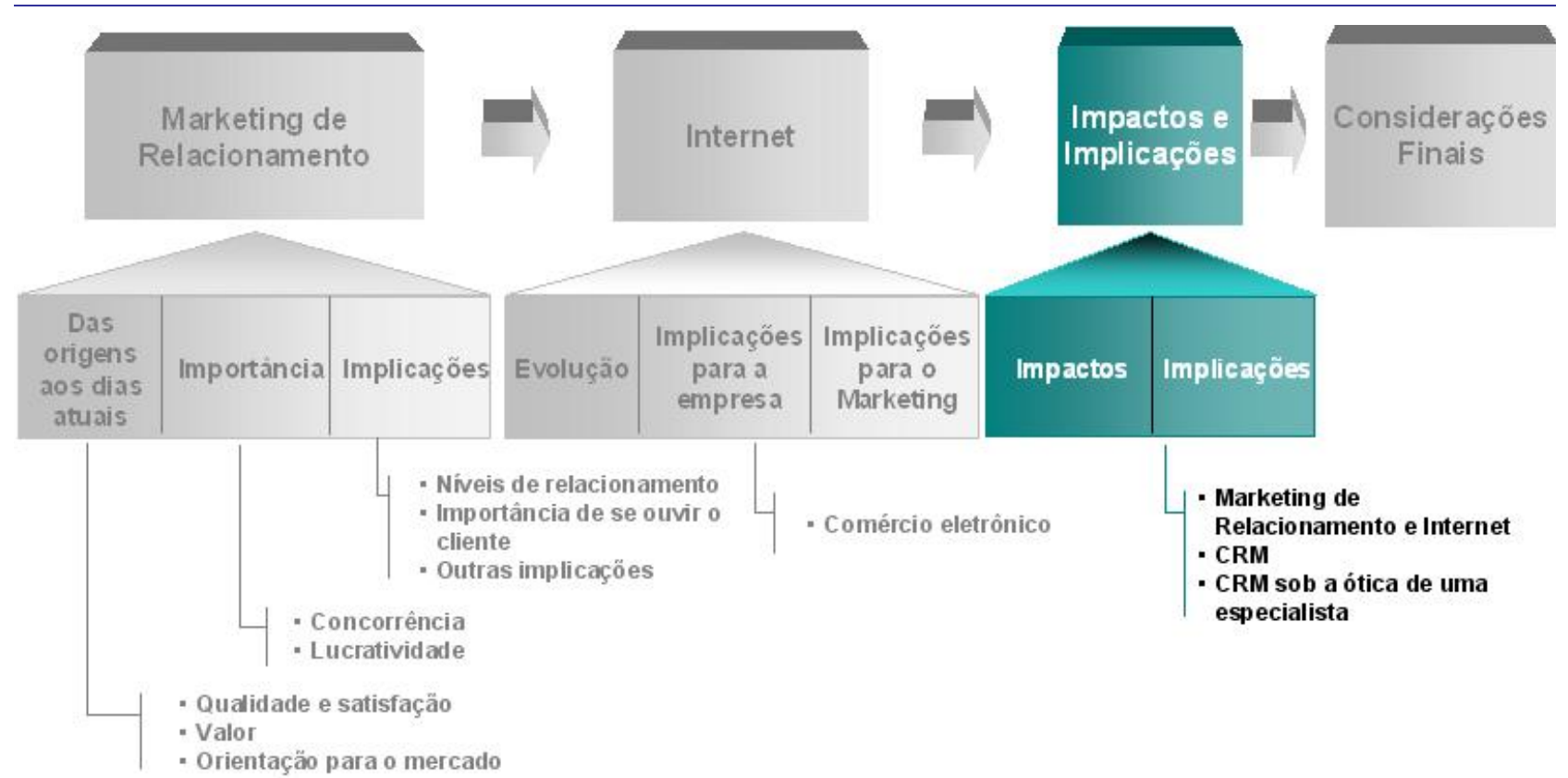

Fonte: a autora.

Em uma análise preliminar, tende-se a acreditar que os compradores na Internet buscam a conveniência ou preços menores. Sterne (2000:30) defende esta posição, porém, acredita que os clientes que compram via Internet possuem expectativas cada vez mais altas, demandando mais do que benefícios simplesmente funcionais como qualidade e características do produto. Desejam acesso a informações sobre produtos, situação do seu pedido (embarque, entrega, produtos alternativos com maior rapidez de entrega), características de seu próprio comportamento de compra (pontos acumulados no programa de fidelidade, gerente de conta, crédito, níveis de desconto) (Sterne, 2000:30), e processos de compra melhores, principalmente em relação à seleção de produtos, conveniência, e recompensas pelo relacionamento com a empresa, com serviços personalizados e benefícios pela sua lealdade (McKinsey, 1999:5). Para a empresa, o comércio eletrônico oferece a promessa de realização de negócios de maneira totalmente direta - sem nenhum contato humano durante a transação - com a esperança de receitas crescentes e custos decrescentes, e com grande possibilidade de atender às expectativas dos clientes. Entretanto, conduzir negócios pela Internet requer mais que a habilidade de simplesmente processar pedidos; é necessário estar pronta e habilitada a servir os clientes por meio de qualquer canal que escolham para aproximar-se da empresa, quer sejam canais tradicionais, de vendas diretas, parceiros ou distribuidores, call center ou o próprio site na Internet (Pombriant, 2000). 
E, justamente neste cenário, colocam-se em discussão o papel e a importância do marketing de relacionamento, o qual tem se desenvolvido ao longo dos anos como uma filosofia, uma estratégia, um processo ou uma forma de administrar capaz de proporcionar benefícios tanto aos clientes como à empresa, seus funcionários e seus fornecedores. Uma vez que pode envolver mudanças culturais, estruturais, de processos, treinamento e incorporação de valores, não é algo trivial, passível de implantação repentina. Como se isto não bastasse, esse processo de transformação sofre influências e impactos do ambiente, que acarretam adaptações e modificações em seu curso de desenvolvimento.

As relações de poder em muitos mercados têm se alterado em função das recentes mudanças no ambiente tecnológico. Os consumidores possuem mais informação sobre os produtos e mais opções de escolha como nunca; há mais alternativas de compras: lojas especializadas, gigantescos shopping centers, catálogos de pedidos pelo correio, redes de compras feitas a partir de sua casa e lojas virtuais na Internet, e são bombardeados com mensagens que se materializam à sua frente por vários canais distintos (McKenna, 1995:87). A habilidade dos consumidores de realizarem compras comparativas em tempo real de quase toda sorte de bens e serviços via Internet, de participarem de vários tipos de leilões, compartilharem informações com outros consumidores em "salas de batepapo" e newsgroups e, em muitos casos, de se libertarem de monopólios geográficos tem lhes atribuído novas fontes de poder (Gurley, 1997, in Ruefli, Whinston e Wiggins, 2001:51). Além disso, Reichheld e Schefter (2000:113) observam que “a tolerância dos clientes com a inconsistência e a mediocridade está desaparecendo rapidamente. No passado, as localizações convenientes das lojas, as forças de vendas agressivas e uma falta geral de informação protegiam as empresas das penalidades de fornecer qualquer coisa que não o melhor produto e qualidade de serviço; os consumidores eram leais por necessidade, e não por escolha. Graças à Internet, estas proteções têm sido derrubadas. Construir lealdade superior do cliente não é mais uma das muitas formas de turbinar os lucros. É essencial para a sobrevivência”.

Ghosh (1998:135) afirma ainda que “as mudanças possibilitadas pela Internet são estratégicas e fundamentais. Entretanto, tais mudanças, as quais ocorrem de maneira distinta nos vários setores, afetarão o relacionamento de cada empresa com seus clientes e as proposições de valor de várias empresas num futuro previsível”.

Em função deste quadro, como figuraria o marketing de relacionamento quando as relações com o cliente passam a ser prioritariamente pelo computador? Como conquistar a lealdade do 
cliente se não há mais o contato face-a-face de outrora, se a cultura e até a língua falada podem ser distintas? A seguir, são apresentadas algumas idéias que podem contribuir para compreender melhor estas questões.

\subsubsection{Impactos da Internet sobre as práticas de Marketing de Relacionamento}

Como já evidenciado anteriormente, permanece uma grande discussão sobre a realização de atividades de marketing por meio da Internet. Segundo Barwise, Elberse e Hammond (2002:24), a meta principal do marketing na Internet é utilizá-la combinada a outros canais e atividades, para construir um relacionamento positivo, lucrativo e de longa duração com o cliente, como no ambiente físico. Dellaert (1999, in Barwise, Elberse e Hammond, 2002:26) explorou como a Internet pode favorecer crescentes contribuições de clientes para os processos de desenho de produtos/serviços, branding (discutindo em grupos online experiências de consumo, por exemplo), serviços (auxiliando outros consumidores na busca de produtos e utilização dos mesmos), e o processo de produção (fazendo seus pedidos eletronicamente), e sugere que a Internet é mais hábil em apoiar as relações vendedor-comprador que o meio tradicional. Adicionalmente, a Internet seria, segundo Sterne (2000:7), o melhor local para uma empresa aplicar seus esforços de serviços ao cliente na atualidade, pois ela possui disponibilidade de 24 horas por dia, 7 dias por semana, além de oferecer uma amplitude quase ilimitada de conhecimento e possuir a habilidade de lembrar dos clientes como indivíduos. Contudo, Gummesson (1999:31) lembra que a transição do contato pessoa-a-pessoa para o contato pessoa-a-máquina reduziu os relacionamentos pessoais em áreas nas quais estes eram imprescindíveis. A interação social se transformou em interação eletrônica, o que envolve uma mudança radical nos relacionamentos.

Algumas empresas enveredam pelo comércio eletrônico por vislumbrarem uma nova forma de realizar negócios; outras, vêem na Internet um complemento às suas operações de "tijolo-eargamassa” (loja física); outras, ainda, procuram tal caminho simplesmente porque a concorrência o está fazendo. Em algumas situações, tal empreendimento chega à empresa da noite para o dia, sem um planejamento sólido das ações e possíveis implicações desta decisão. Como resultado, encontra uma estrutura organizacional inadequada, o perfil dos profissionais, muitas vezes, insuficiente, a rede de distribuição despreparada, os parceiros nas transações financeiras ainda em processo de aprendizagem e, o que é pior, todo o esforço de anos em trazer o cliente para dentro da empresa, e aproximá-lo num relacionamento de ganhos mútuos fica esquecido em meio à profusão tecnológica e a promessa de que tudo irá melhorar. 
McKenna (1992:1) afirma que “a tecnologia está transformando as escolhas, e as escolhas estão transformando o mercado”. A tecnologia criou a seguinte promessa: qualquer coisa, de qualquer modo, em qualquer tempo. Ela "permite ainda que a informação flua bilateralmente entre o cliente e a empresa, criando um ciclo de feedback que os integre” (McKenna, 1992:10-18).

Todas essas questões evidenciam a importância da Internet no marketing, e, em especial, no relacionamento com o cliente. Embora muitas manchetes tenham noticiado a "quebra de todas as regras de negócios pela Internet”, Reichheld e Schefter (2000:106) defendem a posição de que, no que tange à lealdade do cliente, as velhas regras são mais válidas do que nunca. Afirmam que a lealdade ainda está relacionada à conquista dos tipos certos de clientes, ou seja, aqueles para quem a empresa pode proporcionar uma experiência superior consistente de forma que eles desejem realizar todos os negócios com essa empresa. Segundo esses autores, o que a Internet faz é levantar novas questões e criar novas oportunidades ao colocar as velhas regras em um novo contexto.

Assim, nesse sentido, Toledo, Nakagawa e Yamashita (2001:53) ressaltam que, à medida que a concorrência aumenta, a empresa não pode deixar de procurar agir sob uma orientação para o mercado. “Ao invés do pensamento dominante ser o da ótica da oferta, é imperativo analisar a ótica da demanda na elaboração de estratégias competitivas, além do exercício de monitoramento dos passos da concorrência”. E para se manter a orientação para o mercado, um dos requisitos essenciais é a criação de valor para o cliente. Reichheld e Schefter (2000:105-106) acreditam que “a lealdade é uma necessidade competitiva: em todos os setores, algumas empresas irão procurar dominar o potencial da Internet para criar valor excepcional para os clientes”. Venetianer (2001:123-124) analisa alguns aspectos, talvez sujeitos ainda à discussão, relacionados ao valor oferecido aos clientes online:

- O preço não é mais um fator preponderante na decisão de compra: fatores como comodidade, segurança na transação, variedade de escolha, rapidez e serviços online têm grande peso na decisão de compra do consumidor online.

- O consumidor online só compra quando percebe valor real na oferta: embora óbvia, nem sempre esta questão é tratada adequadamente pelas empresas.

- Branding é mais importante que preço, uma vez que a Internet é habitada por inúmeras empresas de reputação discutível. 
A Internet pode aumentar significativamente a criação de valor para o cliente de três maneiras, superando seus concorrentes em valor (Simon e Schumann, 2001:366-371; Ghosh, 1998:132):

1. Crescente compartilhamento de informações entre compradores e vendedores, tanto sobre a empresa, suas linhas de produtos, serviços e capacidades da empresa à disposição dos clientes, como as preferências e hábitos dos mesmos, numa comunicação bidirecional.

2. Maiores oportunidades para segmentação de mercado e “customização” em massa: dadas as características da interatividade, não só são facilitadas as recomendações sobre os produtos existentes como também a criação de novos produtos. Os registros de informações sobre clientes podem ser usados para servir novos segmentos pela Internet ou propor vendas complementares, com a possibilidade de desenvolvimento de uma diferenciação de preço mais eficaz e de aumento do valor total para o cliente.

3. Redução significativa dos custos de transação, facilidade de realizar negócios, e melhorias reais nos produtos e serviços ao cliente: possibilitadas pelo fato de a Internet estar disponível todo o dia, possuir habilidades interativas, independência geográfica e a facilidade de que os pedidos sejam enviados com o mínimo de erros, além de poder utilizar seu acesso direto aos clientes e oferecer-lhes serviços adicionais ou links para outros negócios que possam servi-lo, a um custo muito baixo.

Outro aspecto fundamental que sofre impactos da Internet é a lealdade. Reichheld e Schefter (2000:106) realizaram uma análise do ciclo de vida do produto, tal como feita dez anos antes (Reichheld e Sasser Jr., 1994) e se depararam com uma economia clássica da lealdade em ação. O modelo geral - perdas iniciais seguidas por lucros crescentes - é exacerbado na Internet: no início de um relacionamento, os desembolsos necessários para adquirir um cliente são, em geral, consideravelmente maiores no comércio eletrônico que nos canais tradicionais de varejo. Nos anos seguintes, contudo, o crescimento dos lucros se acelera a uma taxa ainda mais rápida e, uma vez que é relativamente fácil para as lojas na Internet ampliar seu espectro de produtos, elas podem vender mais e mais tipos de bens aos seus clientes leais, ampliando e aprofundando o relacionamento ao longo do tempo. Segundo esses autores, as evidências indicam que os clientes via Internet tendem a consolidar suas compras com um fornecedor principal, na medida em que comprar a partir do site do fornecedor se torna parte de sua rotina. Além de comprarem mais, os clientes leais também indicam novos clientes para um fornecedor, estabelecendo uma outra boa fonte de lucros. Os clientes indicados são lucrativos no comércio tradicional também, porém, novamente, a Internet 
amplifica o impacto, uma vez que o efeito do mouse (word of mouse) se espalha muito mais rápido que a propaganda de boca (word of mouth). Muitos varejistas eletrônicos já possibilitam o envio de recomendações a partir de seu próprio site. Devido ao fato de os clientes indicados representarem baixo custo de aquisição, eles começam a gerar lucros muito mais cedo em seu ciclo de vida. A combinação de todos estes fatores econômicos sugere que o valor da lealdade é freqüentemente maior na Internet que no mundo físico. Para todas as empresas que realizam negócios pela Internet, a implicação é clara: não é possível gerar lucros superiores no longo prazo a menos que se atinja uma lealdade superior do cliente (Reichheld e Schefter, 2000:107).

Honeycomb (2001:2) propõe que, num mundo perfeito de serviço ao cliente, toda troca traria deleite ao cliente, resultando em satisfação e lealdade cada vez maiores, o que levaria a compras em volume e freqüência maiores e mais lucrativas. O cliente feliz então contaria a outros sobre sua experiência, criando o melhor investimento no planeta: a propaganda “de boca”. Raut (2002:1-3) vai além: embora o senso comum sugira que um cliente em deleite pode ser mais leal que um cliente satisfeito, é importante reconhecer que o deleite do cliente é um alvo móvel. Algumas maneiras para tentar atingir o deleite do cliente capturado digitalmente são (Raut, 2002:1-3; Honeycomb, 2001:2):

- Programas de lealdade: o maior valor para o cliente deste tipo de programa é "quanto mais você compra, mais você tem benefícios”. A lealdade prende o consumidor à marca ao “levantar barreiras de saída”.

- Marketing colaborativo: é uma estratégia de negócios centrada no cliente para fornecerlhe valor por meio de parcerias. Este conceito está relacionado à identificação de marcas de interesse de seus clientes e à criação de oportunidades para que tais marcas lhes ofereçam incentivos que não tenham sido possíveis no nível individual. É uma situação do tipo ganha-ganha-ganha para todas as entidades: empresa, clientes e parceiros.

- Marketing pró-ativo: trata-se da identificação das necessidades dos clientes antes mesmo que eles próprios o façam, a fim de fornecer-lhes informações e auxiliá-los a decidir sobre uma compra. Isto é particularmente aplicável a novos produtos ou versões de produtos.

- Vendas cruzadas: identificam e oferecem ao cliente produtos do portfólio da empresa que possam beneficiá-lo. A empresa pode manter em seu banco de dados de clientes informações sobre os relacionamentos com os mesmos, conhecimento que pode ser utilizado de maneira inteligente para assegurar que a organização consiga um "valor do 
cliente durante a sua existência” mais alto ao vender-lhe o máximo possível de produtos relevantes de seu portfólio.

- Janela única de serviço: trata-se da habilidade de reconhecer um cliente como uma única entidade por todos os vários produtos/serviços que a empresa lhe oferece; a empresa deve ser vista como um todo por ele, e não como vários departamentos separados e não integrados.

- Suporte 24x7: os clientes estão ativos 24 horas por dia, 7 dias por semana, e iniciativas como call centers e helpdesks se tornam mais efetivas com o uso de soluções tecnológicas mais robustas e redimensionáveis, com um histórico detalhado de interações com sua base de clientes, a fim de permitir-lhes oferecer um serviço muito mais eficiente para cada cliente individual. Algumas das características de um bom contact center:

- Um sistema de gerenciamento de e-mails enviados, com características como segmentação, construção de correio dinâmico, rastreamento de performance etc.

- Um sistema de resposta automática que pode ser utilizado para envio de alertas e $e$ mails;

- Um sistema de gerenciamento de e-mails recebidos, com características como autoresposta, respostas pré-formatadas para agilizar o retorno, apoio ao pessoal de serviço ao cliente na pesquisa de respostas apropriadas na base de dados, ferramentas de colaboração; os e-mails podem ser direcionados de modo inteligente ao atendente apropriado de serviço ao cliente com base na carga de trabalho, expertise ou, até mesmo, humor do cliente.

- Self-service assistido, pelo qual o cliente pode ter acesso a áreas relevantes do site da organização, auxiliado por um agente de serviços virtual; o self-service é o serviço mais eficiente em termos de custos que uma empresa pode prover. Caso as respostas desejadas não possam ser obtidas por esse meio, os clientes têm a opção de um diálogo com a empresa via e-mail ou chat ao vivo. Os melhores softwares permitem que resultados do questionamento sejam publicados em uma base de dados dinâmica crescente, de maneira que as consultas futuras possam ser respondidas também por esse meio. Segundo Forbes (2002:1), cada vez que um cliente encontra uma resposta para sua questão no site da empresa ao invés de telefonar ou enviar-lhe um e-mail, a empresa pode economizar algo entre US\$5 e US\$30, dependendo do custo operacional por ocorrência. Além disso, muitos clientes preferem encontrar suas próprias respostas 
online, pela economia de tempo propiciada. Dependendo de quão bem for implantado, o self-service pode chegar a responder de 75 a 95\% das questões dos clientes.

- Chat ao vivo: fornece um nível de interação pessoal, one-to-one, em tempo real, com o objetivo principal de minimizar os abandonos de "carrinhos de compras".

- Feedback automatizado do cliente: sem uma ferramenta permanente que promova o diálogo e solicite o feedback do cliente, a navegação se dará por suposições e especulações, desconectada dos desejos dos clientes. Os melhores mecanismos de feedback pesquisam e tabulam automaticamente dados da satisfação do cliente após cada consulta. Pesquisas online “customizáveis” podem questionar os clientes sobre qualquer assunto além de coletar dados demográficos, testar conceitos de produtos, rastrear o reconhecimento da marca ou conduzir um debate em tempo real pelo site.

O passo seguinte é gerenciar e medir o que a empresa forneceu ao cliente por meio de (Honeycomb, 2001:5): (1) gerenciamento do fluxo de trabalho, que assegura que as consultas dos clientes sejam destinadas ao funcionário mais apropriado, permitindo-lhe gerenciá-las da forma mais adequada; (2) relatórios, que oferecem subsídios aos administradores na tomada de decisões e no gerenciamento da função de serviço ao cliente; (3) hospedagem, alternativa aplicável quando as empresas não possuem tempo, conhecimento ou pessoal necessário para administrar o sistema em seus próprios servidores, minimizando os impactos na estrutura e nos recursos técnicos da empresa, com vantagens como redução de custos, confiabilidade, acesso à tecnologia e ferramentas atualizadas e de redimensionamento ágil; (4) integração, que diz respeito à conexão com outras aplicações da empresa.

Wiegran e Koth (1999:2) acreditam que a retenção de clientes online compreenda três elementos básicos: a lealdade do cliente, a participação na carteira (share of wallet), e a margem do produto. Desta forma, esses autores propõem algumas características dos sites que podem apoiar a retenção de clientes (quadro 5), sendo algumas delas também de efeitos positivos nas lojas físicas.

\begin{tabular}{|c|c|c|c|c|c|}
\hline \multirow[b]{2}{*}{$\begin{array}{l}\text { Elementos da retenção de } \\
\text { clientes }\end{array}$} & \multicolumn{5}{|c|}{ Características de um site } \\
\hline & $\begin{array}{l}\text { Informação de } \\
\text { valor agregado }\end{array}$ & Personalização & $\begin{array}{c}\text { Comunicação } \\
\text { inteligente }\end{array}$ & $\begin{array}{l}\text { Conteúdo gerado } \\
\text { pelo usuário }\end{array}$ & $\begin{array}{c}\text { Programas de } \\
\text { lealdade }\end{array}$ \\
\hline - Lealdade do cliente & $\checkmark$ & $\sqrt{ }$ & $\sqrt{ }$ & $\checkmark$ & $\checkmark$ \\
\hline - Participação na carteira & $\checkmark$ & - & $\checkmark$ & $\checkmark$ & $\checkmark$ \\
\hline - Margem do produto & $\checkmark$ & - & $\checkmark$ & - & - \\
\hline
\end{tabular}

Fonte: Wiegran e Koth (1999:3). 
A comunicação inteligente se refere à comunicação online, que objetiva aumentar o volume de vendas, e offline, que visa à atração do cliente ao site da empresa; o conteúdo gerado pelo usuário pode ser proveniente tanto de seu feedback como da comunicação direta entre usuários. Informações de valor agregado também possuem grande peso sobre a retenção de clientes. Todas as características mencionadas pelos autores podem colaborar com a lealdade do cliente, se bem desenvolvidas.

Embora para conquistar a lealdade dos clientes sempre tenha sido necessário, antes de tudo, conquistar sua confiança, isto se torna ainda mais imperativo na Internet, uma vez que os negócios são conduzidos à distância e os riscos e incertezas são ampliados: o cliente não pode olhar nos olhos do vendedor, não pode dimensionar o tamanho da loja e nem ver ou tocar os produtos que está comprando. Uma pesquisa de Reichheld e Schefter (2000:107) revelou que os compradores online consideram "um site que eu conheça e confie" o atributo mais importante para conquistar sua compra na Internet. Todos os demais atributos, incluindo custos mais baixos e maior sortimento ficaram bem distantes da primeira resposta. A conclusão, um tanto polêmica, desses autores, é que o “preço não dita as regras na Internet; a confiança é que o faz”. Em decorrência da maior confiança, os clientes ficam mais dispostos a fornecer informações pessoais, as quais permitem à empresa desenvolver um relacionamento mais íntimo com os mesmos, oferecendo produtos e serviços desenhados sob medida para suas preferências individuais; isto, por sua vez, aumenta a confiança e fortalece a lealdade. Tal círculo vicioso pode rapidamente se transformar em uma vantagem durável sobre a concorrência.

Similarmente, Ghosh (1998:129) acredita que quando um cliente opta por realizar uma compra em um site ele está fazendo um investimento de seu tempo e de sua atenção. Leva um certo tempo para que os clientes descubram como utilizar um site e se tornem confortáveis em fazê-lo. Se o site envolve personalização, os clientes devem fornecer dados para delineamento de seu perfil e, talvez, atualizá-los ao longo do tempo; eles podem até mesmo modificar seus próprios sistemas para fazer um melhor uso das conexões eletrônicas. Podem também oferecer informações sensíveis, como números de cartão de crédito, com a confiança de que o site irá trabalhar com tais informações de maneira discreta. Por tais razões, uma vez estabelecido um relacionamento com um vendedor eletrônico, o cliente médio, provavelmente, não irá novamente envidar esforços com muitos fornecedores. Para Ghosh (1998:133), as pessoas se sentem confortáveis em comprar em lojas que conhecem, virtual ou fisicamente, pois elas podem "passear" facilmente por corredores familiares e encontrar o que estão procurando. 
Segurança e privacidade são fatores críticos na construção de relacionamentos online. Na opinião de Evans e Wurster (1999:91), duas questões limitam as estratégias baseadas em informações ricas sobre os clientes. A primeira relaciona-se às restrições de privacidade, a qual requer que os clientes sejam informados sobre o assunto e concordem com quaisquer trocas de dados, cada vez mais uma condição para se realizarem negócios. A segunda questão é a opção dos consumidores em pesquisar e organizar informações por si mesmos: não é necessário fornecer todos os seus dados para obter informações ou serviços. Muitos sites de comércio eletrônico estabelecem políticas explícitas que responsabilizam os proprietários das lojas pela qualidade dos produtos vendidos e os padrões de segurança e privacidade, uma vez que são cada vez mais assustadores os índices de fraudes ocasionadas a partir da captura de dados de clientes pela Internet; muitos consumidores ainda temem fornecer o número de seu cartão de crédito nas compras online (Boone e Kurtz, 2001:133). Um estudo do U.S. Department of Commerce verificou que 40\% dos americanos estão muito preocupados com aspectos de confidência na Internet, e 25\% estão preocupados de alguma maneira com essa questão (Lieberman, 1999:2A, in Boone e Kurtz, 2001:133). Os autores Boone e Kurtz (2001:133) e Ellsworth e Ellsworth (1997:95) afirmam que esta é uma área em que vários grupos, organizações e empresas trabalham, desenvolvendo aspectos como autenticação e transações seguras, segurança do site, privacidade, criptografia, verificação de identidade etc. Algumas soluções já desenvolvidas para minimizar o problema são: (1) criação de uma conta; (2) compra com dinheiro virtual; (3) e-mails e formulários criptografados; (4) cartões de crédito especialmente criados para uso na Internet ou cheques.

Muitas empresas mantêm um log, ou seja, um arquivo que guarda registros de quais pessoas

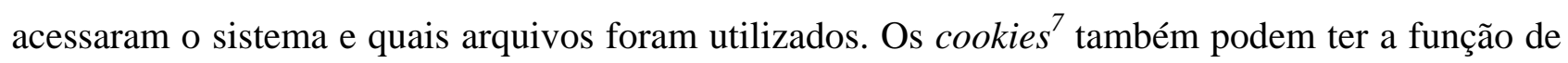
guardar o histórico de navegação do usuário pela rede. No entanto, é conveniente que se aja com cautela para não invadir a privacidade do cliente, tornando todo o trabalho de análise de informações sobre os mesmos uma arma contra suas visitas. De acordo com a Federal Trade Comission, uma investigação de 674 sites comerciais mostrou que 92\% deles coletava informações pessoais sobre seus visitantes, mas apenas $14 \%$ revelou o que fazia com tais dados (Wingfield,

\footnotetext{
${ }^{7}$ Cookie: pequeno arquivo de dados automaticamente descarregado no computador do internauta, e que pode identificálo como uma entidade única toda vez que retornar aos sites que o produziu (Winer, 1999:379; Boone e Kurtz, 2001:521; Venetianer, 2001:88; Sterne, 2000:195). Geralmente ocultos, sua finalidade é guardar informações sobre o usuário, seu computador e seus hábitos de navegação pela Internet, objetivando utilizá-las no futuro para personalizar determinadas transações entre ele e um determinado site da Internet, geralmente de natureza comercial, já acessado anteriormente (Venetianer, 2001:254).
} 
1998:R20, in Boone e Kurtz, 2001:133). E, como se isto não bastasse, outro fator de muito incômodo aos internautas é o envio desmedido de mensagens eletrônicas não solicitadas (spams) por parte de empresas que desejam oferecer algo, com as quais muitos destes internautas sequer tiveram contato. Essa correspondência não solicitada tem sido alvo de sérias medidas por parte de empresas e provedores, envolvendo inclusive legisladores e organizações não governamentais (Venetianer, 2001; Sterne, 2000). Venetianer (2001:91) evidencia a existência de uma modalidade de e-mail consentido, denominada de opt-in e-mail, base do marketing de permissão, no qual o destinatário dá seu consentimento expresso prévio para receber por meios eletrônicos correspondência comercial ou propaganda. Como foi destacado na pesquisa mencionada por Boone e Kurtz (2001:129), ilustrada no quadro 4 (seção 2.2.2.1), o principal desestimulador de compras pela Internet é a questão da privacidade/segurança.

O marketing de permissão é um conceito que oferece ao consumidor a opção de aceitar voluntariamente o marketing que querem lhe apresentar (Godin, 2000:39). A lógica está no fato de que se supõe que os voluntários ofereçam mais atenção à mensagem, sendo, posteriormente, recompensados por dar atenção a mensagens cada vez mais relevantes. O marketing de permissão prega que fazer marketing interrompendo as pessoas, ou seja, abordando-as com mensagens não esperadas, quer seja por malas-diretas ou por “janelas” que surgem em sua tela de computador, não é mais eficaz em termos de custos. Ao contrário, é preciso estabelecer fundamentos e processos onde as pessoas interessadas possam fazer marketing umas para as outras, criando redes de consumidores. A empresa deve apostar no conceito de transmissão “viral” de uma mensagem, ou seja, deixar que o mercado propague informações sobre seus produtos e serviços de maneira que lhe dê permissão para que continue o diálogo sem que seja necessário pagar por isto a cada vez. A melhor opção é criar produtos dinâmicos que valham a pena ser propagados/proliferados, e que atraiam a atenção para a empresa.

A experiência de compra de um consumidor online é composta de três elementos principais: qualidade da interface, qualidade do encontro e qualidade da execução (fulfillment) (Chang, 2000, in Barwise, Elberse e Hammond, 2002:15), a qual, para produtos físicos, exige logística de "tijolose-argamassa”, em geral, de alto custo (Strauss e Hill, 2001, in Barwise, Elberse e Hammond, 2002:16). Os autores Barwise, Elberse e Hammond (2002:15) interpretam esta idéia como processo, experiência e resultados, recomendando às empresas assegurar a excelência nessas três dimensões. 
A falta de foco no site dificulta ainda mais o desenvolvimento de lealdade: quanto maior a gama de clientes que uma empresa tenta servir, maior é o desafio de veicular um site que atenda às expectativas de todos. Ao procurar acomodar todos os níveis de conhecimento técnico, todas as exigências dos serviços, todas as sensibilidades a preço e todos os graus de preferência de marca, a empresa precisa estar constantemente adicionando novas características e funções, tornando os sites mais complexos em termos de uso e mais lentos para serem carregados (Reichheld e Schefter, 2000:109-110). Becker-Olsen (2000, in Barwise, Elberse e Hammond, 2002:24) verificou em pesquisas que os mais importantes fatores determinantes do comportamento de compra online são a habilidade do site em carregar suas páginas rapidamente, disponibilidade de nomes de marca familiares e uma política clara de retorno.

Evans e Wurster (1999:86) afirmam que a navegação é o campo de batalha no qual a vantagem competitiva será conquistada ou perdida, possuindo três dimensões: alcance, adesão, riqueza. Até mesmo coisas periféricas como o desenho do site são determinantes para que os consumidores escolham entre diferentes produtos/marcas (Mandel e Johnson, 1999, in Barwise, Elberse e Hammond, 2002:17). Sites bem desenhados são objetivos, de desenho simples, fornecem segurança e privacidade e, mais importante, são de fácil navegação, de visualização rápida e possuem formatos visuais de tela familiares, a fim de melhor orientar os visitantes, segundo convenções aceitas na Internet (Boone e Kurtz, 2001:144; Reichheld e Schefter, 2000:109-110).

Embora tais elementos possam melhorar a navegabilidade e conveniência de escolher um produto ou serviço oferecido pela empresa proprietária do site, existem agentes inteligentes que atuam em nome dos consumidores individuais. Tais agentes buscam na Internet os produtos que melhor atendam às suas necessidades, e podem influenciar de maneira significativa a escolha da marca ou canal de distribuição para suprir uma determinada marca, negociando preços e/ou entrega, e possivelmente convidando os fornecedores a fazerem seus lances (“leilão reverso”) e/ou formando um cartel com outros consumidores (ou seus agentes) para negociar o melhor preço. Se autorizado, o agente também pode efetuar a compra em nome do consumidor (Häubl e Trifts, 2000, in Barwise, Elberse e Hammond, 2002:18; Dolan e Moon, 2000, in Barwise, Elberse e Hammond, 2002:18). Adicionalmente, Maes (1999, in Barwise, Elberse e Hammond, 2002:19) espera que a tecnologia dos agentes tenha impacto dramático sobre a economia ao predizer o desaparecimento dos intermediários existentes e a emergência de novos tipos de intermediários, como também uma redução no capital necessário para abrir um negócio e, conseqüentemente, maior escopo para 
pequenos negócios voltados a nichos específicos. Além disso, o autor antevê ganhos de eficiência tanto para compradores e vendedores decorrentes da redução dramática dos custos de marketing e de vendas, como também uma mudança clara e global no equilíbrio de poderes entre compradores e vendedores. Sabe-se, no entanto, que tais mudanças ainda estão sujeitas a uma série de fatores, uma vez que nem todos ainda confiam nesses agentes para realizar suas compras.

Vários pesquisadores realizaram investigações acerca do tempo que os consumidores levam para acessar as informações desejadas, incluindo o tempo de espera durante um download das páginas (Dellaert e Kahn, 1999, in Barwise, Elberse e Hammond, 2002:15), a avaliação dos clientes sobre o tempo que a empresa leva para atender seus pedidos (Voss, 2000, in Barwise, Elberse e Hammond, 2002:16), e o tempo de resposta aos e-mails de reclamações (Strauss e Hill, 2001, in Barwise, Elberse e Hammond, 2002:16). Esses autores verificaram que a satisfação do cliente aumenta com respostas rápidas e que é importante considerar indicadores de medidas em áreas como confiança, tempo de resposta, qualidade da resposta e navegabilidade.

A falta de foco também influi negativamente em termos de lucratividade, como mostram Reichheld e Schefter (2000:110-112). “A simples aritmética da economia da lealdade torna claro que na maioria dos negócios pela Internet, os clientes precisam ficar com a empresa por dois ou três anos, apenas para que a empresa recupere seu investimento de aquisição inicial. Um grande percentual dos novos clientes - até 50\% em alguns setores - abandona a empresa antes de seu terceiro aniversário com um site de comércio eletrônico”, observam. Esses autores afirmam ainda que o valor real de se acompanharem as medidas de lealdade é que isto permite que as empresas vejam além das panacéias do sucesso nos negócios. Em seus estudos, descobriram que os cinco principais determinantes da lealdade residem em velhos princípios básicos de serviço ao cliente: suporte de qualidade ao cliente, entrega no prazo, apresentações de produto persuasivas, embarque e manuseio convenientes e a um preço justo, e políticas de privacidade claras e confiáveis.

Em suma, esses autores acreditam que a lealdade é determinada pelo conjunto total de interações entre a empresa e seus clientes. Assim, sob esta ótica, a Internet se torna uma ferramenta, e não uma estratégia. Suas características únicas são utilizadas para melhorar a comunicação com os clientes, melhorar o aprendizado organizacional sobre suas necessidades e aumentar a capacidade de resposta, reduzir os custos de transação e aprimorar a conveniência, itens importantes para o desenvolvimento de relacionamentos fortes e duradouros. “A lealdade não é conquistada apenas 
com tecnologia, e sim, pela entrega de experiência superior ao cliente”. A integração também fortalece a lealdade.

“A Internet é uma poderosa ferramenta para fortalecer os relacionamentos, mas as leis básicas e as recompensas de se construir lealdade não se alteraram. Ao encorajar compras repetitivas entre um núcleo de clientes lucrativos, as empresas podem iniciar uma espiral de vantagens econômicas. Este efeito da lealdade lhes permite compensar seus empregados de maneira mais generosa, prover aos investidores maiores fluxos de caixa e reinvestir mais agressivamente para aprimorar ainda mais o valor entregue aos clientes.” (Reichheld e Schefter, 2000:113).

Venetianer (2001:12) cita Mark McDonald, executivo da Arthur Andersen que afirma que "um site é apenas um ponto de partida que permite a uma empresa realizar transações comerciais eletrônicas na Internet. No entanto, é o relacionamento que a empresa estabelece com o seu ambiente de negócios que fundamenta a sua expansão". Ele acredita que "a diferença entre ser bem ou mal sucedido em comércio eletrônico encontra-se naquilo que a empresa faz nos bastidores”. Bayne (2000:12) também adverte que a empresa não consegue atender às necessidades dos clientes apenas com a tecnologia. Os bons serviços ao cliente começam com pessoas e processos. Além disso, Venetianer (2001:12) ressalta a importância do comprometimento da alta administração em todo o processo, uma vez que comercializar bens e serviços pela Internet é uma decisão estratégica e, como tal, tem reflexos na empresa como um todo.

Gummesson (1999:84) acredita que, como o telefone, a Internet é uma "construtora de relacionamentos” entre empresas e clientes, entre organizações e dentro das organizações. A Internet é uma rede eletrônica de redes de relacionamentos na qual é possível optar pela interação. Os relacionamentos pela Internet são praticamente extensíveis a qualquer pessoa com um computador, um programa, um modem e uma forma de conexão. Ghosh (1998:130) acrescenta que a quase onipresença da Internet, a facilidade com que qualquer pessoa se conecta a qualquer outra, torna potencialmente possível para um participante na cadeia de valor usurpar o papel de qualquer outro participante.

Em função dos impactos da Internet sobre as práticas de marketing de relacionamento das empresas, são apresentadas, a seguir, algumas implicações desta tecnologia, ou seja, quais são as principais mudanças e ações na realidade da empresa em função de sua decisão de comercializar produtos e/ou serviços via Internet, referentes ao marketing de relacionamento. 


\subsubsection{Implicações da Internet relacionadas ao Marketing de Relacionamento}

Blattberg e Deighton (1991:8, in Barwise, Elberse e Hammond, 2002:6) notam que, no início da década de 90, a tecnologia já permitia ao marketing interativo dirigir-se a clientes identificáveis individualmente. De alguma forma, o mundo do marketing está retornando aos velhos tempos do marketing one-to-one, quando os vendedores conheciam seus clientes e personalizavam ofertas de produto e apresentações de vendas para as necessidades específicas de cada indivíduo.

A tecnologia está mudando a maneira pela qual os programas de fidelidade operam (Winer, 1999:375; Boone e Kurtz, 2001:163). Além disso, as bases de dados têm desempenhado um papel relevante na mudança do marketing de massa para o marketing precisamente direcionado (Griffin e Avram, 1998:A-4, A-15, in Boone e Kurtz, 2001:165). O database marketing diz respeito à utilização de computadores para analisar dados e então identificar e focar grupos específicos de clientes potenciais. É uma ferramenta particularmente eficaz para construir relacionamentos, pois permite aos vendedores pesquisar uma vasta quantidade de informações de clientes para melhor direcionar seus esforços de marketing. As empresas podem analisar informações demográficas, rastrear padrões de compra, chamadas de serviços, identificar o tipo de trabalho feito, desenvolver o perfil de relacionamento de seus clientes, “customizar” suas ofertas de produtos e promoção de vendas, reduzir erros, personalizar o serviço ao cliente. Um trabalho de retenção de clientes bem sucedido requer informações sobre os mesmos e utilização criteriosa dessas informações (Boone e Kurtz, 2001:164-165; Winer, 1999:382). Além disso, Winer (1999:21) adverte ainda que, se a empresa não estiver utilizando extensivamente tais informações para direcionar produtos a seus clientes e oferecer um serviço global melhor, estará aquém da concorrência. O principal objetivo é transformar produtos tradicionalmente oferecidos ao mercado de massa em produtos aparentemente personalizados para os indivíduos, a chamada “customização em massa”, discutida mais adiante.

Um database marketing administrado de maneira eficaz melhora a retenção de clientes e taxas de referência, impulsiona o volume de vendas, e reduz os custos diretos e despesas de marketing. Cada comprador é único pelas prioridades individuais em relação a características de um produto, como preço, serviço, qualidade, entre outros. As bases de dados armazenam e analisam tais informações, revelando características e requisitos de clientes específicos (Griffin e Avram, 1998:A-4, A-15, in Boone e Kurtz, 2001:164). Além disso, o banco de dados de clientes auxilia a empresa nos seguintes aspectos (Vavra, 1992): 
- Ao permitir identificar os clientes mais relevantes e apresentar-lhes a oferta adequada no momento correto, provoca aumento na eficiência e eficácia dos esforços de marketing.

- Administrar a vasta quantidade de dados de que a empresa necessita para interagir com seus clientes de maneira verdadeiramente personalizada.

- Manter um “diálogo” verdadeiro com clientes ao descobrir interações contínuas, identificando mudanças no ato de compra e permitindo antecipar mudanças futuras.

- Facilitar o desenvolvimento de novos produtos ao se conhecer quem compra um determinado produto, como este satisfaz o cliente e se quaisquer mudanças enriqueceriam o seu desempenho.

- Aumentar o grau de intimidade pela qual os clientes são “conhecidos”, pelo enriquecimento da base de dados com levantamentos e dados de estilo de vida.

- Fornecer mais apoio às áreas de serviços ao cliente, canais de interação com o mesmo.

Além disso, Barwise, Elberse e Hammond (2002:54) afirmam que a tecnologia online tem o potencial de: (1) reduzir o custo de pesquisas com clientes, que podem ser rápida e facilmente conduzidas via Internet (Winer, 1999:365); (2) permitir “customização” a baixo custo do marketing mix; (3) apoiar algumas atividades relacionadas ao mercado, como leilões e comunidades de marca em áreas nas quais não eram previamente viáveis; (4) dar aos clientes acesso às empresas (e talvez, também a recíproca), a qualquer hora, de qualquer local; (5) abolir alguns tipos de intermediários e criar novos; (6) reforçar expressivamente a globalização, tudo isto sujeito ao contexto em questão.

Desta maneira, a Internet pode auxiliar as empresas a aprimorar as bases de dados de informações de clientes e aplicar estas informações na melhoria do serviço ao cliente. As conexões da Internet trazem feedback instantâneo dos clientes, o que auxilia os profissionais de marketing a responder rapidamente às mudanças de mercado. Os sites fornecem valor real aos visitantes e à empresa patrocinadora ao permitir o processamento de informações e apresentações, com apoio de informações armazenadas em bases de dados, o que tem sido facilitado devido aos avanços no desenvolvimento de softwares, com maior segurança (Boone e Kurtz, 2001:165-166).

Alguns autores como Mick e Fournier (1998, in Barwise, Elberse e Hammond, 2002:5) descobriram que a chamada "tecnofobia" entre os clientes é inteiramente racional e baseada em experiência prévia, na qual a tecnologia parece ter tornado sua vida mais complicada. Desta forma, McKenna (1992:23) ressalta que “o executivo de marketing deve ser também interativo, tanto internamente, sintetizando a capacidade tecnológica com as necessidades do mercado, como 
externamente, trazendo o cliente para a empresa, como participante do processo”. Assim, McKenna (1995:93) defende a idéia de que os profissionais de marketing não precisam conhecer os detalhes técnicos dos sistemas de informação, mas precisam desenvolver um entendimento do negócio da tecnologia e como utilizá-la estrategicamente. Mais importante ainda, os profissionais de marketing precisam reconhecer como a tecnologia está mudando o comportamento dos clientes para que possa satisfazer suas necessidades num futuro breve. O profissional de marketing é agora um integrador de sistemas (McKenna, 1995:95). Michael Schrage, codiretor do MIT Media Lab’s eMarkets Initiative, citado por Kevin Kelly em New Rules for the New Economy, afirma que "é preciso mudar a noção da tecnologia gerenciando informações para a idéia da tecnologia como uma mídia de relacionamentos” (Rifkin, 2000).

\subsubsection{Marketing de Relacionamento e Internet}

Reichheld e Schefter (2000:109) lembram que, dado o alcance global da Internet e a ausência de limites de horário de funcionamento, há uma grande tentação por parte das empresas em procurar atrair o maior número possível de potenciais clientes, por presumirem que os custos fixos decorrentes dos altos investimentos no desenvolvimento do site e no desenho dos processos devam ser amortizados sobre o maior número possível de clientes. Assim, elas se vêem tomadas por um frenesi de aquisições indiscriminadas de clientes, medindo seu sucesso simplesmente pelo número de page views ${ }^{8}$, visitantes singulares e vendas acumuladas, ignorando o fundamento de que a seleção cuidadosa dos clientes pode ser determinante do sucesso ou fracasso de um negócio.

Para identificar quais clientes atrair e quais evitar, o primeiro passo é analisar claramente as diferentes categorias de clientes online. Esses autores constataram, por meio de estudos, que, ao contrário do que se imagina, a maior parte dos clientes busca prioritariamente conveniência, e não preço. "Eles desejam realizar negócios com um site que torne suas vidas mais fáceis, e estão dispostos a pagar mais por esta conveniência. Racionais em relação ao preço, mas não obsessivos em relação a ele, detêm também uma forte inclinação à lealdade. (...) Um outro grande grupo de clientes são influenciados primariamente pela marca e estão, da mesma maneira, em busca de relacionamentos estáveis e duradouros” (Reichheld e Schefter, 2000:110). Esses autores afirmam

\footnotetext{
${ }^{8}$ Page view: cada vez que uma página Web é requisitada por alguém, por meio de um browser; são utilizadas com freqüência para rastrear o número de oportunidades de um banner ser visto por um visitante (Sterne, 1997:409); uma métrica comum para mensurar o tráfego de um Web site, em geral, correspondendo a ver todos os componentes de uma página da Web (imagens, textos etc.).
} 
ainda que o modo como um site é desenhado e colocado no mercado produz um grande impacto sobre os tipos de clientes que atrai: os clientes leais, em sua maioria, chegam a seus sites por meio de indicações; já os que procuram preço, em geral são atraídos por descontos promocionais ou propaganda em geral. Daí pode-se imaginar que, se uma empresa na Internet aplica indiscriminadamente a maior parte de seus recursos em banners e cupons online, sem investir da mesma forma na construção de comunidades e promoção de indicações, provavelmente irá sofrer perdas a longo prazo em sua base de clientes.

Outra característica interessante observada por esses autores é que os clientes das lojas de “tijolo-e-argamassa” não deixam nenhum registro de seu comportamento, a menos que comprem algo; ainda assim, os dados são, geralmente, superficiais. No entanto, nas lojas virtuais, o comportamento de compra é transparente: todos os movimentos podem ser documentados eletronicamente, como já comentado. Se um cliente sai de uma loja virtual quando uma tela de preços aparece, ele provavelmente é sensível a preço; se navega de página em página sem sequer iniciar uma transação, pode estar frustrado por não encontrar o que deseja. Ao fornecer tais dados, a Internet oferece às empresas oportunidades sem precedentes para conhecer seus clientes em profundidade e personalizar suas ofertas de maneira a atender às suas preferências. Muito poucas empresas, no entanto, agem para tomar proveito de todo o potencial: Reichheld e Schefter (2000:111) verificaram que menos de 20\% delas mal acompanham a retenção de clientes.

McKenna (1995:88) afirma ainda que o marketing online requer ações como:

- Substituir a mentalidade de broadcast que tem dominado o marketing por uma disposição de dar aos clientes acesso à empresa, observar suas ações e feedback para desenvolver e melhorar produtos;

- Focar a satisfação do cliente em tempo real, oferecendo-lhe suporte, auxílio, orientações e informações necessárias para conquistar sua lealdade;

- Estar disposto a aprender como a tecnologia da informação está transformando tanto o comportamento do consumidor como o marketing, e ver sob novos ângulos o papel do marketing dentro da organização.

Itens como notas técnicas sobre as características e usos do produto, FAQs (frequently asked questions - perguntas mais freqüentes) que proporcionam respostas às consultas mais realizadas (Sterne, 2000:47-61), atualizações de softwares, correções de erros, são somente alguns dos elementos que a empresa pode oferecer a seus clientes por intermédio de uma ampla gama de 
canais, simultaneamente; pode ainda permitir a seus clientes decidir quais tipos de informação desejam receber (Kosiur, 1997:18). Além disso, a empresa deve aprender com os e-mails recebidos: dúvidas, dicas sobre como melhorar seus produtos, avaliação sobre o serviço geral da empresa, preços, prazos de entrega etc. Boone e Kurtz (2001:161) observam que, cada vez mais, as empresas estão monitorando grupos de discussão online como uma forma de rastrear comentários e atitudes de clientes sobre o valor recebido. Bayne (2000:12) também recomenda que as empresas se concentrem mais na praticidade e facilidade de uso de seu site de comércio eletrônico que na sua aparência. Servir bem aos clientes não significa esperar suas reclamações: é preciso antecipar-se a eles, e perguntar-lhes que tipo de serviço desejam (Sterne, 2000:107).

Além disso, Praeger (2001) afirma que, se o caminho para construir lealdade na Internet é a confiança, esta pode ser obtida mediante a presença de: (1) qualidade e serviços ao cliente, com respostas rápidas e precisas e autonomia dos atendentes para resolução de problemas, sistema de rastreamento de pedidos e resposta aos e-mails; (2) experiência positiva ao cliente, navegação fácil e agradável, com informações necessárias e de fácil localização sobre produtos; (3) facilidade de fazer o pedido; (4) sistemas e processos livres de erros; (5) aspecto humano dos contatos: o cliente deve poder conversar diretamente com uma pessoa, se assim o desejar.

Nas vendas pela Internet, a McKinsey (1999:14) identifica um modelo para a troca de valores, composto por quatro estágios e sintetizado no quadro 6.

\section{Quadro 6 - Troca de valores: um processo de quatro estágios}

\begin{tabular}{ll|l|l}
\hline \multicolumn{1}{c|}{ Fase } & \multicolumn{1}{c}{ Cliente oferece } & \multicolumn{1}{c}{ Cliente recebe } \\
\hline 1. & Atração & $\begin{array}{l}\text { Tempo e atenção enquanto navega; } \\
\text { informações da transação }\end{array}$ & $\begin{array}{l}\text { Experiência do tipo “um tamanho } \\
\text { serve para todos” }\end{array}$ \\
\hline $\begin{array}{l}\text { 2. } \\
\text { Personalização orientada pelo }\end{array}$ & Informações sobre preferências & Experiência personalizada \\
\hline $\begin{array}{l}\text { 3. } \\
\text { personalização orientada pelo }\end{array}$ & Reações e feedback & Ofertas sob medida e recomendações \\
\hline 4. Colaboração baseada em confiança & $\begin{array}{l}\text { Preferências mais sensíveis, } \\
\text { informações de perfil }\end{array}$ & $\begin{array}{l}\text { Consultoria na solução de problemas } \\
\text { e experiência “customizada” }\end{array}$ \\
\hline
\end{tabular}

Fonte: McKinsey (1999:14).

Neste modelo, à medida que o relacionamento se torna mais profundo, as trocas de valores aumentam em intensidade e qualidade, proporcionando benefícios para ambas as partes: o ganho maior para os clientes é um serviço cada vez mais personalizado e, para as empresas, a sua lealdade. 
Uma questão importante para varejistas e gerentes de marca é se os consumidores exibem maior ou menor lealdade online, comparando-se com a lealdade offline. Danaher et al. (2000, in Barwise, Elberse e Hammond, 2002:23) compararam a lealdade do consumidor (participação nos requisitos da categoria e freqüência média de compra) para bens embalados comprados online versus compras efetuadas em lojas tradicionais. A lealdade para marcas com alta participação de mercado foi significativamente maior no ambiente virtual, com o reverso ocorrendo para as marcas de baixa participação. As marcas de nicho (com um pequeno, porém altamente leal grupo de seguidores) saíram-se melhor que o esperado, enquanto as marcas “change of pace” (compradas não tão freqüentemente mas por um grande segmento da população relevante) foram piores que o esperado. Esse comportamento sugere que marcas com alta participação de mercado possuem clientes mais fiéis nas compras pela Internet. No entanto, acredita-se que é possível também que esta atitude esteja relacionada ao perfil do consumidor pela Internet, aos preços e prazos de entrega, e também às condições da compra: pela Internet, o cliente não tem contato com o produto e, talvez, sinta-se “mais seguro” comprando de uma marca já conhecida.

Reibstein (2000:221) ressalta a importância da seguinte questão: “como os varejistas eletrônicos constroem a lealdade do cliente?”. Tal questionamento se deve à preocupação dos sites em serem capazes de reter todo o tráfego gerado, após um período inicial sem geração de lucros. Segundo esse autor, no primeiro trimestre de 1999, aproximadamente metade da receita total de comércio eletrônico foi gerada por compradores que compravam pela primeira vez. Entretanto, o crescimento de compradores repetitivos era, aproximadamente, 75\% maior que o de compradores novatos. A freqüência da compra repetitiva foi medida perguntando-se aos clientes quantas vezes eles haviam comprado naquela loja nos últimos seis meses. Os resultados de sua pesquisa indicam que a compra repetitiva do mesmo fornecedor é freqüente para alguns clientes, variando de modo significativo de acordo com a categoria de produto. Além disso, esse autor observou que, à medida que a freqüência de compra aumentava, o número de itens por compra também era crescente, tornando todos os compradores repetitivos importantes.

Outra medida de lealdade online avaliada por esse autor é o "share of requirements", ou participação nas necessidades, considerada por ele como sendo "dentro de uma dada categoria, o percentual de vezes que um consumidor compra de um determinado fornecedor”, chegando à média de 35,6\% das vezes, em uma pesquisa. Surpreendentemente, os níveis de lealdade parecem ser mais altos com a porção mais jovem dos clientes: 39,8\%. Quando questionados sobre a propensão a 
comprar do mesmo fornecedor novamente, 52,3\% dos entrevistados afirmaram estar altamente propensos a comprar, enquanto 5,6\% disseram estar altamente propensos a não comprar.

Figura 27 - Impacto dos níveis de performance sobre a probabilidade de comprar novamente do mesmo fornecedor

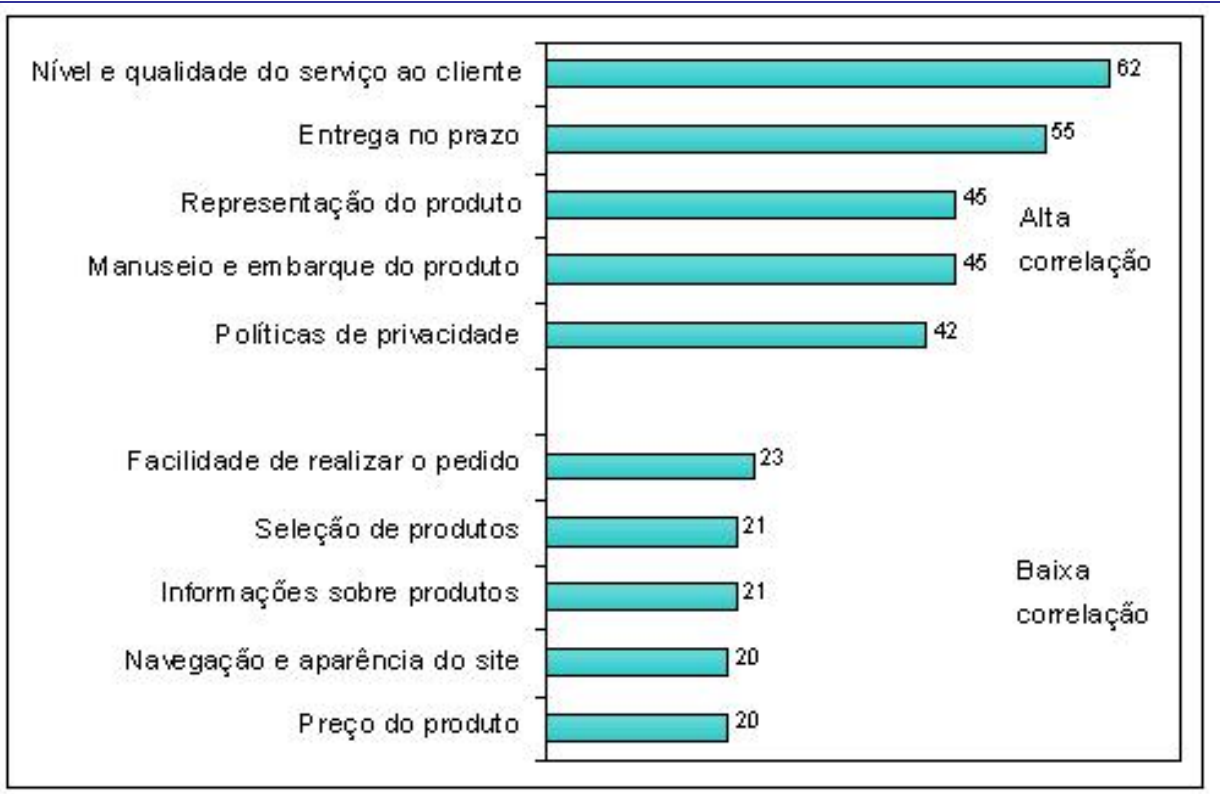

Fonte: Reibstein (2000:224).
Entretanto, na análise de correlação entre a probabilidade de comprar novamente do mesmo fornecedor e os níveis de performance, o atributo que teve a maior correlação com a compra repetitiva foi $\mathrm{o}$ nível e qualidade do apoio ao cliente, como mostra a figura 28. Isto significa que, se o cliente estivesse muito satisfeito com o nível do serviço ao cliente, haveria uma grande probabilidade de ele retornar. O atributo "serviço ao cliente" foi uma das características do fornecedor que tiveram a menor taxa de performance geral nessa pesquisa. Assim, a maneira mais fácil de perder permanentemente um cliente seria a ausência de serviço ao cliente ou presença de um serviço pobre. A segunda característica mais importante indicada para conquistar, ou não perder clientes de compras repetitivas, foi a entrega no prazo prometido. Os clientes afirmaram aceitar melhor uma espera maior na entrega do produto que receber uma promessa de prazo que lhes gerasse expectativas que não fossem atendidas (Reibstein, 2000:224). "Mais de 90\% das empresas não possui a integração necessária entre vendas e serviços para dar suporte ao comércio eletrônico” (Kalakota e Robinson, 1999:110).

A Internet possui uma capacidade sem precedentes de reunir comunidades dos mais variados interesses, em âmbito global. Dholakia e Bagozzi (2001:191) evidenciam alguns aspectos interessantes sobre as comunidades virtuais: (1) as experiências que ocorrem dentro da comunidade são criadas por seus membros mediante participação coletiva, e subseqüentemente consumidas coletivamente, como co-produção de serviços pelos consumidores (Kozinets, 1998, in Dholakia e 
Bagozzi, 2001:191; Venetianer, 2001:135); (2) os membros estão, em geral, privados das dicas sociais evidentes como aparência física, aspecto, voz, e outras características de identidade pública. Venetianer (2001:135) acrescenta que as comunidades virtuais dão vitalidade ao comércio eletrônico pela interação freqüente entre seus membros, uma vez que os internautas se sentem confortáveis em relação a elas, e facilitam o desenvolvimento de novos produtos e serviços, devido à convergência de interesses e à facilidade de coleta de opiniões, além de poderem criar barreiras à entrada de concorrentes. Uma comunidade virtual pode expandir o mercado, aumentar a visibilidade da marca e melhorar a lucratividade (vários autores ${ }^{9}$, in Barwise, Elberse e Hammond, 2002:27). No entanto, Muniz e O’Guinn (2001, in Barwise, Elberse e Hammond, 2002:28) salientam que uma comunidade forte de marca pode também ser uma ameaça às empresas: a comunidade poderia, por exemplo, rejeitar coletivamente os esforços de marketing ou mudanças no produto, ou ser alvo de sabotagens de concorrentes. Quatro tipos de comunidades de consumidores foram identificados por Armstrong e Hagel (1996, in Dholakia e Bagozzi, 2001:191):

- Comunidades de transação, originalmente desenvolvidas para facilitar a compra e venda de bens e serviços no ambiente digital, não têm fim social, devido ao seu dinamismo: os membros podem filiar-se à comunidade ou abandoná-la de maneira bastante fácil. Se, por um lado, isto pode resultar em compromisso limitado, e conseqüentemente, benefícios reduzidos para o consumidor, pode, pelo outro, criar maior presteza em participar e tomar vantagem dos benefícios oferecidos: podem ter acesso a um grande volume de informações sobre produtos, por diversos critérios à sua escolha e também a informações geradas por si próprios, com características de propaganda “de boca”, como opiniões sobre conteúdo e produto. Pouco se sabe, no entanto, sobre os efeitos de tais informações sobre as decisões de compra.

- Comunidades de interesse que congregam consumidores que interagem extensivamente em torno de um assunto, como as listas de distribuição eletrônica e newsgroups de assuntos específicos, nos quais a participação envolve muita comunicação interpessoal. Embora possam modelar preferências e tendências de ação dos consumidores, nada se conclui ainda sobre a intensidade dos relacionamentos nestas comunidades em relação aos tradicionais. As comunidades de marca podem ser inseridas neste grupo.

- Comunidades de fantasia, que permitem aos consumidores criar novos ambientes, personagens ou estórias e manipular sua própria identidade, filtrando as evidências e criando

${ }^{9}$ Hagel, 1999; Hagel e Armstrong, 1997; Hagel e Singer, 1999. 
anonimato. Embora poucos estudos tenham sido desenvolvidos sobre a influência desse tipo de atributo sobre os vários processos de consumo, nos processos de propaganda “de boca”, o anonimato voluntário pode ter sua credibilidade reduzida.

- Comunidades de relacionamento, orientadas aos indivíduos que se reúnem em torno de algumas experiências de vida, podem levar à formação de relacionamentos pessoais profundos, transformando-se em importantes grupos de referência, com influências tanto no contexto do grupo como nas práticas gerais de consumo de seus membros.

McKenna (1992:92) salienta que as pessoas consideram as mensagens mais dignas de crédito e mais convincentes quando as ouvem diretamente de outras pessoas, principalmente das que elas respeitam. Ao tomar decisões de compra, os membros confiam menos nos anúncios e mais nos membros da comunidade com os quais podem discutir suas experiências de compra e usos de bens e serviços específicos, retornando ao site por várias vezes (Boone e Kurtz, 2001:141). Barwise, Elberse e Hammond (2002:24), por outro lado, observam que há também evidências de que a Internet é meramente mais utilizada pelos consumidores como um canal alternativo de compras, que propriamente um meio de fortalecer seus relacionamentos com marcas ou outros consumidores. Becker-Olsen (2000, in Barwise, Elberse e Hammond, 2002:24) descobriu que os consumidores estariam mais interessados em realizar compras conveniente e rapidamente que em navegar e desenvolver relacionamentos. Este pensamento é apoiado por Peterson (1997, in Barwise, Elberse e Hammond, 2002:24), para quem os relacionamentos de marketing são, por natureza, mais orientados à troca que às relações. Tais idéias lançam dúvidas sobre as conclusões e afirmações de alguns autores (vários autores ${ }^{10}$, in Barwise, Elberse e Hammond, 2002:24; Reichheld e Schefter, 2000), que sugeriram que as comunidades desempenham um papel importante na criação de clientes leais. Entretanto, acredita-se que, embora estas afirmações, tanto favoráveis como contrárias, possam ser verdadeiras conforme o tipo de produto e o grau de desenvolvimento da comunidade, é possível inferir que empresas que estejam em contato com mais freqüência com seus clientes tenham maiores chances de desenvolver relacionamentos mais profundos com os mesmos, uma vez que se estabelece um fórum de discussão em que a comunicação é facilitada e incentivada.

Outro aspecto bastante facilitado pela Internet é a personalização ou “customização”. Segundo Hof (1998, in Boone e Kurtz, 2001:130), uma pesquisa com 25 sites de comércio eletrônico altamente “customizados” revelou que o movimento para a “customização” atraiu 47\% a

${ }^{10}$ Steinfield et al., 1995; Bauer et al., 1999; Armstrong e Hagel, 1996; Hagel, 1999. 
mais de clientes durante o primeiro ano e aumentou as receitas em 52\%. Embora os custos com software de personalização tenham variado entre US\$ 50 mil e US\$ 3 milhões, estes custos foram recuperados em doze meses a partir das vendas online adicionais.

Para criar valor, as empresas podem disponibilizar informações personalizadas em seu site em função do histórico de compras e preferências declaradas do internauta (Churchill e Peter, 2000:484), dado que a tecnologia da Internet fornece ferramentas interessantes para tanto, como a geração dinâmica de conteúdo baseada em perfis (Windham, 1999). Já Fingar, Kumar e Sharma (2000) acreditam que a “customização" proporciona valor ao cliente ao lhe permitir encontrar soluções que melhor atendam às suas necessidades e ao lhe poupar tempo nessa busca. A empresa, por meio da "customização", pode não apenas indicar uma solução específica para seus clientes, mas também, à medida que o relacionamento evolui, saber mais sobre seu comportamento de compra individual, o que lhe abre um leque de possibilidades de vendas cruzadas (cross-selling) ou complementares (up-selling). Sterne (2000:235-244) identifica diversos níveis de personalização: reconhecimento, oferta de recomendações de produtos e de serviços ao cliente, acesso a perfis, pela exigência de senha de acesso, rastreamento das páginas pelas quais o cliente navegou em seu último acesso ao site, pró-atividade em antecipar necessidades dos clientes etc.

Gummesson (1999:88) analisa como a produção, serviços, entrega e marketing estão integrados pela tecnologia de informação, o que leva a conseqüências diretas para a segmentação de mercado, cujo desenvolvimento pode ser caracterizado da seguinte forma:

1. Tudo era "customizado" na sociedade artesanal, geralmente com alta qualidade técnica, mas de alto custo para o consumidor comum. Cada indivíduo era seu próprio segmento.

2. A produção em massa na sociedade industrial, com economias de escala, reduziu os preços mas o mesmo produto para todos resultou em inadequação entre o produto e as necessidades individuais. Todos os indivíduos pertenciam ao mesmo segmento e eram expostos ao marketing de massa.

3. Uma segmentação simples no marketing de massa de produtos manufaturados em massa, em termos de variáveis sócio-demográficas, possibilitou a ocorrência de um número limitado de variações.

4. Uma segmentação refinada por nichos mais sutilmente definidos de acordo com o estilo de vida e comportamento de compra anterior aumentou as possibilidades de ajustes individuais. 
5. A produção “customizada” em massa une vantagens da larga escala com as necessidades individuais, direcionada a indivíduos ou comunidades de consumidores com necessidades compartilhadas. Volta-se aos segmentos individuais da sociedade artesanal, porém com tecnologia diferente. As economias de escala também podem ser chamadas de economias de escopo.

Hoje, é possível personalizar não apenas computadores, mas também carros, jóias e vários outros produtos ou serviços, como viagens e seguros, por um site na Internet. Se bem desenvolvida, a “customização” em massa proporciona vantagem competitiva para a empresa que a pratica, além de possibilitar o aumento da demanda global de certos produtos e serviços (Turban et al., 2000). Para alguns autores, a maior aplicação da Internet é a “customização” em massa.

A maior parte dos profissionais de negócios imaginam o marketing como uma oportunidade de radiodifusão em massa, mas a Internet é um meio de transmissão individual: a empresa atinge as pessoas uma a uma, por intermédio de mensagens direcionadas. A Internet é, para a maioria das aplicações, uma mídia de direcionamento individual, e não um mercado de massa. A audiência pode ser de um dos usuários qualificados, pois eles escolhem visitar o site da empresa e estão executando uma ação positiva (Ellsworth e Ellsworth, 1997:22). A noção de "marketing de massa customizado" pode parecer não fazer sentido mas é uma estratégia interessante: um relacionamento pseudopessoal pode ser eficiente (Gummesson, 1999:27).

Desta forma, a lealdade e retenção de clientes também são afetadas pela “customização” em massa, também chamada marketing “one-to-one”, ou "1-1”, conceito bastante explorado por autores como Peppers e Rogers (1994). Trata-se de um processo pelo qual uma empresa desenvolve um sistema para "customização”, ou algo próximo disto, segundo especificações de cada cliente, para um produto ou serviço amplamente comercializado e, talvez, oferecido em muitas configurações diferentes. Isto gera um sentimento de que o produto foi feito especialmente para o cliente, um importante componente afetivo, relacionado à atitude, de um relacionamento comprador-vendedor (Winer, 1999:378). A tecnologia de informação, ao prover rápida comunicação e facilitar a flexibilização, torna a “customização” em massa e a personalização factíveis e econômicas (Ruefli, Whinston e Wiggins, 2001:50).

Gilmore e Pine II (1997, in Winer, 1999:379) caracterizam quatro abordagens distintas para a “customização” em massa: 
- As empresas que praticam “customização” colaborativa conversam com os clientes individuais para auxiliar a determinar suas necessidades, identificar o produto exato para atendê-las e então produzi-lo.

- As empresas que praticam “customização” adaptativa oferecem um produto padrão, porém “customizável”, desenhado de modo a permitir que os usuários o alterem de acordo com suas próprias especificações.

- As empresas que praticam “customização” cosmética apresentam um produto padrão de maneira distinta para clientes distintos, como uma empresa que vende um produto para diferentes cadeias varejistas, entregando produtos com embalagem, tamanhos, e outras características peculiares e específicas a cada uma.

- As empresas que praticam “customização” transparente fornecem a cada cliente produtos ou serviços únicos, sem lhes dizer que tais produtos tenham sido feitos especialmente para eles, interessante quando os clientes não desejam declarar suas necessidades repetidamente. Os serviços de Internet, como por exemplo a Amazon.com, produzem recomendações de livros “customizadas”, enviadas via $e$-mail a seus clientes, com base em compras anteriores.

Winer (1999:379) observa um ponto comum entre os quatro tipos de abordagem apresentados: as empresas percebem que os clientes são heterogêneos e desejam diferentes combinações de características e benefícios dos produtos. Este reconhecimento vai além da segmentação de mercado, uma vez que a customização em massa cria um sentimento entre os clientes de que a empresa se preocupa com eles a ponto de desenvolver produtos que atendam precisamente às suas necessidades. O resultado desejado é um relacionamento mais duradouro.

Embora a tecnologia possibilite cada vez mais a “customização”, há fatores que a dificultam: os clientes comportam-se ora como parte de um grupo, encaixando-se em classificações psicográficas e sociais, ora libertam-se, tornando-se iconoclastas, criando e violando padrões. A tecnologia, com o marketing de banco de dados, permite gerenciar melhor estes aspectos.

Estudos de comportamento do consumidor podem auxiliar a determinar táticas eficazes para o relacionamento online (Wind e Mahajan, 2001:189). Gianforte (2001:1), por outro lado, lembra que, infelizmente, a maior parte das empresas falha em explorar efetivamente o potencial total da Internet como um veículo de serviço ao cliente: elas não reconhecem o quão poderosa pode ser esta ferramenta nas estratégias de negócios das empresas, são lentas na resposta às necessidades dos clientes, não desenvolvem um processo prático para oferecer a informação que seus clientes 
desejam, ou falham em manter tal informação atualizada. Há um custo para essas falhas. Segundo esse autor, as empresas que não desenvolvem um serviço eficaz pela Internet acabam gastando cerca de 20 vezes mais a cada ocorrência de suporte ao cliente que seus concorrentes, ao manter uma estrutura de call center para responder até mesmo perguntas mais rotineiras e repetitivas. As empresas com um serviço pobre também perdem clientes frustrados, que procuram a concorrência para satisfazer às suas necessidades.

Gianforte (2001:7) enumera os benefícios do serviço via Internet, os quais podem ser reflexo do sucesso de se tomar total vantagem da Internet como um meio para a prestação de serviço superior ao cliente: (1) custo reduzido do serviço ao cliente; (2) serviço ao cliente mais rápido e maior satisfação; (3) habilidade de se adequar a picos de volume sazonais; (4) liberação de pessoal.

Gianforte (2001:1) afirma que, lamentavelmente, muitos executivos que ficariam sobressaltados se suas equipes de vendas e de serviços ao cliente não tivessem capacidade de resposta ou fossem ignorantes sobre os produtos da empresa, não mostram a mesma preocupação sobre um site que apresente tais características. Segundo ele, os visitantes de sites são bastante sensíveis a demoras. Pode ser apenas uma questão de segundos antes que desistam de sua pesquisa e tentem buscar informações em outro lugar. Relata ainda que os inovadores no serviço via Internet provaram que é possível responder a um grande percentual de questões de clientes online, sem despender dinheiro e tempo. Para um serviço bem sucedido, devem ser observados alguns atributos básicos em sua execução, princípios considerados muito eficazes, como resultado dos erros e acertos de milhares de empresas com sites na Internet (Gianforte, 2001:5-7; Forbes, 2002:1-3):

1. Certificar-se de que o site possa "ouvir” tanto as mensagens explícitas como as implícitas dos clientes.

2. Dar aos clientes o que eles desejam, rapidamente, se possível, em um único clique; o conteúdo self-service deve estar voltado às perguntas mais freqüentes dos clientes.

3. Tornar os recursos de serviço eletrônico fáceis de serem encontrados e utilizados, com gráficos e conteúdo interativo, por exemplo; é importante também possibilitar aos clientes recorrer aos e-mails, chat ou atendentes por telefone, em caso de dificuldades.

4. Fornecer canais múltiplos de contato, respeitando as várias preferências dos clientes.

5. Não colocar um número de discagem gratuita ou formulário de e-mail antes do conteúdo self-service. 
6. A regra "80/20"; estudos mostram que os implementadores do serviço eletrônico têm conseguido responder $86 \%$ de todos os questionamentos online com um conjunto razoavelmente pequeno de itens de sua base de conhecimento. A regra prevê que mais que $80 \%$ das questões são respondidas por apenas $20 \%$ de uma base de suporte de conhecimento.

7. Permitir que os clientes avaliem a empresa; não é possível melhorar se não houver medidas para avaliação; é preciso acompanhar sempre a performance.

8. Distribuir a base de conhecimento da empresa entre todos os canais de interação com os clientes, como e-mail e telefone, por exemplo.

9. Fornecer um mapa das lojas físicas e representações regionais da empresa, e não apenas seus endereços.

10. Considerar a terceirização em termos de hospedagem do site, o que pode reduzir custos de hardware e software, bem como do pessoal para implementar e manter o sistema de serviço pela Internet.

11. “Automatizar, automatizar, automatizar”, principalmente a criação e manutenção da base de dados self-service. Sem a automatização, o trabalho requerido para um serviço via Internet bem sucedido seria bastante desgastante. $\mathrm{O}$ adequado gerenciamento do conhecimento exige a execução de funções que, se negligenciadas, podem resultar em desatualização do conteúdo e insatisfação do cliente. A automação pode auxiliar nessas tarefas, economizando tempo e sendo bastante eficiente.

12. Ter um apoio interno forte.

A excelência dos serviços via Internet requer mais que apenas a tecnologia correta, exigindo processos ajustados, técnicas corretas e trabalho de equipe (Forbes, 2002:1-3). Venetianer (2001:45) acrescenta que as empresas que montaram bons sites de assistência online descobriram que houve, logo em seguida, uma substancial diminuição do uso de linhas 0800 , a redução do volume de $e$ mails e o aumento da produtividade dos seus atendentes por telefone. Sterne (2000:213) sugere que as empresas contratem um comprador oculto para seus sites para avaliá-los: tempo de resposta a $e$ mails, retorno de telefonemas, tempo de espera, simpatia dos atendentes. Também considera essencial a presença de canais abertos para que os clientes se manifestem e se esforcem em desenvolver um relacionamento. As empresas poderiam, por exemplo, selecionar mensalmente alguns clientes, e conversar com os mesmos por telefone, perguntando-lhes sobre o seu atendimento, o que mais gostariam que fosse implementado em seu site etc. 
Em relação à avaliação do marketing de relacionamento, Sterne (2000:10) também analisa o conceito de "valor de um cliente durante a sua existência", que é baseado na premissa de que a parte mais custosa do relacionamento é o seu início: pode custar centenas ou milhares de dólares encontrar um cliente potencial, qualificá-lo como um prospect e aproximá-lo como um cliente. A seguir, é preciso tratá-lo como um ativo, calculando o valor presente líquido do lucro que um único cliente gerará ao longo do tempo.

Ao propor formas de avaliação do desempenho da empresa em relação aos desejos do cliente, Fischer (1999, in Sterne) acredita que o valor do produto ou serviço percebido pelo cliente seja um bom indicador. "Valor é o trade-off entre as conseqüências positivas e negativas da compra e do uso”. Essa autora compara a diferença entre satisfação e valor, conforme o quadro 7, a seguir:

Quadro 7 - Comparação entre satisfação e valor

\begin{tabular}{l|l}
\hline \multicolumn{1}{c|}{ Orientação para a Satisfação } & \multicolumn{1}{c}{ Orientação para o Valor } \\
\hline Mede apenas as conseqüências positivas & Mede os trade-offs \\
\hline Mede uma marca & Compara os principais concorrentes \\
\hline Foca o produto & Foca o uso do produto \\
\hline Foca os atributos & Usa atributos, conseqüências e valores \\
\hline Fornece visão de curto prazo & Fornece visão mais a longo prazo \\
\hline Encoraja mudanças incrementais & Encoraja mudanças radicais \\
\hline
\end{tabular}

Fonte: Fischer (1999, in Sterne, 2000:222).

Essa autora afirma que, para conhecer seus clientes individualmente, a empresa deve monitorar sua recentidade (há quanto tempo ele comprou da empresa?), freqüência (qual sua freqüência de compra da empresa?) e valor monetário (quanto ele gasta em compras dessa empresa?), conhecidos pela sigla RFV, enquanto navegam por seu site de comércio eletrônico. Com isto, é possível preparar um ranking de clientes aos quais podem ser destinados os gastos da empresa com ofertas de serviços e, ao mesmo tempo, identificar os "maus" clientes. Este procedimento permite à empresa tratar de maneira diferenciada clientes que mereçam tal distinção.

Seybold (1998, in Sterne, 2000:5), aponta oito fatores críticos de sucesso, no que tange ao imperativo de serviços ao cliente: (1) focar os clientes corretos; (2) ter em suas mãos a experiência total do cliente; (3) melhorar os processos de negócios que tenham impacto sobre o cliente; (4) fornecer uma visão de $360^{\circ}$ do relacionamento com o cliente; (5) deixar que os clientes ajudem a si 
próprios; (6) auxiliar os clientes a realizarem seu trabalho; (7) prover serviço personalizado; (8) encorajar o desenvolvimento de comunidades.

Um serviço ao cliente bem sucedido requer que se olhe para os produtos, a empresa e os métodos de serviço ao cliente pelos olhos do cliente. Pouco importa ao cliente se a empresa está organizada por linhas de produtos, unidades de negócios ou esferas de influência política; ele apenas deseja que suas questões sejam respondidas e seus problemas, resolvidos (Sterne, 2000:42), assim como deve ocorrer no mundo físico.

Tom Peters (1997, in Sterne, 2000:4) ressalta a necessidade de se focarem os desejos mais fortes dos clientes, e não apenas a sua satisfação, nem, simplesmente, seu prazer. Para ele, o prazer é temporário, enquanto os desejos são mais intensos, fortemente emocionais. Sterne (2000:4) complementa que os fortes desejos levam os clientes para além do ponto de recomendar uma empresa para outras pessoas, tornando-os os melhores vendedores da empresa. Porém, não se pode criar este forte desejo a menos que a empresa possua uma organização, processos, ética, site de serviços que possam apoiar os clientes em todas as suas consultas, problemas, necessidades, esperanças e sonhos.

“Ao longo da era na qual estamos entrando, a ênfase deverá estar em contratação de sistemas; os relacionamentos comprador-fornecedor serão caracterizados pelo contato contínuo e pela evolução dos relacionamentos, com o propósito de efetivar os sistemas. (...) À medida que o cliente adquire experiência, a tecnologia terá sua importância reduzida em relação à do sistema, que capacita o cliente na obtenção dos benefícios tecnológicos. Serviços, entrega, confiabilidade, nível de resposta e qualidade de interações humanas e organizacionais entre fornecedor e comprador terão importância maior que a própria tecnologia” (Levitt, 1994:46).

Assim sendo, a tecnologia pode ser um grande aliado das empresas na oferta de produtos e serviços a seus clientes. Resta à empresa saber dosar o nível de tecnologia adequado a cada tipo de produto ou serviço e a cada tipo de cliente, dentro de suas limitações de recursos financeiros e humanos, sem perder de vista a concorrência. Boone e Kurtz (2001:144) lembram que os profissionais de marketing deveriam educar-se não tanto sobre os detalhes da tecnologia, mas sobre como os sites aprimoram as comunicações com os clientes e como tais comunicações podem beneficiar a empresa. Além disso, identificar as necessidades e desejos dos consumidores é crítico para os profissionais de marketing tanto online como offline. 


\subsubsection{CRM: Customer Relationship Management}

A riqueza de conteúdo em pesquisas e o volume de dinheiro investido por muitas empresas e conseqüente atenção dedicada pelas empresas de consultoria e de desenvolvimento de software ao CRM já poderiam render, por si, vários estudos. Contudo, embora não figure como tema central deste estudo, a sua importância para este trabalho reside em seus fundamentos no marketing de relacionamento e a sua freqüente associação à tecnologia. Estima-se que, em 2003, o mercado de CRM no Brasil chegue a R \$135 milhões (cerca de US\$45 milhões), segundo estimativas da empresa de consultoria E-Consulting (Manzoni Jr., 2003:20). A tendência de crescimento do mercado de software para CRM é impulsionada por empresas com foco na melhoria da satisfação e lealdade do cliente, bem como no aumento das receitas com clientes existentes (Kalakota e Robinson, 1999:111).

Por receber tanta atenção e tanto investimento, o termo CRM ganhou popularidade e passou a ser referenciado em diversas ocasiões, e nem sempre com o mesmo significado. O termo também ficou bastante associado a uma categoria específica de software. Neste estudo optou-se por utilizar a sigla em inglês, já que a mesma é amplamente empregada em trabalhos publicados no Brasil.

Kalakota e Robinson (1999:110-111) argumentam que tornar-se voltado para o cliente significa ter interações consistentes, dependentes e convenientes com o mesmo, em todos os encontros com ele. Indo mais além, Khirallah (2000:1, in Ragins e Greco, 2003:25) assume que, em sua essência, o CRM é “uma estratégia de negócios que procura assegurar que toda interação do cliente com a empresa, quer seja de venda ou de prestação de serviços, seja apropriada, relevante e consistente, independentemente do canal de comunicação utilizado”. Sowalskie (2001, in Ragins e Greco, 2003:25) considera o CRM uma estratégia central de negócios para gerenciamento e otimização das interações dos clientes pelas interfaces tradicionais e eletrônicas oferecidas por uma empresa. Um site eficaz, por exemplo, pode auxiliar na construção de relacionamentos entre a empresa e seus stakeholders (Weiss, 1999, in Ragins e Greco, 2003:25), especialmente seus clientes. Ragins e Greco (2003:25), por sua vez, avaliam que o objetivo do CRM é modelar as percepções dos clientes a respeito da empresa e de seus produtos mediante a identificação dos clientes, criação de conhecimento sobre eles e a construção de relacionamentos comprometidos com os mesmos. Na mesma linha de raciocínio, Kalakota e Robinson (1999:110-111) definem o CRM como a "combinação de processos de negócios e tecnologia que busca compreender os clientes de uma empresa sob uma perspectiva multifacetada: quem são, o que fazem, e do que gostam”. Esses 
autores vêem o CRM como uma estratégia integrada de vendas, marketing e serviços, que depende de ações coordenadas. Ragins e Greco (2003:25) e Kalakota e Robinson (1999:111) concordam que o gerenciamento eficaz de relacionamentos com clientes é uma fonte de diferenciação competitiva. Desta maneira, o CRM pode ser visto como uma estratégia de negócios ou um arcabouço de integração, e não um produto.

Sob perspectiva um pouco distinta, o SAS Institute (2000?a:1) define o CRM como "um processo pelo qual uma empresa maximiza a informação do cliente em um esforço de aumentar a lealdade e reter os negócios com clientes ao longo de sua vida”. Segundo o instituto, o CRM combina uma abordagem progressiva para coletar dados dos clientes com bancos de dados avançados e tecnologias de suporte à decisão, os quais auxiliam a transformar dados em conhecimento de negócios. Ao maximizar o uso da informação do cliente, as empresas podem monitorar e compreender melhor o seu comportamento. Em resposta à essa nova inteligência conquistada, a empresa pode remodelar seus sistemas de front e back-office de maneira a assegurarse de que está oferecendo o que o cliente realmente deseja.

Bretzke (1999:139), por sua vez, trata o CRM como uma estratégia com raízes no marketing de relacionamento e que impacta a gestão da empresa, principalmente em termos de relacionamento com os clientes e infra-estrutura do setor. Segundo essa autora, a tecnologia do CRM, sem o redesenho dos processos e um modelo de relacionamento que faça uma entrega sustentada de valor a longo prazo para o cliente, será apenas um projeto de informatização de call center ou de vendas, não conduzindo efetivamente ao estágio da resposta em tempo real. Pinheiro (2000:108) avalia que, "para especialistas, o significado embutido nessas três letras remete mais à estratégia que à tecnologia. Trata-se de privilegiar o consumidor ao produto, integrar todos os canais de contato disponíveis, aprofundar o conhecimento sobre o cliente e usar desse conhecimento para construir laços de fidelidade com o mesmo, uma opção estratégica que pode significar a diferença entre sucesso e fracasso nos negócios”.

Segundo Rigby, Reichheld e Schefter (2002:101-102), quando eficaz, o CRM possibilita às empresas obter dados sobre seus clientes de maneira rápida, identificar os clientes de maior valor, aumentar a sua lealdade ao fornecer produtos e serviços padronizados, ao mesmo tempo em que se reduzem os custos de servi-los e se torna mais fácil conquistar clientes similares no mercado. Sterne (2000:292) acrescenta ainda como promessas do CRM serviços mais rápidos, maiores lucros, coordenação da equipe, maior satisfação do cliente, maior retenção de clientes e lealdade. 
Day (s.d., in Knowledge at Wharton - Marketing, 2002), com base em pesquisas, sugere três abordagens distintas para o desenvolvimento do CRM. A primeira é a abordagem orientada para o mercado, que torna o CRM o elemento central de uma estratégia que foca a entrega de valor superior ao cliente por meio de elementos como serviço excepcional e disposição em atender a necessidades individuais. A segunda abordagem sugerida é baseada em iniciativas direcionadas aos aspectos internos da organização, como organizar dados internos com maior eficiência para reduzir custos de serviços, auxiliar as equipes de vendas a fechar negócios de forma mais rápida, e direcionar melhor as atividades de marketing, tarefas normalmente associadas ao pessoal de tecnologia da informação e que possuem pouca conexão com a estratégia competitiva. A terceira abordagem utiliza ações defensivas, como programas de lealdade, desenhadas para evitar perda de espaço para a concorrência.

O SAS Institute (2000?a:1) enumera como metas do CRM: (1) construir relacionamentos de longo prazo e lucrativos com clientes selecionados; (2) aproximar-se destes clientes em cada ponto de contato; (3) maximizar a participação da empresa na "carteira do cliente”. Kalakota e Robinson (1999:110-111), sob visão mais pragmática, vêem como metas: (1) utilizar relacionamentos para aumentar as receitas, ampliando a lucratividade ao identificar, atrair e reter os melhores clientes; (2) utilizar informações integradas para serviços excelentes, economizando tempo e minimizando as frustrações dos clientes, surpreendendo-os ao mostrar-lhes o quanto a empresa sabe sobre eles; (3) introduzir processos e procedimentos de vendas mais repetíveis, consistentes em termos de gerenciamento de contas e vendas; (4) criar novos valores e instigar a lealdade; (5) implementar uma estratégia de solução mais pró-ativa, antecipando os problemas antes que estes ocorram.

Sowalskie (1999, in Ragins e Greco, 2003:26) acredita que o CRM seja impulsionado por três fatores essenciais: (1) os clientes possuem mais poder pela informação, tecnologia, opções de escolha, globalização e desregulamentação; (2) competição crescente; (3) a Internet e o e-business, que facilitam a emergência de novos canais de distribuição e aperfeiçoam as vendas e o marketing, bem como a eficácia e a eficiência dos serviços. Já para o Gartner Group (2000:4), as forças impulsionadoras do CRM são: (1) diferenciação em um mundo com concorrência cada vez mais acirrada; (2) foco na intimidade com o cliente como uma estratégia-chave; (3) emergência de tecnologias habilitadoras; (4) demanda por parte dos clientes; (5) surgimento de canais de $e$ business; (6) potencial de crescimento das receitas e de economia de custos; (7) pressão por parte de parceiros e concorrentes; (8) pressão dos fornecedores de tecnologia da informação. Ragins e Greco (2003:27), contudo, ponderam que o CRM requer que a empresa veja os relacionamentos com 
clientes como um meio de aprender sobre suas necessidades e desejos e como melhor criar, satisfazer e sustentá-los, ao mesmo tempo em que auxilia a empresa a atingir seus objetivos. Esses autores afirmam também que o CRM pode aprimorar o valor do relacionamento tanto para clientes como para a empresa.

A empresa de consultoria Accenture analisou a evolução do CRM, conforme o quadro 8, a seguir (Keane, 2002:47):

\begin{tabular}{|c|c|c|c|}
\hline Evolução & $\begin{array}{c}\text { Fase } 1 \\
\text { Início dos anos } 1990\end{array}$ & $\begin{array}{c}\text { Fase } 2 \\
2000-2002\end{array}$ & $\begin{array}{c}\text { Fase } 3 \\
\text { A partir de } 2002\end{array}$ \\
\hline $\begin{array}{l}\text { Metas do } \\
\text { CRM }\end{array}$ & $\begin{array}{l}\text { - Melhorar a eficiência dos canais } \\
\text { - Aumentar a satisfação dos } \\
\text { clientes }\end{array}$ & $\begin{array}{l}\text { - Melhorar as interações com os } \\
\text { clientes } \\
\text { - Aumentar a retenção de clientes }\end{array}$ & $\begin{array}{l}\text { - Predizer o comportamento } \\
\text { dos clientes }\end{array}$ \\
\hline $\begin{array}{l}\text { Estratégia } \\
\text { de CRM }\end{array}$ & $\begin{array}{l}\text { - Fornecer meios mais eficientes de } \\
\text { interação com os clientes }\end{array}$ & $\begin{array}{l}\text { - Fornecer múltiplos pontos de } \\
\text { contato com os clientes }\end{array}$ & $\begin{array}{l}\text { - Integrar comunicação e } \\
\text { marca entre os canais }\end{array}$ \\
\hline Resultados & $\begin{array}{l}\text { - Os clientes receberam transações } \\
\text { mais convenientes, mas os canais } \\
\text { não estavam integrados }\end{array}$ & $\begin{array}{l}\text { - Os clientes passaram a ter mais } \\
\text { opções de interação com a } \\
\text { empresa, mas as experiências } \\
\text { eram fragmentadas entre os } \\
\text { pontos de contato }\end{array}$ & $\begin{array}{l}\text { - Os clientes passam a ter } \\
\text { uma experiência de } \\
\text { integração entre todos os } \\
\text { canais sem precedentes }\end{array}$ \\
\hline $\begin{array}{l}\text { Foco do } \\
\text { marketing }\end{array}$ & $\begin{array}{l}\text { - Aquisição de clientes } \\
\text { - Vendas de produtos }\end{array}$ & $\begin{array}{l}\text { - Retenção de clientes } \\
\text { - Vendas cruzadas }\end{array}$ & $\begin{array}{l}\text { - Conversa com os clientes } \\
\text { - Valorização da marca }\end{array}$ \\
\hline
\end{tabular}

Fonte: Accenture (s.d., Keane, 2002).

Como se pode observar nesse estudo, à medida que o foco do marketing evoluiu, metas e estratégias para alcançá-las também evoluíram e as interações entre empresas e clientes se tornaram mais vantajosas para ambas as partes. Como resultado, a integração passou a representar papel fundamental na postura da empresa perante seus clientes, no sentido de melhor compreendê-los e satisfazê-los.

É interessante que as empresas capturem informações na prospecção do cliente, nas influências pré-vendas, dados de pós-vendas dos clientes, e, eventualmente, dados de cobrança e de embarque, e todas as interações dos clientes de qualquer canal, e as armazenem em um único repositório que permita análises extensivas. Esta abordagem multicanal, de visão única, auxilia a empresa a criar fortes relacionamentos com seus clientes ao fornecer uma visão ampla de todas as interações: o contato subseqüente com o cliente será mais tranqüilo, uma vez que a empresa terá uma melhor compreensão da história desse cliente com ela própria (Lykins, 2002:11). Além disso, ao fornecerem maiores informações sobre os padrões de compra e comportamento dos mesmos, habilitar novos pontos de contato via Internet e prover características importantes, como a 
personalização, as tecnologias do CRM podem auxiliar no processo de construção de relacionamentos fortes com clientes (Sommer, 2000:41). Todavia, Butler (2000, in Ragins e Greco, 2003:28) identifica dois desafios significantes para o CRM relacionados aos negócios multicanal: a consistência de resposta entre os diferentes pontos de contato entre os clientes e a empresa; a necessidade de se enxergar holisticamente o CRM, como parte dos processos da empresa, e não como uma série tática de transações, o que requer informações de todos os departamentos envolvidos na criação de inteligência sobre o cliente.

Os pacotes de softwares de CRM são compostos por vários módulos, decorrentes do natural crescimento das funcionalidades necessárias aos departamentos de marketing, de outras aplicações relacionadas ao gerenciamento do relacionamento com o cliente e das necessidades da nova filosofia de negócios centrada no cliente. Na figura ilustrada no anexo C, por exemplo, o Meta Group esquematiza o fluxo de informações e o tipo de interação entre três tipos de CRM: Operacional, Analítico e Colaborativo (2000, in Peoplesoft, 2002). Segundo Sommer (2000:44), o CRM Operacional está relacionado à automatização dos pontos de contato do front-office integrados horizontalmente; o Analítico envolve a análise dos dados coletados pelo Operacional; e o Colaborativo envolve o uso de interfaces colaborativas como e-mail, conferência, chat, e resposta interativa de voz nas interações entre empresa e clientes. A título de ilustração, os softwares para CRM podem incluir alguns dos módulos apresentados no quadro 9, a seguir:

Quadro 9 - Módulos componentes dos softwares de CRM

\begin{tabular}{c|l}
\hline Módulos & \multicolumn{1}{c}{ Função/Descrição } \\
\hline $\begin{array}{c}\text { Gerenciamento da } \\
\text { campanha de } \\
\text { marketing }\end{array}$ & $\begin{array}{l}\text { Criar e gerenciar um ou mais projetos de marketing, medir a sua eficácia, analisar a eficácia } \\
\text { do tipo de mídia escolhida etc. }\end{array}$ \\
\hline Otimização do cliente & $\begin{array}{l}\text { Permite à empresa obter dados sobre os clientes individuais, predizer padrões de compra, } \\
\text { “customizar” as ofertas, oferecer produtos com base em informações de perfis, sincronizar } \\
\text { ofertas ao longo de todos os canais de distribuição e verificar as respostas. }\end{array}$ \\
\hline $\begin{array}{c}\text { Gerenciamento do } \\
\text { serviço ao cliente }\end{array}$ & $\begin{array}{l}\text { Cuidados e gerenciamento pós-venda aos clientes, podendo contar com integração entre } \\
\text { computadores e telefonia, serviços (perguntas mais freqüentes, links, respostas interativas } \\
\text { etc.), rastreamento ou status do pedido, administração de problemas ou acidentes, automação } \\
\text { do helpdesk, análise de performance de funcionários etc. }\end{array}$ \\
\hline $\begin{array}{c}\text { Automação do serviço } \\
\text { de campo }\end{array}$ & $\begin{array}{l}\text { De acordo com o setor, pode incluir a gestão da programação de manutenções, administração, } \\
\text { gestão do inventário e vendas do serviço de campo, coleta de dados de clientes/mercados no } \\
\text { serviço de campo, gestão de contratos e retornos e serviços. }\end{array}$ \\
\hline
\end{tabular}




\begin{tabular}{|c|c|}
\hline $\begin{array}{c}\text { Gestão do } \\
\text { conhecimento }\end{array}$ & $\begin{array}{l}\text { Habilidade de acessar, armazenar, distribuir e transferir conhecimento importante armazenado } \\
\text { na empresa, em poder dos funcionários, contido em documentos, ou armazenados } \\
\text { eletronicamente, o que inclui informações técnicas sobre produtos, precificação, informações } \\
\text { externas (conhecimento competitivo, dados econômicos), enciclopédia de marketing, } \\
\text { informações sobre clientes etc. }\end{array}$ \\
\hline $\begin{array}{l}\text { Automação de } \\
\text { marketing }\end{array}$ & $\begin{array}{l}\text { Configurador de produto/preço, gerenciamento de campanha, gestão de oportunidades, } \\
\text { otimização do cliente e enciclopédia de marketing, permitindo à empresa analisar o mercado, } \\
\text { clientes e dados competitivos, gerar documentos sobre vendas e marketing em geral. }\end{array}$ \\
\hline $\begin{array}{l}\text { Gerenciamento de } \\
\text { oportunidades }\end{array}$ & $\begin{array}{l}\text { Conjunto de ofertas que permite à empresa descobrir oportunidades segundo vários critérios, } \\
\text { definir direções, disparar automaticamente ações de marketing, estabelecer prioridades, } \\
\text { acompanhar e realizar análises de tendências e previsões. }\end{array}$ \\
\hline $\begin{array}{r}\text { Gest } \\
\text { relacionam } \\
\text { parc }\end{array}$ & $\begin{array}{l}\text { Gestão de distribuição, suporte aos canais de marketing, gestão de fundos, precificação e } \\
\text { configuração de produtos, vendas cruzadas, atividades colaborativas, marketing em conjunto, } \\
\text { acompanhamento de pedidos, atributos do site/portal, entre outros. }\end{array}$ \\
\hline $\begin{array}{r}\text { Automação } \\
\text { profiss }\end{array}$ & Gerenciamento do tempo, cobrança, contabilidade dos projetos e programação. \\
\hline Rel & $\begin{array}{l}\text { Ferramentas que permitem consultas rápidas, oferecendo a possibilidade de geração de } \\
\text { relatórios ad hoc, padronizados, com informações executivas, informações de suporte à } \\
\text { decisão, processamento analítico online, entre outros. }\end{array}$ \\
\hline $\begin{array}{r}\text { Autori } \\
\text { disposição } \\
\text { em } \mathrm{r}\end{array}$ & $\begin{array}{l}\text { Auxilia no manuseio de produtos em retorno, o que inclui as disposições, análise de controle } \\
\text { de qualidade, atualização de dados de clientes, acompanhamento das razões de retorno, entre } \\
\text { outros. }\end{array}$ \\
\hline $\begin{array}{l}\text { Automação da força de } \\
\text { vendas e } \\
\text { Gerenciamento de } \\
\text { território }\end{array}$ & $\begin{array}{l}\text { Ferramentas que auxiliam o desempenho desta função, como gestão de tempo e viagens, } \\
\text { perfis dos contatos, histórico, programação de visitas, análises dos canais de vendas, gestão e } \\
\text { alinhamento dos territórios abrangidos, geração de propostas, precificação, análises de vendas, } \\
\text { medidas de performance de vendas, garantias, gestão de conhecimento, perfis por território, } \\
\text { análise e acompanhamento de resultados, atribuição de territórios, análise competitiva, } \\
\text { suporte pós-vendas, entre outros. }\end{array}$ \\
\hline $\begin{array}{l}\text { Gerenci } \\
\text { eventos }\end{array}$ & $\begin{array}{l}\text { Ferramentas para acompanhar, analisar e gerenciar eventos especiais como seminários, } \\
\text { conferências e eventos pela Internet, incluindo o planejamento e programação, } \\
\text { acompanhamento do desenvolvimento dos temas, informações de contato e perfil dos } \\
\text { participantes e palestrantes e análise de custos e resultados. }\end{array}$ \\
\hline $\begin{array}{l}\text { Gerenc } \\
\text { telen }\end{array}$ & $\begin{array}{l}\text { Envolve hardware e software para administrar os chamados internos e externos à empresa, } \\
\text { incluindo auto-discagem, roteamento e distribuição de chamadas, gestão da lista de chamadas, } \\
\text { entrada de pedidos, dados de perfil dos clientes, acompanhamento e gestão de chamadas, } \\
\text { definição de scripts, resposta de voz automática etc. }\end{array}$ \\
\hline $\begin{array}{l}\text { Administração de } \\
\text { garantias }\end{array}$ & $\begin{array}{l}\text { Permite à força de vendas e serviços acompanhar as garantias dos clientes, compreendendo } \\
\text { garantias específicas, guarda e análise de documentos, rastreamento de números de série e } \\
\text { lote, alertas e disparo de ações quando se atingem certos limites de data/hora, ferramentas de } \\
\text { atualização de vendas, renovação de garantia, acompanhamento de performance, auditoria de } \\
\text { registros e histórico, entre outros. }\end{array}$ \\
\hline
\end{tabular}

Fonte: Microsoft Great Plains Business Solutions (2001:47-49).

Entretanto, há ressalvas a serem feitas. Dados do Gartner Group, empresa de pesquisa e consultoria, revelam que 55\% dos projetos de CRM não produzem resultados. Rigby, Reichheld e Schefter (2002:101-102) mencionam também uma pesquisa realizada em 2001 pela empresa de consultoria Bain \& Company sobre ferramentas administrativas, que analisou o uso corporativo e a satisfação das empresas quanto a técnicas de gerenciamento e apontou o CRM entre os três últimos 
colocados em termos de satisfação, entre 25 ferramentas populares. Outra pesquisa citada por eles revela que 20\% de 451 executivos seniores afirmaram, em 2000, que suas iniciativas de CRM não só falharam em proporcionar crescimento lucrativo, mas também deterioraram relacionamentos de longa data com clientes. Cerca de $80 \%$ das falhas na implantação de CRM se devem à falta de planejamento (Bretzke, 1999:142) e, em quase 100\% dos casos, o grande erro na implementação do CRM está na falta de definição da estratégia empresarial (Müller e Melo, 2001:93).

Dempsey (2002) relata que grandes fornecedores de aplicações complexas recorriam ao CRM para dar conta da automação de serviços das equipes de vendas, armazenando e extraindo dados contidos na memória dos vendedores. Embora a teoria se mostrasse atraente a qualquer empresa que tivesse perdido contatos importantes com a demissão de um vendedor, a prática encontrou resistência por parte de profissionais que relutavam em compartilhar segredos de conquistas individuais. O CRM tornou-se, rapidamente, vítima de seu próprio sucesso. Outra dificuldade comum, nem sempre esperada, é a necessidade de gastos extras em consultoria para garantir a integração dos sistemas legados, já existentes na empresa. Por acreditar que a chave para o crescimento reside na redefinição do CRM como uma estratégia capaz de conquistar novos clientes e manter os já convertidos, Dempsey (2002) cita John Wookey, executivo da Oracle da Califórnia, que acredita que a alta taxa de insucesso de muitos projetos resulta do fato de que "o foco inicial, lançado sobre as equipes de vendas, encobriu a questão fundamental: como aperfeiçoar e gerenciar o relacionamento com clientes.”

Rigby, Reichheld e Schefter (2002:101-102) pesquisaram, ao longo de dez anos, as razões pelas quais as iniciativas de CRM falham com tanta freqüência. Os resultados sugerem que uma das razões é o fato de que a maior parte dos executivos simplesmente não entendem o que estão implementando, exceto “quanto custa, e quanto tempo vai levar”. O CRM é entendido por esses autores como algo que "alinha os processos de negócios com as estratégias dos clientes para construir sua lealdade e aumentar os lucros ao longo do tempo”. Note-se que as palavras “tecnologia” e “software” estão ausentes dessa definição. Entretanto, há uma equivocada suposição por parte da maioria dos executivos de que o CRM é apenas uma ferramenta de software que irá gerenciar os relacionamentos com os clientes em seu lugar. O CRM é, na realidade, "um conjunto de estratégias e processos voltados para o cliente, apoiado por software relevante, com o propósito de ampliar a lealdade do cliente e, eventualmente, a lucratividade corporativa” (Rigby, Reichheld e 
Schefter, 2002:101-102). Assim, esses autores alertam para quatro obstáculos a serem evitados para que o CRM seja bem sucedido, enunciados a seguir:

1. Implementar o CRM antes de desenvolver uma estratégia voltada para o cliente: há uma tendência de focar a tecnologia da informação e não os resultados do negócio (Chung e Sherman, 2002). Muitos executivos entendem a tecnologia do CRM como uma estratégia de marketing, adequando suas estratégias à tecnologia adquirida do fornecedor e, como se isto não bastasse, delegam a gestão do relacionamento com o cliente a seus CIOs (Chief Informatics Officers). Para evitar tal equívoco, Rigby, Reichheld e Schefter (2002:101) e Davids (1999, in Ragins e Greco, 2003:29) sugerem inicialmente a identificação dos clientes interessantes para a construção de relacionamentos com a empresa, considerando que os clientes possuem necessidades e desejos diferentes, bem como valor potencial e presente distinto para a empresa. Esta identificação trará respostas apropriadas para o desenvolvimento da estratégia da empresa: investir para reconquistar ou melhorar relacionamentos lucrativos; gerenciar custos para manter os grupos de menores margens; ou livrar-se dos grupos não atrativos. Embora complexa, tal tarefa pode ter sucesso se a empresa refletir sobre as seguintes questões:

a. Quanto deve mudar a proposição de valor da empresa para conquistar maior lealdade do cliente?

b. Qual o nível de “customização” apropriado e lucrativo para a estratégia da empresa?

c. Qual é o valor potencial de se aumentar a lealdade dos clientes da empresa? Quanto isto varia por segmentos de clientes?

d. Quanto tempo e dinheiro pode ser alocado para o CRM neste momento?

e. Se a empresa acredita em relacionamentos com clientes, por que não está direcionando seus passos para um programa de CRM hoje? O que é preciso fazer para construir relacionamentos com clientes sem gastar um único centavo com tecnologia?

Davids (1999, in Ragins e Greco, 2003:29) também acrescenta que utilizar iniciativas que não beneficiam os clientes de fato contribui para o insucesso das práticas de CRM.

\section{Implantar uma tecnologia de CRM antes de criar uma organização voltada para o}

cliente: ter uma estratégia, segundo esses autores, não é suficiente: a instalação de uma solução de CRM somente será bem sucedida após a reestruturação de todos os processos relacionados a clientes de maneira a atender às necessidades dos clientes, do serviço ao 
cliente à entrega dos pedidos, das descrições dos cargos às medidas de performance e aos sistemas de compensação e de treinamento, entre outros.

3. Assumir que quanto mais tecnologia de CRM melhor: os objetivos do CRM podem ser atingidos sem grandes investimentos em tecnologia, por exemplo, simplesmente motivando os empregados a terem mais consciência das necessidades dos clientes. A introdução da tecnologia pode ser gradativa, modular, experimental.

4. Procurar observar, seguir os clientes, e não tentar persuadi-los: os clientes prefeririam que a empresa criasse cartões de fidelidade ou que lhes disponibilizasse mais caixas para pagamento de suas compras? As respostas dependem do tipo de empresa e dos tipos de relacionamento que a empresa e seus clientes desejam desenvolver entre si. Tais relacionamentos podem variar entre os setores, entre empresas e entre clientes de uma empresa. Infelizmente, tais considerações tendem a ser ignoradas pela gerência da empresa ao utilizar o CRM, com conseqüências desastrosas. A empresa pode tentar forjar relacionamento com os clientes, mas será que eles desejam desenvolvê-lo? Se a empresa falhar em construir relacionamentos com clientes que os valorizam, ela estará arriscada a perdê-los para a concorrência. Se a empresa tentar construir relacionamentos com clientes desinteressados, ela será considerada impertinente, irritando clientes potenciais.

Os executivos freqüentemente se enganam quanto à promessa dos softwares de CRM, em relação à dura realidade de criar uma estratégia exclusiva para adquirir clientes, desenvolver relacionamentos com os mesmos e retê-los. A figura 29 destaca os cinco imperativos do CRM, segundo Rigby, Reichheld e Schefter (2002:106), situando a tecnologia nesse contexto.

Neste modelo, os autores apresentam os cinco imperativos do CRM e indicam alguns caminhos para alcançá-los. Pode-se notar a atuação da tecnologia como uma ferramenta poderosa e interessante para a complexa estratégia de gerenciamento de relacionamentos com clientes, porém, como um fator de apoio à identificação e aquisição do cliente correto, ao desenvolvimento da proposição correta de valor, à instituição dos melhores processos, à motivação dos empregados e ao aprendizado da retenção dos clientes. Uma vez definidos os requisitos para a estratégia de CRM da empresa, poderá determinar de qual forma a tecnologia integrará o processo. 


\section{Figura 28 - O imperativo do CRM}

\section{- Imperativo do CRM}
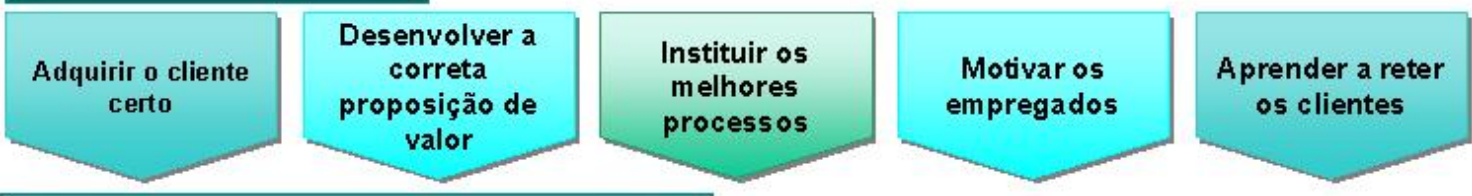

A empresa consegue atingi-lo quando:

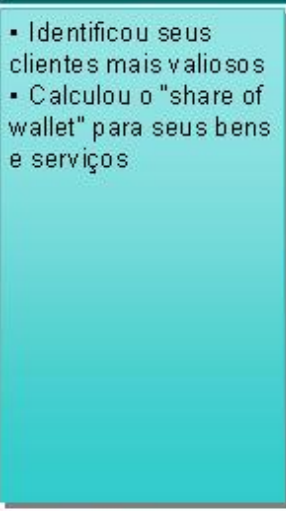

- Estudou de quais
produtos ou serviços
seus clientes
necessitam hoje e irão
necessitar no futuro
- Pesquisou quais
produtos ou serviços
seus concorrentes
oferecem na
atualidade e irấo
oferecer no futuro
- Vislumbrou quais
produtos ou serviços
oferecerá no futuro.

- Pesquisou a melhor maneira de entregar seus produtos ou serviços a seus clientes, incluind o as alianças a serem combatidas, as tecnologias nas quais será necessário investir e as capacidades de serviços a serem desenvolvidas ou adquiridas

\section{A tecnologia CRM pode auxiliar...}

\begin{tabular}{|l|l|}
\hline - Analisando a receita & $\begin{array}{l}\text { - Capturando dados } \\
\text { relevantes de }\end{array}$ \\
por cliente e dados de & comptos para identificar \\
clientes de alto valor no & produto e serviço \\
momento e no futuro & - Criando novos \\
- Dire cionando melhor & canais de distribuiçâo \\
os esforços de & - Desenvolvendo \\
marketing da empresa & novos modelos de \\
precificaçấo & - Construindo \\
& comunidades \\
\hline
\end{tabular}

- Processando
transaçốes mais
rapidamente
- Fornecendo
melhores informações
para a linha de frente
- Gerenciando a
logística e a cadeia de
fornecimento de
maneira mais eficiente
- Catalisando o
comércio colaborativo

- Sabe de quais
ferramentas seus
empregados
necessitam para criar
relacionamentos com
clientes
- Identificou os
sistemas de recursos
humanos a serem
implantados para
aumentar a lealdade
dos empregados

- Aprendeu porque os clientes deixam a empresa e como recuperá-los - Analisou o que a concorrência está fazendo para conquistar os clientes de alto valor da empresa - Sua gerência sênior monitora constantemente os índices de abandono de clientes

- Alinhando incentivos
e indicadores
- Ajustando sistemas
de gestão do
conhecimento

- Rastreando níveis
de abandono e de
retenção de clientes
- Rastreando níveis
de satisfaçẫo dos
clientes

Fonte: Rigby, Reichheld e Schefter (2002:106).

Desta forma, Lykins (2002:12) enumera, como fatores-chave para o sucesso do CRM: (1) a estratégia de CRM deve ter uma visão voltada ao cliente (estratégia de negócios); (2) criar uma visão empresarial do cliente; (3) criar uma arquitetura flexível, que lhe permita expandir-se com o negócio; (4) adotar uma abordagem incremental, evolucionária, com implantação planejada e paulatina, com controle sobre o ROI.

Adicionalmente, o Gartner Group (2000:5) relaciona alguns desafios para a empresa relacionados ao CRM: (1) demanda da consistência entre as bases tradicionais de poder em uma empresa, aumento da necessidade por processos novos e padronizados e levantamento de questões de estrutura e governança, como, por exemplo, “a quem pertence o relacionamento com o cliente”; (2) adequação/coordenação do CRM às iniciativas já existentes como programas de lealdade, 
centros de serviço ao cliente, gerenciamento de vendas, e-business; (3) a abordagem dos softwares de CRM nem sempre permite fácil integração aos sistemas existentes na empresa e também não consegue atender a particularidades da empresa; (4) com altos riscos de falhas, existe o dilema de ser um pioneiro ou de aguardar a evolução do mercado.

Além disso, o Gartner Group (2000:8) adverte sobre alguns pontos: (1) os custos de sistemas são, freqüentemente, subestimados; a integração com os sistemas existentes tende a ser a principal origem dos custos; (2) implantar os sistemas é apenas uma parte do processo; os sistemas são necessários, mas absolutamente insuficientes; (3) a principal razão para as falhas nas iniciativas de CRM não é tecnologia, mas atenção insuficiente às pessoas e aos processos; (4) é um erro mergulhar num programa de CRM integral, sem determinação de conquistas intermediárias: é muito mais seguro dividir os esforços em etapas; (5) é preciso esperar retornos rápidos para investimentos limitados a cada etapa; (6) o CRM é uma jornada, e não uma meta; e mais, é uma jornada sem fim.

O CRM estrategicamente eficaz requer a aplicação inteligente da tecnologia. Deve-se lembrar que isto é mais que uma solução de software; está relacionado a como a informação do cliente é usada para criar relacionamentos contínuos com o mesmo (Ragins e Greco, 2003:26). Entretanto, o CRM não envolve apenas uma ferramenta, tecnologia, ou produto; um CRM bem sucedido requer a mudança do pensamento reativo para o pró-ativo (Sommer, 2000:41). O CRM deve fazer parte de uma estratégia corporativa, da qual todas as áreas compartilham.

Lykins (2002:13) também considera que o CRM pode evoluir para uma completa estratégia de CVM - Customer Value Management, na qual a empresa é totalmente voltada ao cliente. Toda interação é monitorada para assegurar que o relacionamento é desenvolvido de maneira consistente entre todos os canais. O foco no CVM pode aumentar o diálogo entre a empresa e seus clientes, construindo confiança e relacionamentos duradouros. Cada vez mais os clientes esperam serviços que antecipem suas necessidades e integrem múltiplos elementos da experiência do cliente em um único local (Landry, 2001:3), o que requer que a empresa seja mais pró-ativa que reativa (Sommer, 2000:41).

Para complementação do estudo, busca de subsídios ao desenvolvimento do roteiro de pesquisa, e para validação das respostas obtidas, entrevistou-se uma especialista em CRM, com experiência de 15 anos em soluções para Contact Center e que trabalha com CRM Analítico e Operacional desde 1998. Seu depoimento encontra-se sintetizado na seção a seguir. 


\subsubsection{O CRM sob a ótica de uma especialista}

Ao resgatar o histórico do CRM, a entrevistada lembra que há algum tempo esta sigla estava na moda, e representava a transformação da empresa como um todo, com a integração de todos os seus canais de contato com o cliente: SAC, Telemarketing, Internet, agências/lojas. Além disso, era preciso integrar as campanhas de conquista, retenção e fidelização, projeto que exigia orçamento alto, com implementação custosa, demorada e complicada. O CRM seria uma das etapas da realidade do relacionamento com clientes, em evolução: Telemarketing Ativo, Call Center, Contact Center, CRM, CRM Analítico. Os softwares também evoluíram, partindo da automatização do call center para a completa integração de todas as áreas de contato com o cliente e com os demais sistemas da empresa, atentando até mesmo para a ampla gama de idiomas necessários para atendimento 24 horas por dia, 7 dias por semana.

Com o intuito de conquistar clientes, a empresa fornecedora de software procura identificar as necessidades de um prospect por meio de um script, que permite verificar se já existe um projeto de CRM, sem sequer mencionar a sigla:

1. Quais os canais de contato entre sua empresa e seus clientes?

2. Quais são os canais de venda? Estes canais são integrados?

3. Existe um programa de campanhas de marketing? Por quais canais elas acontecem?

4. Existe algum projeto de análise de informações e automatizações de campanhas?

5. Qual o objetivo, o que a empresa espera de um projeto como este?

6. Qual o prazo esperado? Qual o orçamento disponível?

7. Qual é a área responsável pelo projeto?

8. Como a empresa trata estratégias de aquisição e retenção de clientes?

Atualmente, as empresas não se interessam mais por um projeto de CRM completo, que acaba por frustrá-las em termos de prazo, custo e funcionalidade. Assim, as soluções de CRM, em geral, são divididas em módulos, implementados e customizados de acordo com as características e necessidades dos clientes. Em geral, as empresas que as fornecem oferecem consultoria, distribuição e implementação de soluções de software. Inicialmente, faz-se um diagnóstico das reais necessidades e expectativas dos clientes a fim de lhes oferecer a melhor solução em termos de funcionalidade, preço e prazo; na fase de implantação, utilizam-se metodologias de gerenciamento de projeto e de garantia de qualidade. Normalmente, as áreas da empresa cliente envolvidas no projeto e na implantação do CRM são Marketing e Tecnologia da Informação: uma é usuária e a 
outra é a que valida e homologa a solução, dando suporte durante o projeto. Se a empresa já possui cultura de relacionamento, não são necessárias mudanças estruturais ou de perfil dos profissionais.

A decisão de investir em CRM surge com a descoberta de problemas como, por exemplo, perda expressiva da base de clientes, queda acentuada nas receitas, descontrole no envio de malasdiretas aos clientes, insucesso das campanhas, percepção de resultados ruins, ou quando não se está conseguindo vender mais para clientes com maior potencial de compra. Os benefícios anunciados ao cliente são: ROI, compreensão do seu real problema, efetividade no gerenciamento de campanhas, retenção, integração de canais, direcionamento correto ao público-alvo. A principal motivação para as empresas é a crença de que essa ferramenta pode auxiliá-las nestas questões, especialmente em termos de retenção e comunicação com os clientes, e também de que se pode economizar tempo: um pacote “customizado” é mais rapidamente implantado que uma solução “caseira”. As empresas desejam uma solução de última geração, analítica, que lhes permita reduzir custos, estabelecer direções para aumentar os índices de retenção da base de clientes e/ou aumentar as vendas para clientes já existentes, e melhorar o atendimento. As expectativas sobre o CRM são muito altas: os executivos que compram uma solução de CRM esperam uma boa implementação e o êxito do produto adquirido; os funcionários, por sua vez, imaginam que irão ganhar tempo, que terão seu serviço facilitado, otimizado, potencializado, sem receio de que a implantação do software reduza o número de postos de trabalho.

A análise para o investimento se baseia no ROI; cada produto possui uma fórmula própria para cálculo da estimativa desse indicador. A análise de custos e benefícios varia entre as empresas, de acordo com os seus objetivos prioritários e o que se define como perda significativa para elas. Os investimentos necessários para a implantação de uma solução de CRM, sem considerar os equipamentos, também variam, em função do número de horas de profissionais necessárias para “customização” e implantação do projeto. O investimento inclui ainda o valor da licença de uso do software, número de pessoas que irão acessá-lo, e que poderão efetuar operações definidas, entre outras peculiaridades. Nenhum valor de investimento para se ter como referência foi revelado. Em geral, as empresas clientes avaliam o retorno de uma solução de CRM pelos resultados das campanhas e o nível de satisfação das empresas clientes que investiram em CRM é alto. São os melhores vendedores da empresa.

Em termos de perspectivas para o CRM, a entrevistada acredita não haver mais a idéia de um projeto de CRM; existem necessidades pontuais de relacionamento, fidelização e retenção, mesmo 
porque o desenvolvimento e a implantação de uma solução são demorados e custosos. Há ferramentas excelentes no mercado, porém, só funcionam com uma sólida estratégia de apoio. A Internet é mais um canal para integração ao CRM.

\subsection{Considerações Finais}

Neste capítulo de revisão bibliográfica foi possível relacionar e compreender os principais elementos constituintes do tema em questão.

Especialmente na seção 2.1, a realização de um retrospecto dos primórdios da idéia do marketing de relacionamento, de sua evolução e de seu intrínseco envolvimento com o próprio conceito de marketing serviu de fundamentação para que se tivesse uma compreensão das práticas de marketing de relacionamento desenvolvidas pelas empresas, sua importância, seus requisitos e suas implicações, na atualidade. Destaca-se nesta seção a discussão sobre os conceitos de marketing de relacionamento, valor e orientação para o mercado, além dos fatores determinantes da lealdade dos clientes.

Na seção 2.2, foi possível traçar um panorama da Internet, com base em sua evolução como ferramenta de negócios, suas implicações para as empresas, mais notadamente, sua aplicação às trocas comerciais, de especial interesse para este estudo, e seus reflexos sobre o marketing. Sabe-se que tal panorama está em franca transformação, como quase tudo que envolva tecnologia e pessoas, embora a um ritmo um pouco mais lento do que na década passada, e, talvez, reservando algumas surpresas ainda por vir. Destacam-se como idéias principais desta seção as características sem precedentes da Internet, de sua quase onipresença e instantaneidade, interatividade e capacidade de lidar com a informação, bem como os fatores incentivadores e desestimuladores de compras pela Internet, segundo a ótica dos clientes, além dos principais efeitos da Internet sobre o marketing mix das empresas.

Por fim, na seção 2.3, foi possível analisar alguns impactos da Internet sobre as práticas de marketing de relacionamento das empresas, e as implicações para estas. Por se tratar de um novo canal de vendas, a Internet apresenta uma série de peculiaridades que podem ser aproveitadas em benefício da empresa e de seus clientes, sem detrimento do relacionamento. É preciso, no entanto, atentar para que o fator humano não seja negligenciado, uma vez que a diversidade de perfis e de preferências de compradores, envolvendo as diferenças entre os níveis de domínio e de adaptação da tecnologia podem interferir nas respostas dos clientes às ações planejadas pelas empresas. Nesta 
seção, evidencia-se o conceito de CRM e acentua-se a discussão sobre os elementos a serem gerenciados, contornados, assimilados ou aproveitados em benefício das empresas, trazidos pela Internet ou já presentes em sua realidade, porém sob influência do novo contexto, como a lealdade, valor, orientação para mercado, comunidades, “customização” e integração, visando à manutenção ou desenvolvimento de vantagem competitiva das empresas.

\section{Metodologia de Pesquisa}

Selltiz et al. (1974:9) esclarecem porque é importante saber como se faz uma pesquisa, salientando o fato de serem constantes as tentativas de criar processos que aumentem a precisão das respostas de pesquisa. Esclarecem ainda que tal conhecimento não apenas é importante para aqueles que o utilizam como instrumento de trabalho, mas também para os que empregam os resultados das pesquisas realizadas, pois capacita-os a julgar se um estudo foi realizado de forma a permitir que se tenha confiança em seus resultados, a saber se estes são aplicáveis à situação específica com que se deparam, e a avaliar a adequação dos métodos por meio dos quais foram obtidos tais resultados.

Lakatos e Marconi (1991:40), considerando as proposições de vários autores, definem método como "o conjunto das atividades sistemáticas e racionais que, com maior segurança e economia, permite alcançar o objetivo - conhecimentos válidos e verdadeiros -, traçando o caminho a ser seguido, detectando erros e auxiliando as decisões do cientista”.

Contudo, Coffey e Atkinson (1996:153) alertam para o fato de que os métodos de coleta e análise de dados não fazem sentido quando tratados em um "vácuo intelectual e divorciados de arcabouços disciplinares mais gerais e fundamentais”. Assim, defendem a idéia de que uma pesquisa deve ir além da mera aderência a um determinado método. Afirmam ainda que os métodos não constituem um fim em si mesmos, lembrando que perspectivas analíticas e técnicas são utilizadas com o intuito de se realizarem descobertas e de se gerarem interpretações dos mundos sociais investigados.

Dessa forma, com o intuito de agregar caráter científico ao assunto em questão, serão apresentadas a seguir as considerações metodológicas feitas para a estruturação da pesquisa que foi integrada ao presente estudo. 


\subsection{Objetivo da pesquisa}

O objetivo que balizou o desenvolvimento desta pesquisa foi o fornecimento de dados primários para o estudo em questão, como complemento da revisão bibliográfica realizada, principalmente no que diz respeito aos aspectos práticos particulares de algumas empresas. Buscouse o conhecimento de algumas práticas de Marketing de Relacionamento no contexto das novas tecnologias, mais especificamente em relação à Internet, bem como a adaptação das empresas às ações necessárias em função delas.

\subsection{Tipo de pesquisa e justificativa da metodologia de pesquisa}

Segundo Reichardt e Cook (1979), quando se possui pouca informação, em situações em que o fenômeno deve ser observado ou em que se deseja conhecer um processo, determinado aspecto psicológico complexo, ou um problema complexo, sem muitos dados de partida, a pesquisa qualitativa é a mais utilizada. Possui caráter mais exploratório, descritivo, e envolve técnicas como análise de dados secundários, estudos de caso, entrevistas individuais, discussão em grupo, teste de associação de palavras, entre outros.

Da mesma forma, Parasuraman (1986:120), assim como Churchill (1979:627), define a pesquisa exploratória como o estudo voltado a desenvolver intuições ou insights ${ }^{11}$ e a fornecer caminhos para quaisquer estudos adicionais necessários. Esse autor aponta como principal propósito deste tipo de pesquisa lançar luz sobre a natureza de uma situação e identificar quaisquer objetivos específicos ou dados necessários a serem tratados em pesquisas adicionais. É bastante útil quando um tomador de decisão deseja entender melhor uma situação e/ou identificar alternativas de decisão. Esse autor destaca ainda que, "em tais pesquisas, o uso de grandes amostras probabilísticas, questionários formais e coisas afins são geralmente desnecessários e não garantidos sob uma perspectiva de custos-versus-benefícios”. Churchill (1979:627) ressalta ainda que o resultado de um estudo exploratório não serão respostas, mas perguntas ou declarações mais específicas de relacionamentos possíveis. Babbie (2001:92) observa que os estudos exploratórios são mais comumente conduzidos em três situações: para satisfazer a curiosidade e o desejo de melhor compreensão do assunto por parte do pesquisador, para testar a viabilidade de se conduzirem

${ }^{11}$ Insight: a ação ou resultado de apreender a natureza interna das coisas ou de ver intuitivamente. Dicionário MerriamWebster OnLine. Disponível em: http://www.m-w.com. Acesso em: 07/06/2001. 
estudos mais extensivos, ou para desenvolver métodos a serem empregados em qualquer estudo subseqüente.

Uma das formas de desenvolvimento de pesquisas qualitativas é o estudo de caso. Yin (1989:13) afirma que os estudos de caso, normalmente, são preferidos quando são colocadas perguntas do tipo "como" ou "por quê", quando o investigador tem pouco controle sobre os eventos e comportamentos relevantes, e quando o foco recai sobre um fenômeno contemporâneo inserido em um contexto da vida real. Tais estudos de casos “explanatórios” também podem ser complementados por dois outros tipos: exploratórios e descritivos. Em qualquer tipo de estudo, os investigadores devem ser cautelosos ao projetar e realizar estudos de casos, a fim de superar as tradicionais críticas ao método. Ainda segundo esse autor, a necessidade distintiva por estudos de caso surge do desejo de entender os fenômenos sociais complexos, pois este tipo de estudo permite que uma investigação retenha as características holísticas e significativas dos eventos da vida real. Sua principal característica, além de incluir observação direta e entrevistas sistemáticas, é a habilidade de lidar com uma ampla variedade de evidências: documentos, artefatos, entrevistas e observações.

Assim, Yin (1989:23) define o estudo de caso como uma pesquisa empírica que investiga um fenômeno contemporâneo dentro do contexto de sua vida real, quando os limites entre o fenômeno e seu contexto não estão claramente evidentes, e na qual múltiplas fontes de evidência são utilizadas. Yin (1989:25) enumera ainda os seguintes tipos de aplicações diferentes para os estudos de caso:

- Explicar as ligações causais nas intervenções na vida real que são complexas demais para a pesquisa ou estratégias experimentais. Esta seria, talvez, a aplicação mais importante dos estudos de caso;

- Descrever o contexto da vida real no qual uma intervenção ocorreu;

- Uma avaliação da intervenção poderia surgir, também em modo descritivo, a partir de um estudo de caso, mesmo com caráter jornalístico;

- Explorar as situações nas quais a intervenção a ser avaliada não possui um conjunto de resultados claros e únicos.

Stake (1994:236) caracteriza o caso como sendo algo específico funcionalmente, uma singularidade e, por esta razão, interessaria ao pesquisador. No entanto, esse mesmo autor afirma que é imperativo entender em que contexto o caso está inserido para sua melhor compreensão. 
Ainda segundo esse autor, um estudo de caso pode ser qualitativo ou quantitativo, ou uma combinação de ambos. Ele menciona Yin (1992), que, ao procurar características comuns às pesquisas qualitativas e quantitativas, encontrou quatro princípios comuns: trazer conhecimento especializado sobre o fenômeno estudado; buscar todos os dados relevantes; examinar interpretações opostas; e, por fim, ponderar e atestar o grau em que as descobertas possuem implicações em outros assuntos. Estes princípios são relevantes em todos os tipos de pesquisa, inclusive no estudo de caso.

Kemmis (1980, in Stake, 1994:237) afirma que um estudo de caso é tanto o processo de aprendizado sobre o caso como o produto deste aprendizado. Esse autor divide os estudos de caso em três tipos, segundo os diferentes objetivos dos pesquisadores.

O estudo de caso intrínseco é aquele realizado em virtude do interesse do pesquisador em compreender melhor um caso em particular, não porque o caso represente outros casos, ou porque ilustre um problema ou situação específica, mas porque, em sua particularidade e seus aspectos comuns, o caso é, por si, de interesse.

Já num estudo de caso instrumental, um caso particular é examinado para fornecer insight sobre um assunto ou permitir o refinamento de uma teoria. O caso é de interesse secundário, ou seja, mesmo comportando um profundo detalhamento, desempenha papel coadjuvante para facilitar o entendimento de algum outro assunto. Além disso, o caso pode ser visto como típico ou não.

Com menos interesse ainda em um caso particular, o pesquisador pode estudar vários casos conjuntamente, a fim de pesquisar o fenômeno, população ou condição geral. Stake (1994:237) chama esta situação de estudo de caso coletivo. Não se trata do estudo do coletivo, mas de um estudo instrumental estendido a vários casos. Esse autor observa também que ultimamente os pesquisadores têm se interessado mais em um fenômeno ou uma população de casos que em um caso individual, o qual não poderia ser entendido sem o conhecimento de outros casos.

Yin (1989:53), igualmente, observa que o mesmo estudo pode conter mais que um único caso, o chamado estudo multi-casos. Segundo ele, os estudos multi-casos são freqüentemente considerados mais convincentes e o estudo global é, portanto, reconhecido como mais robusto. Por outro lado, nem sempre os princípios para os casos únicos podem ser satisfeitos pelos casos múltiplos: o caso incomum ou raro, o caso crítico, e o caso revelador provavelmente envolvem 
apenas casos únicos, por definição. Além disso, esse autor lembra que a condução de um estudo de multi-casos, geralmente, consome mais tempo e recursos.

Em relação à polêmica da generalização, Yin (1989:21) traz algumas argumentações interessantes: os estudos de caso permitem generalizações teóricas (generalizações analíticas), e não para populações ou universos; sua meta é expandir e generalizar teorias e não freqüências. Neste método de generalização, uma teoria previamente definida é utilizada como um modelo contra o qual os resultados empíricos de um estudo de caso são comparados (Yin, 1989:38).

Coffey e Atkinson (1996:162) observam que estudantes e comentaristas estão freqüentemente confusos em relação à possibilidade de generalização de pesquisas qualitativas, as quais, geralmente, são pequenas em escala e focadas em pontos particulares da sociedade. Embora haja muitos pontos a serem considerados, esses autores acreditam que os pesquisadores qualitativos devam estar cientes sobre como podem e devem generalizar. Quando os pesquisadores estudam manifestações locais de cultura e ordem social, não devem assumir que tais mundos sociais são representativos de populações maiores, e não devem tratar seu campo de pesquisa ou seus informantes como se fossem amostras no sentido estatístico. Por outro lado, suas idéias não são confinadas ao detalhamento descritivo do local. Desenvolvendo e refinando, ou até mesmo criando conceitos, os pesquisadores objetivam transcender o local e o particular. Algumas inferências podem levar os pesquisadores de casos ou descobertas específicas a níveis genéricos, que lhes permitem mover conceitualmente ao longo de uma ampla gama de contextos sociais.

Esses autores esclarecem ainda que a relação entre o particular e o genérico é de ordem diferente daquela entre uma amostra e uma população. Segundo eles, a pesquisa qualitativa captura múltiplas versões de múltiplas realidades, tornando-se necessário reconciliar o particular e o universal, movendo da unicidade de um caso ou configuração individual para um entendimento dos processos mais gerais em curso. No entanto, esses autores alertam para o fato de que transcender o local e o particular é importante, mas isto deve ser visto dentro de um contexto que assegure que as análises sejam metodológica e retoricamente convincentes. Miller e Crabtree (1994: 348, in Coffey e Atkinson, 1996:163) defendem a seguinte visão: “o contexto local e a história humana, dos quais o estudo de cada indivíduo e da comunidade humana é um reflexo, são as metas primárias da pesquisa qualitativa, e não sua possibilidade de generalização”. Para Coffey e Atkinson (1996:163), no entanto, todo delineamento do particular deveria ser subsidiado por um entendimento de formas e processos mais gerais. Normalmente, argumentam, ao se estudar um contexto particular, um único 
caso, um indivíduo ou um pequeno grupo de pessoas, não se espera extrapolar os resultados diretamente para uma população. Esses autores afirmam que os dados qualitativos, analisados com muita atenção em seus detalhes, compreendidos em termos de seus modelos e formatos internos, devem ser utilizados para o desenvolvimento de idéias teóricas sobre os processos sociais e as formas culturais, os quais possuem relevância além dos dados propriamente ditos. Tal trabalho intelectual exige interação criativa e disciplinada com os dados qualitativos.

Da mesma forma, Stake (1994:238) lembra que muitos cientistas sociais têm escrito que o estudo intrínseco de um caso particular não é tão importante como os estudos desenvolvidos para se obterem generalizações pertinentes a uma população. Tais cientistas enfatizam o estudo de caso como uma tipificação de outros casos, como uma exploração que leva a outros estudos que produzam generalizações, ou como um primeiro estágio na construção de teoria. Todavia, o estudo de caso pode ser visto positivamente como um pequeno passo em direção a uma grande generalização (Campbell, 1975, in Stake, 1994:238), mas a generalização não deve ser o foco de todas as pesquisas (Feagin, Orum, e Sjoberg, 1991, in Stake, 1994:238; Simons, 1980, in Stake, 1994:238). Os prejuízos surgem quando o compromisso com a generalização ou com a criação de teoria prevalece, e o pesquisador desvia sua atenção de características importantes para o entendimento do caso propriamente dito.

Esse autor complementa que os estudos de caso são valiosos para o refinamento da teoria, e ao sugerirem complexidades para investigações futuras, assim como para auxiliar a estabelecer os limites das possibilidades de generalização. Acrescenta ainda que o estudo de caso pode ser uma força disciplinada para a definição de políticas públicas e para provocar reflexões sobre a experiência humana. Embora a epistemologia formal necessite de desenvolvimento adicional, de alguma forma, as pessoas extraem da descrição de casos individuais implicações para outros casos, nem sempre corretamente, mas com uma confiança compartilhada por pessoas de visões distintas. Stake (1994:245) conclui, afirmando que o propósito do estudo de caso não é representar o mundo, mas representar o caso. Os critérios para conduzir o tipo de pesquisa que leva a uma generalização válida necessitam de modificação para se adequarem à busca por efetiva particularização. Esse autor afirma ainda que a utilidade do estudo de caso para os usuários e criadores de políticas está na extensão de sua experiência. Os métodos do estudo de caso qualitativo são amplamente os métodos para disciplinar a experiência pessoal e particular. 
A pesquisa em questão é de natureza qualitativa, e por conseqüência, exploratória; caracteriza-se, ainda, como descritiva, com dados coletados em um estudo de campo, na forma de estudo de multi-casos, com realização de entrevistas e utilização também de dados secundários. A crença de que uma pesquisa exploratória é a mais indicada para este tema deve-se à escassa presença que o mesmo ainda apresenta nos meios acadêmicos, não se pretendendo que os resultados sejam extrapolados para a população. Além disso, um nível de profundidade mais acentuado é prerrogativa das pesquisas qualitativas, que são muito úteis para firmar conceitos e objetivos a serem alcançados e sugerir variáveis a serem estudadas com maior dimensão de alcance $a$ posteriori.

\subsection{Hipóteses/questões}

Algumas definições de “hipótese” citadas por Lakatos e Marconi (1991:123):

- "Hipótese é uma proposição enunciada para responder tentativamente a um problema” (Pardinas, 1969);

- “A hipótese do trabalho é a resposta hipotética a um problema para cuja solução se realiza toda investigação” (Boudon e Lazarsfeld, 1979);

- “A hipótese é uma proposição antecipadora à comprovação de uma realidade existencial. É uma espécie de pressuposição que antecede a constatação dos fatos. Por isso se diz também que as hipóteses de trabalho são formulações provisórias do que se procura conhecer e, em conseqüência, são supostas respostas para o problema ou assunto da pesquisa” (Trujillo, 1974);

- “A hipótese é uma tentativa de explicação mediante uma suposição ou conjetura verossímil, destinada a ser provada pela comprovação dos fatos” (Ander-Egg, 1978).

Estas definições sinalizam a inadequação de se definirem hipóteses para uma pesquisa exploratória, sobretudo porque não se têm, a priori, alternativas de solução para o problema. Entretanto, a pesquisa exploratória pode, por sua vez, levantar algumas questões e até suscitar algumas hipóteses para estudos posteriores. Além disso, pelo fato de a pesquisa ser exploratória, não haveria elementos que conduzissem à rejeição ou aceitação de uma hipótese preliminarmente apresentada. Como respaldo, Selltiz et al. (1974:48) afirmam que "não tem sentido considerar como mais ‘científico’ um estudo que começa com hipóteses do que aquele que termina com hipóteses”. 


\subsection{População}

Na etapa de definição da população, é preciso que se faça uma análise detalhada:

- Dos atributos dos elementos componentes do universo e, por conseguinte, da amostra a ser selecionada;

- Dos filtros decorrentes da definição desses atributos;

- Do sistema de referência a ser usado como base para a identificação da população.

No desenvolvimento desta etapa, o item relativo ao sistema de referência gerou uma série de consultas a órgãos oficiais e reflexões a respeito da escolha da(s) melhor(es) alternativa(s) dentre as que se mostraram viáveis. Algumas questões criaram dificuldades para a seleção das melhores alternativas, como exposto a seguir.

O primeiro aspecto que requer uma análise mais criteriosa refere-se aos atributos e filtros considerados. A população visada correspondeu às empresas de médio e grande porte que atuam no mercado consumidor (business-to-consumer, ou B2C) e satisfazem a três filtros: (1) utilizam-se da Internet como ferramenta de intermediação na oferta de produtos e serviços aos clientes, (2) fazemno há pelo menos um ano, (3) possuem histórico de atuação no marketing de relacionamento. A atuação no marketing de relacionamento poderia ser identificada pela prática de algumas atividades, tais como:

- Manutenção de um canal de comunicação direto entre os clientes e a empresa, quer seja por meio de um número de discagem gratuita (0800), um endereço postal, um endereço de e-mail, ou uma caixa de sugestões para consultas, reclamações e sugestões, com o devido retorno, de maneira a permitir que os clientes se expressem espontaneamente em relação aos serviços e produtos da empresa, conforme sugerem Reichheld e Sasser Jr. (1994:335); Hart, Heskett e Sasser Jr. (1994:281); Finkelman e Goland (1994:270).

- Busca sistemática e contínua de informações sobre insatisfações e desejos não diretamente revelados pelos clientes à empresa, inclusive com vistas ao desenvolvimento de novos produtos, como observam Boone e Kurtz (2001:162-163); Hutchison e Stolle (1994:101); Hart, Heskett e Sasser Jr. (1994:273).

- Treinamento do pessoal da linha de frente para que saiba ouvir e atender aos clientes, com autonomia para agir em função das demandas levantadas, segundo autores como Hart, Heskett e Sasser Jr. (1994:285); Finkelman e Goland (1994:268); Boone e Kurtz (2001:157), entre outros. 
- Desenvolvimento e aplicação de políticas de orientação para o mercado, conforme observam autores como McKenna (1992:2); Shapiro (1994:7); Narver e Slater (1990:21); Jaworski e Kohli (1993:57).

- Desenvolvimento e implantação de programas de fidelidade e de outras práticas que valorizem a manutenção dos clientes, segundo autores como Boone e Kurtz (2001:163); Winer (1999:374).

Como as informações para este filtro não eram conhecidas de antemão, excetuando-se o caso de algumas empresas que tiveram sua história divulgada por mídias especializadas, pretendeu-se identificar as empresas com experiência em marketing de relacionamento por meio de questões indiretas no roteiro de entrevista, englobando fatores que evidenciassem a prática do marketing de relacionamento.

Com respeito à delimitação geográfica da população, foi relativamente difícil defini-la segundo este critério, uma vez que a Internet tem abrangência mundial, mas o estudo se concentrou nas empresas com sede na Grande São Paulo, por este ser um local de grande importância em termos econômicos para o país e onde há maior concentração de empresas com aplicação destas novas tecnologias. Segundo a pesquisa Info100, da revista Info Exame, a Grande São Paulo foi responsável por praticamente 80\% das transações de comércio eletrônico feitas no Brasil em 2001 (Vieira, 2002:36). Contudo, as informações sobre a experiência e as atividades das empresas podem transcender esta delimitação. Isto porque, ao se examinarem as transações comerciais de uma empresa via Internet, podem ser encontrados clientes cuja localização ultrapasse até mesmo os limites nacionais, possibilitando a agregação de informações sobre estes públicos que contribuam para um melhor entendimento dos mecanismos que regem o relacionamento das empresas com seus clientes no contexto do comércio eletrônico.

Quanto ao porte das empresas, embora a Internet possa ser muito útil tanto a empresas de pequeno quanto de grande porte, dada toda a infra-estrutura necessária para atender clientes via Internet (logística, recursos tecnológicos) e também o interesse na associação desta a práticas de marketing de relacionamento, seria mais enriquecedora para o trabalho uma pesquisa com empresas de médio e grande porte para que estes efeitos pudessem ser observados. Contudo, com o exame de bibliografia mais atual, principalmente as publicações que destacam as práticas de comércio eletrônico, percebeu-se que as empresas de grande porte é que poderiam contribuir melhor para este estudo, haja vista sua maior disponibilidade de recursos a serem aplicados tanto em programas de 
marketing de relacionamento como em infra-estrutura de comércio eletrônico. Assim, no quesito porte, a população, para efeito deste estudo, passou a constituir-se de empresas de grande porte.

A classificação de porte de empresa adotada pelo Banco Nacional de Desenvolvimento Econômico e Social (BNDES) (25/04/01) e que foi utilizada neste estudo é a seguinte:

- Microempresas: receita operacional bruta anual ou anualizada até R\$700 mil (setecentos mil reais, ou US\$304 307,48 ${ }^{12}$ ).

- Pequenas Empresas: receita operacional bruta anual ou anualizada superior a R $\$ 700$ mil (setecentos mil reais) e inferior ou igual a R\$6.125 mil (seis milhões e cento e vinte e cinco mil reais, ou US\$2 661 770,48).

- Médias Empresas: receita operacional bruta anual ou anualizada superior a R\$6.125 mil (seis milhões e cento e vinte e cinco mil reais) e inferior ou igual a R\$35 milhões (trinta e cinco milhões de reais, ou US\$15 210 116,90).

- Grandes Empresas: receita operacional bruta anual ou anualizada superior a R\$35 milhões (trinta e cinco milhões de reais, ou US\$15 210 116,90). No entanto, cabe aqui uma observação: serão também consideradas como Grandes Empresas aquelas que, embora possuam receita operacional bruta inferior a $\mathrm{R} \$ 35$ milhões, pertençam a grupos econômicos cujo faturamento consolidado ultrapasse esse valor.

Considera-se receita operacional bruta anual como a receita auferida no ano-calendário com o produto da venda de bens e serviços nas operações de conta própria, o preço dos serviços prestados e o resultado nas operações em conta alheia, não incluídas as vendas canceladas e os descontos incondicionais concedidos. Na hipótese de início de atividades no próprio ano-calendário, os limites referidos na classificação de porte serão proporcionais ao número de meses em que a pessoa jurídica ou firma individual houver exercido atividade, desconsideradas as frações de meses. Nos casos de empresas em implantação, seria considerada a projeção anual de vendas utilizada no empreendimento, levando-se em conta a capacidade total instalada. Quando a empresa fosse controlada por outra empresa ou pertencesse a um grupo econômico, a classificação do porte se daria pela consideração da receita operacional bruta consolidada. O faturamento percebido pelas empresas considerado para efeito desta classificação é referente ao ano-exercício de 2001.

\footnotetext{
12 Cotação do dólar norte-americano em 25/04/2001: R \$2,3011 (Banco Central do Brasil). Isto serve apenas como referência, pois não significa que a tabela do BNDES siga o critério de atualização pela variação do dólar norteamericano.
} 
O horizonte de tempo de pelo menos um ano em atividades de comercialização pela Internet permite que se tenha mais graus de liberdade na escolha de empresas que não tenham grandes faturamentos pela Internet mas que têm potencial para isto.

Com relação ao sistema de referência, inicialmente, seria utilizada a lista das maiores empresas de e-commerce da revista Info Exame de dezembro de 2001, ou a próxima edição que publicasse este ranking. Contudo, como se trata de um mercado altamente dinâmico, optou-se, como segunda alternativa, por utilizar o ranking das "100 maiores empresas de comércio eletrônico do ano de 2002”, da revista Business Standard, de novembro de 2002, por estar mais atual em relação à época em que a coleta da dados seria iniciada. Tal ranking foi apoiado metodologicamente pelo instituto de pesquisas IDC Brasil (Manzoni Jr. e Sayon, 2002:20).

Entretanto, durante o planejamento do campo, o sistema de referência escolhido apresentou alguns inconvenientes:

1. Embora trouxesse o ranking das 100 maiores empresas de comércio eletrônico do ano de 2002, apenas 40 delas referiam-se ao mercado Business-to-Consumer, alvo desta pesquisa, reduzindo, assim, o espectro de empresas a serem consideradas.

2. Considerando-se a classificação de porte do BNDES mencionada, e as mudanças no cenário econômico, o qual, apesar das dificuldades por que passaram algumas empresas de comércio eletrônico, mostrou um acréscimo de até 120\% nas vendas em lojas virtuais no final de 2002 em relação ao ano anterior (Gazeta Mercantil, 2003), a maior parte dessas 40 empresas eram de grande porte.

3. Por solicitação de algumas empresas entrevistadas, não foram contactadas empresas diretamente concorrentes das mesmas, restringindo-se assim, ainda mais o leque de opções, que já estava reduzido de algumas empresas cuja sede não fica na Grande São Paulo.

4. Algumas das empresas restantes já nasceram exclusivamente com o objetivo de efetuar transações comerciais pela Internet, sem experiência anterior como loja física e, portanto, sem condições de efetuar uma análise de impactos da Internet como intermediadora de transações sobre o seu negócio.

5. Algumas das empresas contactadas alegaram manter política de não atendimento a pesquisas de cunho acadêmico; outras, sequer responderam ao contato inicial, mostrandose refratárias a estudos acadêmicos. 
Além disso, percebeu-se que o sistema de referência de novembro de 2002, em que pese revelar as empresas que se destacaram nas atividades de comércio eletrônico, deixou de captar outras empresas também notáveis em atividades de comercialização, mas que não estavam ainda entre as empresas de maior faturamento em vendas pela Internet, embora desenvolvam práticas interessantes para o objetivo desta pesquisa.

Esse sistema de referência, embora tenha se mostrado insuficiente para captar empresas que realmente tenham se destacado, também facilitou a definição da população.

Assim, o sistema de referência efetivamente utilizado foi uma combinação dos rankings das maiores empresas privadas por origem de capital, que correspondem às 100 maiores empresas não financeiras nacionais e às 100 maiores empresas não financeiras estrangeiras, publicados pela Gazeta Mercantil (Gazeta Mercantil, 2002:112;114). Tais rankings podem ser visualizados no anexo A.

\subsection{Amostragem}

Amostragem não probabilística é um procedimento subjetivo no qual a probabilidade de seleção para cada unidade da população é desconhecida de antemão (Parasuraman, 1986:450). Da mesma forma, Chein (1960:577-578) caracteriza o uso da amostragem não probabilística em situações em que não se possui meio para estimar a probabilidade que cada elemento tem de ser incluído na amostra e em que não existe segurança de que todos os elementos tenham alguma oportunidade de serem incluídos. Cita como principais vantagens desta amostragem a conveniência e a economia, que podem superar os riscos de não se utilizar uma amostragem probabilística. Complementarmente, Boyd Jr. e Westfall (1972:431) colocam a amostragem não probabilística como a mais indicada quando "estimativas grosseiras são adequadas, se os recursos são muito limitados, ou se se espera que o erro total da pesquisa seja composto principalmente por erros não amostrais e se deseja alocar recursos limitados para a redução destes erros”. Exemplificam com uma pesquisa sobre a administração das finanças de consumidores em um universo de domicílios de alta renda, onde o pesquisador estaria disposto a sacrificar resultados que lhe permitiriam obter medidas objetivas de precisão a fim de maximizar a exatidão das respostas dos entrevistados.

A amostragem intencional é uma modalidade da amostragem não probabilística e tem por suposição básica a idéia de que com um bom julgamento e uma estratégia adequada, seja possível escolher os casos que devam ser incluídos na amostra e, desta forma, chegar a amostras que 
satisfaçam às necessidades de pesquisa. Uma estratégia comum deste tipo de amostragem é escolher casos julgados como típicos da população de interesse, supondo-se que os erros de julgamento na seleção tenderão a ser contrabalançados. Entretanto, os experimentos com amostragem intencional sugerem que, sem uma base objetiva para fazer julgamentos, esta suposição não é exata (Chein, 1960:584). Os autores Boyd Jr. e Westfall (1972:422-423) definem a amostragem por julgamento (ou intencional) como uma abordagem na qual um especialista no assunto pesquisado escolhe uma amostra que ele acredita ser a melhor para aquele estudo particular, isto é, que seja, de alguma forma, significativa para o estudo em questão. Esses autores apontam a dificuldade existente no fato de que a amostra deve ser encontrada empiricamente para que produza resultados satisfatórios; além disso, ressaltam que não há um meio objetivo de avaliar a confiabilidade dos resultados da amostra sob tais circunstâncias. Apesar destas limitações, este método pode ser útil quando o tamanho total da amostra for extremamente pequeno.

“Às vezes é apropriado selecionar uma amostra com base no conhecimento de uma população e o propósito do estudo. A amostragem deste tipo é chamada intencional ou por julgamento" (Babbie, 2001:179), e pode ser adequada para pré-testes, em situações em que se deseja estudar um subconjunto pequeno de uma grande população na qual muitos membros são facilmente identificados mas a enumeração de todos eles é impossível, ou quando se deseja estudar casos que fogem à regra em termos de modelos de atitude e comportamento.

Por se tratar de uma pesquisa qualitativa, em que não se pretendia trabalhar com uma grande amostra de modo que fosse representativa, mas sim, com uma amostra significativa que pudesse lançar alguma luz sobre o estudo em questão e permitisse uma investigação com mais profundidade, a amostragem foi não probabilística intencional, inicialmente baseada na tabela 1:

Tabela 1 - Número de empresas para a amostra

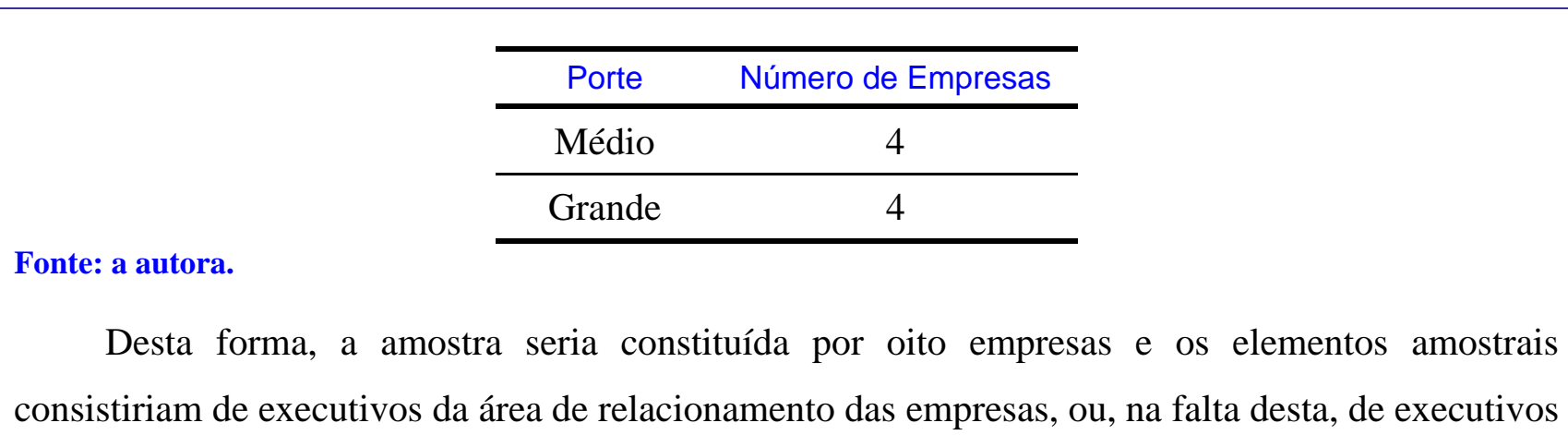


com alto nível de familiaridade com o tema da pesquisa. Com a redefinição da população, foram entrevistadas apenas empresas de grande porte.

Para a definição da população, foram considerados três filtros para as empresas: (1) utilizamse da Internet como ferramenta de intermediação na oferta de produtos e serviços aos clientes, (2) fazem-no há pelo menos um ano, (3) possuem histórico de atuação no Marketing de Relacionamento. Por ser este último filtro bastante complexo em termos de aplicação, decidiu-se entrevistar mais de quatro empresas por célula. No caso de se obter empresa que não atendesse ao último filtro, poderiam ser extraídos outros dados da mesma, referentes à experiência com a Internet e assuntos correlatos. As informações destas empresas poderiam contribuir para maior compreensão do tema do estudo, como de fato ocorreu.

Desta maneira, a amostra selecionada constituiu-se de oito empresas, sendo todas elas de grande porte, segundo a classificação do BNDES.

\subsection{Dados necessários e fontes de obtenção dos dados}

Os dados foram provenientes tanto de fontes primárias, obtidos por meio de entrevistas junto às empresas pertencentes à amostra selecionada, como de fontes secundárias, como os sites das empresas que fizeram parte da amostra, alguns relatórios de entidades de classe, publicações especializadas e pesquisas de mercado que já começam a se tornar regulares, algumas delas apenas a título de ilustração ou complemento, pois não se tem controle sobre o rigor metodológico com que tenham sido realizadas.

Além disso, realizou-se uma entrevista com um especialista em CRM que, ao atuar como um referencial neutro, independente e isento, pudesse agregar informações que dessem sustentação ao conteúdo obtido nos depoimentos das empresas em relação a esse tema. A postura do respondente foi genérica, sem menção de experiência com implantação de projetos em empresa pertencente à amostra, e sem relacionamento comercial que pudesse macular a credibilidade do depoimento.

\subsection{Instrumento de coleta de dados e variáveis}

Stouffer (1941, in Stake, 1994:238), esclarece que os pesquisadores que realizam estudos de caso procuram tanto o que é comum como o que é particular sobre o caso, mas o resultado final geralmente apresenta algo único. A unicidade é provavelmente notável, estendendo-se a: (1) natureza do caso; (2) seu passado histórico; (3) a configuração física; (4) outros contextos, 
incluindo econômico, político, legal e estético; (5) outros casos por meio dos quais o caso é reconhecido; (6) os informantes por intermédio dos quais o caso pode ser conhecido. Assim, segundo Stake (1994:238), para estudar o caso, muitos pesquisadores irão buscar dados sobre os itens enumerados anteriormente. Desta forma, neste trabalho, as peculiaridades de cada caso serão investigadas em detalhes.

A seguir, são detalhados o instrumento de coleta de dados utilizado neste estudo e as variáveis componentes da pesquisa.

\subsubsection{Instrumento de coleta de dados}

Churchill (1979:627) não recomenda questionários estruturados e nem planos de amostragem probabilística para pesquisas exploratórias uma vez que a ênfase destes estudos não está na busca de sumários estatísticos, e sim, em conseguir insights sobre o problema.

Desta maneira, por se tratar de uma pesquisa qualitativa, foi utilizado um roteiro com perguntas, composto por várias questões abertas e algumas perguntas fechadas. Foram utilizados neste roteiro alguns termos familiares aos entrevistados, relacionados à teoria de Marketing de Relacionamento e às atividades das empresas pela Internet, incluindo fatores trazidos pela Internet que pudessem ter configurado uma nova situação para a empresa ou desencadeado mudanças em seu modo de operar relacionadas ao marketing de relacionamento. Para facilitar o pós-campo, algumas respostas possíveis já estavam explicitadas no roteiro, sem o conhecimento do entrevistado, cujo depoimento ocorreu de forma espontânea. O roteiro utilizado encontra-se no apêndice A.

\subsubsection{Variáveis}

O roteiro de pesquisa foi composto essencialmente por questões abertas; adicionalmente, houve também algumas questões fechadas, para as quais foi necessário criar escalas nominais e ordinais.

Tal roteiro foi esquematizado em forma de blocos de temas desenvolvidos para o alcance dos objetivos deste estudo. As variáveis componentes de cada bloco, em sua maioria, estavam na escala nominal por se referirem a perguntas abertas. No caso das perguntas fechadas, utilizaram-se variáveis na escala nominal e ordinal. As variáveis na escala ordinal derivaram de perguntas sobre freqüência de alguma atividade e faixas de tempo. 


\subsection{Forma de abordagem}

Churchill (1979:627) afirma que, em pesquisas exploratórias, a abordagem por meio de entrevistas pessoais é mais apropriada que por entrevistas telefônicas, as quais, por sua vez, são mais apropriadas que uma pesquisa pelo correio, uma vez que o questionamento não estruturado é mais útil nos relatos de experiência. Assim, a abordagem neste estudo foi feita mediante entrevistas pessoais, as quais, com permissão dos entrevistados, foram gravadas. Conforme solicitação de algumas empresas, encaminhou-se uma carta de apresentação, que pode ser visualizada no anexo B.

\subsection{Coleta de dados}

A coleta de dados foi realizada mediante entrevistas pessoais realizadas pela própria autora do trabalho com executivos da área de relacionamento com clientes das empresas componentes da amostra selecionada. Pelo fato de as empresas nem sempre designarem uma unidade administrativa formal para esta área, as entrevistas foram realizadas com executivos de marketing com alto nível de familiaridade com o tema da pesquisa, ou com o responsável na empresa pela área de comércio eletrônico. Em alguns casos, ambas as situações coincidiram.

\subsection{Validade}

A validade de uma medição diz respeito a quanto o processo de medição está simultaneamente isento de erros amostrais e de erros não amostrais, e está relacionada à seguinte questão: “está sendo medido o que se imagina estar medindo?” (Kinnear e Taylor, 1996:232).

Em pesquisas qualitativas, não faz sentido falar-se em erros amostrais. Por outro lado, os erros não amostrais não são controláveis - não se pode indicar um limite superior para sua incidência - e nem mensuráveis.

À medida que aumenta o tamanho da amostra, há possibilidade de maior incidência de erros não amostrais. Entretanto, pelo fato de a dimensão amostral ser grande, é possível que tais erros se diluam, minimizando o comprometimento dos resultados. No caso de pesquisas qualitativas, uma amostra de pequena dimensão permite um melhor monitoramento das ocorrências de erros não amostrais. Contudo, pelo fato de o porte amostral ser pequeno, os impactos de um erro não amostral poderão ser mais comprometedores. 
Assim, dado que, no presente estudo, a amostra a ser analisada foi de pequena magnitude, existiu grande preocupação com a minimização dos erros não amostrais. Uma vez que lidar com este tipo de erro constitui tarefa bastante complexa, ao se pretender que sejam minimizados estes erros, alguns aspectos devem ser alvo de maior atenção, detalhados na seção seguinte.

\subsubsection{Tipos de erros não amostrais}

Nesta pesquisa, os tipos de erros não amostrais aos quais se dedicou especial atenção são:

- Erro na definição do problema de pesquisa: caso não se defina adequadamente o problema de pesquisa, o estudo pode tomar rumos indesejáveis ou divergentes em relação ao seu objetivo inicial. A principal pergunta do problema pode não ser respondida, e tempo, recursos e esforços terão sido despendidos em vão, acarretando conseqüências até mesmo irreversíveis em termos de acesso à amostra selecionada. Para evitar a ocorrência de tal erro, analisou-se cuidadosamente a bibliografia de referência, e, tendo claro o objetivo do estudo, procurou-se definir em termos precisos e objetivos o problema a ser pesquisado.

- Erro na definição da população da pesquisa: uma definição imprecisa da população pode trazer viés ao estudo, quer seja em termos de imprecisão, quer seja em termos de não alcance dos objetivos propostos ou até mesmo de conclusões equivocadas em relação ao problema principal do estudo. Para evitar a ocorrência deste erro, pretendeu-se proceder a um exame minucioso dos sistemas de referência possíveis, dos critérios de delimitação da população, da abrangência geográfica, setorial e de porte das empresas e da exeqüibilidade da pesquisa, à luz dos objetivos do estudo e do problema de pesquisa.

- Erro de substituição de informação: a declaração sincera das respostas aos questionamentos, bem como a interpretação imparcial das mesmas são críticas para que a pesquisa seja válida e possa contribuir para a ampliação do conhecimento a respeito do assunto. Para minimizar este tipo de erro é preciso que tanto o entrevistado como o entrevistador saibam qual o conteúdo exato do questionamento, sem ambigüidade nos termos utilizados.

- Erro de medida: deve-se ter bem claro o que se está pretendendo medir; caso isto não ocorra, dúvidas vão surgir no momento da confecção do questionário/roteiro de pesquisa ou até mesmo na sua aplicação. Por exemplo, para avaliação dos impactos da Internet 
sobre o Marketing de Relacionamento, quais variáveis ou indicadores deveriam ser coletados em campo? O cumprimento dos objetivos fica comprometido sem esta definição. A fim de minimizar a ocorrência de tal erro, pretendeu-se fazer um planejamento lúcido a respeito das medidas a serem tomadas na pesquisa, apoiado por registros bibliográficos e dados secundários, sem perder de vista os objetivos do trabalho, a população visada e o problema de pesquisa.

- Erro experimental: condições ambientais ou relacionadas ao contexto da coleta de dados podem influenciar as respostas; têm-se como exemplo a pressão de tempo que poderia levar o entrevistado a ocultar informações para que a entrevista fosse mais breve. Com o intuito de reduzir estes erros o máximo possível, pretendeu-se evitar um roteiro muito longo e também procurar horários mais adequados para a entrevista.

- Erro de sistema de referência: a partir do sistema de referência será obtida a amostra a ser utilizada na pesquisa, pois ele constitui uma forma de representação da população. Assim, um sistema de referência inadequado também pode levar a conclusões que comprometam o resultado e a validade da pesquisa. Para tanto, a idéia foi analisar cuidadosamente as alternativas de sistemas de referências para que fosse eleito um que atendesse aos objetivos do estudo da forma mais imparcial e completa possível, como detalhado na seção População (3.4) deste relatório.

- Erro de não resposta: é um tipo de erro muito difícil de ser combatido, pois, em caso de omissão de resposta, não há como considerá-la; para minimizar este tipo de erro, a estratégia foi procurar não fazer perguntas indiscretas ou constrangedoras, tentando obter a informação com perguntas indiretas ou a partir de outras fontes, além de se mostrar a importância da contribuição do respondente para o estudo em questão.

- Erro de escala: escalas erradas podem levar à imprecisão das respostas e, por conseqüência, das medidas e dos resultados do estudo, distorcendo as conclusões. Da mesma maneira, um tratamento inadequado das escalas pode distorcer os resultados da pesquisa. O roteiro de perguntas do presente estudo é composto por várias perguntas abertas com declaração espontânea e algumas perguntas fechadas com declaração estimulada. É neste último tipo que podem surgir problemas de escalas. Pretendeu-se dedicar bastante atenção à escolha das escalas de modo a se buscar sua adequação, bem como dar o tratamento adequado às respostas colhidas segundo uma escala. 
- Erro dos entrevistadores: entrevistadores mal preparados, sem conhecimento dos termos utilizados ou dos procedimentos normais de uma entrevista podem pôr todo o trabalho de planejamento a perder, prejudicando o estudo. No caso, como as entrevistas foram feitas pela própria autora do trabalho, este erro tendeu a ser minimizado.

- Erro nas declarações dos respondentes: práticas da concorrência poderiam levar uma empresa a fazer declarações com o mesmo teor para não ser considerada em desvantagem, gerando erro não amostral. Quando as declarações estão relacionadas a fatos, pode-se tentar buscar outras evidências que confirmem estas informações, como publicações e entrevistas com outras pessoas que tenham competência para ratificar as informações, ou obter esta confirmação por meio da inclusão de perguntas indiretas no próprio roteiro de questões; no caso de opiniões, porém, é muito difícil detectar se as declarações são verdadeiras ou não. Além disso, Heneman (1974, in Narver e Slater, 1990:22) mostrou que os elementos de uma amostra estão mais propensos a darem respostas não enviesadas quando seu anonimato é assegurado. E, complementarmente, com a consciência da importância da veracidade das informações, os respondentes podem prestar sua melhor contribuição.

- Erro no instrumento de coleta de dados: para garantir que as variáveis sob estudo estão sendo contempladas, o instrumento de coleta de dados deve ser cuidadosamente elaborado e submetido a um pré-teste que possa contribuir para sua melhoria. Adotou-se esta estratégia para tentar minimizar erros desta natureza.

- Erro na metodologia de abordagem adotada: deve-se analisar qual a melhor metodologia a fim de não intimidar os respondentes e também para maximizar o aproveitamento do contato em termos de coleta de dados. Neste caso, por se tratar de uma pesquisa exploratória, acreditou-se que a entrevista pessoal seria a melhor abordagem, pois como poderiam existir muitas sutilezas em termos de comportamento e cultura da empresa, uma entrevista pessoal poderia explorar melhor estes aspectos.

- Erro de ambiente de pesquisa: o ambiente pode influir nos resultados da pesquisa: situações de desconforto ou insegurança para o respondente podem impedir que ele contribua de forma favorável para a pesquisa. Na medida do possível, as entrevistas foram realizadas numa sala de reuniões da própria empresa para se evitar a interferência de telefonemas. 
- Erro de análise: a análise deve ser criteriosa e imparcial para que não se chegue a resultados enviesados. Na etapa do tratamento dos dados coletados adotou-se uma postura neutra, sem a interferência de juízos de valor ou de preconceitos.

Pode-se observar que existem várias fontes de erros não amostrais, e até esperar depoimentos baseados em situações ideais, e não em situações reais, obstrução de informações consideradas estratégicas e problemas nas próprias tarefas de planejamento da pesquisa. Assim, objetivou-se dedicar bastante atenção às etapas de planejamento, de execução e de análise da pesquisa, de modo a minimizar os erros não amostrais, avaliando e criticando cada etapa.

\subsubsection{Pré-teste}

O pré-teste é um mecanismo de controle recomendado para tentar minimizar vários tipos de erros, conforme seção 3.10.1. Realizou-se um pré-teste para verificação de possíveis problemas no instrumento e nas condições de coleta de dados, utilizando amostragem por conveniência e a colaboração de especialistas no assunto. Segundo Boyd Jr. e Westfall (1972:422), os elementos da amostra por conveniência são escolhidos com base na acessibilidade ou facilidade de medição ou de articulação e, embora este tipo de amostragem não seja indicado para a maior parte das pesquisas, é particularmente válido para a fase de pré-teste de um estudo para melhoria do questionário ou roteiro de pesquisa.

O pré-teste foi realizado com duas pessoas, sendo uma delas especialista em pesquisa sobre tecnologia, com formação em administração de empresas, e outra, microempresária do ramo de floricultura. Ainda que as pessoas entrevistadas não fizessem parte da população visada, suas contribuições foram positivas no sentido de evidenciar a possibilidade de:

- eliminar algumas questões que não estariam atendendo aos objetivos da pesquisa;

- reformular o enunciado de algumas questões de maneira a melhorar sua compreensão;

- alterar a ordem de colocação de algumas questões;

- acrescentar opções às questões com possíveis respostas previstas;

- mudar algumas escalas;

- incluir um esquema gráfico para melhor visualização dos vários módulos do CRM.

Além dessas observações, o pré-teste também foi bastante útil na estimativa do tempo gasto para realização das entrevistas: cerca de uma hora e meia. 


\subsection{Validade de conteúdo}

A validade de conteúdo envolve um julgamento subjetivo de um expert a respeito da adequação da medição, muito utilizado em pesquisas de marketing para determinar a validade da medição (Kinnear e Taylor, 1996:235).

O depoimento da especialista em CRM foi um dos expedientes utilizados para obter subsídios para a elaboração do roteiro de perguntas e para o desenvolvimendo da abordagem do tema junto às empresas. Adicionalmente, contribuiu para a complementação de conhecimentos teóricos adquiridos na revisão da literatura e para a preparação prévia da entrevistadora para condução das entrevistas. Com maior capacidade crítica adquirida junto à especialista em CRM, foi possível identificar a importância de detalhes revelados espontaneamente pelas empresas, ter maior compreensão das suas reações diante de cada questão e explorar com mais profundidade as perguntas, obtendo, assim, informações mais significativas. Por este motivo, o conteúdo desta entrevista foi inserido no capítulo de fundamentação teórica, seção 2.3.2.3.

\subsection{Análise dos dados}

Coffey e Atkinson (1996:2) recomendam que nunca se coletem dados para uma pesquisa qualitativa sem que ocorra, simultaneamente, uma análise substancial dos mesmos. Ressaltam ainda que não há uma única forma correta de analisar dados qualitativos; da mesma maneira, é essencial buscar meios de trabalhar os dados para que se possa refletir sobre os mesmos, e encontrar formas produtivas de organizar e examinar o material coletado.

Ainda segundo esses autores, a análise não é simplesmente uma questão de classificar, categorizar, codificar, comparar dados; não se trata simplesmente de identificar formas de discurso ou regularidades de ação. Mais fundamentalmente, a análise é uma questão de representação ou reconstrução do fenômeno social. Não se deve meramente reportar o que se descobre; é preciso criar um relatório sobre a vida social, e, ao fazer isto, construir versões dos mundos sociais e dos atores sociais observados (Coffey e Atkinson, 1996:108).

Vários autores procuraram definir a análise de dados qualitativos, alguns em termos de subprocessos claros, distintos e identificáveis. Segundo as perspectivas desses autores, a análise é, pelo menos a princípio, sistemática e desenvolvimentista (Coffey e Atkinson, 1996:8). 
Huberman e Miles (1994, in Coffey e Atkinson, 1996:7), por exemplo, definem a análise de dados como três subprocessos interligados: redução de dados, apresentação dos dados e construção e verificação de uma conclusão. A redução de dados consiste em seleção e condensação dos mesmos, pela escolha de um arcabouço conceitual e pelo refinamento de instrumentos, casos e questões. Os dados são sumarizados, codificados e divididos em temas, grupos e categorias. A apresentação dos dados refere-se ao modo como os dados, já reduzidos, são mostrados em formato diagramático, pictorial ou visual, a fim de sugerir o que tais dados acarretam. Segundo esses autores, “a apresentação dos dados deveria ser vista como um agrupamento de informações organizadas e compactadas que possibilita a chegada a conclusões ou tomada de ações”. O subprocesso seguinte consiste na interpretação dos dados apresentados, momento em que passam a ter significado para a pesquisa. Isto pode ser executado com o emprego de uma grande variedade de diferentes táticas, como, por exemplo, a busca por casos comparativos e contrastantes, verificação e exploração de temas, modelos e regularidades, e o uso de metáforas.

Da mesma maneira, Dey (1993, in Coffey e Atkinson, 1996:8) descreve a análise de dados qualitativos em termos de identificação e ligação entre categorias analíticas. Assim, a análise é um processo de divisão dos dados em seus componentes constituintes para revelar seus temas e modelos característicos. Esse autor, similarmente, divide a análise de dados qualitativos em três processos relacionados: descrição, classificação e conexão. Assim, a análise deve oferecer, inicialmente, descrições completas e abrangentes do contexto da ação, das intenções do ator social e dos processos nos quais a ação social está inserida. A classificação, por sua vez, é necessária para agregar significado, por meio da associação dos dados a temas e códigos. A seguir, o autor sugere que os dados categorizados ou codificados devem ser analisados em termos de modelos e conexões que possam surgir. "Conectar conceitos é o equivalente analítico de colocar argamassa entre os tijolos” (Dey, 1993:47, in Coffey e Atkinson, 1996:8).

Por outro lado, Wolcott (1994, in Coffey e Atkinson, 1996:8) usa o termo "transformação" para descrever uma grande variedade de estratégias de exploração e interpretação de dados qualitativos, restringindo o termo "análise” a um significado mais específico. Esse autor argumenta que os dados qualitativos podem ser transformados de diversas formas e para finalidades distintas. Seus métodos são divididos em três tipos: descrição, análise e interpretação. A descrição surge da premissa de que os dados devem falar por si próprios; sua meta é contar a história dos dados da forma mais descritiva possível, e o julgamento analítico dos dados deveria estar próximo dos 
mesmos, da forma que foram originalmente registrados. Já a análise é uma forma mais especializada de transformar dados e consiste no processo pelo qual o pesquisador expande e estende os dados além de um julgamento meramente descritivo. Por meio de uma atenção sistemática e cuidadosa aos dados são identificados fatores e relacionamentos-chave. Assim, o autor caracteriza a análise como cautelosa, controlada, estruturada, formal, direcionada, sistemática, fundamentada, metódica, particular, cuidadosamente documentada e imparcial. A ênfase reside na busca por temas e modelos a partir dos dados. A interpretação, segundo Wolcott (1994, in Coffey e Atkinson, 1996:9), é o método em que o pesquisador procura oferecer sua própria interpretação do que está ocorrendo. É aqui que se procuram o entendimento e a explanação, “além dos limites do que pode ser explicado com o grau de certeza usualmente associado com a análise”. Segundo esse autor, ao contrário da análise, a interpretação é livre de regras, informal, sem limites, esteticamente satisfatória, idealista, especializada e imparcial.

A diferença entre esse autor e os anteriores é que ele não coloca a descrição, a análise e a interpretação necessariamente como parte de um todo e nem as vê como mutuamente exclusivas; a transformação de dados qualitativos pode se feita em qualquer um dos três níveis ou em alguma combinação dos mesmos.

Considerando a complexidade e a polêmica gerada pelo que possa significar a análise de dados, Tesch (1990, in Coffey e Atkinson, 1996:10) identifica alguns aspectos regulares às várias definições por ela pesquisadas: “a análise é um processo cíclico e uma atividade de reflexão; o processo analítico deve ser abrangente e sistemático, mas não rígido; os dados são segmentados e divididos em unidades significativas, mas a conexão com o todo é mantida; e os dados são organizados de acordo com um sistema derivado dos próprios dados”. Segundo Coffey e Atkinson (1996:10), a análise é, em suma, uma atividade indutiva e controlada pelos dados. A análise de dados qualitativos requer conhecimento metodológico e competência intelectual; não significa a adesão a qualquer abordagem correta ou conjunto certo de técnicas; é imaginativa, artística, flexível e reflexiva. Deve ser também metodológica, estruturada, especializada e rigorosamente intelectual.

Esses autores ressaltam ainda que as decisões sobre representação dos dados são muito importantes pois a representação possui implicações significativas para a análise. O pesquisador, inevitavelmente, expressa mensagens explícitas e implícitas sobre os mundos sociais e sobre seu entendimento sobre eles, constrói atores sociais e ações sociais, reconstrói culturas com seu próprio ato de representação. Desta forma, é dever do pesquisador não apenas ter consciência do fato de que 
ele faz tais coisas, mas também que as faz cuidadosa, responsável e explicitamente (Coffey e Atkinson, 1996:137).

É possível pensar em teoria em termos de ter e usar idéias e isto parece menos desencorajador que pensar que os dados e a sua análise devam utilizar teoria, contribuir com ela, torná-la significativa ou construí-la. A relação da análise com o uso de idéias pode ocorrer em diferentes níveis e diferentes estágios da pesquisa. Ter idéias é parte de todo o processo de pesquisa, podendo estar relacionadas ao problema de pesquisa, ao que instiga o pesquisador, aos atores sociais, ao que se deseja focar, explorar, descobrir, encontrar, confirmar ou a provar que uma idéia não é verdadeira. O pesquisador também tem arbítrio sobre quais tipos de dados serão coletados, o que será feito com eles e suas hipóteses sobre o que representam estes dados (Coffey e Atkinson, 1996:140).

As idéias podem ser do próprio pesquisador, que também pode usar ou transformar idéias de outras pessoas, como pesquisadores da mesma área, filósofos, profissionais e os próprios respondentes. Da mesma maneira, a análise dos dados pode ser subsidiada por suas próprias idéias ou pode ser fundamentada nas visões de seus respondentes. Os tipos de idéias utilizados, transformados ou aplicados também podem ser influenciados pelo seu entendimento, simpatia, curiosidade ou antagonismo em relação a particulares “escolas de idéias”. Isto é, em essência, o que é usar teoria. O pesquisador integra suas idéias com sua coleta de dados e a sua análise, gerando novas idéias e construindo sobre idéias existentes. Ter idéias e teorizar sobre os dados são essenciais para a empreitada da pesquisa. Mais importante, talvez, é o fato de que teorizar e construir teoria são parte do processo de análise e interpretação de dados qualitativos (Coffey e Atkinson, 1996:140).

Coffey e Atkinson (1996:153) defendem também que as idéias sobre os dados e o real trabalho de análise e interpretação residem precisamente nas operações intelectuais que vão além dos dados. Devem ser trabalhados à luz de uma vasta gama de recursos intelectuais, derivados de perspectivas teóricas, tradições substantivas, literatura de pesquisa e outras fontes.

Stake (1994:240) coloca ainda que, não importa quanto os pesquisadores que realizam estudo de casos pretendam compartilhar seus conhecimentos, não importa quão inteligentes e elaborados sejam seus textos, eles, como outros, transmitem aos leitores algumas de suas interpretações pessoais dos eventos e relacionamentos, e falham em passar outras. Eles sabem que o leitor também 
irá adicionar e subtrair, inventar e modelar, reconstruindo o conhecimento de forma a deixá-lo organizado de modo diferente e mais próximo de lhe ser útil pessoalmente. Assim, esse autor enumera as maiores responsabilidades do pesquisador que realiza estudos de caso como segue:

- Limitar o caso, conceituando o objeto do estudo;

- Selecionar fenômenos, temas, ou assuntos - as questões de pesquisa -, para seu foco;

- Buscar modelos de dados para desenvolvimento dos assuntos;

- Triangular, ou seja, buscar outras fontes de evidências para observações e bases importantes para a interpretação;

- Selecionar interpretações alternativas a serem investigadas;

- Desenvolver assertivas ou generalizações sobre o caso.

Alguns destes itens também são comuns aos demais pesquisadores qualitativos. Quanto maior o interesse intrínseco do pesquisador no caso, maior o foco de estudo que será dedicado à unicidade, ao contexto particular, aos assuntos e história do caso. Stake (1994:244) também menciona as principais opções de estilo que os pesquisadores que realizam estudos de caso podem adotar:

- Até que ponto transformar o relatório numa história;

- Em que medida comparar com outros casos;

- Em que nível deve-se formalizar as generalizações ou deixá-las aos leitores;

- Em que medida, no relatório, deve-se incluir a descrição do pesquisador como participante;

- Manter o anonimato ou não, e em que nível.

Neste estudo, foi utilizada para apoio à análise uma planilha para sistematização dos dados coletados, permitindo melhor visualização e mapeamento das empresas pesquisadas e dos depoimentos. Dada a natureza da pesquisa, não foram calculadas estatísticas a partir dos dados coletados.

\section{Organização e análise dos dados coletados}

Os dados foram coletados no período de novembro de 2002 a abril de 2003, período esse que incluiu os meses de dezembro e janeiro, particularmente tumultuados devido aos esforços de vendas e fechamentos de final de ano.

Antes da análise, uma breve caracterização das empresas sobre as quais os dados para esta pesquisa foram coletados. Foram entrevistadas oito empresas de grande porte, sendo uma delas 
fornecedora de serviços, três, da categoria de empresas de comércio, e quatro, de indústria e comércio de produtos. Cinco dessas empresas constam na relação das 100 maiores empresas de capital nacional do Balanço Anual da Gazeta Mercantil (2002), e cinco estão entre as 100 maiores empresas da região Sudeste, segundo a mesma publicação; essas empresas ocupam posições de destaque nos respectivos rankings setoriais. Quatro das empresas entrevistadas figuraram entre as 100 maiores empresas de comércio eletrônico em 2002, segundo pesquisa realizada pela Info Exame (Reggiani, 2003:70-77). Duas empresas receberam prêmios em três categorias consideradas no Prêmio Consumidor Moderno de Excelência em Serviços ao Cliente 2003 (Cantero, Rizzo e Werneck, 2003). Duas das empresas entrevistadas não constavam do sistema de referência por não terem seu balanço anual publicado, mas foram selecionadas em função do setor a que pertencem, sob licença do tipo de amostragem escolhido.

A ordem em que as empresas se apresentam neste relatório é aleatória, e não guarda qualquer relação com seu faturamento ou tempo de vendas pela Internet. Com o intuito de preservar o sigilo de sua identidade e dos entrevistados, as empresas serão identificadas conforme a tabela 2, a seguir:

\section{Tabela 2 - Empresas entrevistadas}

\begin{tabular}{|c|l|c|c|}
\hline \multirow{2}{*}{$\begin{array}{c}\text { Nome } \\
\text { fictício }\end{array}$} & \multicolumn{1}{|c|}{ Setor de Atividade } & \multicolumn{2}{|c|}{ Tempo de Atividade (anos) } \\
\cline { 3 - 4 } & & $\begin{array}{c}\text { No setor, } \\
\text { no Brasil }\end{array}$ & $\begin{array}{c}\text { Em Comércio } \\
\text { Eletrônico }\end{array}$ \\
\hline A & Comércio varejista - supermercados & 54 & 8 \\
\hline B & Indústria de veículos - montadoras & 77 & 2 \\
\hline C & Serviços de logística - transportes aéreos & 25 & 3 \\
\hline D & Indústria de higiene e limpeza - cosméticos & 34 & 4 \\
\hline E & Serviços de comunicação - editoras de revistas & 53 & 4 \\
\hline F & Indústria têxtil - cama, mesa e banho & 20 & 1 \\
\hline G & Comércio varejista - produtos para cultura e lazer & 4 & 4 \\
\hline H & Comércio varejista - lojas de departamento e eletrodomésticos & 3 & 3 \\
\hline
\end{tabular}

Fonte: a autora.

Sete das empresas entrevistadas já desenvolviam ações de marketing de relacionamento antes mesmo do início de suas atividades de comércio pela Internet. A exceção coube à Empresa H, cuja estratégia de relacionamento nasceu junto com a sua loja virtual, a qual surgiu como uma nova operação, independente das atividades da empresa física. Desta forma, embora não faça parte da população propriamente dita por não possuir histórico de marketing de relacionamento em suas lojas físicas, essa empresa proveu informações muito ricas para o presente estudo. Cabem ainda alguns destaques sobre as empresas entrevistadas, no que tange ao marketing de relacionamento. A 
Empresa A foi pioneira em relacionamento no varejo, a Empresa B foi a primeira a criar um cartão de crédito de afinidade em seu setor e a Empresa C foi a primeira a lançar um programa de fidelidade de empresa aérea no Brasil. A Empresa D desenvolveu um modelo de relacionamento com seus clientes muito peculiar, por meio de sua rede de representantes, e não deseja prescindir disso. Por outro lado, a Empresa E, embora já viesse há algum tempo praticando ações pontuais de marketing de relacionamento, apenas recentemente decidiu criar uma área exclusivamente dedicada a esta função. A Empresa F, por sua vez, embora seja uma empresa de indústria e comércio de produção em larga escala, não permite que essa característica a impeça de atender a pedidos especiais de seus clientes. A Empresa G, embora nova no Brasil, conta com uma experiência de quase 50 anos desde a fundação de sua matriz européia, o que lhe permite transferir boa parte dessa experiência às operações brasileiras, principalmente no que diz respeito aos cuidados com a satisfação do cliente.

As entrevistas foram orientadas por um roteiro de pesquisas, dividido em três blocos principais: (1) caracterização da empresa no que se refere a práticas de Marketing de Relacionamento; (2) caracterização da empresa em relação às suas operações como fornecedora pela Internet; (3) impactos sobre o Marketing de Relacionamento verificados pela introdução da Internet como intermediadora das atividades de comércio na empresa e as implicações decorrentes. As respostas e uma análise dos dados coletados são apresentadas a seguir, preservando-se esta organização em blocos. Na apresentação dos resultados das entrevistas é destacada a essência dos depoimentos, omitindo-se referências às empresas que não tenham se manifestado em relação ao item em questão. A seqüência de apresentação priorizou o encadeamento dos temas em cada bloco e não a ordem dos itens do roteiro de pesquisa. Na seção “Considerações Gerais”, ao final de cada um dos blocos, é feita uma apreciação crítica das informações obtidas nas entrevistas, procurando, quando pertinente, analisá-las à luz das recomendações e observações dos autores pesquisados na revisão bibliográfica. No apêndice $B$, encontram-se alguns trechos dos depoimentos coletados.

\subsection{Caracterização da empresa em relação a práticas de Marketing de Relacionamento}

Neste primeiro bloco, explorou-se como as empresas trabalham com o marketing de relacionamento, por meio de questões relacionadas ao tema. 


\subsubsection{Existência de departamento formalmente responsável pelos relacionamentos com clientes}

No quadro 10, pode-se visualizar uma síntese das unidades administrativas formalmente responsáveis por desenvolver atividades de marketing de relacionamento, indicadas pelas empresas entrevistadas. Nesta questão, pretendia-se verificar a existência de departamentos com denominação específica para relacionamento e, portanto, voltados exclusivamente a esta função, ou se outras áreas estariam acumulando tais atividades. As células assinaladas com (:) indicam que o item correspondente foi declarado como existente na estrutura organizacional da empresa.

Quadro 10 - Departamentos formalmente responsáveis pelos relacionamentos com clientes

\begin{tabular}{|c|c|c|c|c|c|c|c|c|}
\hline \multirow[b]{2}{*}{ Unidades } & \multicolumn{8}{|c|}{ Empresas } \\
\hline & A & B & $\mathrm{C}$ & D & $\bar{E}$ & $\mathrm{~F}$ & $\bar{G}$ & $\mathrm{H}$ \\
\hline Departamento com denominação específica para relacionamento & ;) & ;)* & $+;$ & (;)** & ;) & ;) & - & - \\
\hline Serviço de Atendimento ao Cliente (SAC) & ;:) & ;:) & (:) & ;:) & ;) & ;:) & ;) & (;) \\
\hline Programa de Fidelidade & ;: & - & (:) & - & - & - & - & - \\
\hline Satisfação do Cliente & ;) & - & ;) & - & - & - & - & - \\
\hline CRM & ;) & ;: & - & - & - & - & - & ;) \\
\hline
\end{tabular}

* Denominação específica apenas para relacionamento com o canal.

** Denominação específica tanto para relacionamento com o canal como com o consumidor final.

Fonte: dados de campo.

Como se pode observar no quadro 10, seis das oito empresas possuem uma área com denominação específica para cuidar dos relacionamentos da empresa com seus clientes, o que denota preocupação com a centralização das atividades de relacionamento em um único departamento. Isso não significa, entretanto, que a atenção com esse tema inexiste nas demais empresas: as atividades associadas à manutenção de relacionamento com clientes estão, em muitos casos, distribuídas entre outras áreas, de acordo com a sua conveniência e necessidade. Um ponto comum entre todas as entrevistadas é a presença de uma unidade administrativa dedicada ao Serviço de Atendimento ao Cliente (SAC).

Na Empresa A, além do SAC e de uma área responsável por tudo o que se refere à satisfação do cliente, existe uma gerência responsável pelo programa de fidelidade da empresa. Todas essas áreas estão subordinadas à Diretoria de Marketing. A área de Atendimento ao Cliente é muito atuante, pois considera o atendimento seu principal diferencial 
A Empresa B possui, subordinada à Diretoria de Suporte a Vendas, a Gerência de $e$-Business, responsável por Internet, um canal para o cliente, e por comércio eletrônico, especificamente no que diz respeito a contatos com clientes consumidores finais. Subordinada à Diretoria de Marketing está a gerência de CRM, oriunda de uma cisão da área de $e$-Business, em função do crescimento do foco da empresa nesse assunto nos dois últimos anos. Além destas, existem as diretorias de Call Center e de Relacionamento com Concessionárias, todas sob a Diretoria Geral de Marketing e Vendas. Operacionalmente, seu call center é terceirizado; contudo, a empresa não teme que um terceiro seja responsável pelo contato com seus clientes, pois acredita que os resultados dependem de como esse processo é conduzido. Nesse caso, a empresa terceirizada é submetida a treinamento específico para a função, desenvolvido pela contratante, e conta com equipe de alto nível em atendimento e que atua sempre sob supervisão de funcionários da montadora, como se fossem seus próprios funcionários. Embora haja associação de terceirização com dificuldade de incorporação dos valores da empresa contratante, o fato de sua parceira ser uma empresa do grupo garante a manutenção dos valores, mesmo havendo alta rotatividade de funcionários.

Na Empresa C, a exemplo da empresa A, há uma gerência responsável pelo seu programa de fidelidade, parte essencial do seu relacionamento com clientes, uma gerência voltada a ouvir os clientes para procurar satisfazê-los e responsável também pelo SAC, uma gerência de call center e uma gerência de Marketing Eletrônico, responsável por Internet e CRM. A empresa mantém um call center exclusivo para reservas e atendimento aos clientes do seu programa de fidelidade.

Pelo fato de a Empresa D possuir dois tipos de clientes - consultora/revendedora e consumidor final -, houve designação em sua estrutura de mais de uma área responsável por relacionamentos: a Gerência de Relacionamento com o Canal, que desenvolve campanhas, incentivos, fidelidade e serviços voltados às suas consultoras; e a Empresa D.net, subordinada à Vice-presidência de Inovação, criada com o objetivo de construir uma rede de relações na Internet, transportando para esse canal, dentro do possível, o seu marketing de relacionamento, e maximizando todas as vantagens desse meio. O SAC, uma área independente das demais áreas de relacionamento, pode ser considerado o seu precursor, porém de maneira receptiva, e não ativa. Foi o primeiro e um dos grandes canais de comunicação com o cliente, permitindo à empresa captar informações importantes sobre qualidade de produtos e problemas na sua utilização, constituindo ainda uma fonte de feedback constante, principalmente para as funções de inovação e de desenvolvimento de produtos. 
Na Empresa E, como fruto de um redesenho feito por uma empresa de consultoria, foi criada, uma Gerência de Relacionamento, sob a Diretoria de Assinaturas, responsável também pelo SAC/Contact Center. Há algum tempo, falava-se freqüentemente em relacionamento na empresa e até se notavam algumas iniciativas com evidência de empenho em seu desenvolvimento, mas tomadas de forma isolada, sem unidade de políticas ou coordenação entre as mesmas. Na reformulação de vários processos proposta pela empresa de consultoria, dedicou-se especial atenção à área de Assinaturas, que era organizada por tipo de mídia, com áreas de Internet, Marketing Direto e Telemarketing, e hoje, é estruturada segundo seus processos: captar um assinante, desenvolver um assinante ou reter um assinante. A área de Relacionamento foi criada para exercer a função de retenção do assinante.

A Empresa F conta com uma Diretoria de Relacionamentos, voltada tanto a fornecedores como a clientes, criada com o objetivo de direcionar mais esforços ao relacionamento entre a empresa, suas lojas, clientes e fornecedores. Em contrapartida, a Empresa G não possui uma área voltada exclusivamente a relacionamentos, mas conta com uma Diretoria de Marketing e Comunicação, subordinada diretamente à Direção Geral da empresa, que acumula essa função. Com o crescimento da empresa e a abertura de lojas em outras cidades, percebeu-se a necessidade de uma comunicação mais efetiva com seus clientes. Assim, cada loja possui a sua área de Comunicação, orientada pelas diretrizes e políticas emanadas da Diretoria de Marketing e Comunicação.

É interessante observar que, embora sem muita tradição em relacionamento, a Empresa $\mathrm{H}$ criou, desde o início de suas atividades pela Internet, uma área de Atendimento ao Cliente, subordinada à Diretoria de Logística, e uma área de CRM, subordinada à Diretoria de Tecnologia e Marketing, com o objetivo de desenvolver esta filosofia.

\subsubsection{Programas de Fidelidade}

Em relação a programas de fidelidade, as empresas apresentam variações de propostas com vistas a beneficiar seus clientes mais fiéis, como sintetizado no quadro 11, a seguir. 
Quadro 11 - Planejamento e Implantação de Programas de Fidelidade

\begin{tabular}{|c|c|c|c|}
\hline Empresa & Descrição & Funcionamento & $\begin{array}{c}\text { Tempo } \\
\text { existência } \\
\text { (anos) }\end{array}$ \\
\hline$A$ & $\begin{array}{|lrr|}\text { Análise } & \text { de grupos de } \\
\text { consumo; } & \text { programa } & \text { criado } \\
\text { parar promover } & \text { maior } \\
\text { aproximação entre a empresa e } \\
\text { seus clientes, ao entender suas } \\
\text { necessidades de consumo. }\end{array}$ & $\begin{array}{l}\text { Organiza, cataloga e analisa dados de compras registradas por meio de } \\
\text { um cartão de compras, incluindo o valor do ticket médio, a freqüência e } \\
\text { o perfil de compra. Com isso, classifica os clientes em freqüentes, } \\
\text { populares, sazonais, eventuais e VIPs, gerando comunicações } \\
\text { adequadas a cada perfil. Além disso, identifica o sortimento mais } \\
\text { adequado a cada loja e capta necessidades específicas de cada grupo, } \\
\text { objetivando atendê-las. }\end{array}$ & 3 \\
\hline B & $\begin{array}{l}\text { Cartão de crédito de afinidade, } \\
\text { sob responsabilidade da área } \\
\text { de CRM. }\end{array}$ & $\begin{array}{l}\text { Oferece a conversão de } 5 \% \text { do valor de cada compra realizada com este } \\
\text { cartão em bônus, que se transformam em descontos na compra de um } \\
\text { automóvel } 0 \mathrm{~km} \text { ou na aquisição de peças originais e serviços } \\
\text { oferecidos em sua rede de concessionárias. }\end{array}$ & 7 \\
\hline C & $\begin{array}{l}\text { De acordo com o total de } \\
\text { pontos acumulados, o cliente } \\
\text { ganha um trecho (ida, volta ou } \\
\text { "perna”), ou ida e volta dentro } \\
\text { da América do Sul. }\end{array}$ & $\begin{array}{l}\text { Os pontos podem ser acumulados a cada check-in pela Empresa C ou } \\
\text { pelas companhias aéreas com as quais ela tem acordo, ou por compras } \\
\text { de seus parceiros de fidelidade, como postos de gasolina, locadoras de } \\
\text { automóveis, restaurantes, hotéis e empresas de telefonia. Existem três } \\
\text { categorias de Cartão Fidelidade: Branca, Azul e Vermelha, que } \\
\text { proporcionam vantagens adicionais como o acúmulo mais rápido de } \\
\text { pontos, franquias de bagagem, salas VIP, promoções especiais etc. }\end{array}$ & 10 \\
\hline $\mathrm{D}$ & $\begin{array}{l}\text { Programa de fidelidade para as } \\
\text { suas consultoras. }\end{array}$ & $\begin{array}{l}\text { Em fase de planejamento. Para o consumidor final, inicialmente, está } \\
\text { em construção um plano de relacionamento para que se adquira massa } \\
\text { crítica suficiente para outras ações. No futuro, com mais experiência no } \\
\text { assunto, quando a empresa tiver conhecimento mais profundo do } \\
\text { consumidor e de seu relacionamento com os produtos e com o canal, é } \\
\text { que deve ser desenvolvido um programa de fidelidade. }\end{array}$ & 0 \\
\hline$E$ & $\begin{array}{l}\text { Clube de Viagem, para } \\
\text { assinantes da sua revista de } \\
\text { turismo. }\end{array}$ & $\begin{array}{l}\text { Toda a carteira ativa de assinantes desta revista recebe um cartão, } \\
\text { enviado antes do período de renovação da assinatura; caso renove, esse } \\
\text { cartão lhe dá direito a um jornal com roteiro de viagens, descontos } \\
\text { especiais em locadoras e outros parceiros do ramo de turismo. }\end{array}$ & 0,3 \\
\hline $\mathrm{F}$ & $\begin{array}{l}\text { Projeto de programa de } \\
\text { fidelidade em estudo. }\end{array}$ & Previsão de & 0 \\
\hline G & $\begin{array}{l}\text { Cartão de fidelidade, pelo qual } \\
\text { se cobra uma anuidade. } \\
\text { Atualmente, passa por um } \\
\text { processo de migração. }\end{array}$ & $\begin{array}{l}\text { Concede descontos nas compras e outros benefícios a seu associado, } \\
\text { como isenção de taxa de estacionamento, gratuidade de frete nas } \\
\text { compras de livros, CDs e outros produtos de pequeno volume pela } \\
\text { Internet, e, duas vezes por ano, oferece convites para uma grande festa } \\
\text { na própria loja, com lançamentos de cantores, escritores e } \\
\text { demonstrações. }\end{array}$ & 2,5 \\
\hline $\mathrm{H}$ & $\begin{array}{l}\text { Dois programas de reversão de } \\
\text { percentual do valor de compra } \\
\text { em bônus (Smart ou Dotz). }\end{array}$ & $\begin{array}{l}\text { O cliente escolhe, no fechamento da compra, a opção do programa do } \\
\text { qual vai participar; os bônus podem se converter em descontos em toda } \\
\text { a rede conveniada. }\end{array}$ & 3 \\
\hline
\end{tabular}

Fonte: dados de campo.

Na Empresa E, há planos de implantação de programas de fidelidade; entretanto, algumas publicações já estão trabalhando isoladamente, como o programa descrito no quadro 11, indicado como o mais bem sucedido de todos. Outros títulos possuem convênio com bandeiras de cartões de crédito, que oferecem vantagens na renovação da assinatura e na anuidade do cartão, e ainda alguns convites e acessos especiais. Contudo, os programas são planejados por produto, e não por 
assinante. A empresa tem a visão do produto, ou das várias assinaturas, mas não vê o assinante. Um projeto em desenvolvimento visa, em primeiro lugar, à qualificação do assinante (diamante, ouro...), o que permitiria à empresa criar uma política de benefícios e ter o controle dos mesmos. Adicionalmente, ao considerar há quanto tempo ele é cliente, quantas assinaturas possui, quantas assinaturas há em seu domicílio, levando em conta o household e a forma de pagamento das mesmas, a empresa poderia criar um indicador do valor do assinante e mapear sua base de clientes.

Por experiência própria e por estudos de caso, a Empresa G concluiu que os brasileiros não estão muito habituados a programas de pontuação no varejo e, provavelmente devido ao histórico de inflação, são mais imediatistas. Assim, transformou seu programa de fidelidade inicial em um sistema que oferece benefícios imediatos; tal programa está novamente em fase de transição, sem custo extra para os afiliados: agregará também as funções de cartão de crédito. Tradicionalmente, o cliente membro do programa já é beneficiado com 5\% de desconto em todas as compras; para a primeira compra no cartão, há um desconto de "boas vindas”, de 10\%. Esse é um apelo muito forte no momento de oferecer o cartão e sua renovação, pois o valor da anuidade é baixo ( $\$ 330$, cerca de US\$10), embora a bandeira de crédito, de propriedade de um banco europeu, seja nova no Brasil.

A Empresa $\mathrm{H}$ chegou a possuir, simultaneamente, três tipos de programas de reversão de percentual do valor da compra em pontos, conversíveis em descontos em toda a rede conveniada. Contudo, como a Empresa E, essa organização planeja desenvolver um programa que diferencie melhor os clientes, pois todos que compram recebem pontos de acordo com o valor gasto, independentemente de sua freqüência. A idéia também é aplicar uma classificação do tipo “ouro, prata, bronze”. Dependendo de quando e de como os clientes foram conquistados, comportam-se de modo diferente e devem ser tratados de maneira distinta, levando-se em conta, entre outras coisas, a margem que eles trazem para a empresa, e não o total da sua compra. A empresa está sendo assessorada na revisão dessa classificação que, anteriormente, era feita apenas com base em RFV (receita, freqüência, valor) e que hoje considera outros eventos como troca efetuada, reclamações registradas, margem. O software de CRM já faz uma classificação de diferencial exclusivo, porém trata-se apenas de uma ação de e-mail Marketing, que envia aos clientes ofertas exclusivas, com alguns incentivos a mais para clientes de mais alto valor de compra. No novo programa, a empresa buscará diferenciar o cliente de acordo com seu valor para ela. 


\subsubsection{Pesquisas de satisfação e fixação de parâmetros relacionados ao atendimento ao cliente na definição de metas anuais}

As pesquisas de satisfação realizadas pelas empresas, os processos de divulgação das opiniões dos clientes ao seu público interno e o estabelecimento de parâmetros relacionados à satisfação dos clientes são desenvolvidos de formas variadas em termos de formato e de intensidade de freqüência. Em que pesem tais variações, é possível detectar aspectos em comum, a saber:

\section{- Formas de pesquisa utilizadas}

O quadro 12 resume as principais formas de pesquisa empregadas pelas empresas entrevistadas para conhecer a opinião de seus clientes, colher sugestões, ouvir suas críticas e reclamações. As células com o símbolo :) indicam presença do item correspondente; o símbolo 8 indica que tal aspecto ainda está em desenvolvimento, e o sinal - expressa ausência do item indicado.

Quadro 12 - Formas de pesquisa utilizadas pelas empresas entrevistadas

\begin{tabular}{|c|c|c|c|c|c|c|c|c|}
\hline Empresas & A & B & $\mathrm{C}$ & D & $E$ & $\mathrm{~F}$ & G & $\mathrm{H}$ \\
\hline Comprador oculto* & - & - & ;) & (;) & - & - & (;) & - \\
\hline Discussões em grupo / focus groups & ;) & (;) ** & ;) & (;) & - & - & - & (;) \\
\hline Entrevistas pessoais e individuais nas lojas & ;) & - & - & - & - & ;) & ;) & - \\
\hline Pesquisas por e-mail & - & - & - & - & - & - & - & (;) \\
\hline Pesquisas telefônicas & - & (;) & ;) & (;) & - & - & - & - \\
\hline Pesquisas via Internet & - & - & 8 & ;) & - & - & - & (;) \\
\hline Questionário enviado aos clientes / Autopreenchimento & - & ;) & ;) & - & - & ;) & - & - \\
\hline
\end{tabular}

* detalhado mais adiante; ** para avaliação do site da empresa.

Fonte: dados de campo.

A área de Conhecimento do Consumidor da Empresa A realiza pesquisas quantitativas e qualitativas esporadicamente, de acordo com demandas de cada marca de lojas do grupo, como, por exemplo, queda nas vendas em determinada loja. Realiza também pesquisas de preço e de sortimento de loja, para que possa operar sobre as margens de lucro.

A Empresa B envia um questionário aos proprietários dos veículos logo após a compra e a cada uso da garantia, cujas respostas contribuem para a construção do Índice de Satisfação do Cliente. Outras formas de pesquisa ocorrem esporadicamente, sem identificação da empresa.

Sempre foi preocupação da Empresa C realizar pesquisas de opinião, em função de um grande Programa da Qualidade que permeia toda a empresa, implantado há muito tempo. A área destinada 
a ouvir os clientes centraliza todos os esforços de coleta de dados a respeito de suas opiniões, críticas e sugestões, conduzindo, pelo menos uma vez ao ano, uma pesquisa qualitativa bastante abrangente. Além disso, realiza-se, periodicamente, uma Pesquisa de Percepção de Qualidade do Serviço pelo Cliente, mais elaborada que uma outra realizada por telefone pelo call center e que está sendo adaptada de forma a poder ser feita também pela Internet. Algumas pesquisas são feitas com o auxílio de agências de propaganda, com a condução de focus groups.

Na Empresa D, a área de Pesquisa de Mercado desenvolve vários tipos de pesquisa ao longo do ano, com, pelo menos, quatro pessoas dedicadas full time a esse fim. São conduzidas pesquisas qualitativas em grupo e quantitativas por telefone e pela Internet, com auxílio de uma empresa terceirizada (e-Bit), tanto com consultoras como com clientes finais.

A Empresa E não realiza pesquisas de opinião, mas pretende fazê-lo, com a finalidade de descobrir os motivos da não conversão e da não renovação. Entende-se por conversão a passagem do $1^{\circ}$ para o $2^{\circ}$ ano de assinatura e, por renovação, a passagem do $2^{\circ}$ para o $3^{\circ}$ ano. Estes são momentos críticos, pois um assinante leva, em média, 2,5 anos para se pagar. É preciso, portanto, entender o porquê da não renovação, e o seu nível de conhecimento e de valorização do processo de assinatura de uma revista em aspectos como: desconto por exemplar, congelamento do preço durante o período de assinatura, entrega sem taxa adicional no domicílio.

A Empresa F tem realizado pesquisas de satisfação com bastante freqüência, pois além de fornecerem retorno sobre os efeitos das ações executadas, são consideradas importantes fontes de informação para aprimoramento de produtos. As pesquisas são realizadas por grandes empresas terceirizadas, nas lojas, feitas pelas próprias vendedoras, ou em entrevistas pessoais, com o preenchimento de formulários.

A Empresa G realiza, trimestralmente, pesquisas nas próprias lojas, com pesquisadores que realizam entrevistas pessoais de curtíssima duração. Já na Empresa $H$, as pesquisas sobre vendas eletrônicas são bimestrais, com objetivos específicos, mas ela também recebe resultados de uma pesquisa de satisfação do cliente, realizada por um terceiro especializado (e-Bit), a mesma empresa utilizada pela Empresa D, logo após a compra. Posteriormente, o cliente também recebe um e-mail consultando-o a respeito de sua satisfação com a entrega, entre outros itens de avaliação do atendimento. Há também pesquisas para verificar sua opinião sobre novas interfaces de vendas pela Internet e, anualmente, também para objetivos específicos, faz-se um focus group. 


\section{- Utilização da técnica do “comprador oculto”}

O “comprador oculto” é uma forma de pesquisa na qual uma pessoa contratada, que não se identifica como tal, efetua compras, avaliando todos os seus aspectos, incluindo o atendimento, informações prestadas e facilidade em obtê-las por si próprio. A denominação desse método em cada empresa é distinta: na Empresa C, é "passageiro fantasma”; na D, “mistery shop”, e na G, “cliente oculto”. Na Empresa C, um viajante não identificado atribui notas a toda a cadeia de serviços da empresa, nas suas várias bases de prestação de serviços, avaliando desde a facilidade de encontrar o número telefônico da empresa para realizar sua reserva, fazer a compra no site e alterar reservas, até elementos do check-in e da aeronave, como limpeza, a presença do tapete vermelho, aspecto da alimentação servida, condições gerais das instalações da aeronave etc. As discussões para avaliação das impressões colhidas pelo "passageiro fantasma” ocorrem semanalmente. Embora não exista ainda efetivamente instaurado pela Empresa G o “cliente oculto”, ela está ciente de que sua matriz européia contratou “compradores ocultos” para lojas do mundo todo e está preparada para, a qualquer momento, receber um relatório sobre a avaliação feita por um deles.

\section{- Canal aberto para manifestação dos clientes}

Todas as empresas entrevistadas possuem SAC telefônico/Call center e oferecem também a possibilidade de seus clientes entrarem em contato por e-mail. O SAC/Call center é terceirizado nas Empresas B e E; a Empresa G dispõe também de SAC pessoal. Na Empresa F, o SAC é o canal de atendimento mais requisitado para o cliente dirigir reclamações e problemas com produtos à empresa ou para solicitar informações sobre os mesmos. Além desses, as empresas disponibilizam outros meios para que os clientes expressem espontaneamente suas opiniões, sendo alguns deles comuns entre si, conforme o quadro 13, a seguir:

Quadro 13 - Canais abertos para manifestação espontânea dos clientes

\begin{tabular}{|c|c|c|c|c|c|c|c|c|}
\hline Empresas & A & B & $\mathrm{C}$ & D & $E$ & $\mathbf{F}$ & $\mathbf{G}$ & $\mathrm{H}$ \\
\hline Autopreenchimento/Caixa de sugestões & ;) & - & (;) & - & - & - & ;) & - \\
\hline Carta/bilhete & - & - & (;) & ;) & - & - & ;) & - \\
\hline Chat & ;) & - & (;) & (:) & - & - & - & (;) \\
\hline E-mail para contato & ;) & - & - & - & (;) & - & ;) & - \\
\hline E-mail enviado a partir o próprio site da empresa & (;) & (:) & (;) & ;) & (:) & (;) & - & (;) \\
\hline Fax & $+;$ & - & (;) & - & - & - & - & - \\
\hline
\end{tabular}

Fonte: dados de campo. 
As formas de contato com as empresas, de maneira geral, são divulgadas em seu próprio site, em embalagens de produtos e, quando cabível, praticamente em toda a comunicação dirigida a seus clientes, que inclui tablóides, anúncios, catálogos, folhetos, outdoors etc. Além disso, as empresas também informam os canais para manifestação na assinatura de filmes (Empresa A), na revista da companhia aérea, na Carta do Presidente, e pelos formulários entregues pelos comissários, a bordo (Empresa C), na contracapa ou editorial da revista (Empresa E), em programas femininos e do tipo Shop Tour, pela televisão (Empresa F), pelos operadores de caixa (Empresa G), sendo também possível a manifestação anônima pelo site da empresa de pesquisa terceirizada (Empresa H).

A Empresa A define-se como uma empresa de espírito voltado totalmente para o atendimento, com um grande trabalho de relacionamento com seus clientes, envolvendo muita comunicação e inovando ao introduzir a figura do ombudsman no varejo. Uma das suas mais recentes inovações, a pedido de seus clientes, foi a instalação de “cachorródromos” em algumas de suas lojas, que são áreas para acomodação dos animais enquanto seus donos fazem suas compras. Outra inovação foi o treinamento de especialistas em vinhos para prestar orientações aos clientes.

A expressão das opiniões do cliente na Empresa C também é intensivamente incentivada por ela. $\mathrm{Na}$ Empresa D, as consultoras e consumidores finais possuem centrais de atendimento separadas para cada um desses grupos. Como não possui loja física, os canais abertos pela empresa para ouvir seus clientes são formas de permitir que pessoas ainda não atendidas possam ter acesso a uma consultora ou sejam orientadas a realizar suas compras diretamente no site.

Para que os clientes expressem suas opiniões, críticas e reclamações, a Empresa E dispõe também do telemarketing ativo de terceiros e do Serviço de Venda de Assinaturas, uma central que processa $90 \%$ dos pedidos de assinaturas provenientes de encartes ou malas-diretas e por telefone. Muitas vezes, o cliente com razão quer apenas ser reconhecido e ouvido.

Na Empresa G, se o cliente desejar falar com o gerente da loja, ele será encaminhado ao responsável, o qual é treinado para procurar resolver os problemas com cortesia, mas também para manter sempre o controle da situação, especialmente em casos de clientes intransigentes. Na opinião do entrevistado, o Código de Defesa do Consumidor incentiva esse comportamento a manifestação dos clientes, mas também dá margem a abusos ao conceder poder a pessoas que, às vezes, nem sabem utilizá-lo. Pode-se citar o exemplo ocorrido de um cliente querer indenização devido a algum mal estar atribuído ao ar condicionado da loja. 


\section{- Disseminação das opiniões dos clientes e resultados das pesquisas de satisfação aos} funcionários

Algumas empresas, como as Empresas B e H. fazem a divulgação das opiniões dos clientes e dos resultados de pesquisas de satisfação para todos os funcionários. Na Empresa B, devido ao fato de o Índice de Satisfação do Cliente fazer parte de suas metas, todos os funcionários devem ter ciência do mesmo. Algumas divulgações das opiniões dos clientes ocorrem por e-mail, mas como este serviço exclui alguns grupos, como o pessoal da fábrica, o meio mais utilizado para atingi-los indistintamente é o mural com "8 laudas”, uma forma de comunicação que traz mensagens relevantes, diretas, curtas, escritas em uma frase, em letras grandes, fixadas em locais de passagem ou pontos de parada como bebedouros e postos de café. Os funcionários da Empresa H tomam conhecimento dos resultados das pesquisas em apresentações mensais dos relatórios que consolidam todas as fontes e das análises estatísticas que mostram a evolução dos índices.

Em outras empresas, a divulgação é restrita a alguns níveis ou departamentos da estrutura organizacional, como ocorre com as Empresas A, D e F. Na empresa A, por exemplo, ela é feita de acordo com os objetivos e ações de pesquisa específicas, informando-se as áreas participantes; dependendo da abrangência da ação, divulgam-se, principalmente por meio de comunicação interna, informações que possam causar impacto em outras áreas. Na Empresa D, o SAC divulga relatórios qualitativos e quantitativos mensais para os gerentes de produto e para as unidades de negócios. Algumas gerências recebem relatórios semanais sobre pesquisas feitas pelo seu site na Internet, além dos relatórios da empresa de pesquisa especializada (e-Bit), e do feedback das solicitações, organizadas e quantificadas de maneira a facilitar a tomada de decisão. Pelo fato de as pesquisas serem freqüentes e bastante valorizadas pela Empresa F, a divulgação de seus resultados é feita em reunião bimestral com todos os gerentes de lojas, para que tomem conhecimento do que está sendo feito a partir dos seus resultados e o quanto as pesquisas são produtivas e eficazes.

As Empresas C, E e G fazem divulgação seletiva: algumas informações tornam-se conhecidas por todos os funcionários, enquanto outras são encaminhadas exclusivamente a escalões mais altos. Na Empresa C, por exemplo, a disseminação dos índices de satisfação aos funcionários é feita pelo Radar da Qualidade, relatório elaborado a partir de dados coletados a bordo, e pelo Painel da Qualidade, implantado em 2003, que sintetiza graficamente os resultados das pesquisas, evidenciando alterações em seus indicadores de qualidade, e que fica exposto em várias áreas da empresa de maneira a ser visualizado por todos os funcionários. Adicionalmente, elaboram-se 
relatórios que são enviados a todos os gerentes e supervisores, semanalmente. Na Empresa E, os comentários, as críticas e reclamações não são divulgados a todas as áreas da empresa; a área comercial, muitas vezes, nem comunica às áreas editoriais os motivos pelos quais se cancelam as assinaturas, como falta de interesse pelo produto ou excesso de anúncios, por exemplo, procedimento este, inadequado, na opinião da entrevistada. O líder de segmento, que atua como um gerente de produto, trabalhando em estrutura matricial entre as áreas comercial e editorial, recebe essas informações, mas não se sabe até que ponto elas são repassadas; existe um certo tabu em dizer à redação que há falta de interesse pela revista, embora as próprias redações encomendem pesquisas que revelam o Índice de Qualidade Editorial, não divulgado à área comercial. Contudo, esse enorme distanciamento entre as áreas comercial e editorial está sendo reduzido aos poucos. Em média, um assinante recebe seis ofertas de renovação, que seguem um cronograma, com abordagens distintas. Há cerca de seis meses, a área comercial iniciou uma revisão desse conjunto e, pela primeira vez, isso está sendo feito com a participação dos diretores de redação e de arte da publicação, para que se mantenha a identidade visual e o posicionamento do produto na oferta, pois são essas pessoas que mais conhecem os produtos, os leitores, seus objetivos e podem entendê-los melhor. Com isso, aflora uma curiosidade sobre os problemas transacionais, ampliando-se os limites do mundo da produção de uma revista para além da redação. O redesenho da consultoria está transformando, de certa forma, esta postura, apostando em que as pessoas entendam melhor o processo como um todo. A operação de revistas é gigantesca, com vários pontos possíveis de falha; desde o trabalho redacional até a impressão e distribuição, são várias as etapas e as pessoas envolvidas; uma má distribuição, no final do processo, pode arruinar tudo. A revista semanal, por exemplo, não pode atrasar. Na Empresa G, as ocorrências relacionadas a atendimento e os resultados das pesquisas são discutidos em reuniões de comitê quinzenais, das quais participam os diretores da empresa, que têm a incumbência de divulgá-los a quem as informações possam interessar, dentre os demais colaboradores da empresa.

Há empresas que utilizam sua Intranet para divulgação das opiniões dos clientes e dos resultados das pesquisas de satisfação quando desejam atingir maior número de pessoas (Empresas B, G e H). Na Empresa G, este meio está sendo utilizado em substituição aos murais, por ser mais rápido, eficiente e interativo que os mesmos. Como os computadores para pesquisa de produtos ficam num balcão de fácil acesso, à vista dos clientes - a empresa deseja que o cliente participe da pesquisa - e por não ser de interesse da empresa que as informações de caráter interno, como notícias sobre alterações no vale-refeição ou resultados de pesquisas de opinião, sejam expostas aos 
clientes, os funcionários da loja têm acesso à intranet nas áreas de convivência, que são locais reservados, com televisão, jornais e revistas, máquinas de refrigerantes e de café, para que possam descansar nos intervalos para refeição ou nas trocas de turno.

\section{- Definição de metas relacionadas à satisfação dos clientes}

As empresas, em geral, não quiseram detalhar a questão das metas. As Empresas E, F e G lamentam não terem ainda instituído a fixação de metas para satisfação dos clientes. A Empresa A não fixa metas anuais de satisfação de clientes, uma vez que visa a horizontes mais curtos. A Empresa B possui metas departamentais, sendo que as metas de satisfação do cliente são coordenadas pela área de Atendimento. Na Empresa C, com base nos resultados das pesquisas, a área responsável por ouvir o cliente determina pesos, tabula dados e estabelece metas de atendimento. A Gerência de Qualidade faz uma pesquisa mais estruturada de maneira a verificar se as metas para satisfação de clientes estão sendo atingidas, divulgadas pelo Painel da Qualidade para cada elo da cadeia de serviços. A avaliação do pessoal de linha de frente, ou seja, check-in, atendimento no balcão, comissariado de bordo, call center, é feita individualmente. Todas as áreas da Empresa D possuem metas relativas à qualidade dos serviços. Uma pesquisa anual mede o nível de satisfação da consultora com relação ao atendimento, em diversos aspectos, compondo um dos indicadores que influem na remuneração variável de boa parte dos gestores da empresa, principalmente da área comercial. A verificação do cumprimento das metas é feita mediante pesquisa da empresa terceirizada (e-Bit), cujos critérios de avaliação fazem um exame tanto da experiência de compra como da experiência de recepção dos produtos, e pelas avaliações constantes de e-mails, chats, SAC e Central de Atendimento à Consultora. A Empresa $\mathrm{H}$ possui um painel eletrônico que apresenta as metas para o período (dia/mês) e o percentual atingido até o momento, online. As metas para atendimento nesta empresa são bem detalhadas. Desde o início da operação, é feita, sistematicamente, a avaliação de dez itens, que incluem facilidade de comprar, de encontrar o produto no site, qualidade do produto, do texto explicativo do produto, entrega (tempo de demora, embalagem), satisfação com o produto propriamente dito, entre outros. Tudo isto funciona como subsídio para a melhoria dos serviços prestados pela empresa.

\section{- Padronização de procedimentos para atendimento a reclamações de clientes}

As empresas entrevistadas apresentam também diferenças quanto à definição de padrões para atendimento a reclamações dos clientes. No quadro 14, as células com (:) indicam a presença do 
item correspondente; o símbolo $:-$ indica pouca presença do item correspondente e o sinal - indica ausência do item correspondente.

Quadro 14 - Padronização de procedimentos para atendimento a reclamações

\begin{tabular}{l|c|c|c|c|c|c|c|c}
\hline \multicolumn{1}{c|}{ Padrões nas Empresas } & A & B & C & D & E & F & G & H \\
\hline Possui padrões & $\odot$ & $\odot$ & $\odot$ & $\odot$ & $\odot$ & $\odot$ & $\odot$ & $\odot$ \\
\hline Utiliza software para apoio aos padrões & - & - & $\odot$ & $\odot$ & - & - & - & $(;$ \\
\hline
\end{tabular}

Fonte: dados de campo.
Praticamente todas as empresas entrevistadas possuem algum tipo de padrão para atendimento de reclamações de clientes.

Esses padrões envolvem políticas de reembolso, independentemente de regulamentação oficial, registro de ocorrências e atitude imediata ou encaminhamento, acompanhamento da solução dos problemas, entre outros. Quase todas as empresas fixam prazos máximos para resposta ao cliente; por outro lado, quase nenhuma se arrisca a definir prazos máximos para a completa solução dos problemas, talvez devido ao grande desafio que isto representa em se tratando de varejo, onde as possibilidades são muitas e as soluções nem sempre dependem exclusivamente das mesmas. A adoção de políticas de reembolso também apresenta variações entre as empresas entrevistadas; a maior parte delas não mantém tais políticas, sendo as questões resolvidas caso a caso. As empresas C, D e H utilizam softwares para propiciar um nível mínimo de padronização.

A Empresa A instituiu “Os dez passos de atendimento dentro da loja”, válidos não só na frente de caixa e no balcão, mas para todos os funcionários. Além das determinações dos órgãos reguladores, a empresa sempre procura exceder positivamente às expectativas dos clientes, como a troca de não perecíveis, mesmo fora do prazo estabelecido para isto. Nessa empresa, todas as ocorrências são registradas para que se tenha um histórico, acessível a todas as áreas envolvidas, de maneira integrada; caso não seja possível resolver a questão de imediato, esta é encaminhada para análise e solução. A área que recebe reclamações e manifestações formais centraliza as ocorrências de todas as lojas e repassa-as ao diretor da regional ou ao gerente da loja. Além disso, acompanha a solução e verifica o atendimento dos padrões, averiguando o cumprimento dos compromissos estabelecidos com os clientes. E quando algo foge do padrão, necessitando de ações locais, estas são levadas ao conhecimento da diretoria regional, que passa a acompanhar o processo.

Na Empresa B, na área responsável pelo Pós-Venda, o “nível 1” de atendimento recebe as demandas por telefone, com procedimentos pré-definidos, e o “nível 2" faz seu acompanhamento, uma vez que tudo é registrado. As questões não contempladas nos procedimentos são tratadas individualmente pela supervisão. 
A área responsável por ouvir os clientes na Empresa C estipula, conforme a gravidade e tipo do problema, padrões de tempo de retorno para os clientes. Esta tarefa tem o suporte de um software, o qual permite a abertura de um processo interno e seu encaminhamento para o setor competente para solução que, em média, leva uma semana. A área responsável por ouvir os clientes é que coordena e acompanha todo o processo, retornando uma solução/resposta ao cliente, ou deixando este retorno a cargo do setor responsável por ela.

Na Empresa D, o controle do uso de padrões é executado também com o auxílio de um instrumento desenvolvido com base num software, o qual registra e encaminha os problemas aos setores competentes para solução. Por meio dele, é possível obter indicadores como quantidade e tipo de reclamações, prazo médio de atendimento, entre outros.

A Empresa E admite que existem poucos padrões para atendimento no seu dia-a-dia; contudo, acredita que a revisão de políticas, em desenvolvimento, vai melhorar esta situação. Hoje, a maior parte dos casos que chegam ao seu SAC é tratada como exceção e, devido ao volume de ocorrências, é encaminhada por e-mail a um supervisor. Se necessário, este supervisor pode enviá-la para o backoffice, o qual pode direcioná-la para a área do processo, que em muitos casos, é a área de Retenção; se, ainda assim, o problema não for resolvido, é necessária a intervenção de um líder de segmento. Ocorre, por exemplo, de um cliente ligar solicitando um brinde e o pessoal do atendimento percorrer todo o fluxo do processo, quando seria mais simples, em alguns casos, enviar o brinde para o cliente; isto é reflexo da falta de políticas, segundo a entrevistada, e desta forma, o atendimento perde autonomia, o que transparece para o mercado como incompetência, desorganização. Às vezes, o cliente descobre o telefone direto de algum desses níveis e a confusão só aumenta. A falta de políticas para classificação dos clientes muitas vezes emperra o relacionamento com os mesmos até no caso de uma simples identificação do mérito de um pedido de brinde no caso de renovação de uma assinatura ou na aquisição de uma nova.

A filosofia da Empresa F envolve dar atenção especial a todos os clientes; todos são especiais e devem ser tratados individualmente. Sempre se solicita aos clientes que, caso haja algum problema, leve-o ao gerente da loja, para que seja solucionado; com isto, pretende-se que, ao contrário da provável evasão, o cliente seja fidelizado. Em geral, o SAC recebe as reclamações e tem total autonomia para resolver a situação; trocas ou reembolsos necessários são processados de imediato, a menos que o caso seja muito sério, envolvendo valores mais altos; nessas situações, instâncias superiores é que tratam do problema. Os produtos problemáticos retornam à fábrica para 
averiguação e integram um gráfico de análise para que a área de Controle de Qualidade possa tomar providências para sanar a origem do problema e evitar reincidências.

A Empresa G acrescenta que, mesmo que o cliente não esteja com a razão, caso se manifeste perante a empresa, receberá uma resposta, esclarecendo ou explicando a situação, e convidando-o a retornar à loja. Se ele tiver razão, a empresa envia uma carta/e-mail agradecendo-lhe e, assim que a correção ou novo procedimento for implantado, ele será novamente avisado. O termômetro do uso de padrões é o próprio cliente: “pôxa, não recebi ainda aquela carta informando como a situação será resolvida...”. O cliente da empresa é tipicamente fiel, que cobra determinadas condutas da empresa por conhecê-las. Fica disponível também uma caixa de sugestões/críticas, cujo acesso é feito apenas pela área de Comunicação de cada loja - e não o Atendimento -, que tabula as informações coletadas e distribui os resultados para os setores envolvidos; a seguir, faz-se um acompanhamento das respostas com envio de retorno aos clientes.

Procedimentos padronizados voltados ao atendimento foram desenvolvidos com o auxílio de uma empresa terceirizada, na Empresa H. Um sistema de informações para o atendimento incorpora uma ferramenta de workflow, presente em todo o processo, gerenciando e registrando as ocorrências. Um único banco de dados integra todas as informações sobre o cliente como seqüência de navegação, procedimentos de compra, e todos os seus contatos com a empresa: reclamações, trocas, devoluções, cancelamentos, fraudes, elogios, sugestões. A evolução do sistema inclui subcategorias, produtos, motivos, expectativas não atendidas, permitindo identificar causas de problemas, como deficiências dos fornecedores e falhas na integração entre a comunicação da empresa e suas operações, como brindes anunciados não entregues. O sistema possui alarmes que sinalizam índices de reclamações concentradas, os quais são analisados prontamente pela empresa, permitindo ações tempestivas e modificações nos processos, se necessário.

\subsubsection{Realização de treinamento/reciclagem para funcionários, relacionado a atendimento}

O treinamento para o pessoal que lida diretamente com os clientes parece ser uma preocupação comum entre as empresas. No entanto, o foco dado ao atendimento propriamente dito nem sempre reflete uma intenção de se manterem relacionamentos saudáveis com eles, embora haja casos notáveis em que cortesia, aparência pessoal e atenção dispensada ao cliente sejam bastante enfatizados; o peso maior, em muitos casos, é técnico-operacional. A preocupação com a 
reciclagem também não é tão presente entre as empresas entrevistadas, em parte devido ao alto nível de rotatividade de funcionários. A empresa $\mathrm{H}$ por características peculiares de recentidade nessa forma de operação e necessidade de direcionamento de recursos a outras prioridades, lamenta ainda não ter planejado treinamentos para seus funcionários que lidam diretamente com os clientes.

A Empresa A provê treinamento padronizado para todos os funcionários das lojas, de acordo com cada seção: perecíveis, mercearia, frente de caixa; além do treinamento inicial, a reciclagem é feita com e pelo chefe de seção, que pulveriza as informações sobre as equipes das lojas, o que reduz o custo. Os conteúdos incluem processos de higiene, manuseio, corte e uso de equipamentos como luvas e touca para setores como açougue, peixaria, frutas, legumes, verduras. Para a frente de caixa e balcão de atendimento, as orientações são mais relacionadas a como receber o cliente e despedir-se dele, como agir diante de uma reclamação, com total foco no bom atendimento. Faz parte dos procedimentos questionar o cliente se algum produto desejado não foi encontrado na loja.

A Empresa B não oferece treinamento a todos os seus funcionários, com exceção dos cursos de ISO 14000, relacionado a meio-ambiente, e ISO 9000, de procedimentos de cada área, que foram aplicados a todos. Este último envolve atendimento ao cliente, mas de forma limitada. O pessoal de contato direto com o cliente recebe um treinamento inicial ao ingressar na empresa, com reciclagens periódicas. O pessoal terceirizado do call center exclusivo para vendas pela Internet, que atende tanto pelo 0800 como por e-mail, é preparado para o relacionamento com o cliente. Essa preparação inclui o conhecimento do produto, do processo de compra, utilização do site, postura, e procedimentos em situações que já ocorreram. No caso de fatos novos, estes são documentados e agregados ao padrão. Em caso de dúvidas, um supervisor, na retaguarda, orienta e toma decisões.

De maneira diferenciada, a Empresa C conta com uma Academia de Serviços, uma estrutura própria para realização de treinamentos e reciclagens, que os promove constantemente. Mensalmente, divulga-se um calendário com os cursos do próximo mês para que os funcionários possam se inscrever. O público-alvo constitui-se de comandantes/pilotos, pessoal de atendimento (check-in, comissariado, atendimento de balcão), e funcionários de maneira geral. A rotatividade de funcionários é alta; contudo, os que se identificam com a filosofia da empresa obtêm oportunidades de ascensão e de transferência para outras áreas na empresa. Os funcionários da linha de frente participam dos treinamentos bimestralmente; os demais funcionários seguem o discernimento de sua chefia. Sistemas de atendimento ao cliente, como check-in, reservas, de formação de preço, além de postura e aparência pessoal são os principais assuntos abordados nos treinamentos. 
Os treinamentos e reciclagens também existem e são periódicos na Empresa D, direcionados tanto ao pessoal dos serviços de atendimento como às consultoras, sendo que, para elas, são ministrados dois níveis ligados à venda e um ligado a produtos, com o objetivo de apresentar seus conceitos, produtos e serviços de maneira adequada a cada cliente, segundo seus interesses, necessidades e conveniência. $\mathrm{O}$ treinamento dos atendentes é feito de forma global; para os atendentes das consultoras, há um grande foco em processos e, no caso dos atendentes dos consumidores finais, a maior ênfase está em informações sobre produtos. A consultora conta com riquíssimo material de apoio, bem como assessoria, cursos, reciclagem e orientação das promotoras de vendas. Na opinião da empresa, essa relação faz com que a empresa tenha o menor turn over entre as empresas de venda direta. A empresa não fomenta a formação de equipes de vendedoras subordinadas a uma consultora, esperando que as pessoas que queiram vender produtos da empresa se cadastrem junto a ela. Entretanto, sabe-se que várias consultoras formam mini-equipes, o que faz o contingente total de consultoras ser aproximadamente três ou quatro vezes maior que o canal formal. Todo esse contingente não participa diretamente das ações de treinamento da empresa; entretanto, até o momento, isso não parece ser empecilho para o relacionamento com os clientes.

Da mesma forma, na Empresa E, os treinamentos são bastante freqüentes, com média mensal, direcionados principalmente para a área de Televendas e SAC, mas também são realizados cursos para média e baixa gerência, pois existe uma política de formação desse pessoal, com regras de conduta etc. Contudo, sem a definição de políticas operacionais, o treinamento tem surtido pouco efeito, pois cada funcionário age segundo seu próprio julgamento. Os treinamentos sobre produtos são muito importantes, pois dão apoio ao atendimento: conhecer o posicionamento do produto é fundamental para que os atendentes saibam que linguagem utilizar, adequada à publicação e ao seu público-alvo. Além desses, há treinamentos de técnicas de vendas e de campanhas; no entanto, os treinamentos sobre contato com o cliente ainda deixam a desejar.

Na Empresa F, os treinamentos são executados em base mensal, voltados principalmente aos atendentes do SAC e às vendedoras. Os temas mais abordados são: produtos, satisfação do cliente, postura frente a ele, fidelização, ética, técnica arrojada de vendas, sem que se interfira na privacidade dos clientes. As vendedoras devem deixá-los sempre bem à vontade, sem precipitação na hora da venda. A idéia é fazer uma venda correta, satisfatória para o cliente, que não suscite trocas nem reclamações posteriores. A empresa chama isto de “venda eficiente”. 
A Empresa G promove treinamentos trimestrais e procura conquistar seus funcionários não apenas pelo argumento salário, o qual, no entanto, ainda tem grande peso na realidade do Brasil. Qualidade de vida, qualidade do trabalho, áreas de convivência e novos serviços procuram ser atrativos de retenção para este capital, porém, nem sempre isso é suficiente. $O$ alvo dos treinamentos é a loja como um todo, principalmente atendentes e caixas, os quais são preparados para atendimento ao cliente, prevenção contra fraudes e como se comportar quando elas ocorrerem. Para os atendentes, são abordadas situações diversas no treinamento como, por exemplo, o “escapismo" e o "mergulho". O escapismo ocorre quando o cliente se aproxima e o atendente abaixa a cabeça e se afasta; o mergulho ocorre quando o cliente pede alguma informação sobre determinado produto e o atendente "mergulha” no computador, mas não interage com o cliente, o qual não sabe se o funcionário está efetivamente pesquisando o produto, nem se entendeu bem a solicitação. Outras técnicas de atendimento também são analisadas, como o gerenciamento do atendimento simultâneo, ou seja, a maneira como o funcionário deve se comportar quando estiver atendendo uma pessoa e outro cliente se aproximar solicitando informações. A empresa segue um programa de treinamento preparado pela matriz européia e adaptado para a nossa realidade, contando com material que inclui vídeos que ilustram o bom e o mau atendimento. Na seleção de funcionários, a empresa prefere contratar estudantes universitários que estejam fazendo filosofia na USP, por exemplo, que poderiam prestar melhor serviço aos clientes por terem perfil de maior afinidade com livros, embora nem sempre seja possível selecionar candidatos com esta qualificação.

A Empresa $\mathrm{H}$ ainda não priorizou o treinamento como ferramenta para desenvolver bons relacionamentos com os clientes, por ser nova e pequena em termos de número de funcionários; alguns deles têm participado apenas de cursos para utilização de ferramentas tecnológicas. O pessoal do atendimento de televendas, que tem contato direto com os clientes, é uma mão-de-obra barata, com alta rotatividade e não tem recebido treinamento. Embora a empresa ofereça à venda cerca de 40 mil itens em seu site e várias dúvidas sobre produtos sejam muito técnicas e específicas, um fluxo padronizado e automatizado de informações auxilia os atendentes nas consultas, que também conta com uma equipe de retaguarda responsável por dar suporte em casos de dúvidas, fraudes, trocas, cancelamento etc. Além disso, todos os produtos inseridos no sistema possuem uma ficha cadastral com informações detalhadas sobre suas características (dimensões, voltagem etc.) e muitas delas estão presentes no site; o monitoramento das ligações por pedido serve como retroalimentação para o tipo de informação a ser incluída no site. Contudo, a empresa pretende ampliar a freqüência de treinamentos, visando especialmente ao pessoal do Atendimento ao Cliente. 


\subsubsection{Autonomia para efetuar pequenos gastos para atendimento além do padrão}

Nenhuma das empresas entrevistadas age como a cadeia de hotéis Marriot, que reserva um certo valor monetário por funcionário para que procure satisfazer a seus clientes além do atendimento padrão, mesmo que não tenha havido nenhuma falha por parte da empresa (Hart, Heskett e Sasser Jr., 1990:288). Entretanto, algumas empresas dão bastante autonomia para que seus funcionários efetuem gastos para satisfazer seus clientes quando algo não funciona bem; outras, não oferecem nenhuma, sendo as questões dessa natureza resolvidas por níveis superiores. Num nível intermediário, há empresas que concedem autonomia limitada por políticas de valores e procedimentos pré-determinados.

No quadro 15, estão resumidas as variações encontradas entre as empresas em relação à autonomia para gastos. Na coluna “Autonomia limitada por” “Julgamento próprio”, encontra-se o nível hierárquico mínimo que possui tal autonomia, e nas demais colunas, as áreas que possuem autonomia com restrições.

Quadro 15 - Autonomia para gastos segundo julgamento próprio

\begin{tabular}{|c|c|c|c|c|c|}
\hline \multirow{2}{*}{ Empresa } & \multicolumn{4}{|c|}{ Autonomia limitada por } & \multirow{2}{*}{ Descrição } \\
\hline & $\begin{array}{c}\text { Julgamento } \\
\text { próprio }\end{array}$ & $\begin{array}{c}\text { ValoresI } \\
\text { hierarquia }\end{array}$ & Tipo cliente & $\begin{array}{l}\text { Procedi- } \\
\text { mentos }\end{array}$ & \\
\hline A & $\begin{array}{c}\text { Gerência de } \\
\text { loja }\end{array}$ & - & - & - & $\begin{array}{l}\text { Não há limite fixo para gastos; a gerência pode até ser } \\
\text { repreendida se não tomar uma atitude em relação a algum fato } \\
\text { que possa afetar a imagem da empresa ou suscitar sanções } \\
\text { jurídicas, como a queda de um cliente dentro da loja. O } \\
\text { gerente, nesse caso, pode desde chamar um táxi para conduzi- } \\
\text { lo a um pronto-socorro, a cobrir as despesas de atendimento } \\
\text { caso o cliente não possua convênio médico. O fato de o } \\
\text { gerente arcar com as responsabilidades do que ocorre em sua } \\
\text { loja justifica sua autonomia. }\end{array}$ \\
\hline B & Supervisão & Atendimento & Supervisão & Atendimento & $\begin{array}{l}\text { A supervisão pode definir, por exemplo, em casos de atrasos } \\
\text { de entrega de produtos por problemas na fábrica, e } \\
\text { dependendo do cliente, que ele receba um produto de reserva } \\
\text { (no caso, um carro) até o seu ser entregue. }\end{array}$ \\
\hline C & $\begin{array}{l}\text { Atendi- } \\
\text { mento } \\
\text { check-in }\end{array}$ & $\begin{array}{c}\text { Todas as } \\
\text { áreas de } \\
\text { atendimento }\end{array}$ & $\begin{array}{l}\text { Atendi- } \\
\text { mento } \\
\text { check-in }\end{array}$ & $\begin{array}{c}\text { Todas as } \\
\text { áreas de } \\
\text { atendimento }\end{array}$ & $\begin{array}{l}\text { Autonomia necessária pelos aspectos críticos da área. Por } \\
\text { exemplo, quando um cliente precisar embarcar e o vôo da } \\
\text { empresa estiver atrasado, dependendo do tipo de cliente, o } \\
\text { atendente tem autonomia para providenciar um endosso para } \\
\text { que voe por outra empresa aérea. }\end{array}$ \\
\hline D & Supervisão & Atendimento & - & Atendimento & $\begin{array}{l}\text { Se o procedimento previr que o atendente pode registrar um } \\
\text { desconto na fatura de um cliente em função de ele ter } \\
\text { reclamado por não ter recebido sua última compra, ele assim o } \\
\text { fará; caso não haja procedimento definido para o caso, a } \\
\text { questão é resolvida por um nível superior. }\end{array}$ \\
\hline
\end{tabular}




\begin{tabular}{|c|c|c|c|c|c|}
\hline E & Retenção & Atendimento & - & Atendimento & $\begin{array}{l}\text { Está em desenvolvimento um projeto de célula anti-attrition, } \\
\text { ou seja, uma equipe com autonomia para tentar evitar que o } \\
\text { cliente deixe a empresa, fazendo-lhe, inclusive, ofertas e } \\
\text { concessões. É preciso, ainda, vender internamente a } \\
\text { importância de se terem pessoas com autonomia na linha, em } \\
\text { contato com o cliente. }\end{array}$ \\
\hline$F$ & Atendimento & Atendimento & - & - & $\begin{array}{l}\text { Se o valor for baixo, como o de um porta-travesseiros, por } \\
\text { exemplo, o atendente que recebeu a reclamação tem } \\
\text { autonomia para ressarci-lo, sem muitas perguntas. Mas se o } \\
\text { caso envolver um valor maior que o produto, em que seja } \\
\text { necessário, por exemplo, material de outras localidades, com } \\
\text { altos custos de frete, a aprovação também sobe na hierarquia. }\end{array}$ \\
\hline G & $\underset{\text { loja }}{\text { Gerência de }}$ & - & - & - & $\begin{array}{l}\text { Os funcionários têm acesso rápido a quem possa conceder } \\
\text { cortesias, como o coordenador de área, o gerente da loja ou o } \\
\text { responsável pelo departamento, por exemplo. Todas as } \\
\text { ocorrências são registradas no sistema e sujeitas à análise } \\
\text { quinzenal ou mensal pela área de Controladoria e Gestão, para } \\
\text { prevenção contra abusos. }\end{array}$ \\
\hline $\mathbf{H}$ & Atendimento & Atendimento & - & - & $\begin{array}{l}\text { Se o gasto for inferior ao valor da margem, o próprio } \\
\text { atendente pode tomar uma decisão; se for próximo ao valor da } \\
\text { compra, a autonomia passa ao nível de supervisão; acima } \\
\text { disso, somente com decisões de escalões superiores, contando } \\
\text { inclusive com assessoria jurídica, se necessário. }\end{array}$ \\
\hline
\end{tabular}

Fonte: dados de campo.

Na Empresa E, foi constituída, em 1996/97, uma célula de trabalho cujo objetivo era atender aos assinantes que tivessem algum problema com a principal revista da empresa, com bastante autonomia para procurar solucioná-los; contudo, essa oportunidade não foi muito bem aproveitada. Embora ainda haja pessoas que façam restrições quanto à implantação da célula anti-attrition, isto representa um avanço em termos de relacionamento na empresa. Com o suporte da classificação de clientes, e formado por pessoal mais bem treinado e com poder para negociação, esse grupo partirá do valor do cliente para tentar convencê-lo a não deixar a empresa, pois, enquanto há clientes classificados como "diamante", por exemplo, que seriam uma grande perda para a empresa, há outros nos quais não vale a pena investir. A empresa afirma que captar um cliente custa, para ela, de 2,5 a 3 vezes mais que mantê-lo, e um assinante leva, em média, 2,5 anos para se pagar. Desta forma, é preciso que o assinante renove sua assinatura pela segunda vez, para que passe a ser lucrativo para a empresa; o degrau é muito grande entre uma nova assinatura e uma renovação. A proposta da célula anti-attrition é tentar reter um assinante pelo menos até o momento em seja compensado o investimento despendido na sua conquista. São necessários cálculos para que se possa saber o quanto se deve reverter de cancelamento de assinaturas para que se justifique a manutenção desta célula. Sabendo disso, é preciso dispensar tratamento diferenciado entre os vários tipos de clientes. O cliente que renova pela primeira vez pode ser um cliente valioso por outras características não explicitadas em pesquisas. Quando o cliente solicita uma nova assinatura e diz 
que deseja, por exemplo, 30\% de desconto, o atendente, com base na classificação do cliente, pode conceder-lhe, ou não. Há alguns anos, quando o assinante reclamava que não havia recebido sua revista, o que ocorria com certa freqüência, a política da empresa era reenviar por correio, o que era bastante custoso. Hoje, o cliente tem a opção de reenvio, caso deseje aquele exemplar específico, ou de extensão da vigência (acréscimo de um exemplar no final da assinatura). Reincidências são investigadas.

\subsubsection{Premiação de funcionários que promovem um bom marketing de relacionamento}

Nota-se também bastante diversidade nas práticas das empresas entrevistadas no que diz respeito à premiação de funcionários que promovam um bom marketing de relacionamento. Das empresas entrevistadas, uma empresa explicitamente reconhece os esforços de seus funcionários no sentido de aplicar a filosofia do relacionamento em seu trabalho diário (Empresa C); outras, por outro lado, valorizam mais o volume de vendas atingido por eles (Empresas A e F); outras, ainda, premiam seus funcionários segundo metas contratadas com os mesmos (Empresa B, D, E, H); e uma empresa não premia (Empresa G). No caso de metas acordadas com os funcionários, para os setores responsáveis pelo contato direto com os clientes ou que desenvolvem programas visando ao aprimoramento dos relacionamentos, as empresas podem estabelecer metas específicas para indicadores relacionados a este tema.

A Empresa A premia seus funcionários por resultados de vendas por acreditar ser difícil definir e mensurar indicadores de marketing de relacionamento.

De maneira distinta, para a Empresa B como um todo, aplica-se uma política de cumprimento de metas e objetivos, a qual diz respeito à participação nos lucros e com base na qual a empresa premia, segundo a consecução dos objetivos individuais de cada funcionário. Embora tal política também inclua objetivos específicos de satisfação do cliente, a premiação não ocorre especificamente para o alcance desses objetivos. E como o pessoal de atendimento ao cliente é terceirizado, não faz sentido a empresa premiá-los, embora lhes ofereça outros tipos de incentivos.

Na Empresa C, elege-se o “funcionário do mês”, que recebe uma passagem com direito a acompanhante. No final do ano, o “funcionário do ano” recebe, além das passagens, um salário adicional. Os candidatos são indicados por um superior e uma comissão julgadora elege o funcionário que mais se destacou em termos de relacionamento com clientes, geralmente, dentre os 
funcionários da linha de frente, pois é difícil avaliar que um funcionário da Contabilidade, por exemplo, tenha contribuído para o relacionamento com o cliente.

Na Empresa D, a premiação segue sistemática distinta. Todos os funcionários são avaliados anualmente em seis competências exigidas pela empresa: alinhamento com valores e crenças da organização, dinamismo, capacidade de “fazer acontecer”, capacidade de comunicação, gestão de pessoas, e relacionamento. Como a empresa entende que esse é o perfil padrão mínimo a ser exigido dos funcionários, caso estes apresentem boa avaliação nesses quesitos, o bônus é concedido, porém, sem distinção.

A Empresa E, não premia e, pelo menos tão cedo, não pretende premiar destaques de marketing de relacionamento. Nessa empresa, a premiação existente ocorre com base no programa DPR (Direção por Resultados), voltado à média gerência, que envolve metas acordadas entre a chefia e o funcionário, as quais lhe garantem percentuais do salário de acordo com seu cumprimento; porém, não há nada especificamente voltado ao relacionamento. A entrevistada dessa empresa acredita que devesse haver incentivos nesse sentido, além de campanhas nas quais todos percebessem a importância do leitor. Embora a Empresa F sempre tenha valorizado o bom marketing de relacionamento, a premiação tem foco em vendas. A empresa divulga internamente os nomes das vendedoras que mais têm recebido elogios dos clientes, mas não há uma sistemática de premiação periódica específica para marketing de relacionamento, não obstante haja perspectivas de que isto se torne uma prática comum. A Empresa $G$ entende que os atendentes e demais funcionários que lidam com o cliente deveriam saber que o relacionamento, o bom atendimento, fazem parte de suas obrigações como profissional. Com isso, extinguiu a premiação para as boas práticas de marketing de relacionamento, pois havia pessoas que executavam-nas apenas pela premiação, e não por satisfação profissional. A empresa acredita que deve manter apenas os bons profissionais; a cultura no país da empresa matriz é bem rígida neste aspecto. Com o desenvolvimento do novo projeto voltado a relacionamento, detalhado mais adiante, a empresa pretende criar um concurso de idéias, no qual o funcionário que apresentar alguma idéia que transforme algum processo, desenvolva alguma área ou implemente um novo serviço que satisfaça ao cliente, aprovada por um comitê, receberá um prêmio.

Na Empresa H, no início de cada ciclo, contratam-se as metas com cada área, que são avaliadas contra os resultados obtidos, medidos objetivamente. Todos os funcionários da área de Atendimento devem fixar metas pessoais, que podem ser revertidas em bônus. A área de CRM 
possui metas específicas de índices de retenção, de freqüência de compra, de valor, que influem na sua avaliação. Embora a avaliação seja mensal, a remuneração pelas metas atingidas é feita com prêmios, anualmente.

\subsubsection{Oferta de produtos/serviços personalizados antes das vendas pela Internet}

À exceção das Empresas E, G e H, as demais empresas ofereciam, antes mesmo do início de suas atividades de comércio pela Internet, algumas formas de personalização.

A Empresa A foi uma das precursoras da personalização no varejo, com processos de comunicação personalizada, como o CD-ROM enviado a seus clientes para que efetuassem pedidos por telefone ou fax, com entrega em domicílio, antes mesmo da Internet.

A personalização na Empresa $\mathrm{B}$ diz respeito à entrega do veículo exatamente com as características desejadas pelo cliente. Nas concessionárias, há um estoque limitado, com algumas unidades para pronta entrega. Nesse caso, o cliente recebe uma previsão de quando o automóvel com as características especificadas estará disponível para retirada; a empresa oferece ao cliente automóveis similares com entrega mais rápida, caso haja alguma opção.

Na Empresa C, a personalização ocorre na forma de serviços exclusivos prestados por uma área destinada aos clientes VIPs, denominada Serviços Especiais, que conta com um banco de dados com informações de clientes muito especiais. Os serviços oferecidos vão de transporte de/para o aeroporto e o tipo de alimentação preferida pelo cliente, às suas preferências de tratamento. Isto existe há muito tempo e, no início, as anotações sobre estas informações eram feitas de forma rudimentar em um caderninho; com a tecnologia, este serviço passou a ser prestado com muito mais precisão e recursos operacionais, para um público maior, com intenções de estender este tratamento a todos os clientes.

A Empresa D não personaliza seus produtos, ou seja, não faz nenhum tipo de ajuste nas fórmulas segundo solicitação, e todos os serviços oferecidos sempre estiveram disponíveis a todos, indistintamente. Para essa empresa, o conceito de personalização é bem forte, no sentido one-to-one e, inicialmente, não havia se posicionado como uma empresa que oferecesse produtos/serviços personalizados, no sentido de não fabricar fórmulas segundo necessidades específicas de clientes. Entretanto, logo tomou consciência de que sua personalização estava vigorosamente presente no seu canal de vendas: as consultoras, cujo serviço, por se tratar de venda direta, pode ser extremamente 
personalizado. Em geral, por conhecer cada cliente pelo nome, seus hábitos de consumo e outras informações de caráter pessoal, além de oferecer os produtos, as consultoras podem fazer recomendações e prestar assessoria de beleza de acordo com as características e preferências de cada cliente seu; possuem condições de sugerir produtos de maneira mais natural e fazer um pequeno estoque de produtos habitualmente solicitados pelos seus clientes, para agilizar a entrega. Isso é possível em função do relacionamento desenvolvido por elas, que têm como clientes as suas próprias amigas e familiares.

A Empresa E, em outro segmento, planeja disponibilizar, em breve, a assinatura do conteúdo editorial de suas revistas pela Internet, o que permitirá alguma personalização.

A Empresa F sempre considerou a personalização de produtos uma opção para seus clientes, em função do programa do produto personalizado nela instituído. Neste programa, a empresa mostra-se receptiva a críticas e sugestões, esperando que o cliente sempre dê um feedback a respeito dos produtos. A partir das sugestões dos clientes, feitas com base nas suas expectativas e necessidades, a empresa pode atendê-los de modo mais eficiente, como, por exemplo, numa demanda por estampas mais escuras, em função de moda, ou por maior variedade de produtos antialérgicos. Um cliente que possua uma cama fora dos padrões, ou que deseje utilizar a mesma estampa do jogo de cama para fazer o bandô de sua cortina dirige-se a uma loja ou manifesta pelo Fale Conosco o seu desejo em termos de tamanhos e cores, e a empresa procurará satisfazê-lo. Ela só não irá atender à solicitação por algum impeditivo técnico, como algo que as suas máquinas não possam produzir. Até hoje, apenas uma única pessoa não conseguiu ser atendida em seu pedido.

\subsubsection{CRM}

Nesta seção serão discutidas as impressões das empresas entrevistadas em relação à sua noção de CRM, políticas definidas para apoiá-lo, estrutura de CRM existente, motivações para implantação, áreas participantes do processo, análise de custos e benefícios para investimento e avaliação de resultados.

\subsubsection{Definição}

Pretendia-se, nessa questão, identificar se a visão da empresa em relação ao CRM era mais estratégica ou mais técnica. Em outras palavras, buscou-se detectar se as empresas entendiam o 
CRM como uma filosofia de trabalho ou como uma ferramenta. Para isso, foi apresentada aos entrevistados a seguinte definição de CRM, com a qual deveriam apontar seu grau de concordância:

“O CRM (Customer Relationship Management) é uma filosofia de trabalho que apóia o marketing de relacionamento, geralmente com base em um software para manipulação de banco de dados que armazena características do perfil dos clientes e seu histórico de compras, a fim de propiciar ações de marketing mais direcionadas às suas necessidades e desejos”.

O quadro 16 apresenta os níveis de concordância declarados pelas empresas pesquisadas. Um dos entrevistados que afirmaram concordar totalmente com a definição apresentada argumentou que, ao contrário do que muitos acreditam, o CRM

Quadro 16 - Concordância com definição de CRM não é apenas uma ferramenta; é um conceito, o qual, para ser implementado, necessita de uma ferramenta. Os entrevistados, em geral, acreditam ser de extrema importância que a empresa tenha um banco de dados com histórico de seus clientes, que possa ser utilizado para melhor atendê-los nas próximas vendas, oferecer-lhes benefícios adicionais por serem clientes fiéis da empresa e, até mesmo, reverter a situação de insatisfação de algum cliente. Já os entrevistados que concordam parcialmente com a definição posta justificaram essa posição considerando que o CRM se define mais como filosofia e conceitos que o software por si. O cerne do CRM não estaria, portanto, no investimento em tecnologia, mas, sim, na redefinição de valores a respeito do cliente e do relacionamento da empresa com ele, e nas ações mais objetivas e direcionadas em função das posições estabelecidas e das informações disponíveis, fornecidas por software ou não.

\subsubsection{Política e estrutura de CRM}

Algumas empresas possuem alguns módulos de CRM já implantados e outros em implantação. À exceção da Empresa A, que não forneceu maiores detalhes sobre sua estrutura de CRM, as estruturas das demais empresas encontram-se esquematizadas nas figuras a seguir, com os comentários feitos pelos entrevistados. Os blocos destacados em verde indicam os módulos já implantados ou em fase de implantação.

A Empresa B possui alguns módulos de CRM implantados, conforme a figura 30. No CRM Operacional, existem Back, Front e Mobile Office, embora as aplicações ainda se restrinjam ao relacionamento com as concessionárias. 


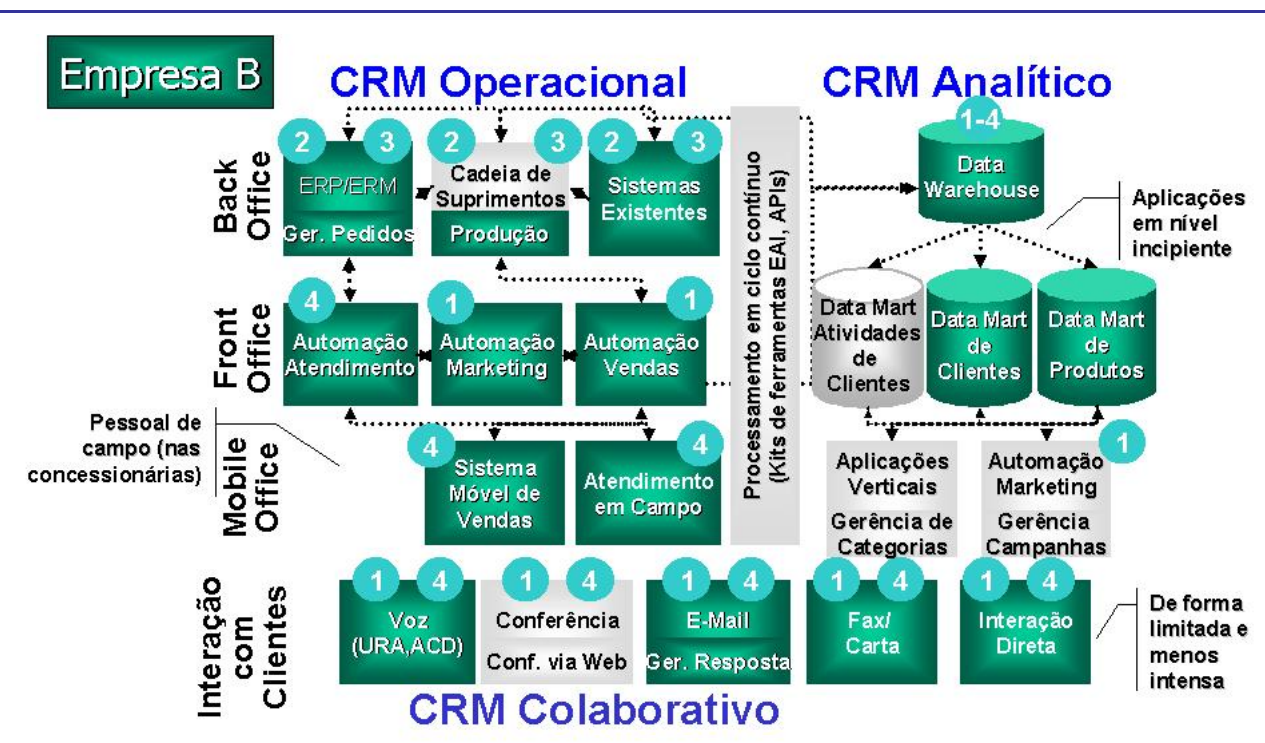

1) Engajamento 2) Transação 3) Fulfill 4) Serviço

Fonte: adaptado de META Group (2000, in PeopleSoft, 2002).

Analítico, possui Data

Warehouse,

Data

Marts de Clientes e de

Produtos,

com

aplicações ainda em

nível incipiente; no

CRM Colaborativo há interação com clientes via unidade de resposta audível (URA), e-mail, fax, carta, e interação direta, de maneira limitada e menos intensa. A empresa não possui uma solução completa de CRM, integrada, que abranja todas as áreas da empresa. A própria empresa desenvolveu os módulos na medida das necessidades detectadas pelo Marketing, integrando-os conforme necessário, iniciando com informações de vendas, depois, de database Marketing e, posteriormente, de Internet; possui módulos que atendem praticamente a todas as suas necessidades, mas com utilização ainda limitada.

Figura 30 - Estrutura de CRM da Empresa C

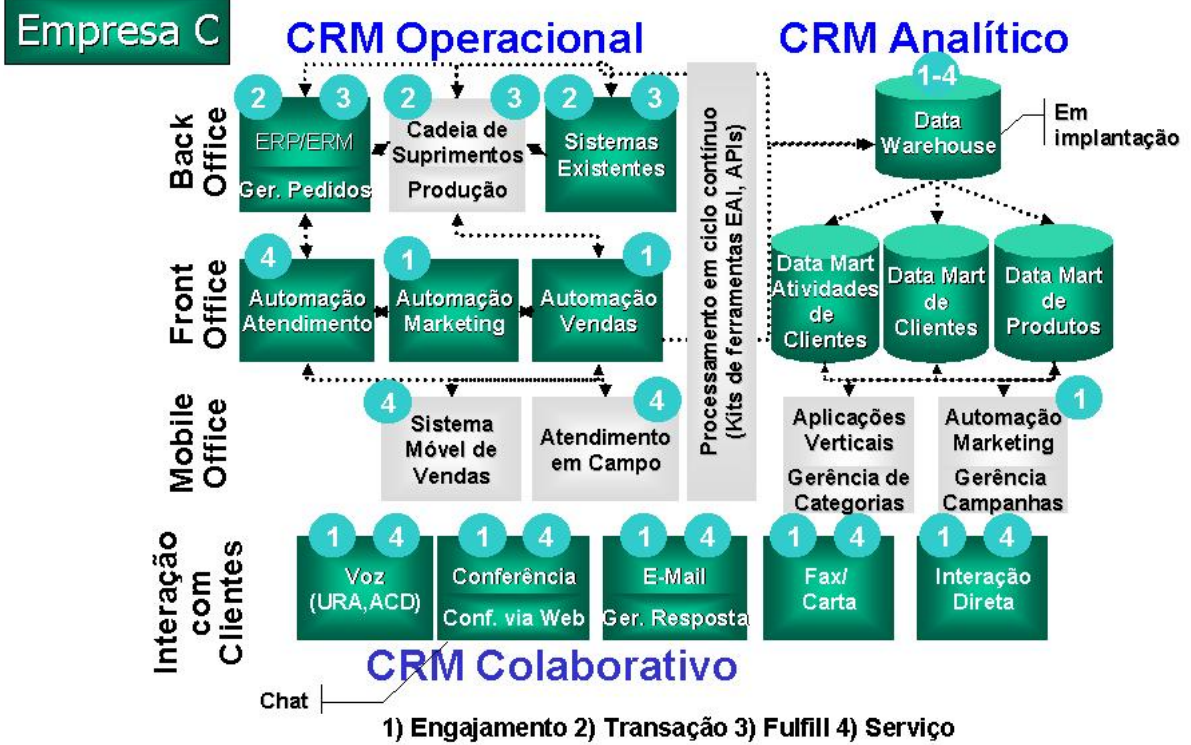

O CRM existe na Empresa C, mas não de maneira ampla, não está permeado por toda a empresa, conforme figura 31. Atualmente, a empresa está estruturando o CRM Analítico; uma boa parte do Operacional já está integrada e o Colaborativo faz parte dos planos futuros da empresa. A fase atual compreende a

Fonte: adaptado de META Group (2000, in PeopleSoft, 2002). 


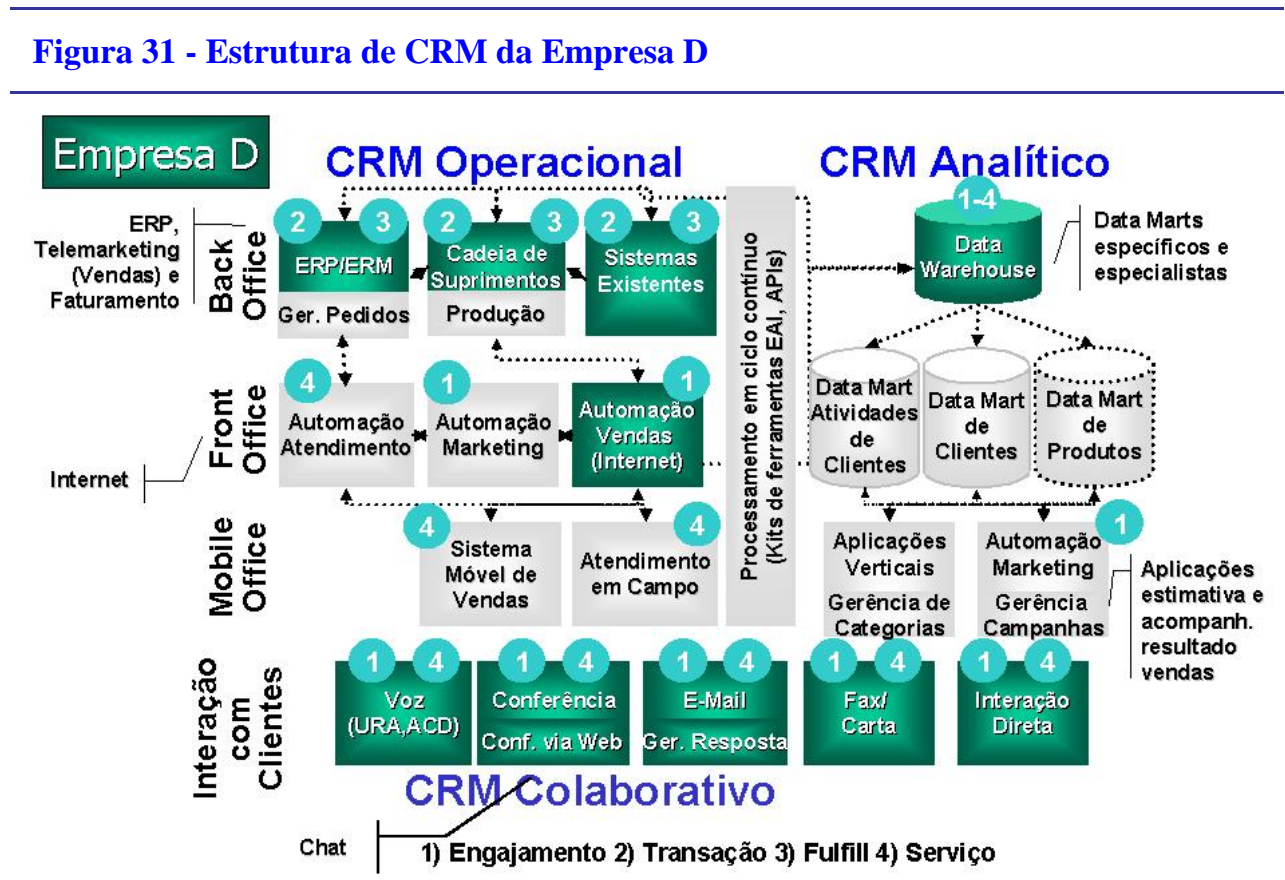

Fonte: adaptado de META Group (2000, in PeopleSoft, 2002).

A Empresa D adota a filosofia do CRM, apoiada em ferramentas ainda não integradas, conforme figura 32. No CRM Operacional, no Back Office, há basicamente dois tipos de sistemas: sistema de ERP (mas não para gerenciamento de pedidos, embora trabalhe na cadeia de suprimentos), e sistemas especialistas da empresa: de telemarketing (vendas) e faturamento. Por se tratar de uma empresa de venda direta, o grande Front Office da área de vendas é a Internet, que interage com o legado e com alguns aplicativos de automação de vendas para que os gerentes de setores possam administrar o canal de vendas e acompanhar suas atividades. No CRM Analítico, há um projeto em andamento; a empresa conta com Data Marts bastante específicos e especialistas, no caminho do que pode ser considerado um Data Warehouse. Além disso, possui aplicações para estimativa e acompanhamento do resultado de vendas. No CRM Colaborativo, para Interação com Clientes, a empresa conta com voz, conferência/chat via Web, e-mail, fax/carta e interação direta. 


\section{Figura 32 - Estrutura de CRM da Empresa E}

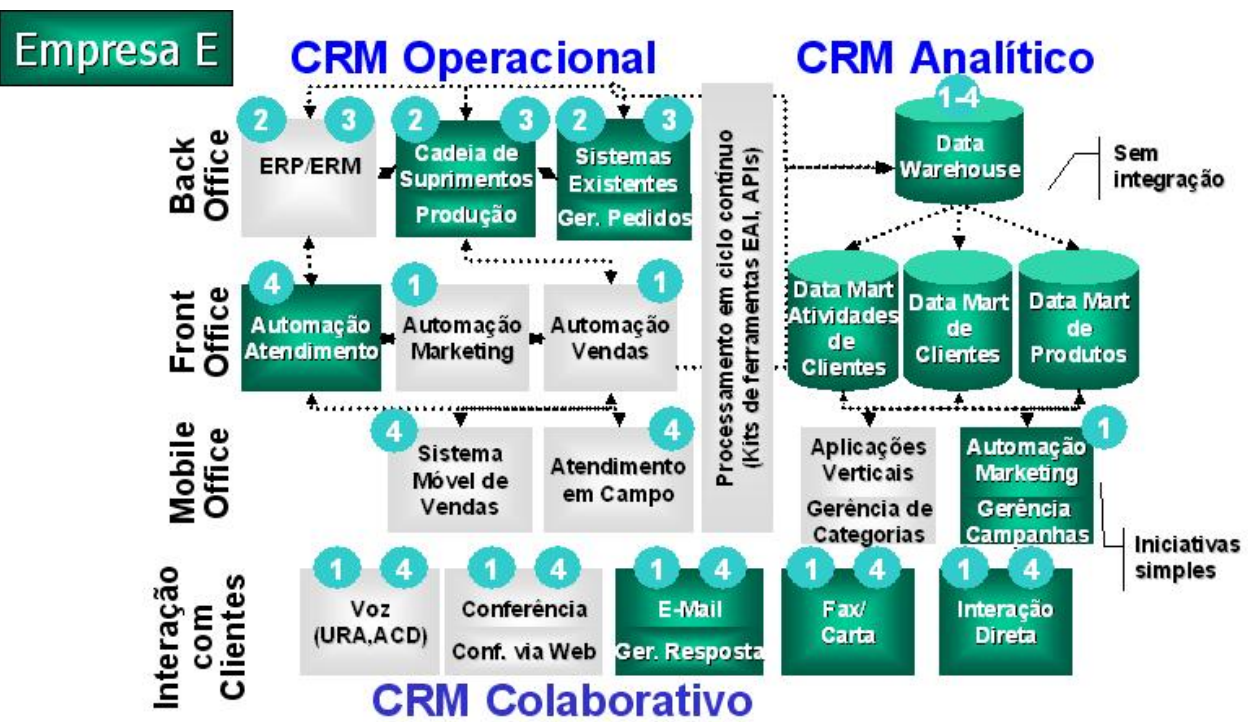

1) Engajamento 2) Transação 3) Fulfill 4) Serviço

Fonte: adaptado de META Group (2000, in PeopleSoft, 2002).

No CRM Operacional da Empresa E, ilustrado na figura 33, faz-se um gerenciamento de pedidos, um rastreamento, mas não com um ERP, e sim, com um sistema legado da empresa (Sistema de Controle de Assinaturas), com foco no produto, e não no cliente; o Front Office funciona bem, com automação no atendimento. No CRM Colaborativo, na Interação com Clientes, a empresa usa e-mail, fax, carta e há interação direta. No CRM Analítico, há alguns Data Marts, mas sem integração com as ações de marketing. O sistema que os alimenta, pertencente a uma empresa coligada, tem uma defasagem de 15 dias. A integração automática está prevista para 2004. A Automação de Marketing e a Gerência de Campanhas possuem iniciativas simples, não integradas. 
Figura 33 - Estrutura de CRM da Empresa F

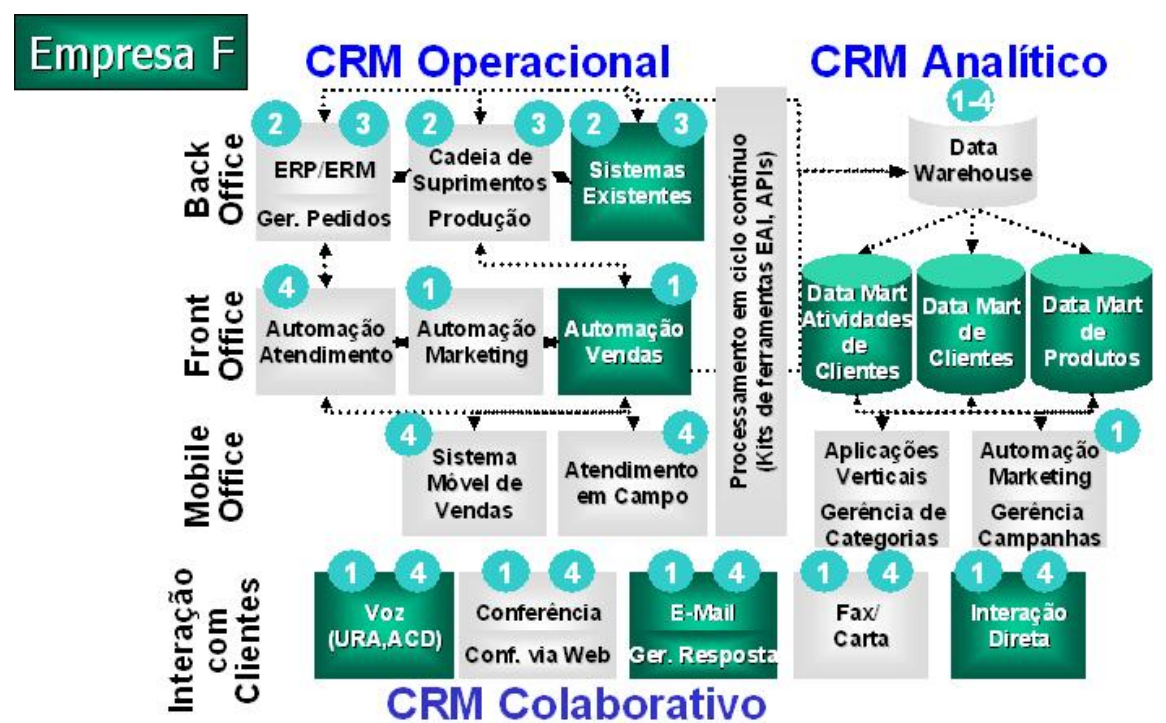

1) Engajamento 2) Transação 3) Fulfill 4) Serviço
As vendedoras da Empresa F possuem um histórico de seus clientes, armazenado em fichas, ainda não informatizado. Esta empresa ainda está dando seus passos iniciais na solução informatizada de CRM (figura 34); não possui ainda software especializado, destinado exclusivamente a este fim. Os softwares existentes na empresa são muito

Fonte: adaptado de META Group (2000, in PeopleSoft, 2002). abrangentes, e reconhece-se a necessidade de se coletarem mais informações. No CRM Operacional, a Automação de Vendas foi implantada com software próprio. Ainda que parcialmente informatizado, a empresa está trabalhando diretamente sobre o CRM Analítico, com algumas bases de dados com informações sobre clientes, suas atividades e produtos, voltadas ao cliente que compra pela Internet. No CRM Colaborativo, há Interação Direta e Gerenciamento de Resposta por e-mail e voz. A aparente falta de pressa para implantação de uma solução informatizada se deve ao fato de que é um objetivo, por filosofia e cultura da empresa, que as vendedoras, inicialmente, entendam o processo, antes da utilização do software; é preciso que entendam a importância da proximidade com o cliente, de se saber qual é o seu perfil de compra e em que fase da vida ele está - quando vai se casar, quando faz aniversário, quantos filhos têm - para que se concretize uma venda e se vislumbre um horizonte de novas vendas. Na opinião da empresa, sem que estes mecanismos estejam incorporados ao dia-a-dia da vendedora, sem que haja essa preparação prévia, caso se adote um software de CRM sem que o componente cultural esteja fundamentado, as vendas serão muito mecânicas, sem o cuidado necessário. Tudo isto está sendo criteriosamente estudado, e sob a atenção da presidência e da diretoria comercial da empresa. 
Figura 34 - Estrutura de CRM da Empresa G

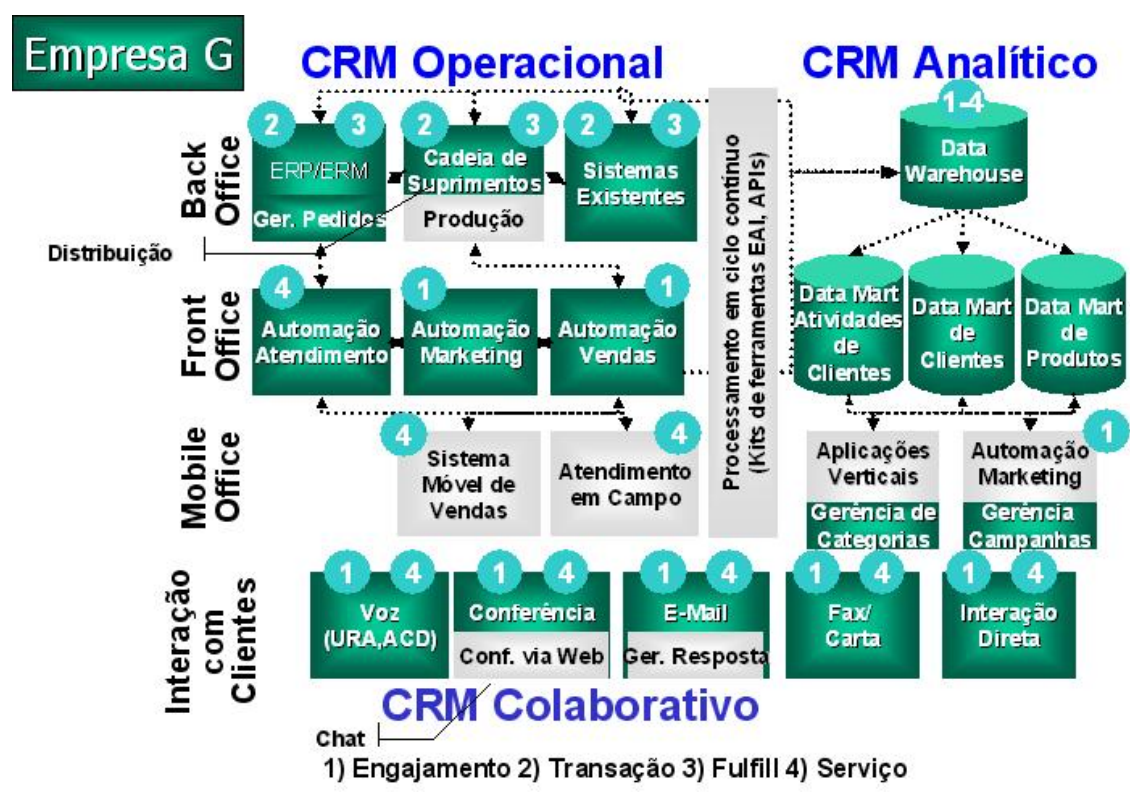

Fonte: adaptado de META Group (2000, in PeopleSoft, 2002).

A Empresa G possui uma estrutura de pessoal pequena, mas bastante eficiente, tendo desenvolvido internamente vários módulos para as funcionalidades de CRM (figura 35). No CRM Operacional, em se tratando de Back Office, a empresa possui um ERP com Gerenciamento de Pedidos, e Gerenciamento da Cadeia de Suprimentos, no que tange à distribuição; no Front Office, a empresa possui Automação de Atendimento, Automação de Marketing e Automação de Vendas. Na Interação com Clientes, a Empresa G conta com recursos de voz, conferência e e-mail, fax/carta, e interação direta. No CRM Analítico, possui Data Warehouse, com Data Marts de Clientes, de Atividades de Clientes, e de Produtos. Possui ainda Gerência de Categorias e de Campanhas.

Figura 35 - Estrutura de CRM da Empresa H

No

CRM

Analítico, a Empresa $\mathrm{H}$

Empresa H CRMOperacional

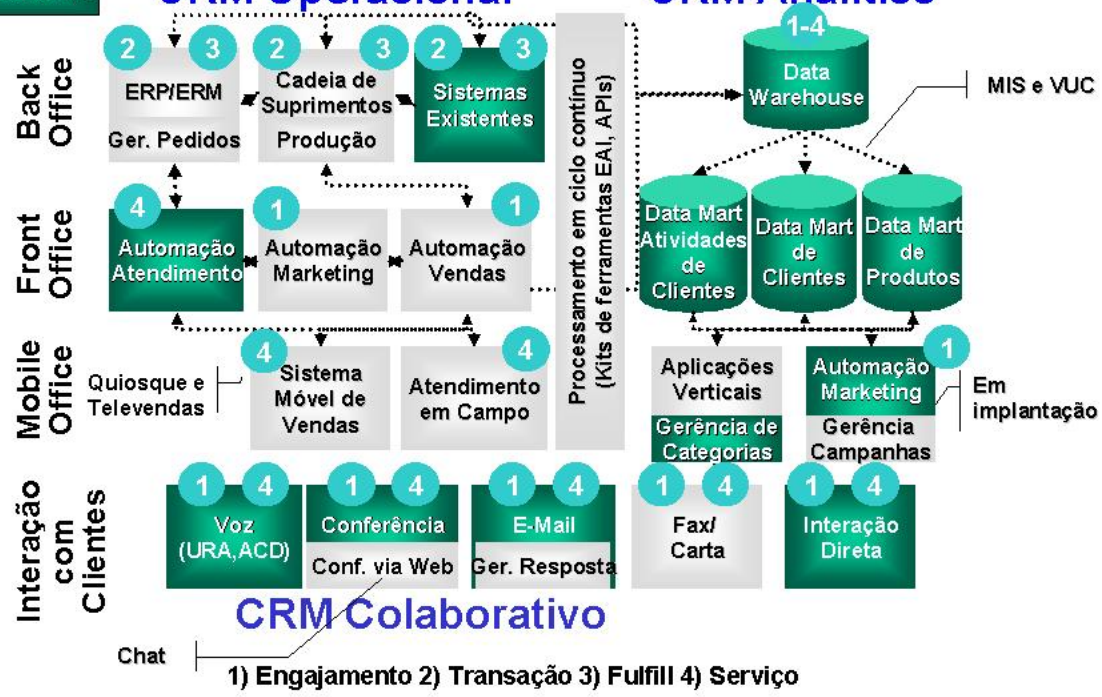
possui, conforme figura 36: Data Warehouse, Data Marts de Atividades, de Clientes, de Produtos, que integram 0 MIS (Management Information System) e o VUC (Visão Única de Clientes), que utilizam ferramentas que

Fonte: adaptado de META Group (2000, in PeopleSoft, 2002). permitem efetuar vários tipos de cruzamentos de dados. Pode-se ter, para cada cliente, qual o seu 
horário costumeiro de compra, o número de visitas já feitas, o número de compras realizadas, valor médio de compra, reclamações feitas, a forma de pagamento preferida, qual sua margem média. Estão em implantação a Gerência de Categorias e Automação de Marketing, com auxílio de empresa terceirizada, que tratam da qualificação automática da base de dados, alimentando os processos de data mining e permitindo a execução de ações personalizadas. No CRM Colaborativo, em termos de Interação com Clientes, a empresa conta com voz, e-mail, chat, e interação direta. E no CRM Operacional, no Mobile Office, trabalha com quiosques e televendas; no Front Office, possui automação do atendimento, modelada pela empresa, que já possuía telefone, e-mail e chat integrados no sistema de workflow, controle e gerenciamento, e desenvolvida por um terceiro.

Todos os sistemas começaram com a definição do conceito pela própria empresa, com desenvolvimento terceirizado, de acordo com as especialidades e background da empresa. Planeja, também com o know-how de outra parceira, apresentar banners personalizados, na linha de publicidade online, com ofertas de interesse do cliente, a partir de cookies. Hoje, a empresa tem condições de saber por qual canal o cliente chegou até ela: por um portal, por uma ação de marketing, ou por uma ação de marketing dentro de um portal. Uma outra empresa parceira de conceituação de marketing a está auxiliando em projetos novos de fidelização e de CRM Analítico, analisando safras de clientes e sazonalidades. Contudo, a Empresa H reconhece que ainda há muito a ser feito.

\subsubsection{Motivações e áreas participantes}

O principal motivo que impulsionou a maioria das empresas pesquisadas a implantar uma solução de CRM é o desenvolvimento de relacionamentos mais fortes com os clientes, indicado pelas Empresas A, C e G. A automação de processos manuais (Empresa B) e a evolução tecnológica natural (Empresa D e H) também foram argumentos para tal implantação.

Como contribuições do CRM para um melhor relacionamento com os clientes, foram mencionados: identificação dos clientes; compreensão dos fatores que resultam em relacionamento bem sucedidos; estabelecimento de parâmetros por meio dos quais a empresa pode dirigir ações de manutenção dos bons clientes; a partir das informações sobre os bons clientes, definição de estratégias para atrair outros bons clientes, ou converter simples clientes em clientes bons; possibilidade de utilização de linguagens mais adequadas a cada público e realização de ações que vão ao encontro do comportamento de compra detectado pela análise dos dados coletados, 
maximizando a utilização dos recursos de marketing. A seguir, uma descrição sucinta do processo de desenvolvimento do CRM nas empresas analisadas.

Nas lojas da Empresa A, a coleta de informações referentes a compras dos clientes é feita pela associação das mesmas ao cartão do programa de fidelidade, na passagem do cliente pelos caixas. Tais informações, juntamente com as obtidas por meio de pesquisas, fornecem subsídios para planejamento de um mix de produtos voltado ao comportamento de compra do consumidor de cada loja. Nota-se que a localização influencia o sortimento das lojas, que são divididas em clusters (top, intermediário, popular, etc.): as lojas de bairros de mais alto poder aquisitivo, por exemplo, recebem maior volume de produtos importados que as lojas localizadas na periferia. Entretanto, o software de CRM utilizado nas lojas é diferente do que se usa no site. As compras pela Internet propiciam mais conhecimento do cliente do que o proporcionado pela loja, o que permite ações de marketing mais direcionadas ao seu estilo de vida e comportamento de compra.

Na Empresa B, com o crescimento do foco em CRM nos últimos anos, praticamente todas as áreas da empresa têm participado do projeto, porém, mais notadamente, a área de Estatística e Previsão de Vendas - provedora de informações para toda a empresa, que responde a perguntas do tipo “quanto vendemos, o que vendemos”. A gerência de e-business, por ter maior conhecimento sobre a Internet, lidera algumas etapas e, em conjunto com a área de Estatística e com o apoio da área de Tecnologia da Informação, desenvolve data marts. Seguem-se reuniões com todas as áreas envolvidas para validação dos modelos desenvolvidos. Em vários níveis, participam do projeto as áreas de Vendas, CRM, Diretoria de Tecnologia de Informação, Faturamento, Banco Empresa B, Contas a Receber, Contas a pagar, e todas as áreas pelas quais o processo prevê fluxo de informações.

A Empresa C decidiu implantar o CRM com vistas a transferir as principais características do Special Services - antecipação e encantamento - a outras categorias de clientes. Em geral, a área de Marketing conjectura: “se conseguíssemos identificar tal aspecto, poderíamos tomar determinada ação” e a área de Tecnologia da Informação viabiliza a idéia, em termos de ferramentas. A ação posterior compreende a execução por parte da linha de frente, que será treinada para tanto.

Na Empresa D, em função do crescimento de seus negócios, as implementações tecnológicas também precisaram crescer e se expandir, para que pudessem continuar apoiando suas operações, 
considerando a necessidade de automatização de processos manuais. Participam do projeto de CRM as áreas de Vendas, Marketing, Atendimento e Tecnologia da Informação.

A Empresa E é pioneira em marketing direto, cujo fundamento é uma base de dados completa e bem administrada. Dessa base para o início de uma solução de CRM, seria simples. Contudo, os grandes dificultadores de uma utilização eficaz e eficiente dessa base de dados englobam duas questões: a falta de integração entre os vários canais de contato com o cliente; e o foco da empresa, que está ainda voltado para o produto, e não para o cliente. Integram a equipe do projeto de CRM as áreas operacionais de Parametrização e Processamento, diretamente relacionadas ao fluxo do produto - são elas que regem o momento em que a oferta deve ser enviada aos assinantes -, além de uma empresa coligada, responsável pelo database Marketing, e as áreas de Retenção, Suporte das Plataformas, Internet, Marketing e Pesquisa.

A Empresa F, embora ainda sem solução integrada de CRM, tem notado resultados positivos com o relacionamento, o qual tem propiciado vendas mais produtivas e eficientes. A fidelização surge como uma conseqüência dessa filosofia, uma vez que, com dados históricos do cliente, a empresa passa a trabalhar com mais desenvoltura; com menos problemas, os vínculos são mais fortes, e o cliente passa a ser mais paciente e mais compreensivo. Como os resultados têm sido muito satisfatórios, a empresa entende que é de suma importância estudar a implantação efetiva de uma solução de CRM.

Na Empresa G, as informações sobre as compras também são capturadas pelo cartão fidelidade: data e hora em que o cliente passou pelo caixa e o que comprou, fornecendo subsídios para o desenvolvimento de análises estatísticas, e permitindo traçar o perfil de sua clientela e analisar eventuais necessidades de modificações em sua comunicação para adequação a determinado público-alvo. Atualmente, não há possibilidade de a empresa coletar dados sobre clientes não associados que pagam com cartão de crédito, pois esse número é criptografado. Por ter interesse nessa visão - clientes que não possuem o cartão associado, mas que são freqüentadores assíduos da loja -, a empresa está em negociação com as empresas envolvidas, objetivando coletar apenas a parte do número do cartão que identifica o cliente.

O CRM já fazia parte do conceito inicial do negócio da Empresa H, que avaliou que este seria um diferencial estratégico importante, principalmente num meio que permite interatividade, como a Internet. No início, a empresa somente disponibilizava à venda o que possuía em estoque, com 
vistas a prestar atendimento de qualidade ao cliente. Posteriormente, a evolução do relacionamento com fornecedores e o conceito de Supply Chain Management (SCM) permitiram a implementação do modelo cross-docking: mediante a integração de sistemas, a Empresa H passou a visualizar o estoque do fornecedor. Assim, os produtos colocados "na sacola” pelo cliente durante sua navegação pelo site da loja são reservados junto ao fornecedor; caso o cliente decida comprar, a Empresa $\mathrm{H}$ compra também. Isto assegura a qualidade do atendimento ao garantir o envio do produto para o cliente, isentando a empresa de investimento pesado em estoque. As áreas componentes da equipe multidisciplinar que participou do desenvolvimento do projeto foram, de maneira mais freqüente, Tecnologia da Informação, Marketing, Comercial, pois o entendimento do consumidor é vital para a seleção de categorias e dos produtos, e Logística.

\subsubsection{Análise de custos e benefícios para implantação}

A avaliação da relação entre custos e benefícios para desenvolvimento do projeto de CRM assume configurações distintas entre as empresas analisadas.

Na Empresa A, esta análise focou a lucratividade em termos globais. O processo decisório estratégico da empresa envolve, necessariamente, quatro áreas: Marketing, Comercial, Logística, Operações. A área de Informática foi envolvida apenas após a decisão de desenvolvimento do projeto. na Empresa B, pelo fato de que, em geral, projetos desse porte são desenvolvidos por empresas terceirizadas com supervisão técnica do pessoal da empresa, a análise de custos é feita por um comitê executivo, o qual analisa os projetos de cada área, com base nos benefícios potenciais de cada um. As áreas que pleiteiam investimentos devem apresentar os ganhos esperados com a implantação de cada projeto, o qual deve estar alinhado com a estratégia global da empresa e as metas para investimento em tecnologia. Para isso, apresenta um plano de negócios com vantagens, custos, retornos financeiros (economias) ou estratégicos (não diretamente mensuráveis), a ser submetido ao comitê executivo. Dependendo das dimensões do projeto, o próprio CIO da empresa, juntamente com o diretor da área interessada, podem aprovar sua execução dentro dos planos de investimento em tecnologia da organização. Na Empresa C, o objetivo final de qualquer ação é sempre atingir maior rentabilidade com cada cliente. Assim, ela analisa as receitas geradas pelo programa de fidelidade comparando os clientes que fazem e os que não fazem parte do programa, para aferir o peso do programa na reconquista do cliente. Com esta análise, em geral, avalia-se que é preciso tornar todos os clientes fiéis: a diferença dos ganhos compensa o investimento no 
programa, com variações no prazo de payback do investimento. A empresa acredita que se o programa for bem administrado, sempre haverá o retorno do investimento.

Na Empresa D, a maior parte dos sistemas, integrados por vários módulos, foram desenvolvidos internamente, na medida das necessidades, tornando a negociação do projeto de CRM mais tranqüila.

A Empresa E avalia o retorno de suas ações apenas em termos de aumento de vendas. Para aprovar uma ação, é preciso que se apresente, no projeto, um compromisso de aumentar as vendas em, por exemplo, 1\% por conta da segmentação. A partir daí, o proponente do projeto deve perseguir os resultados, que também influenciam a sua participação nos lucros. Em geral, as economias são mais fáceis de se calcularem; os incrementos em vendas representam maior complexidade, especialmente no mercado editorial, sujeito aos acontecimentos do mundo como guerras, eleições, epidemias. O planejamento sempre tem um alto grau de dificuldade.

Não foi feita análise de custos e benefícios para o desenvolvimento do projeto de CRM na Empresa G; o próprio diretor de Informática, Logística e Comércio Eletrônico detectou a necessidade, fez uma proposta e o comitê diretivo da empresa aprovou o projeto, que foi desenvolvido e implantado pela área de Informática; a área de Comunicação, principal usuária, está aperfeiçoando o sistema.

A plataforma de comércio eletrônico da Empresa H tem uma meta de rentabilidade, baseada numa fórmula: agregando os seus elementos, chega-se ao Time to Profitability (TTP). O projeto do CRM foi conduzido por uma gerência de projetos, tendo um diretor como patrocinador e uma equipe multidisciplinar que analisa objetivos, custos, metas, avaliação, cronograma, retorno; a validação ocorre desde o início do projeto.

\subsubsection{Avaliação de resultados}

A seguir, são apresentados no quadro 17 a avaliação e os comentários a respeito dos resultados já alcançados com o CRM. 
Quadro 17 - Avaliação dos resultados do CRM

\begin{tabular}{|c|c|}
\hline pre & \\
\hline A & $\begin{array}{l}\text { uito satisfatórios, pois aponta erros, acertos, oportunidades de melhoria e sinaliza caminhos para a } \\
\text { nquista de maior fidelidade. }\end{array}$ \\
\hline B & $\begin{array}{l}\text { Regulares, mas com avanço considerável. A empresa conta com um data warehouse, e ainda que não } \\
\text { totalmente integrado aos diversos departamentos que necessitam de informações, e que não tenha sido } \\
\text { implementado com alto investimento em software, já possibilita o balizamento de algumas ações, } \\
\text { representando o início de um trabalho maior. Pela Internet, é possível coletar informações em maior } \\
\text { volume e, talvez, com maior precisão sobre seus clientes; embora isto esteja sendo feito, alimentando os } \\
\text { data marts, a empresa ainda não os está utilizando em sua totalidade. E quando um cliente é } \\
\text { reconhecido automaticamente no site, mesmo que nem sempre seja possível vender-lhe produtos pela } \\
\text { Internet, pois atualmente são comercializados apenas cinco modelos por esse meio, é possivel oferecer- } \\
\text { lhe produtos e prestar-lhe informações. Sob a ótica do cliente, por outro lado, ela acredita que algo novo } \\
\text { e complexo, como o marketing de relacionamento, só pode ser implementado aos poucos, aprendendo, } \\
\text { praticando, aprimorando-se, descobrindo e executando. O engajamento da empresa se revela na criação } \\
\text { de um departamento dedicado exclusivamente a isto, e, embora paulatinamente, tem investido, estudado } \\
\text { a Internet, e tomado pequenas ações em várias frentes, com diversos canais abertos para o cliente se } \\
\text { manifestar. O marketing de relacionamento envolve muito mais que simplesmente ter uma plataforma } \\
\text { de comércio eletrônico, de atendimento a clientes, e manter sistemas de informação que armazenem } \\
\text { seus dados. Envolve algo mais profundo, o conhecimento do cliente, de seu histórico, saber por qual } \\
\text { meio ele preferiria comprar e pagar, por que motivo ele está adquirindo o produto e garantir que aquilo } \\
\text { que lhe está sendo oferecido é o que ele realmente deseja. Nesse sentido, a empresa ainda está em } \\
\text { evolução. }\end{array}$ \\
\hline C & $\begin{array}{l}\text { Entretanto, } \\
\text { orreta, ainda }\end{array}$ \\
\hline D e F & Muit \\
\hline $\mathbf{E}$ & $\begin{array}{l}\text { sulares. A empresa se situa ainda em fase de aprendizagem, que ocorre num momento delicado, em } \\
\text { a empresa se encontra em situação financeira complicada. Assim, sob pressão da necessidade de } \\
\text { cemento de vendas, a área de Internet adota política de saturação de e-mails com ofertas, o que, de } \\
\text { a forma, contraria toda a filosofia de segmentação e reconhecimento do assinante, proporcionada } \\
\text { o CRM. }\end{array}$ \\
\hline $\mathbf{G}$ & $\begin{array}{l}\text { dita que ainda há muito a ser feito para que se filtrem melhor as } \\
\text { do o processo. }\end{array}$ \\
\hline $\mathbf{H}$ & $\begin{array}{l}\text { Satisfatórios, até o momento, pois há ainda muitos objetivos a serem perseguidos. Contudo, além de a } \\
\text { empresa possuir um branding forte em relação aos seus concorrentes, possui o maior índice de } \\
\text { conversão } 13 \text { do mercado nacional, comparável à empresa norte-americana Amazon.com. No Brasil, há } \\
\text { uma concentração muito grande: dez players relevantes respondem por } 90 \% \text { do movimento total e } \\
\text { destes, três são alvo de } 50 \% \text { das compras. }\end{array}$ \\
\hline
\end{tabular}

Fonte: dados de campo.

Nota-se uma grande diversidade de avaliações, que podem ser, em alguns casos, mais reflexo de sua própria autocrítica e do nível de expectativas em relação à questão, do que dos próprios resultados, objetivamente.

${ }^{13} \mathrm{O}$ índice de conversão avalia, de todos os clientes que visitam o site, quantos se revertem em compras, ou seja, mede o índice de conversão de visitantes em pedidos. 


\subsubsection{Outras iniciativas de marketing de relacionamento existentes e novas práticas a serem implantadas}

Além das práticas já abordadas, as empresas possuem outras iniciativas em curso e planos de novas implementações que abrangem, principalmente, avanços nos processos de comunicação entre a empresa e seus clientes e promoções esporádicas, geralmente privilegiando seus associados do programa de fidelidade. Algumas empresas, no entanto, reservaram-se o direito de não divulgá-las ainda.

A Empresa A, além de em CRM, tem investido em promoções sazonais ou esporádicas que beneficiam clientes que compram pela Internet como, por exemplo, a oferta de ingressos para eventos patrocinados pelas empresas do grupo, por e-mail Marketing, selecionando clientes pelo valor do seu ticket médio de compra, entre outras iniciativas pontuais. A seleção dos clientes a serem contemplados é feita de acordo com os objetivos estratégicos de aproximação da empresa junto ao cliente: prospecção, retomada de contato, fidelização. O marketing institucional da empresa é muito atuante, patrocinando diversas ações culturais, esportivas, educacionais e projetos com as prefeituras das cidades, o que a aproxima cada vez mais de seus clientes. Além disso, trabalha não só com conceito de supermercado, mas com o conceito de loja, com sortimentos adequados e ambiente agradável, para que as pessoas se sintam bem em entrar em suas lojas.

A Empresa B lançou, no ano passado, a promoção de dois anos do primeiro carro vendido pela Internet: na compra de outro veículo pela mesma via, o cliente receberia um desconto. Foi algo bastante específico e direcionado, não divulgado por e-mail ou mala direta, num trabalho mais incipiente de CRM. Algumas estratégias de implantação futura não puderam ser divulgadas.

A Empresa C tem procurado identificar perfis de clientes no banco de dados de seus associados do programa de fidelidade, que serão garimpados em bancos de dados de empresas conveniadas, num processo de troca, a fim de se analisar por que pessoas com o mesmo perfil ainda não são clientes da empresa. Isto envolve, além da negociação com as empresas que fornecem o banco de dados, uma solicitação de autorização ao cliente para que sejam utilizados seus dados a fim de se fazerem promoções, constituindo um processo bastante complexo.

Em termos de Internet, a Empresa D está implementando uma estratégia de marketing de relacionamento por e-mail para todos os clientes que se cadastram pelo site, por meio da qual a empresa envia mensagens de aniversário, de tempo de relacionamento com a empresa, que 
compram com mais freqüência, de maior valor de compra. É uma estratégia de estreitamento de relações que tem um custo interessante, para um público diferenciado, de alto potencial, de alta escolaridade, formador de opinião, podendo atingi-lo até de maneira lúdica, diferentemente dos folhetos, impressos e malas-diretas tradicionais. Para o futuro, estão planejadas ações que constituem uma evolução dos programas já existentes, mas que ainda não podem ser divulgadas. Outras empresas do grupo da Empresa E possuem algumas práticas mais desenvolvidas de marketing de relacionamento, como resultado de alguns anos de experiência. A Empresa F possui, em esboço, um programa de fidelização de clientes, com cartão fidelidade, proposta de milhas pela Internet, bônus, além de outras idéias ainda em gestação.

A Empresa $G$ tem se empenhado em se relacionar com seus clientes: todos os associados do programa de fidelidade recebem um exemplar da revista Contato e todos os clientes recebem um calendário de eventos do mês e catálogos de promoção (Leituras de Verão, Dia das Mães). Além dessas iniciativas, em se tratando de relacionamento, estão em curso dois projetos importantes: Relacionamento com o Fornecedor, que não será detalhado por não fazer parte do objetivo desta pesquisa, e o CLIO, ou Obsessão pelo Cliente. Este programa é uma iniciativa do grupo europeu proprietário da empresa, o qual objetiva desenvolver ações com a finalidade de proporcionar satisfação ao cliente, a qualquer custo. Assim, todas as áreas da empresa devem se envolver e se preocupar com esse tema. A área de $\mathrm{RH}$, por exemplo, elaborou uma proposta de melhorar o atendimento na loja; a área de Informática está desenvolvendo uma proposta de revisão de processos para facilitar a escolha do cliente, com mensagens automáticas e pré-venda facilitada. Todas as diretorias estão empenhadas em aumentar o nível de satisfação do cliente. Isto não depende apenas da Empresa G, como corporação, mas, fundamentalmente, dos seus funcionários e parceiros. Se, por um lado, a empresa consegue administrar relativamente bem a questão dos funcionários, pelo outro, há aspectos relacionados a seus parceiros (fornecedores de produtos e serviços, bancos, empresas de cartão de crédito e financiamento) que fogem ao controle da empresa. Por exemplo, se um cliente fizer uma compra parcelada no cartão e receber a fatura com o valor total debitado, ele voltará à loja para reclamar, mesmo que o problema não tenha se originado lá. Para ele, a loja não o atendeu bem, e ela deverá tentar contornar a situação. A empresa sempre se preocupou com isto e o programa vem reforçar esta postura.

A Empresa $\mathrm{H}$ também enumera, dentre suas atividades de marketing de relacionamento, o $e$ mail marketing, o marketing direto, o marketing offline - mídia, revistas, canais de TV a cabo, o 
que demanda uma certa segmentação - e o marketing online. Além disso, em breve, o cliente poderá selecionar que tipo de informação deseja sobre o processo de compra, dentre as 24 etapas monitoradas, e por qual meio (telefone, e-mail, fax etc.).

\subsubsection{Critérios para avaliação de desempenho}

A partir de uma lista de itens referentes a marketing de relacionamento apresentada, os entrevistados foram solicitados a indicar quais critérios são utilizados para avaliação dos itens listados que se encontram presentes em sua empresa. Alguns entrevistados não souberam indicar quais seriam esses critérios; algumas respostas deixam transparecer a ausência dos mesmos. Há, contudo, empresas que exibem critérios claros e objetivos. A Empresa A preferiu omitir sua opinião. A seguir, são apresentados os resultados dos depoimentos para cada um dos itens pesquisados.

\section{- Departamento responsável pelos relacionamentos com clientes da empresa}

As empresas B, C, F e $\mathrm{H}$ trabalham com metas pessoais e por departamento, que são confrontadas com os resultados atingidos, periodicamente. A Empresa $G$ declarou não possuir ainda critérios para esse tipo de avaliação.

Na Empresa D, são várias as áreas que têm relacionamento com seus clientes e cada uma é avaliada segundo indicadores específicos de sua atividade. $\mathrm{O}$ atendimento receptivo tanto para consultoras como para consumidores finais possui índices como Tempo Médio de Atendimento e Atenção dedicada; a EmpresaD.net é avaliada pela audiência do site, número de reclamações, elogios e sugestões. Além disso, a empresa possui uma pesquisa estruturada de gap, por meio da qual ela se compara com outras empresas do mercado, focando-se no canal de vendas. Por meio dessa pesquisa, o relacionamento da Empresa D com o canal é avaliado profundamente e são norteadas, em grande parte, suas ações em termos de relacionamento.

A Empresa E monitora, basicamente, o Índice de Retenção do Assinante, que é a taxa de vendas pelo Marketing Direto e a quantidade de multicompradores, ou número de assinaturas por assinantes. Na realidade, o objetivo não é só continuar com o cliente, mas que ele compre outros títulos também, que equivaleria a aumentar seu ticket médio de compra. 


\section{- Programas de fidelidade}

A Empresa C monitora com muita atenção o aumento anual dos clientes cadastrados no programa de fidelidade; as metas, segundo a empresa, têm sido superadas sucessivamente. Quem já faz parte do programa, pode sofrer um upgrade de categoria (Branca, Azul, Vermelha), em função do número de pontos acumulados; assim, o número de upgrades também indica melhoria no programa de fidelidade. Entretanto, também influenciam este indicador alguns fatores que fogem ao controle da empresa, como por exemplo, clientes fidelidade que são promovidos de cargo ou mudam de emprego e deixam de ter a necessidade de viajar freqüentemente. As análises são complexas, feitas minuciosamente, caso a caso, perfil a perfil.

A Empresa E, embora não possua ainda um programa de fidelidade que considere o assinante como um todo, avalia as iniciativas por publicação por meio das variações nas taxas de vendas. Já a Empresa G lamenta a inexistência de critérios definidos, baseando-se no feeling de seus gestores como termômetro dos programas. A Empresa $\mathrm{H}$ define, periodicamente, metas de aumento do ticket médio de compra, freqüência e recentidade: não é interessante que o cliente fique muito tempo ausente.

\section{- Processo de levantamento de dados sobre opinião e satisfação dos clientes}

Na Empresa B, o departamento de Pesquisa interage com os demais, coordenando pesquisas feitas por empresas terceirizadas, que analisam os dados e apresentam os resultados. Ao final de cada pesquisa é atribuída uma nota final a ela, em relação ao alcance dos objetivos propostos.

A Empresa C promove a reavaliação e adequação constante das metodologias, a fim de eliminar variáveis de percepção dos clientes de fundo emocional, fixando-se em variáveis reais, que reflitam sua verdadeira opinião a respeito do serviço. Avalia-se, por exemplo se a implantação ou não de determinado serviço fará realmente diferença. É preciso que a empresa tenha clara esta visão a fim de priorizar os investimentos relevantes.

Na Empresa D, os critérios para avaliação desse item são o número de interações dos clientes com a empresa e os objetivos da interação, e na Empresa E, isso será feito pela célula anti-attrition, que está em processo de desenvolvimento.

Nas Empresas F e G, os critérios para avaliação dependem do objetivo específico a ser atingido com as pesquisas; a análise é feita sobre o que a empresa deseja saber sobre o segmento, ou 
sobre o mercado específico, para alavancagem de vendas de categorias específicas, relacionada ao gerenciamento de categorias, ou ao alcance de determinados públicos. Na Empresa H, esse processo é avaliado pela própria central de atendimento, de maneira direta; de forma indireta, a consultoria eBit faz a avaliação.

\section{- Canal para manifestação espontânea de clientes}

As Empresas B e G não atribuíram índices para este item. A Empresa C, avalia este aspecto por meio da avaliação de sua área de relacionamento. Na Empresa E, o SAC e a área de Internet é que fazem os monitoramentos; o SAC gera relatórios, por indicadores fechados, avaliando casos específicos, os quais, na opinião da entrevistada, são inócuos. A Empresa $\mathrm{F}$ avalia a eficiência desses canais pelo nível de sobrecarga no sistema telefônico, uma vez que deseja que o cliente se sinta livre para se manifestar, de maneira fácil e rápida. Além disso, o Fale Conosco possui um controle estatístico para evitar que o cliente fique mais que um dia sem resposta. A Empresa $\mathrm{H}$ faz um monitoramento por meio de relatórios mensais.

\section{- Padrões/procedimentos formais para atendimento de reclamações de clientes}

Na Empresa C, a área responsável por ouvir os clientes possui rígido controle sobre os padrões pré-determinados e é muito sensível ao humor dos passageiros nas reclamações ou elogios, representando esse estado de espírito de forma consolidada com cor azul (bom) ou vermelha (ruim) no Painel do Cliente, para divulgação aos funcionários. A meta é estar sempre no azul. Já na Empresa F, merece destaque a preocupação com a reavaliação constante, para análise de recorrências dessa natureza. Sempre que necessário, é criado um novo procedimento. Na Empresa G, embora não haja critérios formais para avaliação, são freqüentes as discussões de casos e sobre formas de avaliação, mas nada muito rígido.

\section{- Treinamento}

Na Empresa B, a avaliação dos treinamentos é feita pelo próprio pessoal de atendimento. Já na Empresa D, é feita por meio da monitoração dos atendimentos. Isso também ocorre na Empresa F, na qual o treinamento é avaliado a partir das metas de desempenho. Em geral, por serem específicos, são avaliados imediatamente, com base no retorno sobre vendas de produtos e de fidelização de clientes. 
A Empresa G realiza treinamentos periódicos, por considerar este aspecto vital para a empresa, e a avaliação é feita sobre o aprendizado e o instrutor, durante o treinamento. Posteriormente, também se observam as atitudes dos funcionários, se não estão praticando o “escapismo” e o “mergulho”. Como já mencionado, é possível também que a empresa receba um relatório com a avaliação feita a partir de um comprador oculto sobre a eficácia e assimilação dos conteúdos do treinamento.

\section{- Efeito sobre a equipe da premiação}

Nenhuma das empresas entrevistadas avalia objetivamente os efeitos sobre a equipe acarretados pela premiação relacionada ao marketing de relacionamento. No entanto, alguns comentários podem ser feitos. A Empresa C avalia como positivos os efeitos do destaque dado ao funcionário, com divulgação no jornalzinho de circulação interna, e convite a participar de um jantar com a presidência e vice-presidência da empresa. Na Empresa G, estuda-se a implantação de um plano de remuneração variável segundo o cumprimento de determinados objetivos, o que, provavelmente, implicará análises para as quais a área de Tecnologia de Informação será solicitada a desenvolver algum aplicativo que forneça as informações necessárias.

\section{- Projeto de produtos em conjunto com o cliente}

Também para este item, que estaria mais voltado às empresas de indústria e comércio, as instituições entrevistadas não revelaram a existência de indicadores objetivos de avaliação de performance. Entretanto, podem ser feitos alguns comentários.

Na Empresa B, essa aproximação é feita por meio de laboratórios com participação de clientes e de pesquisas que coletem opiniões e sugestões. O primeiro automóvel vendido pela empresa pela Internet foi um projeto executado no Brasil nesses termos. Houve até uma peça de comunicação com pessoas que haviam participado do projeto, com o slogan: "O melhor carro que você já fez" a Empresa C, uma empresa de serviços, foi implantado em janeiro de 2003 o Conselho de Clientes, no qual, mensalmente, reúnem-se de 30 a 40 clientes selecionados dentre os vários grupos (os que mais voam, agências de viagens, que compram pela Internet, que mais respondem a pesquisas) com diretores e vice-presidente, com o intuito de levantar pontos adicionais de melhoria de seus serviços. A reunião é estruturada com base numa pauta e registro em ata, para que se avaliem as possibilidades de concretizar o que foi discutido; completam o programa visitas às instalações da empresa e aos centros de manutenção. Embora ainda em estágio inicial, esta iniciativa está sendo 
tratada com muita seriedade e promete trazer resultados bastante interessantes para a empresa, segundo seus patrocinadores.

A Empresa H, atuante no comércio, realiza várias sessões de discussões com compradores, não compradores, internautas, homens, mulheres, com vale-compras e missões específicas de simulação de compra, que levam ao desenvolvimento de protótipos do site para que as pessoas os avaliem e os validem.

\section{- Implantação e resultados do CRM}

Embora as empresas tenham feito análises de viabilidade para implantação do CRM, e até mesmo já possuam alguma opinião a respeito dos resultados obtidos até o momento, elas se consideram ainda no estágio de implantação inicial do CRM e, desta forma, sem condições de apontar critérios objetivos para avaliação de desempenho. A Empresa C acredita que, embora em fase inicial, os resultados do CRM se materializarão no desenvolvimento de produtos e promoções específicos para cada cliente, cujo retorno poderá ser mais simplesmente avaliado pelo site; como o varejo online ainda não é muito grande, a empresa consegue trabalhar com promoções com seus parceiros de maneira relativamente mais fácil. A Empresa $\mathrm{H}$ se baseia em indicadores que não podem ser divulgados.

\section{- Produtos e serviços personalizados}

Neste item as instituições entrevistadas que oferecem produtos e serviços personalizados revelaram a não existência de indicadores objetivos de avaliação de performance.

\subsubsection{Opinião sobre o sucesso das práticas de Marketing de Relacionamento}

A seguir, no quadro 18, são apresentadas as opiniões pessoais dos entrevistados sobre cada uma das práticas de marketing de relacionamento presentes em sua empresa e sua opinião geral sobre o marketing de relacionamento. A Empresa A preferiu omitir sua opinião sobre as práticas, individualmente. 
Quadro 18 - Avaliação pessoal das práticas de marketing de relacionamento na respectiva empresa

\begin{tabular}{|c|c|c|c|c|c|c|c|c|}
\hline Práticas & A & B & C & D & $\mathbf{E}$ & $\mathbf{F}$ & G & $\mathbf{H}$ \\
\hline $\begin{array}{l}\text { Departamento responsável pelos relacionamentos com } \\
\text { clientes da empresa }\end{array}$ & - & ;) & ;) & ;) & • & (:) $:$ & ;) & ;) \\
\hline Programas de fidelidade & - & (:) & $+;)$ & - & - & $+;)$ & ;:) & ;) \\
\hline $\begin{array}{l}\text { Processo de levantamento de dados sobre opinião/satisfação } \\
\text { dos clientes }\end{array}$ & - & $\bullet$ & ;): & ;) & :) & (;) & ;) & ;) \\
\hline Canal para o cliente se manifestar espontaneamente & - & (;); & ;); & ;) & ;) & ;): & ;:); & $+;)$ \\
\hline $\begin{array}{lllll}\text { Padrões/procedimentos } & \text { formais } & \text { para } & \text { atendimento } & \text { de } \\
\text { reclamações de clientes } & & & & \\
\end{array}$ & - & ;) & (;) & ;) & $: \theta$ & ;): & ;) & ;) \\
\hline Treinamento para funcionários sobre atendimento a clientes & - & (;) & ;:) & ;) & (;) & (:); & ;:): & $\because: 0$ \\
\hline $\begin{array}{l}\text { Premiação de funcionários que promovem um bom Marketing } \\
\text { de Relacionamento }\end{array}$ & - & $\bullet$ & ;) & - & $\because: 0$ & ;): & - & (;) \\
\hline Projetos de produtos em conjunto com clientes & - & $(;)$ & (;); & - & - & (;):-; & - & $+;)$ \\
\hline Implantação do CRM & - & - & ;) & - & (;) & $+;)$ & ;) & ;) \\
\hline Produtos / serviços personalizados & - & - & (;) & ;) & - & (;): & (;) & (ㅇ / :) \\
\hline 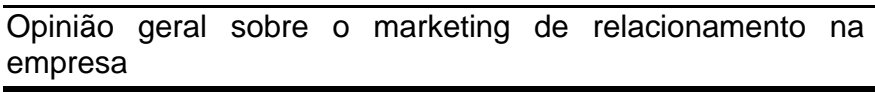 & (;) & (;) & ;) & ;) & - & ;): & $\begin{array}{l}(;) ; 1 \\
:: 0\end{array}$ & ;) \\
\hline
\end{tabular}

Fonte: dados de campo.
Legenda:
;): Bem sucedidas
$(2:$ Mal sucedidas
- Não sabe avaliar
(-):-) : Muito bem sucedidas
$\theta::$ : Muito mal sucedidas
- : Não se aplica

É apresentada, a seguir, a síntese de alguns comentários e ressalvas feitos pelos entrevistados a respeito deste item. Um ponto comum a vários deles foi a observação quanto ao estágio primário de implantação do CRM, que ainda dificulta qualquer avaliação por sua parte. Novamente, o conceito atribuído pelos entrevistados reflete um balanço entre a sua visão do item pesquisado em relação às suas expectativas, muitas vezes influenciado pela forte autocrítica, também comum a algumas empresas. Isto não as impede, no entanto, de verificar que, embora não estejam totalmente satisfeitas com o desempenho em relação ao esperado, comparativamente à concorrência, podem se considerar numa posição superior, como, por exemplo a Empresa $\mathrm{H}$, em relação à questão da personalização de produtos e serviços.

A Empresa A considera sua experiência em marketing de relacionamento muito bem sucedida pelos resultados em termos do grau de fidelização de seus clientes, o que envolve não apenas o quanto se gera de retorno financeiro, mas também a freqüência do retorno do cliente à empresa. Esta empresa está convicta de corresponder às expectativas de seus clientes ao lhes prestar um bom atendimento.

A Empresa B não sabe avaliar o processo de levantamento de dados de maneira geral pois não são feitas pesquisas pelo site. Após a compra, como nas concessionárias, o cliente recebe uma carta 
com formulário para pesquisa de satisfação. Embora as perguntas sejam diferenciadas para compradores pelo site e compradores das concessionárias, o processo é o mesmo. Considera o marketing de relacionamento, em linhas gerais, bem sucedido, pois acredita que a empresa esteja caminhando na direção correta, mesmo porque, numa empresa deste porte, não há alternativa senão conduzir paulatinamente as ações planejadas.

A Empresa C possui uma forte autocrítica e auto-avaliou-se apenas como bem sucedida em alguns tópicos devido a esse componente cultural; entretanto, avalia-se como muito bem sucedida, se comparada à concorrência, principalmente pelos esforços da área responsável por ouvir o cliente e do Conselho de Clientes no que concerne à prestação de serviços cada vez mais personalizados. É difícil para a empresa, em fase de crescimento, desenvolver medidas; num período de maior estabilidade, talvez isso possa ser feito de maneira mais planejada. Em relação aos padrões, ressalta que ainda existem alguns tipos de reclamação difíceis de serem tratados de maneira padronizada e também vê oportunidades de melhoria no que se refere a treinamentos. Em se tratando da premiação de funcionários, acredita que é preciso melhorar alguns pontos, de maneira a cobrir toda a estrutura da empresa: o profissional da Contabilidade, por exemplo, também precisa sentir que seu trabalho contribui para a satisfação do cliente. Na sua avaliação, o marketing de relacionamento, de modo geral, está sendo bem sucedido, haja vista a repercussão positiva emanada dos seus clientes.

A Empresa D avalia a personalização como bem sucedida, se se considerar o atendimento da consultora. Embora a empresa conte com um grande reconhecimento de marca, isso é conseqüência menos de mídia e mais dos méritos da consultora, pois a empresa está longe de ser uma grande investidora em mídia eletrônica do país. O seu grande sucesso está além da qualidade de seus produtos; a empresa reconhece o importante papel de seu canal de vendas bem administrado, preparado e de bom nível, para sustentação da marca. Considera que o marketing de relacionamento está sendo bem sucedido e que pode evoluir para “muito bem sucedido” na medida em que consiga implantar instrumentos mais sofisticados de avaliação de perfil de clientes, de maneira que o relacionamento se torne mais one-to-one.

No caso da Empresa E, alguns pontos estão sendo trabalhados, como o investimento na célula anti-attrition, que analisará as causas do rompimento com a empresa, planos de avanços no CRM, em 2004, e pesquisas e projetos-piloto junto a leitores na linha editorial. Por outro lado, os canais para manifestação espontânea do cliente funcionam bem individualmente, mas não estão integrados: se o cliente utilizar mais de uma forma de contato com a empresa, será solicitado a relatar todo o 
problema novamente. Algumas outras questões também precisam ser revistas: premiação para quem se empenha em desenvolver um bom marketing de relacionamento, e o treinamento, que embora seja freqüente, deveria atingir a todos os níveis da empresa, pois ainda há miopia em relação ao que seja um bom relacionamento, a começar pelos programas de fidelidade: não existe nenhum com foco no cliente, mas há vários concentrados nos produtos. Além disso, não se questiona se as ações tomadas pela empresa são desejadas e, até mesmo, valorizadas pelos clientes, embora se acredite que representem o máximo em qualificação do assinante, e que isto é "fazer CRM". Algumas revistas dão brindes caríssimos na renovação da assinatura, mas não se avalia se este seria o brinde ideal para o Brasil todo ou se é isto que cativa o assinante. A empresa pode perder dinheiro com essa prática. É preciso saber quem é ele, do que ele gosta, se a forma, dia e horário de entrega estão adequados, entre outros detalhes transacionais. Muitas vezes, a empresa faz o melhor de si, sem ouvi-lo, e continua sem atendê-lo, envolvendo muita energia que poderia ser canalizada para objetivos mais claros se a empresa ouvisse o seu cliente. Há iniciativas como a distribuição de ingressos para eventos, feita por determinada publicação, em que se selecionam, por exemplo, os assinantes mais antigos que aniversariam no mês para recebê-los. No entanto, não se analisam os efeitos dessa promoção sobre os assinantes contemplados. É possível que eles falem com outras pessoas sobre isto e a impressão geral seja positiva. Contudo, também podem relatar o fato a um assinante de outra revista, que pode ficar furioso por não ter tido chance de participar da mesma promoção, tendo mais tempo de casa. Assim, é preciso ter uma política única para a empresa, e não considerar apenas a publicação, mas o assinante. Trata-se de uma questão bastante complexa: há várias ações isoladas, porém não vinculadas a políticas ou estratégias de CRM. Atualmente, a média é de cerca de 1,7 assinaturas para cada assinante, com tendência de crescimento. Como a média é maior que um, conclui-se que o número de multi-assinantes é grande, o que reforça ainda mais a necessidade de que a empresa desenvolva relacionamentos com esses clientes, que passe a olhar para os assinantes, e não para as assinaturas. Em termos gerais, a Empresa E não sabe como avaliar o desempenho do seu marketing de relacionamento como um todo. Atualmente, o planejamento para as ações é coerente e realista: não se trata de nada que vá mudar os resultados da empresa, ou que vá demandar grandes investimentos; a empresa vai fazer o básico, que é viável e que deverá fazer a diferença.

A entrevistada da Empresa F acredita que a empresa esteja no caminho certo, pois tem obtido retornos muito bons em termos de fidelização e de crescimento nas vendas. 
A Empresa G também é muito crítica consigo mesma. À mínima falha descoberta, ela procura analisar os motivos da ocorrência. O entrevistado considera a forte autocrítica como positiva, pois impulsiona a empresa a buscar sempre níveis melhores de performance. Assim, considera as práticas existentes de marketing de relacionamento muito bem sucedidas; porém, como ainda está em fase de desenvolvimento, com muitas ações a serem implantadas, considera o marketing de relacionamento muito mal sucedido. Acredita que este conceito tende a melhorar com o programa CLIO, que é vital para a empresa e que provém de uma solicitação vinda da presidência mundial, o que agrega maior incentivo para que as ações sejam executadas com seriedade.

Na opinião do entrevistado da Empresa H, o marketing de relacionamento está sendo bem sucedido, pois conseguiu atingir lucro líquido neste ano. Não está muito bem ainda pois existem muitos desafios, como o equilíbrio de contas. Por ser uma empresa nova, não ampliou muito o seu quadro, o que gera restrições na capacidade de condução de vários projetos em vários setores. A empresa recorre muito a terceirizações criteriosas, que permitem que ela se dedique, com suas dimensões atuais, a assuntos mais urgentes. Esta empresa considera que as suas implantações em termos de definição de metas relacionadas a atendimento, pesquisas sobre satisfação dos clientes, divulgação de canais para manifestação dos clientes, e a disseminação indistinta dessas informações para todos os funcionários da empresa representam uma grande transformação em relação à empresa física, a qual, por sua vez, realiza pesquisas anuais, com uma avaliação estatística das lojas e dos consumidores, porém com resultado muito superficial, massificado. Na loja eletrônica, é muito importante para o bom andamento dos negócios entender o cliente individualmente, é preciso ter um relacionamento "pessoal” com ele.

\subsubsection{Considerações Gerais}

A preocupação com o relacionamento com o cliente se reflete de formas e intensidades distintas na estrutura organizacional das empresas. Algumas delas possuem uma ou mais áreas formalmente responsáveis por seus relacionamentos; outras, diluem tal responsabilidade entre várias áreas. A posição das áreas no organograma das empresas e a distribuição de atribuições entre as mesmas fornecem uma idéia da importância relativa do relacionamento com o cliente para cada empresa.

Com relação a programas de fidelidade, há uma ampla gama de estratégias em atividade, que variam de acordo com as características dos produtos/serviços ofertados e disponibilidade de 
recursos em cada empresa. A classificação desenvolvida por Coyles e Gokey (2002:3-5), a qual assume que nem todos os relacionamentos podem ou devem ter a mesma duração ou o mesmo grau de intimidade, pode ser reconhecida nos depoimentos de algumas empresas como meio para definição das diferentes táticas/ações requeridas para administrar cada um dos segmentos e ampliar a lealdade dos clientes. O cliente realmente é mais fiel devido ao programa ou trata-se apenas de um comportamento inercial? Como algumas empresas declararam não avaliar efetivamente o desempenho de seus programas de fidelidade, o emprego da classificação dos clientes poderia fornecer subsídios para o aprimoramento dessas iniciativas ao orientar a elaboração de alternativas de premiação vinculadas à análise das razões que levam o cliente a se filiar, visando a um investimento realmente profícuo.

No que diz respeito às maneiras de se ouvir o cliente, níveis e formas diversificados de pesquisa, bem como a abertura de vários canais para manifestação espontânea por parte dos clientes e encaminhamentos distintos das questões levantadas têm sido praticados pelas empresas. Cabe destacar também a prática comum entre algumas empresas da utilização do “comprador oculto” , como propõem Boone e Kurtz (2001:160), muito apropriada para uma avaliação completa da experiência de compra. As empresas entrevistadas reconheceram a importância da monitoração contínua e da rapidez nas ações sobre reclamações e sugestões recebidas, como sugerem Hart, Heskett e Sasser Jr. (1994:281); contudo, tais atividades não estão sendo efetivamente executadas por todas as empresas entrevistadas. Verificou-se também nos depoimentos que as empresas adotam canais e níveis distintos de disseminação aos funcionários das informações sobre as interações dos clientes; isto fornece feedback essencial para que se valorizem as boas práticas, corrijam-se procedimentos, revejam-se as posturas e deficiências e se verifique a eficácia do marketing de relacionamento. Apesar da existência de áreas para atendimento ao cliente em todas as empresas pesquisadas, é curiosa a ausência de mais ombudsmen institucionalizados, conforme defende Giangrande (1999:21), embora algumas delas tenham concordado que todos os funcionários da empresa, do porteiro ao presidente, devam atuar como ombudsman. É de extrema importância que as empresas ouçam seus clientes para entender como estes as valorizam e no que podem melhorar, e descubram quais os motivos considerados pelos mesmos ao tomar uma decisão de compra e o quanto o relacionamento pode interferir nisto.

Em relação à definição de metas de satisfação dos clientes, poucas empresas foram objetivas em seus depoimentos, embora todas, inclusive as que não as possuem, dessem sinais de aprovar tal 
medida. Nota-se nas empresas um contraste entre controles bastante simples e outros mais sofisticados. Acredita-se que a definição de indicadores é realmente complexa, como expressaram alguns entrevistados, e deriva da maturidade da empresa em relação ao marketing de relacionamento e do que esta espera do mesmo. O conceito de relacionamento difere entre as empresas: manter/reter clientes, satisfazer clientes para mantê-los, vender mais para os mesmos clientes ou estimular o aumento do ticket médio de compra, encantar, mais do que satisfazer os clientes, tratá-los de modo personalizado etc. Uma reflexão sobre estas noções talvez pudesse trazer alguma luz à questão da definição de metas, considerada importante por todas as empresas entrevistadas. Os critérios para avaliação dos itens referentes a marketing de relacionamento não foram muito detalhados por questões estratégicas, por desconhecimento do entrevistado, ou por inexistência dos mesmos. No entanto, há sinais de que alguns dos índices revelados trazem imprecisão em sua conceituação, uma vez que alguns sistemas das empresas, em fase de remodelagem, não poderiam ainda fornecer tais dados.

Da mesma forma, acredita-se que a premiação de funcionários que promovem um bom marketing de relacionamento está bastante associada à idéia que as empresas têm desse conceito e de como os seus funcionários devem incorporá-lo em suas atividades. Por outro lado, as políticas vigentes de premiação, se ora incentivam as boas práticas, ora podem levar os funcionários a executarem ações de maneira mecânica, sem comprometimento, o que pode implicar um risco: as boas práticas existem apenas enquanto a premiação existir. A premiação é positiva no sentido de reconhecer os funcionários que mais se destacam; contudo, acredita-se que um bom atendimento aos clientes deveria ser parte do padrão de atitudes de todo profissional de forma espontânea, sem o estímulo de gratificações. Embora haja empresas que premiam seus funcionários pelo bom atendimento, como recomenda a literatura, há outras que praticam a premiação sobre os resultados obtidos em vendas, por serem estes mais diretamente mensuráveis.

A definição de procedimentos-padrão para tratar de reclamações e compensar os clientes por erros cometidos é muito útil, como sugerem autores como Hutchison e Stolle (1994:106) e Finkelman e Goland (1994:268), mesmo porque, pelo fato de as empresas pesquisadas serem de grande porte, com maior probabilidade de ocorrência de tais problemas, a falta dessas referências tornaria o seu dia-a-dia demasiadamente complicado. Em algumas delas, a escassez de procedimentos, aliada à carência de políticas, sobrecarrega a supervisão e áreas de apoio, e pode até gerar ações inadequadas ou desagradar ao cliente. Um grande desafio é definir padrões; desafio 
maior, porém, é controlá-los, pois isso envolve alguma complexidade na definição dos métodos de acompanhamento, o qual é executado em algumas empresas com softwares específicos.

As empresas, em geral, demonstram alguma preocupação com o treinamento de seus funcionários em termos de atendimento ao cliente. Isso se revela cada vez mais um diferencial entre as empresas na medida em que a competição se acirra e o amadurecimento dos clientes em relação a seus direitos como consumidor avança; para enfrentar com mais segurança essa realidade, é preciso que todos os funcionários estejam preparados para “representar” a empresa perante os clientes. Os entrevistados deixaram transparecer que esta é uma responsabilidade de cujo peso nem sempre os funcionários estão cientes e para a qual freqüentemente não estão preparados. O conteúdo técnicooperacional nos treinamentos ainda parece ser prioritário para algumas empresas, que talvez assim o vejam por terem que lutar contra o intenso turn over dos postos de atendimento. No entanto, inferiuse de alguns depoimentos que o desafio maior está no aspecto cultural e comportamental, em como incutir no pessoal da linha de frente a consciência de que o sucesso da empresa e, por conseqüência, dos seus funcionários, pode depender dos clientes. Dessas noções talvez provenha o esmero de algumas empresas pesquisadas em promover treinamentos e reciclagens freqüentes a seus funcionários, como elementos fundamentais no fornecimento do produto ampliado da empresa; outras, apesar de considerar o treinamento essencial, ainda não conseguiram dispor de recursos para realizá-lo com maior freqüência. Uma das empresas declarou preocupar-se em selecionar pessoas com perfil acadêmico que permita prestar melhor atendimento a seus clientes; contudo, a correlação entre tal perfil e a qualidade dos serviços nem sempre é positiva. Constitui um princípio de difícil aplicação e que exige maior perspicácia das empresas a identificação, na seleção, de pessoas que estejam dispostas a se engajar no espírito da empresa, conscientes da necessidade do cultivo do relacionamento com clientes, como sugerem Hart, Heskett e Sasser Jr. (1994:287).

Quanto ao aspecto da personalização, tratar os clientes individualmente, conhecer suas preferências e hábitos de consumo, sugerir-lhes produtos alinhados a estas informações e fornecerlhes o que desejam, no momento em que desejam, pode auxiliar a diferenciar a empresa de seus concorrentes. Com a evolução dos recursos tecnológicos, isto pode ser feito para praticamente todos os clientes. Entretanto, embora louvável, soa um pouco ambicioso que uma empresa ofereça, como padrão, serviços especiais a todos os seus clientes, como pretendem algumas empresas. Certos tipos de tratamento devem continuar exclusivos dos clientes VIPs; do contrário, esta vantagem, do ponto de vista do cliente, deixa de existir. Assim, no confronto com a teoria, há um hiato entre o que as 
empresas dizem praticar e o que de fato praticam. É preciso, portanto, não confundir personalização com tratamento especial. Há algum tempo, estas expressões podiam ter significados equivalentes; no entanto, hoje, é possível oferecer produtos/serviços personalizados potencialmente a todos os clientes e serviços especiais somente aos clientes de maior valor para a empresa.

Conforme pesquisa realizada no final de 2002 pela empresa de consultoria EConsulting, com profissionais de áreas de tecnologia (119) e dos setores de marketing, serviços e atendimento (114), há visões distintas sobre o CRM entre os grupos (Manzoni Jr., 2003:20), o que resultaria na falta de Figura 36 -Visão sobre o CRM

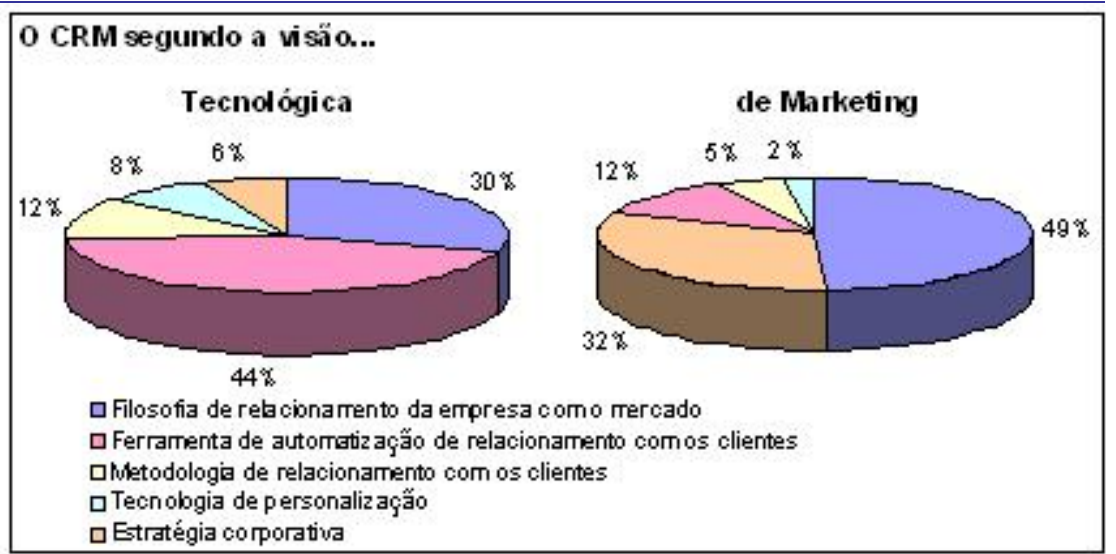
convergência nos projetos. Essa

Fonte: E-Consulting, in Manzoni Jr. (2003:20). pesquisa revela que a maioria dos profissionais de tecnologia acredita que o CRM seja uma ferramenta de automatização do relacionamento com os clientes, e que os profissionais de marketing, em sua maioria, acreditam que o CRM seja uma filosofia de relacionamento com o mercado (figura 37). Isto sinalizaria, segundo o sócio da consultoria, Daniel Domeneghetti, que os profissionais de tecnologia estão mais distantes e possuem pouca noção do negócio. Para ele, se o CRM ficasse sob a tutela das áreas de marketing, traria mais sintonia entre as áreas em relação ao negócio, evitando visões distorcidas do mesmo. A tendência de distorção observada na pesquisa da E-Consulting não se verificou neste estudo, em parte porque os representantes das empresas entrevistadas agregam funções de marketing e tecnologia em suas atividades e também por desempenharem cargos executivos, com uma visão mais global da empresa. O grupo de empresas entrevistadas que concorda parcialmente com a definição de CRM apresentada destacou que, na aplicação do CRM, a tecnologia é importante, mas como meio, e não como fim. Já o grupo que concorda totalmente com a definição aparenta adotar uma posição mais pragmática em relação ao CRM ao não dissociá-lo do uso da tecnologia. Embora o CRM tenha sido entendido como estratégia, filosofia ou conceito, invariavelmente, as empresas não o desvincularam do software ao analisar seus resultados, possivelmente em função das exigências de seu porte. Porém, há que se 
atentar para que não se gerem investimentos em tecnologia sem que a empresa esteja estratégica, estrutural e culturalmente preparada para tanto.

Em termos de adoção de solução tecnológica de CRM nas empresas pesquisadas, percebe-se uma preferência por implementá-lo gradativamente. Enquanto algumas empresas adquiriram uma solução de um fornecedor especializado, outras, como uma tendência apontada pela especialista em CRM entrevistada, priorizam e implantam os módulos de acordo com suas necessidades e disponibilidade de recursos. Um projeto completo para grandes empresas não sai por menos de R\$ 300 mil e pode chegar a R\$3 milhões (aproximadamente US\$130 mil e US\$1,3 milhões, respectivamente) (Sordili, 2001). Algumas empresas possuem sistemas que podem ser adaptados para atender também às necessidades do CRM; contudo, um grande desafio é a integração desses sistemas de modo a proporcionar a toda a empresa uma visão única das interações do cliente com a mesma. O fato de uma empresa possuir mais módulos implantados que outra não significa, necessariamente, que a primeira esteja adiantada em relação a esta no CRM. Algumas empresas estão procurando se estruturar bem, acompanhando a estabilização dos processos, a adaptação das pessoas e a disponibilidade de recursos para dar o passo seguinte; outras, procuram atuar em várias frentes, porém com pequena profundidade, até que ocorra o aprendizado e se sintam seguras para novas investidas. Especialista em CRM e entrevistados compartilham do mesmo sentimento de que planejamento cuidadoso e intenso comprometimento das áreas envolvidas e da alta administração da empresa são essenciais para o sucesso dessas implementações.

Conforme autores como Cymbaum (1997:184-204, in Cymbaum e Málacco, 1999:27) e Shapiro e Sviokla (1994:XVI), a construção do relacionamento com os clientes deve ser feita de maneira coordenada e integrada por toda a empresa. Alguns depoimentos sinalizam a premência de se resolverem inicialmente problemas internos para poderem avançar no relacionamento com seus clientes: em muitos casos, a “simples” reorganização do fluxo de informações, com comunicação fluida e valorização dos profissionais, pode resultar em melhor atendimento aos clientes. Não é possível desenvolver ações que afetam a corporação como um todo sem integração entre suas partes; é necessária uma complementação, e não competição entre as mesmas. As empresas, em geral, avaliam seu atual estágio de desenvolvimento segundo critérios bem distintos. Empresas que têm forte autocrítica, mesmo com projetos bem avançados, acreditam que ainda há muito a ser feito e não estão plenamente satisfeitas com seus programas; outras, com comportamentos mais ousados e mais recursos, acreditam que estão em um nível bem avançado de relacionamento; e outras, com 
menos recursos, consideram o que conseguiram uma grande vitória. Isso sinaliza que os níveis de satisfação quanto ao avanço no relacionamento com os clientes se manifestam de acordo com as ambições e as condições de cada empresa. Contudo, se, por um lado, uma forte autocrítica pode ser estimulante - caracterizando a busca pela perfeição -, pelo outro, pode ser desencorajadora, dependendo da maneira como for colocada: "não importa o quanto se esforce, nunca chegará ao nível da perfeição”, ou “a empresa nunca se dará por satisfeita”.

Algumas das empresas, embora tenham demorado um pouco mais para se engajar em relacionamentos mais consistentes, estão preocupadas em se preparar conceitual e culturalmente para que as mudanças ocorram. Também é interessante que a empresa faça periodicamente um exercício de empatia: "se eu fosse cliente dos produtos/serviços da minha empresa, estaria satisfeito?”. Nota-se que as empresas detêm conhecimento suficiente para praticar um bom marketing de relacionamento e até intencionam fazê-lo. Contudo, muitas vezes, esbarram em outras prioridades, na resistência e desinteresse por parte dos funcionários, na falta de recursos, entre outros fatores desestimulantes.

Apesar da pequena amostra, acredita-se que o tempo de atividade no setor não influi no relacionamento da empresa com seus clientes. O que parece fazer diferença são a cultura e as idéias de sua direção no que diz respeito ao relacionamento, à sua orientação para o mercado, e à sua proposição de valor para o cliente. Poder-se-ia imaginar que as empresas que estão há mais tempo no mercado tenderiam a dispor de mais recursos e embasamento para a implantação de programas de relacionamento. Entretanto, empresas que desde o início de suas atividades têm colocado o relacionamento como parte essencial de seu dia-a-dia mostram que, mais significativo que o tempo de atividade no setor, é o empenho dedicado ao desenvolvimento do marketing de relacionamento, que pode levar a uma maior maturidade nas relações com clientes, com mais chances de evolução e conseqüente ganho em termos de imagem e lucratividade para a empresa. A execução de muitas dessas práticas envolve, de fato, o comprometimento de recursos; no entanto, as empresas precisam definir o quão comprometidas estão com o marketing de relacionamento.

\subsection{Caracterização da empresa em relação às suas operações como fornecedora pela Internet}

Neste bloco, foram identificadas algumas características das empresas entrevistadas no que tange à Internet, apresentadas a seguir. 


\subsubsection{Objetivos da criação do site da empresa na Internet}

No quadro 19, encontra-se um resumo das principais motivações de cada empresa e o ano em que foi criado seu site na Internet; a seguir, comentários sobre as implementações de cada uma.

Quadro 19 - Principal motivação para criação do site da empresa na Internet

\begin{tabular}{c|c|c|c|c|c|c|c|c}
\hline & A & B & C & D & E & F & G & H \\
\hline $\begin{array}{c}\text { Ano de } \\
\text { criação }\end{array}$ & 1995 & 1998 & 1995 & 1999 & 1999 & 2002 & 1999 & 1999 \\
\hline $\begin{array}{c}\text { Principal } \\
\text { motivação }\end{array}$ & $\begin{array}{l}\text { Comércio } \\
\text { eletrônico }\end{array}$ & $\begin{array}{l}\text { Comunicação } \\
\text { institucional }\end{array}$ & $\begin{array}{l}\text { Comunicação } \\
\text { institucional }\end{array}$ & $\begin{array}{l}\text { Canal de } \\
\text { relacionamento, } \\
\text { prestação de } \\
\text { serviços e mídia }\end{array}$ & $\begin{array}{l}\text { Vendas, } \\
\text { renovações e } \\
\text { atendimento, } \\
\text { visando à redução } \\
\text { de custos }\end{array}$ & $\begin{array}{l}\text { Comércio } \\
\text { eletrônico }\end{array}$ & Presença & $\begin{array}{l}\text { Comércio } \\
\text { eletrônico com } \\
\text { relacionamento }\end{array}$ \\
\hline
\end{tabular}

Fonte: dados de campo.

O principal objetivo da Empresa A ao criar seu site na Internet foi atender às necessidades de um grupo de clientes que já demonstrava potencial para este mercado, como evolução à utilização do CD-ROM para compras, modernizando a marca. A marca lançada para vendas na Internet é voltada a clientes das classes A e B, que constituem a maior parte de seu público. Esta foi a primeira marca de supermercado a fazer comércio eletrônico na América Latina.

A Empresa B criou seu site inicialmente para que seus clientes pudessem buscar informações sobre os produtos e sobre a empresa, em 1998; na etapa seguinte, em 1999, transformou-o num canal de comunicação com o cliente; em 2000, passou às vendas, aprimorando o canal de relacionamento com ele. Com isso, passou a coletar e armazenar informações sobre o cliente, também de grande importância para o relacionamento com o mesmo, com ganhos de imagem de empresa de alta tecnologia. As vendas da Empresa B pela Internet tiveram início no Brasil; foi um piloto mundial, por iniciativa própria, e não por uma determinação da matriz, que aprovou a idéia brasileira, e enviou uma equipe para participar conjuntamente desse projeto. Da mesma maneira, criado em 1995 com objetivo meramente institucional, o site da Empresa C, em 1996/97, passou a realizar atendimentos por e-mail de reservas e alterações; em 1999 passou a ser transacional, permitindo efetuar reservas e compras; hoje é mais sofisticado em termos de venda e prestação de serviço aos clientes do seu programa de fidelidade. Já dentre as empresas que declararam visar prioritariamente ao comércio eletrônico, a Empresa D possibilitou à consultora comunicar-lhe seus pedidos pela Internet desde 1999; o cliente final passou a comprar pela Internet dois anos depois. O objetivo principal da criação do site foi atender a um grupo de consumidores que desejavam conhecer/obter os produtos da empresa, mas que não tinham ou haviam perdido contato com uma 
consultora, ou que não tinham disposição para ligar para o atendimento gratuito da empresa e fazer seu pedido ou solicitar a indicação de uma consultora.

Também visando a efetuar transações eletrônicas, a Empresa E criou três sites na Internet: Vendas, com o objetivo de vender mais, aumentar o número de assinaturas vendidas, a um custo menor; Renovações, para que os clientes façam as renovações pela Internet, e com isso, a empresa economize com processos via papel; Atendimento, com o objetivo de economizar em chamadas telefônicas. Enquanto o primeiro site visa primordialmente ao incremento de receitas/redução de custos no sentido de se vender mais com menor custo, o segundo e o terceiro sites visam muito mais à economia em comunicações.

Inicialmente, a Empresa F possuía uma página, mas sem divulgação de produtos. A decisão de lançar uma loja virtual surgiu num ímpeto repentino, para entrar no mercado e atender a seus clientes de modo mais eficiente, que estavam demandando vendas pela Internet - a empresa recebeu cerca de 500 e-mails com essa solicitação, especialmente de clientes do interior e de outros estados que têm dificuldade em adquirir os produtos da empresa, a qual ainda não possui lojas em todo o território nacional. Atualmente, 70\% dos clientes das lojas são da Grande São Paulo.

O principal objetivo da Empresa G ao implementar seu site na Internet foi criar presença, pois, na época, a mensagem era: “os pioneiros serão premiados”. Embora esta crença já tenha sofrido várias alterações, nunca houve grandes investimentos por parte da empresa que, ainda, não almeja ser a maior em vendas, apesar de ser rentável já há dois anos. Ela mudou algumas estratégias e embora tenha um departamento muito humilde de comércio eletrônico, entrega as encomendas e se relaciona com o cliente conforme o esperado, mantendo o nome da empresa, dentro do possível, nos padrões mundiais. A livraria comprada pela Empresa G já possuía comércio eletrônico. Mesmo depois de alterado o nome do site, ele ainda continua pobre, sem muito conteúdo, com poucas imagens: não traz todas as capas e resenhas dos livros, os nomes das faixas das músicas, as especificações técnicas do produto. Como a empresa necessitava rentabilizar o site, procurou reduzir custos de salários/pessoal e gastos com compra de mídia. Em contrapartida, contou com a eficiência dos sites de busca e com a condição de que os produtos da empresa podem ser considerados commodities, o que lhes dá vantagem competitiva ao trabalhar sobre preços. 


\subsubsection{Fases da Internet como ferramenta de negócios}

As empresas identificaram por quais fases da Internet passaram e em qual fase se posicionam na atualidade, segundo referências de Kosiur (1997) e de Sterne (2000). A seguir, seus depoimentos conforme cada critério.

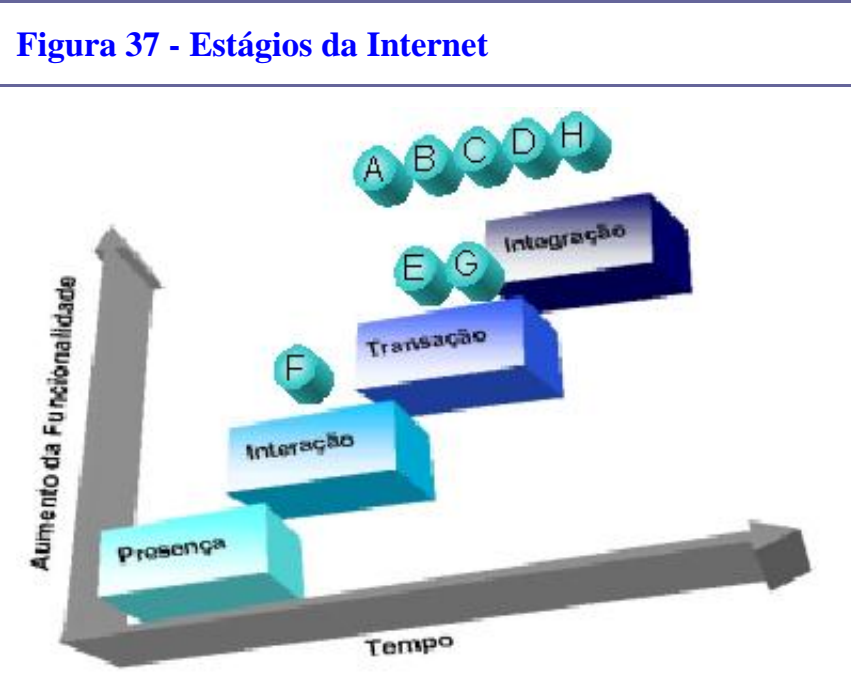

Fonte: adaptado de Kosiur (1997).

\section{- Fases da Internet, segundo Kosiur}

À exceção da Empresa F, que iniciou suas atividades pela Internet a partir da fase de Interação, com a intenção de gerar vendas, as demais empresas iniciaram suas atividades na fase da Presença (figura 38).

As empresas que ainda não se situam na fase de Integração afirmam que ainda há o que ser melhorado em termos de transação, e que os relacionamentos existem, porém ainda não totalmente automatizados, embora haja estudos

para que as integrações se promovam cada vez mais. Mesmo no caso das empresas que afirmaram estar na fase de Integração, há algumas ressalvas: embora a automatização com os clientes em relação a pedidos e pagamentos exista em todas, a integração com os fornecedores ainda é parcial, em amadurecimento, ou inexistente. A Empresa A evidencia ainda o desafio de integrar seus sistemas institucionais, de comércio eletrônico e CRM. Na Empresa C, está em curso a implantação de vendas B2B, com a eliminação quase total de papel nas transações com agências de turismo. Além disso, estabeleceu-se uma meta de que $60 \%$ das emissões de bilhetes, quer seja diretamente aos clientes, quer seja por agências, sejam feitas pela Internet. A Empresa D observa ainda que a utilização da Internet como mídia para comunicação com públicos específicos, formadores de opinião, ganhou mais importância entre as fases de Transação e de Integração, fato importante do ponto de vista da empresa e não explicitamente mencionado por Kosiur (1997). Antes disso, o site das empresas na Internet era muito receptivo, mais se aproximando de um call center ou de um SAC. Hoje, é mais evidente a possibilidade de levar uma comunicação mais dirigida, mais personalizada, com capacidade até de mensuração de resultados tanto em termos de vendas, como em relação ao interesse dos públicos com os quais a empresa quer interagir. Na TV, isso não é possível, a menos que se façam pré-testes ou pesquisas de recall em várias cidades; na mídia 
eletrônica, o retorno é muito mais rápido, sendo que a empresa não só consegue fazer campanhas bastante orientadas a públicos específicos, freqüentadores de determinados sites, como também avaliar rapidamente se a peça está funcionando ou não e, se o objetivo for vendas, se realmente está vendendo, ou não. Isto só começou a evoluir com mais intensidade na fase atual da Internet, pós Transação.

\section{- Fases da Internet, segundo Sterne}

Excetuando-se a Empresa F, que afirmou situar-se na fase da Página do Produto, e a Empresa G, que se situou na fase do Web site Corporativo, as demais se colocaram na fase do Web site Participativo. A Empresa A ressaltou que, dependendo do site do Grupo que o cliente usar para “entrar” na empresa, poderá obter acesso imediato a informações institucionais ou ao comércio eletrônico (figura 39).

\section{Figura 38 - Fases da Internet.}

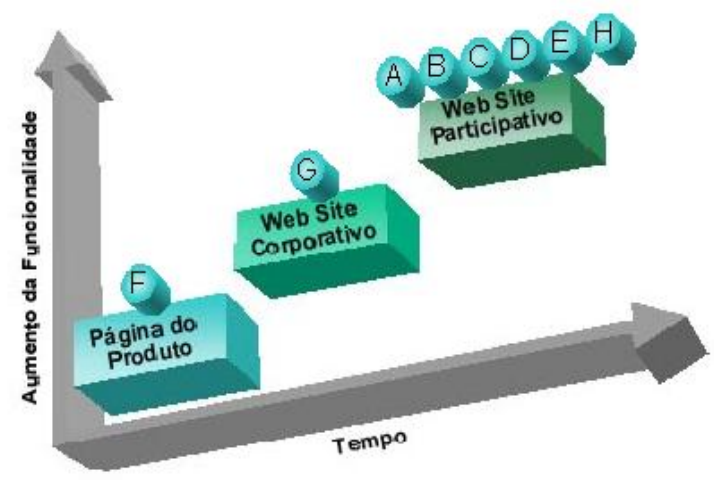

Fonte: adaptado de Sterne (2000).

\subsubsection{Vantagens da realização de negócios pela Internet}

As empresas mencionaram várias vantagens da realização de negócios pela Internet, conforme se pode visualizar no quadro 20. O símbolo (:) indica que o item correspondente foi mencionado pela empresa, e o sinal - indica o contrário.

Quadro 20 -Vantagens da comercialização de serviços e produtos pela Internet

\begin{tabular}{|c|c|c|c|c|c|c|c|c|}
\hline Vantagens para a empresa & A & B & C & D & $E$ & $\mathbf{F}$ & G & $\mathrm{H}$ \\
\hline Diminuição de custos operacionais & ;) & - & ;) & (;) & ;) & - & ;) & (;) \\
\hline Melhoria da comunicação com o cliente & ;) & ;:) & ;:) & (;) & ;:) & - & - & (;) \\
\hline Maior agilidade no atendimento ao cliente & - & ;) & ;) & - & - & - & - & (:) \\
\hline Penetração em novo mercado & ;) & ;) & - & (;) & ;) & ;) & - & (;) \\
\hline Divulgação/exposição de fotos de produtos & - & ;:) & - & (;) & - & ;) & - & (;) \\
\hline Coleta e gerenciam. informações sobre clientes & ;) & ;) & ;) & (;) & ;) & ;) & - & (:) \\
\hline Disponibilidade 24 horas por dia, 7 dias por semana & - & ;) & - & - & - & - & - & (;) \\
\hline Fidelização & ;:) & - & - & - & - & - & - & - \\
\hline Mais um canal de vendas/distribuição & - & ;) & - & - & - & - & ;) & - \\
\hline Facilidade de aferição e gestão de resultados & ;) & - & - & - & - & - & - & (;) \\
\hline Maior facilidade criação/implantação peças promocionais & - & - & - & - & ;:) & - & - & (;) \\
\hline Branding/Presença & - & - & - & (;) & - & - & (;) & - \\
\hline Idéia de preços mais baixos, pelo cliente* & - & - & - & - & ;) & - & - & - \\
\hline
\end{tabular}

* será discutida mais adiante. Fonte: dados de campo. 
As Empresas A e G concordam que a redução de custos é bastante considerável pelo fato de não ser necessário arcar com os custos de uma loja física; a Empresa $\mathrm{H}$ acrescenta que o custo de operação não aumenta proporcionalmente ao crescimento da operação, possibilitando-lhe auferir maiores margens. Contudo, as Empresas A e $\mathrm{H}$ mencionaram que é fundamental que se consiga atingir uma boa escala. A Empresa C evidencia também a conquista de custos menores de intermediação, uma vez que a mesma já havia feito investimentos tecnológicos na formatação do bilhete eletrônico, o e-ticket, antes mesmo da Internet, que veio a viabilizar mais facilmente este projeto. Quando o cliente compra pela Internet, simplesmente se apresenta ao check-in com o número do bilhete ou o localizador de sua reserva e seu RG e recebe o cartão de embarque. A Empresa G não acredita que, no geral, as vendas pela Internet envolvam custos muito menores pois o custo do produto é o mesmo. No seu caso, não há custo de estoque pois o picking (separação dos produtos encomendados para envio ao cliente) é feito na própria loja: não há depreciação, não se responde pelo giro de estoque e, portanto, não é necessário arcar com os custos de uma gestão tradicional de produtos. Diante deste cenário, a loja eletrônica se preocupa apenas com o que será exposto em sua home page, pagando apenas um pequeno “aluguel” da loja. Caso fosse necessário manter um galpão com estoque e sua administração, a operação de vendas pela Internet seria muito mais onerosa; porém, como o volume de vendas de ambas as lojas é alto, as operações se viabilizam. A Empresa B não quis se manifestar sobre redução de custos.

A penetração em novo mercado também foi bastante comentada pelas empresas, principalmente, em termos geográficos, e por atingir pessoas com pouco tempo para fazer compras e um público que não seria atingido pelas mídias tradicionais como folhetos, encartes, mala-direta, telefone, vendas pessoais.

A grande vantagem das operações pela Internet apontada pela Empresa E foi a possibilidade de agregar novas oportunidades ao seu negócio, com redução de custos: alcançar um público novo, do qual a empresa não possuía mailing para atingi-lo, a um custo mais baixo; mais liberdade de criação, com ferramentas não disponíveis para o papel, permitindo ações com mais interatividade, a um custo menor; captar e qualificar nomes em vendas e central de concursos, com atributos, e de maneira mais barata; economizar custos no processo de comunicação/interface com o cliente, em termos de vendas, renovação, e SAC: tratando de problemas por e-mail, reduzem-se os custos de ligações telefônicas, principalmente do 0800; se o cliente faz uma assinatura, ao invés de lhe enviar uma carta de confirmação, a empresa pode lhe enviar um e-mail; ao invés de lhe enviar pelo correio um boleto bancário para cobrança, pode-se enviar um e-mail com o boleto para que ele mesmo o 
imprima. O destaque dado pela Empresa $\mathrm{H}$ às vendas pela Internet enaltece o processo, que é todo automatizado, de alta qualidade, altamente personalizado, muito eficiente, com gestão dos números de forma absoluta. Por este meio, é possível criar uma promoção e colocá-la rapidamente no ar, com métricas sobre o que foi implantado. No mundo físico, são necessários alguns meses para desenvolvimento, comunicação e implantação da promoção.

Algumas empresas enumeraram também vantagens do ponto de vista do cliente, que usufrui da conveniência e comodidade que o meio propicia: compra o que quer, como quer, no local e momento em que desejar, e, muitas vezes, a um preço mais baixo, evitando transtornos como trânsito e dificuldade para estacionar, com segurança e economia de tempo. Além disso, a Internet facilita a escolha do produto: é possível fazer simulações de configuração de produtos como automóveis, por exemplo, e pesquisas em várias lojas em pouco tempo, além de poder se beneficiar de ofertas e oportunidades que surgem com muito mais freqüência que nas lojas físicas. O cliente também consegue comprar com maior rapidez: sem contato com uma pessoa, pode resolver tudo de maneira automatizada. A Empresa B destaca ainda o fato de que, sem intermediários, é preciso muito mais transparência entre a empresa e seus clientes.

\subsubsection{Desvantagens da realização de negócios pela Internet}

Da mesma forma, as empresas apontaram algumas desvantagens em relação ao uso da Internet como meio de realização de negócios, apresentadas no quadro 21. Entretanto, alguns dos aspectos enumerados como desvantagens na realização de negócios pela Internet, na realidade, constituem dificuldades e desafios enfrentados no cenário atual, e não problemas decorrentes da Internet em si, como avalia o entrevistado da Empresa E sobre o fato de existirem poucas pessoas com acesso à Internet hoje: não chega a ser uma desvantagem; talvez seja mais um potencial ainda não explorado. As células contendo o símbolo :) indicam menção do item correspondente pela empresa; as células com o sinal - indicam o contrário.

Quadro 21 - Desvantagens da comercialização de serviços e produtos pela Internet

\begin{tabular}{|c|c|c|c|c|c|c|c|c|}
\hline Desvantagens & A & $\mathrm{B}$ & $\mathrm{C}$ & D & $\mathrm{E}$ & $\mathrm{F}$ & $\mathbf{G}$ & $\mathrm{H}$ \\
\hline Ainda há desconfiança/ insegurança por parte do cliente & - & ;) & (:) & - & - & - & - & (;) \\
\hline Atrito com canal distribuição & - & - & ;) & - & - & - & - & - \\
\hline Baixo volume de transações & ;) & - & - & - & - & (;) & - & - \\
\hline Cultura/ baixa penetração como opção de compra & - & ;) & ;) & - & (;) & - & - & (;) \\
\hline Elementos que fogem ao controle da empresa & - & - & (;) & - & - & - & - & (;) \\
\hline Prejuízo ao contato com o cliente & - & - & - & (;) & - & - & - & - \\
\hline Segurança/ fraudes freqüentes com cartões de crédito & - & - & (;) & - & - & - & (:) & (;) \\
\hline
\end{tabular}

Fonte: dados de campo. 
Para a Empresa A, não se tem ainda o volume suficiente de clientes de comércio eletrônico que se espera para que haja retorno. Para essa empresa, o maior desafio da Internet é a integração entre mundo físico e virtual; é descobrir o quanto o “.com” interfere no movimento da loja física.

A Empresa B, por sua vez, comenta que, se, por um lado, a maior transparência possibilitada pela Internet pode ser considerada uma vantagem para os clientes, para a empresa, a conotação poderá ser diferente, uma vez que a Internet deixa menor margem em termos de erros, exigindo mais da empresa, embora isso não constitua exatamente uma desvantagem. Outro aspecto comentado é o fato de que, apesar de vender diretamente pela Internet, a empresa decidiu manter também quiosques de acesso ao site da empresa nas concessionárias, pois o cliente, mesmo efetuando a compra a partir de sua casa, continua indo à loja para fazer test-drive e esclarecer dúvidas com os vendedores. Ainda existem barreiras, pois a compra de um automóvel é diferente da compra de um CD, cujo cantor e algumas de suas músicas normalmente já são conhecidos pelos clientes. Como o valor envolvido é bem mais alto, a menos que o cliente já conheça o carro, necessita ter um contato prévio com o veículo. Com isso, o contato com o cliente não foi prejudicado: a empresa acredita ainda que teria problemas culturais se o cliente deixasse de ir à concessionária, eliminando o relacionamento pessoal com os vendedores.

A Empresa D reconhece que a Internet é um instrumento de relacionamento mais "frio" e, como tudo o que envolve tecnologia, está mais sujeita a erros ou imperfeições de modelos e de entrada de dados para execução do marketing de relacionamento. Comparando-o a uma consultora, o site está mais sujeito a cumprimentar o cliente pelo seu aniversário numa data errada, ou lembrarlhe do aniversário de um parente já falecido. Outro exemplo de falha comum é partir do pressuposto de que uma pessoa que tenha comprado produtos para bebês no site seja mãe. Embora se possa trabalhar para que as informações sejam mais precisas para minimizar esse tipo de falha, a vida das pessoas evolui e as informações armazenadas sobre os clientes nem sempre acompanham essa evolução. Os efeitos colaterais dessas limitações são gafes e erros terríveis, podendo até mesmo gerar resultados contrários aos esperados em termos de marketing de relacionamento. O entrevistado acrescenta que a Internet não é tão ágil e imediata em relação ao telefone; se o cliente liga, consegue fazer contato na hora, se for pela Internet, será preciso esperar que alguém veja seu e-mail. Embora haja a questão do tato, normalmente bastante valorizado por clientes que compram produtos têxteis, a Empresa $\mathrm{F}$ acredita que o cliente que compra via Internet já conhece os produtos 
da empresa e sua qualidade e que a impossibilidade de toque não é empecilho para a compra de seus produtos por este canal.

Sob outro ângulo, a Empresa H vê com preocupação o fato de que nem todos os elementos da cadeia envolvidos no negócio - mais notadamente fornecedores e parceiros de cobrança - estão totalmente preparados e estruturados para a integração digital; algumas empresas de cartão de crédito ainda utilizam o telefone para confirmação de dados para autorização da compra. Isto passa a ser problemático quando se sabe que mais de $80 \%$ das compras na sua loja eletrônica são feitas por este meio. O financiamento integra uma das suas principais estratégias de marketing e, para isto, a empresa depende largamente das empresas de cartão de crédito, que possuem níveis de interesse distintos. A conscientização está ocorrendo aos poucos. Outro fator que foge ao controle da empresa, levantado pela Empresa C, é a dependência das operadoras de telecomunicações e dos provedores de acesso à Internet: se a Embratel estiver com problemas, a Internet terá um desempenho ruim; se o provedor do cliente estiver fora do ar, ele não terá acesso à compra via Internet. A desvantagem relacionada aos conflitos com o canal será discutida na seção 4.3.6.

\subsubsection{O cliente que compra pela Internet}

As empresas entrevistadas compararam os clientes que compram pela Internet com os clientes de suas lojas físicas. Os resultados dessa análise são apresentados no quadro 22, a seguir. Alguns entrevistados delinearam o perfil de seus compradores ou o perfil do comprador pela Internet, em geral. O símbolo (:) indica as situações mencionadas pela empresa; o mesmo símbolo, em azul claro, indica que aquele aspecto recebeu destaque por parte do entrevistado por caracterizar a maior parcela de seus compradores (Empresas F e G) ou por corresponder à conquista de novos públicos (Empresa E), e o sinal - indica que a situação não foi mencionada.

\footnotetext{
Quadro 22 - O comprador pela Internet
}

\begin{tabular}{|c|c|c|c|c|c|c|c|c|}
\hline O cliente que compra pela Internet & A & B & $\mathrm{C}$ & $\mathrm{D}$ & $E$ & $\mathbf{F}$ & G & $\mathrm{H}$ \\
\hline $\begin{array}{l}\text { É o mesmo cliente da loja tradicional, que ora compra pela Internet, ora } \\
\text { na loja tradicional }\end{array}$ & (;) & ;) & - & ;) & ;) & ;) & ;) & ;) \\
\hline Passou a comprar pela Internet e não compra mais na loja tradicional & - & - & (;) & (;) & (;) & ;) & ;) & - \\
\hline Não era cliente da loja e compra apenas pela Internet & - & - & - & (;) & (;) & (;) & (;) & - \\
\hline $\begin{array}{l}\text { Não era cliente da loja e passou a comprar tanto pela Internet como na } \\
\text { loja tradicional }\end{array}$ & - & - & - & (;) & (;) & - & (:) & - \\
\hline
\end{tabular}

Fonte: dados de campo. 
A Empresa A não vê sua loja virtual como concorrente das lojas físicas; é um canal alternativo da marca existente no mundo físico. Uma das marcas da Empresa A é mais característica de compras por conveniência, é um supermercado de vizinhança; outra marca já é mais direcionada a compras abastecedoras, para o mês todo, com ticket médio maior. Mais de $90 \%$ dos clientes da loja virtual são clientes da loja tradicional. O site não "rouba cliente da loja”; entretanto, ao atrair clientes virtuais com característica de compra abastecedora para a marca que normalmente é associada à compra de conveniência, prospecta clientes que poderiam estar realizando compras desta natureza na concorrência, ou seja, traz para a marca clientes que não teriam a característica daquela marca. O cliente “.com” é um cliente mensal pela Internet: ele compra algumas coisas pela Internet, como a compra abastecedora de mês (já tem sua lista de compras gravada no site), e produtos perecíveis e de conveniência na loja física, pois há custo de entrega e é necessário acessar o site para efetuar a compra.

A Empresa E considera particularmente importantes os clientes captados exclusivamente pela Internet por constituírem parte de um público não atingido, que não recebia nenhuma comunicação da empresa e foi conquistado por uma nova mídia. O entrevistado ainda observa que, quando se coloca um encarte na revista, ele atinge quem já é assinante, com grande facilidade; algumas dessas pessoas migraram para a Internet. Porém, uma vez trazido para a empresa via Internet, ele passa a se relacionar com ela por meio de todos os canais.

A Empresa F especificou o perfil típico de seu cliente: mulher, com mais de 30 anos, casada, que trabalha fora de casa, classes A e B, com nível universitário, filhos e, geralmente, pouco tempo para fazer compras; há, no entanto, uma boa parcela de homens que compram pela Internet, até mesmo jogos de cama de casal. Por outro lado, a Empresa B observa que o perfil do internauta tem uma grande intersecção com o do comprador de automóvel em termos de idade, sexo, nível social e escolaridade. Além disso, normalmente, quem tem condições de comprar um carro 0 km já está mais habituado ao contato com a Internet. É um perfil mais jovem, mas há também pessoas de mais idade. A Empresa D complementa o perfil do comprador pela Internet descrevendo-o com uma brincadeira feita pelo provedor iG, que compara a Internet no Brasil à Bélgica, que tem uma população de 10 milhões de habitantes, majoritariamente das classes sociais A e B, de alto nível de escolaridade, com alto poder aquisitivo. A população que tem acesso à Internet no Brasil beira, atualmente, 15 milhões de pessoas, entre usuários domésticos e corporativos, numa realidade bem diferente do país como um todo. Entretanto, esta situação, segundo o entrevistado, parece estar em 
vias de se alterar, uma vez que a classe $\mathrm{C}$ tem cada vez mais acesso à Internet, e com as mudanças previstas pela Anatel, a realidade de Internet no Brasil poderá se aproximar mais da realidade da sua população em geral. Como não há mídia para a loja digital da Empresa G, os clientes que chegam a ela, sem conhecer a loja física, provavelmente o fazem por meio de algum site de busca. Os clientes que compram apenas pela Internet estão, em sua maioria, localizados em regiões onde não há loja física da empresa, principalmente no Japão, de onde os dekasseguis ${ }^{14}$ compram solicitando entrega lá ou mesmo no Brasil, como presentes em datas especiais como Dia das Mães, Natal etc. A loja atende também a vários clientes em Portugal e EUA, para entrega no Brasil.

Para a Empresa H, o perfil de compra da mulher, cuja participação nas compras pela Internet tem crescido, é muito interessante: quer qualidade, satisfação, emoção na compra, o que demanda um melhor preparo das interações no site. O homem é mais objetivo e mais racional na compra: pesquisa preços, visita sites concorrentes; a mulher, não: se ela se envolve ou se identifica com o contexto do site e gosta da sua mensagem, ela compra, independentemente de comparação de preços. Embora 95\% do público em geral já tenha feito alguma compra na loja física da Empresa $\mathrm{H}$, há diferenças marcantes entre os clientes típicos da loja digital e da loja física. Enquanto o perfil típico da loja digital é masculino, mais jovem, de classe social, renda e nível cultural mais elevado, o público típico da loja física é feminino, de faixa etária um pouco mais alta, renda, classe social e nível cultural mais baixo. A loja digital adquiriu um público com perfil mais qualificado em função de o próprio perfil do pessoal que já comprava pela Internet ser mais diferenciado. Por outro lado, uma vantagem em relação à concorrência é que embora o público que tem mais afinidade com a marca ainda não tenha chegado à Internet, a empresa já é líder em seu setor.

\subsubsection{Considerações Gerais}

Autores como Boone e Kurtz (2001:25) e Churchill e Peter (2000:45) evidenciam a presença da tecnologia como parte importante do ambiente de marketing, o ambiente tecnológico de marketing. Tal importância se reflete nas ações das empresas entrevistadas na medida em que a tecnologia se mostra alvo de várias decisões por parte delas. A mais relevante para este estudo foi a sua decisão de utilizar a Internet como veículo para comercialização de bens ou serviços.

Pelo tempo de atividade em comércio eletrônico informado pelas empresas, nota-se que algumas delas puderam usufruir de um período de maturação entre o início do uso comercial da

\footnotetext{
${ }^{14}$ Dekassegui: imigrante (no caso, brasileiro) no Japão.
} 
Internet, em meados da década de 90, e seu efetivo ingresso nessa operação. No início do comércio eletrônico pela Internet, somente as empresas que possuíam recursos para contratar uma empresa especializada para desenvolver seu site é que implantavam tal operação. Eram, principalmente, start ups, empresas que não existiam em "tijolos-e-argamassa” e que contavam com o entusiasmo e, principalmente, com os recursos das incubadoras para iniciarem seus negócios pela Internet. O ingresso mais "tardio" nessa atividade agregou mais segurança a algumas das empresas pesquisadas, uma vez que muitas das dificuldades existentes, como logística de entrega, têm sido gradativamente superadas. As empresas que integram este estudo passaram pelo boom (aceleração) e pela bolha (desaceleração) da Internet. Algumas fizeram história; outras, mais cautelosas e com escassez de recursos, aguardaram o melhor momento para ingressar nesse canal; outras, ainda, simplesmente não tiveram escolha, pressionadas pela concorrência ou por seus clientes. A maioria dos entrevistados participou do projeto de comércio eletrônico em suas respectivas empresas desde o seu início, designados internamente ou contratados especialmente para este fim. Hoje essas empresas desfrutam de certo conforto para falar de suas operações pela Internet e não se constrangem em declarar que ainda estão em fase de aprendizado, crescimento e amadurecimento, mesmo em se tratando de empresas de grande porte. Há sites que oferecem ainda poucos recursos, proporcionando apenas o suficiente para viabilizar trocas comerciais pela Internet; outros, mais arrojados, além de oferecer serviços extras a seus clientes, realizam intensa coleta de dados, pesquisas de opinião, análises sobre a navegação do visitante etc.

Em relação ao posicionamento das empresas nas Fases da Internet, segundo visão de Kosiur, pôde-se captar em alguns depoimentos, talvez de empresas mais críticas ou realistas, certo receio de não se classificar ainda na fase de Integração, embora algumas o tenham feito, com ressalvas. O grande desconforto nessa atitude parece ter sido a expressão "automatização quase que total dos processos da empresa”, que envolvia também o relacionamento com fornecedores. A integração é parcial e, muitas vezes, não depende apenas da empresa. Ainda sobre este modelo, foi interessante a observação feita por um dos entrevistados a respeito da omissão do emprego da Internet como mídia, talvez não tão evidente em 1997, quando Kosiur o elaborou. Na proposta de Sterne (2000), embora se note um crescente acúmulo de atributos, não se vê a divisão em fases por ele desenvolvida como uma seqüência obrigatória de estágios, pois se acredita que a caracterização de um determinado site como pertencente a uma ou outra categoria apenas reflita as escolhas e adequações da empresa condizentes com os objetivos desse site. 
Em relação às vantagens proporcionadas pelo comércio eletrônico, o item mais lembrado foi a coleta e gerenciamento de informações sobre clientes, o que sugere a identificação de oportunidades para o relacionamento ou, mais especificamente, para o CRM; logo a seguir, está a redução de custos operacionais, a qual torna muito atraente esta forma de realizar negócios, a melhoria da comunicação com os clientes, fundamental para o relacionamento com os mesmos, e a penetração em um novo mercado, relevante em termos estratégicos. Os entrevistados se colocaram também na posição de clientes pela Internet, mencionando os aspectos vantajosos sob este ponto de vista. Quanto às desvantagens citadas pelas empresas, muitas delas parecem constituir, efetivamente, dificuldades decorrentes de uma realidade em transformação, as quais, com a evolução dos negócios, podem ser superadas com mais tranqüilidade, como a desconfiança e os aspectos culturais dos clientes, e o baixo volume de transações; questões como o atrito com o canal de distribuição e a falta de agilidade na resposta ao cliente devem ser alvos de esforços das empresas para a sua solução. Talvez as reais desvantagens estejam nos elementos que fogem ao controle da organização, ou sobre os quais pouco se tem influência. Podem-se citar como exemplo a ausência de incentivos do governo para financiamento de microcomputadores, o que dificulta o acesso de classes de renda mais baixa à Internet, e as características inerentes a essa tecnologia, como a ausência de contato pessoal direto, que torna o relacionamento mais "frio", a dependência da acurácia dos dados informados ao sistema e das regras nele definidas, que podem não corresponder sempre à realidade, a dependência de provedores de acesso e das operadoras de telecomunicações, entre outros, que devem igualmente ser contornados ou minimizados pela empresa.

Uma pesquisa dedicada a avaliar os determinantes do comportamento dos consumidores nas compras via Internet verificou que internautas experientes e com pouca disponibilidade de tempo seriam mais propensos a realizar compras online (Bellman et al., 1999, in Dholakia e Bagozzi, 2001:189). Esse fato também se verifica nas declarações dos entrevistados, que evidenciaram a utilização da Internet por seus clientes como fator de economia de tempo, canal preferido principalmente nas situações em que já sabem o que desejam comprar: uma lista de compras habituais já gravada, um automóvel já conhecido, vôos e destinos, cosméticos de uso freqüente, peças de jogos de cama, mesa e banho, livros, CDs, aparelhos eletro-eletrônicos. Alguns dos aspectos motivadores identificados por outra pesquisa (Boone e Kurtz, 2001:129) foram mencionados pelas empresas entrevistadas como vantagens para os clientes nas compras pela Internet: economia, conveniência, melhor seleção e a eliminação do contato com aglomerações de clientes e vendedores. Em relação aos fatores desestimuladores da compra online, o aspecto mais 
lembrado na pesquisa de Boone e Kurtz foi a privacidade/segurança, que corresponde a dois dos itens considerados pelas empresas entrevistadas como desvantajosos para comercialização de serviços/produtos pela Internet: a desconfiança/ insegurança por parte do cliente e as fraudes com cartões de crédito. Esta convergência entre os aspectos motivadores ou desestimuladores de compras pela Internet e as declarações das empresas pesquisadas em relação a vantagens e desvantagens das vendas online dão sinais de que as empresas têm noção de seus pontos fortes e dos que precisam ser mais trabalhados, relativamente ao sentimento dos clientes sobre as compras pela Internet.

Conforme análise da maior parte das empresas entrevistadas, não houve uma migração em massa de clientes dos canais tradicionais para a Internet: o cliente internauta é, em sua maioria, cliente da loja tradicional, que alterna seus canais de compra. Uma vez familiarizado com a marca no mundo físico, este se sente mais confortável em comprar da mesma marca na Internet, segundo suas necessidades de conveniência, preço e prazo de entrega. Outro aspecto bastante interessante é a conquista de clientes que compram apenas pela Internet, um grupo que não era atendido pela loja física e passou a relacionar-se com a empresa exclusivamente por meio eletrônico. E mais curiosa ainda, embora com menor incidência, é a aquisição de clientes que compravam inicialmente pela Internet, não eram atingidos por outros meios, e passaram a ser clientes também da loja física. Estas situações podem ser influenciadas por uma série de fatores, dentre os quais a natureza do produto e complexidade na escolha (é preferível tocar, provar, ver ou sentir o aroma do produto antes de adquiri-lo?); grau de urgência em ter o produto em mãos; despesa com frete (para pequenos valores, pode não ser vantajoso adquirir o produto pela Internet); comodidade, conveniência. Observa-se também que as empresas estão atentas ao perfil de seus clientes pela Internet, avaliando-os como mais exigentes e de perfil socioeconômico mais elevado, embora vislumbrem perspectivas de maior inclusão da classe C no médio prazo.

\subsection{Impactos sobre o Marketing de Relacionamento verificados pela introdução da Internet como intermediadora das atividades de comércio na empresa}

Tendo tomado contato com as características das empresas em relação às suas práticas de marketing e também sobre seu posicionamento frente à Internet, neste bloco, foram explorados os impactos causados pela Internet sobre as práticas de marketing de relacionamento das empresas e as reações decorrentes destes impactos. 


\subsubsection{Vendas pela Internet}

Todas as empresas afirmaram que o percentual de vendas pela Internet, em relação às vendas totais da empresa, têm mostrado tendência crescente. As Empresas A e C não divulgaram o percentual atual de vendas pela Internet em relação ao total de vendas da empresa. A Empresa A justificou esta ocultação com o fato de ainda não se encontrar em seu estágio de maturidade, revelando apenas que a média é de 35 mil compras/mês pelo site; a Empresa $\mathrm{C}$ alegou motivos estratégicos. As respostas das demais empresas encontram-se na tabela 3, a seguir.

Tabela 3 - Percentual de vendas pela Internet em relação às vendas totais da empresa

\begin{tabular}{c|c|c|c|c|c|c|c}
\hline $\mathbf{A}$ & $\mathbf{B}$ & $\mathbf{C}$ & $\mathbf{D}$ & $\mathbf{E}$ & $\mathbf{F}$ & $\mathbf{G}$ & $\mathbf{H}$ \\
\hline- & $25 \sim 30 \%$ & - & $1 \%$ & $25 \%$ & $10 \%$ & $3 \%$ & $12 \%$ \\
\hline
\end{tabular}

Fonte: dados de campo.

As Empresas A, D, E e G julgam que este percentual tende a crescer, porém acreditam que as vendas pelos canais tradicionais continuem superiores às vendas pela Internet. As perspectivas de cada uma dessas empresas estão sintetizadas no quadro 23:

Quadro 23 - Visão das empresas sobre o crescimento das vendas eletrônicas

\begin{tabular}{c|l|l|l|l}
\hline Empresas & \multicolumn{1}{|c|}{ A } & \multicolumn{1}{c|}{ D } & E & G \\
\hline $\begin{array}{c}\text { Vendas pela } \\
\text { Internet }\end{array}$ & $\begin{array}{l}\text { Crescerão, porém } \\
\text { num ritmo mais lento }\end{array}$ & $\begin{array}{l}\text { Continuarão crescendo mais } \\
\text { que as dos canais tradicionais }\end{array}$ & $\begin{array}{l}\text { Terão um leve } \\
\text { crescimento }\end{array}$ & $\begin{array}{l}\text { Terão um leve } \\
\text { crescimento }\end{array}$ \\
\hline
\end{tabular}

Fonte: dados de campo.

A Empresa A acredita que as vendas pela Internet nunca crescerão a taxas tão altas quanto no seu início; a idéia de que a Internet vai tomar o espaço do mundo físico é um mito. A Empresa E acredita já ter chegado a um volume muito representativo; para crescer mais que isso, seria necessário que a Internet no Brasil crescesse mais, que existissem mais internautas e que estes passassem a comprar cada vez mais. Já há quase seis meses, o percentual de $25 \%$ das vendas de novas assinaturas realizadas pela Internet (não considerando renovações) se mantém estável na Empresa E; este número é bastante expressivo, se comparado aos cerca de 13\% do início de 2002. Hoje, a Internet é o segundo maior canal de vendas de assinaturas da empresa, sendo superado, ainda, pelo marketing direto. Embora avalie ser possível alcançar 30\% de vendas pela Internet em relação às suas vendas totais, não acredita que este índice vá muito além, nas atuais condições. Para que isto ocorra, talvez dependa mais de fatores externos que de fatores internos. Hoje, o crescimento de vendas da Empresa G pela Internet se dá a uma taxa média de 20\% ao ano; contudo, 
a empresa não acredita que estas superem as vendas das lojas físicas: aos sábados, chegam a passar pelos terminais de PDV, nas três lojas, 4500 pessoas.

A Empresa F acredita que a proporção de vendas pela Internet em relação às vendas totais não se alterará; por se tratar de um produto que as pessoas preferem tocar antes de adquirir, as vendas das lojas físicas serão sempre superiores às vendas eletrônicas, que atingiram o ponto de equilíbrio em seu $4^{\circ}$ mês de atividade.

As Empresas B, C e H acreditam que a proporção seja alterada, sendo que as vendas pela Internet devam ser superiores às vendas pelos canais tradicionais. Embora não se tenha ainda como objetivo instituído na Empresa B a comercialização de todos os modelos pela Internet - trata-se de uma questão que está sendo resolvida ainda no plano estratégico -, a tendência é de que o desempenho por este canal seja cada vez melhor. A Empresa C pondera que os conflitos com os canais ainda são uma questão bastante delicada a ser resolvida, o que talvez retarde um pouco a inversão da relação. Da mesma forma, na Empresa $H$, espera-se que as vendas pela loja virtual sejam superiores às vendas das lojas físicas, ainda que isso leve algum tempo. As vendas nas cerca de 100 lojas físicas estão estagnadas há sete anos; com a retirada dos módulos de supermercados, as vendas diminuíram, embora o fluxo diário estimado nas lojas físicas seja de um milhão de pessoas. Entretanto, as vendas pela Internet seriam ampliadas drasticamente se a empresa comprasse alguns players. A empresa afirmou que o seu percentual de vendas eletrônicas, no Natal de 2002, foi de 20 a 50\% acima da concorrência.

\subsubsection{Impactos da Internet sobre o negócio da empresa}

As empresas analisaram os efeitos da Internet sobre alguns aspectos de seu negócio, cujos resultados, apresentados no quadro 24, são comentados a seguir. A maior parte das empresas não quis revelar números sobre esses impactos.

Quadro 24 - Variações observadas no negócio da empresa após adoção das vendas pela Internet

\begin{tabular}{|c|c|c|c|c|c|c|c|c|}
\hline Variações & $A$ & B & $\mathrm{C}$ & D & $\bar{E}$ & $\mathbf{F}$ & $\mathbf{G}$ & $\mathrm{H}$ \\
\hline No faturamento da empresa & 1 & 1* & 1* & 수 & 1 & $\stackrel{\leftrightarrow 4}{\rightarrow} *$ & 1 & $\boldsymbol{1}$ \\
\hline No número de clientes & 1 & 1* & 1* & 1 & 1 & $\boldsymbol{1}$ & 1 & 1 \\
\hline Nos segmentos atingidos & 1 & 1* $*$ & $\stackrel{\stackrel{\leftarrow}{\rightarrow}}{\rightarrow}$ & 1 & $\boldsymbol{1}$ & $\boldsymbol{1}$ & 1 & $\boldsymbol{1}$ \\
\hline Nos custos de transação & 7 & - & 7 & 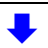 & 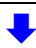 & $\stackrel{\leftarrow \leftarrow}{\rightarrow 1}$ & 7 & 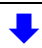 \\
\hline
\end{tabular}

* não se pode afirmar com certeza que tenha ocorrido em função da Internet Fonte: dados de campo.

\section{Legenda:}

: Aumento

: Redução $\stackrel{\leftrightarrow}{\rightarrow}$ : Manteve-se estável $\quad$ - : A empresa não quis comentar 


\section{- Variações no faturamento da empresa}

A Empresa A planeja investimentos maiores para 2003, em termos estratégicos, o que sinaliza que a Internet é um elemento interessante para os negócios da empresa, que se sente confortável em relação a este canal.

As Empresas B, C e F fazem uma ressalva quanto à sua afirmação de diferenças em seu faturamento, pois não têm condições de afirmar que tais resultados se devam à adoção da Internet como meio de comercialização de produtos e serviços. Na Empresa B, o projeto piloto de comércio eletrônico contou com um modelo novo, popular, com bastante procura, e que era vendido pela Internet. Não se pode estabelecer uma relação de causa e efeito entre a comercialização pela Internet e o incremento das vendas, pois ambos ocorreram simultaneamente. Da mesma forma, a Empresa C teve seu faturamento aumentado, mas não em função da Internet, que lhe permitiu, principalmente, oferecer mais serviços ao cliente do programa de fidelidade, como consultas ao seu extrato de pontos. A Empresa F, considerou que seu faturamento se manteve estável, pois houve aumento, mas não necessariamente em função da Internet.

Praticamente $100 \%$ das vendas pela Internet da Empresa D representam aumento no seu faturamento, pois, em geral, são provenientes de pessoas ainda não atendidas pelos canais tradicionais; pessoas bem atendidas ainda não migraram para as compras pela Internet.

Na Empresa E, de maneira geral, cerca de 2/3 do aumento no faturamento é incremental, e 1/3 representa uma migração de outros canais. Constitui uma substituição saudável, pois é feita a um custo menor; entretanto, os referenciais são dinâmicos e difíceis de serem medidos. Essa estimativa tem por base o fato de que cerca de 2/3 dos assinantes que compram pela Internet são novos para a empresa, e não seriam atingidos por outro canal; a fração de $1 / 3$ restante tem potencial de ser atingido por outros canais, ou seja, se a empresa parasse de vender pela Internet, apenas 1/3 continuaria comprando pelos canais tradicionais. Talvez uma parte deste grupo seja incremental, e também não fosse atingida por outros canais por eles terem um custo mais alto, e não serem acionados com tanta freqüência como a Internet. Como as ações pela Internet têm custo menor, a empresa consegue realizar muito mais ações por este meio comparativamente aos demais canais.

A Empresa G vendia pela Internet para o Rio de Janeiro; a partir do momento em que inaugurou uma loja naquela cidade, as vendas pela Internet para aquela localidade aumentaram, devido ao fato de que a marca se tornou mais notória. Ressalte-se também que há clientes que 
pesquisam na Internet e se dirigem até a loja física, que também sofreu uma alavancagem de vendas em função da Internet. Dessa forma, um canal alavanca o outro.

\section{- Variações no número de clientes}

A Empresa A teve um aumento significativo no número de clientes, contando hoje com uma base cadastrada de 300 mil pessoas que já compraram pela Internet, desde o início de suas atividades por esse canal. Quando suas vendas ainda eram feitas com base no CD-ROM, pelo 0800, no início da criação da operação pelo site, a proporção era de $10 \%$ de pedidos pelo site e $90 \%$ pelo 0800. Com a evolução da operação pela Internet, esta proporção se inverteu, sendo mais de 70\% pelo site e o restante pelo 0800. Para a empresa, as despesas são menores com as vendas pela Internet, pois não há despesa de ligação.

A Empresa B observou um aumento em sua base de clientes; no entanto, novamente, não soube informar quanto se deveu ao produto e quanto se deveu ao canal. Da mesma forma, o acréscimo verificado pela Empresa $C$ em sua carteira de clientes não ocorreu apenas em função da Internet. A Empresa D agregou clientes à sua base com as vendas pela Internet, mas em menor grau. Em geral, o comprador pela Internet já foi cliente um dia, mas deixou de ser atendido por uma consultora, por perda de contato causada por mudança de endereço ou por outros motivos. A Empresa E avaliou em 2/3 o aumento da sua base de clientes, e a Empresa F estimou um aumento de 20\% em sua carteira de clientes, em função das vendas pela Internet. A Empresa H afirma que, embora pelas suas lojas físicas passem cerca de um milhão de clientes por dia e na loja virtual, no mês de dezembro de 2002, tenham passado três milhões de pessoas, houve um acréscimo real na carteira de clientes pois o público atingido é diferenciado.

\section{- Variações nos segmentos atingidos}

As Empresas A, D, E e H obtiveram conquistas em termos de segmentos atingidos no que se refere ao alcance de outros perfis de clientes, distintos do perfil habitual de sua empresa. $\mathrm{O}$ aumento de segmentos atingidos pela Empresa $\mathrm{G}$ se deu principalmente em termos geográficos. Na Empresa A, o público típico de sua marca física de compras por conveniência é mais voltado a alimentos, feminino, com mais de 25 anos de idade, das classes sociais A e B; a marca de hipermercados é a preferida das compras de produtos eletrônicos e de informática, com público tipicamente masculino e maior participação da classe C. O perfil do cliente do site engloba ambos os perfis. A classe C tem tido acesso crescente à Internet, com maior popularização e mais linhas de financiamento dos 
microcomputadores e mais facilidade de pagamentos pela Internet que pelo mundo físico. Sendo a população brasileira composta por muito mais pessoas da classe C que das classes A e B, no futuro, a empresa pretende direcionar maior foco a esta parcela da sociedade, um grande grupo de clientes em potencial. Embora os canais tradicionais de venda da Empresa D atendam também a um público de alta renda, a empresa consegue, pela Internet, melhor penetração junto a esse público mais seleto; a Internet é diferenciada neste sentido. Da mesma forma, a Empresa E observou o incremento de novos assinantes à sua base de dados, pertencentes a segmentos não atingidos pelos canais tradicionais. Com as vendas pela Internet, a Empresa H também conquistou um público mais diferenciado, com maior penetração de mercado.

A Empresa B constatou o aumento de segmentos atingidos, porém, mais uma vez, tem dificuldade em estabelecer relações de causa e efeito e aferir a parcela de responsabilidade da Internet. Na Empresa C o número de segmentos atendidos se manteve estável, pois houve, na realidade, uma transferência de canal.

\section{- Variações nos custos de transação}

A Empresa A afirma que, dependendo da operação, quanto maior a escala, menores os custos de transação. No entanto, como possui frota própria para garantir a entrega e um processo de picking próprio, quanto maior o volume, maior deve ser esta estrutura. Assim, é preciso uma boa administração para que se consigam manter as margens.

Nas Empresas C, D e G, houve diminuição de custos e alguns ainda estão em processo de redução; já nas Empresas E e H, notou-se redução considerável nos custos, que estão muito mais baixos em comparação às operações tradicionais. Na Empresa F, os custos mantiveram-se estáveis.

\subsubsection{Posição estratégica das empresas}

As empresas comentaram alguns aspectos proporcionados pela Internet que poderiam favorecer ou prejudicar a sua posição estratégica. A Empresa $\mathrm{H}$ preferiu não se pronunciar a respeito deste assunto.

\section{- Oportunidades proporcionadas pela Internet}

A Empresa A se preocupa muito com sua imagem perante seus clientes; e as vendas pela Internet agregam modernidade à marca, uma das poucas no Brasil a oferecer este diferencial no 
ramo de varejo de alimentos. Possivelmente, o alcance deste status de modernidade consumiria muito mais tempo e recursos por outros meios.

Do mesmo modo, a Internet proporcionou à Empresa B uma forte imagem de liderança, ao lhe possibilitar o desenvolvimento de várias inovações. Foi a primeira montadora a vender pela Internet, a primeira a vender a preço único nacional, com frete incluído. Foi a primeira, e talvez ainda continue sendo, a única montadora a ter centros de distribuição em outras regiões, e a realizar vendas diretas em massa. No nordeste do país, estes procedimentos geraram aumento das vendas, pois os clientes daquela região estavam habituados a pagar mais, em função da maior distância dos centros produtivos. Com a aquisição dessa imagem de inovação em termos de tecnologia, de conceitos e de processos de negócios, a empresa causou uma revolução na indústria automobilística. A concorrência teve que segui-la, a começar pela questão do frete incluso. Por se tratar de uma subsidiária brasileira de uma grande multinacional, a Empresa B aparenta contar com uma boa estrutura para desenvolvimento de seus programas e o sucesso desse empreendimento possibilitoulhe firmar uma imagem extremamente positiva, ampliando-se o respeito por parte das demais unidades mundiais em relação a ela.

A Empresa C vislumbra melhoras no sistema de integração B2B com seus fornecedores e, também, no futuro, com as agências.

A Empresa D destaca as oportunidades de atender a um público ainda não servido pelos canais tradicionais, de reduzir custos no processo, principalmente os relacionados ao canal de vendas e de utilizar a Internet como mídia segmentada, a um custo mais baixo.

A Empresa E também ressalta as oportunidades de se atingirem prospects que não seriam atingidos por outros canais de venda e de aumentar o espectro de prospects. Sempre fizeram parte do seu planejamento estratégico ações que visassem à oxigenação, ou seja, à conquista de clientes novos, que nunca haviam sido assinantes de publicações da casa. A Internet é um canal com grande oxigenação; por meio dela, foi possível suprir uma ansiedade estratégica da empresa.

Uma oportunidade vislumbrada pela Empresa F com o avanço das operações pela Internet é a expansão dos negócios da empresa pelo surgimento de franquias em outras localidades, uma vez que a marca se torna mais conhecida. 
A Empresa $G$ destaca como oportunidade a conquista de notoriedade cada vez maior da empresa, uma vez que ela não faz propaganda pelas mídias tradicionais, e, em contrapartida, o aumento das vendas nas lojas físicas para clientes que têm seu primeiro contato com a empresa pela Internet por sites de busca, como ocorreu, por exemplo, no Rio de Janeiro.

\section{- Ameaças ocasionadas pela Internet}

A única ameaça apontada pela Empresa A surgiria apenas se a sua operação pela Internet prestasse um serviço sem excelência de qualidade, que prejudicasse a imagem da marca também no mundo físico; se um cliente fosse mal atendido em suas compras pelo site, transferiria a má impressão para a loja física. Com as preocupações e cuidados tomados pela empresa em relação ao marketing de relacionamento, desde o início de suas operações, esta ameaça não tem fundamento.

Similarmente, na Empresa B, embora isto faça parte das atribuições da empresa, a ameaça surgiria se os processos não fossem realizados corretamente e com atenção, pois quase não há margem para erros; há maior transparência e mais informações para o cliente que, por sua vez, tem um perfil mais exigente. Os problemas e os atrasos ficam mais evidentes para ele do que nas compras diretamente da concessionária. Além disso, a empresa se torna muito dependente da tecnologia; caso o site saia do ar, a empresa não vende: é como se a loja estivesse fechada.

As Empresas D e G avaliam que as operações pela Internet são vulneráveis a ações fraudulentas, principalmente nas compras com cartão de crédito, tendo sido alvo de alto volume de ocorrências, e as invasões de hackers, que podem prejudicar toda a notoriedade conquistada pela empresa. Outra ameaça ressaltada pela Empresa D é a perda da medida entre o que a automatização pode fazer pela empresa e até que ponto isso é benéfico: alguns processos devem permanecer, necessariamente, offline, a fim de se precaver contra prejuízos no relacionamento com clientes.

A Empresa E não vislumbra ameaças graves, nem no sentido de que a concorrência poderia copiar suas estratégias, pois isto também seria possível nas mídias tradicionais. Não acredita que a empresa tenha se exposto ou se arriscado mais efetuando negócios pela Internet.

Os produtos da Empresa F têm características peculiares: não são muito pesados, porém, são volumosos, o que gera uma dificuldade extra: os custos de frete, dependendo da localidade de entrega, são iguais ou até maiores que o preço do produto, inviabilizando algumas remessas. Várias alternativas estão em análise para que esta questão seja resolvida o quanto antes, pois representa um empecilho para a expansão geográfica dos negócios da empresa. 


\subsubsection{Impactos da Internet sobre o marketing de relacionamento}

Neste tópico, as empresas revelaram os impactos causados pela Internet sobre suas práticas de marketing de relacionamento. Em função de a Empresa H não possuir histórico anterior nesse tema, não faz sentido analisar os impactos da Internet sobre o marketing de relacionamento, daí a ausência de seu depoimento em alguns itens. Entretanto, sua experiência pôde trazer contribuições para este estudo na medida em que, como a empresa foi criada como uma organização independente da sua loja física, muitas funções e processos foram planejados considerando o relacionamento e as peculiaridades das vendas pela Internet. Essa empresa declarou que o fato de tudo ser novo tem sido importante para os seus resultados e tal planejamento pode, de certo modo, equiparar-se às implicações ocasionadas pelos impactos provocados pela Internet relatadas pelas outras empresas entrevistadas.

\section{- Estrutura organizacional}

As empresas avaliaram sua estrutura organizacional como insuficiente ou inadequada em termos de departamentos, cargos e processos, para manter o marketing de relacionamento ativo também nas vendas pela Internet.

\section{- Perfil de pessoal}

As empresas detectaram a necessidade de mudanças no perfil de pessoal, mas majoritariamente em função da necessidade de adaptação à nova situação de negócios, e não de novas contratações por insuficiência de quadro.

\section{- Formas de interação e de relacionamento com os clientes}

A Empresas A e B afirmaram que a Internet é um canal que fornece mais informações e possibilita conhecer com mais detalhes o comportamento, hábitos e estilo do cliente, como por exemplo, quais links ele acessa, como ele navega entre as páginas. A Empresa A acrescenta, no entanto, que ainda é um desafio analisar e compreender o comportamento do mesmo cliente na loja e no site. As Empresas C e D ressaltam que a comunicação com o cliente é facilitada pela Internet, principalmente pelo e-mail, e o grau de personalização tende a ser maior que o de outros meios. A Empresa C destaca ainda que a Internet possibilita o aprimoramento das informações de cadastro e o envio de promoções. 


\section{- Benefícios oferecidos aos clientes}

Em relação aos benefícios oferecidos aos clientes, os impactos se traduziram no surgimento de oportunidades de prestação de serviços adicionais, fornecimento de descontos, prazos de entrega mais curtos, maior tempo disponível para compras, e fornecimento de informações em maior volume e com maior rapidez.

\section{- Estrutura tecnológica}

As empresas pesquisadas verificaram a necessidade de várias mudanças em termos de estrutura tecnológica, não tanto em função do relacionamento, mas primordialmente, para dar condições de funcionamento à sua nova operação. As Empresas A, B, F e H por exemplo, utilizamse de serviços de terceiros para hospedagem de seu site.

A Empresa B passou por uma grande mudança em termos de estrutura tecnológica. Atualmente, seu site é hospedado numa multinacional do ramo de informática, e a parte de vendas, na matriz dessa mesma empresa, nos EUA. A decisão por esta configuração foi tomada em função de se tratar de um projeto-piloto global, com utilização de ferramentas globais, com inúmeras pessoas observando e acompanhando o processo; era preciso ter uma estrutura "de guerra” para isto. Como o site da matriz americana, já com estrutura “de guerra”, estava hospedado nos EUA, o site da Empresa B, voltado para vendas no Brasil, com protótipo brasileiro, em português, também ficou sendo hospedado lá.

A Empresa C declarou que foram poucas as mudanças, sem grandes impactos para a empresa, dado que já possuía um programa de relacionamento com seus clientes bastante consolidado. Já na Empresa D, novas ferramentas foram desenvolvidas, com provisão do treinamento necessário e conseqüente mudança no perfil dos profissionais envolvidos, com muitos impactos na empresa.

Da mesma forma, na Empresa E, foi necessário construir toda uma plataforma sistêmica para dar suporte ao negócio, principalmente em termos de relacionamento, que envolve uma maior complexidade. O sistema legado - sistema já existente na empresa - , que administra as assinaturas, está hospedado em mainframe (computador de grande porte), exigindo que se desenvolvesse um banco de dados em plataforma baixa ${ }^{15}$ e um sistema online para que as transações pudessem ser processadas entre os dois ambientes. $\mathrm{O}$ atendimento online permite a interação do próprio cliente

\footnotetext{
${ }^{15}$ Plataforma baixa: estrutura composta por microcomputadores, em contraposição ao mainframe.
} 
com o sistema, acessando informações sobre suas assinaturas, solicitando assinaturas adicionais, e expressando suas opiniões, críticas e reclamações. Tudo isso envolveu um grande investimento, com a vantagem de que, uma vez montada a estrutura de base, os projetos referentes a relacionamento poderão ser desenvolvidos sem maiores dificuldades.

A Empresa F também necessitou efetuar várias mudanças em sua estrutura tecnológica a fim de que seu site, também hospedado em empresa terceirizada, pudesse realizar vendas. Na Empresa $\mathrm{G}$, as alterações foram relacionadas ao aumento de $\operatorname{links}^{16}$, servidores de rede e firewalls ${ }^{17}$. A hospedagem do site ocorre na própria sede administrativa da empresa no Brasil. A Empresa $\mathrm{H}$ montou uma estrutura totalmente nova e independente para as vendas pela Internet, com hospedagem terceirizada, e está migrando para o sistema de collocation, em que a empresa fornece os equipamentos para que um terceiro administre.

\section{- Funcionalidade das operações}

O maior impacto em termos de funcionalidade das operações causado pela Internet ocorreu na entrega do produto, anteriormente retirado nas próprias lojas ou junto a intermediários. Excetuandose a Empresa E, que já entregava seus produtos em domicílio, as demais empresas detectaram a necessidade de modificações em seus processos de separação e remessa de produtos. Embora o negócio da Empresa C não forneça um produto físico, ela vislumbrou na Internet a possibilidade de facilitar a eliminação do bilhete aéreo, processo que já estava em andamento. A necessidade de mudanças nas operações tornou inevitável às empresas a reconsideração do seu relacionamento com os canais de distribuição. Além disso, em algumas empresas, verificou-se a necessidade/ oportunidade de aceitação de outros meios de pagamento.

\section{- Outros impactos}

A Empresa E observa que a Internet lhe permite praticar marketing de relacionamento independentemente das políticas definidas pela Gerência de Relacionamento, com mais intensidade e eficiência, a um custo menor. É possível, por exemplo, enviar um extrato semanal informando aos clientes que possuem e-mail cadastrado junto à empresa a sua situação no programa de relacionamento; por carta remetida pelos correios, isto seria inviável em termos de custos. Na

\footnotetext{
${ }^{16}$ Link: ligação, conexão; canal de comunicação; banda/velocidade disponível.

${ }^{17}$ Firewall: recursos de hardware e software destinados, essencialmente, a proteger a estrutura de Internet da empresa contra invasões de hackers.
} 
Internet, as informações também podem estar disponíveis online, no site da empresa; pelos canais tradicionais, o assinante teria que ligar, entrar em contato com o call center. É possível disparar muito mais ações a qualquer hora do dia e trabalhar com interatividade; o cliente também pode acessar o site da empresa a qualquer momento.

A decisão de algumas empresas de praticar comércio eletrônico via Internet também causou impactos ao relacionamento com seus canais de distribuição, cujo efeito será detalhado na seção seguinte.

\subsubsection{Implicações para as empresas da nova situação configurada pela Internet}

Os impactos causados pela Internet às empresas suscitaram algumas reações por parte destas com repercussão sobre o marketing de relacionamento, sintetizadas no quadro 25 e comentadas a seguir. As células com $(;)$ indicam que o item correspondente foi alvo de ações da empresa; o símbolo - indica o contrário; e o símbolo 8 indica planos futuros para o aspecto em questão.

Quadro 25 - Implicações decorrentes dos impactos da Internet sobre aspectos do marketing de relacionamento

\begin{tabular}{|c|c|c|c|c|c|c|c|c|}
\hline Reações & A & B & C & D & $E$ & $\mathbf{F}$ & $\mathbf{G}$ & $\mathrm{H}$ \\
\hline Estrutura organizacional & ;) & ;) & ;) & ;: & ;) & ;: & ;:) & (;) \\
\hline Perfil de pessoal & ;) & - & ;) & ;:) & - & ;:) & ;:) & ;) \\
\hline Mudanças na abordagem nas relações com clientes & ;) & ;) & ;) & ;) & ;) & (:) & ;) & (:) \\
\hline Mudança nos canais de comunicação empresa-clientes & ;) & ;) & ;) & ;) & ;) & - & ;) & (:) \\
\hline $\begin{array}{l}\text { Alterações na busca sistemática de informações sobre desejos } \\
\text { e necessidades satisfeitos/não satisfeitos, declarados/ocultos }\end{array}$ & ;) & ;) & ;) & (:) & ;) & (:) & ;:) & ;) \\
\hline Alterações no tratamento de sugestões, críticas e reclamações & - & ;) & ;) & ;) & - & ;) & - & (:) \\
\hline Modificações no conjunto de benefícios ofertados & $+;$ & ;) & ;) & (:) & - & - & - & (:) \\
\hline Criação de programas de lealdade & ;) & - & ;) & 8 & ;) & 8 & ;) & (:) \\
\hline Criação de políticas de privacidade & ;) & ;) & ;) & ;) & ;:) & ;) & ;:) & (;) \\
\hline Forma de coleta de dados e tipos de dados coletados & ;) & - & ;) & ;) & ;:) & (:) & ;:) & ;) \\
\hline Gerenciamento e análise dos dados coletados sobre os clientes & ;) & - & ;) & ;) & ;) & ;) & ;) & (:) \\
\hline Oferecimento de produtos ou serviços personalizados & ;) & ;) & ;) & ;) & - & ;) & ;) & (); \\
\hline Alterações no desenho e funcionamento do site & ;) & ;) & ;) & ;) & ;) & (:) & ;) & (): \\
\hline Formas de o cliente obter informações sobre o seu pedido & ;) & ;) & - & ;) & ;) & (:) & ;) & (:) \\
\hline Novos procedimentos operacionais de vendas & - & ;) & ;) & ;) & - & ;) & ;) & (;) \\
\hline $\begin{array}{l}\text { Diferenciação de tratamento entre clientes que compram pela } \\
\text { Internet e os que compram pelos meios tradicionais }\end{array}$ & (:) & (:) & ;) & (:) & - & (:) & ;) & ;) \\
\hline Alterações políticas investimento em tecnologia de informação & ;) & ;) & - & - & - & - & - & (:) \\
\hline
\end{tabular}

Fonte: dados de campo. 


\section{- Estrutura organizacional}

Algumas empresas fizeram apenas adaptações em sua estrutura pré-existente, como as Empresas A e G; outras, criaram novas áreas de operação do comércio eletrônico ou de apoio a ele, como as Empresas B, C, D, F e H; a Empresa E sofreu redução de estrutura.

A Empresa A realizou mudanças para adequação ao comércio eletrônico, uma vez que o marketing de relacionamento é pulverizado, ou seja, todas as marcas têm responsabilidade sobre este assunto. Inicialmente foi criada uma Unidade de Negócios Comércio Eletrônico, mas há uma mudança de estrutura em curso: cada marca terá sua própria estrutura de comércio eletrônico, assim como ocorre com o seu SAC, que designou um grupo para cada Unidade de Negócios. Assim, se uma determinada marca de supermercados vende pela Internet, haverá um pessoal, na estrutura da marca, responsável pelos relacionamentos por este meio, pois as vendas são consideradas uma atividade multicanal. Há previsão de criação de uma nova diretoria de Internet; entretanto, a área de e-Commerce de cada marca estará subordinada à diretoria da marca do mundo físico. O atendimento, na área de relacionamento com os clientes, é segmentado por marcas. Dentro da marca, há um grupo que responde a e-mails, um grupo que atende aos telefonemas, e um grupo que verifica urnas, pois o treinamento para cada tipo de canal de comunicação é diferente.

Na Empresa B, foi criada uma estrutura de atendimento específica para clientes via Internet. Além da área de e-business, que já existia em função do site da empresa, criou-se, para o projeto de comércio eletrônico, uma equipe provisória centrada em Internet para consolidar as vendas por este canal. Os conhecimentos adquiridos por esta equipe, após a sua dissolução, foram disseminados nas áreas de origem dos seus componentes, para que não se perdesse a sua essência. Cargos já existentes acumularam novas atribuições em face da demanda de novas funções.

Na Empresa C, criou-se a Gerência de Marketing Eletrônico e o respectivo cargo de gerente, e houve reestruturação no atendimento para resposta aos $e$-mails dos clientes.

A Empresa D decidiu criar um departamento exclusivo para administrar a operação de vendas pela Internet, o Empresa D.net, procurando manter a filosofia de relacionamento com seus clientes. Houve criação de novos cargos e ampliação do número de postos de atendimento ao cliente.

Na Empresa E, o grande impacto da Internet se refletiu sobre os custos. A empresa consegue fazer mais por menos: mais um canal de vendas, com menor estrutura em todos os canais. A Internet requereu a criação de um departamento novo, com cargos novos. Não houve aumento do 
número de postos de atendimento, mas com um volume de pessoas menor em relação ao SAC normal, a área tem conseguido manter o índice de 25\% das vendas mensais da empresa.

A Empresa F, com estrutura bastante enxuta, criou a área de e-Commerce, que, por administrar um site de vendas, está subordinada à Diretoria Comercial e cuida tanto das vendas como do atendimento aos clientes via Internet. Criada inicialmente de forma experimental, foi crescendo na medida das necessidades. Na área de Logística, foram criados os cargos de assistente administrativo da loja virtual e gerente da loja virtual, e assistente administrativo, que cuida das peças e todo o desenvolvimento de comunicação e arte, e um responsável pela logística da loja virtual. É como se houvesse sido criada uma empresa pequena dentro da maior, sendo apoiada por esta no que fosse necessário e possível, com a contratação de profissionais para as áreas sem estrutura ou know-how suficiente. Não houve alteração do número de postos de atendimento, que conta com três atendentes.

A Empresa G já previu em seu planejamento inicial a constituição de estrutura para vendas pela Internet, com uma diretoria responsável por informática, logística e comércio eletrônico, uma vez que a empresa adquirida já praticava comércio eletrônico. O número de postos de atendimento ao cliente é de seis pessoas; o diretor da área também responde a e-mails, desempenhando também a função de Web admin - administrador do site, respondendo por ele. Não há 0800 no call center. As modificações para melhorias no processo vêm sendo feitas com bastante intensidade. Há movimentos tanto para melhoria dos processos do site, como dos processos da loja (picking), e das áreas comerciais que efetuam compras para suprir eventuais pedidos de produtos que não existirem no estoque da loja. Estas ações englobam automatização, relatórios, e acordos com a loja física. Trata-se de um processo complexo, principalmente em épocas de lançamento de livros, em que há a expectativa de que todos os exemplares sejam esgotados em um curto espaço de tempo. Como o mesmo estoque é compartilhado entre as lojas físicas e virtual, surgem conflitos, uma vez que a receita gerada na loja física influencia o cálculo da remuneração variável do seu gerente, não sendo interessante para ele que os livros sejam vendidos pela Internet. A empresa está fazendo um trabalho de conscientização para dissipação dos conflitos dessa natureza.

Na Empresa H, desde o início de suas atividades, foram criadas as áreas de Atendimento ao Cliente e CRM. 


\section{- Perfil de pessoal}

Na Empresa A, no início, predominava uma visão da Internet diferente da que existe hoje acarretando mudanças no perfil dos profissionais; muitas pessoas deixaram a empresa e as que ficaram, com o passar do tempo, assimilaram a filosofia de atendimento, de serviço, fazendo prevalecer a cultura da empresa. Só houve contratações no nível estratégico - Diretoria, que deram direcionamento ao negócio; não houve substituições, mas agregaram-se pessoas com novos conhecimentos. Nos níveis tático e operacional, aproveitaram-se os conhecimentos do pessoal que lida com o dia-a-dia da empresa, familiarizados com as operações e peculiaridades do negócio regiões atendidas, forma de separação dos pedidos, qual o melhor veículo para entrega, qual o melhor processo de picking. No nível estratégico, há uma pessoa responsável por acompanhar constantemente a evolução do mercado da Internet e do comportamento do consumidor. Ministrouse treinamento para todos os envolvidos.

Na Empresa B, não houve mudança no perfil, mas foi necessária uma adaptação de cultura superar o temor ao computador, presente em muitos funcionários: em épocas de inovações é preciso ter disposição para aprendizado e adaptação, vencendo a ansiedade em relação a mudanças. $\mathrm{Na}$ época do projeto, montou-se uma equipe para conduzi-lo, com pessoas que tivessem perfil inovador/empreendedor. Implantado o projeto, essas pessoas foram distribuídas entre as áreas, para que disseminassem os conhecimentos adquiridos. Não houve resistência, sendo necessário apenas que as pessoas aprendessem a pensar de uma nova maneira. Não foi necessário contratar especialistas, a própria equipe de projeto participou de alguns treinamentos. Como todo o processo de vendas pela Internet era novo, na época da implantação, contratou-se uma empresa para ministrar treinamento aos funcionários das concessionárias, as quais, possivelmente, tenham sofrido as maiores mudanças, principalmente em termos de operacionalização da venda.

Na Empresa C, no nível tático, criou-se o cargo de Gerente de Marketing Eletrônico, constituindo-se a equipe correspondente de profissionais técnicos especializados. A empresa contratou uma empresa terceirizada para desenvolvimento de sua comunicação online, sem contratação de funcionários para tanto. No nível operacional, houve apenas alterações em termos de operação dos sistemas, para a qual se realizou treinamento específico; a filosofia da empresa no que diz respeito ao atendimento permaneceu. Na Empresa D também houve mudanças. Em muitas áreas, passou a ser desejável que a pessoa tivesse alguma experiência com a Internet. Nas áreas de comunicação e de marketing de relacionamento, é desejável o seu conhecimento como instrumento. 
O comércio eletrônico desencadeou treinamentos em ferramentas, novos procedimentos e processos, principalmente, nas áreas financeira, logística, atendimento, fiscal e marketing.

No caso da Empresa E, a área de Internet foi constituída majoritariamente com funcionários da própria empresa, realocados de áreas de marketing e oriundos do programa de trainee da empresa, sem impacto em termos de acréscimo de despesas. Não houve mudanças no perfil dos funcionários pois se tratava de uma área totalmente nova; contudo, a área tem um perfil diferente das demais pois, por envolver toda a operação “Internet em Assinaturas”, comporta analistas de marketing, Web designers, e pessoal que dá apoio técnico a esses analistas, com todo o conhecimento necessário para desempenhar estas funções. Quaisquer ações nesta operação que envolvam conhecimentos de outras áreas são decididas após consultas, ou até mesmo realizadas em conjunto, especialmente no que diz respeito ao marketing de relacionamento.

A Empresa F realizou mudanças no perfil de seus funcionários mediante treinamento para o pessoal de atendimento a vendas pela Internet. Toda a operação Internet (Fale Conosco, Logística) sofreu ajustes, com sistemas e formas de faturamento diferentes, embalagens diferenciadas, exigindo adaptação e treinamento das pessoas envolvidas. Além disso, contratou também especialistas em tecnologia, arte, desenvolvimento de sistemas e e-mail Marketing. Foram vários os treinamentos realizados, que incluíram os Sistemas de Administração, Crédito e Cartão de Crédito, arte e softwares novos para desenvolvimento de sistemas.

Na Empresa G, está em implantação um trabalho que objetiva provocar uma mudança no aspecto cultural e no perfil das pessoas, para uma visão mais integrada da empresa. Na área de Comércio Eletrônico, a maior parte dos funcionários já trabalhavam na loja e foram promovidos para suas funções atuais. Priorizaram-se treinamentos para picking na loja e para envio de $e$-mails: não há e-mail padrão, em que apenas se digita o nome do cliente e o envia, à exceção do enviado imediatamente após a compra, confirmando-a: “obrigado por comprar na Empresa G...”. Os demais, principalmente os relacionados a dúvidas de clientes e que serão a base para o relacionamento, são respondidos de maneira personalizada. A partir de algumas idéias de como deve ser feito, todos os e-mails são respondidos individualmente pelo pessoal de atendimento, que também faz picking na loja. Todos do departamento de Comércio Eletrônico cuidam do processo como um todo e, assim, conseguem dar respostas mais adequadas aos clientes. A Empresa H, por ter sido constituída com vistas a operar pela Internet, direcionou suas contratações para os perfis mais adequados. 


\section{- Mudanças na abordagem nas relações com clientes}

Houve mudanças na abordagem da Empresa A em função de seu entendimento de que clientes que compram pela Internet costumam ser mais exigentes, pois o nível das pessoas é diferente. A Empresa B também modificou sua abordagem quanto ao atendimento, antes reativo e, atualmente, pró-ativo, para impulsionar vendas. De forma mais objetiva, a Empresa C direcionou seus esforços para a personalização e para o marketing de permissão, conforme definição de Godin (2000), apresentada na seção 2.3.1, em função do maior volume de dados coletados. A Empresa D modificou sua abordagem ao notar que os assuntos que passaram a fazer parte do atendimento mudaram, principalmente em relação ao site, como, por exemplo, erro no acesso à página, ou a não localização de determinada funcionalidade pelo cliente. A Empresa E também realizou modificações uma vez que a mídia - eletrônica - é distinta, atingindo, em média, um público mais jovem que o perfil normal de clientes da empresa, o que requer uma abordagem um pouco diferente e mais prática. Fazer uma peça para a Internet, hoje, é muito diferente da produção de uma peça em papel: enquanto nas comunicações por papel pode-se trabalhar com mais detalhes, a Internet requer maior dinamismo. O produto vendido é o mesmo, porém, a abordagem, totalmente diferente. A Empresa F preocupou-se em passar de uma postura formal para uma postura mais amável, amigável, acreditando que os clientes demandassem esse tipo de atitude para o fortalecimento das relações. A Empresa $G$ adotou a diferenciação no preço dos livros nos dois canais; foi preciso orientar o pessoal da loja para que desenvolvessem argumentação convincente para clientes que viessem a questionar o fato. Na Internet, a Empresa $\mathrm{G}$ não se relaciona com o cliente de forma próativa, mas de maneira reativa; não se faz, ainda, uso do e-mail marketing, embora haja planos de desenvolvê-lo. Atualmente, pelo fato de a empresa não possuir estrutura para responder rápida e adequadamente aos e-mails que possam retornar a partir das ações de e-mail marketing com questionamentos, críticas e comentários, ela prefere não adotar essa prática. A empresa prefere ser reativa às manifestações dos clientes, e pró-ativa apenas em relação a pesquisas de seu interesse. A empresa acredita ser bastante complexo o relacionamento com clientes pela Internet, exigindo o conhecimento minucioso do processo de relacionamento por e-mail.

\section{- Mudança nos canais de comunicação entre a empresa e seus clientes}

Praticamente todas as empresas afirmaram ter introduzido modificações em seus canais de comunicação a fim de que a empresa se adaptasse às vendas pela Internet, sem prejuízo do relacionamento. A Empresa C observou que a Internet propicia mais interação entre a empresa e 
seus clientes, facilitando a comunicação. A Empresa D ampliou o número de interações e melhorou o tempo de resposta em relação a alguns mecanismos offline como carta e fax; possibilitando o atendimento de mais pessoas em menos tempo. As Empresas E e G declararam que as interações ocorrem principalmente por e-mail, pois ainda não possuem chat/conference call. A Empresa $\mathrm{F}$ afirmou que não houve mudanças, pois, embora o Fale Conosco esteja mais amigável, o restante da empresa ainda está um pouco resistente. O pessoal de Marketing está receoso, pois algumas mudanças podem significar alterações na imagem da empresa para o mercado, o que pode não ser positivo. Possivelmente, isto irá melhorar ainda mais o relacionamento com os clientes, porém, estão em andamento alguns estudos para avaliar se a mudança para uma imagem mais amigável será positiva ou não, uma vez que a empresa está se saindo bem na atual configuração.

- Alterações na busca sistemática de informações sobre desejos e necessidades satisfeitos e não satisfeitos dos clientes, declarados ou ocultos

A Empresa A revelou que, com a Internet, há possibilidade de obtenção de mais informação. A Empresa B, por sua vez, tenta analisar, pela navegação do cliente, por que ele chegou até um certo ponto e não efetuou a compra; no entanto, análises desse tipo são muito complexas. Já a Empresa $\mathrm{C}$ acredita que os mecanismos de pesquisa pela Internet serão mais eficazes que os tradicionais. A Empresa D avalia que a partir do momento em que se abre um canal online, as pessoas ficam mais exigentes em relação a prazos, e cobram da empresa, com "naturalidade”, implementações com a utilização dos recursos tecnológicos. Isso foi bastante visível no processo de automatização da força de vendas dessa empresa, no qual a intermediação feita pelas promotoras no contato entre a empresa e a consultora teve sua dimensão reduzida com a entrega direta dos produtos e com a comunicação dos pedidos via serviço 0800. A criação do site na Internet foi uma alternativa ao 0800; as promotoras, que antes recebiam relatórios semanais, passaram a receber informações diariamente, pelo sistema. É interessante como a Internet muda as expectativas das pessoas a partir do momento em que se possui mais dinamismo e mais opções.

A Empresa E acredita que a Internet permite que a empresa conheça muito melhor seu cliente, por meio de pesquisas freqüentes. Hoje, a empresa mantém um banco de dados muito mais detalhado, viabilizado pelo custo mais baixo da mídia, atualizado automaticamente com atributos dos clientes coletados por preenchimento de questionário no ato do pedido de compra da assinatura pela Internet. Por telefone, isso teria um custo muito mais elevado. 


\section{- Alterações no tratamento das sugestões, críticas e reclamações dos clientes}

As empresas A, E e G não realizaram modificações no tratamento das sugestões, críticas ou reclamações provenientes dos clientes. A Empresa A observa apenas que surgiram novos tipos de demandas/sugestões/reclamações, que não existiam no mundo físico, como por exemplo, "marquei minha entrega para horário tal e ainda não recebi minhas compras”; entretanto, o padrão de atendimento da companhia permanece o mesmo. A Empresa E relata que, em termos de marketing de relacionamento, ainda não há um volume significativo para isto.

Por outro lado, as Empresas B, C, D e F acreditam que a Internet pode favorecer estas alterações, pois a empresa tem mais interação com os clientes, podem-se tratar sugestões, críticas e reclamações com maior rapidez, possibilitando o retorno de $100 \%$ das interações e também quantificação das mesmas. A análise de sugestões dos clientes é uma constante na Empresa F, que procura aprimorar o atendimento e o relacionamento. Todos os itens que os clientes solicitam ou sugerem, se possível, são implantados de imediato; caso contrário, entram numa lista de projetos futuros. Como exemplo, tem-se a lista de casamento pela Internet, que foi sugerida e aprovada por clientes e já está em implantação.

\section{- Modificações no conjunto de benefícios ofertados para os clientes}

A Empresa A oferece brindes e amostras, entregues com as compras feitas pelo site, não ofertados nas lojas físicas. Entretanto, o maior benefício proporcionado pela empresa é o serviço: conveniência, economia de tempo para o cliente. Para entregas em algumas localidades, é possível marcar um horário aproximado de chegada das compras.

A Empresa B concedeu frete incluso a todos os carros, inicialmente aos vendidos pela Internet e, posteriormente, a todos os demais, praticando um preço único nacional.

A Empresa C oferece descontos para compras feitas pela Internet. Na Empresa D, as compras feitas pela Internet são entregues pelos Correios. Para os clientes finais, isso pode resultar em prazos de entrega menores em relação às compras com uma consultora, que precisa, para ter o produto à disposição, fazer um pedido mínimo. Além disso, eles podem contar com maior disponibilidade de horário e comodidade para realização de pedidos e consultas, automaticamente. Para a consultora, a Internet permite o acesso a mais informações sobre produtos e campanhas no site da empresa e a possibilidade de envio de pedidos em qualquer dia e horário, com a comodidade de fazê-lo sem a pressão de alguém tomando nota do pedido. Cerca de 50\% das consultoras já 
acessaram o site pelo menos uma vez e 60 mil das 300 mil cadastradas o fazem regularmente. Em 2002, cerca de 25\% dos pedidos chegaram à empresa pela Internet.

Na Empresa E, o assinante que cadastre um e-mail provavelmente receberá comunicações sobre promoções mais rapidamente do que via postagem, mas as ofertas serão as mesmas para ambos os canais. A Internet oferece o benefício de ser um canal a mais, mais rápido, mais interativo e dinâmico para o cliente se comunicar com a empresa, podendo atingir um segmento de mercado potencial que ainda não é assinante, nem está habituado a comprar revistas em banca. O programa de relacionamento da empresa não pretende diferenciar ou privilegiar o assinante que se comunica com ela pela Internet em detrimento do que faz contato por outros canais. A diferenciação ocorrerá exclusivamente com base na classificação dos assinantes em relação ao número de assinaturas que possui e do seu tempo como cliente da casa.

A Empresa F destaca como benefício proporcionado pela Internet o fornecimento de mais informações; a rapidez de entrega é uma tentativa de oferecer mais benefícios aos clientes: a transportadora tem atendido a nichos de mercado bastante exigentes, mas estuda-se a utilização de serviços do tipo Sedex para satisfazer o cliente em termos de custo e prazo de entrega.

A Empresa G ressalta como benefícios aos clientes o oferecimento de descontos em produtos, principalmente nos livros, que são ofertados a preços reduzidos; além disso, para os clientes associados, são concedidas isenções no frete para algumas categorias de produtos.

\section{- Criação de programas de lealdade}

Na Empresa A, o programa de fidelidade para compras nas lojas é exclusivo do mundo físico; as compras pelo site possuem outros tipos de programas de fidelização, pois a interação com o cliente e o processo de coleta de dados é diferente; nas Empresas B e G, o programa já existia antes das vendas pela Internet e é válido para todos os canais. No caso da Empresa G, apenas se incrementou a segurança das informações nas transações com cartão de crédito, uma vez que a empresa preza muito esse aspecto; os dados são confidenciais, e tratados com sigilo.

Na Empresa C houve aprimoramento do programa já existente, oferecendo mais serviços aos clientes cadastrados no Programa Fidelidade.

Na Empresa E, o programa de fidelidade, já em desenvolvimento, abrangerá todas as publicações, sendo válido para todos os clientes, sem distinção, independentemente de qual meio 
utilize para requisitar sua assinatura. Nas Empresas D e F, o programa faz parte de seus planos futuros e será implementado em várias etapas.

\section{- Criação de políticas de privacidade}

Todas as empresas responderam afirmativamente a essa questão. Isso já existia na empresa E, com uma pequena modificação para e-mails: o e-mail marketing só é feito com base de dados opt-in (e-mail permitido). A Empresa $\mathrm{G}$ afirmou que não vende dados de clientes para terceiros.

\section{- Forma de coleta de dados de clientes e tipos de dados coletados}

A Empresa A coleta dados basicamente com o objetivo de compreender o comportamento de compra de seus clientes: valor do ticket médio, itens selecionados, seqüência de seções visitadas, navegação. A Empresa G conhece o perfil de compra de seus clientes, de maneira geral, pelo CRM, mas não sabe quem são individualmente; reconhece-os apenas se forem clientes associados.

As Empresas B e E coletam dados por intermédio de pesquisas e do seu cadastro de compra/ assinatura. Na Empresa B, quando o cliente efetiva a compra, fornece dados para um cadastro, com criação de identificação e senha, e para a emissão da nota fiscal, em seu nome. Pesquisas realizadas junto aos clientes, não pela Internet, também são uma boa fonte de dados sobre os mesmos. A Empresa E utiliza o login, mas não são coletadas informações extras vinculadas a isso, ao contrário do que ocorre com a Empresa C, na qual o número de inscrição em seu programa de fidelidade funciona como identificação do cliente no acesso ao site.

As Empresas D, F e H utilizam-se de cookies. Na Empresa D, o cliente se cadastra e, se aceitar, fica registrado um cookie em seu computador. Na Empresa F, o cadastro das compras pela Internet é muito rico, com o máximo de dados possível para que se possa traçar um perfil, porém, sem invasões. A avaliação dos dados é feita por perfil, mediante análises estatísticas. Na Empresa $\mathrm{H}$, os cookies identificam o roteiro de navegação executado pelo visitante. Os dados coletados variam de acordo com a etapa de compra, mas, em sua maioria, alimentam os sistemas de faturamento e cobrança, além do endereço para entrega. A empresa utiliza login com senha para permitir o acesso à área de compras. Alguns dados são coletados para promover melhor qualificação das bases. Embora a empresa planeje trabalhar com dados dos clientes de maneira a conhecê-los melhor, como ainda não está preparada para isso, prefere não coletar dados indiscriminadamente. Em breve, passará a solicitar que o cliente informe sua profissão, pois descobriu haver uma forte correlação entre este dado e seu comportamento de compra. 


\section{- Gerenciamento e análise dos dados coletados sobre os clientes}

As empresas, em geral, utilizam-se de ferramentas para gerenciamento e análise dos dados coletados, com estudo do perfil e comportamento de compra dos clientes, quer sejam desenvolvidos internamente ou com o suporte de empresas de consultorias especializadas, softwares proprietários e sistemas desenvolvidos in house (Empresas A e B), Data Base Marketing (Empresas C e E), relatórios “Webtrends”, e-Bit, e construídos internamente (Empresa D), gráficos e estatísticas mensais (Empresa F) são alguns exemplos dessas ferramentas. Na empresa E, a área de Data Base Marketing, responsável pela inteligência de banco de dados, fornece suporte nesse aspecto, consolidando todos os dados captados pelos vários canais utilizados. Se a empresa desejar realizar uma ação de venda utilizando e-mail marketing, essa área auxiliará a selecionar o melhor mailing possível para isto. Esse processo é tão importante para a empresa que se constituiu uma área responsável exclusivamente pela análise dos dados.

Nas Empresas G e H, o gerenciamento e as análises de dados ocorrem internamente; na Empresa G, quando há disponibilidade de tempo do diretor de comércio eletrônico; na Empresa $H$, isto é feito periodicamente, por uma equipe que realiza um mining nos dados coletados.

\section{- Oferecimento de produtos ou serviços personalizados para seus clientes}

Apenas as Empresas B e $\mathrm{F}$ declararam praticar alguma das formas de personalização apresentadas.

- Produtos/serviços padronizados com opções pré-definidas de variação (Empresa B): atualmente, estão disponíveis para venda pela Internet cinco modelos de automóveis, pois há uma ampla gama de combinações possíveis entre cor, modelo, acessórios/opcionais etc. Anteriormente, as opções eram limitadas ao estoque da concessionária; caso o cliente desejasse um produto com características distintas, era necessário encomendá-lo, com um prazo de entrega maior. Com as vendas pela Internet - vendas diretas da fábrica -, o cliente escolhe qual carro deseja e a empresa tenta atendê-lo. A empresa procura realizar previsões de modo a sempre ter disponível todos os tipos de modelos de carros e como o estoque não fica mais nas concessionárias, e sim, nos centros de distribuição da própria empresa pelo Brasil, amplia-se o leque de opções de modelos já prontos disponíveis para entrega. No momento do pedido, o cliente apenas escolhe em qual concessionária irá retirar o veículo. Caso não haja disponibilidade do produto nos centros de distribuição que abastecem as concessionárias, a central de vendas verifica os veículos em trânsito 
para algum desses centros; a seguir, procura em todas as concessionárias do Brasil, e, caso não encontre, a empresa verifica na planta; se não houver disponibilidade, o cliente entra numa lista de espera e aguarda a produção do produto. A empresa informa ao cliente outras opções de entrega mais rápida que se aproximam de seu pedido, caso o mesmo não esteja disponível.

- Produtos/serviços totalmente personalizados: Empresa F, estendendo o benefício oferecido já na loja física a seus clientes pela Internet.

- Outros tipos de personalização:

A Empresa A tem realizado um laboratório com a Ambev, o qual oferece, nas compras pelo site, um barril de chope gelado para festas, a ser retirado posteriormente. Só ocorre em compras pelo site, pois a operação é bastante complexa.

A Empresa C proporciona, com as vendas pela Internet, maior sofisticação na personalização, possibilitada pelo armazenamento de informações individuais sobre os clientes, como por exemplo, preferências quanto à refeição, e extensiva a maior número de clientes.

Na Empresa D, com as vendas pela Internet, criou-se um serviço personalizado que possibilita ao cliente fazer perguntas/consultas pelo site, com indicação de tratamento mais adequado ao seu tipo de pele, cabelo, e preferências. A comunicação na forma de newsletters enviadas pela empresa também está cada vez mais segmentada.

Na Empresa G, o site era bastante ativo no que concerne ao reconhecimento de um cliente assíduo: ao se identificar, com base em informações de seu histórico de compras, pelo CRM, ele recebia informações sobre produtos de sua preferência. A empresa viu-se obrigada a desabilitar essa funcionalidade pois o site começou a apresentar queda de performance, uma vez que, pelo fato de as páginas serem dinâmicas, a cada carga de página, as informações eram atualizadas. A personalização, no entanto, é identificada na possibilidade de entregar também, em casos de produtos para presente, uma carta impressa com texto enviado pelo cliente, bastante comum em datas comemorativas ou especiais como Dia das Mães, Dia dos Namorados etc.

A Empresa H informou que apenas as informações sobre pontuação dos programas Smart e Dotz tornaram-se personalizadas, com acompanhamento mais próximo por parte da empresa. 


\section{- Alterações no desenho e funcionamento do site}

Um resumo das principais alterações executadas pelas empresas em seus sites em função do marketing de relacionamento encontra-se no quadro 26, seguida de seus comentários. O símbolo :) expressa modificação no item correspondente; o símbolo :-) indica que não houve mudanças no site; e o símbolo 8 indica que o item está em estudo ou faz parte dos planos futuros da empresa.

Quadro 26 - Mudanças no desenho e funcionamento do site em função do marketing de relacionamento

\begin{tabular}{|c|c|c|c|c|c|c|c|c|}
\hline Modificações & A & B & C & D & $\mathbf{E}$ & $\mathbf{F}$ & G & H \\
\hline Suporte técnico/atendimento ao cliente & (:) & ;) & ;) & ;) & ;) & ;) & ;) & (;) \\
\hline Catálogo de produtos & (:) & ;) & ;:) & ;) & :) & ;:) & ;) & (;) \\
\hline Realização de transações financeiras & (:) & (:) & $\odot$ & (:) & 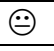 & 8 & (:) & ;) \\
\hline Possibilidade de negociação de preços ou descontos & 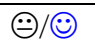 & :) & 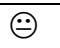 & ;) & :) & 8 & (-) & 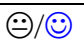 \\
\hline Mudanças no layout/navegação & ;:) & ;) & ;) & ;) & ;) & ;) & ;) & (:) \\
\hline Personalização de conteúdo conforme interesse do cliente & (;) & ;) & ;) & ;) & 8 & $\dot{\theta}$ & $\dot{\theta}$ & (:) \\
\hline Realização de vendas cruzadas & (;) & 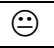 & 8 & 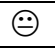 & ;) & $\dot{\theta}$ & (;) & (:) \\
\hline Realização de vendas complementares & ;) & ;) & 8 & ;) & (:) & $\dot{\theta}$ & (;) & ;) \\
\hline Criação de comunidades & (;) & 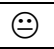 & 8 & ;) & 8 & 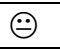 & 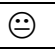 & 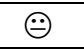 \\
\hline Monitoramento contínuo da performance do site & ;) & ;) & ;) & ;) & ;) & ;) & ;) & ;) \\
\hline Atualização periódica de equipamentos e sistemas & (;) & (:) & ;) & (:) & (:) & (;) & (;) & (:) \\
\hline
\end{tabular}

Fonte: dados de campo.

As empresas A, E e H declararam, não obstante a evolução dos softwares, preocupar-se com as necessidades de relacionamento com seus clientes na elaboração e modificação de seus sites. A Empresa G passou de um site de presença para um site de operação de vendas. A Empresa $H$ tem realizado modificações nas interfaces, nos processos e no nível de informação sobre produtos.

A maioria das empresas pesquisadas não oferece a possibilidade de negociação de preços ou descontos. Entretanto, a Empresa A afirmou que, embora não seja um processo formal, se o cliente ligar para o seu SAC alegando ter encontrado no concorrente um produto por um preço mais baixo, há possibilidade de pechinchar. Na Empresa H, a princípio, não existe essa possibilidade, mas, sob condições especiais, no televendas, pode-se negociar.

A Empresa B afirmou não possibilitar a negociação, pois o preço para vendas pela Internet já é o mais baixo. Entretanto, nas concessionárias, às vezes, o vendedor oferece um brinde adicional, como pára-choques pintados da cor do carro, tapetes, negociação do carro usado. A venda é da Empresa B, diretamente para o cliente que lhe paga; a concessionária que faz a entrega do veículo recebe uma comissão. Se aceitar o carro usado como parte do pagamento, ela o comprará do cliente e este pagará o carro novo para a Empresa B. A Empresa D também não admite a possibilidade de 
negociação, porém oferece descontos e promoções em seu site. No caso da Empresa E, há adoção da mesma política de preços para todos os canais. O novo programa de relacionamento trará a necessidade de diferenciação de preços, mas não devido ao uso da Internet para compra/renovação de assinaturas. A Empresa $\mathrm{F}$ afirmou que esta possibilidade está em estudo.

A Empresa B informou que a personalização existe no site institucional, e não no de vendas; a Empresa C pretende oferecer cada vez mais personalização de conteúdo de interesse do cliente; e a Empresa D oferece algum nível de personalização.

Em relação a mudanças no layout/navegação, as Empresas E e F informaram estar em melhoria contínua, sendo que a primeira realiza revisões mensais.

A Empresa A desenvolveu comunidades, como por exemplo, venda de computadores para associações médicas, culinária.

\section{- Formas de 0 cliente obter informações sobre 0 andamento de seu pedido}

Algumas empresas possibilitam ao cliente acompanhar o andamento de seu pedido pelo próprio site (Empresas A, B, D, G, H), por e-mail (Empresas E, F, H) ou pelo telefone (Empresas A, D, G, H). O cliente da Empresa E recebe um e-mail de confirmação do pedido e uma carta em papel do tipo "welcome", com indicação das edições inicial e final, manual e código do assinante. Na Empresa F, o cliente entra em contato por e-mail e recebe as informações passo-a-passo também por esta via. Há estudos para aprimoramento desse acompanhamento. Na Empresa G, o cliente pode configurar uma página pessoal, indicar e cadastrar pessoas para facilitar entregas posteriores e acompanhar, por ela, o andamento de seu pedido; o acompanhamento pode também ser feito pelo telefone, que fornece informações como, por exemplo, "seu pedido já foi enviado para os Correios”; “só temos parte da sua encomenda” etc. Na Empresa H, são monitoradas 24 etapas do processo de venda, sendo possível acompanhá-las pelo site; entretanto, a empresa envia e-mail automatizado, em que o cliente recebe informações sobre quatro dessas etapas. No futuro, a empresa planeja oferecer, no momento do fechamento da compra, a opção de escolher sobre quais etapas os clientes gostariam de obter informações e por qual meio.

\section{- Novos procedimentos operacionais de vendas}

As Empresas A e B criaram centrais de distribuição regional, de onde partem os pedidos feitos pela Internet. A Empresa A estruturou equipes de picking e distribuição, localizadas em cidades-chave como São Paulo, Rio de Janeiro e Brasília. A Empresa B efetuou modificações em 
sua logística de distribuição, no processamento dos pedidos, que foram totalmente modificados, nas formas de cobrança, e no follow-up das ordens, que antes era feito junto às concessionárias e passou a ser diretamente com a montadora.

Para a Empresa C, a mudança mais significativa foi a desintermediação, eliminando um dos elos da cadeia e possibilitando ao cliente realizar o check-in sem bilhete. O processo de emissão de bilhetes já havia sofrido algumas modificações, em função do e-ticket, que elimina a necessidade do bilhete aéreo em papel, tornando o processo mais simples.

As principais mudanças na Empresa D também ocorreram na entrega, que passou a ser via Correios para o comércio eletrônico, na estrutura montada para realizar esta remessa, embora simples, e na adoção de outros meios de cobrança, como cartão de crédito e transferência eletrônica de fundos, com maior flexibilidade para os clientes.

Na Empresa E, uma vez incluído o pedido no sistema de Vendas de Assinaturas, os processos são os mesmos utilizados em outros canais. O preço da assinatura é o mesmo, pois não há acréscimo de frete no valor do produto, que já era entregue em domicílio, antes mesmo das vendas pela Internet.

Para a Empresa F, as transformações também foram inúmeras, inclusive na parte fiscal, numa grande reforma administrativa e tecnológica. Há uma parte dos produtos remetidos que, por se tratarem de brindes, não podem ser acompanhados por nota fiscal com valor da mercadoria; além disso, houve mudanças na logística e no processamento dos pedidos, uma vez que a distribuição era feita pelas lojas. Pelas características da remessa, as embalagens também receberam atenção especial.

Na Empresa G, as modificações são realizadas continuamente. Os pagamentos das compras pelo site, até o momento, só podem ser feitos com cartão de crédito, o qual só é submetido à cobrança quando todo o pedido estiver pronto para ser despachado, pois nem tudo o que consta no catálogo do site existe em estoque: em alguns casos, a empresa depende de fornecedores para completar a encomenda; a entrega, em geral, leva até dois dias. Em outras lojas virtuais, o cliente faz um depósito identificado ou paga via boleto, e só então o seu produto é despachado. Nesse caso, se algum produto não estiver disponível, a loja deve reembolsar o cliente ou procurar o produto no varejo para atendê-lo. A Empresa G acredita que esse procedimento pode gerar perdas: estrutura de pessoal para devoluções e procura de produtos em falta, e aquisição da mercadoria a preço de mercado, e não a preço de custo. Assim, a empresa está implantando novos procedimentos que 
aceitarão pagamento por boleto bancário e que permitirão que este seja impresso apenas quando todos os produtos escolhidos estiverem reservados e prontos para entrega. Será um pouco mais trabalhoso, uma vez que o cliente terá que acessar duas vezes a Internet - uma para a seleção dos produtos e, após receber o e-mail avisando que a encomenda está pronta, novamente, para emissão do boleto para pagamento - porém, evitando transtornos de devolução de pagamentos. Além disso, havia a opção de, em casos de compra de mais de um produto, o cliente informar se desejava entrega total ou parcial, o que gerava variações no valor total do frete, pois a entrega é realizada pelos Correios. Assim, a empresa passou a adotar o seguinte procedimento: caso haja apenas uma parte da encomenda disponível para a entrega, a empresa calcula o frete total e divide pelo número provável de entregas. O cliente pagará o custo total do frete se a entrega for total; da mesma maneira, pagará o frete parcialmente, se a entrega for parcial. Embora isso não seja vantajoso para a empresa, ela arca com os custos de sua ingerência sobre a gestão de estoque. Se o fornecedor não entrega, o problema é da empresa, e não do cliente. As promoções para cada canal de vendas também são diferenciadas, como por exemplo, a campanha "Bons negócios”, na loja física, que oferta livros já depreciados e que possuem poucos exemplares, com até 85\% de desconto. Tais livros não podem ser colocados em promoção no site, pois se corre o risco de se ter muito mais demanda do que exemplares, uma vez que a loja virtual fica aberta 24 horas por dia. Todas as promoções no site são gerenciadas com muita atenção, uma vez que, a partir do momento em que o estoque acabar, a promoção deve ser retirada do ar.

- Diferenciação de tratamento entre clientes que compram pela Internet e os que compram pelos meios tradicionais

Apenas a Empresa E revelou não ter nenhuma diferenciação de tratamento entre os dois tipos de clientes. As diferenças no prazo de entrega dizem respeito apenas aos produtos que requerem entrega também no mundo físico, ou seja, que o próprio cliente não retira já no ato da compra. O quadro 27, a seguir, resume as principais informações obtidas.

Quadro 27 - Principais diferenças entre compras pela Internet e compras pelas vias tradicionais

\begin{tabular}{|c|c|c|c|c|c|c|c|c|}
\hline Diferenças & A & B & C & D & $\mathbf{E}$ & $\mathbf{F}$ & G & $\mathrm{H}$ \\
\hline Preço & (:) & (;) & (;) & (:) & - & ;) & ;) & (;) \\
\hline Prazo de Entrega & (;) & (;) & - & (;) & - & - & - & (;) \\
\hline Formas/condições de pagamento & (:) & (:) & - & (;) & - & (:) & (;) & (;) \\
\hline
\end{tabular}

Fonte: dados de campo. 
Em relação ao preço/custo da compra pela Internet, há algumas observações interessantes a serem feitas. Nas compras de produtos que são entregues ao cliente pela própria empresa ou por serviços terceirizados, em geral, cobra-se o valor do frete ou uma taxa de entrega. A Empresa A, que entrega os produtos com frota própria, cobra um preço mais elitizado, em função do perfil de seu cliente pela Internet, e também taxa de entrega: os preços das vendas pela Internet são também “clusterizados”, acompanhando o preço top de uma loja do município. Na Empresa B, mesmo cobrando frete e designando comissão à concessionária que entrega o veículo ao cliente, o preço final é realmente mais baixo, uma vez que a empresa foi pioneira na política de "preço único nacional”, com frete incluso. Para não prejudicar suas consultoras, a Empresa D manteve sua comissão e conservou o mesmo preço de venda ao consumidor final (preço “cheio”), acrescido do valor do frete. Há diferenças de preços também na empresa F: há promoções na Internet que não são ofertadas nas lojas físicas e vice-versa. Além disso, o preço também varia segundo o local de entrega, pois é sensível às variações no frete.

A Empresa E, com distribuição realizada por empresa do grupo, não cobra taxa de entrega em função das vendas pela Internet, pois as revistas para assinantes já eram entregues sem taxa. Contudo, mesmo com custo reduzido, também não pratica política de preços mais baixos pela Internet. Algumas empresas, mesmo com frete, conseguem praticar um preço menor, em função da redução expressiva de custos operacionais. Nas compras de serviços, como passagens aéreas, por exemplo, não existe “entrega” e, portanto, não se cobra frete; há possibilidade de se reduzirem os preços devido à desintermediação (Empresa C).

A Empresa E ressalta que, embora tenha uma política de preços iguais para qualquer canal de vendas, por existirem no mercado lojas que praticam políticas de diferenciação de preços, sendo os preços mais baixos pela Internet, algumas pessoas podem ser levadas a pensar que ela trabalha da mesma forma. Enquanto na Empresa E a noção de que o preço seja mais baixo é considerada uma vantagem, na Empresa G - que pratica menores preços para alguns produtos pela Internet em função de custos mais baixos e também de promoções -, isso até gera alguns transtornos, pois as pessoas acreditam que todos os produtos deveriam ser mais baratos na Internet; em contrapartida, a empresa costuma ser bastante agressiva em sua política de preços de livros pela Internet, e alguns clientes desatentos imaginam que o preço informado no site da empresa também seja válido na loja, ficando decepcionados com a não confirmação do fato. 
Na Empresa A há diferenças de tratamento, mas não necessariamente com vantagens ou desvantagens, e sim, uma adaptação às características exclusivas de cada compra. As compras não são mais baratas por esta via; os maiores benefícios anunciados ao cliente são a comodidade, a conveniência e a qualidade. Dependendo da região - alguns bairros de São Paulo -, é possível marcar o horário de entrega das compras, e receber a encomenda em até quatro horas, mas o padrão é de 24 horas. As condições de pagamento incluem ticket, boleto, cheque; nas lojas, aceitam-se também cartões de crédito e dinheiro, mas não se pode pagar por meio de boleto bancário.

Na Empresa B, não há diferenciação de tratamento, porém os processos são diferentes, o que acarreta diferenças no preço, prazo de entrega, condições de pagamento, mas não porque a empresa queira dar preferência a algum tipo de cliente.

No caso da Empresa D, embora a compra pela Internet seja mais custosa, o prazo de entrega, na média, é menor por este canal, pois os produtos são despachados pelos Correios. Algumas consultoras mantêm um pequeno estoque dos itens mais procurados em casa, mas não de produtos com grande variedade de cores, por exemplo, por representar um investimento relativamente alto.

Na Empresa F, também são várias as diferenças. O parcelamento dos pagamentos com cartão de crédito pode ser feito em até três vezes pela Internet, e em até quatro vezes nas lojas; a entrega de compras pela Internet tem um prazo de três dias, se for em São Paulo. As lojas físicas são tratadas como rede, e há uma mídia toda direcionada a essa rede de lojas; as campanhas pela Internet são diferentes e exclusivas para a loja virtual.

Na Empresa G, apenas o preço e condições de pagamento na loja são diferentes: aceitam-se dinheiro e cartão de crédito; no site, apenas cartão. Em breve, o site aceitará pagamentos com boleto bancário e débito em conta, que não existirão na loja física. Para produtos que o cliente compra na loja mas prefere que sejam entregues ou para produtos comprados pela Internet, o prazo de entrega é o mesmo.

\section{- Alterações nas políticas de investimento em tecnologia de informação}

Na Empresa A, objetiva-se deixar o site cada vez mais fácil e rápido de navegar. Para tanto, se for preciso introduzir novos mecanismos, isto será feito. Da mesma forma, a Empresa B tem investido mais em e-business. A Empresa E declarou não ter realizado alterações nas políticas de investimento em tecnologia da informação, pois os critérios são os mesmos, priorizando, principalmente, o retorno sobre o investimento (ROI). 


\subsubsection{Outras implicações}

\section{- Canais de distribuição}

Embora não seja foco central deste estudo, a Internet trouxe impactos e implicações também para o relacionamento das empresas com seus canais de distribuição. Dentre as empresas entrevistadas, três contam com intermediários para realização de suas vendas: Empresas B, C e D. Hirsh (1996:22) evidencia três funções básicas desempenhadas pelos canais de distribuição que lhes conferem grande participação nos contatos com o cliente: (1) fluxo de informações sobre as ofertas do fornecedor e sobre as necessidades dos clientes (bastante evidente na Empresa C); (2) logística, para levar os produtos para o consumidor final (bem visível na Empresa B); (3) serviços adicionadores de valor, que incrementam o produto oferecido pelo fornecedor, item que apóia o depoimento da Empresa D, a qual apostou no relacionamento de seu canal com os clientes finais para expandir-se. A decisão de comercializar produtos e serviços pela Internet configurou três situações distintas no que diz respeito ao papel dos intermediários e ao relacionamento entre estes e a empresa.

Pelas características de distribuição de seus produtos, o contato da Empresa B com seus clientes era feito necessariamente por intermediação das concessionárias, com as quais a parceria tem sido boa. Para elas, a venda pela Internet também é positiva, dado que elas podem reduzir seu investimento em estoque. Elas foram envolvidas desde o início do projeto de vendas online, mesmo porque seria impossível fazer algo sem que fossem comunicadas e que estivessem preparadas. Uma vez que serviços como instalação de acessórios e revisões se mantêm, e que os clientes continuam indo às lojas para realizar o test-drive, tirar dúvidas e retirar o produto - que garante uma comissão à loja que o entrega -, o relacionamento entre a Empresa $\mathrm{B}$ e as concessionárias não foi abalado com a inovação das vendas pela Internet.

Embora a maioria dos clientes que compram no site da Empresa C já comprassem diretamente da mesma - por telefone, diretamente no balcão do aeroporto ou nas lojas - e não por agências de viagem, as vendas pela Internet geraram um conflito com seu principal canal de distribuição, que não viu com bons olhos este avanço. A empresa já havia feito investimentos tecnológicos na criação do bilhete eletrônico, o e-ticket, anterior às vendas pela Internet, e que já excluía as agências do fluxo de compras de bilhetes aéreos por esse meio. A venda direta pela Internet elimina o benefício do canal, pois a sua comissão não é embutida na tarifa e não lhe pode ser repassada. Como não há produto físico, pois os clientes realizam o check-in apenas com o localizador da reserva e/ou com 
um documento de identificação, as agências se sentiram bastante prejudicadas com esta implantação e os conflitos ainda constituem uma pendência bastante delicada para a empresa.

No caso da Empresa D, ocorre situação diversa: os produtos são entregues diretamente ao cliente, mas a consultora continua sendo remunerada. A Empresa D declarou ter optado por levar os produtos aos clientes finais por intermédio de consultoras por acreditar no potencial dos indivíduos e na força das relações. Durante o processo de compra, após a seleção dos produtos, o cliente é questionado sobre a existência de uma consultora da empresa que já o tenha atendido. Caso a resposta seja afirmativa, $10 \%$ do valor de sua compra é destinado a ela; caso contrário, a partir do CEP indicado por ele, o sistema lhe indica uma consultora, vinculando-o a ela. O site informa o cliente de que seus dados serão fornecidos a essa pessoa para que ela possa realizar o atendimento pós-venda e atendê-lo em novas solicitações, e de que ela será remunerada por sua compra. Esta é uma forma de atender o cliente, com agilidade, entregando-lhe os produtos rapidamente, mas sem lesar a consultora, uma vez que o site não foi construído para absorver a sua remuneração ou gerar mais lucro sem intermediação. A empresa é bastante diligente no desenvolvimento de seu $e$ commerce, respeitando a consultora e os clientes que ela já havia desenvolvido ao longo da parceria. Os clientes que compram pela Internet, em geral, desejam que os produtos sejam entregues rapidamente e, por isso, o site pode ser interessante também para a consultora. Quando ela estiver em férias ou impossibilitada de atender a um pedido com urgência, poderá indicá-lo a seus clientes, de maneira que o pedido seja feito, os produtos sejam entregues, continue sendo remunerada, e não perca o seu cliente para um concorrente qualquer. Tratam-se de situações que diferem até mesmo pelas características dos produtos em questão, porém que podem servir de fonte de inspiração ou de reflexão para novas incursões no e-commerce de empresas que trabalham com intermediários no mundo físico.

- Freqüência com que os clientes encontram respostas para perguntas mais comuns no site

As Empresas A, B e F afirmaram que os clientes sempre encontram respostas para suas perguntas mais comuns no site; as Empresas C, D, E, G e H afirmaram que os clientes quase sempre encontram informações referentes a suas dúvidas mais freqüentes em seu site. Praticamente todas as empresas declararam monitorar o volume e os tipos de questões que mais chegam à empresa, geralmente, pela área responsável pelos relacionamentos (Empresa A), por ouvir o cliente (Empresa C), ou call center/outros canais (Empresas D, E e F), que funcionam como radar e como 
termômetro para este fim: quanto mais interações a empresa recebe por outros canais, maior a certeza de que é possível colocar no site estas respostas.

Nos sites das Empresas A, B e H, existe o FAQ (Frequent Asked Questions), onde estão respondidas as questões mais freqüentemente levantadas pelos clientes. A Empresa A reforça que, caso não consiga esclarecer suas dúvidas, o cliente pode contactar a empresa por e-mail, ligação 0800 ou chat online. Na Empresa B, em todas as reuniões, conversas, relatórios e análise de dados do call center são feitos cruzamentos que fornecem subsídios para avaliar se o conteúdo é suficiente e re-alimentar o site, se necessário.

A Empresa $\mathrm{F}$ avalia que a comunicação não está sendo eficiente se vários clientes solicitam informações que se encontram no site da empresa que é, então, modificado a partir do momento em que se percebe grande incidência dos mesmos questionamentos. A Empresa E avalia, no entanto, que algumas questões, muito específicas, ainda requerem que o assinante ligue. A Empresa $\mathrm{H}$ revelou estatísticas. Para cada pedido, há, em média, uma interação com o setor de atendimento e cinco interações de clientes diferentes na página de FAQ. Assim, a empresa estima que cerca de 80\% das dúvidas são respondidas pelo site. A Empresa G, a partir de reclamações ou solicitações, estuda as possibilidades de inclusão de determinada informação no site, sempre de maneira reativa.

\section{- Prazo para resposta aos e-mails de clientes}

As empresas B, F e G afirmaram ter determinado a meta de 24 horas para resposta aos $e$ mails; as Empresas A, C, D afirmaram que o prazo para resposta é de 48 horas; a Empresa E afirmou que o prazo varia entre 25 e 72 horas. A Empresa H revelou que os prazos variam em função do teor da comunicação: se é uma questão crítica, como reclamações, há um prazo crítico; elogios e dúvidas têm um prazo mais flexível, mas a empresa não precisou esses prazos em horas.

\section{- Facilidade de contato pessoal, não automatizado}

Todas as empresas oferecem um número telefônico para contato, sendo que as empresas A, B, C, D, E oferecem um número para ligações gratuitas. A Empresa $G$ atende apenas em horário comercial. As Empresas A, C, D e H oferecem também a alternativa de o cliente entrar em contato com a empresa por meio de chat online. 


\section{- Oferecimento da opção de recebimento por e-mail de informações sobre atualizações}

À exceção da Empresa G, todas as demais empresas oferecem a opção de o cliente receber informações sobre atualizações de produtos e novidades do site. A Empresa $G$ prefere ainda não oferecer esta possibilidade pois pode-se abrir um espaço para que o cliente demande mais informações da empresa, que, por sua vez, não tem estrutura ainda para atender a um volume potencial de clientes que retornariam com dúvidas.

\subsubsection{Expectativas/necessidades dos clientes em relação às compras pela Internet e esforços da empresa para satisfazê-las}

No quadro 28, são apresentadas as principais expectativas e necessidades dos clientes segundo a visão das empresas pesquisadas.

Quadro 28 - Expectativas dos clientes em relação às compras pela Internet, segundo visão das empresas

\begin{tabular}{|c|c|c|c|c|c|c|c|c|}
\hline Expectativas & A & B & $\mathbf{C}$ & $\mathbf{D}$ & $\mathbf{E}$ & $\mathbf{F}$ & $\mathbf{G}$ & $\mathbf{H}$ \\
\hline Bom sortimento & - & - & - & - & - & - & - & (:) \\
\hline Comodidade & ;) & - & - & (;) & - & - & - & - \\
\hline Facilidade na compra/navegação & - & - & - & (:) & (:) & - & - & - \\
\hline Praticidade/agilidade & (:) & - & - & - & - & - & - & (:) \\
\hline Preços mais baixos & - & - & (;) & (;) & - & - & - & (:) \\
\hline Qualidade dos produtos & - & - & - & - & - & (;) & - & - \\
\hline Rapidez na compra/navegação & - & - & - & ;) & (:) & - & - & - \\
\hline Receber o que Ihe foi prometido & - & (:) & - & - & - & - & - & - \\
\hline Receber rápido sua compra & - & - & - & (:) & - & ;) & (;) & - \\
\hline Segurança & (;) & - & - & - & - & - & - & - \\
\hline Ser ouvido & - & - & (:) & - & - & - & - & - \\
\hline
\end{tabular}

Fonte: dados de campo.

A Empresa C acredita, com a criação do site na Internet, ter suprido mais efetivamente os anseios de seus clientes no que diz respeito a descontos nos preços e ao acesso à empresa. A Empresa D avalia que as expectativas dos clientes são altas. Entre outras coisas, embora não seja um item eliminatório, os clientes reclamam bastante do preço; no relatório da empresa de pesquisa (e-Bit), sua menor nota é neste quesito.

A Empresa E revela que seu site é desenhado para cumprir as exigências dos clientes, monitoradas por meio de pesquisas, com feedback bastante positivo. As pessoas consideram o site da empresa rápido, e de fácil entendimento. O cliente acessa o site, compra, informa dados para entrega e para cobrança, e está concluída a transação. O site da Empresa E é o que tem maior 
percentual de internautas que compram pela primeira vez, segundo dados dos relatórios e-Bit. Desta forma, se a pessoa nunca comprou pela Internet, vai precisar mais ainda de um site fácil de se utilizar - é a proposta desta empresa.

A Empresa F também avalia que não é o preço, primordialmente, que leva o cliente a comprar pela Internet. Isto se deve também ao perfil de pessoas que compram por essa via: mais exigentes, de um nível socioeconômico mais alto, priorizam a qualidade. Além disso, muitos de seus clientes são pessoas que estão em fases mais maduras de suas vidas, mudando de casa ou renovando seu enxoval, em busca de algo de maior qualidade. Da mesma forma, a Empresa G acredita que o cliente não coloca o preço como fator principal ao optar pela compra pela Internet.

A Empresa H evidencia que a Internet é particularmente interessante para realizar compras pelo fato de que há produtos com alto grau de dificuldade de localização que podem ser encontrados numa loja virtual. E há locais que não possuem acesso a determinados tipos de produtos, possibilitado apenas pelas compras via Internet.

Todas as empresas pesquisadas, à exceção da Empresa G, declararam estar muito comprometidas em seus esforços para satisfazer às necessidades dos clientes. A Empresa $G$ afirmou estar comprometida de alguma maneira, pois o desempenho da empresa depende do empenho de todas as pessoas da empresa, em fase de aculturação.

\subsubsection{Benefícios desejados num relacionamento com a própria empresa pela Internet, supondo-se cliente da mesma}

A Empresa A acredita que o principal benefício desejado pelos clientes seria uma cobertura geográfica maior, com hora marcada para entrega.

Na Empresa B, o cliente desejaria comprar qualquer carro, com as características que quisesse, pagando da maneira que preferisse, com a possibilidade de financiamento por meio de outros bancos e consórcios, o qual é possível nas compras tradicionais, e não apenas pelo banco e pelo consórcio nacional próprios desta empresa, únicas opções disponíveis pela Internet.

A Empresa C acredita que o cliente desejaria uma área no site para pechincha, como ocorre numa loja de “tijolos-e-argamassa”, benefício que falta, de modo geral, nas compras pela Internet.

O cliente da Empresa D desejaria que ela pudesse oferecer aos seus clientes produtos certos, 
no tempo certo, e tornar-se mais próxima do cliente, que está relacionado ao que a consultora faz: lembrar o cliente de que ele adquiriu um produto e que, talvez esteja na hora de o repor. A empresa já envia um e-mail quinzenal com um resumo dos lançamentos e aviso sobre promoções; a cada 21 dias, é lançada uma edição/resumo de uma revista eletrônica do site, sobre saúde e beleza; porém, talvez careça ainda de um pouco mais de contato "pessoal”.

A Empresa E acredita que a maior demanda de seus clientes pela Internet seria por uma política mais clara de benefícios para quem já é assinante da empresa, como redução de preços nas próximas assinaturas para quem já possui alguma, algo próximo de um programa de fidelização; já há estudos nesse sentido. Atualmente, a empresa dá muito foco aos novos clientes e não oferece muitos benefícios para os clientes antigos.

A entrevistada da Empresa F utiliza muito de sua experiência pessoal como compradora pela Internet para avaliar e aprimorar os serviços prestados pela sua empresa, uma vez que se encaixa no perfil típico do cliente da loja. Sente falta, particularmente, de um sistema de busca mais prático, mais objetivo, que permita ao cliente chegar ao produto de maneira mais direta. Hoje, a filosofia da empresa é oferecer produtos coordenados, uma coleção completa. O cliente precisa passar por todos os produtos da coleção até ter a possibilidade de comprar um item separadamente, ou seja, se desejar apenas um edredom, ele necessariamente passará por lençóis, porta-travesseiros e saia coordenados. Esta idéia é interessante para apresentação do portfólio da empresa; entretanto, se o cliente desejar um produto específico, essa navegação poderá deixá-lo irritado. A empresa poderia oferecer as duas possibilidades, embora a estratégia de vendas da empresa seja buscar sempre a venda do conjunto coordenado. Outra possibilidade seria oferecer a chance de pesquisa direta, por produto individual, mas com links do tipo “veja também...”, que levariam aos demais produtos da coleção. No entanto, como a empresa conta com estrutura e recursos enxutos, tecnologicamente, esta implementação seria bastante complexa no momento, embora haja alguns projetos em andamento. A criação do site teve como premissa que os clientes pudessem ter acesso aos produtos desejados com navegação fácil e rápida. É importante que o internauta tenha opções e liberdade; é preciso ter flexibilidade para atender aos clientes da Internet. A tentativa de firmar parceria com os Correios, para utilização do Sedex para remessa de encomendas também foi algo solicitado pelos clientes. É preciso empatia por parte da empresa, que ela se coloque no lugar do cliente e procure atendê-lo da melhor maneira possível. 
A Empresa G acredita que o cliente desejaria que a empresa aceitasse o cartão associado com crédito pelo site, que lhe fornece descontos decorrentes da associação ao programa, porém não lhe permite ainda utilizar sua função de crédito para compras. A empresa reconhece que esta constitui uma falha gravíssima, e afirma que não irá implantar nenhum serviço adicional enquanto não estiver tudo regularizado em termos de relacionamento com o banco atual.

O cliente da Empresa H desejaria uma segmentação mais aprimorada, a fim de que recebesse apenas as informações realmente necessárias, pois a segmentação da comunicação por e-mail marketing ainda não consegue filtrar adequadamente os clientes potenciais de modo a não extrapolar seu nível desejado de informação.

\subsubsection{Situação do relacionamento entre empresa e clientes, após a introdução das vendas pela Internet}

Todas as empresas, com exceção da Empresa C, que faz algumas ressalvas, acreditam que as relações entre empresa e clientes irão melhorar, pois a Internet possibilita a troca de informações em tempo real, com análise mais efetiva de resultados (Empresa A), em função do maior volume de informações possíveis de serem coletadas (Empresa F), com oportunidade de interagir com mais freqüência e de maneira mais personalizada, oferecendo informações e serviços mais relevantes para todos os seus públicos (Empresa D); além disso, constitui um canal adicional, e mais ágil que os outros: ao possibilitar o envio de mais informações ao cliente, a um custo menor, permite à empresa utilizá-lo com mais intensidade que os demais canais (Empresa E). Adicionalmente, as vendas pela Internet exigem mais transparência, interessante para o cliente e para a empresa (Empresa B); a empresa passa a preocupar-se em tornar sua comunicação mais amável e amigável, o que é especialmente importante por uma constatação: a faixa etária de clientes pela Internet tem aumentado nos últimos anos, o que sinaliza que a população de mais idade, a qual, em geral, não possui muita afinidade com computadores, está tendo mais acesso à Internet, fato particularmente interessante para alguns setores (Empresa F). A loja fica praticamente disponível todo o tempo: o cliente tem acesso à loja quando desejar - por telefone, e-mail ou loja física (Empresa G). A Empresa $\mathrm{H}$ avalia que, embora não houvesse relacionamento anterior, é mais interessante para a empresa oferecer e para o cliente receber um tratamento automatizado, segmentado, personalizado, de alta qualidade, e em aprimoramento contínuo. 
A Empresa C avalia que, com a Internet, as relações entre empresa e clientes vão mudar sensivelmente. Atualmente, os clientes estão acostumados a serem atendidos por uma moça de boa aparência, simpática e sorridente; a Internet, ao contrário, é um ambiente "frio”, voltado ao autoserviço. A sociedade está caminhando para o auto-serviço (self-service): as pessoas estão criando infra-estrutura de lazer dentro de casa, para que elas se satisfaçam sem sair, por questões de segurança. No que for possível o auto-serviço, as pessoas irão preferi-lo, pois querem tomar maior controle sobre o que estão comprando. Desta forma, as empresas que estiverem prontas para atenderem online seus clientes e conseguirem se preparar para tanto, principalmente com a ajuda da Internet, serão beneficiadas.

A Empresa E observa que está mudando como um todo, e não devido à Internet, com o desenvolvimento de um amplo programa de marketing de relacionamento que a afetará de modo global, provavelmente com mudanças em vários aspectos da operação da empresa, como política de preços e/ou benefícios. Tais políticas serão válidas no âmbito geral da empresa, sendo aplicáveis também às vendas pela Internet e terão seus reflexos no marketing de relacionamento pela Internet.

\subsubsection{Considerações gerais}

Estar comercialmente presente na Internet não é tarefa simples. E avaliar se a empresa está obtendo melhores resultados com as vendas pela Internet também constitui uma questão delicada. Em vários dos casos estudados, após a empresa adotar as vendas pela Internet, os custos transacionais apresentam tendência de redução, ao passo que o faturamento, o número de clientes e o número de segmentos atingidos sinalizam tendência de crescimento. Embora nem todas as empresas tenham revelado a magnitude dessas variações, sabe-se que é complexo avaliar o quanto desse crescimento se deve ao produto em si, ao canal, ao mercado ou às demais ações que acompanham todo o processo.

Em alguns casos, as boas perspectivas em relação à Internet parecem ter sido expressadas pelos entrevistados para reforçar a justificativa da existência da própria área na empresa; contudo, coincidem com o potencial de crescimento das vendas pela Internet anunciado nas publicações e relatórios de empresas especializadas, mesmo passada a fase inicial de fascinação com a Internet. Muitos lamentam o fato de a penetração da Internet não ser maior: várias empresas não conseguem eliminar por completo os processos via papel e nem se relacionar com todos os seus clientes via Internet, simplesmente pelo fato de que a parcela da população que possui acesso a esse recurso, 
cultura para compras por esse canal e versatilidade de meios de pagamentos ainda é restrita. Embora ainda apenas um pequeno contingente de pessoas acesse a Internet no Brasil, e desse público, uma parcela ainda menor realize compras online, os entrevistados concordam que há um grande mercado a ser explorado. Há empresas que realmente esperam que suas vendas se desloquem de um meio ao outro; outras, ingressaram nessa operação apenas para complementar as opções de contato com seus clientes ao abrir mais um canal de vendas, ou para suprir as necessidades de parte de seus clientes, mas não esperam que as vendas pela Internet superem as vendas dos canais tradicionais. As empresas acreditam que isso talvez dependa mais de fatores como acesso da população e criação de cultura de compras pela Internet, do que de ações da própria empresa. Nota-se também que as avaliações de crescimento em função do comércio eletrônico ainda causam certa perplexidade nas empresas devido à dificuldade operacional inerente. O processo de estimativa de incremento da carteira de clientes de algumas empresas, por exemplo, não foi detalhado ou se mostrou inconsistente: em geral, as empresas não sabem afirmar com precisão qual seria a sobreposição entre os grupos que compram pelos diversos canais.

Dentre as oportunidades proporcionadas pelos negócios via Internet apontadas pelas empresas estão: ganhos de imagem perante seus clientes e/ou sua matriz no exterior; fortalecimento da marca junto a seus fornecedores, denotando principalmente modernidade, inovação e liderança tecnológica; divulgação da marca em localidades onde não se possui loja física; alcance de novos segmentos de mercado; expansão das vendas; redução de custos. Dentre as ameaças, podem ser consideradas as mais preocupantes: o risco de se macular a marca física, pela associação a um serviço de má qualidade prestado pela marca digital; invasões de hackers; fraudes, que podem afetar a empresa, clientes e parceiros; a perda de noção sobre o grau adequado de automatização, sob pena de prejudicar o relacionamento com os clientes; e vulnerabilidade criada pela intensa dependência da tecnologia, se não devidamente dimensionados os sistemas de contingência.

Os impactos e implicações declarados estão bastante associados não só ao marketing de relacionamento, mas às próprias vendas pela Internet. Os principais impactos da Internet sobre o marketing de relacionamento verificados pelas empresas pesquisadas estiveram relacionados à insuficiência ou inadequação de departamentos, cargos, processos e perfil de funcionários, ao surgimento/subtração de formas de relacionamento, aos benefícios oferecidos aos clientes, à estrutura tecnológica, e à funcionalidade das operações. Outros impactos da Internet foram verificados na disponibilidade em tempo integral da loja virtual, nas formas diferenciadas de acesso, 
interação, comunicação e coleta de dados, e por conseguinte, nas maiores oportunidades para conhecer o consumidor e oferecer-lhe ações mais direcionadas, com aferição de resultados e potencial de redução de custos de transação. Por outro lado, esta forma de comércio gerou algumas implicações, como a exigência de revisão na estrutura organizacional e no perfil de pessoal em vários níveis da empresa, aculturação, educação em relação a mudanças, capacitação em ferramentas tecnológicas. Alterações no processo de vendas e sobre o marketing mix também se fizeram necessárias: apresentação dos produtos/serviços, esclarecimento de dúvidas, atendimento ao cliente, cobrança, logística de entrega, administração de estoques, relações com intermediários, além de elementos adicionais, como segurança e privacidade, com efeitos sobre as práticas de relacionamento e as expectativas dos clientes. Muitas empresas afirmaram fazer revisões constantes para verificar a adequação e desempenho do site e dos serviços por ele oferecidos. Todavia, no confronto entre a teoria e a realidade, há empresas que, embora cientes de seu site estar 24 horas no ar, não mantêm estrutura de atendimento pessoal (chat, telefone) durante todo esse período.

Dependendo da natureza da operação, a decisão pelo comércio eletrônico implicou em diferenças de preços, de formas de pagamento, maior prazo de entrega em relação ao cliente comprar na loja física e levar imediatamente suas compras, ou menor, como nos casos em que foi possível eliminar etapas do processo. De qualquer maneira, segundo os entrevistados, o que as empresas oferecem de maior benefício com as vendas eletrônicas é a conveniência, a praticidade, a economia de tempo, elementos muito valorizados nos dias atuais, especialmente pelo perfil de cliente que compra pela Internet. O fator "preços mais baixos” foi citado por algumas empresas como sendo ainda parte das expectativas dos clientes; outras declararam que estes não tomam esse fator como preponderante ao optar pela compra online. No início das vendas pela Internet, procurava-se predominantemente preço; a seguir, passou-se também a buscar um bom prazo de entrega. Hoje, resolvidas essas questões, outras surgem para diferenciar uma empresa da outra. Uma experiência de compra positiva (esclarecimento de dúvidas, cobrança realizada corretamente, entrega no prazo prometido, produtos íntegros e de qualidade) pode representar um diferencial rumo à fidelização dos clientes, não só em relação aos concorrentes da empresa no mundo digital, como também no mundo físico. 
Figura 39 - Serviços oferecidos pelas 100 maiores empresas de comércio eletrônico do Brasil

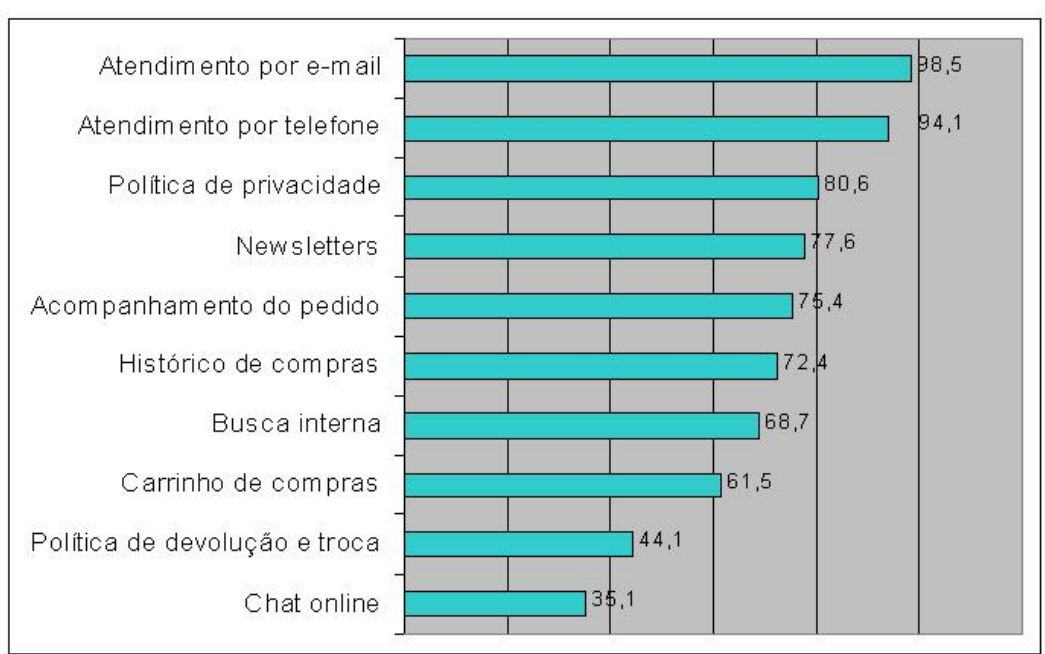

Fonte: Reggiani (2003:73).
$\mathrm{Na}$ figura 40, encontram-se os resultados de uma pesquisa realizada pela revista Info Exame, que elegeu as 100 maiores empresas de comércio eletrônico de 2002. Segundo essa pesquisa, 98,5\% das empresas procuram resolver problemas de clientes por e-mail (Reggiani, 2003:73). Vários dos itens referidos nessa pesquisa fazem parte dos serviços oferecidos também pelas empresas entrevistadas neste estudo, o que

sinaliza que as suas práticas estão, de certa forma, equiparadas às das maiores empresas brasileiras de comércio eletrônico de 2002, com a possibilidade de algumas delas terem feito parte de ambas as amostras. Em consulta aos sites das empresas entrevistadas, em complementação aos depoimentos colhidos, pôde-se observar que todos os sites possuem um link do tipo "Fale Conosco" ou “Atendimento ao Cliente”, para que sejam enviados às empresas comentários, críticas, sugestões, elogios e dúvidas. Tal link fornece um endereço de e-mail aos clientes, possibilita-lhes enviar uma mensagem pelo próprio site da empresa, oferece-lhes estas duas opções de comunicação, ou lhes permite conversar online com um atendente, por meio de chat. $\mathrm{O}$ fato de a empresa disponibilizar um formulário em seu site para que os clientes se manifestem explicita um cuidado em viabilizar a comunicação de clientes que não possuem endereço de $e$-mail e facilitar o processo para quem já o possui. Mesmo atuando no comércio eletrônico, é imprescindível que se divulgue no site da empresa o número de telefone de seu SAC, uma vez que, em situações emergenciais, nem sempre é possível conseguir uma conexão à Internet; mesmo havendo tal conexão, nem sempre os e-mails são respondidos em tempo hábil. Nos sites de todas as empresas pesquisadas, são publicados os endereços de suas lojas físicas, os respectivos números de telefone, e os números de suas centrais de atendimento, oferecendo aos clientes mais alternativas de contato. Adicionalmente, as empresas têm se aproveitado da facilidade self-service da Internet a qual, como observam Forbes (2002:1), Raut (2002:1-3) e Honeycomb (2001:2), pode proporcionar agilidade para os clientes e economia para a empresa, principalmente nas recepções de ligações do serviço 0800. Para tanto, o self-service deve 
ser adequadamente estruturado e ter o respaldo de um atendimento pessoal, caso não se encontrem as informações desejadas. Nas vendas pela Internet, sai de cena o vendedor típico para dar lugar ao atendente de SAC. Esse profissional continua com a incumbência de prestar o melhor serviço possível aos clientes da empresa, com as mesmas necessidades de treinamento, porém, com capacitação adicional em eventuais ferramentas necessárias ao atendimento pela Internet. Dependendo de sua atuação, o cliente pode optar por comprar ou não daquele site e, o que é mais importante, decidir repetir ou não a experiência.

A maior parte das empresas afirmaram possuir diferenças de tratamento entre clientes que compram via Internet e clientes que compram pelas vias tradicionais, porém, em função dos processos e não com intenção de privilegiar um ou outro canal, embora, no início das atividades de um canal seja compreensível que este seja especialmente promovido para se tornar conhecido.

Em função de se estar trabalhando com um perfil diferenciado de clientes, as empresas notam diferenças de comportamento entre clientes que compram pelas lojas físicas e os que compram pela loja eletrônica, os quais trazem outros tipos de questionamentos, anseios e necessidades, o que provocou mudanças na abordagem nas relações com clientes, quer seja no sentido de passar de uma postura reativa para uma mais pró-ativa ou vice-versa, quer seja no de procurar direcionar melhor sua comunicação, diante do perfil dos clientes que compram via Internet. A pró-atividade faz parte dos princípios do marketing voltado para o valor, conforme Churchill e Peter (2000:10). A estratégia de aproximação dos clientes por meio da criação de comunidades observada nos estudos de Moe e Fader (2000, in Barwise, Elberse e Hammond, 2001:21), supõe que as pessoas que visitam uma loja com maior freqüência, seja física ou virtualmente, estejam mais propensas a comprar. Essa estratégia tem sido considerada por algumas das empresas pesquisadas, nas quais há algumas poucas iniciativas em atividade. Contudo, como evidenciam autores como Danaher et al. (2000, in Barwise, Elberse e Hammond, 2001:23) e como apontado por algumas empresas, ainda é um desafio analisar e compreender o comportamento de compra do mesmo cliente no site e na loja física, e qual o grau de influência das comunidades sobre este comportamento. Em relação à personalização, também há bastante espaço para desenvolvimento, embora haja várias práticas pulverizadas entre as empresas. Notam-se, entretanto, algumas incongruências dentre a noção das empresas e a teoria apresentada pelos autores sobre esse tema, principalmente relacionadas à dificuldade de diferenciação entre os vários níveis de personalização. 
Há empresas que enfatizam em toda a sua comunicação a importância do relacionamento e da responsabilidade social da empresa; embora também façam menções à qualidade de seus produtos, consideram-na um pré-requisito; o mote principal de sua mensagem é a valorização do relacionamento. Com o lema “uma rede de relações”, uma das empresas tem implementado várias ações nesse sentido. Além disso, desenvolve embalagens para algumas linhas com os nomes dos produtos escritos em braile, o que sinaliza preocupação com a inclusão social dos deficientes visuais, iniciativa bastante positiva sob o ponto de vista do marketing de relacionamento.

O fato de uma empresa não ter declarado que tomou providências em determinados aspectos concernentes ao marketing de relacionamento em decorrência da Internet não significa que não tenha sido afetada por seus impactos ou que tenha permanecido inerte a eles. Em alguns casos, a empresa já possuía um arcabouço de políticas, estrutura e procedimentos consistentes, de modo que não foi necessária nenhuma alteração mais significativa para adequar-se à nova realidade.

Embora em algumas empresas se tenha conversado com pessoal responsável por Internet, em geral, essas pessoas têm um perfil híbrido: são especialistas em tecnologia e em negócios. Para implantar uma tecnologia de maneira eficiente, é preciso que se tenha uma visão clara das funções que sofrerão intervenção tecnológica, ou que serão facilitadas pela tecnologia. O conceito de marketing de relacionamento não pode ser ignorado. Pôde-se observar, a partir das entrevistas, que há grande variação no grau de proximidade e integração entre áreas responsáveis por Internet e Marketing de Relacionamento. Há empresas em que ambas se confundem, todas as ações são voltadas para vendas e relacionamento; em outras, trabalham em cooperação; e há empresas com pontos de intersecção, mas sendo o relacionamento tratado segundo o canal de contato. Mesmo empresas novas têm conseguido desenvolver e executar um planejamento tal que a tecnologia tem superado algumas de suas dificuldades, como uma estrutura bastante enxuta e escassez de treinamentos, e lhes proporcionado grandes vantagens em outros aspectos, como padronização e automatização quase que total de toda a sua operação de vendas pela Internet. Outro aspecto que vale salientar, fundamental para o êxito destas atividades, é a concentração, nem sempre possível ou conveniente em todas as empresas, das decisões de tecnologia da informação e de parte das decisões de marketing em uma mesma diretoria, permitindo desenvolver ferramentas tecnológicas com foco intenso na visão estratégica do negócio.

A conduta das empresas em relação à implantação de novos conceitos, envolvendo soluções tecnológicas ou não, também apresenta um amplo espectro de variações. Algumas empresas contam 
com o apoio de empresas de consultoria; outras, dependem do expertise e know-how de seus profissionais, que buscam nos livros e universidades embasamento teórico sobre as práticas a serem consideradas e aplicadas à sua realidade; outras, ainda, podem usufruir da experiência e estrutura de suas matrizes internacionais. O ponto comum entre todas elas é a visão de que os fundamentos do relacionamento devem estar presentes em todos os aspectos de seu negócio, quer seja pela Internet ou não, o que demanda educação e informação de todos os funcionários, intenso empenho dos líderes dessa mudança e patrocínio da alta administração da empresa. Todas as empresas entrevistadas possuem experiências interessantes a transmitir, não importando o setor ou há quanto tempo se iniciou nas práticas de marketing de relacionamento ou no comércio pela Internet. Em épocas de intensa competição como a atual, em que um simples clique de mouse pode transportar o cliente de uma loja a outra, é imprescindível que canalizem os preceitos do relacionamento aliados aos recursos da Internet para a conquista de maior competitividade.

\subsection{Panorama das práticas das empresas no contexto do binômio marketing de relacionamento e Internet}

No quadro 29 a seguir, as células marcadas com um “ $X$ ” representam os aspectos indicados pelos próprios entrevistados como mais deficitários em termos de marketing de relacionamento (bloco I); as células marcadas com "Y" retratam a auto-classificação das empresas nas fases da Internet, segundo referência de Kosiur (1997) (bloco II); e as células marcadas com “Z” indicam os aspectos que não foram alvo de modificações/implicações decorrentes da Internet que seriam esperadas por parte das empresas (bloco III). Cabe salientar que a adesão às possibilidades de ações a seguir apresentadas dependem dos objetivos estratégicos, dos dados contábeis e financeiros e da cultura da organização, variáveis cuja análise não faz parte do objeto deste estudo. Desta maneira, o caráter das sugestões inerentes ao bloco III é apenas ilustrativo do uso prático dos conceitos teóricos referentes a marketing de relacionamento.

Antes da apresentação do quadro 29, é preciso que se façam algumas ressalvas:

- A ausência de marcação no bloco III não garante que as ações previstas já estejam realizadas de forma adequada; tanto em caso positivo como negativo, é imprescindível um monitoramento contínuo para o seu aprimoramento.

- A presença de marcação no bloco III pode implicar/sugerir um hiato entre as ações/atividades apresentadas na teoria e a prática declarada pelas empresas devido a: 
a. Despreparo/imaturidade da empresa por falta de entendimento da contribuição destas ações para o uso mais eficiente do comércio eletrônico na busca da excelência do relacionamento com clientes.

b. Despreparo/imaturidade da empresa por falta de recursos financeiros, tecnológicos, de pessoal etc.

c. Despreparo/imaturidade da empresa por ambos os motivos apresentados em a. e b.

d. Canalização de esforços pelas empresas norteada por objetivos que priorizam outro nível de relacionamento com o cliente.

- A presença de marcação no bloco III, pode significar, ainda, que, para determinada empresa, as ações sugeridas já faziam parte do seu cotidiano antes mesmo da sua experiência com comércio eletrônico, não demandando uma mudança de postura dentro deste novo cenário. 
Quadro 29 - Panorama das empresas: Marketing de Relacionamento e Internet

\begin{tabular}{|c|c|c|c|c|c|c|c|c|c|}
\hline Blocos & Empresas & A & B & C & D & $\mathbf{E}$ & $\mathbf{F}$ & G & $\mathbf{H}$ \\
\hline \multirow{10}{*}{ 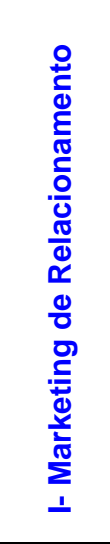 } & Programas de lealdade & & & & $\mathrm{X}$ & $\mathrm{X}$ & & & \\
\hline & Pesquisas de opinião/satisfação dos clientes & & & & & & & & \\
\hline & Canais de comunicação com cliente & & & & & $X$ & & & \\
\hline & Definição de metas de satisfação dos clientes & & & & & $X$ & $X$ & $X$ & \\
\hline & Administração de padrões para atendimento de reclamações & & & & & $X$ & & & \\
\hline & Treinamento para funcionários sobre atendimento a clientes & & & & & & & & $X$ \\
\hline & Valorização de funcionários em função do marketing de relacionamento & & & & & $\mathrm{x}$ & & & \\
\hline & Projetos de produtos em conjunto com clientes & & & & & $X$ & & & \\
\hline & Implantação do CRM & & $X$ & & & $X$ & $X$ & $X$ & \\
\hline & Produtos / serviços personalizados & & & & & & & & $X$ \\
\hline \multirow{4}{*}{ 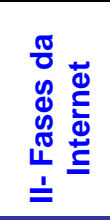 } & Presença & & & & & & & & \\
\hline & Interação & & & & & & $\mathrm{Y}$ & & \\
\hline & Transação & & & & & Y & & Y & \\
\hline & Processo/Integração & Y & Y & Y & Y & & & & Y \\
\hline \multirow{16}{*}{ 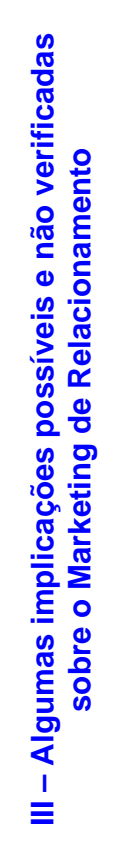 } & Perfil de pessoal & & Z & & & Z & & & \\
\hline & Abordagem nas relações com clientes & & & & & & & & \\
\hline & Canais de comunicação empresa-clientes & & & & & & Z & & \\
\hline & Pesquisas sobre desejos e necessidades dos clientes & & & & & & & & \\
\hline & Tratamento das sugestões, críticas ou reclamações de clientes & Z & & & & Z & & Z & \\
\hline & Benefícios ofertados & & & & & Z & Z & Z & \\
\hline & Programas de lealdade & & Z & & & & & & \\
\hline & Políticas privacidade & & & & & & & & \\
\hline & Forma de coleta de dados e tipos de dados coletados & & Z & & & & & & \\
\hline & Gerenciamento e análise dos dados coletados & & Z & & & & & & \\
\hline & Oferecimento de produtos ou serviços personalizados & & & & & Z & & & \\
\hline & Desenho e funcionamento do site & & & & & & & & \\
\hline & Formas de o cliente obter informações sobre o seu pedido & & & & & & & & \\
\hline & Novos procedimentos operacionais de vendas & Z & & & & Z & & & \\
\hline & $\begin{array}{l}\text { Diferenciação de tratamento entre clientes que compram pela } \\
\text { Internet e os que compram pelos meios tradicionais }\end{array}$ & & & & & Z & & & \\
\hline & Políticas de investimento em tecnologia de informação & & & Z & Z & Z & Z & Z & \\
\hline
\end{tabular}

Fonte: dados de campo.

$\mathrm{Na}$ abordagem das relações com clientes, um dos itens do bloco III, deve-se ressaltar que as boas maneiras e a atenção que os clientes associam com bons serviços pessoais precisam ser parte integrante dos padrões da empresa para contratação, performance e, sobretudo, treinamento. A formação/capacitação do funcionário deve ser voltada tanto aos aspectos técnico-operacionais como aos aspectos comportamentais perante os clientes da empresa. 
Não obstante a complexidade da tarefa de avaliar numericamente os efeitos da implantação do marketing de relacionamento em uma empresa, uma vez que os investimentos precisam ser justificados, deve-se partir de uma definição clara de metas e de critérios para avaliação, com reavaliação periódica. Talvez seja este o aspecto mais deficitário das empresas, que têm consciência da importância e das vantagens do marketing de relacionamento, porém não têm medidas para avaliá-lo. Várias análises podem surgir a partir do conhecimento que os profissionais de marketing possuem de seu negócio e a partir de dados que os sistemas podem fornecer, sejam eles chamados de CRM ou não.

É preciso que a estrutura de atendimento seja bem administrada, quer seja por $e$-mail, chat ou telefone, e totalmente integrada, de modo que o cliente veja a empresa como uma unidade, e que esta tenha, também, uma visão única do cliente. Adicionalmente, o relacionamento baseado apenas no conhecimento pessoal dos vendedores ou atendentes fragiliza a empresa: caso essas pessoas deixem a organização, as informações sobre os clientes se esvairão, pois o relacionamento é do funcionário com o cliente, e não da empresa com o mesmo. Daí emerge a importância de sistemas que armazenem e tratem analiticamente as informações dos clientes, principalmente em se tratando de empresas de grande porte, característica facilitada pelos recursos tecnológicos freqüentemente utilizados nas vendas pela Internet.

Acrescente-se que alguns dos entrevistados afirmaram utilizar-se de sua experiência pessoal como compradores pela Internet para avaliar as práticas de outras empresas, comparando-as às suas, por meio de benchmarking. Acredita-se que esta seja uma prática interessante no sentido de que se exercita a empatia: colocar-se no lugar do cliente, para tentar sentir o que ele sente ao ser atendido pela sua empresa.

Ainda que o marketing de relacionamento não faça parte das prioridades de algumas empresas, ações dirigidas ao seu aprimoramento a médio ou longo prazo certamente trariam contribuições para o alcance de seus principais objetivos, qualquer que seja a sua natureza.

\section{Conclusões}

Não é possível afirmar com certeza que o relacionamento pela Internet seja melhor ou pior em relação aos canais normais de comercialização, uma vez que se podem verificar aspectos negativos e positivos em todos eles. A despeito do porte das empresas, a percepção acerca destes fatores varia em função do setor de atividade da empresa, da natureza de seus produtos ou serviços, do seu 
entendimento do que seja marketing de relacionamento e do grau de assimilação desse conceito no dia-a-dia de suas operações, além das expectativas e do grau de afinidade com recursos tecnológicos de seus clientes. Essa variação é reforçada pela diferença de nível de desenvolvimento de suas práticas, resultado de sua orientação estratégica, disponibilidade de recursos e esforço pessoal dos envolvidos. As características da tecnologia da Internet permitem às empresas enriquecer a interface com seus clientes, oferecendo-lhes recursos adicionais como personalização e comunidades, além de agilidade, comodidade, conveniência e economia de tempo. Entretanto, suprimem o contato face-a-face dos canais tradicionais de vendas.

Há sinais de que, no entanto, uma boa estratégia de relacionamento, com postura pró-ativa por parte da empresa, sem negligência do fator humano, pode ser bastante benéfica para 0 desenvolvimento de relações via Internet. A pró-atividade pode existir quando a empresa procura antecipar as necessidades ou estimular as necessidades latentes de seus clientes, atuar na prevenção de possíveis problemas, evitando, assim, o mau atendimento, e trabalhar na concepção do serviço/produto de modo a oferecer o melhor valor, aos olhos dos clientes.

Com base neste estudo, chega-se a uma reflexão acerca das práticas de marketing de relacionamento, das implementações nos sites das empresas e das mútuas interferências entre a filosofia inerente ao marketing de relacionamento e as operações pela Internet. Padrões elevados no marketing de relacionamento podem constituir forte vantagem competitiva e, como afirma Porter (2001:64), as empresas que utilizam a Internet aliada às formas normais de competição é que terão maiores chances de sucesso.

\section{Restrições/limitações do estudo}

Algumas limitações do estudo são decorrentes da própria determinação da população submetida à restrição de uma delimitação geográfica -, da escolha da amostra - intencional -, e do tipo de pesquisa: as informações levantadas são sinalizadoras de comportamentos e não permitirão inferências estatísticas.

Além disso, não fez parte do foco deste estudo pesquisar a orientação estratégica da empresa. Acrescente-se que foram pesquisadas apenas empresas de grande porte, pelo critério de faturamento, o que exclui as empresas que por algum motivo não foram bem sucedidas ou que estão com receitas diminuídas. Trata-se de uma realidade em evolução, sujeita a muitas transformações. 


\section{Sugestões para estudos futuros}

A partir dos resultados obtidos, podem surgir idéias de pesquisas sobre quais seriam as perspectivas para as empresas que ainda não adotaram a Internet como meio para fazer negócios, em relação ao marketing de relacionamento; podem-se conduzir também estudos quantitativos que tragam subsídios para analisar se esta nova forma de fazer negócios seria aplicável em determinado setor da economia e se haveria aplicação bem sucedida tanto em mercados business-to-business (mercado empresarial) como em mercados business-to-consumer (mercado consumidor); outros trabalhos poderiam investigar quais mudanças ocorrem no perfil dos profissionais das empresas que trabalham com marketing de relacionamento e que adotaram aplicações de Internet para realização de seus negócios com clientes, e quais mudanças estruturais têm sido executadas nas empresas com estas características.

Também poderia ser objeto de um estudo futuro investigar fatores determinantes da adesão às compras online sob a ótica dos clientes.

Além disso, este trabalho permite que, em estudos posteriores, façam-se algumas indagações envolvendo os impactos da Internet sobre a estratégia de marketing e o comportamento do consumidor, como por exemplo:

1. O comportamento do consumidor muda quando a Internet é utilizada como um canal para o comércio?

2. Os consumidores são mais ou menos leais quando compram online? Quais fatores determinam a lealdade do cliente em um ambiente online?

3. Como difere o papel das marcas nos ambientes online e offline?

4. Como os canais online e offline devem ser combinados? Os canais online canibalizam os canais offline?

5. Como o marketing na Internet evoluirá para um marketing que utilize uma ampla gama de mídias digitais convergentes (broadband, mobile, interactive television)?

Tais questões fornecem subsídios para o estabelecimento de hipóteses que poderiam ser testadas em estudos futuros, podendo ser exemplificadas com os enunciados a seguir:

1. O comportamento do consumidor varia segundo os canais de comercialização.

2. O consumidor que compra pelos canais online é mais suscetível a ações de marketing de relacionamento que os que compram pelos canais tradicionais. 
3. A lealdade do consumidor online varia em função do setor de atividade em questão.

4. O consumidor é mais fiel nas compras online que nas compras offline.

5. A lealdade do cliente nas compras online é mais influenciada por uma experiência anterior positiva com a empresa do que pelo preço.

6. As marcas têm maior influência nos resultados da empresa no ambiente online que no ambiente offline.

7. Uma marca bem sucedida no ambiente offline também o será no ambiente online.

8. Dependendo do setor de atividade, os canais online canibalizam os canais offline.

9. O marketing na Internet atingirá melhores resultados quando recursos tecnológicos de maior capacidade estiverem disponíveis a maior número de pessoas.

\section{Referências bibliográficas e obras consultadas}

\subsection{Referências bibliográficas}

A. T. KEARNEY. e-Business performance: snapshots of sales innovation on the web. [Chicago]: A. T. Kearney, 22 Feb. 2000. Disponível em: $<$ http://www.atkearney.com/ATK/Publications/ic_detail/1,1071,1045,00.html>. Acesso em: Nov. 2000.

BABBIE, E. R. The practice of social research. $9^{\text {th }}$ ed. Belmont, CA: Wadsworth-Thomson Learning, 2001.

BANCO CENTRAL DO BRASIL. Cotação do dólar americano. Brasília, 25 abr. 2001. Disponível em: <http://www.bcb.gov.br>. Acesso em: 17 out. 2001.

BANCO NACIONAL DE DESENVOLVIMENTO ECONÔMICO E SOCIAL. Porte de empresa. Rio de $2001 . \quad$ Disponível em: <http://www.bndes.gov.br/produtos/consulta/porte/porte.asp> . Acesso em: 25 abr. 2001.

BARTELS, R. The development of marketing thought. Homewood, IL: Richard D. Irwin, 1962.

BARWISE, P.; ELBERSE, A.; HAMMOND, K. Marketing and the Internet: a research review. London: London Business School, 2002. Disponível em: <http://www.marketingandtheinternet.com>. Acesso em: out. 2002.

BAYNE, K. M. Humanize your web customer service. e-Business Advisor, San Diego, p. 12-17, Aug. 2000.

BELCH, G. E.; BELCH, M. A. Advertising and promotion: an integrated marketing communications perspective. $6^{\text {th }}$ ed. New York: McGraw-Hill, 2003.

BISHOP, Bill. Strategic marketing for the digital age. Lincolnwood (Chicago), IL: American Marketing Association/ NTC Business Books, 2000.

BLATTBERG, R. C.; DEIGHTON, J. Manage marketing by the customer equity test. Harvard Business Review, Boston, p.136-144, July/Aug. 1996. 
BOONE, L. E.; KURTZ, D.L. Contemporary marketing. $10^{\text {th }}$ ed. Orlando: Harcourt College, 2001.

BOOZ·ALLEN \& HAMILTON; WHARTON SCHOOL. The customer profitability conundrum. Strategy + Business/Knowledge Wharton, White paper. [S.l.], 10 Apr. 2002. Disponível em: $<$ http://www.strategy-business.com/media/general/sb_kw_12-04-02.pdf $>$. Acesso em: 14 jan. 2003.

BOYD JR., H. W.; WESTFALL, R. Marketing research: texts and cases. $3^{\text {rd }}$ ed. Homewood, IL: Richard D. Irwin, 1972. p. 422-433.

BRETZKE, M. Marketing de relacionamento e competição em tempo real. São Paulo: Atlas, 1999.

BROWN, S. W.; FISK, R. P. (Org.). Marketing theory: distinguished contributions. New York: John Wiley, 1984.

CANTERO, C.; RIZZO, L.; WERNECK, T. Elas são excelentes. Consumidor Moderno, São Paulo, a. 8, n. 69, p. 44-78, 2003.

CARR, N. G. TI já não importa. Harvard Business Review, Santiago, p. 30-37, maio 2003.

CHEIN, I. Uma introdução à amostragem. In: SELLTIZ, C.; JAHODA, M.; DEUTSCH, M.; COOK, S. W. Métodos de pesquisa nas relações sociais. ed. rev. São Paulo: Editora Pedagógica e Universitária, 1974. Apêndice B, p. 571-611.

CHOI, S. Y.; WHINSTON, A. B.; STAHL, D. O. The economics of electronic commerce. Indianapolis: Macmillan Technical Publications, 1997.

CHUNG, S.; SHERMAN, M. Emerging marketing. The McKinsey Quarterly, New York, n. 2, 2002.

Disponível

em:

<http://www.mckinseyquarterly.com/article_page.asp?tk=384629:1164:16ear=1164eL2=16eL31 7>. Acesso em: 19 fev. 2002.

CHURCHILL, G. A. Marketing research: methodological foundations. $2^{\text {nd }}$ ed. Hinsdale, IL: Dryden, 1979.

CHURCHILL, G. A.; PETER, J. P. Marketing: criando valor para o cliente. São Paulo: Saraiva, 2000.

COBRA, M. O futuro estratégico das organizações. In: Administração Estratégica do

Mercado. São Paulo: Atlas, 1991. cap. 15, p. 151-156.

COFFEY, A.; ATKINSON, P. Making sense of qualitative data: complementary research strategies. Thousand Oaks: Sage, 1996.

CONSTANTINIDES, E. From physical marketing to Web marketing: the web-marketing mix. Proceedings of the 35th Hawaii International Conference on System Sciences, Big Island, 7-10 Jan. 2002. Disponível em: <http://dlib2.computer.org/conferen/hicss/1435/pdf/14350205.pdf>. Acesso em: ago. 2003.

COYLES, S.; GOKEY, T. C. Customer retention is not enough. McKinsey Quarterly, New York, n. 2, 2002. 2 Disponível em: $<$ http://www.mckinseyquarterly.com/article_page.asp?tk=384629:1176:16ear=1176eL2=16eL3= 20>. Acesso em: 18 abr. 2002. 
CRESCITELLI, E. Marketing de relacionamento: um estudo sobre as relações entre vendedores varejistas e fabricantes de eletrodomésticos. 2003. 214 f. Tese (Doutorado em Administração) Faculdade de Economia, Administração e Contabilidade, Universidade de São Paulo, São Paulo.

CYMBAUM, J. O.; MÁLACCO, R. L. S. Qualidade de atendimento no varejo: um desafio de recursos humanos. In: ANGELO, C. F. de; GIANGRANDE, V. Marketing de relacionamento no varejo. São Paulo: Atlas, 1999. cap. 2, p. 27-41.

DEIGHTON, J.; BARWISE, P. Digital Marketing Communication. In: WIND, J.; MAHAJAN, V. Digital marketing: global strategies from the world's leading experts. New York: John Wiley, 2001. cap. 13, p. 339-361.

DEMPSEY, M. Fornecedor de CRM simplifica sistemas para manter clientes. Valor Econômico, São Paulo, 29 e 30 nov. 2002 e 1 dez. 2002. Financial Times, p. B4

DHOLAKIA, U.; BAGOZZI, R. P. Consumer behavior in digital environments. In: WIND, J.; MAHAJAN, V. Digital marketing: global strategies from the world's leading experts. New York: John Wiley, 2001. cap. 7, p. 189.

DODD, A. Z. The essential guide to telecommunications. $2^{\text {nd }}$ ed. Upper Saddle River, NJ: Prentice-Hall PTR, 2000.

DOMINGUEZ, S. V. Valor percebido como elemento estratégico para obter a lealdade dos clientes. Caderno de Pesquisas em Administração, São Paulo, v. 7, n. 4, p. 53-64, out./dez. 2000.

DRUCKER, P. Além da revolução da informação. HSM Management, São Paulo, n. 18, p. 4855, jan./fev. 2000.

DUTTA, S.; KWAN, S. K.; SEGEV, A. Strategic marketing and customer relationship in eletronic commerce. CITM Working Paper 1023-WP-1997. Berkeley, 1997. Disponível em: <http://groups.haas.berkeley.edu/citm/publications/papers/wp-1023.pdf> . Acesso em: dez. 2001.

E-BIT. Evolução do comércio eletrônico brasileiro: 2000-2003. Webshoppers, São Paulo, 8. ed. Ago. 2003. <http://www.ebit.com.br/ebit1/empresa/relatorio/webshoppers/WebShoppers8.pdf>. Acesso em: 29 ago. 2003.

ELLSWORTH, J. H.; ELLSWORTH, M. Marketing on the Internet. $2^{\text {nd }}$ ed. New York: John Wiley, 1997.

ERDEN, A. S.; UTECHT, R. L. Marketing on the Internet: a critical review. Journal of Academy of Business, Cambridge, p. 102-106, Sep. 2002.

EVANS, P.; WURSTER, T. S. Getting real about virtual commerce. Harvard Business Review, Boston, p. 85-92, Nov./Dec. 1999.

FINGAR, P.; KUMAR, H.; SHARMA, T. Entreprise e-commerce: the software componente breakthrough for business-to-business commerce. Tampa, FL: Meghan-Kiffer, 2000.

FINKELMAN, D.; GOLAND, T. O caso do cliente queixoso. In: SHAPIRO, B. P.; SVIOKLA, J. J. Mantendo clientes. São Paulo: Makron Books, 1994. cap. 14, p. 253-272.

FONSECA, M. A. Como preparar o pessoal de atendimento. In: ANGELO, C. F. de; GIANGRANDE, V. Marketing de relacionamento no varejo. São Paulo: Atlas, 1999. cap. 4, p. 55-64.

FORBES, S. Best practices for online self-service. Norwalk, CT, 4 Apr. 2002. Disponível em: <http://www.tmcnet.com/tmcnet/articles/040402rn.htm>. Acesso em: 24 abr. 2002. 
FOURNIER, S.; DOBSCHA, S.; MICK, D. G. Preventing the premature death of relationship marketing. Harvard Business Review, Boston, p. 43-50, Jan./Feb. 1998.

GALE, B. T. Managing Customer Value. New York: Free Press, 1994.

GARTNER GROUP. Making Customer Relationship Management work. Exp Premier. Stamford, CT: Gartner Group, July 2000.

GAZETA MERCANTIL. Sites superam suas previsões. 6 jan. 2003. Telecomunicações e Informática, p. B-9.

. Balanço anual. São Paulo, a. XXVI, n. 26, jun/2002. Publicação anual.

GHOSH, S. Making business sense of the Internet. Harvard Business Review, Boston, p. 126135, Mar./Apr. 1998.

GIANFORTE, G. Insider's guide to customer service on the Web: ten secrets for successful eService. Bozeman, MT, 2001. Disponível em: <http://www.rightnow.com/resource/brief.html>. Acesso em: 24 abr. 2002.

GIANGRANDE, V. Marketing de relacionamento e o papel do ombudsman. In: ANGELO, C. F. de; __ . Marketing de relacionamento no varejo. São Paulo: Atlas, 1999. cap. 1, p. 15-26.

GODIN, S. Marketing de permissão: transformando desconhecidos em amigos e amigos em clientes. 3 ed. Rio de Janeiro: Campus, 2000.

GRALLA, P. Como funciona a Internet: edição totalmente nova. São Paulo: Quark, 1996.

GUMMESSON, E. Total relationship marketing - rethinking marketing management: from 4Ps to 30Rs. Oxford: Butterworth Heinemann, 1999.

HART, C. W. L. O poder das garantias incondicionais de serviço. In: SHAPIRO, B. P.; SVIOKLA, J. J. Mantendo clientes. São Paulo: Makron Books, 1994. cap. 9, p. 161-178.

.; HESKETT, J. L.; SASSER JR., W. E. A lucrativa arte da recuperação de serviços. In: SHAPIRO, B P.; SVIOKLA, J. J. Mantendo clientes. São Paulo: Makron Books, 1994. cap. 15, p.273-290.

HIRSH, E. R. How to treat customers right: winning the channels challenge. Strategy and Business, New York: Booz•Allen and Hamilton, issue 4, p. 21-33, 3 ${ }^{\text {rd }}$ quarter 1996.

HOLOVKO, B. I. Comitês de clientes. In: ANGELO, C. F. de; GIANGRANDE, V. Marketing de relacionamento no varejo. São Paulo: Atlas, 1999. cap. 9, p. 119-129.

HONEYCOMB, J. Insider's guide to the key elements of a complete Internet customer service solution. Bozeman, 2001.2 Disponível em: <http://www.rightnow.com/resource/complete.html>. Acesso em: 24 abr. 2002.

HOU, J.; REGO, C. Internet marketing: an overview. Mississipi, Nov. 2002. Disponível em:

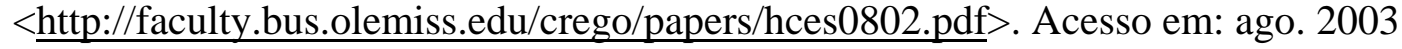

HUTCHISON JR., W. M.; STOLLE, J. F. Como administrar o serviço ao cliente. In: SHAPIRO, B. P.; SVIOKLA, J. J. Mantendo clientes. São Paulo: Makron Books, 1994. cap. 6, p. 95-119.

INTERNATIONAL TELECOMMUNICATIONS UNION. Genebra, 19 Jan. 2000. Disponível em: < http://www.itu.int/ITU-D/ict/statistics/at_glance/Internet97.pdf> . Acesso em: ago. 2003.

Genebra, 24 Apr. 2003. Disponível em: <http://www.itu.int/ITUD/ict/statistics/at_glance/Internet02.pdf>. Acesso em: ago 2003. 
JAWORSKI, B. J.; KOHLI, A. Marketing orientation: antecedents and consequences. Journal of Marketing, Chicago, v. 57, p. 53-70, July 1993.

JONES, D. G. B.; SHAW, E. H. A history of marketing thought. In: WEITZ, B. A.; WENSLEY, R. Handbook of marketing. Thousand Oaks: Sage, 2002. cap. 2, p. 39-65.

JONES, T. O., SASSER JR., W. E. Why satisfied consumers defect. Harvard Business Review, Boston, p. 88-99, Nov./Dec. 1995.

KALAKOTA, R.; ROBINSON, M. e-Business: roadmap for success. Reading, MA: AddisonWesley, 1999.

KALYANAM, K.; MCINTYRE, S. The e-marketing mix: a contribution of the e-tailing wars. Journal of the Academy of Marketing Science, Miami, v. 30, n. 4, p. 483-495, 2002.

KEANE, B. A guide to the trends, industries and players in IT services. Prudential Financial, Newark, NJ, 5 Dec. 2002.

KINNEAR, T. C.; TAYLOR., J. R. Marketing research: an applied approach. $5^{\text {th }}$ ed. New York: McGraw-Hill, 1996.

KNOWLEDGE AT WHARTON - MARKETING. Why some companies succeed at CRM (and many fail). Philadelphia, 15 Jan. 2003. Disponível em: <http://knowledge. wharton.upenn.edu/articles.cfm?catid=4\&articleid=699> Acesso em: 16 jan. 2003.

KOHLI, A.; JAWORSKI, B. J. Marketing orientation: the construct, research, propositions and managerial implications. Journal of Marketing, Chicago, v. 54, p. 1-18, Apr. 1990.

KOSIUR, D. Understanding electronic commerce: how online transactions can grow your business. Redmond,WA: Microsoft Press, 1997.

KOTLER, P. Administração de marketing: análise, planejamento, implementação e controle. 3. ed. São Paulo: Atlas, 1994.

. Marketing management: analysis, planning, implementation and control. The Millenium Edition. Upper Saddle River, NJ: Prentice-Hall, 2000.

1993.

. ; ARMSTRONG, G. Princípios de marketing. Rio de Janeiro: Prentice-Hall do Brasil,

LAKATOS, E. M.; MARCONI, M. de A. Metodologia Científica. São Paulo: Atlas, 1991.

LANDRY, Susan. A relationship strategy alone doesn't cut it in the Edge Economy. GartnerG2 Report. RPT-1001-0153. Stamford, CT: Gartner Group, 7 Nov. 2001. Disponível em: http://www3.gartner.com/1_researchanalysis/focus_areas/g1g2_special_reports/g1g2special1.ht ml. Acesso em: dez. 2001.

LAUDON, K. C.; LAUDON, J. P. The Internet: electronic commerce and electronic business. In: _ _ Management information systems: organization and technology in the networked enterprise. 6. ed. Upper Saddle River, NJ: Prentice Hall, 2000. cap. 10, p.290-329.

LEGGETT, R.; COHEN, D.; MALKOUN, D., GOULD, G. Inflection point: a handbook for understanding and investing in the European technology services industry. Goldman Sachs Report, New York, 26 Jan. 2001.

LEONARD, L. The dynamic effects of the web on marketing services: an emarketing services definition. Framingham: IDC,12 Dec. 2000. 
LEVITT, T. Após a venda ter sido realizada. In: SHAPIRO, B. P.; SVIOKLA, J. J. Mantendo clientes. São Paulo: Makron Books, 1994. cap. 3, p. 41-55.

LYKINS, D. Focus on your customers. e-Business Advisor, San Diego, vol. 20, n. 6, p. 10-13, Aug. 2002.

MAHEDY, S.; JOE, D. The Internet: a net revolution. Salomon Smith Barney Report, New York,18 May 2000.

MALAVIYA, P.; SPARGO, S. Relationing to customers: how and when to strengthen your customer relationships. INSEAD R\&D: Working Papers, Fontainebleau, 2002. Disponível em: http://knowledge.insead.fr/docs/2002-41.pdf. Acesso em: 3 jul. 2002.

MANZONI JR., R. Desafinados. Business Standard: negócios e tecnologia na Era da Informação, São Paulo, n. 25, p. 20, abr. 2003a.

Modelo para exportação. Business Standard: negócios e tecnologia na Era da Informação, São Paulo, n. 2, nov. 2002, p. 34-37.

; SAYON, M. A elite brasileira do comércio eletrônico. Business Standard: negócios e tecnologia na Era da Informação, São Paulo, n. 2, p. 19-33, nov. 2002.

MCCARTHY, E. J.; PERREAULT JR., W. D. Basic marketing: a global managerial approach. $10^{\text {th }}$ ed. Boston: Irwin, 1990.

MCKENNA, R. Marketing de relacionamento: estratégias bem-sucedidas para a era do cliente. Rio de Janeiro: Campus, 1992.

1995.

Real-time marketing. Harvard Business Review, Boston, Reprint 95407. July/Aug.

MCKINSEY and COMPANY. Superior marketing in the next era of e-commerce. McKinsey Marketing Practice, New York, 1999. Disponível em: $<$ http://www.sojoinc.com/newsletter/feb2002/e-marketing_whitepaper.pdf $>$. Acesso em: mar. 2000.

MENEZES, E. J. C.; ANGELO, C. F. de. Utilização do mix de serviços como estratégia para diferenciação competitiva no varejo. In: ANGELO, C. F. de; GIANGRANDE, V. Marketing de relacionamento no varejo. São Paulo: Atlas, 1999. cap. 5, p. 65-76.

MICROSOFT GREAT PLAINS BUSINESS SOLUTIONS. The history and future of Customer Relationship Management. In: MICROSOFT GREAT PLAINS BUSINESS SOLUTIONS. The essential guide for selecting today's business software. Fargo, ND: 2001. cap. 8, p. 45-52.

MOHAMMED, R.; CAHILL, A.; JAWORSKI, B. J.; FISHER, R. Internet marketing: building advantage in a networked economy. New York: McGraw Hill, 2001.

MÜLLER, J. E.; MELO, A. de S. Processos de CRM na integração dos canais de relacionamento com o cliente. In: CARVALHO, D. T. de; NEVES, M. F. (Org.) Marketing na nova economia. São Paulo: Atlas, 2001. cap. 9, p. 85-94.

NAKAGAWA, M. Propaganda na internet: desafios e oportunidades no Brasil. 2003. 181 f. Dissertação (Mestrado em Administração) - Faculdade de Economia, Administração e Contabilidade, Pontifícia Universidade Católica de São Paulo, São Paulo.

NARVER, J. C.; SLATER, S. F. The effect of a marketing orientation on business profitability. Journal of Marketing, Chicago, p 20-35, Oct. 1990. 
NEVIN, J. R. Relationship marketing and distribution channels: exploring fundamental issues. Journal of the Academy of Marketing Science, Miami, p. 327-334, Fall 1995.

NICKLES, F.; WOOD, M. B. Marketing de relacionamento, qualidade, valor. Rio de Janeiro: LTC, 1999.

NOVAK, T.; HOFFMAN, D. L.; DUHACHEK, A. The influence of goal-directed and experiential activities on online flow experiences. Nashville: Vanderbilt University, 2001.

PARASURAMAN, A. Marketing research. Reading, MA: Addison-Wesley, 1986.

PEOPLESOFT. Gerenciamento do relacionamento com clientes no mercado de serviços financeiros. PeopleSoft White Paper Series, São Paulo, p. 7, jan. 2002.

PEPPERS, D.; ROGERS, M. Marketing um-a-um: marketing individualizado na era do cliente. Rio de Janeiro: Campus, 1994.

PETERSON, R. A.; BALASUBRAMANIAN, S.; BRONNENBERG, B. J. Exploring the implications of the Internet for consumer marketing. Journal of the Academy of Marketing Science, Miami, v. 25, n. 4, p. 329-346, Fall 1997.

PERREAULT, JR., W. D.; MCCARTHY, E. J. Princípios de Marketing. 13 ed. Rio de Janeiro: LTC, 2002.

PINHEIRO, G. Renovam-se as esperanças. Consumidor Moderno: o guia das relações de consumo no Brasil, São Paulo, n. 40, a. 6, p. 108, nov. 2000.

POMBRIANT, D. Web commerce meets the consumer. Aberdeen.com, Boston: Aberdeen Group, $2000 . \quad$ June Disponível em: http://www.aberdeen.com/ab_abstracts/2000/06/06002079.htm. Acesso em: 10 ago. 2000.

PORTER, M. E. Strategy and the Internet. Harvard Business Review, Boston, p. 63-78, Mar. 2001.

. Vantagem competitiva. Rio de Janeiro: Campus, 1989.

PRAEGER, J. Together forever: developing loyalty online. Ad Resource: Internet advertising and Web site promotion resources. [S.l.], 9 Aug. 2000. Disponível em: $<$ http://adres.internet.com/feature/article/0,1401,8961_433811,00.html>. Acesso em: 11 out. 2000.

RAGINS, E. J.; GRECO, A. J. Customer Relationship Management and e-business: more than a software solution. Review of Business, 24, 1. Jamaica, NY: ABI/Inform Global, p. 25-30, Winter 2003.

RAUT, P. Ensuring Customer Delight. [S.l.]: 24 jan. 2002. CRMGuru. Disponível em: <http://www.crmguru.com/features/2002a/0124pr.html>. Acesso em: 24 abr. 2002.

RAVALD, A.; GRÖNROOS, C. The value concept and relationship marketing. European Journal of Marketing, Bradford, v. 30, n. 2, p. 19-30, 1996.

REGGIANI, L. Os reis do e-commerce. Info Exame, a. 18, n. 206, São Paulo, p.70-75, maio 2003.

REIBSTEIN, D. J. The Internet buyer. In: WIND, J.; MAHAJAN, V. Digital marketing: global strategies from the world's leading experts. New York: John Wiley, 2001. cap. 8, p. 221-225. 
REICHARDT, C. S.; COOK, T. D. Beyond qualitative versus quantitative methods. In: COOK, T. D.; REICHARDT, C. S. Qualitative and quantitative methods in evaluation reseach. Beverly Hills, CA: Sage, 1979. p. 7-32.

REICHHELD, F. F. A estratégia da lealdade: a força invisível que mantém clientes e funcionários e sustenta crescimento, lucros e valor. Rio de Janeiro: Campus, 1996.

.; SCHEFTER, P. E-loyalty: your secret weapon on the Web. Harvard Business Review, Boston, p. 105-113, July/Aug. 2000.

.; SASSER JR., W. E. Zero clientes perdidos: a qualidade chega aos serviços. In: SHAPIRO, B. P.; SVIOKLA, J. J. Mantendo clientes. São Paulo: Makron Books, 1994. cap. 18, p. 335-350.

RIFKIN, J. The age of access. The standard: intelligence for the Internet economy. [S.l.] 13 Mar. 2000. Disponível em: http://www.thestandard.com/article/article_print/0,1153,12726,00.html. Acesso em: 12 fev. 2001.

RIGBY, D. K.; REICHHELD, F. F.; SCHEFTER, P. Avoid the four perils of CRM. Harvard Business Review, Boston, p. 101-109, Feb. 2002.

ROBERTS, M. L. Internet marketing: integrating online and offline strategies. New York: McGraw-Hill, 2003.

REVISTA DA SOCIEDADE DIGITAL. A inclusão digital no Brasil: uma revolução tão poderosa quanto a dos livros impressos, São Paulo: Chantal, a. I, n. 1, p. 11-13, dez. 2001.

RUEFLI, T. W.; WHINSTON, A.; WIGGINS, R. R. The digital technological environment. In: WIND, J.; MAHAJAN, V. Digital marketing: global strategies from the world's leading experts. New York: John Wiley, 2001. cap. 2, p. 46-48.

SAS INSTITUTE. Implementing the customer relationship management foundation: analytical CRM. A SAS Institute White Paper. Cary, NC: SAS Institute, [2000?a].

SCHARTZ, E. I. Digital Darwinism: breakthrough business strategies for surviving in the cutthroat web economy. New York: Broadway Books, 1999.

SCHUMANN, D. W.; ARTIS, A.; RIVERA, R. The future of interactive advertising viewed through an IMC lens. Journal of Interactive Advertising, Michigan, v. 1, n. 2, Spring 2001. Disponível em: < http://jiad.org/vol1/no2/schumann/index.html>. Acesso em: ago. 2003.

SELLTIZ, C.; JAHODA, M.; DEUTSCH, M.; COOK, S. W. Métodos de pesquisa nas relações sociais. ed. rev. São Paulo: Editora Pedagógica e Universitária Ltda., 1974.

SERMOUD, G. Na calada da noite. The Industry Standard, n. 8, p. 4. São Paulo: IDG, jul. 2001.

SERRALVO, F. A. O marketing de varejo e o comportamento do consumidor: uma análise das interações de compra e venda. 1993. 161 f. Dissertação (Mestrado em Administração) Faculdade de Economia e Administração, Pontifícia Universidade Católica de São Paulo, São Paulo.

SHAPIRO, B. P. Na realidade, o que é 'orientação voltada para o mercado?'. In: SVIOKLA, J. J. Mantendo clientes. São Paulo: Makron Books, 1994. cap. 1, p. 5-17.

.; SVIOKLA, J. J. Mantendo clientes. São Paulo: Makron Books, 1994.

SHETH, J. N.; GARDNER, D. M. History of marketing though: an update. In: BROWN, S. W.; FISK, R. P. Marketing theory: distinguished contributions. New York: John Wiley, 1984. 
SHETH, J. N.; GARDNER, D. M.; GARRET, D. E. Marketing theory: evolution and evaluation. New York: John Wiley, 1988.

SHETH, J. N.; PARVATIYAR, A. Handbook of relationship marketing. Newbury: Sage, 1999.

. The evolution of relationship marketing. International Business Review, [S.l.], v. 4, n. 4, 1995, p. 471-481.

SILVEIRA, E. Brasil - serviços de telecomunicações: Internet. Relatório Setorial LAFIS, 7 ago. 2003.

SILVEIRA, J. A. G. da. Serviços do Varejo. In: ANGELO, C. F. de; GIANGRANDE, V. Marketing de relacionamento no varejo. São Paulo: Atlas, 1999. cap. 6, p. 77-85.

SILVEIRA, T. da. Um estudo sobre a gestão do conhecimento sobre valor para o cliente e a performance organizacional. 2002. 198 f. Tese (Doutorado em Administração) - Faculdade de Economia, Administração e Contabilidade, Universidade de São Paulo, São Paulo.

SIMON, H.; SCHUMANN, H. Pricing opportunities in the digital age. In: WIND, J.; MAHAJAN, V. Digital marketing: global strategies from the world's leading experts. New York: John Wiley, 2001. cap. 14, p. 362-390.

SOMMER, R. What's the secret to successful CRM? e-Business Advisor, San Diego, p. 41-45, Aug. 2000.

SORDILI, A. Tecnologia não é tudo. Negócios Exame. São Paulo, 17 ago. 2001. Disponível em: <http://www.uol.com.br/negociosexame/complementos/revista0011_28c.html>. Acesso em: ago. 2001.

STAKE, R. E. Case studies. In: DENZIN, N.; LINCOLN, Y. S. Handbook of qualitative research. Thousand Oaks: Sage, 1994. cap. 14, p. 236-247.

STERNE, J. Customer service on the Internet: building relationships, increasing loyalty, and staying competitive. $2^{\text {nd }}$ ed. New York: John Wiley, 2000.

SUDHARSHAN, D. Marketing strategy: relationships, offerings, timing e resource allocation. Upper Saddle River, NJ: Prentice Hall, 1995.

SZAFIR-GOLDSTEIN, C. O conceito de valor percebido: um estudo de caso na indústria de papel e celulose sobre a utilização da percepção dos clientes sobre o produto. 2000. $231 \mathrm{f}$. Dissertação (Mestrado em Administração) - Faculdade de Economia, Administração e Contabilidade, Universidade de São Paulo, São Paulo.

TAKEUCHI, H.; QUELCH, J. Qualidade é mais do que fazer um bom produto. In: SHAPIRO, Benson P.; SVIOKLA, John J. Mantendo clientes. São Paulo: Makron Books, 1994. cap. 8, p. 145-159.

TAPSCOTT, D. Rethinking strategy in a networked world (or why Michael Porter is wrong about the Internet). Strategy and Business, issue 24, New York: Booz-Allen e Hamilton, $3^{\text {rd }}$ Quarter 2001. Disponível em: <http://www.strategybusiness.com/press/article/?art=14904epg=0rpid=15157> . Acesso em: dez. 2001.

THE ECONOMIST: a Survey of Business and the Internet. The net imperative. New York: The Economist Newspaper Group, 26 June 1999.

TOLEDO, G.; GOUVÊA, M. A.; RODRIGUES FILHO, L. N. Service Attributes, perceived value and pricing: an empirical study with the Brazilian Post Office. In: BALAS 2000. 
Management of integrated markets: one America? Caracas: Business Association of Latin American Studies/Instituto de Estudios Superiores de Administración, 2000.

TOLEDO, G. L.; NAKAGAWA, M. H.; YAMASHITA, S. S. O composto de marketing no contexto estratégico da Internet. Revista de Administração Mackenzie, São Paulo: Editora Mackenzie, a. 3, n. 1, p. 33-78, 2002.

TURBAN, E.; LEE, J.; KING, D.; CHUNG, H. M. Electronic commerce: a managerial perspective. Upper Saddle River, NJ: Prentice Hall, 2000.

VAVRA, T. G. Marketing de relacionamento = Aftermarketing. São Paulo: Atlas, 1992.

VENETIANER, T. e-Commerce na corda bamba. Rio de Janeiro: Campus, 2001.

VIEIRA, E. A capital dos negócios digitais, Exame SP, ed. 16, São Paulo, jul. 2002. Suplemento da revista Exame, ed. 771, p. 36-37.

VOLPI, A. O SAC ouve o cliente; o ombudsman fala por ele. Consumidor moderno, São Paulo, ano 8, n. 58, p. 30-32, jun. 2002.

WEBSTER JR., F. E. The rediscovery of the Marketing concept. In: COOK JR., V.; LARRÉCHÉ, J. C.; STRONG, E. C. Readings in Marketing strategy. $2^{\text {nd }}$ ed. Reawood, CA: The Scientific Press, 1989.

WHITELEY, R. A empresa totalmente voltada para o cliente: do planejamento à ação. Rio de Janeiro: Campus, 1997.

WIEGRAN, G.; KOTH, H. Customer retention in on-line retail. Journal of Internet Banking and Commerce, Ottawa, Oct. 1999. Disponível em: <http://www.arraydev.com/commerce/jibc/990907.htm>. Acesso em: 12 nov. 1999.

WIND, J.; MAHAJAN, V. The challenge of digital marketing. In: Digital marketing: global strategies from the world's leading experts. New York: John Wiley, 2001. cap. 1, p. 3-25.

WINDHAM, L.; SAMSEL, J. Dead Ahead: the Web dilemma and the new rules of business. New York: Allworth Press,1999.

WINER, S. R. Marketing management. Upper Saddle River, NJ: Prentice Hall, 1999.

YIN, R. K. Case study research: design and methods. Rev. ed. Applied social research methods series; v. 5. Newbury Park, CA: Sage, 1989.

ZEITHAML, V. A.; PARASURAMAN, A.; BERRY, L. L. Delivering quality service. New York: Free Press, 1990.

\subsection{Obras Consultadas}

ABERDEEN GROUP. RedCelsius: Web commerce meets the customer. Aberdeen.com, Boston, June 2000. Disponível em: <http://www.aberdeen.com/cgi-bin/rf.cgi $>$. Acesso em: 10 ago. 2000.

ABRAMO, P. Pesquisa em Ciências Sociais. In: HIRANO, S. (Org.). Pesquisa Social: projeto e planejamento. São Paulo: T. A. Queiroz Editor, 1979. p. 21-88.

ALAN, W.; NIAL, L. Marketing intelligence and planning, v. 21, $2^{\text {nd }}$ ed. Bradford: West Yorkshire, 2003. p. 79. 
BARUA, A.; DESAI, P. S.; SRIVASTAVA, R. Economic perspectives on digital marketing. In: WIND, J.; MAHAJAN, V. Digital marketing: global strategies from the world's leading experts. New York: John Wiley, 2001. cap. 5, p. 103-104.

BÊ-Á-BÁ DA INTERNET. A História da Internet. São Paulo, [s.d.]. Disponível em: <http://www.uol.com.br/mundodigital/beaba/fase1.htm>. Acesso em: 15 nov. 2001.

BLECHER, N. O consumidor infeliz. Exame, São Paulo, ano 29, n. 6, ed. 605, p. 64-70, 13 mar. 1996.

BLECHER, N. O melhor das melhores. Exame, São Paulo, ano 30, n. 22, ed. 621, p. 24-92, 23 mar. 1996.

BOTTONI, F. Consumidor ainda está insatisfeito com o e-commerce. Info Exame, São Paulo, 06 mar. 2001. Disponível em <http://www2.uol.com.br/info/aberto/infonews/032001/060320012.shl>. Acesso em: 06 mar. 2001.

CARR, N. G. Hypermediation: commerce as clickstream. Harvard Business Review, Boston, p.40-41, Jan./Feb. 2000.

CASTELLS, M. A revolução da tecnologia da informação. Mercado Global, n. 107, São Paulo, p. 1, jun. 2000.

CHRISTENSEN, C.; TEDLOW, R. Patterns of disruption in retailing. Harvard Business Review, Boston, p. 40-41, Jan./Feb. 2000.

CIGLIANO, J. et al. The price of loyalty. The McKinsey Quarterly, New York, n. 4, p. 68-77, 2000.

Disponível em: $<$ http://www.mckinseyquarterly.com/article_page.asp?tk=384629:949:16ear=949eL2=16eL3=20 >. Acesso em 24 abr. 2002.

COBRA, M.; RANGEL, A. Serviços ao cliente: uma estratégia competitiva. São Paulo: Marcos Cobra, 1992.

COLLINS, J. C.; PORRAS, J. I. Feitas para durar: práticas bem-sucedidas de empresas visionárias. 2. ed. Rio de Janeiro: Rocco, 1995.

COREY, E. R. Industrial marketing: cases and concepts. $4^{\text {th }}$ ed. Upper Saddle River, NJ: Prentice-Hall, 1991.

COX, B. The law of averages: CRM on the Web. e-Commerce Guide. [S.l.], 11 Aug. 2000. Disponível em: < http://ecommerce.internet.com/news/insights/trends/article/0,3551_435911,00.html>. Acesso em: 30 ago. 2000.

DEBRUICKER, F. S.; SUMME, G. L. Assegure-se de que seus clientes retornarão. In: SHAPIRO, B. P.; SVIOKLA, J. J. Mantendo clientes. São Paulo: Makron Books, 1994. cap. 10, p. 183-196.

ECCLES, R. G. A revolução das medidas de desempenho. jan./fev. 1991. In: SHAPIRO, B. P.; SVIOKLA, J. J. Mantendo clientes. São Paulo: Makron Books, 1994. cap. 21, p. 383-396.

GIANFORTE, G. Insider's guide to delighting the Internet age customer: how today's most successful marketing managers out-service their competition online. Bozeman, MT, 2001. Disponível em: <http://www.rightnow.com/resource/ia_white.html>. Acesso em: 24 abr. 2002.

GODIN, S. Unleashing the ideavirus. [S.l.], 17 Sep. 2000. Disponível em: $<$ http://www.ideavirus.com>. Acesso em: out. 2000. 
GOLDMANN, H. Marketing de relacionamento deve substituir atendimento ao cliente. Folha de São Paulo, São Paulo,19 fev. 1996, Folha Management, Suplemento especial.

GOUVÊA, M. A. Apostilas do Curso de Metodologia II. Programa de Pós-graduação em Administração da Faculdade de Economia, Administração e Contabilidade da Universidade de São Paulo. São Paulo, 2000.

GRANT, A. W. H.; SCHLESINGER, L. A. Realize your customer's full profit potential. Harvard Business Review, Boston, p. 59-72, Sept./Oct. 1995.

HAMEL, G.; PRAHALAD, C. K. Competindo pelo futuro. Rio de Janeiro: Campus, 1995.

HAYES, B. E. Measuring customer satisfaction: survey design, use, and statistical analysis methods. $2^{\text {nd }}$ ed. Milwaukee, WI: American Society for Quality Press, 1998.

HOFFMAN, D. L.; NOVAK, T. P. How to acquire customers on the web. Harvard Business Review, Boston, p. 179-188, May/June 2000.

HUNT, S. Modern marketing theory: critical issues in the philosophy of marketing science. Cincinnati: South Western, 1991.

IKEDA, A. A. Marketing de relacionamento em organizações de fomento ao turismo. 2000. 181 f. Tese (Livre Docência em Administração) - Faculdade de Economia, Administração e Contabilidade, Universidade de São Paulo, São Paulo.

KAY, J. Capacidades diferenciadoras. Mercado Global, ano XXII, n. 100, São Paulo, p. 1, 2. trim. 1996.

KENNY, D.; MARSHALL, J. F. Contextual marketing: the real business of the Internet. Harvard Business Review, Boston, p. 119-125, Nov./Dec. 2000.

KLEBER, K. Os limites do mercado brasileiro. In: GAZETA MERCANTIL. Balanço anual. São Paulo: Gazeta Mercantil, a. XXVI, n. 26, jun/2002, p. 6-13. Publicação anual.

KOHLI, R. Infrastructure for e-business. In: WIND, J.; MAHAJAN, V. Digital marketing: global strategies from the world's leading experts. New York: John Wiley, 2001. cap. 3, p. 5977.

KOTLER, P. A generic concept of marketing. In: BROWN, S. W.; FISK, R. P. Marketing theory: distinguished contributions. New York: John Wiley, 1984. cap. 9. p. 89-99.

MACOMBER, C. Please customers: 3 ways to improve service. e-Business Advisor, San Diego, p. 12-20, Sep. 2001.

MANZONI JR., R. Surpresa geral. Business Standard: negócios e tecnologia na Era da Informação, São Paulo, n. 25, p. 18-19, abr. 2003b.

MCCALLUM, J. Growth traps: five strategies for failure. GartnerG2. Stamford, CT: Gartner Group, May, 2001.

MCKENNA, B. CRM: know the dangers. Uk.Internet.com: the UK portal for ebusiness professionals, 9 Aug. 2000. Disponível em: <http://www.uk.internet.com/Article/100388>. Acesso em: 23 ago. 2000.

NAUMANN, E.; JACKSON JR., D. W.; ROSENBAUM, M. S. How to implement a customer satisfaction program. Business Horizons, p. 37-46, Jan./Feb. 2001. 
OCHMAN, B. L. Marketing guru Al Ries talks about the Web. [S.l.] 28 July 2000. Webreview.com. Disponível em: <http://webreview.com/pub/2000/07/28/feature/index03.html>. Acesso em: 10 ago. 2000.

PASTORE, M. E-tailers stil lacking in customer service. [S.l.], 16 Aug. 2000. Disponível em: $<$ http://cyberatlas.internet.com/markets/retailing/print/0,1323,6061_435761,00.html >. Acesso em: 30 ago. 2000.

POPCORN, F. O relatório Popcorn: centenas de idéias de novos produtos, empreendimentos e novos mercados. Rio de Janeiro: Campus, 1994.

PRAHALAD, C. K.; HAMEL, G. A competência essencial da corporação. In: MONTGOMERY, C. A.; PORTER, M. E. (Org.). Estratégia: a busca da vantagem competitiva. Rio de Janeiro: Campus, 1999. cap. 3, p. 293-316.

PRICEWATERHOUSECOOPERS. Creating loyalty out of chaos: the inevitability of $e$-business. PricewaterhouseCoopers, e-business Leaders Series, 1999.

PURK, M. Relationship marketing: a white paper on leveraging customer information to built customer equity. A.T. Kearney, 1998.

REHAUT, M.; DWYER, D. Internet Technology 101.2. New York: Salomon Smith Barney, Mar. 28 2001, p. 166.

REINARTZ, W. J.; KUMAR, V. The impact of customer relationship characteristics on profitable lifetime duration. Revised Edition, Nov. 2001. Fontainebleau: INSEAD R\&D Working Papers. Disponível em: <http://knowledge.insead.fr/docs/2001-108.pdf>. Acesso em: 30 jun. 2002.

REIS, A. H. M. de A. M. Pesquisa qualitativa em marketing: uma visão crítica a respeito da utilização desta metodologia no Brasil... 1994. 231 f. Dissertação (Mestrado em Administração) - Faculdade de Economia, Administração e Contabilidade, Universidade de São Paulo, São Paulo.

RIES, A. Como ter uma presença significativa na Internet sem perder o foco no seu negócio. Revista Meiodigital, São Paulo, p. 28-29, dez. 2000.

SANT'ANNA, J. P. Empresas brasileiras demonstram desconhecer o conceito de CRM. Meio \& Mensagem, São Paulo, ed. 973, 27 ago. 2001, Marketing e Negócios. Disponível em: $\leq$ http://www.meioemensagem.com.br/mmonline/jsp/Navega.jsp?pIdConteudo=15536> . Acesso em: 16 set. 2002.

SAS INSTITUTE. Implementing a CRM-based campaign management strategy. A SAS Institute White Paper. Cary, NC: SAS Institute, [2000?b].

SCHONFELD, E. The guru’s guru. Business 2.0, v. 2, n. 9, San Francisco, CA, Oct. 2001.

SHAPIRO, B. P.; SLYWOTZKY, A. J. A qualidade dos clientes define o futuro da empresa. Folha de São Paulo, São Paulo, 06 nov. 1998, Folha Management, Suplemento especial.

SHOSTACK, G. L. Criando serviços que satisfazem. In: SHAPIRO, B P.; SVIOKLA, John J. Mantendo clientes. São Paulo: Makron Books, 1994. cap. 81, p. 87-88.

SLYWOTZKY, A. The age of the choiceboard. Harvard Business Review, Boston, p.40-41, Jan./Feb. 2000.

STEVENSON, W. J. Estatística aplicada à administração. São Paulo: Harbra, 1986. 
SUE, P.; MORIN, P. A strategic framework for CRM. LGS Group, Feb. 2001. Disponível em: $<$ http://www.crm-forum.com/library/art/art-100/art-100.html $>$. Acesso em: 22 mar. 2001.

THE INTERNET ARCHIVE. Internet archive wayback machine. [S.l., s.d.]. Disponível em: $<$ http://www.archive.org > . Acesso em: mai. 2003.

TROIANO, J. O consumidor na Era do Relacionamento. Mercado Global, ano XXII, n. 100, p. 7-12, 2. trim. 1996.

VENETIANER, T. Como vender seu peixe na Internet. 4. ed. Rio de Janeiro: Campus, 2000.

VOLPI, A. A história das relações de consumo no Brasil: capítulo 2. Consumidor Moderno, São Paulo, a. 8, n. 68, 2003, p. 42-50.

WERNECK, T. O CRM que deu certo. Consumidor Moderno, São Paulo, a. 8, n. 68, 2003, p. 22-30.

WHITELEY, R. Ouvir o cliente é o melhor caminho para o sucesso. Folha de São Paulo, São Paulo, 11 set. 1995. Folha Management, suplemento especial.

WOLFE, D. B. Developmental relationship marketing: connecting messages with mind: a empathetic marketing system. Journal of Consumer Marketing, Bradford, v. 15, n. 5, p. 449-467, 1998.

YAMASHITA, S. S. Tudo o que os consumidores sempre quiseram dizer, mas as empresas teimam em não ouvir. 1996. Trabalho de conclusão de curso (Graduação em Administração) Faculdade de Economia, Administração e Contabilidade da Universidade de São Paulo, São Paulo. 


\section{9. $\quad$ Apêndices}

\subsection{Apêndice A - Roteiro de Pesquisa}

\section{Pesquisa sobre os Impactos da Internet sobre as Práticas de Marketing de Relacionamento das Empresas e as Implicações Decorrentes}

(as identidades da empresa e do respondente serão mantidas em sigilo)

Data:

Hora Início:

Número:

\section{Marketing de Relacionamento}

1.1. (ESPONT.) A empresa possui algum departamento (gerência de relacionamento, por exemplo) formalmente responsável pelos relacionamentos com seus clientes?

1. $\square$ Sim. Nome:

Posição no organograma (solicitar cópia do organograma):

Há quanto tempo existe? anos meses Razões de sua criação:

\section{2. $\square$ Não. Pretende criar?}

1. $\square$ Sim. Prazo: __ anos __ meses.

Nome, nível e razões:

2. $\square$ Não. Por quê?

1.2. (ESPONT.) Programas de fidelidade são ações que a empresa toma de forma a premiar os clientes que retornam à empresa com certa freqüência e que, portanto, mostram-se fiéis a ela. A empresa dispõe de algum programa de fidelidade? Há quanto tempo?

1. $\square$ Sim, há anos meses. Descreva:

2. $\square$ Não. Pretende implantar?

1. $\square$ Sim. Prazo: anos meses.

Responsável:

2. $\square$ Não. Por quê?

1.3. (ESPONT.) A empresa já realizava pesquisas de opinião/satisfação com seus clientes em relação a produtos e/ou serviços (atendimento, assistência técnica, entrega etc.), antes mesmo da Internet? Com que freqüência?
1. $\square$ Esporadicamente
2. $\square$ Semanalmente
3. $\square$ Quinzenalmente
4. $\square$ Mensalmente
5. $\square$ Trimestralmente
6. $\square$ Outra periodicidade

7. $\square$ Não realiza. Pretende realizar?
7.1. $\square$ Sim. Prazo: anos
Responsável:
7.2. $\square$ Não. Por quê?
(Pule para a questão 1.4) meses.

1.3.1. (ESPONT.) As forma (s) de pesquisa utilizada (s) são:
1. $\square$ Entrevistas pessoais e individuais
4. $\square$ Auto-preenchimento
2. $\square$ Discussões em grupo
3. $\square$ Formulários via Internet
5. $\square$ Pesquisa telefônica
6. $\square$ Outra. Qual?

1.4. (ESPONT.) A empresa mantém um canal aberto para o cliente se expressar espontaneamente? Como?

1. $\square$ Caixa de sugestões na própria loja

2. $\square$ e-mail para contato

3. $\square$ Serviço pessoal de atendimento ao cliente

4. $\square$ Serviço telefônico de atendimento ao cliente

5. $\square$ Carta

6. $\square$ Outro. Qual?
7. $\square$ Não possui. Pretende implantar?

7.1. $\square$ Sim. Prazo: __ anos __ meses.

Responsável:

7.2. $\square$ Não. Por quê?

(Pule para questão 1.5.) 
1.4.1. (ESPONT.) Como este(s) canal(is) é(são) divulgado(s) para os clientes?
1. $\square$ Embalagem do produto
5. $\square$ Convite feito por funcionário
2. $\square$ Propaganda institucional
6. $\square$ e-mail
3. $\square$ site na Internet
7. $\square$ Outro. Qual?
4. $\square$ Folhetos/catálogos/formulários espalhados pela loja

1.5. (ESPONT.) Na definição de metas/objetivos anuais, é feita a fixação de parâmetros quanto à satisfação dos clientes em relação ao atendimento (exemplo: reduzir o número de reclamações em x\%)? Quais os critérios para tanto? Quem são os responsáveis?

1.6. (ESTIMUL.) Há padrões para o atendimento de reclamações de clientes?

1.6.1. $\square$ Sim.

1. $\square$ Prazos pré-definidos para resposta ao cliente

2. $\square$ Prazos definidos para a solução completa do problema

3. $\square$ Políticas de reembolso e/ou substituição de produtos ou serviços, independentemente de determinação do Código de Defesa do Consumidor

4. $\square$ Registro das ocorrências e atitude imediata para sua solução

5. $\square$ Registro das ocorrências e encaminhamento para setor competente

6. $\square$ Acompanhamento de solução dos problemas

7. $\square$ Outro:

1.6.1.1. Se há padrões formalizados, como é feito o controle do seu uso? O que ocorre se os padrões não forem seguidos? (pule para questão 1.7)

1.6.2. $\square$ Não há padrões formalizados. Descreva resumidamente as providências adotadas pela empresa quando o cliente faz uma reclamação

1.6.2.1. Pretende padronizar procedimentos?
1. $\square$ Sim. Prazo: anos meses. Responsável:
2. $\square$ Não. Por quê?

1.7. (ESPONT.) A empresa costuma realizar treinamento formal/reciclagem para seus funcionários relacionado a atendimento ao cliente? Com que freqüência?
1. $\square$ Esporádica
2. $\square$ Trimestral
3. $\square$ Semestral
4. $\square$ Anual
5. $\square$ Bienal
6. $\square$ Outra periodicidade

7. $\square$ Não realiza. Pretende passar a realizar?
7.1. $\square$ Sim. Com que freqüência? (veja escala ao lado)
1. $\square$ 2. $\square$ 3. $\square$ 4. $\square$ 5. $\square$ 6. $\square$
7.2. $\square$ Não.
Por quê?

1.7.1. (ESPONT.) Qual o público-alvo desses treinamentos?
1. $\square$ Funcionários da linha de frente (balcão)
5. $\square$ Pessoal do serviço de atendimento ao cliente
2. $\square$ Vendedores
3. $\square$ Telefonistas/secretárias
6. $\square$ Média e baixa gerência
7. $\square$ Outros:

4. $\square$ Entregadores

1.7.2. (ESPONT.) Quais os principais conteúdos? 

1. $\square$ Informações sobre produtos/serviços
2. $\square$ Linguagem/cortesia
4. $\square$ Políticas de concessões
3. $\square$ Visão global e sistêmica dos processos da empresa
5. $\square$ Procedimentos em casos de reclamações
6. $\square$ Outros

1.8. (ESPONT.) Os funcionários que lidam diretamente com o cliente possuem autonomia para efetuar pequenos gastos para atender algum cliente além do atendimento padrão?

1. $\square$ Sim. Até que valor? R\$

\section{2. $\square$ Não. (Pule para questão 1.9.)}

1.8.1. Se sim, há diferenciação de limite de gastos por nível hierárquico?

1. $\square$ Sim. Em que termos?

2. $\square$ Não.

1.8.2. Se sim, relate algum caso em que isto se aplicou:

1.9. (ESPONT.) Como a empresa divulga as opiniões e atitudes dos clientes para todas as áreas da empresa?

1. $\square$ Em reuniões específicas para tratar de clientes

2. $\square$ Em reuniões, quando há fatos relevantes

3. $\square$ Por meio de boletins ou relatórios periódicos

4. $\square$ Por meio de boletins ou relatórios esporádicos

5. $\square$ Em murais
6. $\square$ No jornalzinho da empresa

7. $\square$ Não divulga para todas as áreas. Para quais áreas divulga?

8. $\square$ Por outro meio

1.10. (ESPONT.) (Mostrar cartão) “O marketing de relacionamento é o processo pelo qual ambas as partes - o comprador e o vendedor - estabelecem um relacionamento eficaz, eficiente, prazeroso, entusiástico e ético: um relacionamento que seja pessoal, profissional e lucrativamente recompensador para ambas as partes” (Porter, 1993:14). "O Marketing de Relacionamento se refere a todas as atividades de marketing direcionadas a estabelecer, desenvolver e manter trocas relacionais bem sucedidas” (Morgan e Hunt, 1994:22, in Gummesson, 1999:243). Tendo em vista estas definições, a empresa premia os funcionários que promovem um bom Marketing de Relacionamento? Com que freqüência?

1. $\square$ Esporádica

2. $\square$ Mensal

3. $\square$ Trimestral

4. $\square$ Semestral

5. $\square$ Anual

6. $\square$ Outra periodicidade
7. $\square$ Não premia. Pretende passar a premiar?

7.1. $\square$ Sim. Prazo: __ anos __ meses.

Responsável:

7.2. $\square$ Não.

Por quê?

(Pule para questão 1.11.)

1.10.1. (ESPONT.) Qual a forma de avaliação e de premiação?

1.11. Antes da Internet passar a fazer parte das operações da empresa, eram oferecidos produtos/serviços personalizados aos clientes (de acordo com características desejadas)? De que maneira?

1.12. (ESTIMUL.) (Mostrar cartão) “O CRM (Customer Relationship Management) é uma filosofia de trabalho que apóia o marketing de relacionamento, geralmente com base em um software para manipulação de banco de dados que armazena características do perfil dos clientes e seu histórico de compras, a fim de propiciar ações de marketing mais direcionadas às suas necessidades e desejos”. Defina o seu grau de concordância com esta afirmação e justifique-o.

1. $\square$ Concordo totalmente

2. $\square$ Concordo, mas não totalmente

3. $\square$ Nem concordo, nem discordo

4. $\square$ Discordo, mas não totalmente

5. $\square$ Discordo totalmente 
1.13. (ESPONT.) A empresa possui política ou estrutura de CRM?

1. $\square$ Sim. (mostre esquema de CRM - Anexo C - e informe I para 2. $\square$ Não. (pule para questão 1.18.) módulos implantados/ fases superadas e $P$ para planejados)

1.14. (ESPONT.) Qual(is) foi(ram) a(s) principal(is) motivação(ões) para implantação de uma solução de CRM?

1. $\square$ Evolução tecnológica "natural”

2. $\square$ Necessidade de automatização de processos manuais

3. $\square$ Igualar-se à concorrência

4. $\square$ Sugestão de empresa de consultoria

5. $\square$ Redução de custos
6. $\square$ Incorporação de novas funções relacionadas

7. $\square$ Desejo de desenvolver relacionamentos mais fortes com clientes e parceiros de negócios

8. $\square$

9.

1.15. Descreva como foi feita a análise de custos x benefícios para que esta decisão fosse tomada.

1.16. Quais foram as áreas participantes do processo de desenvolvimento do CRM e quais os respectivos papéis (decisão de implantação, operação, controle)?

1.17. (ESTIMUL.) Na sua opinião, os resultados obtidos até agora com o CRM estão sendo:
1. $\square$ Muito insatisfatórios
2. $\square$ Insatisfatórios
3. $\square$ Regulares
4. $\square$ Satisfatórios
5. $\square$ Muito satisfatórios

1.17.1. Por quê?

1.18. Há outras iniciativas de Marketing de Relacionamento realizadas pela empresa? Quais?

1.19. Quais outras práticas de Marketing de Relacionamento a empresa pretende implantar, qual o prazo previsto e os responsáveis por esta implantação?

1.20. (ESTIMUL.) Para cada um dos itens mencionados a seguir, referentes a Marketing de Relacionamento e presentes na sua empresa, quais são os critérios para medição de seu desempenho?

1. Departamento responsável pelos relacionamentos com clientes da empresa

2. Programas de fidelidade

3. Processo de levantamento de dados sobre opinião/satisfação dos clientes

4. Canal para o cliente se manifestar espontaneamente

5. Padrões/procedimentos formais para atendimento de reclamações de clientes

6. Treinamento para funcionários sobre atendimento a clientes

7. Efeito sobre a equipe da premiação de funcionários que promovem um bom Marketing de Relacionamento

8. Projetos de produtos em conjunto com clientes 
Internet e Marketing de Relacionamento: impactos em empresas que atuam no mercado consumidor

9. Implantação e resultados do CRM

10. Produtos / serviços personalizados

11. Outra (especificar):

1.21. (ESTIMUL.) Na sua opinião as práticas de Marketing de Relacionamento estão realmente sendo:

\begin{tabular}{|c|c|c|c|c|c|}
\hline Prática & $\begin{array}{c}\text { Muito mal } \\
\text { sucedidas }\end{array}$ & $\begin{array}{c}\text { Mal } \\
\text { sucedidas }\end{array}$ & $\begin{array}{c}\text { Bem } \\
\text { sucedidas }\end{array}$ & $\begin{array}{c}\text { Muito bem } \\
\text { sucedidas }\end{array}$ & $\begin{array}{l}\text { Não sabe } \\
\text { avaliar }\end{array}$ \\
\hline $\begin{array}{l}\text { 1. Departamento responsável pelos relacionamentos } \\
\text { com clientes da empresa }\end{array}$ & & & & & \\
\hline 2. Programas de fidelidade & & & & & \\
\hline $\begin{array}{l}\text { 3. Processo de levantamento de dados sobre } \\
\text { opinião/satisfação dos clientes }\end{array}$ & & & & & \\
\hline 4. Canal para o cliente se manifestar espontaneamente & & & & & \\
\hline $\begin{array}{l}\text { 5. Padrões/procedimentos formais para atendimento } \\
\text { de reclamações de clientes }\end{array}$ & & & & & \\
\hline $\begin{array}{l}\text { 6. Treinamento para funcionários sobre atendimento a } \\
\text { clientes }\end{array}$ & & & & & \\
\hline $\begin{array}{l}\text { 7. Premiação de funcionários que promovem um bom } \\
\text { Marketing de Relacionamento }\end{array}$ & & & & & \\
\hline 8. Projetos de produtos em conjunto com clientes & & & & & \\
\hline 9. Implantação do CRM & & & & & \\
\hline 10. Produtos / serviços personalizados & & & & & \\
\hline 11. Outra (especificar): & & & & & \\
\hline
\end{tabular}

1.22. (ESTIMUL.) Na sua opinião, de maneira geral, o Marketing de Relacionamento está sendo:

1. $\square$ Muito mal sucedido

1.22.1. Por quê?

2. $\square$ Mal sucedido

3. $\square$ Bem sucedido

4. $\square$ Muito bem sucedido

5. $\square$ Não sabe avaliar

\section{Internet}

2.1. (ESPONT.) Com qual(is) objetivo(s) a empresa criou seu site na Internet?

1. $\square$ Comunicação institucional

2. $\square$ Portal de transações de vendas de produtos/ serviços

3. $\square$ Igualar-se à concorrência

4. $\square$ Promoção e informações sobre produtos/serviços

6. $\square$ Atendimento/suporte ao cliente

5. $\square$ Imagem
7. $\square$ Aumentar a satisfação do cliente

8. $\square$ Facilitar aos clientes a realização de suas compras

9. $\square$ Redução de custos

10. $\square$ Desenvolver relacionamentos mais fortes com clientes e parceiros de negócios

11. $\square$ Outros

2.2. Há quanto tempo a empresa realiza negócios como fornecedora por intermédio da Internet? anos meses.

2.3. (ESTIMUL.) Por quais “fases” da Internet como ferramenta de negócios a empresa passou? 


\subsubsection{Segundo Kosiur (1997):}

1. $\square$ Presença, na qual as empresas desenvolviam sites para tornar públicas e disponíveis informações institucionais e de seus produtos e serviços.

2. $\square$ Interação, em que os sites institucionais ganharam interatividade mediante consultas no próprio site, formulários, registros de informações, consultas online ao banco de dados e facilidade no envio de $e$-mails a partir do próprio site.

3. $\square$ Transação, na qual surgiu o e-commerce pela Internet e aperfeiçoou-se a criptografia, permitindo que informações sigilosas, como números de cartões de crédito, fossem enviadas de maneira mais segura.

4. $\square$ Processo/Integração, marcada pelo processo de automatização quase total dos processos da empresa, incluindo os que envolvem o relacionamento com fornecedores e clientes, como pedidos e pagamentos.

2.3.2. Segundo Sterne (2000):

1. $\square$ Página do Produto, na qual os cliques no site eram uma alternativa a folhear um catálogo.

2. $\square$ Web site Corporativo, com informações sobre a empresa e seus produtos, políticas e opiniões, white papers e press releases, programações de eventos, mensagem da presidência, organograma etc.

3. $\square$ Web site Participativo, que permitia aos visitantes do site interagir com ele, ao invés de apenas visualizar anúncios estáticos.

2.4. (ESTIMUL.) Na sua opinião, quais as vantagens de se realizarem negócios por meio da Internet?

1. $\square$ Diminuição de custos operacionais

2. $\square$ Melhoria da comunicação com o cliente

3. $\square$ Maior agilidade no atendimento ao cliente

4. $\square$ Penetração em novo mercado
5. $\square$ Divulgação/exposição de fotos de produtos

6. $\square$ Coleta e gerenciamento de informações sobre clientes

7.

8.

2.5. (ESTIMUL.) Na sua opinião, quais as desvantagens de se realizarem negócios por meio da Internet?
1. $\square$ Prejuízo ao contato com o cliente
2. $\square$ Não se aplica ao meu negócio
3. $\square$ Custos operacionais altos
4. $\square$ Alto investimento sem retorno satisfatório

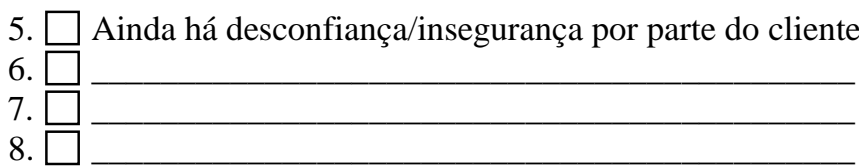

2.6. (ESTIMUL.) O cliente que compra pela Internet, em geral:

2.6.1. $\square$ É o mesmo cliente da loja tradicional, que ora compra pela Internet, ora compra na loja tradicional.

2.6.2. $\square$ Passou a comprar pela Internet e não compra mais na loja tradicional.

2.6.3. $\square$ Não era cliente da loja e compra apenas pela Internet.

2.6.4. $\square$ Não era cliente da loja e passou a comprar tanto pela Internet como na loja tradicional.

2.6.5. $\square$ Outra possibilidade:

2.6.6. $\square$ Não sei avaliar.

\section{Marketing de Relacionamento e Internet - Impactos e Implicações}

3.1. Desde que a empresa iniciou suas atividades pela Internet, o percentual de vendas pela Internet, anualmente, em relação às vendas totais da empresa, tem mostrado tendência:
crescente
$\square$ decrescente
estável.

3.2. Atualmente, qual o percentual de vendas via Internet em relação ao total de vendas da empresa? $\%$.

3.3. (ESTIMUL.) Há perspectivas de que esta proporção, no médio/longo prazo:

1. $\square$ Não se altere.

2. $\square$ Seja alterada, sendo que as vendas pela Internet devam ser superiores às vendas pelos canais tradicionais.

3. $\square$ Seja alterada, sendo que as vendas pelos canais tradicionais devam ser superiores às vendas pela Internet.

\subsubsection{Por quê?}


3.4. (ESTIMUL.) Quais os impactos trazidos pela Internet sobre o negócio da empresa?
1. $\square$ Variações no faturamento da empresa em
2. $\square$ Variações no número de clientes: em
$\%$ 1.1. $\square$ acrescentou 1.2. $\square$ diminuiu 1.3. $\%$
2.1. $\square$ acrescentou 2.2.
diminuiu 2.3.
3.1. $\square$ acrescentou 3.2. $\square$ diminuiu 3.3.
estabilizou
3. $\square$ Variações nos segmentos atingidos:
4.1. $\square$ acrescentou 4.2. $\square$ diminuiu 4.3.
estabilizou
4. $\square$ Variações nos custos de transação:
estabilizou
estabilizou

3.5. (ESTIMUL.) Com relação à posição estratégica da empresa, as negociações pela Internet têm proporcionado:

5.1. $\square$ Oportunidades. Quais?

5.2. $\square$ Ameaças. Quais?

3.6. (ESTIMUL.) Quais os impactos trazidos pela Internet em relação ao Marketing de Relacionamento? Especifique.

1. $\square$ Formas de interação e de relacionamento com os clientes

2. $\square$ Benefícios oferecidos aos clientes

3. $\square$ Estrutura organizacional

4. $\square$ Perfil de pessoal

5. $\square$ Estrutura tecnológica

6. $\square$ Funcionalidade das operações (logística de distribuição, processamento dos pedidos, cobrança, follow-up das ordens etc.):

7. $\square$ Outros

3.7. (ESTIMUL.) A decisão da empresa de realizar negócios pela Internet trouxe mudanças (marque O - ocorridas) ou existem planos de mudanças na empresa (marque P - planejadas) que tenham relação com o Marketing de Relacionamento para que ela pudesse se adaptar à nova situação? Estas mudanças estariam relacionadas a:

\begin{tabular}{|c|c|c|}
\hline $\mathbf{O} / \mathbf{P}$ & Prazo & Mudanças ocorridas ou planejadas \\
\hline & & 1. $\square$ Perfil dos profissionais, em termos de: \\
\hline & & $1.1 \square$ Substituição/contratação de pessoal \\
\hline & & - No nível estratégico. Especifique: \\
\hline & & - No nível tático. Especifique: \\
\hline & & - No nível operacional. Especifique: \\
\hline & & - Especialistas em _ \\
\hline & & $\begin{array}{l}1.2 \square \text { Realização de treinamento específico em } \\
\text { para os cargos }\end{array}$ \\
\hline & & $1.3 \square$ Outra mudança no perfil: \\
\hline & & 2. $\square$ Estrutura organizacional, em termos de: \\
\hline & & $2.1 \square$ Criação/extinção de departamentos. Especifique quais e razões: \\
\hline & & $2.2 \square$ Criação/extinção de cargos. Especifique quais e razões: \\
\hline & & $\begin{array}{l}\text { 2.3 } \square \text { Alteração no número de postos de atendimento ao cliente. Especifique qual a variação e } \\
\text { razões: }\end{array}$ \\
\hline & & 3. $\square$ Mudanças na abordagem nas relações com clientes. Especifique: \\
\hline & & 4. $\square$ Mudança nos canais de comunicação entre a empresa e seus clientes, tais como \\
\hline & & $\begin{array}{l}\text { 5. } \square \text { Alterações na busca sistemática de informações sobre desejos e necessidades satisfeitos e não } \\
\text { satisfeitos dos clientes, declarados ou ocultos, tais como__ }\end{array}$ \\
\hline & & 6. $\square$ Alterações no tratamento das sugestões, críticas ou reclamações colhidas junto aos clientes, \\
\hline
\end{tabular}


Internet e Marketing de Relacionamento: impactos em empresas que atuam no mercado consumidor

\begin{tabular}{|c|c|c|}
\hline & & como \\
\hline & & 7. $\square$ Modificações no conjunto de benefícios ofertados para os clientes, como \\
\hline & & 8. $\square$ Criação de programas de lealdade, como \\
\hline & & 9. $\square$ Oferecimento de produtos ou serviços personalizados para seus clientes: \\
\hline & & $9.1 \square$ Produtos/serviços padronizados com opções pré-definidas de variação \\
\hline & & $\begin{array}{l}9.2 \square \text { Produtos/serviços padronizados, com possíveis modificações, segundo especificações dos } \\
\text { clientes }\end{array}$ \\
\hline & & 9.3 $\square$ Produtos/serviços totalmente personalizados \\
\hline & & $9.4 \square$ Outro tipo de personalização _ \\
\hline & & 10. $\square$ Alterações no desenho/funcionamento do site da empresa. Especifique. \\
\hline & & 10.1 $\square$ Suporte técnico e atendimento ao cliente \\
\hline & & $10.2 \square$ Catálogo de produtos \\
\hline & & 10.3 $\square$ Realização de transações financeiras \\
\hline & & 10.4 $\square$ Possibilidade de negociação de preços ou descontos \\
\hline & & 10.5 $\square$ Mudanças no layout ou navegação. \\
\hline & & 10.6 $\square$ Personalização de páginas com conteúdos de interesse do cliente_ \\
\hline & & 10.7 $\square$ Realização de vendas cruzadas_ \\
\hline & & 10.8 $\square$ Realização de vendas complementares _. \\
\hline & & 10.9 $\square$ Criação de comunidades_ \\
\hline & & $10.10 \square$ Monitoramento contínuo da performance do site \\
\hline & & $10.11 \square$ Atualização periódica de equipamentos e sistemas \\
\hline & & $10.12 \square$ Outras_ \\
\hline & & 11. $\square$ Criação de políticas de privacidade dos dados que recebe de seus clientes, como \\
\hline & & 12. $\square$ Alterações nas políticas de investimento em tecnologia de informação. Especifique. \\
\hline & & $\begin{array}{l}\text { 13. } \square \text { Novos procedimentos operacionais de vendas (recepção de pedidos, cobrança etc.). } \\
\text { Especifique. }\end{array}$ \\
\hline & & 14. $\square$ Outros. Quais? \\
\hline
\end{tabular}

3.8. (ESTIMUL.) Em sua opinião, com que freqüência os clientes podem encontrar respostas para suas perguntas mais comuns no Web site da empresa:
1. $\square$ sempre
2. $\square$ quase sempre
3. $\square$ raramente
4. $\square$ nunca
5. $\square$ não sabe responder.

3.8.1. Como a empresa avalia se as respostas estão sendo suficientes/satisfatórias e qual a sistemática para inclusão de novas perguntas/respostas?

3.9. (ESPONT.) A empresa procura responder aos e-mails dos clientes dentro de um período de:
1. $\square 24$ horas após o recebimento
2. $\square 25$ a 72 horas após o recebimento
3. $\square 73$ horas a uma semana após o recebimento
4. $\square$ mais de uma semana a um mês após o recebimento
5. $\square$ raramente responde
6. $\square$ não sabe avaliar.

3.10. (ESTIMUL.) Os clientes possuem uma maneira fácil de entrar em contato com atendimento ao cliente pessoal (não automatizado)?
1. $\square$ Sim.
2. $\square$ Não.

3.11. (ESTIMUL.) A empresa oferece aos clientes a opção de receber por $e$-mail, automaticamente, informações sobre atualizações dos produtos e novidades do site?
1. $\square$ Sim.
2. $\square$ Não. 
3.12. Como o cliente pode saber como está o andamento de seu pedido?

3.13. Há diferenciação de tratamento entre clientes que compram pela Internet e clientes que compram pelos meios tradicionais? Quais são as diferenças e por quê? (preços, prazo de entrega, condições de pagamento, rapidez no atendimento a consultas e reclamações etc.)

3.14. Como a sua empresa coleta dados a respeito de seus clientes pela Internet e que tipo de dados são coletados? (utiliza cookies, login com senha de identificação)

3.15. Como são feitos o gerenciamento e análise desses dados?

3.16. Quais as expectativas/necessidades de seus clientes em relação às compras via Internet e quais delas são atendidas por esta forma de relacionamento, na sua empresa?

3.17. (ESTIMUL.) Como o senhor caracterizaria os esforços da sua empresa para satisfazer as necessidades de seus clientes que compram pela Internet?
1. $\square$ Não comprometida
2. $\square$ Comprometida de alguma maneira.
3. $\square$ Muito comprometida.

3.18. Se o(a) senhor(a) fosse cliente de sua loja, quais seriam os benefícios ou serviços desejados num relacionamento com sua loja na Internet?

3.19. (ESTIMUL.) Na sua opinião, após o advento da Internet, as relações entre a empresa e seus clientes irão:
1. $\square$ Melhorar
2. $\square$ Piorar
3. $\square$ Não irão se alterar

3.19.1. Por quê?

\section{Identificação}

4.1. Nome: Tempo na empresa: anos.

4.2. Empresa:

4.3. Ramo de atividade:

4.4. Tempo da empresa no uso da Internet em suas negociações: Tempo da empresa no setor: anos.

4.5. Departamento/Setor: Cargo:

4.6. Telefone e e-mail para contato (esclarecimento de dúvidas): 4.6.1. Telefone: e-mail:

Agradecimentos e compromisso de divulgação dos resultados da pesquisa. 


\subsection{Apêndice B - Extratos das entrevistas}

\section{- Marketing de Relacionamento e Fidelidade}

“O varejo vende commodities: uma determinada marca de produto está disponível em várias lojas concorrentes. Entretanto, a nossa empresa se preocupa em desenvolver relacionamentos com os clientes; o que diferencia a busca do produto é o que a loja oferece adicionalmente a eles e é isso que determina a sua fidelidade.” “A fidelidade do cliente está intimamente ligada a quanto a empresa o conhece.” (Empresa A)

“Os relacionamentos são lucrativos também em termos de imagem (branding). O que se gasta do orçamento com relacionamento não necessariamente retorna imediatamente, em termos financeiros, mas sim em termos de imagem corporativa, branding, o que é difícil de ser mensurado.” (Empresa A)

“O assento da aeronave é o 'mesmo', mas o serviço total é prestado de maneira especial.” "Na realidade, a empresa aumenta ou diminui o prazo de payback, mas, se bem administrado, o programa de fidelidade sempre se paga.” (Empresa C)

“É preciso ouvir do cliente do que ele precisa, por que está cancelando a assinatura, para que a empresa possa entender o que pesa para ele.” “Como a empresa trabalha muito com o desenvolvimento de clientes dentro da base ativa já existente (vender mais para o mesmo cliente) pelo uso de folders encartados nas revistas, quando ela consegue vender mais para seu próprio cliente, ele vai ser novo para aquele produto mas é antigo em outro. O primeiro passo é mudar essa visão. O sistema enxerga o produto, e não o cliente.” "Quer queira, quer não, as ações têm que dar retorno financeiro para a empresa. Em seu Planejamento Operacional, as ações de relacionamento sem incremento de vendas foram cortadas. Relacionamento deve pressupor ou economia, ou aumento de vendas. Atualmente, a empresa não tem métricas de assinantes, apenas de assinaturas; é uma necessidade detectada, envolvendo todos os títulos que eles possuem.” "Algumas ações são discriminativas, elas segregam e não agregam.” "Há quem acredite que, se a empresa enviar e-mails para todo mundo, ela venderá mais. Em valores absolutos, é possível que isso ocorra. Porém, que efeitos uma empresa espera obter enviando e-mails indiscriminadamente, inclusive para quem já é cliente da empresa? Além disso, o fato de muitas empresas enviarem esse tipo de e-mail torna a tentativa de conquista um transtorno para quem recebe. Em sua maioria, constituem peças padronizadas, como panfletos colocados em sua caixa de correio ou entregues nos semáforos.” "De qualquer modo, a empresa está muito comprometida em melhorar seu relacionamento. Foi criada uma área para este fim, já consolidada; não é mais um projeto, um piloto”. (Empresa E)

“A empresa procura fazer o possível e o impossível para que o cliente se sinta feliz comprando da Empresa F”. “A empresa toda é um conjunto para satisfazer o cliente. É preciso que toda a empresa trabalhe para satisfazê-lo, desde o pessoal de vendas até o pessoal de backup, fiscais etc., para que ele tenha um retorno rápido e fique satisfeito com o produto e com o atendimento.” (Empresa F) 
- CRM

“É possível fazer marketing de relacionamento sem banco de dados. É claro que é muito mais fácil com o auxílio da tecnologia, que permite a análise do histórico de cada cliente, cruzamento de dados etc. E, mesmo com a tecnologia, não são necessários softwares sofisticados” (Empresa B)

“CRM é muito mais que apenas software, é a leitura do software, as decisões e ações possíveis a partir das informações que ele propicia, que devem ser depuradas e trabalhadas para que se retorne ao cliente com ações mais direcionadas e objetivas.” (Empresa A)

"O CRM é muito mais filosofia; o software é apenas um dos instrumentos. Na entrada da sede da empresa, há um painel onde se podem visualizar os valores da empresa relacionados ao cliente. O cliente é o ponto central. Tudo o que se faz deve ser em razão dele; toda a atividade da empresa deve estar em torno dele. A área de CRM tenta transmitir a todos os stakeholders da empresa a importância do cliente.” (Empresa H)

"Não é o software que coordena o CRM; primeiro, é preciso quebrar paradigmas, mudar conceitos e filosofia da empresa: a maior dificuldade existente é a de parar de olhar o produto e olhar o cliente, pensar por ele, ele é o seu patrão. Todo professor, e todo livro sobre CRM falam a mesma coisa. É o dono da mercearia que sabe que você consome azeitonas pretas e o avisa quando elas chegam. CRM é fazer isto, é muito simples. O sistema apóia a empresa, mas ela não precisa gastar muito. A empresa precisa de um software, mas ele não é a base." "Há revistas que são de interesse do leitor apenas durante uma fase de sua vida. A idéia é reter assinantes, e não assinaturas. $\mathrm{O}$ assinante migra de um título para outro, mas continua cliente da empresa. Isso se depreende de uma análise de banco de dados, que é mais confiável e seguro e não de pesquisas, nas quais as pessoas respondem o que elas acham que devem responder, e não necessariamente, a situação real.” (Empresa E)

“O CRM sozinho também não resolve: é preciso ter, antes, uma ferramenta de análise estruturada de dados, para que possa conhecer suficientemente o cliente a ponto de planejar ações de marketing de relacionamento com o CRM. Sem isso, a empresa não consegue utilizar o CRM, por melhores ferramentas que possua.” (Empresa D)

“O CRM traz uma série de possibilidades; a partir da identificação dos clientes com os quais a empresa já mantém um bom relacionamento, permite melhorá-lo e, fundamentalmente, entender as razões pelas quais o relacionamento com alguns clientes é melhor que com outros.” (Empresa G)

\section{- Treinamento}

"Nunca é suficiente, mas é o que a empresa consegue fazer. A empresa tem feito a sua parte ao adequar conteúdos e criar estrutura para tanto. Depende muito de cada funcionário, tanto de seu perfil, como de seu empenho.” (Empresa C)

"Todos sabem o que fazer, mas o maior empecilho é o desenvolvimento de políticas e de ferramentas mais adequadas. A conscientização já está ocorrendo.” (Empresa E) 


\section{- Vantagens de se comercializarem bens e serviços pela Internet}

“À medida que a empresa entende melhor o cliente, sabe melhor o que ele deseja e não precisa oferecer muitas opções além das que ele próprio definiu.” (Empresa B)

"Vender direto ao cliente pela Internet proporciona interação mais fácil com ele, permite entender melhor o que ele deseja, o que está procurando, conhecê-lo e cadastrá-lo, de maneira que se possam analisar seus interesses e necessidades.” (Empresa C)

"Há cerca de dois anos, as empresas que vendiam pela Internet tinham um problema sério de logística de entrega. Atualmente, isso não existe mais: a maior parte dos problemas foi resolvida pelos Correios que, vendo uma grande queda no volume de cartas em circulação, adaptaram-se e voltaram seus esforços para a entrega de mercadorias e encomendas, principalmente de produtos comprados via Internet. Assim, a entrega não é mais considerada um diferencial, uma vantagem competitiva. A vantagem competitiva é aquilo que a empresa tem, mas que seu concorrente não tem e não terá no curto/médio prazo. Hoje, com a questão das entregas resolvida, a vantagem competitiva é o preço, para produtos commodities como livros e CDs, e uma loja física para produtos técnicos, como garantia de que o cliente sempre terá um local de suporte onde ir para poder reclamar. As grandes empresas de sucesso são as que têm uma loja física.” (Empresa G)

\section{- Mudanças na abordagem nas relações com clientes}

“Se a empresa enviar um e-mail para o cliente, é muito fácil para ele enviar um questionamento, crítica ou comentário para a empresa. E, uma vez que a empresa abordou o endereço de $e$-mail do cliente, ele se acha com o direito, que realmente existe, de receber uma resposta, a qual, também é de direito dele, deve ser rápida. Atualmente, a empresa não tem estrutura para devolver estas respostas num prazo adequado, por isso, não pratica e-mail marketing." "Quando se implanta e-mail marketing, é preciso que muitas das perguntas e respostas que possam surgir em decorrência desta ação sejam parte da comunicação da empresa e de fácil acesso, condição esta que não é trivial; é preciso colocar-se no lugar do cliente e avaliar se as informações são suficientes e claras.” (Empresa G)

“A Empresa G é bastante competitiva em termos de preço. O que ocorre, muitas vezes, é que o cliente vê todas as informações sobre o livro que deseja em sites de outras livrarias e acaba comprando no site da Empresa G ou em outro que lhe traga o menor preço, após pesquisar em sites que comparam preços.” "A empresa tem políticas de preços mais baixos pela Internet pois a concorrência a obriga a fazer isto. Se um cliente estacionar seu carro na loja da empresa, ele não irá até o shopping só para pesquisar preço. Mas, se ele estiver comprando pela Internet, mais dois cliques o levam até o site do concorrente e ele pesquisará preço, que faz parte do processo de decisão de compra.” (Empresa G)

"O cliente deve ser bem tratado sempre. Muitas vezes, o profissional da Internet se preocupa apenas com a tecnologia, esquecendo-se de que o que ele está produzindo será dirigido a outras pessoas, não considerando o negócio como um todo, e, por conseqüência, ignorando o cliente.” (Empresa F) 


\section{Anexos}

\subsection{Anexo A - Sistema de Referência Utilizado}

AS MAIORES POR ORIGEM DE CAPITAL

\section{As 100 maiores empresas Nacionais}

\begin{tabular}{|c|c|c|c|}
\hline CLASS. & EMPRESA & SEDE & $\begin{array}{c}\text { RECEITA } \\
\text { LIQQUIDA } \\
\text { RS MIL }\end{array}$ \\
\hline 1 & Petróleo lpiranga & RJ & 8939.267 \\
\hline 2 & TMAR & RJ & 8.480 .582 \\
\hline 3 & Páode Açúcar & SP & 7.211 .853 \\
\hline 4 & Embraer & SP & 6.735 .144 \\
\hline 5 & CVRD & RJ & 6.385 .000 \\
\hline 6 & Brasil Telecom & DF & 6.158 .408 \\
\hline 7 & Varig & RS & 5.251 .008 \\
\hline 8 & AntarcticalCBB & SP & 4.094 .037 \\
\hline 9 & CSN & RJ & 3.284 .294 \\
\hline 10 & Sada & SC & 3.277 .623 \\
\hline 11 & Copene & $B A$ & 3.137 .906 \\
\hline 12 & Gerdau & RJ & 3.072 .644 \\
\hline 13 & CPFL & SP & 3.056 .270 \\
\hline 14 & Usiminas & MG & 2942383 \\
\hline 15 & Copersucar & $S P$ & 2.780 .277 \\
\hline 16 & Tam & SP & 2.710 .618 \\
\hline$\pi$ & Votorantim & $S P$ & 2.600 .000 \\
\hline 18 & Casas Bahia & SP & 2528.787 \\
\hline 19 & Perdigáo & SP & 2424.864 \\
\hline DD & Copesul & RS & 2359.645 \\
\hline 21 & TVGlobo RJ & RJ & 2324.603 \\
\hline 2 & Sendas & RJ & 2324.132 \\
\hline 23 & Ponto Frio & RJ & 2093.365 \\
\hline 24 & CST Tubarăo & ES & 1.977 .038 \\
\hline D & Ipiranga Dist & RS & 1.926 .346 \\
\hline कृ & Norbeto Odebrecht & RJ & 1.888 .344 \\
\hline Z & OPP Química & BA & 1.759 .578 \\
\hline B & Cospa & $S P$ & 1.712 .172 \\
\hline Z & Alacadáo & SP & 1.674 .374 \\
\hline 30 & VCP & SP & 1.541 .562 \\
\hline 31 & Coeba & $B A$ & 1.516 .697 \\
\hline 32 & Coamo & $P R$ & 1.490 .299 \\
\hline 3 & Petroquímica Uniä́o & $S P$ & 1.446 .589 \\
\hline 34 & Rio Branco & $S P$ & 1.409 .077 \\
\hline 3 & Cisa & ES & 1.383 .576 \\
\hline 36 & Lojas Americanas & RJ & 1.358 .628 \\
\hline 3 & Bertin & SP & 1349.644 \\
\hline 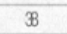 & $B C P$ & SP & $1,324.321$ \\
\hline 3 & Martins & MG & 1.320 .333 \\
\hline 4 & Acesita & MG & 1.312368 \\
\hline 41 & CRAlmeida Eng & RJ & 1.307 .674 \\
\hline 4 & Camargo Corréa & SP & 1.205 .187 \\
\hline 4 & Aracruz Celulose & ES & 1.180 .590 \\
\hline 4 & Eơliora Abril & SP & 1.121.094 \\
\hline 46 & Abrás & PA & 1.094 .637 \\
\hline 46 & Ultragaz & SP & 1.071 .517 \\
\hline 47 & Variglog & $\mathrm{SP}$ & 1.064 .876 \\
\hline 48 & Vianna & CE & 1.044 .910 \\
\hline 4 & Sé & $S P$ & 1.043 .637 \\
\hline 50 & Açominas & MG & 1.027 .258 \\
\hline 5 & CBA & SP & 1.009 .422 \\
\hline
\end{tabular}

\begin{tabular}{|c|c|c|c|}
\hline CLASS. & EMPRESA & SEDE & $\begin{array}{c}\text { RECEITA } \\
\text { LIQUIDA } \\
\text { RS MIL }\end{array}$ \\
\hline 52 & Celpe & PE & 1.002 .675 \\
\hline 53 & Suzano & SP & 998.668 \\
\hline 54 & Trikem & $B A$ & 985.056 \\
\hline 5 & $\mathrm{Ale}$ & MG & 970.073 \\
\hline 50 & Weg & $\mathrm{SC}$ & 955.183 \\
\hline 5 & Caraba Metais & $B A$ & 946.153 \\
\hline$B$ & MBR & RN & 937.900 \\
\hline 59 & Marlim & RJ & 921.528 \\
\hline BD & Vasp & SP & 918365 \\
\hline ๘ & Andrade Gufierez & MG & 911.581 \\
\hline Q2 & $\mathbb{P P Q}$ & RS & 883.570 \\
\hline 63 & Telemig Celular & MG & 869.010 \\
\hline 64 & Esoolsa & ES & 867.796 \\
\hline Б) & Cotia Trading & ES & 866.419 \\
\hline 60 & Hautec Philoo & AM & 864.210 \\
\hline 6 & Natura & SP & 861.322 \\
\hline 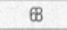 & CPernambucanas SP & SP & 857.409 \\
\hline$\theta 9$ & ZaffariP Alegre & RS & 838.620 \\
\hline$\pi$ & Quéroz Gavāo Const & RN & 833.817 \\
\hline$\pi$ & Celba & $P A$ & 813.369 \\
\hline 72 & Rio Sul & RJ & 805.779 \\
\hline 73 & RGE & RS & 805.179 \\
\hline 74 & Arcom & MG & 801.340 \\
\hline$\pi$ & Caramuru & GO & 769.161 \\
\hline 76 & ATL Algar & RJ & 764.051 \\
\hline$\pi$ & Samarco & MG & 763.519 \\
\hline 78 & Avipal Avicultura & RS & 742.404 \\
\hline 79 & BahiaSul & $B A$ & 732.288 \\
\hline 80 & GBarbosa & SE & 730.671 \\
\hline 81 & Marooodo & RS & 729.806 \\
\hline 82 & MMC & SP & 725.000 \\
\hline 83 & Supergasbrás Dist & RN & 720.141 \\
\hline 84 & Cocopercentral & SC & 715.909 \\
\hline क & llambé & MG & 709.808 \\
\hline$\infty 6$ & CoimexExpd & ES & 696.008 \\
\hline 8 & Polbrast & SP & 688774 \\
\hline B & Alunorte & $\mathrm{PA}$ & 606.684 \\
\hline$\not 2$ & Tigre & SC & 661.028 \\
\hline 90 & Lojas Riachuelo & $S P$ & 658941 \\
\hline 9 & Cemat & MT & 654.137 \\
\hline$\Phi$ & Pollieno & $B A$ & 649.599 \\
\hline $\mathscr{B}$ & Petroflex & RJ & 648.839 \\
\hline 94 & Ripasa & $S P$ & 631.291 \\
\hline 5 & Moinhos Cruzeiro do Sul & RS & 629.613 \\
\hline 96 & Jamyr Vasconcellos & RN & 616930 \\
\hline 9 & lia & RJ & 613.512 \\
\hline $\mathscr{B}$ & Meios de Pagamento & SP & 605205 \\
\hline 9 & MRS Logística & RJ & 602501 \\
\hline \multirow[t]{3}{*}{100} & Irmäo Bretas & MG & 601374 \\
\hline & Total das 100 maiores & & 170.996 .857 \\
\hline & Acumulado das empresas nacionais (6746) & & 400.693 .424 \\
\hline
\end{tabular}

Balanço Anual 


\section{As 100 maiores}

\section{empresas Estrangeiras}

\begin{tabular}{|c|c|c|c|}
\hline CLASS. & EMPRESA & SEDE & $\begin{array}{c}\text { RECEITA } \\
\text { LíQUIDA } \\
\text { RS MIL }\end{array}$ \\
\hline 1 & Volkswagen & SP & 10.200 .000 \\
\hline 2 & Carrefour & SP & 9.236 .683 \\
\hline 3 & TelefônicaSP & SP & 8.963 .078 \\
\hline 4 & Shell & RJ & 8.906 .456 \\
\hline 5 & Embratel & RJ & 7.270 .200 \\
\hline 6 & Esso & RJ & 7.117 .000 \\
\hline 7 & General Motors & SP & 7.013 .430 \\
\hline 8 & Fiat & MG & 6.440 .949 \\
\hline 9 & Texaco & RJ & 6229.005 \\
\hline 10 & Eletropaulo & $S P$ & 5.887 .944 \\
\hline 11 & Bunge Alimentos & SC & 5.357 .474 \\
\hline 12 & Ford Motor & SP & 4.300 .000 \\
\hline 13 & Cargil & SP & 4225.990 \\
\hline 14 & Daimler Chysler & SP & 4.138 .463 \\
\hline 15 & Light & RN & 3.829 .049 \\
\hline 16 & Gessy Lever & SP & 3.589 .178 \\
\hline$\pi$ & Sonae & RS & 3.411 .419 \\
\hline 18 & Nestlé & SP & 3.295 .822 \\
\hline 19 & Siemens & SP & 3.096219 \\
\hline 20 & Telesp Celuar & SP & 2946.234 \\
\hline 21 & Ericsson & $S P$ & 2551.997 \\
\hline 22 & BanderanteEnergia & SP & 2.521 .721 \\
\hline$\not 2$ & Basf & SP & 2.505 .620 \\
\hline 24 & Nokia & SP & 2211.068 \\
\hline 2 & Avon & SP & 2200.000 \\
\hline क & SouzaCruz & RJ & 2.166 .900 \\
\hline 2 & Bunge Fertilzantes & SP & 2.141236 \\
\hline$\not B$ & XeroxCom & ES & 2.100 .000 \\
\hline$\not 2$ & Makso & SP & 2098.764 \\
\hline 30 & Tractebel Energia & SC & 2.083 .025 \\
\hline 31 & HondaAM & AM & 1.981 .661 \\
\hline 32 & Coirbra & SP & 1.944 .701 \\
\hline 3 & Agip Distribuidora & SP & 1.919 .981 \\
\hline 34 & NEC & SP & 1.695 .724 \\
\hline 3 & Bompresco Supermercados & $\mathrm{PE}$ & 1.606554 \\
\hline 3 & Alcoa & MG & 1.626 .212 \\
\hline 3 & Mutbrás & SP & 1.600 .594 \\
\hline 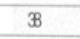 & McDonad's & SP & 1.600 .000 \\
\hline$\dddot{B}$ & Elektro & $\mathrm{SP}$ & 1.572 .039 \\
\hline 40 & Teleri Celular & RN & 1.496 .552 \\
\hline 41 & Walmart & SP & 1.482899 \\
\hline 4 & Renault & PR & 1.424 .435 \\
\hline 4 & Agip do Brasil & SP & 1.420 .912 \\
\hline 44 & Cerj & RN & 1.392 .067 \\
\hline 46 & Bayer & SP & 1.363001 \\
\hline 46 & AES & RS & 1.325 .320 \\
\hline 4 & Scania Latin America & SP & 1.322 .375 \\
\hline 48 & Phodia & SP & 1.288 .794 \\
\hline 48 & Belgo Mineira & MG & 1.282348 \\
\hline 50 & Prelli Pneus & SP & 1.265 .021 \\
\hline 5 & Hewett-Packard & SP & 1233.755 \\
\hline
\end{tabular}

\begin{tabular}{|c|c|c|c|}
\hline CLASS. & EMPRESA & SEDE & $\begin{array}{l}\text { RECEITA } \\
\text { LIQUIDA } \\
\text { RS MIL }\end{array}$ \\
\hline 52 & Seara & SC & 1.199 .575 \\
\hline 53 & Acatel Telecoms & SP & 1.182 .721 \\
\hline 54 & Nortel Networks & SP & 1.150 .000 \\
\hline 5 & ABB & SP & 1.134 .962 \\
\hline 56 & Parmalat & SP & 1.127 .027 \\
\hline 5 & DuPont & SP & 1.074 .126 \\
\hline$\$$ & Alcan & SP & 1.066 .520 \\
\hline 59 & $3 M$ & SP & 1.034 .000 \\
\hline$\theta$ & Bompreço BA & BA & 1.013 .006 \\
\hline 61 & Goodyear & SP & 1.000 .000 \\
\hline Q2 & Volvo & PR & 915.000 \\
\hline ๓ & CocaColaSpal & SP & 901.999 \\
\hline 64 & Codice & $\mathrm{CE}$ & 899.522 \\
\hline డ5 & Kodak & SP & 890836 \\
\hline 6 & Philips AM & AM & 869.965 \\
\hline$\theta$ & Comgás & SP & 809.184 \\
\hline BB & Dow & SP & 867.057 \\
\hline 69 & Frangosul & RS & 854,940 \\
\hline$\pi$ & White Martins Gases & RJ & 843.708 \\
\hline$\pi$ & Microsoft & SP & 842.000 \\
\hline 72 & Celular CRT & RS & 829.461 \\
\hline 73 & Universal Leaf & RS & 828.77 \\
\hline 74 & Embraco & SC & 827.950 \\
\hline$\pi$ & Dow AgroSciences & $S P$ & 809881 \\
\hline 76 & Clariant & SP & 794.181 \\
\hline$\pi$ & Electrolux & $\mathrm{PR}$ & 766.648 \\
\hline 78 & Visteon & SP & 758.647 \\
\hline 79 & Roche & SP & 753291 \\
\hline 80 & Sabbá & AM & 750.757 \\
\hline 81 & FleischmannRoyal & PR & 743.500 \\
\hline 82 & AES Tietêt & SP & 738.299 \\
\hline 83 & Matrix Internet & $\mathrm{SC}$ & 736369 \\
\hline 84 & RhodiaSter Fibras & SP & 720.482 \\
\hline क & Belgo Bekaert & MG & 718.590 \\
\hline 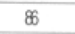 & TRW Automotive & SP & 711.625 \\
\hline 8 & Holcim & SP & 708.445 \\
\hline $\mathscr{B}$ & Peugeot Citröen & RJ & 695.739 \\
\hline $\mathscr{B}$ & Ultrafertil & SP & 694.480 \\
\hline 90 & $V \& M$ & $M G$ & 692.071 \\
\hline 91 & Cenbra & MG & 686.114 \\
\hline$\Phi$ & Samsung AM & AM & 673.509 \\
\hline 9 & Saint-Gobain Vidros & SP & 660.639 \\
\hline 94 & Kaiser Brasl & SP & 652.854 \\
\hline क5 & Eaton & SP & 639.212 \\
\hline 9 & Kraft Foods & PR & 638.707 \\
\hline 9 & Confablindl & SP & 632696 \\
\hline $\mathscr{B}$ & Novartis & SP & 631.350 \\
\hline 9 & Chapecó Alimentos & SC & 627.478 \\
\hline \multirow[t]{3}{*}{100} & Mahle Metal Leve & $S P$ & 62.141 \\
\hline & Total das 100 maiores & & 210.460 .088 \\
\hline & Acumulado das empresas estrangeiras (885) & & 286.267 .962 \\
\hline
\end{tabular}

Balanço Anual 


\subsection{Anexo B - Carta de Apresentação da FEA/USP}

São Paulo, 7 de março de 2003

\section{À Empresa X}

Prezados Senhores

A presente tem a finalidade de apresentar a senhora Sandra Sayuri Yamashita, aluna do Programa de Pós Graduação em Administração - Mestrado, junto ao Departamento de Administração da Faculdade de Economia, Administração e Contabilidade da Universidade de São Paulo.

Destacamos que, como requisito final do citado Programa, o candidato ao título de mestrado precisa apresentar um projeto de conclusão de curso, uma dissertação de mestrado, de cunho acadêmico e técnico, a qual deve incluir um trabalho empírico, como pressuposto metodológico. Esse trabalho empírico pode ser representado por uma pesquisa, envolvendo grande massa de dados, ou um estudo de caso, situação em que o interesse se concentra no aprofundamento em um determinado tema de pesquisa.

A aluna, Sandra Yamashita, optou pela segunda alternativa, razão pela qual procurou essa empresa para solicitar as informações pertinentes ao tema do trabalho. Salientamos que as informações que forem coletadas pela aluna serão mantidas em caráter confidencial e terão por única finalidade sua incorporação à sua dissertação de mestrado. A empresa poderá receber um exemplar do trabalho concluído. Caso haja interesse de o aluno publicar o trabalho em um veículo acadêmico, isso só será feito mediante anuência formal da empresa.

Contando com a colaboração inestimável de V.Sas, agradecemos antecipadamente.

Atenciosamente

Prof. Dr. Geraldo Luciano Toledo

(Coordenador do Curso) 
10.3. Anexo C - Esquema CRM - Três tipos de CRM

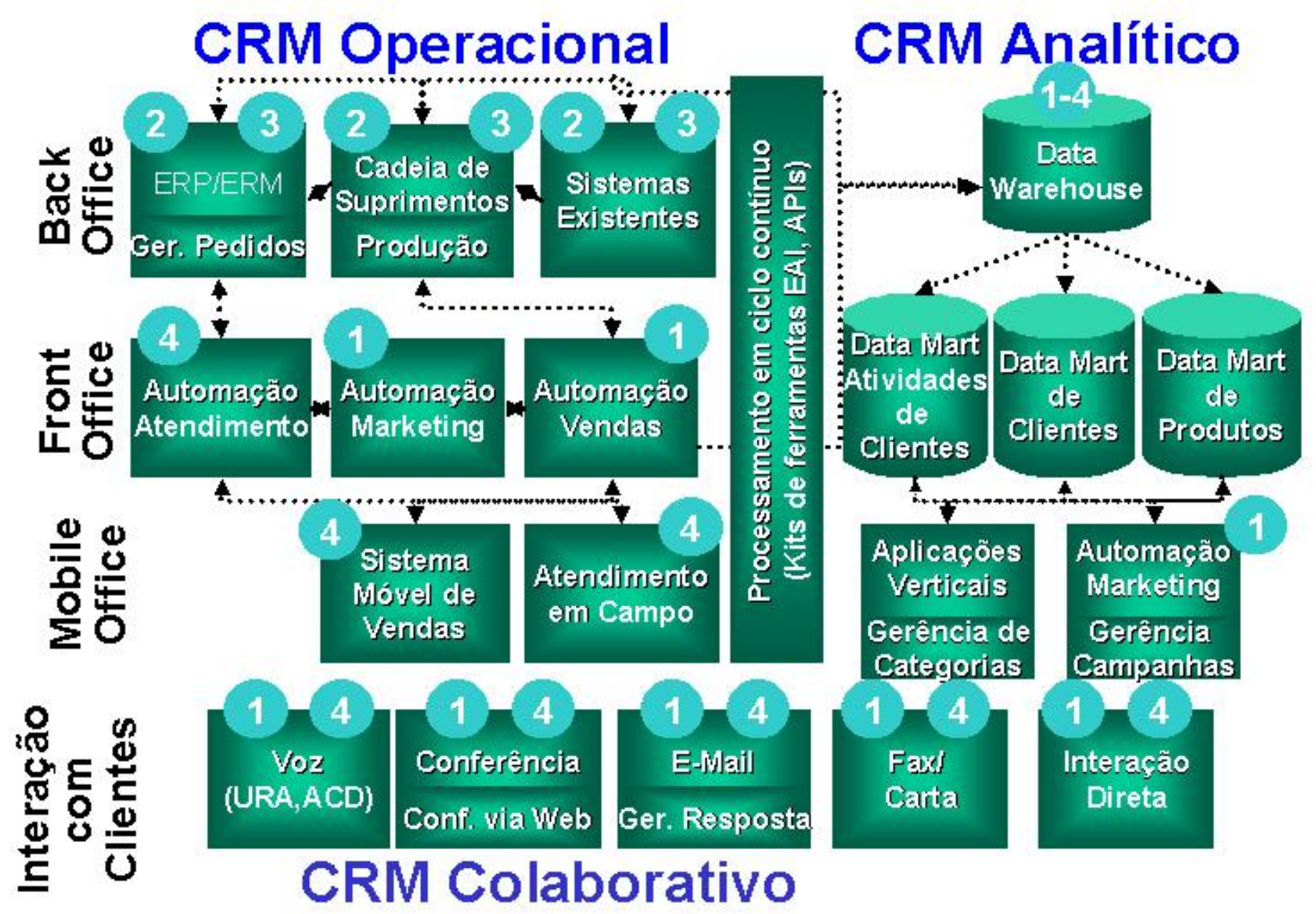

1) Engajamento 2) Transação 3) Fulfill 4) Serviço

Fonte: META Group (2000, in PeopleSoft, 2002). 